FRANKLIN KELLY MIGUEL

Aplicação da Teoria de Portfólio de Markowitz para a Geração de Energia Elétrica Proveniente de

Empreendimentos Eólicos no Brasil

São Paulo

2016 
FRANKLIN KELLY MIGUEL

\title{
Aplicação da Teoria de Portfólio de Markowitz para a Geração de Energia Elétrica Proveniente de Empreendimentos Eólicos no Brasil
}

\author{
Tese apresentada à Escola Politécnica da \\ Universidade de São Paulo como parte dos \\ requisitos necessários à obtenção do título de \\ Doutor em Ciências. \\ Área de Concentração: Sistemas de Potência. \\ Orientador: Prof. Dr. Dorel Soares Ramos.
}

São Paulo 
TERMO DE JULGAMENTO 
Este exemplar foi revisado e corrigido em relação à versão original, sob responsabilidade única do autor e com a anuência de seu orientador.

São Paulo de de

Assinatura do autor:

Assinatura do orientador:

\section{Catalogação-na-publicação}

MIGUEL, Franklin Kelly

Aplicação da Teoria de Portfólio de Markowitz para a Geração de Energia Elétrica Proveniente de Empreendimentos Eólicos no Brasil / F. K. MIGUEL -- versão corr. -- São Paulo, 2016.

$312 \mathrm{p}$.

Tese (Doutorado) - Escola Politécnica da Universidade de São Paulo. Departamento de Engenharia de Energia e Automação Elétricas.

1.Teoria de Portfólio 2.Modelo de Otimização de Portfólio de Markowitz 3.Volatilidade da Geração Eólica 4.Contratação de Energia I.Universidade de São Paulo. Escola Politécnica. Departamento de Engenharia de Energia e Automação Elétricas II.t. 


\section{AGRADECIMENTOS}

Agradecimentos especiais ao professor Dorel Soares Ramos, pela orientação e pelo constante estímulo transmitido durante todo o trabalho.

A todos os professores pelas relevantes discussões no decorrer do curso, em especial à professora Eliane Aparecida Faria Amaral Fadigas, que me ensinou tudo o que sei sobre geração de energia eólica e aos professores José Roberto Securato e Fernando Amaral de Almeida Prado Junior, que me apresentaram a teoria de Markowitz.

Aos amigos da Copel, em especial à Adriana Baratto, ao Márcio Raphael e ao Júlio Neto, e aos amigos Débora Cintia Marcilio, Daniel Henrique Marco Detzel, Ana Paula Oening e Lúcio de Medeiros, todos do LACTEC, pelas relevantes e incontáveis contribuições.

À Copel e ao Programa de Pesquisa e Desenvolvimento Tecnológico do Setor de Energia Elétrica da ANEEL pelo patrocínio.

Ao Gabriel, Rafael e Cláudia pela paciência e compreensão.

Aos meus pais pela educação, formação e valores.

$\mathrm{E}$ a todos que colaboraram direta ou indiretamente, na execução deste trabalho. 


\section{RESUMO}

A geração hidrelétrica é dependente da afluência, no entanto, é possível minimizar a variação da energia natural afluente por meio dos reservatórios. Por sua vez, a geração eólica tem como desvantagem a volatilidade devido a sua dependência em relação ao vento. Nesse sentido, uma carteira otimizada de projetos eólicos possibilita a redução da volatidade da energia gerada pelo conjunto, na medida em que aproveita as complementariedades do vento. No Brasil, os Estados da Bahia, Rio Grande do Norte, Ceará, Rio Grande do Sul e Piauí concentram 90\% da capacidade instalada das usinas eólicas em operação, em construção ou contratada, com uma previsão da fonte atingir $11,6 \%$ de participação na matriz elétrica. A pesquisa tem como objetivo desenvolver uma metodologia de apoio baseada na teoria de portifólio de Markowitz que poderá ser utilizada pelo órgão de planejamento energético brasileiro para a definição da quantidade de energia a ser contratada por fonte e local, por meio de leilões de energia regionais e por fonte, com o objetivo de se obter uma carteira otimizada de empreendimentos, que reduza a volatilidade. O método também pode servir de apoio ao investidor para se obter um portfólio de usinas que minimize o risco de exposição financeira no mercado de curto prazo. Nenhum estudo aplicando a teoria de portifólio de Markowitz em usinas eólicas do Brasil foi encontrado na literatura. Os resultados obtidos demonstram que a carteira formada pelas usinas eólicas existentes não está na fronteira eficiente e poderia ser otimizada com aumento da expectativa de geração ou redução do risco. No mesmo sentido, a otimização da carteira também reduziu o risco de exposição ao mercado de curto prazo.

Palavras-Chave: Teoria de Portfólio. Modelo de Otimização de Portfólio de Markowitz. Volatilidade da Geração Eólica. 


\begin{abstract}
Even though the hydroelectric generation is highly dependent on the river flows, it is possible to minimize the volatility of the energy generation in a given period using the storage capacity of the reservoirs. In contrast, to minimize the volatility of the wind generation is burdensome due to its dependency on wind. Accordingly, an optimized portfolio of wind projects all together allows the reduction of the volatility of the energy generation for the complementarity of wind from different locations. In Brazil, the states of Bahia, Rio Grande do Norte, Ceara, Rio Grande do Sul and Piauí concentrate 90\% of the installed capacity of wind power plants in operation, under construction or contracted with a font forecast to reach $11.6 \%$ share the electric matrix. The Thesis aims to develop a support methodology based in portfolio theory of Markowitz that can be used by the Brazilian-planning agency in future, to define the amount of energy to be contracted by source and location, through regional and source energy auctions, to obtain an optimized portfolio projects, with reduced volatility. The methodology can also serve to support the investor to obtain a portfolio of plants that minimize the risk of financial exposure to short-term market. No study applying Markowitz's portfolio theory in wind farms of Brazil was found in the literature. The results show that the portfolio of the existing wind farms is not on the efficient frontier and could be optimized with increased expectation of generating or reducing the risk. Similarly, the optimization of the portfolio also reduced the risk of exposure to short-term market.
\end{abstract}

Keywords: Portfolio Theory. Model Markowitz Portfolio Optimization. Volatility of Wind Generation. 


\section{LISTA DE FIGURAS}

Figura 1 - Campo de Vento Médio e Densidade Média de Potência Eólica no Atlântico Sudoeste, Calculados no Período entre Agosto de 1999 até Dezembro de 2009. ...36

Figura 2 - Projeto Eólico Offshore Asa Branca.

Figura 3 - Modelo Conceitual da Circulação Global Atmosférica, Indicando as Células Meridionais e as Direções dos Ventos Próximos à Superfície. .76

Figura 4 - Localização das Estações SONDA.

Figura 5 - Rosa dos Ventos (Aeroporto Afonso Pena, em São José dos Pinhais - PR), ano de 1951, hora 09:00).

Figura 6 - Rede de Estações Meteorológicas do INMET.

Figura 7 - Estações Meteorológicas com Dados de Vento Disponibilizadas pelo NOAA.

Figura 8 - Frequência de Ocorrência da Velocidade do Vento, Curva de Potência do Aerogerador E126 da Enercon e Estimativa da Energia Média Gerada.

Figura 9 - Curva de Potência do Aerogerador, Curva Densidade de Probabilidade de Weibull para a Velocidade do Vento e Curva da Energia Gerada.

Figura 10 - Modelo Proposto Básico.

Figura 11 - Procedimento para Obter o Risco Sistêmico.

Figura 12 - Distribuição Espacial das Coordenadas Selecionadas do Vortex.

Figura 13 - Potencial Eólico, Sistema de Transmissão e Pontos Adquiridos para a Porção Norte da Área de Estudo

Figura 14 - Potencial Eólico, Sistema de Transmissão e Pontos Adquiridos para a Porção Sul da Área de Estudo. 182

Figura 15 - Modelo Proposto Completo..........................................................182

Figura 16 - Procedimento Básico para Obter a Curva da Fronteira Eficiente..........204

Figura 17 - Modelo Proposto para PCHs. ......................................................249

Figura 18 - Modelo Proposto - Simulação das Receitas.........................................260 


\section{LISTA DE GRÁFICOS}

Gráfico 1 - Capacidade Instalada das Usinas Eólicas no Mundo - Acumulada e Anual.

Gráfico 2 - Evolução da Capacidade Instalada das Usinas Eólicas no Brasil. .44

Gráfico 3 - Previsão da Evolução da Capacidade Instalada das Usinas Eólicas no Brasil.

Gráfico 4 - Capacidade Instalada Acumulada das Usinas Eólicas Offshore. 48

Gráfico 5 - Estrutura de Custos Usinas Eólicas. 50

Gráfico 6 - Evolução dos Custos de Instalação. 51

Gráfico 7 - Capacidade Instalada Média por Parque Eólico Offshore. 52

Gráfico 8 - Evolução da Capacidade Instalada Média por Turbina (MW). 54

Gráfico 9 - Evolução da Distância e Profundidade dos Parques Eólicos. .54

Gráfico 10 - Influência da Distância na Energia Gerada. .55

Gráfico 11 - Distância e Profundidade dos Parques Eólicos por Países. .56

Gráfico 12 - Distribuição da Capacidade Instalada das Usinas do PROINFA. 58

Gráfico 13 - Distribuição da Capacidade Instalada das Usinas PCHs Contratadas do PROINFA.

Gráfico 14 - Distribuição da Capacidade Instalada das Usinas Eólicas Contratadas do PROINFA.

Gráfico 15 - Distribuição da Capacidade Instalada das Usinas Termoelétricas Biomassa (UTEs) Contratadas do PROINFA. .58

Gráfico 16 - Capacidade Instalada das Usinas Eólicas Construídas, em Construção e Contratadas por Estado.

Gráfico 17 - Mecanismo de Contabilização do Contrato de Energia do LFA. .64

Gráfico 18 - Mecanismo de Contabilização do Contrato de Energia do LEN. 68

Gráfico 19 - Mecanismo Anual de Incentivo - Contabilização do CER. .71

Gráfico 20 - Mecanismo Anual de Ressarcimento - Contabilização do CER. .71

Gráfico 21 - Mecanismo Quadrienal de Contabilização do CER. .73

Gráfico 22 - Função Densidade de Probabilidade de Rayleigh (V= 7, 10 e 12 m/s).89 
Gráfico 23 - Função Densidade de Probabilidade de Weibull (Variando c)

Gráfico 24 - Função Densidade de Probabilidade de Weibull (Variando k)..............91

Gráfico 25 - Potência Eólica e Máxima Potência Mecânica....................................94

Gráfico 26 - Curva de Potência e Coeficiente de Potência do Aerogerador E126 da Enercon.

Gráfico 27 - Curva Normal da Produção Anual de Energia. 105

Gráfico 28 - Estimativa da Produção Anual de Energia para Vários Níveis de Confiança. 105

Gráfico 29 - Comportamento do Risco em Função da Diversificação.

Gráfico 30 - Efeito do Número de Títulos Sobre o Risco da Carteira nos EUA. .....118

Gráfico 31 - Efeito do Número de Títulos Sobre o Risco da Carteira no Reino Unido. 118

Gráfico 32 - Otimização do Risco e Retorno para uma Carteira Teórica com Diversos Valores de Correlação.

Gráfico 33 - Plano Variância x Retorno. 123

Gráfico 34 - Plano Variância x Retorno - Retas Secantes e Tangentes. 123

Gráfico 35 - Esquema para obter a Curva da Fronteira Eficiente.

Gráfico 36 - Plano $R_{i} \times R_{m}$ 129

Gráfico 37 - Fronteira Eficiente das Usinas Eólicas do PROINFA (Dados em Energia). 146

Gráfico 38 - Frequencia de Uso das Usinas Eólicas do PROINFA nas 10 Carteiras Otimizadas (Dados em Energia Gerada). 149

Gráfico 39 - Histórico do Fator de Capacidade das 45 Usinas Eólicas do PROINFA. 150

Gráfico 40 - Fronteira Eficiente das Usinas Eólicas do PROINFA (Dados em Fator de Capacidade).

Gráfico 41 - Frequência de Uso das Usinas Eólicas nas 10 Carteiras Otimizadas (Dados em Fator de Capacidade) - Usinas Eólicas do PROINFA. 154

Gráfico 42 - Correlação entre as Usinas Eólicas Osório e Sangradouro - Estado do Rio Grande do Sul (Parâmetros adimensionais - Fator de Capacidade). 155

Gráfico 43 - Correlação entre as Usinas Eólicas Dos Índios e Sangradouro - Estado do Rio Grande do Sul (Parâmetros adimensionais - Fator de Capacidade). 155 
Gráfico 44 - Correlação entre as Usinas Eólicas Dos Índios e Osório - Estado do Rio Grande do Sul (Parâmetros adimensionais - Fator de Capacidade). 156

Gráfico 45 - Histórico do Fator de Capacidade das Usinas Eólicas do Estado do Rio Grande do Sul. 156

Gráfico 46 - Correlação entre a Usina Eólica Água Doce e a Usina Eólica Canoa Quebrada, localizadas no Estado de Santa Catarina e Ceará (Parâmetros adimensionais - Fator de Capacidade).

Gráfico 47 - Usina Eólica Equivalente do Estado do Ceará (Fator de Capacidade). 158

Gráfico 48 - Usina Eólica Equivalente do Estado da Paraíba (Fator de Capacidade). 159

Gráfico 49 - Usina Eólica Equivalente do Estado do Piauí (Fator de Capacidade).159

Gráfico 50 - Usina Eólica Equivalente do Estado do Rio Grande do Norte (Fator de Capacidade). 159

Gráfico 51 - Usina Eólica Equivalente do Estado do Rio de Janeiro (Fator de Capacidade). 160

Gráfico 52 - Usina Eólica Equivalente do Estado do Rio Grande do Norte (Fator de Capacidade). 160

Gráfico 53- Usina Eólica Equivalente do Estado do Rio Grande do Sul (Fator de Capacidade). 160

Gráfico 54 - Usina Eólica Equivalente do Estado de Santa Catarina (Fator de Capacidade). 161

Gráfico 55 - Usina Eólica Equivalente - Fator de Capacidade Médio 161

Gráfico 56 - Fronteira Eficiente e Carteira Atual para as Usinas Eólicas Equivalentes do PROINFA (Parâmetros adimensionais - Fator de Capacidade). 162

Gráfico 57 - Histórico do Fator de Capacidade das Usinas do PROINFA. 164

Gráfico 58 - Fronteira Eficiente e Carteira Atual para as Usinas Eólicas do PROINFA (Parâmetros adimensionais - Fator de Capacidade). 166

Gráfico 59 - Fronteira Eficiente e Carteira Atual para as UTEs Biomassa do PROINFA (Parâmetros adimensionais - Fator de Capacidade). 167

Gráfico 60 - Fronteira Eficiente e Carteira Atual para as PCHs do PROINFA (Parâmetros adimensionais - Fator de Capacidade). 167

Gráfico 61 - Fronteira Eficiente e Carteira Atual para as Usinas do PROINFA (Parâmetros adimensionais - Fator de Capacidade). 168 
Gráfico 62 - Fronteira Eficiente e Carteira Atual para as Usinas do PROINFA (Parâmetros adimensionais - Fator de Capacidade).

Gráfico 63 - Série Histórica do Fator de Capacidade - Usinas Eólicas Equivalentes.

Gráfico 64 - Série Histórica do Fator de Capacidade - Usinas Biomassa Equivalentes.

Gráfico 65 - Série Histórica do Fator de Capacidade - Usinas PCHs Equivalentes.

Gráfico 66 - Série Histórica do Fator de Capacidade - Usinas Equivalentes.

Gráfico 67 - Fronteira Eficiente e Carteira Atual - Usinas Eólicas Equivalentes (Parâmetros adimensionais - Fator de Capacidade).

Gráfico 68 - Fronteira Eficiente e Carteira Atual - UTEs Biomassa Equivalentes (Parâmetros adimensionais - Fator de Capacidade).

Gráfico 69 - Fronteira Eficiente e Carteira Atual - PCHs Equivalentes (Parâmetros adimensionais - Fator de Capacidade).

Gráfico 70 - Fronteira Eficiente e Carteira Atual - Usinas Equivalentes (Parâmetros adimensionais - Fator de Capacidade).

Gráfico 71 - Variação do Risco pelo Número de Ativos para as Usinas Eólicas Individualizadas (Parâmetros adimensionais - Fator de Capacidade).

Gráfico 72 - Variação do Risco pelo Número de Ativos para as Usinas Eólicas Equivalentes (Parâmetros adimensionais - Fator de Capacidade).

Gráfico 73 - Série Histórica da Velocidade Horária do Vento da Coordenada Anta para o Período de 1994 a 2014.

Gráfico 74 - Série Histórica da Velocidade Média Mensal da Coordenada Anta para o Período de 1994 a 2014. 190

Gráfico 75 - Histograma da Velocidade do Vento da Coordenada Anta para o Período de 1994 a 2014.

Gráfico 76 - Participação dos Fabricantes de Aerogeradores no Brasil. 191

Gráfico 77 - Curvas dos Aerogeradores Selecionados. 192

Gráfico 78 - Curva de potência do aerogerador Enercon E-115 (2.500 kW).

Gráfico 79 - Comparativo entre as Curvas de Potência e Coeficientes de Potência para o Aerogerador GE 2.5/88.

Gráfico 80 - Diferenças entre a Energia Gerada quando Calculada e Interpolada Diretamente da Curva do Aerogerador (cálculos para Parnaíba - TO). 
Gráfico 81 - Séries de Energia Gerada Horária para a Coordenada Dom Pedrito (RS) - Aerogerador Enercon E-115 (2.500 kW) - Janeiro de 2002, 2004 e 2014.

Gráfico 82 - Séries de Energia Gerada Horária para a Coordenada Afrânio (PE) Aerogerador Enercon E-115 (2.500 kW) - Janeiro de 1994, 2006 e 2011.

Gráfico 83 - Histograma de Frequências Relativas para Janeiro de 1994 na Coordenada Parada (CE) e Curva de Potência do Aerogerador Enercon E-115 (2.500 $\mathrm{kW})$.

Gráfico 84 - Séries de Energia Gerada Mensal para a Coordenada Dom Pedrito (RS) e Aerogerador Enercon E-115.

Gráfico 85 - Séries de Energia Gerada Mensal para a Coordenada Afrânio (PE) e Aerogerador Enercon E-115. 203

Gráfico 86 - Curvas de Fronteiras Eficientes para cada Modelo de Aerogerador - Série Mensal de Energia Gerada (kWmédios). 207

Gráfico 87 - Frequencia de Uso das Coordenadas nas Carteiras Otimizadas - Série Mensal de Energia Gerada 210

Gráfico 88 - Curvas de Fronteiras Eficientes para cada Modelo de Aerogerador - Série Mensal de Fator de Capacidade. 211

Gráfico 89 - Fronteiras Eficientes para cada Modelo de Aerogerador (Energia Gerada) 213

Gráfico 90 - Fronteiras Eficientes para cada Modelo de Aerogerador (Fator de Capacidade) 213

Gráfico 91 - Fronteira Eficiente do Aerogerador Wobben/Enercon e Carteiras Atual, PROINFA e Individuais (Série de dados energia gerada mensal - kWmédios).......214

Gráfico 92 - Fronteira Eficiente do Aerogerador Wobben/Enercon e Carteiras Atual, PROINFA e Individuais (Série de dados fator de capacidade mensal). 216

Gráfico 93 - Curvas de Fronteiras Eficientes para cada Modelo de Aerogerador - Série Horária de Energia Gerada (kWh)

Gráfico 94 - Curvas de Fronteiras Eficientes para cada Modelo de Aerogerador - Série Horária do Fator de Capacidade. 218

Gráfico 95 - Fronteiras Eficientes para cada Modelo de Aerogerador (Energia Gerada). .220

Gráfico 96 - Fronteiras Eficientes para cada Modelo de Aerogerador (Fator de Capacidade). 220

Gráfico 97 - Frequencia de Uso das Coordenadas nas Carteiras Otimizadas (Fator de Capacidade). 222 
Gráfico 98 - Fronteira Eficiente do Aerogerador Wobben/Enercon e Carteiras Atual, PROINFA e Individuais (Energia Gerada em Base Horária). .223

Gráfico 99 - Fronteiras Eficientes para o Aerogerador Wobben/Enercon - Série histórica de energia gerada horária (kWh) e mensal (kWmédio). .225

Gráfico 100 - Fronteira Eficiente Considerando todos os Aerogeradores (Energia Gerada).

Gráfico 101 - Peso dos Modelos dos Aerogeradores nas Carteiras Otimizadas (Série histórica de energia gerada mensal). 228

Gráfico 102 - Peso das Coordenadas nas Carteiras Otimizadas (Série histórica de energia gerada mensal). 228

Gráfico 103 - Fronteira Eficiente Considerando todos os Aerogeradores e Curva dos Aerogeradores Selecionados (Série histórica de energia gerada mensal - kWmédios). 229

Gráfico 104 - Fronteira Eficiente Considerando todos os Aerogeradores (Série histórica de energia gerada horária - kWh). 230

Gráfico 105 - Fronteira Eficiente Considerando todos os Aerogeradores e Curva dos Aerogeradores Selecionados (Série histórica de energia gerada horária - kWh)...231

Gráfico 106 - Peso dos Modelos dos Aerogeradores nas Carteiras Otimizadas (Série histórica de energia gerada horária). 231

Gráfico 107 - Peso das Coordenadas nas Carteiras Otimizadas (Série histórica de energia gerada horária). 232

Gráfico 108 - Fronteiras Eficientes - Série Histórica de Energia Gerada Horária (kWh) e Mensal (kWmédios) 233

Gráfico 109 - Percentual de Participação dos Aerogeradores - Otimização Sem Considerar os Valores para os Aerogeradores. 236

Gráfico 110 - Percentual de Participação dos Aerogeradores - Otimização considerando os valores dos Aerogeradores da TABELA 42. 237

Gráfico 111 - Percentual de Participação dos Aerogeradores - Otimização considerando os valores dos Aerogeradores da TABELA 43. 237

Gráfico 112 - Fronteira Eficiente com Restrição de Transmissão por Barra. 241

Gráfico 113 - Fronteira Eficiente com Restrição de Transmissão por Subárea.......242

Gráfico 114 - Fronteira Eficiente com Restrição de Transmissão por Área. 242

Gráfico 115 - Fronteira Eficiente com Restrição de Transmissão no raio de 150km. 
Gráfico 116 - Fronteira Eficiente com Restrição de Transmissão no raio de 300km.

Gráfico 117 - Variação do Risco pelo Número de Ativos - Aerogerador Wobben/Enercon (Base mensal). 245

Gráfico 118 - Variação do Risco pelo Número de Ativos - Aerogerador Wobben/Enercon (Base horária). 246

Gráfico 119 - Função do Fator de Correlação da Energia Gerada Mensal pela Distância entre as coordenadas.

Gráfico 120 - Função do Fator de Correlação da Energia Gerada Horária pela Distância entre as coordenadas.

Gráfico 121 - Distribuição espacial das PCHs selecionadas juntamente com as coordenadas dos dados de vento (via Google Maps, mapa disponível em http://tinyurl.com/gkoo6oj).

Gráfico 122 - Série de Vazões Médias Mensais Referentes ao Ano de 1994 para a PCH Ado Popinhaki.... .254

Gráfico 123 - Série de Energias Geradas Referentes ao Ano de 1994 para a PCH Ado Popinhaki. 255

Gráfico 124 - Fronteira Eficiente para as Usinas PCHs 257

Gráfico 125 - Fronteira Eficiente para as Usinas Eólicas. 257

Gráfico 126 - Fronteira Eficiente para as Usinas PCHs e Eólicas. 258

Gráfico 127 - Energia Anual Gerada na Coordenada Parnaíba e a Mediana (P50) Aerogerador Wobben/Enercon.

Gráfico 128 - Garantia Física das Coordenadas. .263

Gráfico 129 - Energia Gerada Anual e Montante Contratado para a Carteira Atual (MWh).

Gráfico 130 - Energia Gerada Anual e Montante Contratado para a Carteira Otimizada (MWh).

Gráfico 131 - Simulação da Receita do Contrato de Energia de Reserva. 268

Gráfico 132 - Energia Gerada e Montante Contratado por Coordenada (MWh).....269

Gráfico 133 - Simulação da Receita do Contrato de Energia de Reserva por Coordenada

Gráfico 134 - Exposição Energética Mensal - Carteira Atual. 276

Gráfico 135 - Exposição Energética Mensal - Carteira Otimizada 276 
Gráfico 136 - Média, Desvio Padrão e VaR da Exposição Financeira da Carteira Atual. 280

Gráfico 137 - Média, Desvio Padrão e VaR da Exposição Financeira da Carteira Otimizada.

Gráfico 138 - Distribuição de Probabilidade e Histrograma da Exposição Financeira ao Mercado de Curto Prazo da Carteira Atual e da Carteira Otimizada - Todas Séries de Vento. 281

Gráfico 139 - Média da Exposição Financeira para Carteira Atual e Otimizada.....283

Gráfico 140 - Desvio Padrão da Exposição Financeira para Carteira Atual e Otimizada. .283

Gráfico 141 - VaR da Exposição Financeira para Carteira Atual e Otimizada. 284

Gráfico 142 - Distribuição de Probabilidade e Histrograma da Exposição Financeira ao Mercado de Curto Prazo da Carteira Atual e da Carteira Otimizada - Todas Séries de Vento. 


\section{LISTA DE TABELAS}

TABELA 1 - Projeção da Disponibilidade Eólica. ...................................................32

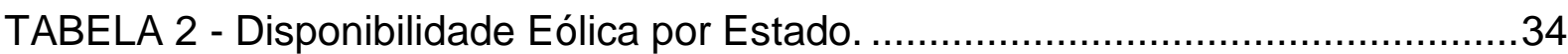

TABELA 3 - Potencial Brasileiro de Geração Eólica Offshore em Função da Distância da Costa e em Função do Intervalo Batimétrico...................................................36

TABELA 4 - Capacidade Instalada das Usinas Eólicas -Principais Países. ..............40

TABELA 5 - Estimativa da Taxa de Crescimento e da Capacidade Instalada..........42

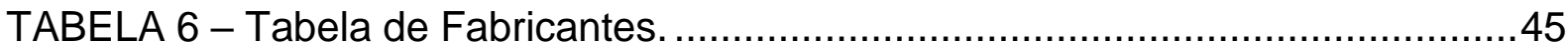

TABELA 7- Capacidade Instalada das Usinas Eólicas Offshore por País..................49

TABELA 8 - Preço da Energia do PROINFA por Tecnologia...................................59

TABELA 9 - Leilões de Fontes Alternativas com Participação de Usinas Eólicas. ...62

TABELA 10 - Leilões de Energia Nova com Participação de Usinas Eólicas.

TABELA 11 - Leilões de Energia de Reserva com Participação de Usinas Eólicas. 70

TABELA 12- Estimativa da Energia Anual Gerada pelo Aerogerador E126 da Enercon

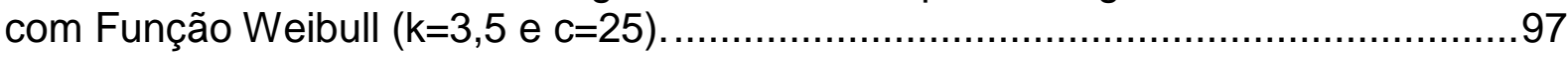

TABELA 13 - Incertezas na Velocidade do Vento. ..............................................103

TABELA 14 - Incertezas na Produção Anual de Energia. .....................................104

TABELA 15 - Incertezas Típicas na Produção Anual de Energia...........................104

TABELA 16 - Produção Anual de Energia e Níveis de Confiança ..........................106

TABELA 17 - Exemplo Numérico do Efeito da Covariância ..................................120

TABELA 18 - Usinas do PROINFA Utilizadas na Otimização..................................143

TABELA 19 - Média e Desvio Padrão da Energia Gerada das Usinas Eólicas do PROINFA. ........................................................................................ 145

TABELA 20 - Exemplos de Carteiras Otimizadas - Usinas Eólicas do PROINFA (Parâmetros em Energia)...............................................................................147

TABELA 21 - Média e Desvio Padrão do Fator de Capacidade das Usinas Eólicas do PROINFA.

TABELA 22 - Exemplos de Carteiras Otimizadas das Usinas Eólicas do PROINFA (Parâmetros em Fator de Capacidade). 
TABELA 23 - Usinas Eólicas Selecionadas pelo Modelo.

TABELA 24 - Fator de Correlação do Fator de Capacidade das Usinas Eólicas. ..157

TABELA 25 - Média e Desvio Padrão do Fator de Capacidade das Usinas Eólicas Equivalentes.

TABELA 26 - Média e Desvio Padrão do Fator de Capacidade das Usinas do PROINFA. 165

TABELA 27 - Risco e Retorno das Carteiras Atuais. 169

TABELA 28 - Risco e Retorno das Carteiras de Menor Risco 169

TABELA 29 - Média e Desvio Padrão do Fator de Capacidade das Usinas Equivalentes 173

TABELA 30 - Risco e Retorno das Carteiras Atuais Equivalentes. 176

TABELA 31 - Risco e Retorno das Carteiras Equivalentes de Menor Risco. 176

TABELA 32 - Resultados das Análises de Homogeneidade e Tendência Disponíveis no Vortex 185

TABELA 33 - Resultado da Aplicação do Método Z-Score Modificado. 188

TABELA 34 - Características Gerais dos Aerogeradores Selecionados. 192

TABELA 35 - Exemplo de Cálculo para Determinação dos Coeficientes de Potência do Aerogerador GE 2.5/88. 196

TABELA 36 - Processo de Cálculo Empírico da Energia Gerada no mês de Janeiro de 1994 para a Coordenada Parada (CE), Utilizando o Aerogerador Enercon E-115. 202

TABELA 37 - Usinas Eólicas Próximas da Coordenada Boninal 205

TABELA 38 - Pesos da Potência na Carteira Atual e na Carteira PROINFA. 206

TABELA 39 - Risco Mínimo e Geração Esperada - Série Mensal de Energia Gerada. 210

TABELA 40 - Exemplos de Carteiras Otimizadas - Aerogerador Wobben/Enercon 215

TABELA 41 - Risco Mínimo e Geração Esperada (Energia Gerada) 222

TABELA 42 - Valor do Investimento dos Aerogeradores Considerando o Resultados dos Leilões Regulados e Arbitrado para os Modelos. 235

TABELA 43 - Valor do Investimento dos Aerogeradores Arbitrados para Outro Cenário de Preço. 235

TABELA 44 - Margem de Escoamento para Cada Coordenada. 239 
TABELA 45 - Exemplos de Carteiras Otimizadas para a Fronteira Eficiente com Restrição de Transmissão por Barra (Risco e retorno em kWh).

TABELA 46 - Exemplos de Carteiras Otimizadas para a Fronteira Eficiente com Restrição de Transmissão por Subárea (risco e retorno em kWh).........................243

TABELA 47 - Exemplos de Carteiras Otimizadas para a Fronteira Eficiente com Restrição de Transmissão por Área (risco e retorno em kWh).............................243

TABELA 48 - Principais Dados das PCHs Selecionadas. …………...................251

TABELA 49 - Dados da PCH Ado Popinhaki Necessários para a Estimativa da Energia Gerada. .254

TABELA 50 - Parâmetros das PCHs e das Usinas Eólicas. ..................................256

TABELA 51 - Risco Mínimo e Geração Esperada..............................................258

TABELA 52 - Composição da Carteira Atual e Carteira Otimizada (Usina Eólica 30 MW - Aerogerador Wobben/Enercon). 260

TABELA 53 - Valores Pesquisados e Adotados para o Cálculo da Garantia Física. 261

TABELA 54 - Resultado da Exposição Energética Mensal. .277

TABELA 55 - Resultado da Exposição Financeira ao Mercado de Curto Prazo Considerando a Matriz dos PLDs dos Submercados NE e S .278

TABELA 56 - Resultado da Exposição Financeira ao Mercado de Curto Prazo considerando a Matriz dos PLDs do Submercado NE. 


\section{LISTA DE ABREVIATURAS E SIGLAS}

\begin{tabular}{|c|c|}
\hline ABEEólica & Associação Brasileira de Energia Eólica \\
\hline$A B D I$ & Agência Brasileira de Desenvolvimento Industrial \\
\hline$A C L$ & Ambiente de Contratação Livre \\
\hline$A C R$ & Ambiente de Contratação Regulada \\
\hline ANEEL & Agência Nacional de Energia Elétrica \\
\hline$A R M A$ & Modelo Auto Regressivo e de Média Móvel \\
\hline ARMAX & $\begin{array}{l}\text { Modelo Auto Regressivo e de Média Móvel com Entrada } \\
\text { Exógena }\end{array}$ \\
\hline BNDES & Banco Nacional de Desenvolvimento Econômico e Social \\
\hline BDMEP & Banco de Dados Meteorológicos para Ensino e Pesquisa \\
\hline CCEAR & Contrato de Comercialização de Energia no Ambiente Regulado \\
\hline CCEE & Câmara de Comercialização de Energia Elétrica \\
\hline CEPEL & Centro de Pesquisas de Energia Elétrica \\
\hline CER & Contrato de Energia de Reserva \\
\hline CFSR & Climate Forecast System Reanalysis \\
\hline CME & Custo Marginal de Expansão \\
\hline CMO & Custo Marginal de Operação \\
\hline CNPE & Conselho Nacional de Política Energética \\
\hline$C t$ & Coeficiente de Tração \\
\hline CVaR & Conditional Value at Risk \\
\hline$C V U$ & Custo Variável Unitário \\
\hline$E A G$ & Energia Anual Gerada \\
\hline Eletrobrás & Centrais Elétricas Brasileiras S.A. \\
\hline$E P E$ & Empresa de Pesquisa Energética \\
\hline
\end{tabular}




\begin{tabular}{|c|c|}
\hline EWEA & European Wind Energy Association \\
\hline$F C$ & Fator de Capacidade \\
\hline GEOS-5 DAS & Goddard Earth Observing System Data Assimilation System \\
\hline GF & Garantia Física \\
\hline GWEC & Global Wind Energy Council \\
\hline GWEO & Global Wind Energy Outlook \\
\hline HIRLAM & High Resolution Limited Area Model \\
\hline KAMM & Karlsruher Atmospharisches Mesoskaliges Modell \\
\hline IBGE & Instituto Brasileiro de Geografia e Pesquisa \\
\hline IBOVESPA & Índice Bovespa \\
\hline ICEA & Instituto de Controle do Espaço Aéreo \\
\hline IEA & Internacional Energy Agency \\
\hline IEC & International Eletrotechnical Commission \\
\hline IGP-M & Índice Geral de Preços do Mercado \\
\hline INPE & Instituto Nacional de Pesquisas Espaciais \\
\hline INMET & Instituto Nacional de Meteorologia \\
\hline IPCA & Índice Nacional de Preço ao Consumidor Amplo \\
\hline LEE & Leilão de Energia Existente \\
\hline LEN & Leilão de Energia Nova \\
\hline$L E R$ & Leilão de Energia de Reserva \\
\hline$\angle F A$ & Leilão de Fontes Alternativas \\
\hline MME & Ministério de Minas e Energia \\
\hline MM5 & Mesoscale Modeling System - 5th Generation \\
\hline MVP & Média-Variância Portfólio \\
\hline NREAP & Nacional Renewable Energy Action Plan \\
\hline
\end{tabular}


NCEP

NCAR

ONS

$\mathrm{PCH}$

PCT

$P D E$

PLD

PROEÓLICA

PROINFA

RPS

SIN

SONDA

UHE

UEE

UTE

WASP®

WRF

ZCIT
National Centers for Environmental Prediction

National Center for Atmospheric Research

Operador Nacional de Energia Elétrica

Pequena Central Hidroelétrica

Pequena Central Termoelétrica

Plano Decenal de Expansão de Energia Elétrica

Preço de Liquidação das Diferenças

Programa Emergencial de Energia Eólica

Programa de Incentivo às Fontes Alternativas de Energia Elétrica

Renewable Portfolio Standard

Sistema Interligado Nacional

Sistema de Organização Nacional de Dados Ambientais

Usina Hidroelétrica

Usina de Fonte Eólica

Usina Termoelétrica

Wind Atlas Analysis Application Program

The Weather Research \& Forecast Model

Zona de Convergência Intratropical 


\section{SUMÁRIO}

2 CAPACIDADE INSTALADA E POTENCIAL DISPONÍVEL DA ENERGIA EÓLICA.

2.1 POTENCIAL EÓLICO ONSHORE NO MUNDO .31

2.2 POTENCIAL EÓLICO ONSHORE NO BRASIL ......................................33

2.3 POTENCIAL EÓLICO OFFSHORE DO BRASIL ....................................35

2.4 CAPACIDADE INSTALADA E PROJEÇÃO - USINAS EÓLICAS ONSHORE NO MUNDO

2.5 CAPACIDADE INSTALADA E PROJEÇÃO - USINAS EÓLICAS ONSHORE NO BRASIL

2.6 CAPACIDADE INSTALADA E PROJEÇÃO - USINAS EÓLICAS OFFSHORE NO MUNDO.

3 ASPECTOS DA COMERCIALIZAÇÃO DE ENERGIA - USINAS EÓLICAS..

3.1 PROINFA

3.2 LEILÕES REGULADOS 59

3.3 CONTRATOS DE COMERCIALIZAÇÃO DE ENERGIA NO AMBIENTE REGULADO (CCEAR) - LEILÕES DE FONTES ALTERNATIVAS (LFA)...62

3.4 CONTRATOS DE COMERCIALIZAÇÃO DE ENERGIA NO AMBIENTE REGULADO (CCEAR) - LEILÕES DE ENERGIA NOVA (LEN)

3.5 CONTRATOS DE ENERGIA DE RESERVA (CER) - LEILÕES DE ENERGIA DE RESERVA (LER) 69

4 FUNDAMENTAÇÃO TEÓRICA E REVISÃO DA LITERATURA 75

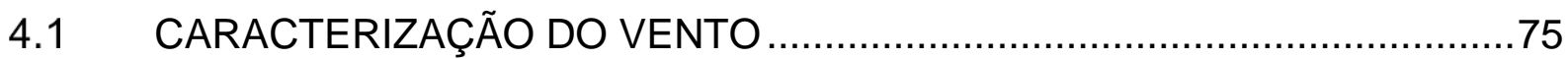

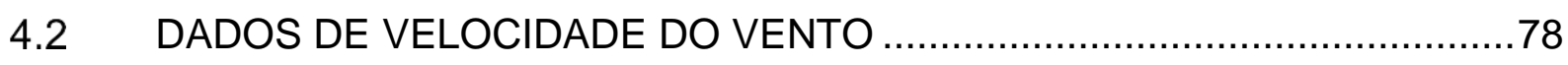

4.3 FUNÇÃO DENSIDADE DE PROBABILIDADE $\ldots \ldots \ldots \ldots \ldots \ldots \ldots \ldots \ldots \ldots \ldots \ldots . . . \ldots 8$

4.4 FUNDAMENTOS DA GERAÇÃO DE ENERGIA EÓLICA .........................92

4.5 GARANTIA FÍSICA DAS USINAS EÓLICAS .................................... 100

4.6 TEORIA DE PORTFÓLIO DE MARKOWITZ .......................................107 
4.6.1 Formulação Matemática para Dois Ativos ............................................109

4.6.2 Formulação Matemática para N Ativos ................................................112

4.6.3 Casos Particulares de Carteiras para N Ativos Independentes............114

4.6.4 Casos Particulares de Carteiras para N Ativos Distribuídos Uniformemente 115

4.6.5 Efeito da Diversificação no Risco da Carteira .......................................116

4.6.6 Importância Da Correlação para a Teoria De Portfólio De Markowitz..119

4.6.7 Cálculo da Fronteira Eficiente ...........................................................122

4.7 TEORIA DE PORTFÓLIO - MODELO SHARPE......................................128

4.8 TEORIA DE PORTFÓLIO DE MARKOWITZ APLICADA AO PLANEJAMENTO DO SETOR ELÉTRICO - ESTADO DA ARTE ..............133

5 APLICAÇÃO DA METODOLOGIA E RESULTADOS …...........................141

5.1 MODELO PROPOSTO APLICADO À SÉRIE DE ENERGIA GERADA DAS USINAS DO PROINFA

5.1.1 Otimização 01 - Usinas Eólicas Individualizadas do PROINFA - Energia Gerada 144

5.1.2 Otimização 02 - Usinas Eólicas Individualizadas do PROINFA - Fator de Capacidade. 149

5.1.3 Otimização 03 - Usinas Eólicas Equivalentes do PROINFA - Fator de Capacidade. 155

5.1.4 Otimização 04 - Todas as Usinas Individualizadas do PROINFA - Fator de Capacidade 163

5.1.5 Otimização 05 - Todas as Usinas Equivalentes do PROINFA - Fator de Capacidade. 170

5.1.6 Cálculo do Risco Mínimo 176

5.2 MODELO PROPOSTO APLICADO À SÉRIE DE DADOS DO VORTEX ...179

5.2.1 Tratamento dos Dados de Velocidade de Vento.....................................183

5.2.2 Aerogeradores Comerciais Instalados no Brasil ..................................191

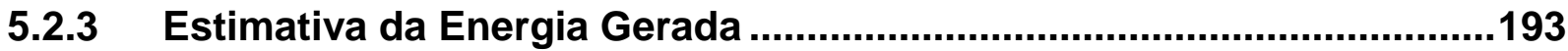

5.2.3.1 Estimativa da Energia Gerada - Base Horária .......................................193

5.2.3.2 Estimativa da Energia Gerada - Base Mensal .......................................200 
5.2.4 Otimizações Realizadas e Resultados - Cálculo da Fronteira Eficiente para Cada Modelo de Aerogerador .203

5.2.4.1 Otimização 01 - Fronteira Eficiente para Cada Aerogerador - Base Mensal 207

5.2.4.2 Otimização 02 - Fronteira Eficiente para Cada Aerogerador - Base Horária 216

5.2.4.3 Otimização 03 - Fronteira Eficiente com Todos os Aerogeradores - Base Mensal e Horária 225

5.2.4.4 Otimização 04 - Fronteira Eficiente para Cada Aerogerador - Base Mensal e Horária com Preços Diferenciados para os Aerogeradores. .234

5.2.4.5 Otimização 05 - Fronteira Eficiente para Cada Aerogerador - Base Horária com Restrição de Transmissão .238

5.2.4.6 Otimização 06 - Cálculo do Risco Mínimo - Base Mensal e Horária 245

5.2.4.7 Cálculo da Curva do Fator Correlação pela Distância das Usinas .246

5.3 MODELO PROPOSTO APLICADO EM PCHS E USINAS EÓLICAS 248

5.3.1 Levantamento da Série Histórica de Energia Gerada - PCHs 249

5.3.2 Cálculo da Fronteira Eficiente para PCHs e Usinas Eólicas 255

5.4 SIMULAÇÕES DE RECEITAS ESPERADAS .259

5.4.1 Cálculo da Garantia Física .261

5.4.2 Simulação da Carteira Considerando o Contrato de Energia de Reserva. .264

5.4.3 Simulação da Carteira Considerando a Venda de Energia no Mercado Livre .273

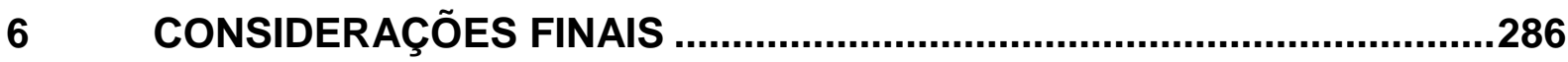

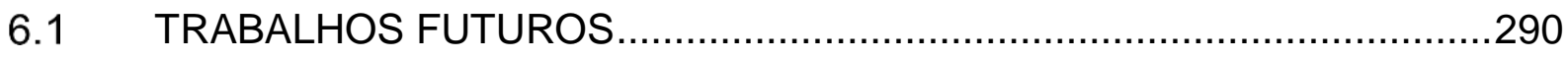




\section{INTRODUÇÃO}

O vento é o resultado da transformação da energia térmica, decorrente da radiação solar, em energia cinética, que provoca o deslocamento de massas de ar, classificados em globais e locais. Uma das características do vento é sua intermitência. $\mathrm{Na}$ aplicação de usinas eólicas para a geração de energia elétrica, pequenas variações na velocidade do vento provocam grandes variações na potência, uma vez que a potência de um aerogerador é proporcional ao cubo da velocidade do vento.

Apesar da volatilidade ${ }^{1}$ na geração, dentre as fontes renováveis de energia, as usinas eólicas têm sido preferencialmente utilizadas em diversos países para o atendimento da expansão do mercado, em razão de metas de redução das emissões de carbono, disponibilidade do recurso e domínio da tecnologia.

No Brasil, as usinas eólicas têm se destacado nos leilões de energia nova, face ao competitivo valor do investimento e à abundância do recurso natural, uma vez que os contratos de comercialização de energia elétrica do ambiente regulado preveem mecanismos que transferem os riscos da volatilidade da geração e exposição financeira ao mercado de curto prazo para os consumidores cativos. Em decorrência, tem-se observado um aumento da participação das usinas eólicas na matriz de elétrica, com previsão de atingir $11,6 \%$ da capacidade instalada total, em 2024, segundo o Plano Decenal de Expansão de Energia 2024, elaborado pela Empresa de Pesquisa Energética (EPE).

Ocorre que a contratação de energia no ambiente regulado dá-se por meio de leilões reversos, onde usinas de diversas fontes e localizadas em diferentes regiões da Federação, competem entre si, pelo menor preço da energia. Em decorrência, o atual modelo de contratação de energia do setor elétrico não privilegia a dispersão geográfica das usinas e a diversificação das fontes.

\footnotetext{
1 O Dicionário Eletrônico Michaelis traz os seguintes significados para o termo Volatilidade: 1. Qualidade de volátil. 2. Quím Propriedade que têm certas substâncias sólidas ou líquidas de se transformar em vapor mesmo à temperatura ordinária. 3. Econ Medida da estabilidade de um índice econômico ou do preço de uma ação, título ou mercadoria. O Dicionário Eletrônico Michaelis traz os seguintes significados para a palavra Intermitência: 1. Qualidade de intermitente; descontinuação. 2. Interrupção momentânea. 3. Interrupção numa série. 4. Intervalo em fenômenos periódicos. 5. Med Manifestação característica de certas febres ou outras doenças por acessos intervalados, fora dos quais o doente parece curado. 6. Fenômeno patológico caracterizado por haver, entre duas pulsações, um intervalo muito maior do que entre as outras; arritmia. Nesse trabalho, os termos volatilidade e intermitência serão usados como sinônimos.
} 
Por sua vez, a participação das usinas eólicas no ambiente de contratação livre ainda é tímida ${ }^{2}$, em razão do risco de exposição financeira do mercado de curto prazo, acentuado pela volatilidade da geração eólica ${ }^{3}$.

De acordo com as Regras de Comercialização da Câmara de Comercialização de Energia Elétrica (CCEE), a diferença entre a quantidade de energia produzida pelo gerador eólico e o montante previsto no contrato de venda é liquidada ao preço do mercado de curto prazo. Desse modo, quando a energia gerada é maior que o montante contratado, a exposição financeira ao mercado de curto prazo é positiva; no entanto, quando a geração de energia é inferior ao montante contratado, a exposição financeira é negativa.

No ambiente regulado, o risco da exposição mensal ao mercado de curto prazo é mitigado para o investidor, na medida em que a contabilização energética é realizada em base anual e o consumidor cativo assume o custo das variações mensais. No ambiente livre, a exposição ao mercado de curto prazo é mensal, cujo risco precisa ser mitigado, pois, individualmente, o consumidor livre e o investidor não conseguem suportá-lo.

Há disponibilidade de recurso eólico em todos os Estados da Federação, no entanto, em dezembro de 2015, de acordo com o Boletim de Dados elaborado pela ABEEólica ${ }^{4}$, os Estados da Bahia, Rio Grande do Norte, Ceará, Rio Grande do Sul e Piauí concentram $90 \%$ da capacidade instalada em operação, em construção ou contratada, uma vez que o marco regulatório privilegia a competição entre as usinas, independente da localização.

A concentração das usinas eólicas nesses Estados pode estar provocando um aumento na volatilidade da geração eólica, uma vez que não possibilita a exploração de eventual complementariedade do recurso energético, a partir da construção de usinas eólicas em outros Estados da Federação. No mesmo sentido, a construção de

\footnotetext{
2 De acordo com o Boletim de Dados, versão dezembro de 2015, produzido pela Associação Brasileira de Energia Eólica (ABEEólica), em 2019, a capacidade instalada de usinas eólicas será de 18,68 GW, sendo que desse total, $12 \%$ está previsto para 0 atendimento ao mercado livre de energia (correspondente a 2.183,4 MW).

${ }^{3}$ Devido ao subsídio do desconto de $50 \%$ na tarifa de uso do sistema de distribuição/transmissão concedido para a usina eólica e para o consumidor que compra energia dessa fonte, existe a oportunidade de os vendedores praticarem preços maiores nesse ambiente em comparação ao preço dos leilões regulados.

${ }^{4}$ Boletim de Dados, versão dezembro de 2015, produzido pela Associação Brasileira de Energia Eólica (ABEEólica). Disponível em: http://abeeolica.org.br/pdf/Boletim-de-Dados-ABEEolica-Dezembro-2015Publico.pdf. Acessado em 10 abr. 2015.
} 
usinas em outros Estados também poderia aumentar a energia gerada média, mantendo o atual nível de volatilidade do conjunto de empreendimentos instalados.

A volatilidade na geração de energia é indesejada para a operação do Sistema Interligado Nacional (SIN), pois implica em maior custo operativo, menor confiabilidade e exigência de maior reserva girante. No caso, o problema para a operação do SIN é acentuado, quando a intermitência é concentrada em algumas regiões (5 Estados), e com participação elevada na matriz elétrica (11,6\%), como é o caso da previsão para as usinas eólicas. Nesse sentido, a própria EPE reconhece no Plano Decenal de Expansão de Energia 2021, a necessidade de "estudo e acompanhamento das implicações técnicas envolvidas na sua inserção na matriz elétrica, especialmente a partir da entrada em operação dos blocos contratados nos leilões de energia".

Para a comercialização da energia, a volatilidade aumenta o risco de exposição ao mercado de curto prazo, com flutuações indesejadas no preço final da energia. Para o ambiente regulado, a volatilidade implica em custo adicional para os consumidores cativos, enquanto que, no ambiente livre, a volatilidade implica em riscos para o vendedor ou para o comprador de energia, dificultando a celebração de contratos de longo prazo e consequentemente, a viabilização de novos projetos nesse ambiente.

Por sua vez, a redução da energia gerada média exige investimentos adicionais para compensar o atendimento ao mercado consumidor. Desta forma, carteiras de empreendimentos que maximizem a expectativa de geração reduzem a necessidade de maiores investimentos, não obstante, podem apresentar maiores volatilidades de geração. Ambas as situações, redução da volatilidade e aumento da expectativa de geração são desejadas, embora seja possível a escolha ótima de apenas uma delas.

Em razão das dimensões geográficas do Brasil, é possível que em determinados momentos exista vento apropriado para a geração de energia em certos locais, e em outros, não. Em outras palavras, para um determinado conjunto de usinas eólicas, geograficamente dispersas, é possível reduzir a volatilidade da geração total, face às compensações existentes entre elas.

A teoria de seleção de portfólios foi desenvolvida por Markowitz (1952) para aplicação em títulos financeiros. Markowitz analisou os riscos e retornos dos ativos financeiros, considerando a variância e o desvio-padrão como representantes do risco e a média (valor esperado) como uma proxy do retorno. 
Para tal, Markowitz utilizou medidas simétricas de risco, assumindo que os investidores apresentam um comportamento compatível com o conceito de simetria de risco e, considerou também que os retornos seguem uma distribuição Normal, assumindo que os investidores possuem uma função de utilidade quadrática. De acordo com a teoria de Portfólio Média-Variância (MVP), com a diversificação dos ativos é possível minimizar o risco para o mesmo valor de rentabilidade, ou aumentar a rentabilidade para o mesmo valor do risco.

Drake e Hubacek (2007) aplicaram a teoria de MVP para distribuir 2,75 GW de capacidade instalada eólica, equivalente a $1,75 \%$ da demanda de eletricidade do Reino Unido, em 4 fazendas eólicas offshore. A teoria de MVP foi aplicada por Roques, Hiroux e Saguan (2009) para usinas eólicas localizadas na Áustria, Dinamarca, França, Alemanha e Espanha, demonstrando que a projeção da expansão eólica realizada pela Tradewind, para 2020, está fora da curva da fronteira eficiente, com um fator de capacidade 6\% inferior. Chupp, Hickey e Loomis (2012) aplicaram a teoria de MVP para definir o portfólio eólico no Estado de Illinois (EUA).

Nenhum trabalho aplicando a teoria de MVP em parques eólicos no Brasil foi encontrado. Em razão do aumento da participação dessa fonte na matriz elétrica, da sua concentração em 5 Estados e da sua intermitência, o desenvolvimento de um método para a aplicação da teoria de MVP em parques eólicos no Brasil é bastante relevante. Assim, é possível estabelecer uma carteira ótima de usinas eólicas que minimiza a volatilidade de geração, ou aumenta o valor da energia gerada média, por meio da distribuição de usinas eólicas em diversos Estados da Federação.

Este trabalho tem por objetivo definir a fronteira eficiente para o segmento eólico no Brasil, a partir da aplicação da teoria de MVP, considerando o histórico de velocidade do vento e de geração de energia, permitindo quantificar os possíveis ganhos (aumento da energia média gerada ou redução da volatilidade).

Para tal, inicialmente, foi utilizada a série histórica de energia gerada das usinas contratadas pelo Programa de Incentivo às Fontes Alternativas de Energia Elétrica (PROINFA). A curva da fronteira eficiente foi encontrada para as usinas eólicas do PROINFA e para todas as usinas do PROINFA (eólicas, biomassa e pequenas centrais hidroelétricas), considerando as usinas individualizadas e agrupadas por Estado e por tipo de fonte.

O PROINFA contratou usinas eólicas, pequenas centrais hidroelétricas e pequenas centrais termoelétricas (biomassa), com limite de potência por fonte e por 
Estado da Federação. Por sua vez, o mecanismo de contratação de energia no ambiente regulado, não impõe limites de usinas por Estado, o que tem resultado na concentração de empreendimentos em 5 (cinco) Estados da Federação (Bahia, Rio Grande do Norte, Ceará, Rio Grande do Sul e Piauí).

Os limites impostos pela regra de contratação do PROINFA resultaram em uma carteira diversificada de ativos de geração disperso geograficamente e por tipo de fonte. $\mathrm{O}$ cálculo da fronteira eficiente (aplicando a teoria de MVP) possibilita avaliar se a diversificação imposta pela regra de contratação do PROINFA resultou em uma carteira ótima de ativos. Para tal, compara-se a relação risco e retorno da carteira atual PROINFA, que considera a média e o desvio padrão da totalidade das usinas do PROINFA, com as carteiras otimizadas, que estão sobre a fronteira eficiente.

A aplicação do método nas usinas do PROINFA apresenta algumas limitações. Os resultados são influenciados pela altura da torre e pela diversidade de modelos dos aerogeradores. Além disso, os dados disponíveis estão em amostragem mensal compondo uma série histórica de 47 meses. No que se refere à dispersão geográfica, as usinas eólicas do PROINFA estão localizadas em 8 Estados.

Após validado o método com os dados do PROINFA, aplicou-se nas séries históricas de energia gerada distribuídas em 22 coordenadas geográficas, constituídas a partir de 12 curvas de potência de aerogeradores comerciais e dados de velocidade do vento obtidos do Vortex.

O Vortex é uma empresa sediada em Barcelona, na Espanha, que comercializa soluções de suporte relacionadas a tecnologias eólicas, solar e offshore para diversos fins. Particularmente para dados de vento, a empresa trabalha com um portfólio de produtos como sistemas específicos para o posicionamento de torres meteorológicas, projetos de fazendas eólicas e séries históricas de dados.

Os dados fornecidos pela Vortex não são provenientes de medições diretas, mas de modelos matemáticos, o que reduz enormemente a possibilidade de erros humanos ou de equipamentos medidores. Foram utilizadas séries históricas de velocidade de vento, todas referenciadas à altura de 100 metros, com amostragem horária, e período de 01/01/1994 a 31/12/2014.

Assim como para o PROINFA, foi verificado os efeitos das regras de contratação no ambiente regulado sobre a carteira de ativos, comparando o binômio risco e retorno da carteira atual, considerando todas as usinas eólicas, com os resultados obtidos para as carteiras otimizadas. 
No caso, a partir da série histórica de velocidade de vento do Vortex, foi possível encontrar séries históricas de energia gerada em base horária e mensal. Assim, a teoria de MVP foi aplicada considerando as séries históricas mensais e horárias, obtendo-se a fronteira eficiente em base mensal (otimizando o problema da comercialização) e em base horária (otimizando o problema da operação).

O trabalho está estruturado em capítulos e subitens (subcapítulos). O trabalho foi dividido em 6 capítulos. O primeiro capítulo é a indrodução que faz uma abordagem geral do problema, apresenta o método proposto, as otimizações realizadas e os principais resultados.

No capítulo 2 apresentam-se os dados da capacidade instalada e do recurso disponível da energia eólica onshore e offshore no Brasil e no mundo. Verifica-se uma consistente taxa de expansão da capacidade instalada mundial e uma acelerada penetração das usinas eólicas na matriz elétrica brasileira. Por sua vez, o recurso eólico onshore disponível no Brasil ainda é bastante siginificativo, que também conta com uma grande disponibilidade eólica offshore, até o momento inexplorado. Este capítulo tem por objetivo demonstrar a penetração da energia eólica na matriz elétrica nacional, bem como a vasta disponibilidade do recurso eólico para aproveitamentos futuros.

O capítulo 3 contém o resultado da contratação do PROINFA e dos Leilões de Energia. As regras do Contrato de Comercialização de Energia no Ambiente Regulado (CCEAR) dos Leilões de Energia Nova e dos Leilões de Fontes Alternativas, assim como as regras do Contrato de Energia de Reserva (CER) dos Leilões de Reserva estão detalhadas ao longo do texto. Este capítulo tem por objetivo demonstrar a concentração das usinas eólicas em 5 Estados, as regras de contratação do PROINFA $e$ as atuais regras de contratação no mercado regulado, bem como detalhar o mecanismo de contabilização e liquidação do CER, uma vez que foram simuladas as receitas para duas carteiras.

O capitulo 4 faz uma revisão da literatura, contemplando noções sobre a função densidade de probabilidade da variável aleatória velocidade do vento, sobre a produção de energia eólica e o cálculo da garantia física. Esse capítulo também aborda a teoria de portfólio de Markowitz e Sharpe, a formulação matemática do cálculo da fronteira eficiente e casos particulares de carteiras. Ao final, o capítulo 4 apresenta aplicações da teoria de portfólio de Markowitz sobre o setor de energia. 
Este capítulo tem por objetivo demonstrar a volatilidade da geração eólica, a teoria de MVP, e a aplicação da teoria de MVP no segmento de energia eólica (fora do Brasil) e em outras aplicações com energia elétrica, evidenciando o ineditismo desse trabalho, na medida em que nenhum outro trabalho aplicando a teoria de MVP no segmento de energia eólica do Brasil foi encontrado.

O método proposto aplicado e o resultado das otimizações estão no capítulo 5. As otimizações foram realizadas com os dados de energia gerada das usinas do PROINFA, e com os dados de energia gerada, calculados a partir do histórico de velocidade do vento obtidos do Vortex, para 22 coordenadas geográficas e para 12 modelos de aerogeradores. Nesse capítulo, o método proposto foi exaustivamente aplicado para diversas situações, com restrições na função objetivo e sem restrições. Além disso, foram realizadas simulações de contratos de energia, com o objetivo de verificar se as carteiras otimizadas resultam em menores riscos de receitas para o empreendedor. Este capítulo tem por objetivo apresentar o método proposto, os resultados das otimizações, demonstrando que a carteira atual e a carteira atual PROINFA não estão sobre a curva da fronteira eficiente, portanto não estão otimizadas, bem como os resultados das simulações, evidenciando que para um contrato no ambiente livre, a carteira otimizada reduz o risco com a aquisição de energia no mercado de curto prazo.

Adicionalmente, o capítulo 6 apresenta as conclusões do trabalho, as limitações dos resultados encontrados, a aplicabilidade da metodologia proposta, bem como recomendações para trabalhos futuros.

Por fim, foi apresentada uma proposta de metodologia que pode ser utilizada como apoio à decisão, por investidores em geração na definição de uma carteira otimizada que reduza o risco de exposição ao mercado de curto prazo e minimize a volatilidade da receita. A metodologia também pode ser aproveitada pela EPE na definição objetiva de leilões regionais e por fonte, na busca da carteira ótima de projetos de geração, sobre a fronteira eficiente, que minimize a volatilidade da geração no curto prazo, reduzindo os riscos da operação energética ou a volatilidade mensal da geração, reduzindo os custos com a exposição ao mercado de curto prazo pelas concessionárias de distribuição, ou alternativamente, reduzindo a volatilidade horária e os custos de operação. 


\section{CAPACIDADE INSTALADA E POTENCIAL DISPONÍVEL DA ENERGIA EÓLICA}

Este capítulo apresenta o levantamento da evolução da capacidade instalada ao longo dos anos, bem como estimativas do potencial eólico onshore e offshore no Brasil e no mundo. Ao final ficará demonstrado que esse tipo de fonte está crescendo com taxas expressivas, aumentando a sua representatividade na matriz elétrica mundial e nacional, com um vasto recurso ainda disponível, o que justifica a importância do presente estudo.

\subsection{POTENCIAL EÓLICO ONSHORE NO MUNDO}

A avaliação do potencial eólico no planeta não é um consenso entre os pesquisadores. A projeção da evolução da tecnologia dos aerogeradores não é tarefa simples. A estimativa do potencial eólico com a tecnologia atual dos aerogeradores pode resultar em subestimada. Por outro lado, projeções do potencial eólico com aerogeradores também estimados e empregando tecnologias de ponta ainda não consolidadas, podem resultar em uma sobre-estimação.

Há vários trabalhos publicados sobre a estimativa da disponibilidade eólica no planeta. A maioria dos autores utiliza a metodologia bottom-up, que consiste em estimar o potencial eólico a partir do histórico da velocidade do vento em vários locais da superfície da Terra, excluindo áreas inadequadas e utilizando-se aerogeradores com a tecnologia disponível ou estimada (CASTRO et al, 2011).

Lu, Mcelroya e Kiviluoma (2009) estimaram o potencial eólico em 78 TW utilizando a versão 5 do Goddard Earth Observing System Data Assimilation System (GEOS-5 DAS), torres de 100 metros de altura e aerogeradores de 2,5 MW, fabricados pela General Electric (GE).

Castro et al (2011) compilaram as projeções publicadas em diversos trabalhos (TABELA 1) e estimaram a disponibilidade eólica no planeta utilizando a metodologia top-down em 1 TW, que considera o princípio da conservação de energia da Terra.

Os autores partiram da estimativa da energia cinética disponível na atmosfera, porém consideraram a disponibilidade dessa energia no intervalo da altura dos aerogeradores (até 200 metros), com as seguintes restrições: i) 80\% da energia é perdida devido às limitações geográficas (áreas de águas profundas com mais de 200 
metros de profundidade, áreas permanentemente cobertas por gelo, altas montanhas, cidades, áreas protegidas e parques naturais, etc); ii) $70 \%$ do vento não intercepta nenhuma pá do aerogerador, considerando uma turbina de 100 metros de diâmetro e as distâncias típicas entre os aerogeradores de 4 vezes o diâmetro da pá, na direção perpendicular ao vento predominante e 7 vezes, na direção paralela; iii) $50 \%$ das áreas disponíveis não são economicamente viáveis para a geração de energia eólica; iv) $25 \%$ da velocidade do vento está fora do intervalo de funcionamento do aerogerador (velocidade de cut-in e cut-off); v) 50\% de perda devido à eficiência na conversão da energia cinética para a energia elétrica, incluindo o coeficiente de Betz ${ }^{5}$.

TABELA 1 - Projeção da Disponibilidade Eólica.

\begin{tabular}{lcc}
\hline \multicolumn{1}{c}{ Autores } & Estimativa Técnica (TW) & Estimativa Econômica (TW) \\
\hline Archer e Caldeira (2009) & 1.500 & - \\
Capps e Zender(2010) & 39 (offshore) & - \\
DeVries etal. (2007) & - & 4.5 (em 2050) \\
EEA (2009) & 8.6 (Europa) & $3.5($ Europa em 2030) \\
Elliott etal. (2004) e Musial (2005) & 1 (EUA) & - \\
Greenblatt (2005) & 70.4 (Global) & - \\
Greenpeace (2008) e & - & 1.0 (em 2050) e 1.2(em 2050), \\
Greenpeace2010 & 11 & 6 \\
Hoogwijk etal. (2004) & 78 (onshore), >7 (offshore) & - \\
Lu etal. (2009) & $17-38$ (onshore, potencial geográfico) & - \\
Miller etal. 2010 & & 6.9 \\
Schindler etal. (2007) & 55.2 (global) & - \\
WEC (1994) & 2.3 (onshore,OCDE) \\
Wijk e Coelingh(1993) & - & - \\
Zerta etal. (2008) & - & 6.9 \\
\hline
\end{tabular}

Adaptado de Castro et al (2011).

Segundo Castro et al (2011), considerando a taxa de crescimento de $25 \%$ ao ano da capacidade instalada, é bem possível que o potencial eólico estimado seja explorado em até 15 anos, considerando a estimativa de recurso disponível de 1 TW. Assim sendo, mesmo considerando a estimativa conservadora do potencial eólico de Castro et al (2011), em razão da crescente penetração na matriz elétrica dessa fonte, que pode ser comprovada pelas recentes taxas de crescimento ${ }^{6}$, investigações sobre a volatilidade da geração e formas de reduzi-la possuem relevância para o setor.

\footnotetext{
${ }^{5}$ No capítulo 4 será abordado o coeficiente de Betz.

${ }^{6}$ Nesse sentido, o relatório Global Wind Report - Annual market update 2014, elaborado pela Global Wind Energy Council (GWEC), aponta que entre os anos de 2005 a 2014, a capacidade instalada eólica cresceu a uma taxa de $23 \%$ ao ano, sendo que em 2014, foram acrescidas 51 GW de capacidade instalada novas.
} 


\subsection{POTENCIAL EÓLICO ONSHORE NO BRASIL}

O Atlas do Potencial Eólico Brasileiro $(2001)^{7}$, elaborado pelo CEPEL utilizando-se o sistema MesoMap, indica a disponibilidade eólica de $143 \mathrm{GW}$ onshore, considerando as áreas com velocidade média anual superior à $7 \mathrm{~m} / \mathrm{s}$, torres de 50 metros de altura, curva de potência de aerogeradores daquela época e fator de ocupação dos aerogeradores de $2 \mathrm{MW} / \mathrm{km}^{2}$.

No estudo, foram desconsideradas apenas as áreas cobertas por água (lagos, rios, açudes). No entanto, tendo em vista que utilizou um fator de ocupação bastante conservador ( $\left.2 \mathrm{MW} / \mathrm{km}^{2}\right)$, eventuais áreas consideradas no estudo, mas que não são viáveis do ponto de vista ambiental ou mesmo social, não comprometem a estimativa, até porque, os equipamentos aerogeradores disponíveis atualmente, são muito mais eficientes.

Segundo o Atlas, para explorar o potencial de $143 \mathrm{GW}$, considerando apenas as áreas com ventos de velocidade média anual superior a $7 \mathrm{~m} / \mathrm{s}$, seriam necessários $71.735 \mathrm{~km}^{2}$, o equivalente a $0,8 \%$ do território nacional ${ }^{8}$. Se considerarmos as áreas com ventos de velocidade média anual superior a $6 \mathrm{~m} / \mathrm{s}$, o potencial disponível seria de 1.335 GW e demandaria 7,8\% do território nacional.

A título de comparação, estima-se que a área inundada pelos reservatórios das usinas hidroelétricas em operação em setembro de 2003 (76 GW de potência instalada ${ }^{9}$ seja da ordem de $36.000 \mathrm{~km}^{2}$, equivalente a $0,4 \%$ do território nacional.

De acordo com os referidos Atlas (CEPEL e ANEEL), o fator de ocupação da área para a fonte eólica e para a geração hidroelétrica é praticamente o mesmo, 2 $\mathrm{MW} / \mathrm{km}^{2}$ e 2,11 MW/km², respectivamente.

Diversos Estados ${ }^{10}$ realizaram seus próprios estudos, alguns recentemente, utilizando praticamente as mesmas premissas e a mesma metodologia adotada no Atlas do Potencial Eólico Brasileiro (2001), porém para as alturas 50, 75 e 100 metros e curvas médias de desempenho de aerogeradores de $500 \mathrm{~kW}, 1,5 \mathrm{MW}$ e 3,0 MW de

\footnotetext{
${ }^{7}$ Metodologia bottom-up.

8 Segundo dados do IBGE, com uma área territorial de $8.515 .767,049 \mathrm{~km}^{2}$, o Brasil é o quinto país do mundo e o maior da América Latina em área territorial.

${ }^{9}$ Dados retirados do Atlas da ANEEL. $2^{2}$ Edição. 2005. Não foi encontrado um dado oficial de área alegada mais recente.

10 Até setembro de 2015, os Estados do Ceará (2001), Bahia (2002 e 2013), Rio de Janeiro (2002), Rio Grande do Sul (2002), Rio Grande do Norte (2003), Paraná (2007), Alagoas (2008), Espírito Santo (2009), Minas Gerais (2010) e São Paulo (2012) haviam publicado seus respectivos Atlas de Potencial Eólico.
} 
potência instalada, respectivamente. É o caso, por exemplo, do Atlas do Potencial Eólico do Estado do Paraná (2007), que apontou um potencial para o Estado do Paraná de 310 MW, 1.360 MW e 3.370 MW, e do Atlas do Potencial Eólico do Estado de Alagoas (2008), que avaliou um potencial para o Estado de Alagoas de $173 \mathrm{MW}$, $336 \mathrm{MW}$ e $649 \mathrm{MW}$, para as alturas 50, 75 e 100 metros $^{11}$, respectivamente, considerando ventos iguais ou superiores a 7,0 m/s. A TABELA 2 apresenta 0 potencial eólico em cada Estado, de acordo com o seu respectivo Atlas Eólico, para as alturas de torre de 50, 75 e 100 metros. O Atlas do Estado do Ceará não avaliou a disponibilidade eólica para torres de 100 metros de altura, assim, por conservadorismo, foi considerada a mesma disponibilidade encontrada para a altura de 75 metros.

O Estado da Bahia tem dois Atlas, sendo o primeiro elaborado em 2002, contendo estimativas para torres de altura igual a 50 metros, e; o segundo, em 2013, contem estimativas para torres em alturas de 80, 100, 120 e 150 metros. Assim, utilizou-se as estimativas para torre de 50 metros do Atlas de 2002. Do Atlas de 2013, foram retiradas as estimativas de 80 metros como uma proxi para altura de 75 metros e a estimativa de 100 metros.

TABELA 2 - Disponibilidade Eólica por Estado.

\begin{tabular}{ccccccccccccccccc}
\hline $\begin{array}{c}\text { Altura (m) / } \\
\text { Disponibilidade } \\
\text { (MW) }\end{array}$ & BA & CE & RN & RS & PR & AL & ES & MG & RJ & SP & Total \\
\hline 50,00 & $5.600,00$ & $94.500,00$ & $9.600,00$ & $15.840,00$ & 310,00 & 173,00 & 129,00 & $10.570,00$ & 746,00 & 9,00 & $137.477,00$ \\
75,00 & $38.600,00$ & $155.600,00$ & $19.400,00$ & $54.430,00$ & $1.360,00$ & 336,00 & 448,00 & $24.742,00$ & $1.524,00$ & 15,00 & $296.455,00$ \\
100,00 & $70.100,00$ & $155.600,00$ & $27.100,00$ & $115.190,00$ & $3.370,00$ & 649,00 & $1.143,00$ & $39.043,00$ & $2.813,00$ & 564,00 & $415.572,00$ \\
\hline
\end{tabular}
Autor (2016).

Fonte: Atlas do Potencial Eólico Brasileiro (2001) e Atlas do Potencial Eólico dos Estados.

Para 10 Estados da Federação, o potencial eólico estimado, para torres de 50 metros de altura é $137 \mathrm{GW}$, muito próximo ao estimado para todo o Brasil no Atlas do Potencial Eólico Brasileiro (2001), que foi de $143 \mathrm{GW}$. Se for considerada a altura da torre de 75 metros, que possui avaliação para todos os 10 Estados da Federação, o potencial eólico estimado é de $296 \mathrm{GW}$, ultrapassando o que foi estimado no Atlas nacional.

\footnotetext{
${ }^{11}$ A simulação foi realizada considerando curvas médias de desempenho de aerogeradores de 500 $\mathrm{kW}, 1,5 \mathrm{MW}$ e 3,0 MW de potência instalada, para as alturas de 50, 75 e 100 metros, respectivamente.
} 
Considerando a avaliação realizada para a altura da torre de 100 metros e utilizando as avaliações com a torre de 75 metros para o Estado do Ceará, o potencial eólico estimado é de 416 GW.

É evidente que a projeção é bastante simplista, mas serve para demonstrar que a disponibilidade eólica é bastante significativa e, dada a competitividade dessa fonte, a perspectiva é de aumento na sua participação na matriz elétrica brasileira; destarte, os estudos da sua volatilidade e complementaridade são de grande relevância.

\subsection{POTENCIAL EÓLICO OFFSHORE DO BRASIL}

O potencial eólico offshore do Brasil foi avaliado por Ortiz e Kampel (2011). O estudo é inédito, pois foi o primeiro a avaliar a disponibilidade de energia eólica offshore para toda a costa brasileira.

Foram utilizados os dados históricos de vento obtidos pelo satélite QuikSCAT entre agosto de 1999 e dezembro de 2009, com resolução temporal diária. A estimativa foi realizada para uma altura de 80 metros, sobre a lâmina d'água, empregando turbinas geradoras AREVA Wind M5000, de $5 \mathrm{MW}$, velocidade nominal de $12,5 \mathrm{~m} / \mathrm{s}$, eficiência de conversão de $39,55 \%$, espaçadas em cerca de 600 metros no eixo meridional e em cerca de 1.200 metros no eixo zonal.

A menor velocidade média do vento foi de $7 \mathrm{~m} / \mathrm{s}$, estimada próxima à costa do Estado de São Paulo, considerada uma velocidade viável economicamente para a geração eólica onshore. A maior foi estimada em $12 \mathrm{~m} / \mathrm{s}$, próxima à costa dos Estados de Sergipe e Alagoas. Os Estados de Santa Catarina, Rio Grande do Sul, Rio Grande do Norte e Ceará, também se destacaram pela disponibilidade do recurso eólico. A Figura 1, reproduzida do trabalho de Ortiz e Kampel (2011), apresenta o resultado das simulações da disponibilidade eólica para a costa brasileira. 
Figura 1 - Campo de Vento Médio e Densidade Média de Potência Eólica no Atlântico Sudoeste, Calculados no Período entre Agosto de 1999 até Dezembro de 2009.

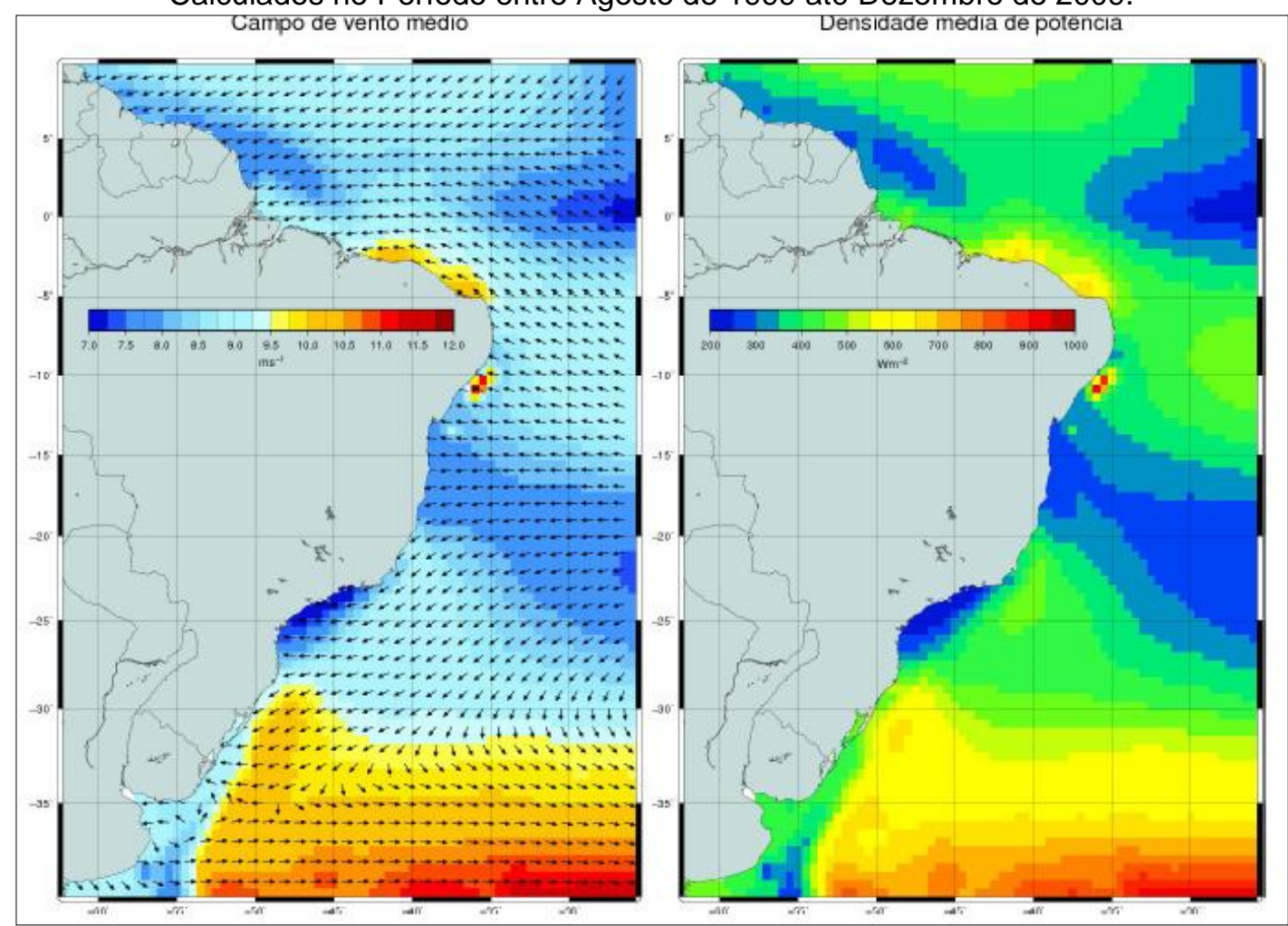

Fonte: Ortiz e Kampel (2011).

Ortiz e Kampel (2011) estimaram o potencial eólico offshore do Brasil, segmentado por faixas de distância da costa e, por intervalo batimétrico cujos resultados estão apresentados na TABELA 3, reproduzida do trabalho dos autores. No trabalho, os autores não apresentaram uma relação entre o intervalo batimétrico ${ }^{12}$ e a distância da costa.

TABELA 3 - Potencial Brasileiro de Geração Eólica Offshore em Função da Distância da Costa e em Função do Intervalo Batimétrico.

\begin{tabular}{cc||cc}
\hline \multicolumn{2}{c|}{ Distância da Costa } & \multicolumn{2}{c}{ Intervalo Batimétrico } \\
Faixa $(\mathrm{km})$ & Potencial Eólico $(\mathrm{GW})$ & Faixa $(\mathrm{m})$ & Potencial Eólico $(\mathrm{GW})$ \\
\hline 0 a 10 & 57 & 0 a 20 & 176 \\
0 a 50 & 259 & 0 a 50 & 399 \\
0 a 100 & 514 & 0 a 100 & 606 \\
0 a 200 M (ZEE) & 1.780 & & Autor (2016). \\
\hline \multicolumn{3}{c}{ Fonte: Ortiz e Kampel (2011). }
\end{tabular}

\footnotetext{
12 A batimetria (ou batometria) é a medição da profundidade dos oceanos, lagos e rios e é expressa cartograficamente por curvas batimétricas que unem pontos da mesma profundidade com equidistâncias verticais (curvas isobatimétricas ou intervalos batimétricos), à semelhança das curvas de nível topográfico (Fonte: https://pt.wikipedia.org/wiki/Batimetria).
} 
Para fins de comparação, o parque Eólico Bard (Alemanha) de $400 \mathrm{MW}$, localizado no Mar do Norte, entrou em operação em 2010, está distante a $100 \mathrm{~km}$ da costa, com uma profundidade média de 40 metros (The European offshore wind industry - key trends and statistics 2011, elaborado pela The European Wind Energy Association - EWEA).

Siegfriedsen, Lehnhoff e Prehn (2002) avaliaram a disponibilidade eólica offshore fora da Europa, indicando que o Brasil possui o $3^{\circ}$ maior potencial, com uma estimativa de geração de $609 \mathrm{TWh} / a n o$, equivalente a $139 \mathrm{GW}$ de potencial, atrás da China (1.033 TWh/ano) e dos EUA (612 TWh/ano).

No Brasil ainda não existe nenhuma usina eólica offshore em operação ou em construção. Alguns investidores têm noticiado interesse nesse segmento. $O$ projeto Asa Branca ${ }^{13}$ é um desses exemplos.

O projeto está localizado na costa do Estado do Ceará, com previsão de instalação de 23 fazendas eólicas, totalizando $480 \mathrm{MW}$. Estima-se que cada fazenda do projeto ocupará uma área de $179 \mathrm{~km}^{2}$, com uma distância de $4 \mathrm{~km}$ da costa e profundidade média entre 4 a 11 metros, da superfície. A Figura 2 apresenta um ilustrativo das 23 fazendas do projeto eólico Asa Branca.

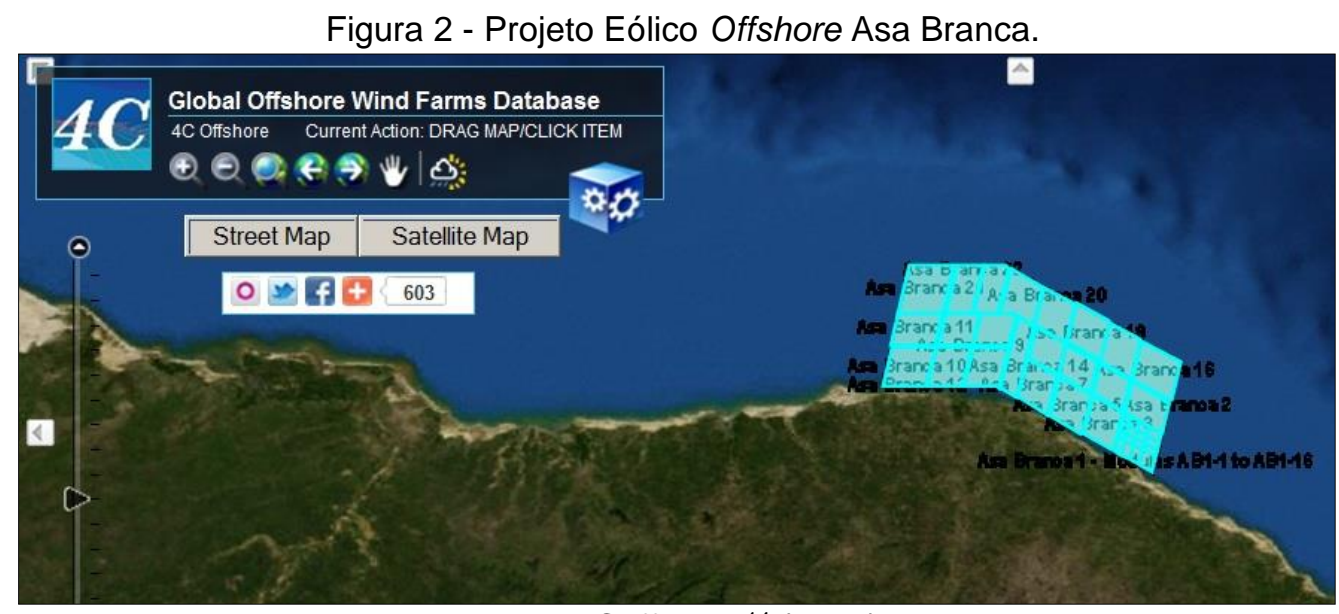

Fonte: 4Coffshore ${ }^{14}$ (2014).

Miguel, Ramos e Santos (2012) ressaltam que o Brasil, por meio da Petrobrás, tem o domínio da tecnologia de exploração de petróleo em águas profundas, bem como uma logística disponível, que pode ser utilizada na exploração da energia eólica offshore.

\footnotetext{
13 Informações obtidas do site www.usinaasabranca.com.br, acessado em 10.04.2014.

14 Reproduzida do site www.4coffshore.com, acessado em 10.04.2014.
} 
Os autores destacam que o mercado de consumo está concentrado nas regiões litorâneas, desta forma, as usinas offshore poderão contribuir para redução das perdas técnicas do sistema de transmissão (Rede Básica).

A disponibilidade eólica onshore no Brasil ainda é abundante. No entanto, os recursos offshore são significativos e precisam ser considerados pelo poder concedente, ou pelo menos entrar no horizonte do Plano Nacional de Energia. Alguns países já estão explorando esse recurso de forma intensiva (ver item 2.6).

Dentre os bens da União, o art. 20 da Constituição Federal lista "os lagos, rios e quaisquer correntes de água em terrenos de seu domínio, ou que banhem mais de um Estado, sirvam de limites com outros países, ou se estendam a território estrangeiro ou dele provenham, bem como os terrenos marginais e as praias fluviais", "o mar territorial", "os recursos naturais da plataforma continental e da zona econômica exclusiva" e "os potenciais de energia hidráulica". No que se refere ao uso dos "potenciais de energia hidráulica" por terceiros, há inúmeras leis e normas disciplinando o assunto. Para usinas hidroelétricas de potência superior a $50 \mathrm{MW}$, a legislação prevê a outorga mediante licitação e a celebração de um contrato de uso do bem público.

Para a exploração de projetos eólicos offshore, não existe um arcabouço legal, não obstante o Brasil dispõe de uma legislação consolidada para a exploração de empreendimentos de petróleo offshore, que pode ser utilizada como base, em conjunto com a legislação para empreendimentos hidroelétricas, para a construção de um marco regulatório específico para os empreendimentos eólicos offshore.

\subsection{CAPACIDADE INSTALADA E PROJEÇÃO - USINAS EÓLICAS ONSHORE NO MUNDO}

Em outubro de 1999, a European Wind Energy Association (EWEA), Greenpeace International e o Forum for Energy and Development publicaram a primeira estimativa de crescimento da indústria eólica, cujo relatório foi denominado de Wind Force 10. Na ocasião, a projeção de que $10 \%$ do consumo mundial de eletricidade seria atendido por energia eólica foi considerada um sonho, conforme a seguir: 
The $10 \%$ Target

On current expectations, wind power is expected to grow at an annual rate of $20 \%$ between 1998 and 2003, resulting in a total of 33,400 MW of installed capacity around the world by the end of that period. To meet the $10 \%$ target, $30 \%$ annual growth from 2004 to 2010 is required, resulting in a total of $181,000 \mathrm{MW}$ installed.

From 2010 onwards, wind power annual growth rates of $20 \%$ will result in a total of 1.2 million MW being installed by the end of the year 2020 .

This will generate 2,966 Terawatt hours of electricity, equivalent to $10.85 \%$ of the expected world consumption of electricity. By 2040, wind power could be supplying more than $20 \%$ of the world's electricity. (WIND FORCE 10,1999$)^{15}$

No entanto, segundo dados do relatório Global Wind Report - Annual market update 2011, elaborado pela Global Wind Energy Council (GWEC), a capacidade instalada eólica no ano de 2010 foi de 197.637 MW, portanto, acima do previsto no relatório Wind Force 10 (que foi de $181.000 \mathrm{MW}$ ).

Entre 1997 a 2012, a capacidade instalada eólica mundial cresceu a uma taxa de $27 \%$ ao ano. Todos os anos nesse período tiveram taxas de crescimento superior a $20 \%$. No ano 2013, em razão da desaceleração da economia mundial, reflexo da crise financeira de 2008, a taxa de crescimento da capacidade instalada ficou em $12 \%$, o que ainda é bastante representativa. Em decorrência, pela primeira vez no histórico observado, a capacidade instalada no ano foi inferior ao ano anterior. No ano de 2014, houve uma forte recuperação da indústria eólica e, pela primeira vez no histórico, a capacidade instalada no ano superou 50 GW. Nesse sentido, o relatório Global Wind Report - Annual market update 2014, elaborado pela Global Wind Energy Council (GWEC), aponta que entre os anos de 2005 a 2014, a capacidade instalada eólica cresceu a uma taxa de $23 \%$ ao ano. A evolução da capacidade instalada está apresentada no Gráfico 1, cujos dados foram obtidos da Global Wind Energy Council (GWEC).

\footnotetext{
15 Tradução livre: A meta de 10\%

Em expectativas atuais, a energia eólica deverá crescer a uma taxa anual de $20 \%$ entre 1998 e 2003, resultando em um total de $33.400 \mathrm{MW}$ de capacidade instalada em todo o mundo até o final desse período. Para atingir a meta de 10\%,30\% de crescimento anual 2004-2010 é necessária, resultando em um total de $181.000 \mathrm{MW}$ instalado.

A partir de 2010 , as taxas de crescimento anuais de energia eólica de $20 \%$ resultarão em um total de 1,2 milhões MW a ser instalada até o final do ano de 2020.

Isto irá gerar 2,966 TWh de electricidade, equivalente a 10,85\% do consumo mundial de electricidade esperado. Em 2040, a energia eólica poderia estar fornecendo mais de $20 \%$ da eletricidade do mundo. (Força do vento 10, 1999)
} 
Gráfico 1 - Capacidade Instalada das Usinas Eólicas no Mundo - Acumulada e Anual.

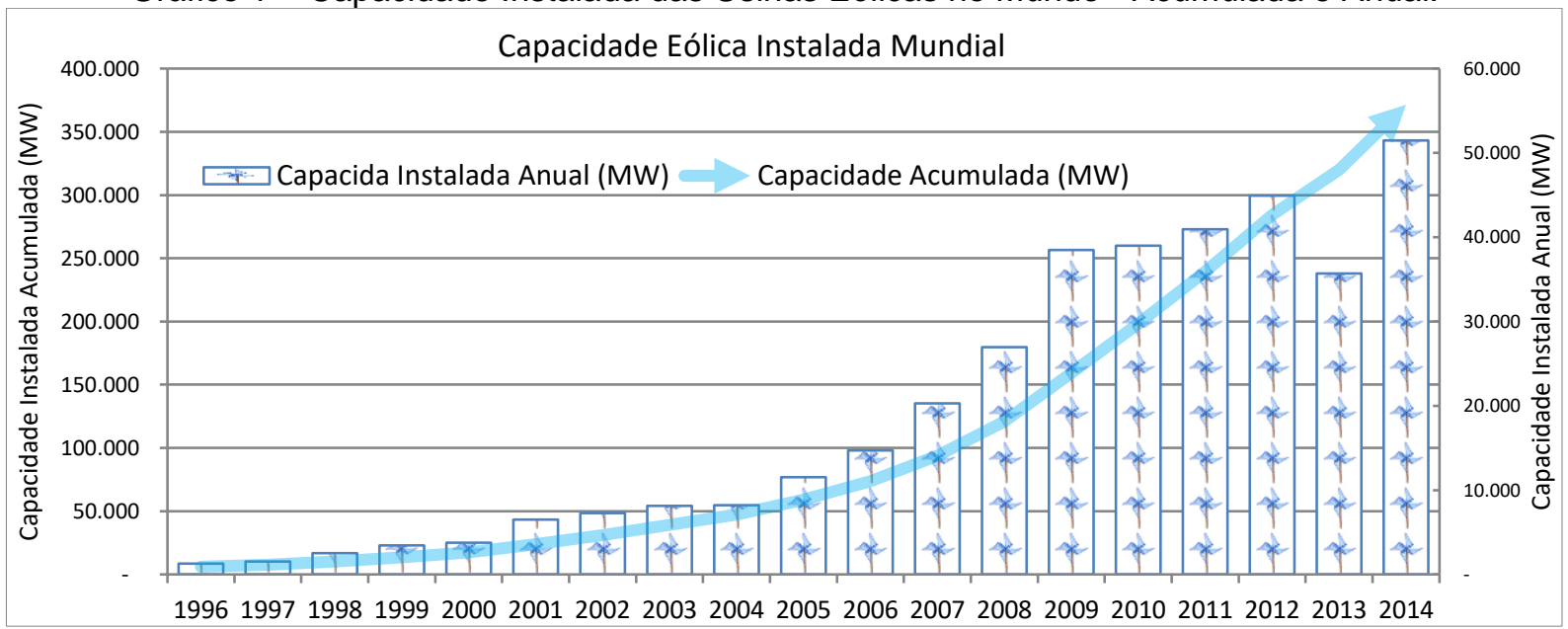
Autor (2016).

Fonte: GLOBAL Wind Report (2012), (2013) e (2014).

Segundo o relatório Global Wind Energy 2014: Annual Market update 2014, publicado em março de 2015, pela Global Wind Energy Council (GWEC), dez países concentram aproximadamente $84 \%$ da capacidade instalada de todas as usinas eólicas do mundo. Todavia, o acréscimo da capacidade instalada nos últimos 5 (cinco) anos, não vem ocorrendo na mesma proporção da capacidade instalada em operação comercial.

A TABELA 4 apresenta a evolução da capacidade instalada entre os anos 2010 a 2014, segregada pelos países que mais investiram nessa fonte.

TABELA 4 - Capacidade Instalada das Usinas Eólicas -Principais Países.

\begin{tabular}{|c|c|c|c|c|c|c|c|c|}
\hline País & $\begin{array}{l}\text { Capacidade } \\
\text { Instalada } \\
\text { Acumulada } \\
\text { até } 2014 \\
\text { (MW) }\end{array}$ & $\begin{array}{l}\text { Participação } \\
\text { na Capacidade } \\
\text { Instalada } \\
\text { Acumulada } \\
\text { até } 2014(\%)\end{array}$ & $\begin{array}{c}\text { Participação } \\
\text { na } \\
\text { Capacidade } \\
\text { Adicionada } \\
\text { em } 2010 \text { (\%) }\end{array}$ & $\begin{array}{c}\text { Participação } \\
\text { na } \\
\text { Capacidade } \\
\text { Adicionada } \\
\text { em } 2011 \text { (\%) }\end{array}$ & $\begin{array}{c}\text { Participação } \\
\text { na } \\
\text { Capacidade } \\
\text { Adicionada } \\
\text { em } 2012(\%)\end{array}$ & $\begin{array}{c}\text { Participação } \\
\text { na } \\
\text { Capacidade } \\
\text { Adicionada } \\
\text { em } 2013(\%)\end{array}$ & $\begin{array}{c}\text { Participação } \\
\text { na } \\
\text { Capacidade } \\
\text { Adicionada } \\
\text { em } 2014 \text { (\%) }\end{array}$ & $\begin{array}{c}\text { Participação } \\
\text { na } \\
\text { Capacidade } \\
\text { Adicionada } \\
\text { Média 2010 } \\
2014(\%)\end{array}$ \\
\hline China & 114.609 & 31,0 & 49,5 & 43,0 & 30,0 & 45,6 & 45,1 & 42,6 \\
\hline EUA & 65.879 & 17,8 & 13,4 & 17,0 & 29,0 & 3,1 & 9,4 & 14,4 \\
\hline Alemanha & 39.165 & 10,6 & 3,9 & 5,0 & 5,0 & 9,2 & 10,2 & 6,7 \\
\hline Espanha & 22.987 & 6,2 & 4,0 & 2,6 & 2,5 & ND & ND & 3,0 \\
\hline Índia & 22.465 & 6,1 & 5,6 & 7,0 & 5,0 & 4,9 & 4,5 & 5,4 \\
\hline França & 9.285 & 2,5 & 2,8 & 2,0 & ND & ND & 2,0 & 2,3 \\
\hline Itália & 8.663 & 2,3 & 2,5 & 2,3 & 2,8 & ND & ND & 2,5 \\
\hline $\begin{array}{l}\text { Reino } \\
\text { Unido }\end{array}$ & 12.440 & 3,4 & 2,5 & 3,2 & 4,2 & 5,3 & 3,4 & 3,7 \\
\hline Canadá & 9.694 & 2,6 & 1,8 & 3,1 & 2,1 & 4,5 & 3,6 & 3,0 \\
\hline Brasil & 5.939 & 1,6 & ND & ND & 2,4 & 2,7 & 4,8 & 3,3 \\
\hline Demais & 58.473 & 15,8 & 12,5 & 12,0 & 14,3 & 18,1 & 13,3 & 14,0 \\
\hline
\end{tabular}

Fonte: GLOBAL Wind Energy Outlook (2010), (2011), (2012), (2013) e (2014).

Na China e no Brasil, considerando o período de 2010 a 2014, a participação média na capacidade instalada adicionada está acima das suas participações na 
capacidade instalada total (destacado em azul na TABELA 4), enquanto, os países EUA, Alemanha e Espanha tiveram uma expressiva redução na participação da capacidade instalada adicionada (destacado em azul claro na TABELA 4).

Em outras palavras, China e o Brasil vêem aumentando as suas participações na capacidade instalada total, enquanto os países EUA, Alemanha e Espanha estão perdendo espaço.

No mesmo período, os países Índia, Franca, Itália e Reino Unido mantiveram o percentual de capacidade instalada adicionada praticamente igual às suas participações na capacidade instalada total, significando que seguem mantendo suas posições.

O Brasil, nos anos de 2012 a 2014, esteve na lista dos 10 países que mais aumentaram a capacidade instalada dos seus parques eólicos e em 2014 passou a deter a 10ª maior capacidade instalada eólica mundial.

Existe uma tendência de desconcentração dos investimentos em energia eólica com o surgimento de novos mercados relevantes, como o Brasil, Romênia e a Suécia. De acordo com os relatórios estatísticos elaborados pela Global Wind Energy Council (GWEC), em 2013, a Dinamarca foi listada entre os 10 países com maior capacidade instalada, retirando a posição que vinha sendo ocupada por Portugal, no entanto, em 2014, o Brasil passou a ocupar a posição da Dinamarca.

No que se refere à expansão eólica, o relatório Global Wind Energy Outlook 2014 apresenta três cenários. O cenário pessimista utiliza o "cenário das novas políticas" do IEA World Energy Outlook, que se baseia na avaliação das direções e intenções atuais, nacionais e internacionais, da política energética e climática, mesmo que eles ainda não tenham sido incorporados às decisões formais ou transformado em lei ${ }^{16}$.

Neste cenário, a penetração da energia eólica do atendimento da demanda elétrica mundial não ultrapassa $11 \%$. O cenário moderado foi elaborado pela GWEC levando em consideração as mesmas premissas do cenário pessimista, e adicionalmente, assume que as metas nacionais e regionais de aumento da participação das energias renováveis, em especial da energia eólica, serão de fato cumpridas. O cenário otimista considera a capacidade da indústria para estimar o

\footnotetext{
${ }^{16}$ Exemplos disso: incluem as metas de redução de emissões adotadas em Cancun no ano de 2010, os vários compromissos com a energia renovável e eficiência a nível nacional e regional, e os compromissos adotados pelos governos em fóruns como o G-8/G-20.
} 
crescimento da expansão eólica. Também pressupõe que os governos estabelecerão políticas de redução de emissões de carbono com o objetivo de manter o aquecimento médio abaixo de $2^{\circ} \mathrm{C}$, acima dos níveis pré-industrial de temperaturas ${ }^{17}$. Neste cenário, a penetração da energia eólica no atendimento da demanda elétrica mundial é da ordem de $25 \%$ a $30 \%$.

A TABELA 5 apresenta as estimativas das taxas de crescimento e capacidade instalada decorrente para cada cenário. Apesar de a capacidade instalada eólica mundial ter crescido a uma taxa de $23 \%$ ao ano (nos últimos 10 anos), mesmo no cenário otimista, estima-se uma redução da taxa de crescimento da indústria, em face do amadurecimento da capacidade instalada.

TABELA 5 - Estimativa da Taxa de Crescimento e da Capacidade Instalada.

\begin{tabular}{|c|c|c|c|c|c|c|}
\hline \multirow[b]{2}{*}{ Período } & \multicolumn{2}{|c|}{ Cenário Otimista } & \multicolumn{2}{|c|}{ Cenário Moderado } & \multicolumn{2}{|c|}{ Cenário Pessimista } \\
\hline & $\begin{array}{c}\text { Taxa de } \\
\text { Crescimento } \\
(\%)\end{array}$ & $\begin{array}{c}\text { Capacidade } \\
\text { Acumulada - Último } \\
\text { Ano (MW) }\end{array}$ & $\begin{array}{c}\text { Taxa de } \\
\text { Crescimento } \\
(\%)\end{array}$ & $\begin{array}{c}\text { Capacidade } \\
\text { Acumulada - Último } \\
\text { Ano (MW) }\end{array}$ & $\begin{array}{c}\text { Taxa de } \\
\text { Crescimento } \\
(\%)\end{array}$ & $\begin{array}{c}\text { Capacidade } \\
\text { Acumulada - Último } \\
\text { Ano (MW) }\end{array}$ \\
\hline 2015 & & 420.363 & & 413.039 & & 396.311 \\
\hline $2016-2020$ & $9 \%$ & 800.615 & $8 \%$ & 712.081 & $7 \%$ & 610.979 \\
\hline 2021-2030 & $6 \%$ & 1.931 .989 & $5 \%$ & 1.479 .767 & $4 \%$ & 964.465 \\
\hline $2031-2040$ & $4 \%$ & 3.024 .473 & $3 \%$ & 2.089 .261 & $3 \%$ & 1.328 .814 \\
\hline 2041-2050 & $3 \%$ & 4.042 .475 & $2 \%$ & 2.672 .231 & $2 \%$ & 1.684 .074 \\
\hline
\end{tabular}

Fonte: GLOBAL Wind Energy Outlook (2014).

Apesar da estimativa de redução das taxas de crescimento, ainda assim, a expansão eólica é bastante expressiva em relação às demais fontes de energia, uma vez que se consolidou como uma fonte segura, de baixo custo e chave na redução dos gases de efeito estufa.

\subsection{CAPACIDADE INSTALADA E PROJEÇÃO - USINAS EÓLICAS ONSHORE NO BRASIL}

As usinas eólicas têm sido responsáveis pelo sucesso dos Leilões de Energia promovidos pelo Ministério de Minas e Energia (MME).

\footnotetext{
${ }^{17}$ Conforme sugerido pelo Painel Intergovernamental sobre Mudanças Climáticas, mais conhecido pelo acrônimo IPCC (da sua denominação em inglês Intergovernmental Panel on Climate Change).
} 
A grande disponibilidade de projetos eólicos conjuntamente com 0 desenvolvimento dessa indústria no Brasil, tem possibilitado o atendimento do crescimento da demanda, com preços competitivos.

A consolidação dessa fonte de energia no Brasil ocorreu com certo atraso em relação aos outros países que também adotam a geração eólica na sua matriz de eletricidade. Muito embora, os esforços tenham sido iniciados em 2001, com o Programa Emergencial de Energia Eólica (PROEÓLICA), que não logrou êxito, em razão do curto prazo para a implantação dos projetos e do baixo preço de compra. Até o Programa de Incentivo às Fontes Alternativas de Energia Elétrica (PROINFA), os projetos eólicos no Brasil eram inexpressíveis, oriundos de iniciativas de algumas empresas, com perspectivas pedagógicas.

O PROINFA foi o catalisador da indústria do segmento eólico no Brasil, a partir de contratos de energia celebrados com preços acima dos preços da energia convencional, com subsídio tarifário. No entanto, a estabilidade regulatória do modelo de contratação de energia no ambiente regulado garantiu a consolidação da inserção da energia eólica na matriz de eletricidade do Brasil.

O segmento eólico no Brasil passa por um círculo virtuoso. A estabilidade regulatória atraiu inúmeros investidores em usinas ou para as indústrias de suporte ${ }^{18}$, aumentando a oferta de projetos e equipamentos, aumentando a competição entre os fabricantes e entre os produtores independentes de energia, reduzindo o preço da energia. Essa constatação pode ser observada pela tendência de queda dos preços dos Leilões Regulados de Energia, pelo aumento da quantidade de projetos cadastrados nos Leilões e pela expansão da capacidade instalada. O Gráfico 2 apresenta a evolução da capacidade instalada das usinas eólicas no Brasil.

O expressivo crescimento da energia eólica na matriz elétrica decorre de uma combinação de fatores relacionados ao cenário externo, ao desenvolvimento tecnológico e da cadeia produtiva, além de aspectos regulatórios, tributários e financeiros.

\footnotetext{
${ }^{18}$ Há se considerar que o baixo crescimento do Produto Interno Bruto da Europa e do EUA, provocado pela crise financeira de 2008, também contribuíram para que os fabricantes de aerogeradores viessem a se instalar no Brasil.
} 
Gráfico 2 - Evolução da Capacidade Instalada das Usinas Eólicas no Brasil.

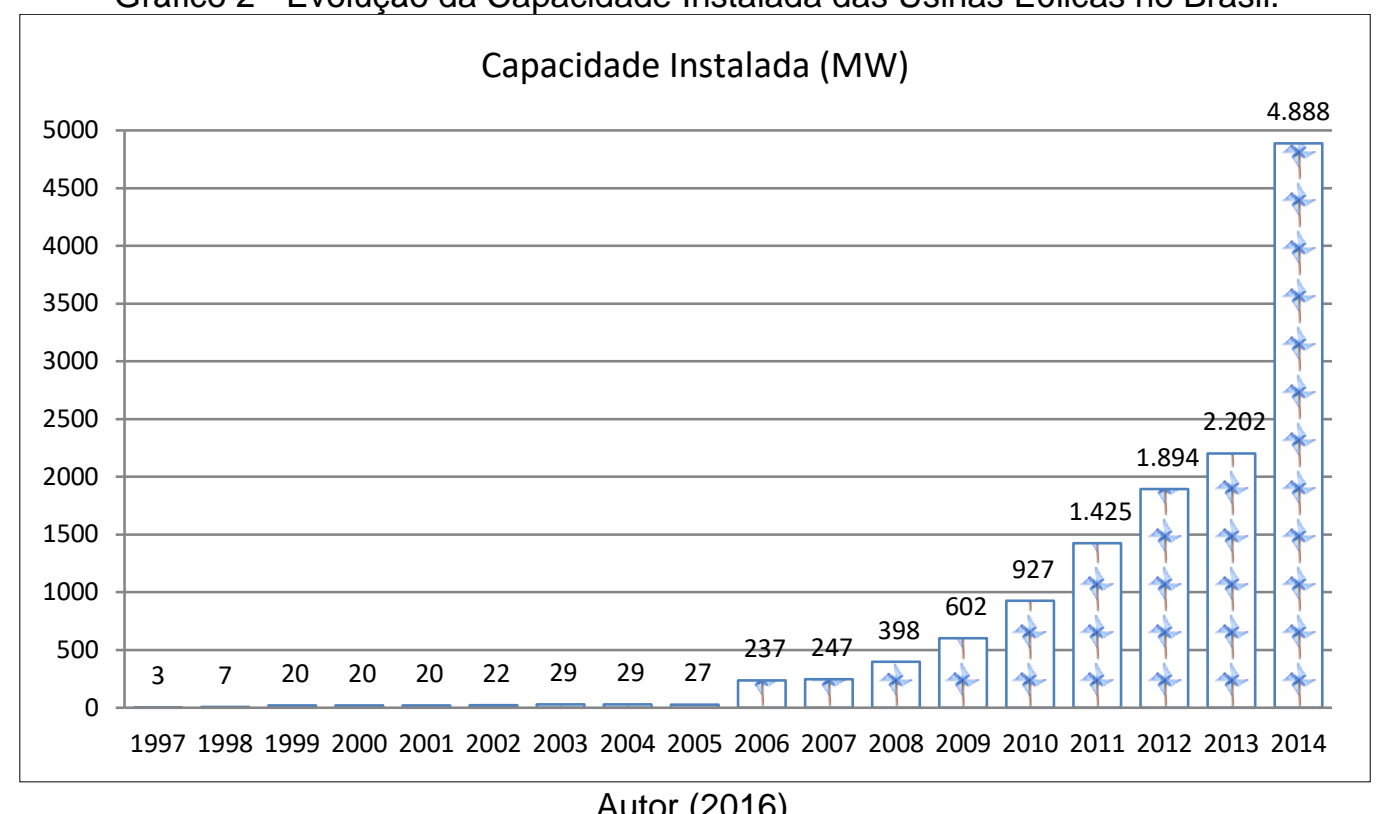

Fonte: Brasil. ANEEL (2005), Balanço Energético 2011, Global Wind Energy Outlook (2011), EPE (2013; 2014), GWEC2013 e GWEC2014.

Desde o PROINFA, vem se instalando no Brasil fabricantes de pás, torres e aerogeradores, com capacidade de atendimento de uma demanda anual de 2.900 MW, elevando a competição entre os fornecedores, conforme TABELA 6.

Deve-se observar que os fornecedores de aerogeradores são em sua essência montadoras, pois podem receber componentes fabricados por outras empresas $\mathrm{e}$ realizar apenas a sua integração. A integração total do aerogerador acontece diretamente no parque eólico, pois somente neste momento a torre, o cubo, as pás e a nacele são acoplados.

Em razão do índice de nacionalização exigido pelo BNDES para financiamento de projetos eólicos, a capacidade anual da indústria está limitada pela produção de naceles (DAVID, 2013).

De acordo com o Plano Decenal de Expansão de Energia 2021 (PDE2021), em 2013 havia um portfólio de projetos eólicos habilitados tecnicamente pela EPE de cerca de 600 empreendimentos cuja potência total supera $16 \mathrm{GW}$. De lá para cá, alguns projetos foram contratados, contudo a oferta ainda é bastante significativa. 
TABELA 6 - Tabela de Fabricantes.

\begin{tabular}{|c|c|c|}
\hline \multicolumn{3}{|c|}{ AEROGERADORES } \\
\hline Montadoras & Local & Capacidade Anual de Produção (MW) \\
\hline Altom $^{19}$ & Camaçari (BA) & 400 \\
\hline Wobben/Enercon & Sorocaba (SP) & 500 \\
\hline Impsa ${ }^{20}$ & Suape (PE) e Guaíba (RS) & 1.000 \\
\hline WEG & Jaraguá do Sul (SC) & 100 \\
\hline Gamesa & Camaçari (BA) & 400 \\
\hline GE & Campinas (SP) & 500 \\
\hline & & 2.900 \\
\hline \multicolumn{3}{|c|}{ TORRES } \\
\hline Fabricante & Local & Capacidade Anual de Produção \\
\hline Gestamp & Cabo de Santo Agostinho & 450 \\
\hline Wobben & Parazinho (RN) e Gravataí (RS) & 500 \\
\hline RM Eólica & Suape (PE) & 450 \\
\hline SAWE/Engebasa-Ivape & Cubatão (SP) & 168 \\
\hline Tecnomaq & Aquiraz (CE) & 100 \\
\hline Torrebrás & Camaçari (BA) & 220 \\
\hline Máquinas Piratininga & Recife (PE) & 150 \\
\hline Alstom & Canoas (RS) & 120 \\
\hline ArcelorMittal/CTZ Eolic Tower & Móvel & 120 \\
\hline ICEC & Mirassol (SP) & 100 \\
\hline Intecnial & Erechim (RS) & 100 \\
\hline Inneo & $\begin{array}{c}\text { Trairi (CE), Caso Nova (BA) e } \\
\text { Palmares (RS) }\end{array}$ & 250 \\
\hline Brasilsat & Curitiba (PR) & 50 \\
\hline & & 2.878 \\
\hline \multicolumn{3}{|c|}{ PÁS } \\
\hline Fabricante & Local & Capacidade Anual de Produção \\
\hline Tecsis & Sorocaba (SP) & 6.000 \\
\hline Aeris/Suzlon & Pecém (CE) & 600 \\
\hline Wobben/Enercon & Sorocaba (SP) e Pecém (CE) & 1.500 \\
\hline \multirow[t]{2}{*}{ Eólice/LM Windpower } & Suape (PE) & 1.000 \\
\hline & & 9.100 \\
\hline
\end{tabular}

Autor (2016).

Fonte: Brasil. Ministério de Desenvolvimento Indústria e Comércio Exterior. Agência Brasileira de Desenvolvimento Industrial (2014).

${ }^{19} \mathrm{Em} 2014$ a GE anunciou a compra dos ativos da Alstom.

${ }^{20}$ A Wind Power, subsidiária da argentina Impsa e uma das empresas âncoras do Complexo Industrial e Portuário de Suape, na Região Metropolitana do Recife, teve sua falência decretada pelo Tribunal de Justiça de Pernambuco em 2014. 
A farta oferta de projetos, preços competitivos, facilidade na obtenção do licenciamento ambiental, aliada com as dificuldades em viabilizar ambientalmente as usinas hidroelétricas, indicam que a expansão das usinas eólicas deve permanecer relevante no atendimento da demanda no horizonte do plano decenal, em especial nas regiões Sul e Nordeste.

No Plano Decenal de Expansão de Energia 2024 (PDE2024), o Ministério de Minas e Energia (MME) prevê um acréscimo de potência eólica de 1.900 MW ao ano (abaixo da capacidade de produção da indústria nacional de naceles, de $2900 \mathrm{MW}$, ao ano), no período de 2015 a 2024 , atingindo ao final do período a $11,6 \%$ de penetração eólica na matriz elétrica. $O$ otimismo do $M M E$ em relação à fonte é demonstrado nas revisões da expansão eólica nos Planos Decenais. A evolução da capacidade instalada prevista no horizonte dos Planos Decenais ${ }^{21}$ de 2019, 2020, 2021, 2022 e 2023 está apresentada no Gráfico 3, valor inferior à capacidade anual de produção de naceles da indústria eólica nacional, mesmo para o PDE 2023.

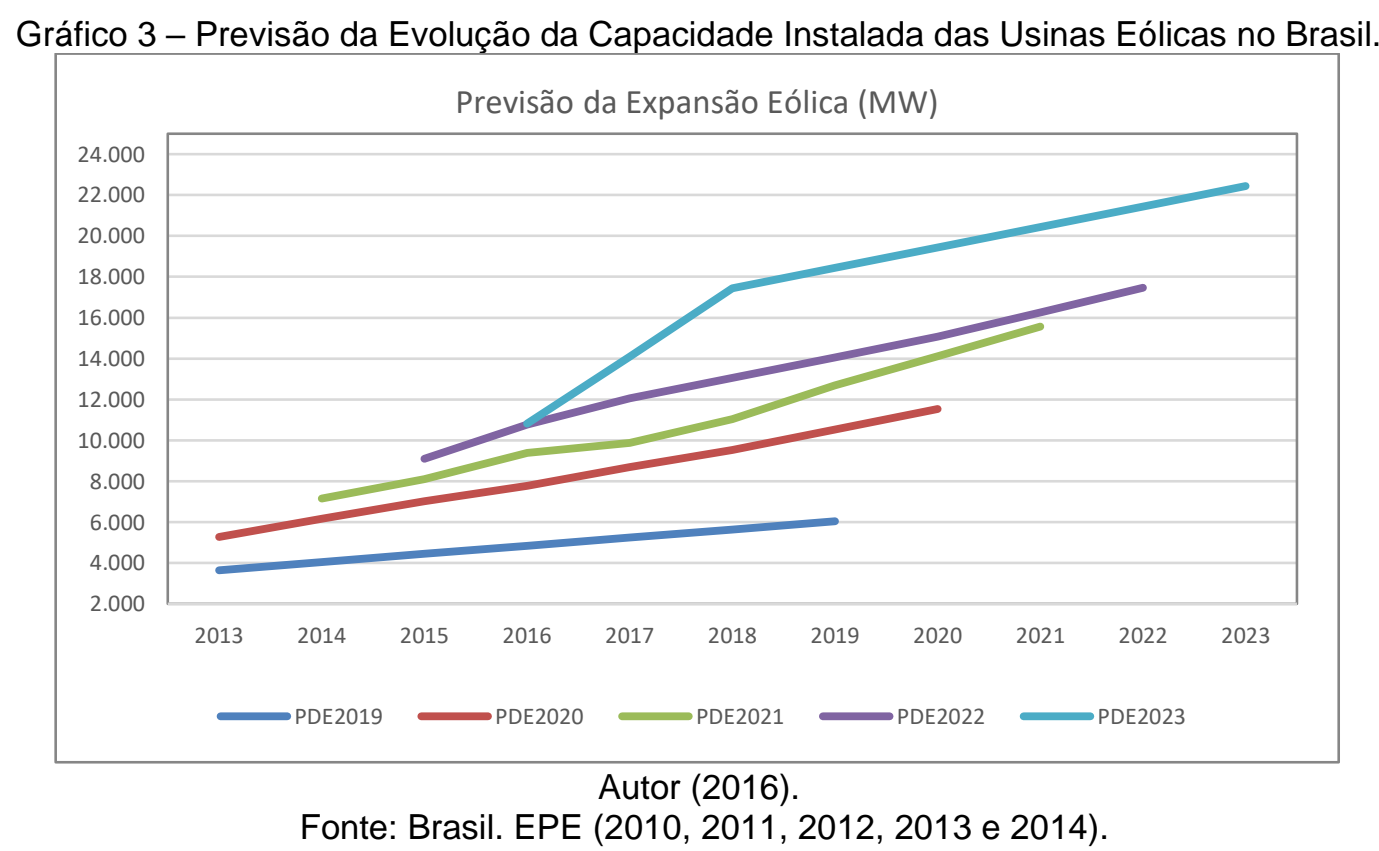

A participação da capacidade instalada das usinas eólicas na matriz de eletricidade parte de 3,5\% (5 GW), em 2014, alcançando 11,6\% em 2024 (PDE2024).

\footnotetext{
${ }^{21}$ Não foi inserido no gráfico a evolução da capacidade instalada eólica prevista no PDE2024, em razão da revisão do crescimento da carga para baixo em relação aos PDE2023. A projeção atual situa-se entre 716 MW médios (2014) e 2.620 MW médios (2023) abaixo da previsão do PDE 2023.
} 
A estimativa da EPE no Plano Decenal de Expansão de Energia 2022 é de um incremento de 968\% no decênio (2012/2022).

No entanto, estima-se que o aumento poderá ser maior, em razão de revés do Ministério de Minas e Energia (MME) nos licenciamentos ambientais das usinas hidroelétricas e das dificuldades em viabilizar a contratação de usinas térmicas a gás natural, face a agilidade de se implantar um parque de usinas eólicas.

A acentuada inserção da fonte eólica na matriz elétrica brasileira é motivo de preocupação, inclusive da própria EPE, quando destaca, no Plano Decenal de Expansão de Energia 2021, a importância do "estudo e acompanhamento das implicações técnicas envolvidas na sua inserção na matriz elétrica, especialmente a partir da entrada em operação dos blocos contratados nos leilões de energia". Neste trabalho, dentre outros temas, foi avaliada a complementariedade da fonte eólica entre si, considerando séries históricas de energia gerada em base mensal e em base horária, o que poderá contribuir com o estudo mencionado no Plano Decenal de Expansão de Energia 2021.

\subsection{CAPACIDADE INSTALADA E PROJEÇÃO - USINAS EÓLICAS OFFSHORE NO MUNDO}

A primeira usina eólica offshore a entrar em operação comercial foi a Vindeby. Localizada na Dinamarca, no mar Kattegat ${ }^{22}$, distante a 2,5 km da costa, instalada em um intervalo batimétrico de 2,5 a 5 metros, começou a operar em 1991, com 11 turbinas eólicas Bonus de 450 kW cada, fabricada pela Siemens, totalizando 4.950 $\mathrm{KW}$ de potência instalada.

Após 24 anos da entrada em operação da usina eólica offshore Vindeby, o relatório Global Wind Energy: Annual Market update 2014, da Global Wind Energy Council (GWEC), contabiliza que a capacidade instalada offshore mundial acumulada totaliza 8.759 MW, o que representa 2,36\% da capacidade instalada de usinas eólicas onshore. A evolução da capacidade instalada acumulada offshore e a relação com a capacidade instalada onshore está ilustrada no Gráfico 4.

\footnotetext{
22 O Kattegat (em dinamarquês), ou Kattegatt (em sueco), por vezes escrito em português Categate, é um estreito entre a Dinamarca e a Suécia, limitado do lado sueco pela costa da Escânia, da Halland, de Gotemburgo e de Bohuslän até à ilha de Marstrand, e do lado dinamarquês pela península da Jutlândia e pelas ilhas de Fyn e da Zelândia. (Fonte: http://pt.wikipedia.org/wiki/Kattegat).
} 
Gráfico 4 - Capacidade Instalada Acumulada das Usinas Eólicas Offshore.

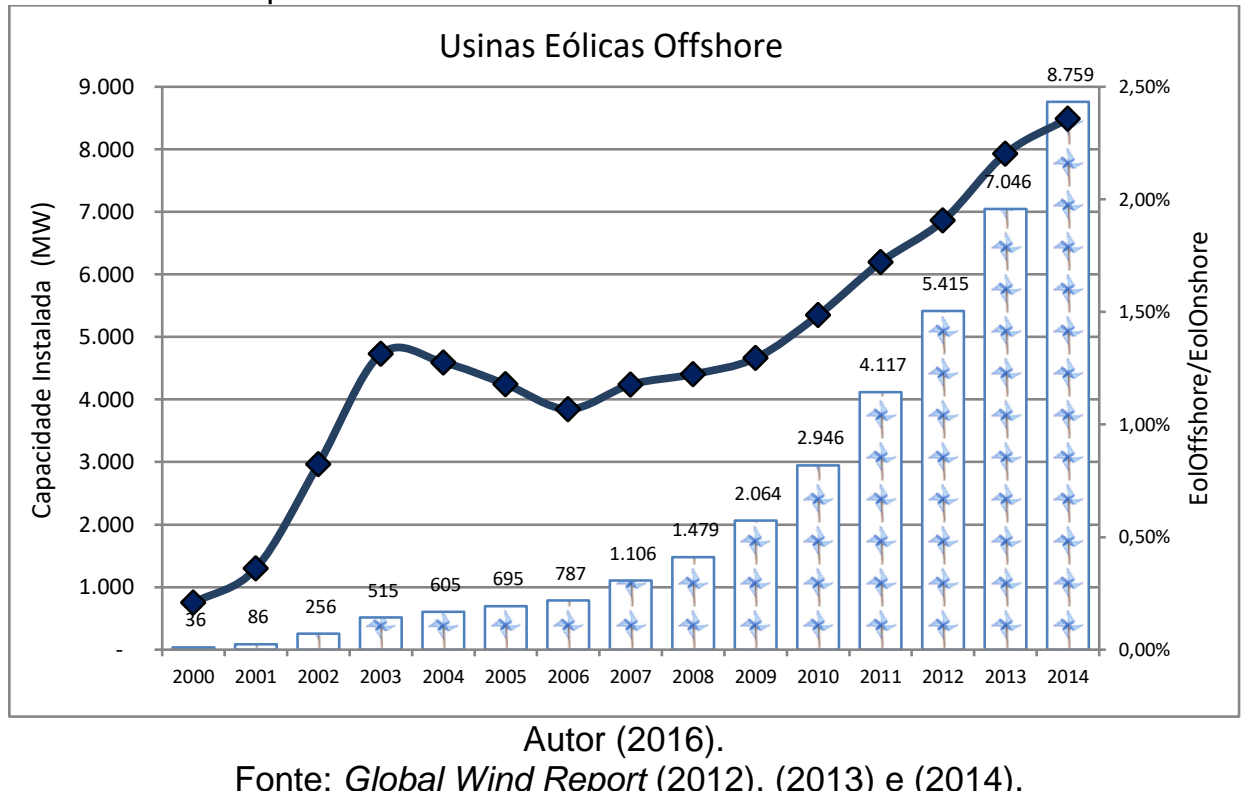

Fonte: Global Wind Report (2012), (2013) e (2014).

A partir do ano 2006, verifica-se que a taxa de crescimento da capacidade instalada das usinas offshore é superior à taxa de expansão das usinas onshore. No ano de 2013 , a capacidade instalada offshore cresceu $30 \%$ em relação ao ano de 2012, enquanto a capacidade instalada onshore cresceu $13 \%$.

Apesar do expressivo crescimento em 2013, o relatório The European offshore wind industry - key trends and statistics 2013, publicado pela European Wind Energy Association (EWAE), pondera que a capacidade instalada offshore ficou abaixo do previsto pela própria EWAE em 2009 e, abaixo do pretendido pelos próprios países da União Europeia, em seus planos de ações nacionais para energia renovável (National Renewable Energy Action Plans - NREAPs), submetidos à Comissão Europeia, conforme Diretiva 2009/28/EC.

Segundo o relatório Global Wind Energy: Annual Market update 2014, da Global Wind Energy Council (GWEC), mais de $91 \%$ das usinas offshore estão atualmente instaladas no norte da Europa, localizadas no mar do Norte, no mar Báltico, nos mares da Irlanda e no Canal Inglês. O restante está localizado praticamente em projetos de demonstração ao largo da costa leste da China. O Reino Unido, Dinamarca, Alemanha, Bélgica e a China concentram 94\% da capacidade instalada das usinas offshore. A TABELA 7 resume a capacidade instalada acumulada em 2013 e 2014 em cada país. 
TABELA 7- Capacidade Instalada das Usinas Eólicas Offshore por País.

\begin{tabular}{ccc}
\hline País & $\begin{array}{c}\text { Capacidade Instalada } \\
\text { Acumulada até 2014 (MW) }\end{array}$ & $\begin{array}{c}\text { Capacidade Instalada } \\
\text { Acumulada até 2013 (MW) }\end{array}$ \\
\hline Reino Unido & $4.494,30$ & $3.680,90$ \\
Dinamarca & $1.271,00$ & $1.271,00$ \\
Alemanha & $1.049,00$ & 520,00 \\
Bélgica & 713,00 & 572,00 \\
China & 658,00 & 429,00 \\
Holanda & 247,00 & 247,00 \\
Suécia & 212,00 & 212,00 \\
Japao & 50,00 & 50,00 \\
Finlândia & 26,00 & 26,00 \\
Irlanda & 25,00 & 25,00 \\
Coreia do Sul & 5,00 & 5,00 \\
Espanha & 5,00 & 5,00 \\
Noruega & 2,00 & 2,00 \\
Portugal & 2,00 & 2,00 \\
EUA & 0,02 & 0,02 \\
\hline Total & $8.759,32$ & $7.046,92$ \\
\hline & Autor (2016). & \\
\hline & Fonte: Global Wind Report (2014). & \\
\hline
\end{tabular}

A previsão para o ano 2020, de acordo com o relatório Global Wind Report Annual Market Update 2012, elaborado pela Global Wind Energy Council (GWEC), era de 80 GW de capacidade instalada, o que representaria 10\% do mercado eólico. Contudo, a previsão mais recente da indústria é menos otimista. De acordo com o relatório Offshore Wind Policy And Market Assessment (2014), elaborado no âmbito do projeto Facilitating Offshore Wind in India (FOWIND), apesar da meta fixada para a União Europeia pelo Renewable Energy Action Plan (NREAP) ${ }^{23}$ de 43,3 GW²4, a previsão realizada pela European Wind Energy Association (EWEA), para o ano 2020, é de 23,5 GW, o que significa triplicar a capacidade instalada atual na União Europeia $^{25}$. Para a China, a previsão é de $10 \mathrm{GW}$, para o Japão, Coreia do Sul e Taiwan, a expectativa é de 2,3 GW.

\footnotetext{
23 Tradução livre: Plano Nacional de Energia Renovável.

${ }^{24}$ Para o ano de 2020, a União Europeia estabeleceu a meta de suprir $35 \%$ do consumo de eletricidade com energia renovável, sendo $12 \%$ desse montante, a partir de energia eólica, resultando em 43 GW de capacidade eólica offshore. A previsão da capacidade instalada foi revista em função da redução da expectativa do consumo de eletricidade em 2020 em 11\%, devido o baixo crescimento dos países da União Europeia.

25 O relatório Wind energy scenarios for 2020, elaborado em julho de 2014 pela European Wind Energy Association (EWEA) faz três cenários para a União Europeia em 2020. Pelo cenário otimista, a capacidade instalada eólica offshore atingirá $28 \mathrm{GW}$ e atenderá $3,5 \%$ da carga, pelo cenário pessimista, a capacidade instalada atingirá $20 \mathrm{GW}$, com uma penetração de $2,4 \%$ da carga. Pelo cenário central, a capacidade instalada atingirá $23,5 \mathrm{GW}$ e atenderá $2,9 \%$.
} 
Em razão do grande potencial eólico onshore e da oferta de gás não convencional, não há expectativa de instalação de novas plantas nos EUA. Destarte, pela previsão menos otimista, em 2020 haverá $35,8 \mathrm{MW}$ de capacidade eólica offshore instalada.

Em países com alta densidade populacional, onde há pouco espaço para a usinas eólicas onshore, a energia offshore tem sido a opção para atendimento de sua demanda e as metas climáticas, como é o caso do Reino Unido, Dinamarca, Alemanha e Bélgica.

Miguel, Ramos e Santos (2012) ressaltam que o fator de capacidade das usinas eólicas offshore é superior ao das usinas onshore, em virtude da rugosidade da superfície e da ausência de obstáculos que impeçam a circulação natural do vento.

De acordo com a Wind Power (2012), segundo dados projetados pelos membros da União Europeia, o fator de capacidade médio onshore é de $23,6 \%$, enquanto que para as usinas offshore é de 33,3\%. Boccard (2009) avaliou o fator de capacidade médio onshore em $21 \%$, com base no histórico de 5 anos das usinas instaladas na União Europeia.

Apesar de ter um fator de capacidade maior, as usinas eólicas offshore ainda são menos competitivas em relação às usinas eólicas onshore em razão da sua estrutura de custos. Miguel, Ramos e Santos (2012) apresentaram uma tabela comparativa de custos entre os dois tipos de usinas, cujos dados foram obtidos da Wind Power (2012) (Gráfico 5).

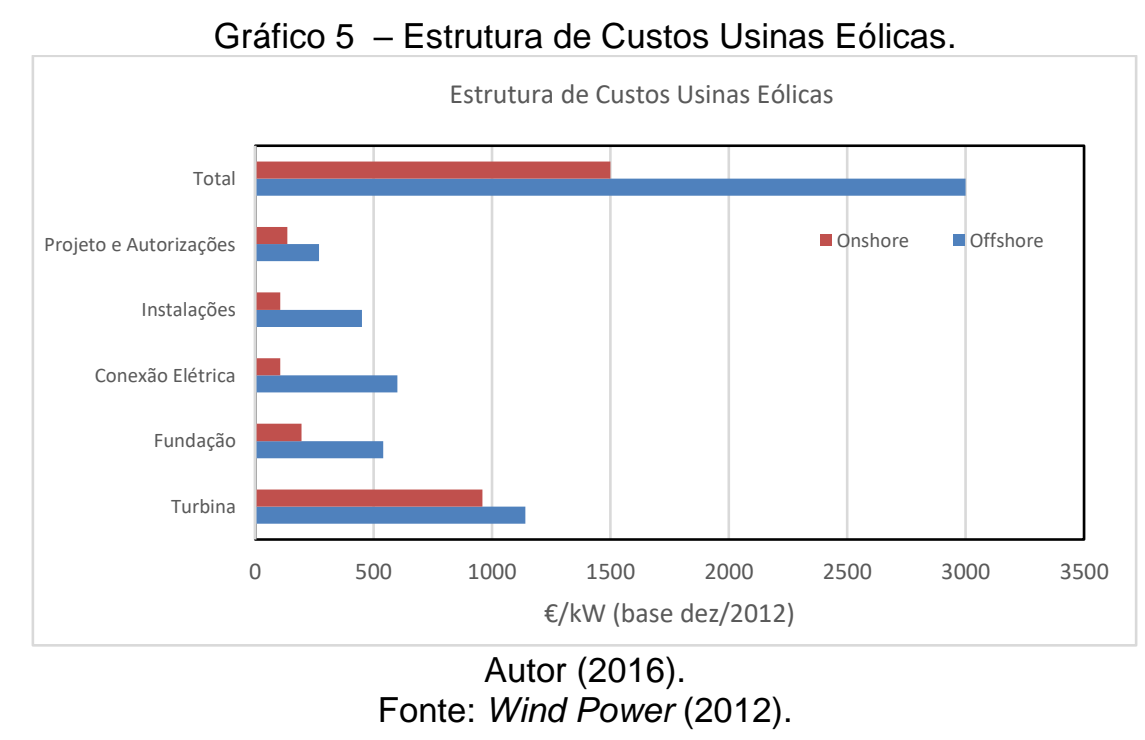


As turbinas offshore são submetidas a altas cargas e tem que ser adaptadas ao ambiente marinho, portanto, devem estar preparadas para as condições de corrosão. Neij et al (2003) demonstraram que o custo de geração reduz a uma taxa de $9 \%$ a $17 \%$ toda vez que a capacidade eólica onshore instalada dobra. Considerando a capacidade instalada no ano de 2012 de 5.415 MW (Gráfico 4), a estimativa para 2020 em 35,8 MW, o custo do investimento em $€ 3.000 / \mathrm{kW}$ instalado (Gráfico 5) e a taxa mínima de redução de custo proposto Neij et al (2003) para usinas onshore (9\% toda vez que a capacidade instalada dobra), estima-se que no ano 2020 , o custo de instalação terá uma redução 17\% em relação ao ano de 2012 e, deverá valer $€ 2.484 / \mathrm{kW}$.

O Gráfico 6 ilustra a evolução os custos de instalação, segundo a expectativa da Technology Roadmap Wind Energy, elaborado pela IEA (2013). A previsão para o ano 2020 é muito próxima da estimada considerando a metodologia proposto Neij et al (2003) (redução de 9\% toda vez que a capacidade instalada dobra).

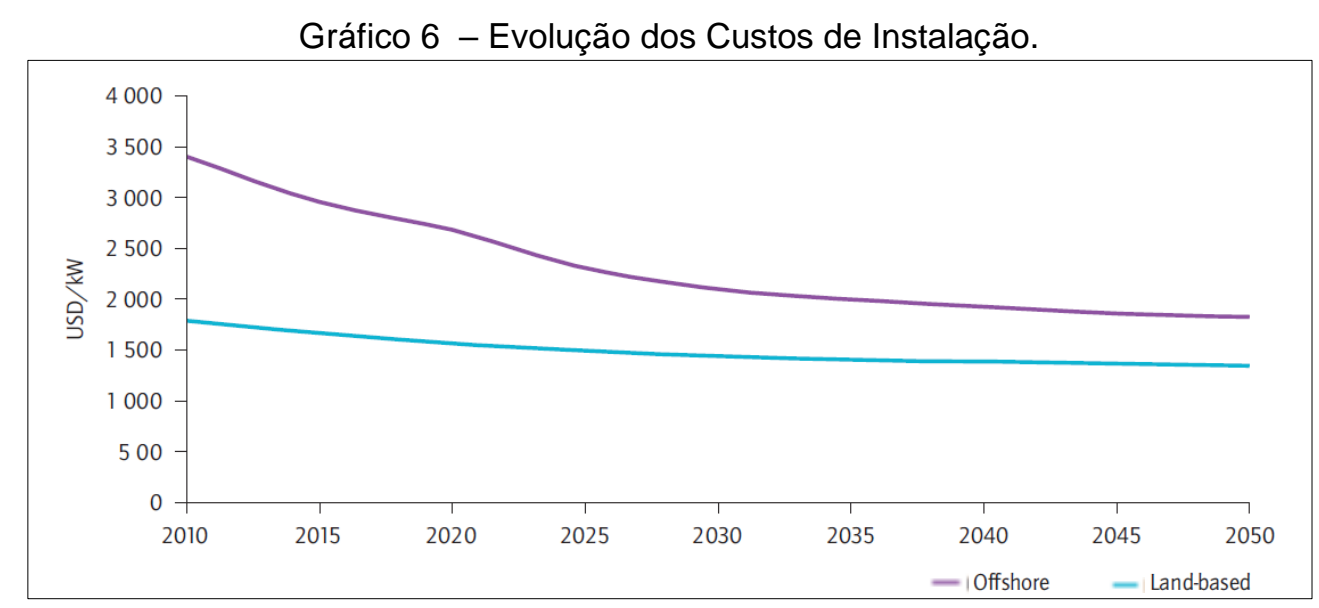

Fonte: Technology Roadmap Wind Energy - IEA.

Apesar da expectativa de redução do custo unitário de instalação apresentada no Technology Roadmap Wind Energy, Van Der Zwaan et al (2012) constatou um aumento nos custos das usinas offshore, entre 2005 a 2012, que foram justificados pelos autores por: i) aumento no preço do cobre e do ferro, ii) aumento na distância das usinas em relação a costa, iii) aumento na profundidade e, iv) tensão entre os fabricantes de turbinas e prestadores de serviço. Os autores asseveram que o cobre e o ferro contribuíram para aumentar entre $20 \%$ a $40 \%$ o custo de instalação das usinas eólicas, considerando os níveis de custo do ano de 2005. 
Segundo informações da Wind Power (2012) e do relatório Offshore Wind Policy And Market Assessment, European Union (2014), elaborado no âmbito do projeto Facilitating Offshore Wind in India (FOWIND), o governo britânico e a indústria eólica firmaram um acordo ${ }^{26}$ para trazer o custo de geração para £100/MWh (equivalente a $€ 124 / \mathrm{MWh}$ ) no ano de 2020.

A pressão do governo sobre a indústria fará com que os preços se reduzam. No caso das usinas offshore, em razão da tecnologia relativamente recente, há espaço para redução dos custos, com o aumento da disponibilidade das plantas, redução dos requisitos de operação e manutenção, redução do tempo de uso de embarcações com o emprego de peças inteiras e redução dos custos das fundações.

Além disso, a entrada de novos fabricantes de aerogeradores e fornecedores de serviços irá trazer benefícios para o custo da energia.

A indústria eólica offshore ainda está em processo de maturação da sua tecnologia. Tem-se verificado algumas tendências, cujos limites ainda são desconhecidos.

A partir de 2009, a capacidade instalada por parque eólico vem aumentando, conforme se verifica no Gráfico 7. O ano 2013 foi impactado pela entrada em operação comercial do parque eólico London Array, de $630 \mathrm{MW}$ de capacidade instalada ${ }^{27}$.

Gráfico 7 - Capacidade Instalada Média por Parque Eólico Offshore.

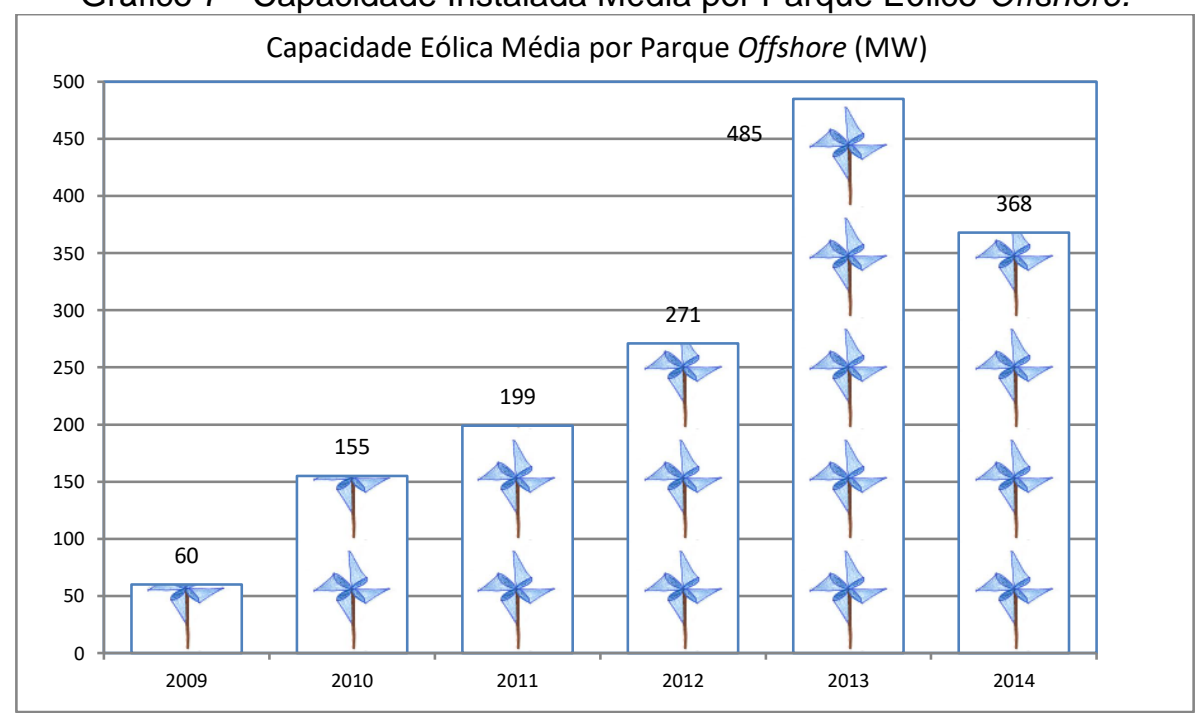

Autor (2016).

Fonte: The European offshore wind industry - key trends and statistics (2014).

${ }^{26}$ Cost Reduction Taskforce and Pathways Project Project.

27 The European offshore wind industry - key trends and statistics 2014. 
O crescimento do tamanho dos parques eólicos offshore é justificado e esperado. Em razão do custo do sistema de transmissão, os investidores adotam a estratégia do aumento da escala, como forma de reduzir o custo unitário da energia produzida ${ }^{28}$. De acordo com Van Der Zwaan et al (2012), a redução do custo unitário de instalação das usinas eólicas offshore está relacionada com o efeito da curva de aprendizagem e o efeito da econômica de escala, que está associado ao crescimento do tamanho dos parques eólicos e da potência instalada das turbinas.

De acordo com os relatórios The European offshore wind industry - key trends and statistics 2010, 2011, 2012, 2013 e 2014, os primeiros aerogeradores tinham capacidade instalada inferior a $1 \mathrm{MW}$. A partir do ano 2000, foram instalados aerogeradores de potência de $2 \mathrm{MW}$. A instalação das primeiras turbinas de $5 \mathrm{MW}$ ocorreram no Parque Eólico Beatrice (Reino Unido), no ano 2007, e no Parque Eólico Hooksiel (Alemanha), no ano 2008. No ano de 2014, foram instalados 340 aerogeradores da Siemens de 3,6 MW29. O aumento da potência dos aerogeradores ter por objetivo a redução do custo unitário da geração, a exemplo do que se observa nas usinas eólicas onshore.

Patel (2005) explica que as turbinas eólicas offshore são maiores que as turbinas onshore com o objetivo de reduzir o custo unitário de instalação. $\mathrm{O}$ autor esclarece que o custo unitário de instalação do parque eólico reduz com o aumento da potência unitária das turbinas eólicas, pois um menor número de barcaças, navios e guindastes são requeridos. O Gráfico 8 ilustra a evolução da potência dos aerogeradores utilizados nas usinas eólicas offshore.

Os primeiros parques eólicos offshore foram construídos próximos da costa e em locais de pouca profundidade. O Parque Eólico Bard (Alemanha), localizado no Mar do Norte, entrou em operação em 2010, está distante a 100 km da costa, com uma profundidade média de 40 metros. Os demais parques eólicos europeus em operação possuem distância da costa inferior a $50 \mathrm{~km}$, sendo que a grande maioria opera em lâmina d'água inferior a 20 metros $^{30}$.

\footnotetext{
${ }^{28}$ Importante registrar que no Brasil, em razão do subsídio no custo de transporte previsto na legislação, atualmente a capacidade instalada dos parques eólicos é no máximo de 30MW.

${ }_{29}$ A Siemens e a MHI Vestas detêm $85 \%$ da capacidade instalada eólica offshore, de acordo com o relatórioThe European offshore wind industry - key trends and statistics 2014.

30 Informações obtidas dos relatórios The European offshore wind industry - key trends and statistics 2010, 2011, 2012, 2013 e 2014.
} 
Gráfico 8 - Evolução da Capacidade Instalada Média por Turbina (MW).

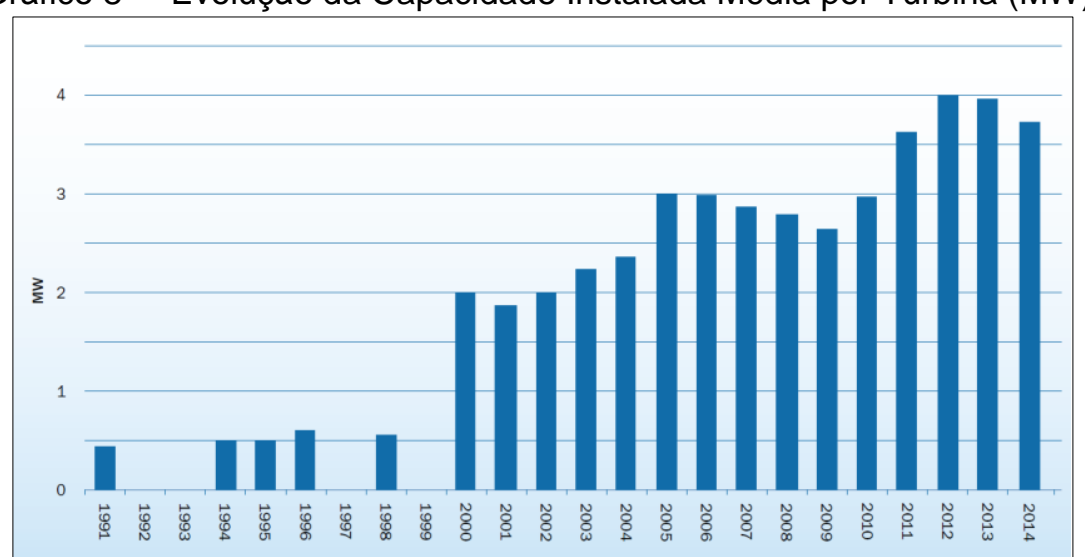

Fonte: The European offshore wind industry - key trends and statistics (2014).

Há uma tendência de afastamento da costa dos parques eólicos e consequentemente aumento da profundidade, conforme se verifica no Gráfico 9.

Gráfico 9 - Evolução da Distância e Profundidade dos Parques Eólicos.

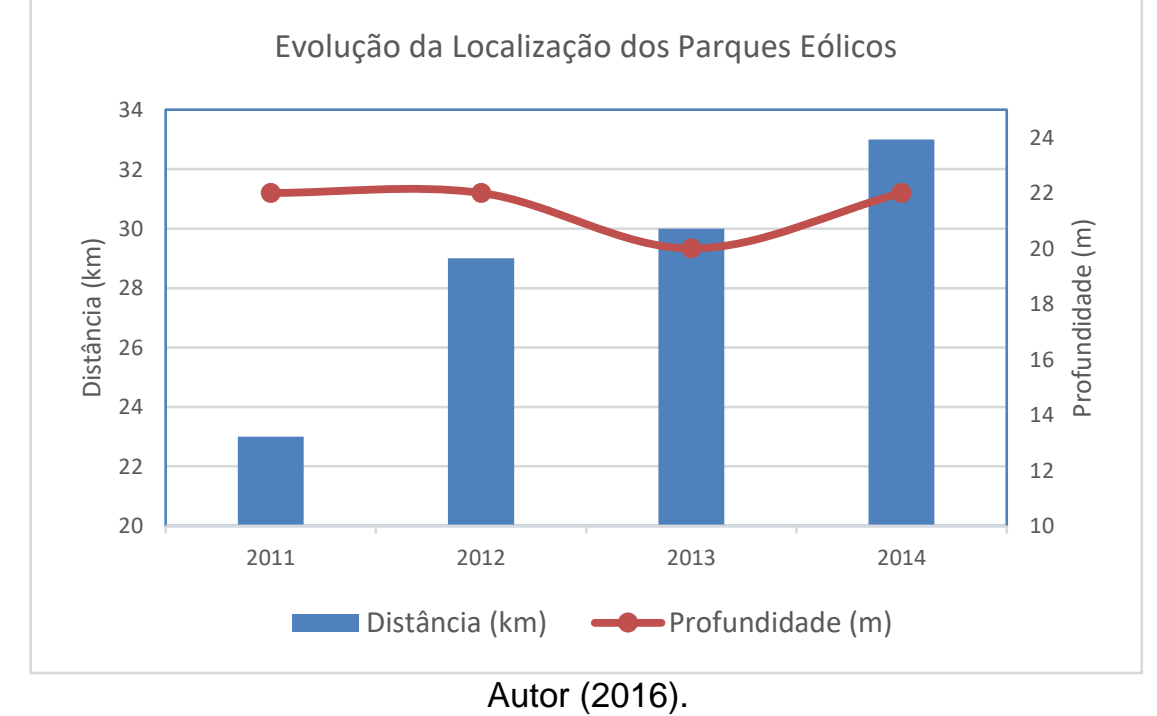

Fonte: The European offshore wind industry - key trends and statistics (2014).

Segundo Patel (2005), a velocidade do vento em mar aberto é de 30 a $40 \%$ maior do que a velocidade do vento na costa, sendo que, para cada $10 \mathrm{~km}$ da costa em direção ao mar, a velocidade aumenta a uma taxa de $1 \mathrm{~m} / \mathrm{s}$. De acordo com o autor, a energia gerada pode aumentar entre 25 a 30\% para usinas eólicas offshore localizadas com distancias superiores a $6 \mathrm{~km}$ da costa, enquanto que para usinas onshore localizadas $6 \mathrm{~km}$ para o interior, a energia gerada reduz entre 12 a $15 \%$. 
O autor propõe uma curva de ganho energético em razão da distância da costa, simulada para uma turbina eólica de $3 \mathrm{MW}$ e altura de 80 metros de instalação, conforme apresentado no Gráfico 10.

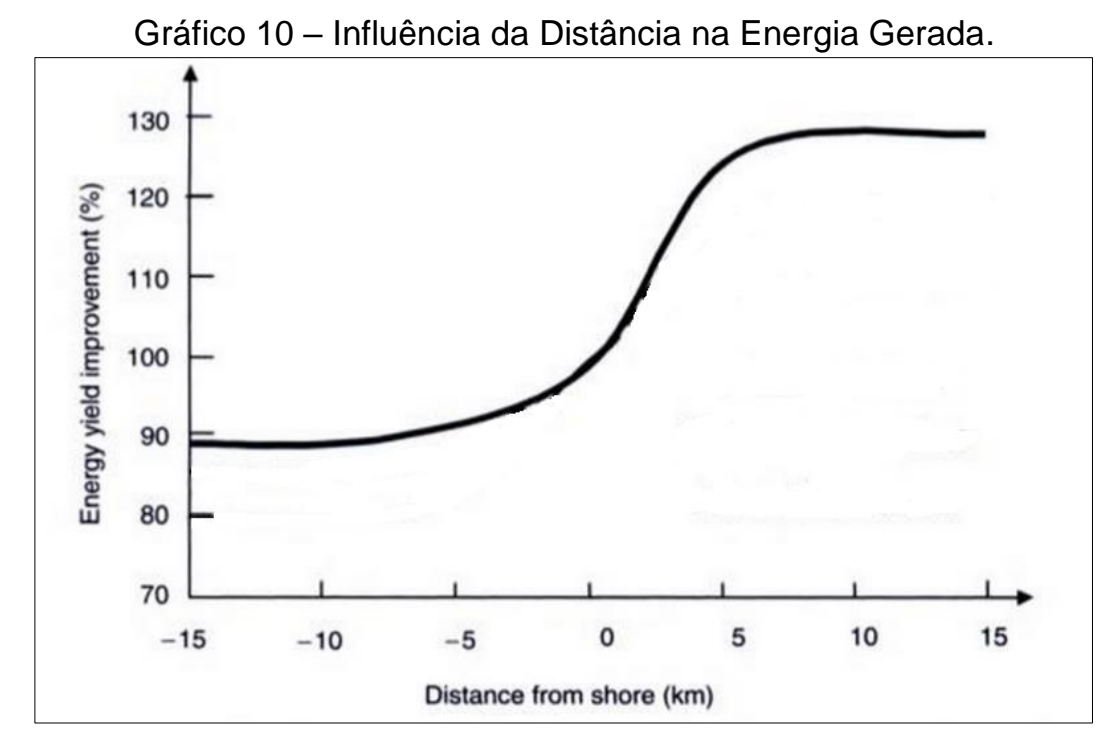

Fonte: Patel (2005). Gráfico ajustado.

Além do aumento na quantidade de energia gerada, conforme demonstrado por Patel (2005), a tendência de distanciamento da costa também pode ser explicada pela ausência de espaço para instalação de novas usinas eólicas. A Alemanha e a Bélgica têm uma faixa litorânea bastante reduzida, ao contrário do Reino Unido e da Holanda, que pode distribuir suas usinas ao longo do seu litoral. Ademais, os projetos eólicos na Alemanha competem com as rotas de navegação e com o turismo, além do que as áreas próximas da costa e das ilhas alemãs são consideradas de preservação ambiental, conforme observado por Viterbo (2008). Tal fato é observado pelo Gráfico 11.

A geração eólica offshore vem apresentando taxas significativas de crescimento, apesar da indústria ainda está em fase de maturação. Os países da Europa, em especial a Inglaterra e Alemanha, têm apostado nessa nova fronteira energética. Por sua vez, o Brasil não pode desprezar esse recurso, especialmente devido ao domínio da tecnologia de plataformas em águas profundas pela Petrobras. 
Gráfico 11 - Distância e Profundidade dos Parques Eólicos por Países.

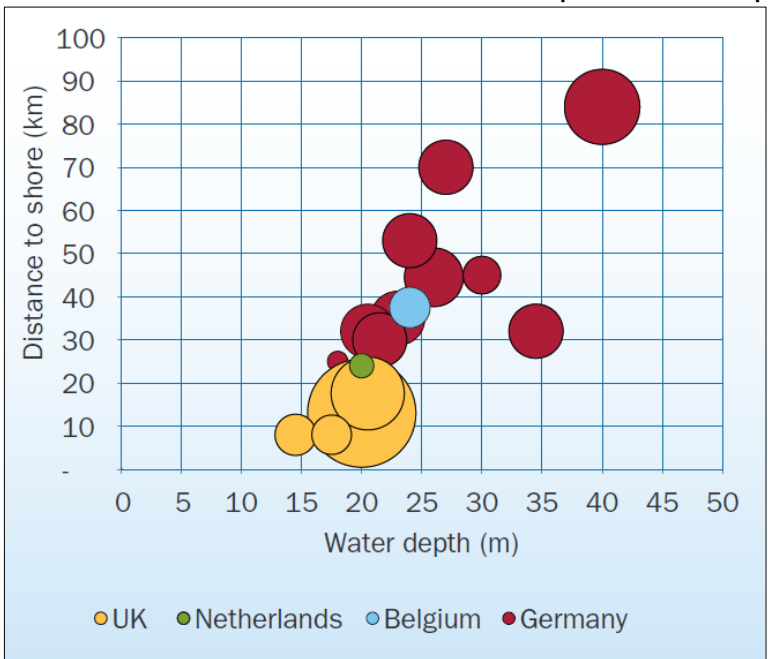

Fonte: The European offshore wind industry - key trends and statistics (2014). 


\section{ASPECTOS DA COMERCIALIZAÇÃO DE ENERGIA - USINAS EÓLICAS}

Este capítulo apresenta o resultado da energia contratada no PROINFA e nos Leilões de Energia. O mecanismo de contabilização do Contrato de Comercialização de Energia no Ambiente Regulado (CCEAR) dos Leilões de Energia Nova e dos Leilões de Fontes Alternativas, assim como o mecanismo de contabilização do Contrato de Energia de Reserva (CER) dos Leilões de Reserva estão também detalhados no texto que se segue.

\subsection{PROINFA}

O Programa de Incentivo às Fontes Alternativas de Energia Elétrica (PROINFA) foi instituído pela Lei no 10.438/2002 com o objetivo de incentivar o desenvolvimento de empreendimentos concebidos com base em fontes eólica, biomassa e pequenas centrais hidrelétricas $(\mathrm{PCH})$ conectados ao SIN.

O PROINFA previu, inicialmente, a contratação de $3.300 \mathrm{MW}$ de potência instalada, rateadas igualmente entre as fontes beneficiadas, limitando-se a contratação por Estado a $20 \%$ das fontes eólica e biomassa e 15\% da $\mathrm{PCH}^{31}$.

A chamada pública foi finalizada no início de 2005 - após três chamadas reclassificatórias e uma nova chamada pública para biomassa, contratando 144 usinas, totalizando 3.299,40 MW de capacidade instalada, sendo 1.191,24 MW provenientes de $63 \mathrm{PCHs}, 1.422,92 \mathrm{MW}$ de 54 usinas eólicas, e 685,24 MW de 27 usinas a base de biomassa, distribuídos em quase todos os Estados da Federação, conforme ilustrado no Gráfico 12, Gráfico 13, Gráfico 14 e Gráfico 15.

A diversidade geográfica dos empreendimentos, assim como a diversidade das fontes, possibilita o aproveitamento da complementaridade dos recursos (vento, vazão dos rios e biomassa), tendo como consequência, a princípio, uma redução na volatilidade de geração total.

\footnotetext{
${ }^{31}$ Essa limitação, no entanto, era preliminar, uma vez que, caso o limite de $1.100 \mathrm{MW}$ de alguma tecnologia não fosse preenchido, o potencial não contratado passaria a ser distribuído entre os Estados que possuíssem as licenças ambientais mais antigas.
} 
Gráfico 12 - Distribuição da Capacidade Instalada das Usinas do PROINFA.

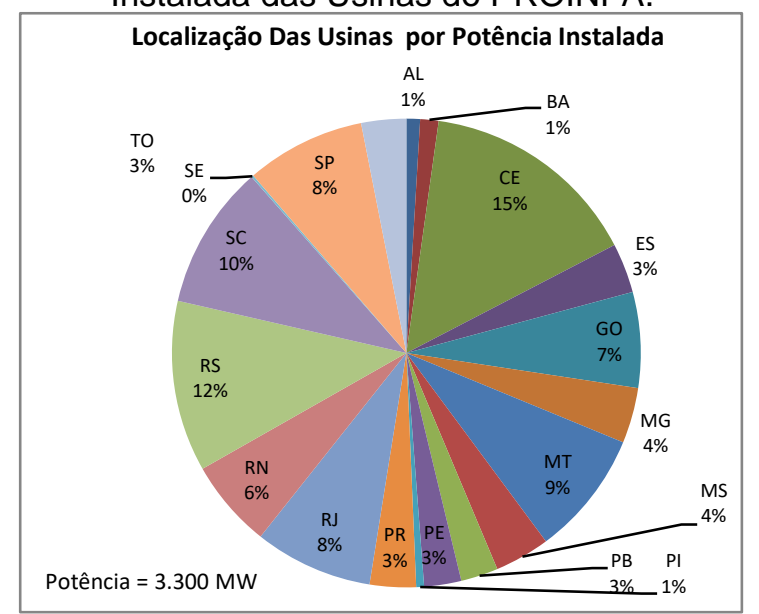

Autor (2016).

Fonte: BRASIL. Eletrobrás (2016).

Gráfico 14 - Distribuição da Capacidade Instalada das Usinas Eólicas Contratadas do PROINFA.

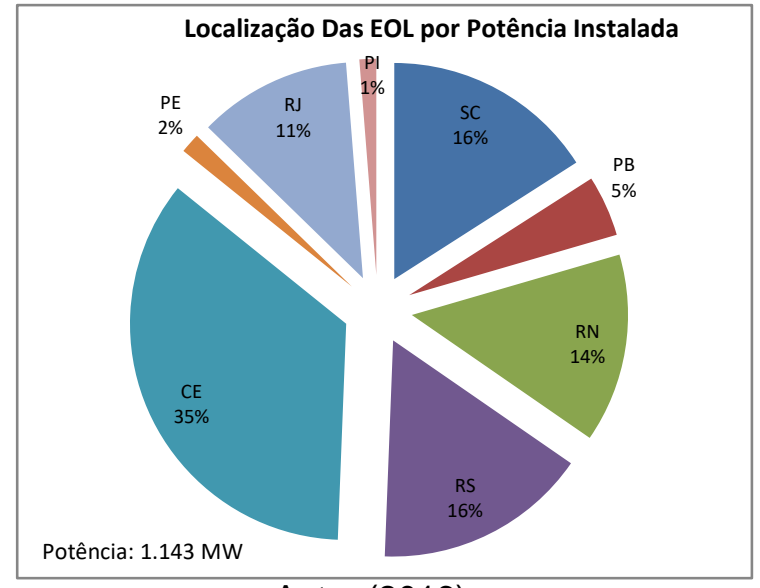

Autor (2016).

Fonte: BRASIL. Eletrobrás (2016).
Gráfico 13 - Distribuição da Capacidade Instalada das Usinas PCHs Contratadas do PROINFA.

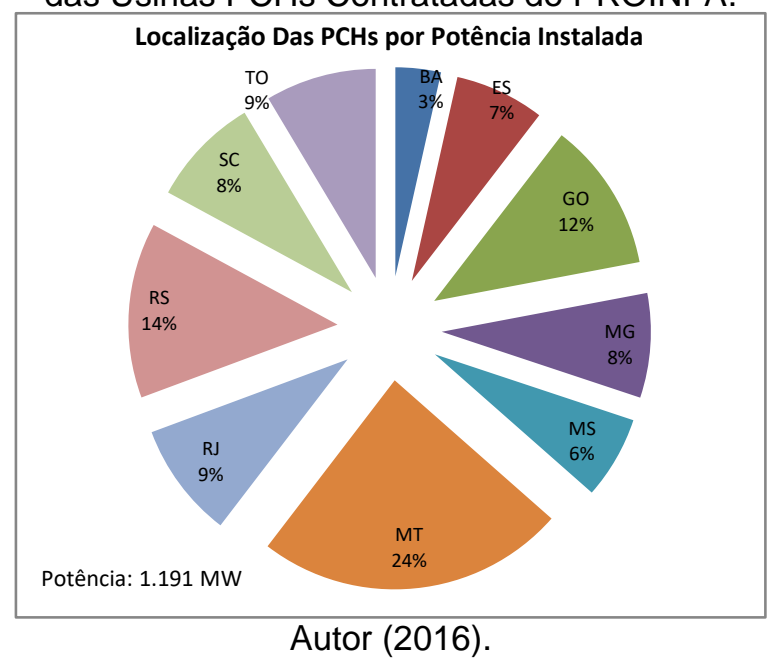

Fonte: BRASIL. Eletrobrás (2016).

Gráfico 15 - Distribuição da Capacidade Instalada das Usinas Termoelétricas Biomassa (UTEs) Contratadas do PROINFA.

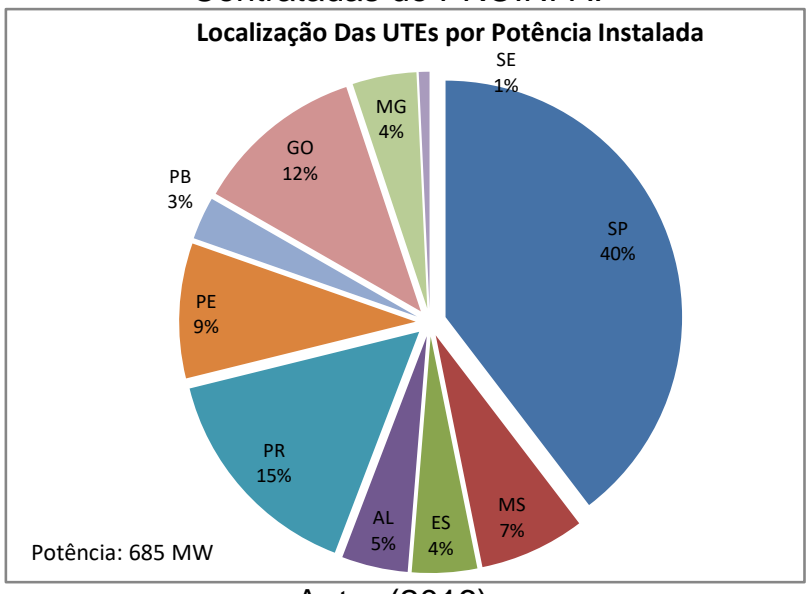

Autor (2016).

Fonte: BRASIL. Eletrobrás (2016).

No capítulo 5 será avaliado se as limitações de contratação previstas na primeira etapa do PROINFA, por fonte e por localidade, resultaram em uma carteira otimizada de investimentos.

Aos vencedores da chamada pública, a Eletrobrás forneceu contratos de longo prazo de 20 anos, com preço fixo da energia gerada (Feed-in Tariffs), diferenciada por fonte, conforme apresentado na TABELA 8.

Os preços da energia do PROINFA refletiam a condição tecnológica da época da contratação, sendo que, atualmente, é notória a redução do preço para o segmento eólico (o item 3.2 e seguintes apresentam os preços atuais, resultados dos Leilões Regulados). 
TABELA 8 - Preço da Energia do PROINFA por Tecnologia.

\begin{tabular}{|c|c|c|}
\hline Fonte & $\begin{array}{l}\text { Preço (mar/2004) - } \\
\text { R\$/MWh }\end{array}$ & $\begin{array}{c}\text { Preço (dez/2015) - R } \$ / M W h \text { - } \\
\text { Atualizado pelo IGPM }\end{array}$ \\
\hline $\mathrm{PCH}$ & 117,02 & 240,27 \\
\hline Eólica & $180,18-204,35$ & $369,96-419,58$ \\
\hline Biomassa Bagaço de Cana & 93,77 & 192,53 \\
\hline Biomassa Casca de Arroz & 103,2 & 211,90 \\
\hline Biomassa Resíduos de Madeira & 101,35 & 208,10 \\
\hline Biogás de Aterro Sanitário & 169,08 & 347,17 \\
\hline
\end{tabular}

A segunda etapa do programa prevê ${ }^{32}$ para o horizonte de 20 anos, o atendimento de $10 \%$ do consumo anual de energia elétrica pelas referidas fontes, distribuídas igualmente, sem limites por Estado.

Até o presente momento o $\mathrm{MME}$ tem sinalizado que não irá fazer uma contratação para a segunda etapa do PROINFA semelhante à primeira etapa, uma vez que a Lei 10.848/2004 instituiu diversos mecanismos de contratação de energia, consoante ao que será apresentado a seguir.

\subsection{LEILÕES REGULADOS}

A Lei 10.848/2004 promoveu mudanças no modelo de contratação de energia para suprimento, que havia sido instituído na década de 90. As concessionárias de distribuição passaram a adquirir energia por meio dos Leilões Regulados realizados pelo MME.

Para atendimento ao mercado das concessionárias de distribuição, o marco regulatório instituiu os seguintes leilões de energia de suprimento ${ }^{33,34:}$ i) Leilões de Energia Nova (segregados em Leilões A-5 e Leilões A-3); ii) Leilões de Energia Existente; iii) Leilões de Fontes Alternativas e iv) Leilões de Projetos Estruturantes.

\footnotetext{
32 Ainda está prevista no art. 3ํㅡㄹ da Lei 10.438/2002, mas o Ministério de Minas e Energia tem aumentado a participação das fontes renováveis na matriz elétrica por meio dos Leilões de Energia previstos na Lei 10.848/2004.

${ }_{33}$ No jargão do setor elétrico costuma-se dizer que esses Leilões geram contratos que formam lastro de energia para atendimento comercial da carga da concessionária de distribuição.

${ }^{34}$ Além desses, há outros mecanismos de aquisição de energia pelas concessionárias de distribuição previstos no marco regulatório, tal como a contratação de geração distribuída.
} 
Até dezembro de 2015, foram realizados 20 (vinte) Leilões de Energia Nova ${ }^{35}$, entre Leilões A-5 e A-3 ${ }^{36}$. Entre 2005 e 2009, as usinas térmicas a combustíveis fósseis, principalmente aquelas que utilizam combustíveis fósseis líquidos, protagonizaram os Leilões. A partir de 2009, os certames passaram a ser dominados pelas usinas eólicas, cuja tecnologia se tornou competitiva e, pelo fato do MME ter restringido a participação de usinas térmicas acima de determinado Custo Variável Unitário (CVU) ${ }^{37}$.

O MME realizou 3 (três) Leilões de Fontes Alternativas, específicos para empreendimentos eólicos, $\mathrm{PCH}$ e usinas térmicas a biomassa. O primeiro ocorreu em 2007 e negociou energia de usinas termoelétricas a biomassa e PCHs. O segundo ocorreu em 2010, com expressiva participação de usinas eólicas. O último ocorreu em 2015 e negociou energia de usinas termoelétricas a biomassa e usinas eólicas.

Além dos leilões de energia de suprimento para atendimento do mercado das concessionárias de distribuição, há previsão no marco regulatório dos Leilões de Energia de Reserva (LER), cuja energia não forma lastro comercial para atendimento ao mercado das concessionárias de distribuição, sendo que sua aquisição é compulsória por todos os consumidores do SIN, num sistema de contratação de energia semelhante ao Single Buyer, onde a CCEE faz o papel do Comprador Único.

Até dezembro de 2015, foram realizados 9 (nove) Leilões de Energia de Reserva. O 1 LER foi exclusivo para contratação da fonte biomassa. O 20 LER exclusivo para a fonte eólica. $O 3^{0}$ e $4^{\circ}$ LER contrataram energia provenientes de fontes biomassa, eólica e $\mathrm{PCH}$. O 5는 LER foi exclusivo para fonte eólica, com a novidade de considerar a capacidade de escoamento da rede. O 6 LER, trouxe a novidade da contratação da fonte solar, com um total de 31 empreendimentos dessa fonte e mais 31 empreendimentos de fonte eólica. O $7^{\circ}$ LER foi um leilão exclusivo para fonte solar, tendo sido contratados $231,5 \mathrm{MW}$ médios. O $8^{\circ} \mathrm{LER}$ negociou usinas eólicos e solar. No $9^{\circ}$ LER não houve negociação.

Segundo o relatório InfoLeilão, elaborado pela CCEE em dezembro de 2015, os leilões de energia para o mercado regulado, desde o ano 2004, negociaram 24.421

\footnotetext{
${ }^{35}$ Não estão sendo considerados os Leilões de Projetos Estruturantes, que contratou a energia da UHE Belo Monte, UHE Santo Antônio e UHE Jirau.

36 O LEN A-5 de 2009 e o LEN A-3 de 2012 foram cancelados em razão do baixo crescimento do mercado das concessionárias de distribuição e não estão inclusos nessa estatística.

${ }^{37}$ A partir de 2009, o MME limitou o valor do CVU das Usinas Térmicas interessadas em participar nos Leilões Regulados, como uma forma de restringir a participação das Usinas à óleo diesel e combustível.
} 
MW médios em Leilões de Energia Nova; 27.375 MW médios em Leilões de Energia Existente; 5.076 MW médios em Leilões de Ajuste; 3.399 MW médios em Leilões de Energia de Reserva; 997 MW médios em Leilões de Fontes Alternativas; e 6.135 MW médios em Leilões de Projetos Estruturantes (UHEs de Santo Antônio, Belo Monte e Jirau).

O MME tem privilegiado a contratação de energia por meio de competição entre as fontes e localidades. Diversamente das restrições previstas do PROINFA, os Leilões Regulados não preveem limites de contratação por fonte ou por localização da usina.

Como consequência, os Leilões de Energia Nova foram dominados num primeiro momento por usinas térmicas de combustíveis líquidos fósseis (óleo diesel e óleo combustível) e a partir de 2010, pelas usinas eólicas, estas concentradas em alguns Estados da federação.

Em dezembro de 2015, o Boletim Mensal de Dados do Setor Eólico elaborado pela ABEEólica, contabilizou 7,96 GW de capacidade instalada construída e 10,11 GW de capacidade instalada em construção ou contratada. Desse total, os Estados da Bahia, Rio Grande do Norte, Ceará, Rio Grande do Sul e Piauí, concentram 90\% da capacidade instalada (16,16 GW), conforme ilustrado no Gráfico 16.

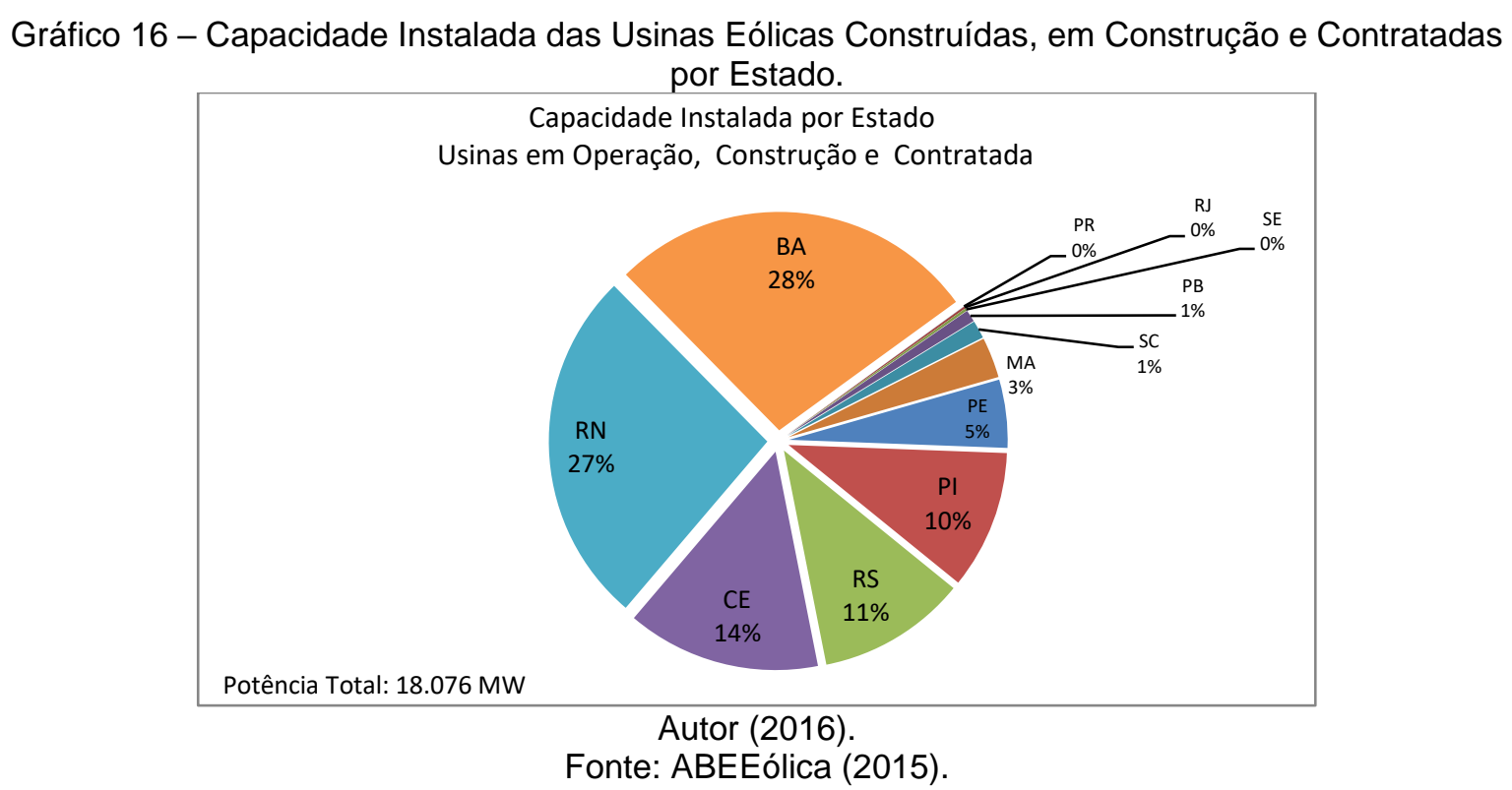


Diversamente da disposição geográfica dos empreendimentos do PROINFA, conforme apresentado no Gráfico 16 , os empreendimentos eólicos resultantes dos Leilões Regulados estão concentrados nos Estados da Bahia, Rio Grande do Norte, Ceará, Rio Grande do Sul e Piauí.

A concentração dos empreendimentos eólicos pode prejudicar 0 aproveitamento de eventual complementaridade da geração e reduzir a confiabilidade da operação energética, na medida em que aumenta a dependência do vento daquela região. Em razão das especificidades de cada tipo de Leilão, nos tópicos seguintes serão apresentadas as principais características dos contratos decorrentes.

\subsection{CONTRATOS DE COMERCIALIZAÇÃO DE ENERGIA NO AMBIENTE REGULADO (CCEAR) - LEILÕES DE FONTES ALTERNATIVAS (LFA)}

O MME realizou 3 (três) Leilões de Fontes Alternativas, sendo que no primeiro leilão não houve a participação de empreendimentos eólicos. A TABELA 9 apresenta os principais resultados dos empreendimentos eólicos nos Leilões de Fonte Alternativa.

TABELA 9 - Leilões de Fontes Alternativas com Participação de Usinas Eólicas.

\begin{tabular}{ccccccc}
\hline Leilão/Ano & $\begin{array}{c}\text { Número de } \\
\text { Empreendimentos }\end{array}$ & $\begin{array}{c}\text { Capacidade } \\
\text { Instalada (MW) }\end{array}$ & $\begin{array}{c}\text { Garantia } \\
\text { Física } \\
(\text { MWmédios })\end{array}$ & $\begin{array}{c}\text { Fator de } \\
\text { Capacidade } \\
\text { (\%) }\end{array}$ & $\begin{array}{c}\text { Energia } \\
\text { Contratada } \\
\text { (MW médios) }\end{array}$ & $\begin{array}{c}\text { Preço- } \\
\text { Dez//2015 } \\
\text { (R\$Wh) }\end{array}$ \\
\hline $\begin{array}{c}2^{\circ} \text { LFA } \\
(2010)\end{array}$ & 50 & $1.519,60$ & 658,50 & 43,33 & 644,34 & 190,60 \\
$3^{\circ}$ LFA & 3 & 90,00 & 42,30 & 47,00 & 29,72 & 187,84 \\
\hline$(2015)$ & $1.609,60$ & 700,80 & 43,49 & 674,06 & 190,48 \\
\hline Total & 53 & \multicolumn{7}{c}{ Autor (2016). } \\
\hline \multicolumn{7}{c}{ Fonte: BRASIL. CCEE (2015). }
\end{tabular}

Neste leilão, o contrato (CCEAR) é firmado na modalidade disponibilidade ${ }^{38}$ com prazo de duração de 20 anos e receita fixa. O investidor não é obrigado a destinar a totalidade da energia do empreendimento para o ambiente regulado, tendo a possibilidade de comercializar a parcela da energia não comprometida com o CCEAR

38 De acordo com o art. 28 do Decreto 5.163/2004, na "modalidade por disponibilidade de energia elétrica, os custos decorrentes dos riscos hidrológicos serão assumidos pelos agentes compradores, e eventuais exposições financeiras no mercado de curto prazo da CCEE, positivas ou negativas, serão assumidas pelos agentes de distribuição, garantido o repasse ao consumidor final, conforme mecanismo a ser estabelecido pela ANEEL". 
no mercado livre ou liquidar ao Preço da Liquidação das Diferenças (PLD), inclusive em caso de antecipação da data de operação comercial.

No entanto, o investidor se obriga a apresentar lastro oriundo de contrato bilateral firmado com terceiros nas seguintes hipóteses: i) caso a data de entrada em operação comercial da usina, fixada no ato de outorga, for posterior à data do início do suprimento do contrato, ou; ii) caso ocorra atraso na entrada em operação comercial do empreendimento, hipótese em que se aplica a regra de repasse prevista na Resolução Normativa ANEEL nº 165, de 19 de setembro de 2005.

O contrato prevê uma receita fixa anual paga mensalmente, independente do montante de energia gerado. Em razão das incertezas na geração, há um mecanismo de conciliação anual e quadrienal da energia gerada, que implica no ressarcimento pela quantidade de energia não gerada, considerando o montante anual e quadrienal contratado.

O CCEAR discrimina o montante de energia contratada para cada ano até o seu termo final, e é dividido em 5 (cinco) quadriênios, prevendo ressarcimento pelo vendedor, quando a geração for inferior à meta fixada (montante contratado), compensadas em 12 meses, no ano seguinte, com a receita fixa do empreendimento. No último leilão, o contrato fixou o ressarcimento no mês civil subsequente, podendo ser estendido para os demais meses, caso a receita do gerador seja inferior ao valor do ressarcimento.

Desta forma, o ressarcimento do gerador ocorre quando: i) o somatório de geração do quadriênio for inferior ao somatório da energia contratada no mesmo período, ou; ii) o somatório de geração no ano for inferior à $90 \%$ da energia anual contratada.

Nos dois casos, o ressarcimento é um percentual da receita fixa (déficit anual ou déficit quadrienal), calculado pela relação entre a energia gerada e a energia contratada no período (para cada ano, utiliza-se a relação entre a energia gerada e 90\% da energia anual contratada). No último Leilão, para fins de ressarcimento, o contrato passou a considerar o maior valor entre o PLD médio do período (anual ou quadrienal) e o valor da receita, além de um acréscimo de $6 \%$ aplicado sobre valor da receita, no ressarcimento quadrienal.

Para fazer frente ao compromisso da energia contratada no quadriênio, o contrato prevê a criação de um "reservatório dinâmico de energia" (no contrato foi denominado de saldo acumulado, semelhante a uma conta gráfica). 
No primeiro ano de cada quadriênio, o "reservatório" poderá armazenar no máximo $30 \%$ da energia contratada, na hipótese da energia gerada no ano tenha sido superior a energia contratada.

No segundo ano de cada quadriênio, o "reservatório" poderá armazenar no máximo $20 \%$ da energia contratada, na hipótese da energia gerada acumulada tenha sido superior a energia contratada.

No terceiro ano, o "reservatório" poderá armazenar no máximo 10\% da energia contratada, na hipótese da energia gerada acumulada tenha sido superior a energia contratada.

No último ano do quadriênio, o "reservatório" não poderá armazenar, mesmo que a energia gerada acumulada tenha sido superior a energia contratada.

A energia armazenada no "reservatório" será destinada para a cobertura de eventuais déficits nos anos seguintes do mesmo quadriênio, limitados a $90 \%$ da energia contratada, uma vez que déficits superiores a $10 \%$ devem ser ressarcidos anualmente. Em outras palavras, o vendedor pode fazer frente a três déficits, passados ou futuros, de, no máximo, 10\% da energia contratada anual. A partir do momento em que é atingido o limite do "reservatório" (saldo acumulado), o excedente de energia gerada pode ser comercializado no mercado livre ou no mercado de curto prazo. O Gráfico 17 ilustra o mecanismo de contabilização descrito.

Gráfico 17 - Mecanismo de Contabilização do Contrato de Energia do LFA.

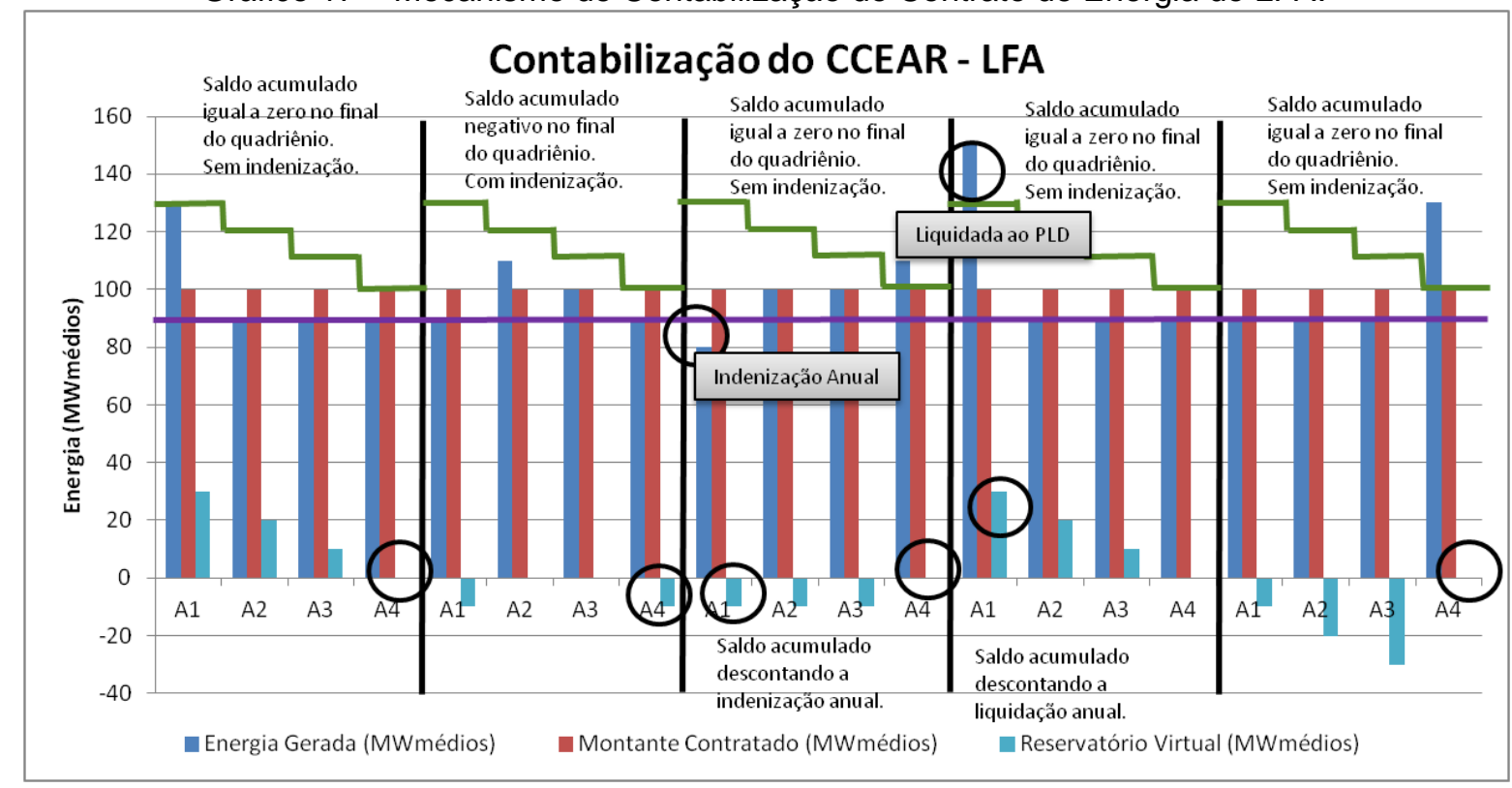

Autor (2016). 
Observa-se no Gráfico 17 que no primeiro, terceiro, quarto e quinto quadriênio, o somatório de geração do quadriênio foi igual ao somatório da energia contratada no mesmo período, sendo assim, não haverá ressarcimento pelo investidor. No segundo quadriênio, o somatório de geração foi inferior ao somatório da energia contratada, havendo ressarcimento pelo investidor.

No primeiro ano do primeiro quadriênio, a energia gerada superou em $30 \%$ a energia contratada atingido o limite possível de armazenamento no reservatório virtual (saldo acumulado). Por sua vez, nos demais anos desse quadriênio, o nível de geração ficou em $90 \%$ da energia contratada. Como consequência, o saldo acumulado foi utilizado nos demais anos do quadriênio para atingir a meta da energia contratada no período (quadriênio) e evitar o ressarcimento.

No segundo quadriênio, apenas no segundo ano, a usina gerou acima da energia contratada do ano, possibilitando o armazenamento no reservatório virtual, porém o saldo acumulado no período (quadriênio) não foi suficiente para fazer frente aos déficits de geração dos demais anos do quadriênio, o que resultou em ressarcimento.

No terceiro quadriênio, em seu primeiro ano, o nível de geração ficou $90 \%$ abaixo do valor contratado, implicando em ressarcimento no ano. Porém, nos dois anos seguintes, o nível de geração ficou igual valor contratado e no último ano, a geração ficou $10 \%$ acima do valor contratado, de modo que o saldo acumulado nesse quadriênio foi zero, evitando o ressarcimento do período.

No primeiro ano do quarto quadriênio, o nível de geração ficou acima do limite de $30 \%$ do valor contratado, implicando em liquidação a energia excedente ao PLD. Porém, nos demais anos, o nível de geração ficou em $90 \%$ do valor contratado, de modo que o saldo acumulado no quadriênio foi zero, evitando o ressarcimento do período.

No quinto quadriênio, os três primeiros anos gerou $90 \%$ do valor contratado, gerando um déficit na conta gráfica de $-30 \%$, que foi totalmente compensado pela geração acima do montante contratado, no quarto ano desse quadriênio.

A receita do CCEAR é composta por uma parcela fixa e outra variável, conforme ilustrado na Equação (1). A parcela fixa compreende o valor da receita definido pelo empreendedor no leilão. 
A parcela variável é composta pelo ressarcimento anual (Equação (3)) e pelo ressarcimento quadrienal (Equação (4)), além da receita com a venda da energia no mercado do curto prazo, para o montante anual de energia gerado acima do montante anual contratual adicionado do reservatório virtual (Equação (2)).

$$
\begin{aligned}
& R_{a}=R F_{a}+\left(R V_{C P}-P_{a}-P_{q}\right) \\
& R V_{C P}=\max \left\{0 ;\left[P L D_{a} x\left(E G_{a}-\text { Delta }_{i} x E C_{a}\right)\right]\right\} \\
& P_{a}=\max \left\{0 ;\left[R F_{a} x\left(\frac{\left(0,9 x E C_{a}-E G_{a}\right)}{E C_{a}}\right)\right]\right\} \\
& P_{q}=\max \left\{0 ;\left[R F_{q} x\left(\frac{\left(E C_{q}-E G_{q}\right)}{E C_{q}}\right)\right]\right\}
\end{aligned}
$$

Onde:

$R_{a}$ é a receita anual do empreendimento, em $\mathrm{R} \$$;

$R F_{a}$ é a receita fixa anual do empreendimento, em $\mathrm{R} \$$;

$R F_{q}$ é a receita fixa quadrianual do empreendimento, em $\mathrm{R} \$$;

$R V_{C P}$ é a receita de venda da energia no mercado de curto prazo, em $\mathrm{R} \$$;

$P_{a}$ é a penalidade anual (ressarcimento), em $\mathrm{R} \$$;

$P_{q}$ é a penalidade quadrianual (ressarcimento), em $\mathrm{R} \$$;

$P L D_{a}$ é o preço médio anual do mercado de curto prazo, em $\mathrm{R} \$ / \mathrm{MWh}$;

$E G_{a}$ é a energia anual gerada, em MWh;

$E C_{a}$ é a energia anual contratada, em MWh;

$E G_{q}$ é a energia quadrianual gerada, em $M W h$ (na apuração da $E G_{q}$, faz-se $E G_{a}$ igual a $90 \%$ da $\mathrm{EC}_{\mathrm{a}}$, quando $\mathrm{EG}_{\mathrm{a}}$ for menor que $90 \%$ da $\mathrm{EC}_{\mathrm{a}}$ );

$E C_{q}$ é a energia quadrianual contratada, em MWh;

Delta $_{i}$ é igual a 1,3; 1,2; 1,1; e 1, para o primeiro, segundo, terceiro e quarto ano do quadriênio, respectivamente, equivalente ao reservatório virtual dinâmico (conta gráfica). 


\subsection{CONTRATOS DE COMERCIALIZAÇÃO DE ENERGIA NO AMBIENTE REGULADO (CCEAR) - LEILÕES DE ENERGIA NOVA (LEN)}

Até dezembro de 2015, foram realizados 20 Leilões de Energia Nova ${ }^{39}$, entre Leilões A-5 e A-3. No entanto, foi somente a partir de 2009, que os certames passaram a ser dominados pelas usinas eólicas, face à competitividade da fonte e à restrição imposta pelo MME a participação de usinas térmicas acima de determinado CVU.

Os leilões de energia para o mercado regulado, desde o ano 2004, negociaram 24.421 MW médios em Leilões de Energia Nova, sem considerar a energia proveniente dos Projetos Estruturantes (UHE Santo Antônio, UHE Jirau e UHE Belo Monte $)^{40}$, sendo que 3.237,22 MW médios de origem eólica. A TABELA 10 apresenta os principais resultados dos Leilões de Energia Nova que tiveram a participação de empreendimentos eólicos.

TABELA 10 - Leilões de Energia Nova com Participação de Usinas Eólicas.

\begin{tabular}{|c|c|c|c|c|c|c|}
\hline Leilão/Ano & $\begin{array}{c}\text { Número de } \\
\text { Empreendimentos }\end{array}$ & $\begin{array}{l}\text { Capacidade } \\
\text { Instalada (MW) }\end{array}$ & $\begin{array}{c}\text { Garantia } \\
\text { Física } \\
\text { (MWmédios) }\end{array}$ & $\begin{array}{c}\text { Fator de } \\
\text { Capacidade (\%) }\end{array}$ & $\begin{array}{c}\text { Energia } \\
\text { Contratada } \\
\text { (MW médios) }\end{array}$ & $\begin{array}{c}\text { Preço - } \\
\text { Dez/2015 } \\
\text { (R\$/MWh) }\end{array}$ \\
\hline $\begin{array}{c}12^{\circ} \text { LEN (A-3) } \\
2011\end{array}$ & 44 & 1067,60 & 484,2 & 45,35 & 406,96 & 134,07 \\
\hline 13은 2011 & 39 & 976,50 & 478,50 & 49,00 & 452,71 & 138,76 \\
\hline $\begin{array}{c}15^{\circ} \text { LEN (A-5) } \\
2012\end{array}$ & 10 & 281,90 & 152,20 & 53,99 & 151,70 & 109,69 \\
\hline $\begin{array}{c}170 \text { LEN (A-3) } \\
2013\end{array}$ & 39 & 867,70 & 380,20 & 43,82 & 332,73 & 147,88 \\
\hline $\begin{array}{c}18^{\circ} \text { LEN (A-5) } \\
2013\end{array}$ & 97 & $2.337,80$ & $1.083,40$ & 46,34 & 974,00 & 140,18 \\
\hline $\begin{array}{l}\text { 19o LEN (A-3) } \\
2014\end{array}$ & 21 & 551,00 & 274,50 & 49,82 & 265,78 & 147,53 \\
\hline $\begin{array}{l}20=\text { LEN (A-5) } \\
2014\end{array}$ & 36 & 925,95 & 435,60 & 47,04 & 415,38 & 151,69 \\
\hline $\begin{array}{c}22^{2} \text { LEN (A-3) } \\
2015\end{array}$ & 19 & 538,80 & 252,10 & 46,79 & 237,96 & 187,24 \\
\hline Total & 305 & $7.547,25$ & $3.540,70$ & 47,10 & $3.237,22$ & 144,12 \\
\hline
\end{tabular}

Fonte: BRASIL. CCEE (2015).

O contrato do LEN é semelhante ao contrato do LFA. Neste leilão, o contrato (CCEAR) é firmado na modalidade disponibilidade com prazo de duração de 20 anos e receita fixa.

O mecanismo de contabilização anual e quadrienal é o mesmo, com diferenças nos valores dos ressarcimentos (penalidades).

39 O LEN A-5 de 2009 e o LEN A-3 de 2012 foram cancelados em razão do baixo crescimento do mercado das concessionárias de distribuição e não estão inclusos nessa estatística.

40 Nos Leilões dos Projetos Estruturantes (UHEs de Santo Antônio, Belo Monte e Jirau) foram negociados 6.135 MW médios. 
O CCEAR contém cláusulas específicas para o vendedor ressarcir ao comprador, observadas as seguintes condições: (i) geração média anual inferior a 90\% do montante contratado; e (ii) geração média quadrienal inferior, em qualquer valor, ao montante contratado. A energia elétrica não suprida será ressarcida pela receita fixa ou PLD médio, o que for maior, no período do ano ou no quadriênio, conforme o caso. O ressarcimento está previsto em 12 parcelas mensais homogêneas.

Para fazer frente ao compromisso da energia contratada no quadriênio, o contrato prevê a criação de um reservatório dinâmico de energia virtual (no contrato foi denominado de saldo acumulado), semelhante ao contrato do LFA, com limites de $30 \%, 20 \%, 10 \%$ e $0 \%$ aplicados sobre o montante de energia contratada, para o primeiro, segundo, terceiro e quarto ano, respectivamente.

A energia gerada acima do limite do saldo acumulado pode ser comercializada no mercado livre ou liquidada no mercado de curto prazo. O Gráfico 18 apresenta o mecanismo de contabilização do CCEAR do LEN, cujas regra são semelhantes ao CCEAR do LFA (PANTOJA, 2013).

Gráfico 18 - Mecanismo de Contabilização do Contrato de Energia do LEN.

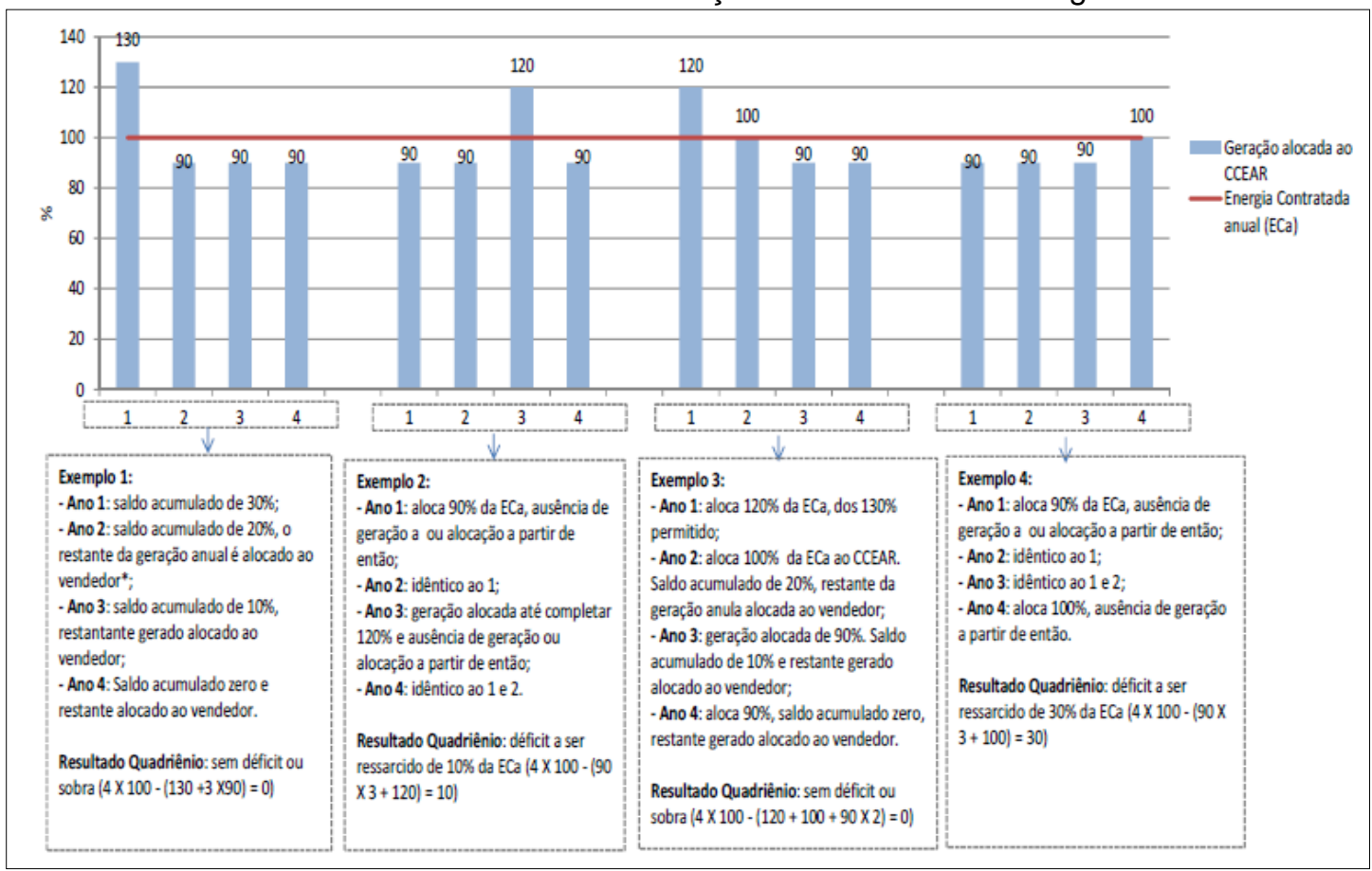

Fonte: Pantoja (2013). 
No $1^{\circ}$ e $3^{\circ}$ quadriênio não há déficit ou sobra de energia, portanto não incide 0 ressarcimento ou a possibilidade de liquidação no mercado de curto prazo. № $2^{\circ}$ e $4^{\circ}$ quadriênio, a energia gerada ficou abaixo da energia contratada, portanto o investidor deverá ressarcir o déficit ao valor do PLD médio ou ao preço do Contrato, o que for maior.

Em síntese, o investidor recebe uma receita fixa anual, caso a energia gerada seja superior a $90 \%$ da energia contratada. Caso o desempenho de produção anual fique abaixo desse limite, deverá ressarcir os compradores pela energia gerada abaixo do limite, valorada ao preço do contrato ou ao PLD médio, o que for maior. Por sua vez, a receita variável anual está condicionada ao nível de produção, que precisa ultrapassar o limite superior da banda (saldo acumulado), podendo ser liquidada no mercado de curto prazo.

No quadriênio, o gerador deve atingir o valor contratado, sob pena da obrigação de ressarcimento do montante de energia deficitário valorado pelo preço do contrato ou pelo PLD médio. Se o nível de geração ultrapassar o valor do contrato, o gerador terá direito a liquidar a energia ao PLD.

\subsection{CONTRATOS DE ENERGIA DE RESERVA (CER) - LEILÕES DE ENERGIA DE RESERVA (LER)}

Até dezembro de 2015, foram contratados 3.399 MW médios em 9 (nove) Leilões de Energia Reserva. O 1 LER foi exclusivo para contratação da fonte biomassa. O 2ํㅡㄴ LER exclusivo para a fonte eólica. O 3ํ e 4 LER contrataram energia provenientes de fontes biomassa, eólica e $\mathrm{PCH}$. O $5^{\circ}$ LER foi exclusivo para fonte eólica, com a novidade de considerar a capacidade de escoamento da rede. O 6 LER, trouxe a novidade da contratação da fonte solar, com um total de 31 empreendimentos dessa fonte e mais 31 empreendimentos de fonte eólica. O $7^{\circ}$ LER foi um leilão exclusivo para fonte solar, tendo sido contratados $231,5 \mathrm{MW}$ médios. $\mathrm{O} 8^{\circ} \mathrm{LER}$ negociou usinas eólicas e solares. No $9^{\circ}$ LER não houve negociação e foi exclusivo para fonte termelétrica a gás natural. A TABELA 11 apresenta os principais resultados dos Leilões de Reserva que tiveram a participação de empreendimentos eólicos. 
TABELA 11 - Leilões de Energia de Reserva com Participação de Usinas Eólicas.

\begin{tabular}{ccccccc}
\hline Leilão/Ano & $\begin{array}{c}\text { Número de } \\
\text { Empreendimentos }\end{array}$ & $\begin{array}{c}\text { Capacidade } \\
\text { Instalada (MW) }\end{array}$ & $\begin{array}{c}\text { Garantia } \\
\text { Física } \\
\text { (MWmédios) }\end{array}$ & $\begin{array}{c}\text { Fator de } \\
\text { Capacidade (\%) }\end{array}$ & $\begin{array}{c}\text { Energia } \\
\text { Contratada } \\
\text { (MW médios) }\end{array}$ & $\begin{array}{c}\text { Preço- } \\
\text { Dez/2015 } \\
\text { (R\$/MWh) }\end{array}$ \\
\hline 20 LER/2009 & 71 & $1.805,70$ & 783,10 & 43,37 & 753,52 & 220,95 \\
30 LER/2010 & 20 & 528,20 & 266,80 & 50,51 & 255,27 & 177,12 \\
40 LER/2011 & 34 & 861,10 & 428,80 & 49,80 & 422,39 & 134,02 \\
50 LER/2013 & 66 & $1.505,20$ & 700,70 & 46,55 & 675,96 & 133,26 \\
60 LER/2014 & 31 & 769,10 & 333,40 & 43,35 & 333,40 & 159,57 \\
80 LER/2015 & 20 & 548,20 & 284,80 & 51,95 & 262,78 & 205,41 \\
\hline Total & 242 & $6.017,50$ & $2.797,60$ & 46,68 & $2.703,32$ & 172,22 \\
\hline \multicolumn{7}{c}{ Autor (2016). }
\end{tabular}

Fonte: BRASIL. CCEE (2015).

Os Contratos de Energia de Reserva (CER) são firmados na modalidade quantidade ${ }^{41}$. Em razão das incertezas associadas à geração de energia eólica, o CER prevê uma contabilização em base anual, associada a uma margem de segurança, mitigando o risco da volatilidade da receita para o empreendedor. Por sua vez, ao longo do ano, é assegurado uma receita fixa ao investidor, independente da quantidade de energia produzida.

A geração de energia anual acima da margem superior do valor contratado implicará em adicional de receita ao investidor (mecanismo de incentivo). Por outro lado, a geração de energia anual abaixo da margem inferior do valor contratado resultará em ressarcimento pelo investidor (mecanismo de penalização). Os desvios anuais em relação às referidas margens são valorados por um percentual do preço do contrato, eliminando o risco da exposição financeira ao PLD. A margem superior foi fixada em 30\% acima do montante contratado e a inferior em 10\% abaixo do valor contratado.

Em caso de geração excedente, o desvio anual que ultrapassar a margem superior será valorado por $70 \%$ do preço do contrato e pago ao investidor. Em caso de geração deficitária, o desvio anual que ultrapassar a margem inferior será indenizado pelo investidor ao preço do contrato acrescido de uma penalidade de $15 \%$. Em ambos os casos, o pagamento ocorre nos 12 meses subsequentes à apuração em parcelas uniformes. O Gráfico 19 e o Gráfico 20 ilustram o mecanismo anual de inventivo e penalidade, respectivamente.

\footnotetext{
${ }^{41}$ De acordo com o art. 28 do Decreto 5.163/2004, nos CCEARs da modalidade quantidade "os custos decorrentes dos riscos hidrológicos serão assumidos pelos agentes vendedores".
} 
Gráfico 19 - Mecanismo Anual de Incentivo - Contabilização do CER.

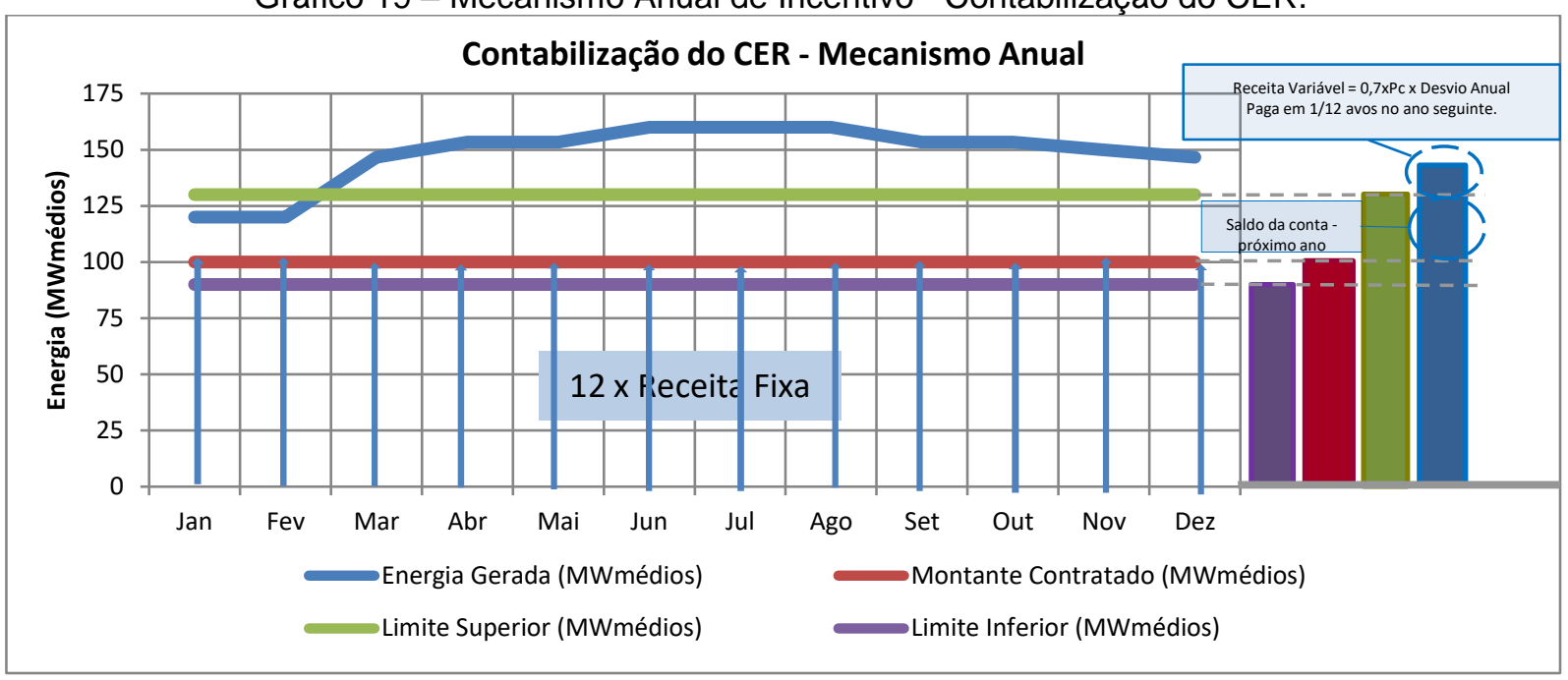

Autor (2016).

No Gráfico 19 a energia gerada no ano ficou acima da margem superior de $30 \%$ do montante contratado. O montante de energia que excedeu esse limite superior será liquidado a $70 \%$ do preço do contrato. O somatório de energia entre o montante contratado e o limite superior é utilizado para compensar déficits de geração dos próximos anos dentro do mesmo quadriênio.

Gráfico 20 - Mecanismo Anual de Ressarcimento - Contabilização do CER.

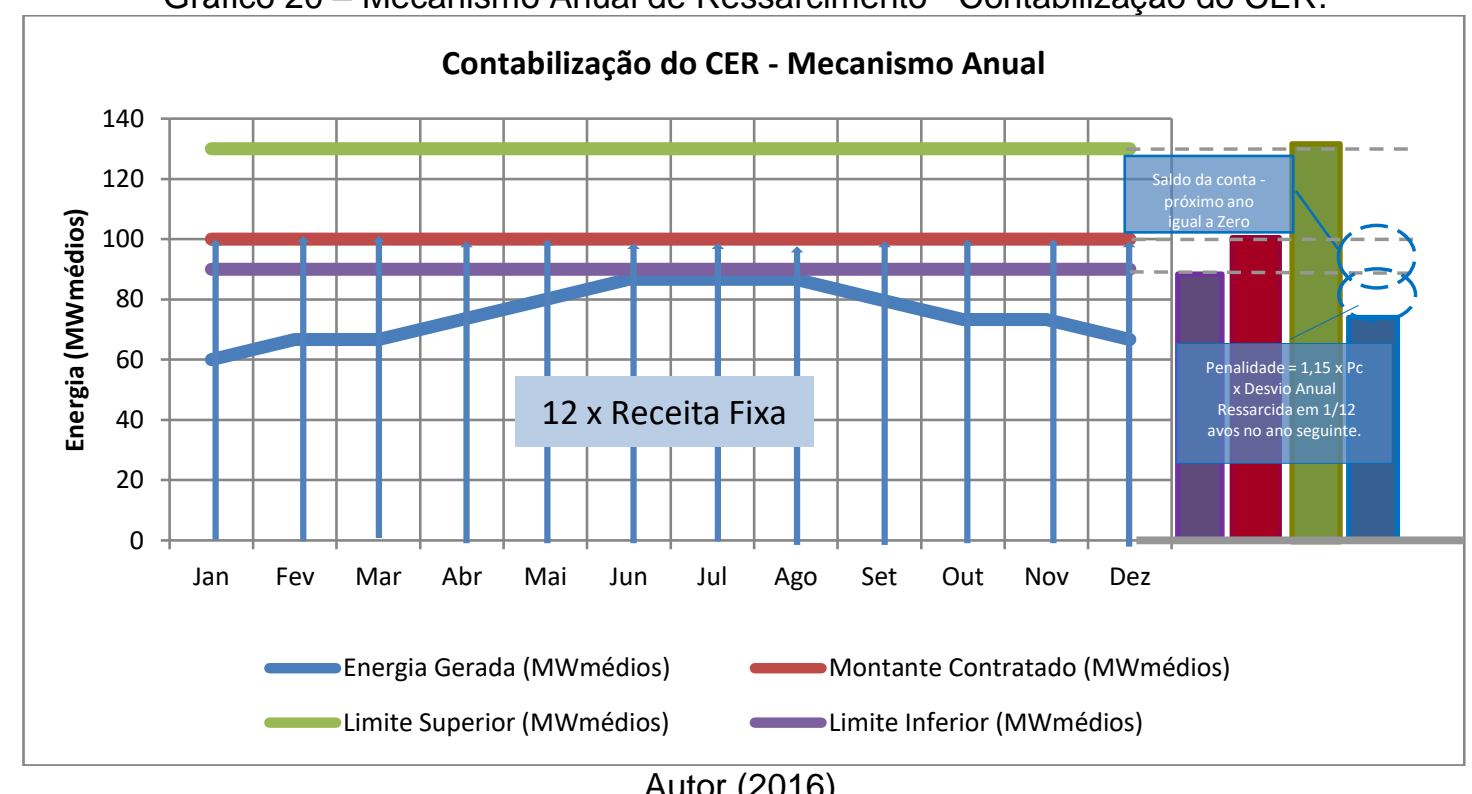

Autor (2016).

No Gráfico 20 a energia gerada no ano ficou abaixo da margem inferior (de 90\% do montante contratado). O montante de energia que não atingiu esse limite inferior será ressarcido pelo investidor ao preço do contrato acrescido de 15\%. 
O somatório do déficit de energia entre o montante contratado e o limite inferior deve ser compensado nos próximos anos dentro do mesmo quadriênio, caso contrário também será ressarcido ao final do quadriênio.

Para os CERs, ao contrário dos CCEARs (itens 3.3 e 3.4), não há exposição ao PLD, na medida em que, anualmente, toda a energia gerada é liquidada ao preço do contrato, com um acréscimo de $15 \%$, no caso de ressarcimento e, por $70 \%$ do preço do contrato, quando ocorrer excedente de geração.

O CER também prevê a divisão em 5 (cinco) quadriênios. Neste caso, o desvio positivo acumulado no quadriênio, contido na faixa de tolerância, poderá ser parcialmente ou totalmente: (i) cedido para outro investidor que tenha sagrado vencedor do mesmo LER, ou; (ii) transferido para o quadriênio seguinte, ou; (iii) ressarcido ao empreendedor, valorado ao preço contratado, em 24 parcelas mensais uniformes, nos dois primeiros anos contratuais do quadriênio em curso.

Por sua vez, o desvio negativo acumulado no quadriênio, contido na faixa de tolerância, após compensado com eventual: (i) cessão de energia obtida de outro investidor ou (ii) saldo de energia transferido do quadriênio anterior, será indenizado pelo investidor, valorado ao preço contratado, nos 12 meses subsequentes, em parcelas uniformes (no LER do ano 2013, o déficit do quadriênio passou a ser indenizado pelo investidor ao preço do contrato acrescido de $6 \%$ ).

Adicionalmente, o CER prevê a reconciliação contratual a cada período de 4 anos, com base na produção efetivamente verificada desde o início do contrato, mitigando as incertezas na estimativa da produção energética, no momento do Leilão, que poderia resultar em prejuízo para os investidores ou para os consumidores ao longo de todo o período contratual.

Para tal, no primeiro quadriênio o valor contratado é igual ao montante de energia associado ao lance vencedor do certame licitatório. Para os demais quadriênios, o valor contratado é igual ao valor médio do montante de energia efetivamente produzido pelo empreendimento apurado desde o início do $1^{\circ}$ quadriênio até o término do quadriênio anterior, limitado ao montante de energia associado ao lance vencedor do certame licitatório.

O Gráfico 21 ilustra o mecanismo quadrienal de incentivos, penalidades e reconciliação contratual. 
Gráfico 21 - Mecanismo Quadrienal de Contabilização do CER.

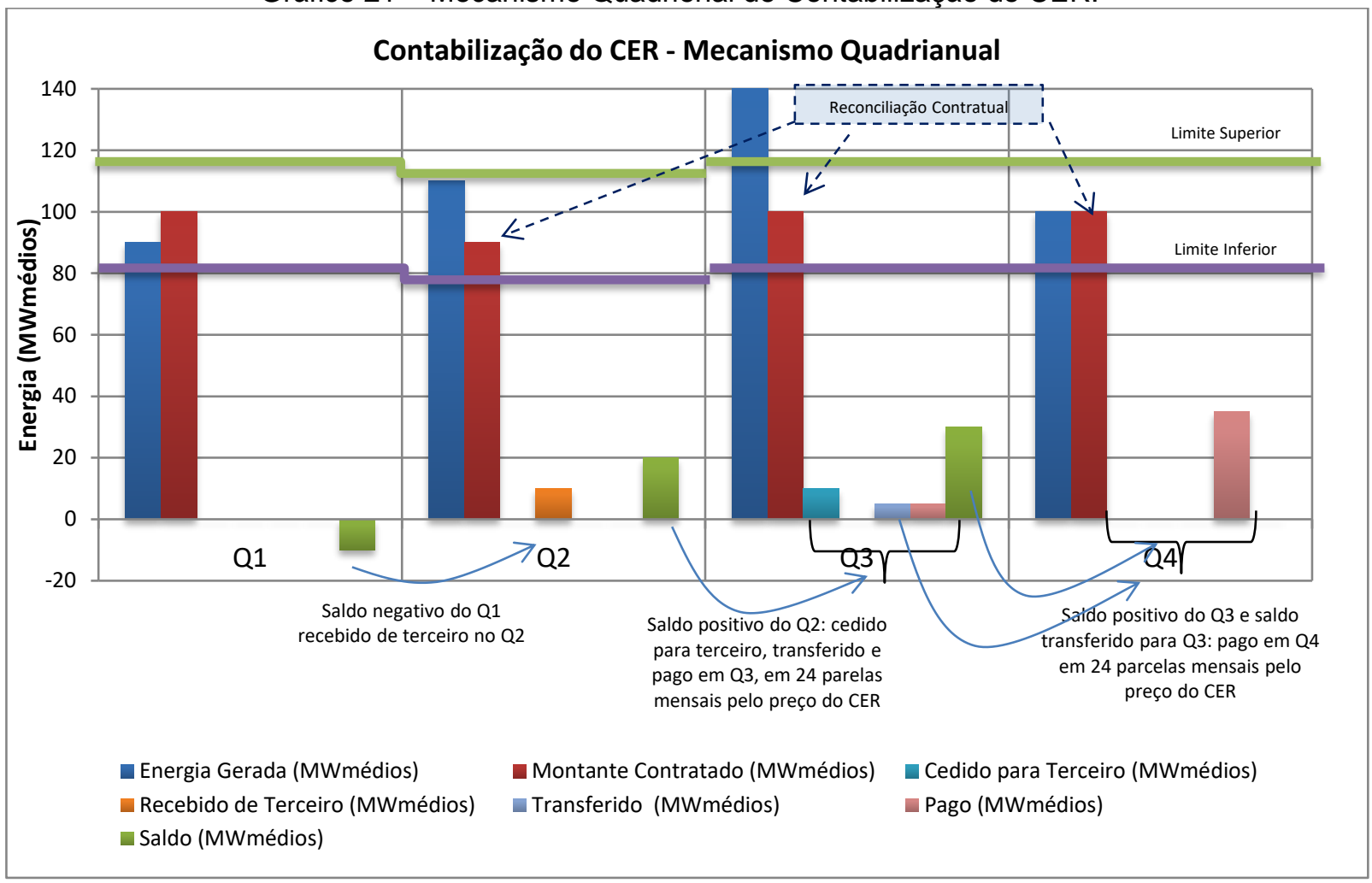

Autor (2016).

No $1^{\circ}$ quadriênio do Gráfico 21, a energia gerada foi inferior ao montante contratado. Neste caso, o investidor optou pela cessão de energia obtida de outro investidor para compensar o déficit. Desse modo, no $2^{-}$quadriênio não haverá ressarcimento do déficit apurado.

Em razão do mecanismo de reconciliação contratual, a energia contratada para o $2^{\circ}$ quadriênio ficou igual à energia gerada no primeiro. Neste quadriênio, houve um excedente de geração em relação ao montante contratado, onde uma parte foi cedida para outro investidor, outra foi transferida para o $3^{\circ}$ quadriênio e a outra liquidada pelo preço do contrato.

Para o $3^{\circ}$ quadriênio também houve a reconciliação do montante contratado, calculado pela média da energia efetivamente gerada no $1^{\circ}$ e no $2^{\circ}$ quadriênio. Neste quadriênio, a energia gerada ficou acima do montante contratado. Assim, além do saldo desse quadriênio, a parcela do saldo do $2^{\circ}$ quadriênio que havia sido transferida para o $3^{\circ}$ quadriênio, ambas serão liquidadas ao preço do contrato.

$\mathrm{Na}$ reconciliação contratual para o $4^{\circ}$ quadriênio, foi considerada a média da energia gerada nos quadriênios anteriores, no entanto, em razão do limite do 
mecanismo de reconciliação contratual, a energia contratada para o $4^{\circ}$ quadriênio ficou igual a energia contratada no $1^{\circ}$ quadriênio.

Em síntese, no CER, o investidor recebe uma receita fixa anual (12 parcelas mensais), que independe da quantidade de energia gerada. A receita variável anual (70\% do preço do contrato) está condicionada ao nível de produção, que precisa ultrapassar o limite superior da banda (30\% acima do montante contratado). Caso o nível de produção não atinja o limite inferior da banda (90\% do montante contratado), o investidor deverá ressarcir pela energia não gerada ao preço do contrato com $15 \%$ de acréscimo.

Por sua vez, a receita variável quadrienal também depende do nível de produção no quadriênio. $O$ excedente é valorado ao preço do contrato, enquanto 0 déficit é valorado ao preço do contrato com $6 \%$ de acréscimo (a partir do LER do ano 2013, o déficit do quadriênio passou a ser indenizado pelo investidor ao preço do contrato acrescido de 6\%).

Ao contrário do LFA e do LEN, no LER o investidor é obrigado a destinar a totalidade da energia do empreendimento para o contrato. Não é possível nessa modalidade contratual, destinar parte da energia ao $\mathrm{ACL}$, mesmo em caso de antecipação da entrada em operação comercial, cuja energia será destinada ao CER. Por outro lado, não existe risco de exposição ao PLD. 


\section{FUNDAMENTAÇÃO TEÓRICA E REVISÃO DA LITERATURA}

Neste capítulo são apresentados os principais conceitos sobre 0 comportamento do vento e as funções de densidade de probabilidade que melhor representam a sua aleatoriedade. Na sequencia, são expostos os fundamentos da geração eólica, sua formulação matemática básica, assim como o conceito de garantia física, considerando o intervalo de confiança de 50\% (P50) e 90\% (P90).

Por fim, o capítulo aborda a teoria de portfólio de Markowitz e Sharpe, a formulação matemática do cálculo da fronteira eficiente e casos particulares de carteiras. Ao final, apresenta-se aplicações da teoria de portfólio de Markowitz sobre o setor de energia.

\subsection{CARACTERIZAÇÃO DO VENTO}

O combustível das usinas eólicas é o vento. Por conseguinte, conhecer o comportamento do vento é fundamental para a estimativa da geração eólica.

De acordo com Fadigas (2011), o vento pode ser classificado como de circulação local e circulação global. Por sua vez, Lutgens e Tarbuck apud Martins, Guarnieri e Pereira (2008) e Pinto (2013) classificam os movimentos atmosféricos nas seguintes escalas de tempo e espaço:

$\checkmark$ Microescala: dimensões de menos de $1 \mathrm{~km}$ e tempos de vida de segundos a minutos;

$\checkmark$ Mesoescala: dimensões de 1 a $100 \mathrm{~km}$ e tempos de vida de minutos a dias;

$\checkmark$ Escala Sinótica: dimensões de 100-5.000 km e tempos de vida de dias a semana;

$\checkmark$ Escala Planetária: dimensões de 1000-40.000 km e duração de semanas a anos.

O vento de circulação global (Escala Planetária) decorre das variações de pressão, temperatura e densidade causadas pelo aquecimento desigual da Terra, em razão da variação geográfica e temporal da radiação solar. 
Martins, Guarnieri e Pereira (2008) esclarecem que os movimentos surgem para promover uma redistribuição de calor (transporte de ar quente para os polos e ar frio para o Equador, diminuindo as desigualdades térmicas). Além do gradiente de pressão, a circulação atmosférica planetária é influenciada pelo movimento de rotação da Terra, em função da conservação do momento do sistema Terra-Atmosfera (força de Coriolis), pela força gravitacional, inércia do ar e atrito com a superfície.

Em relação à circulação global (Escala Planetária), Custódio (2009) adota o modelo de Ferrel (1856). Neste modelo simplificado, a circulação em cada hemisfério é descrita por três células meridionais de circulação, cada qual apresentando direções de vento predominantes à superfície, denominadas de célula tropical (ou de Hadley), temperada (ou de Ferrel) e polar, conforme ilustrado na Figura 3 reproduzida de Martins, Guarnieri e Pereira (2008).

Figura 3 - Modelo Conceitual da Circulação Global Atmosférica, Indicando as Células Meridionais e as Direções dos Ventos Próximos à Superfície.

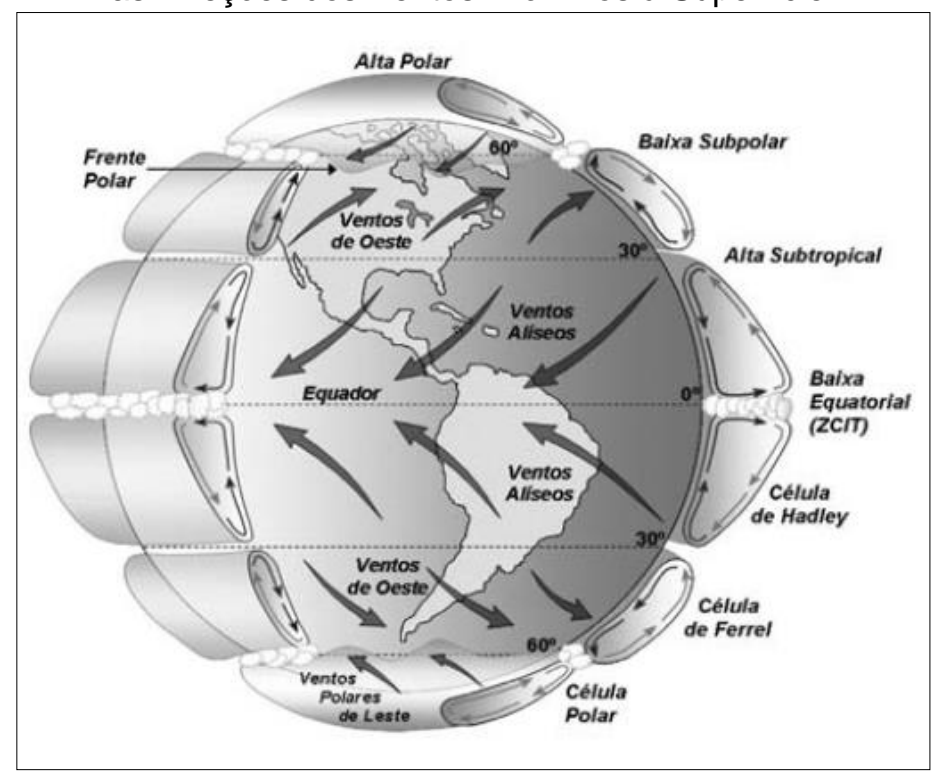

Fonte: Martins, Guarnieri e Pereira (2008).

Nas células tropicais (ou Hadley), as correntes de ar dirigidas para o Equador na superfície são defletidas pela força de Coriolis, assim, no hemisfério Sul, produzem ventos sudoeste, denominados de ventos alísios.

Nas células temperadas (ou de Ferrel), entre $30^{\circ}$ e $60^{\circ}$ de latitude, as correntes de ar de superfície também são defletidas pela força de Coriolis, formando ventos noroeste, denominados de ventos ocidentais. Por fim, as células polares são caracterizadas por um anticiclone polar, com ventos do Leste. 
Na região do equador há um cinturão de baixa pressão, em razão da maior concentração da radiação solar, denominada de Zona de Convergência Intratropical (ZCIT), predominando ventos fracos.

As circulações atmosféricas variam ao longo do ano em função da modificação da incidência da radiação solar e não são zonalmente uniformes como representadas no modelo simplificado de células meridionais de circulação. Assim, por exemplo, os ventos alísios deslocam-se em função da ZCIT, que no verão do hemisfério sul, desloca-se para latitudes ao sul do Equador e, no inverno, para latitudes ao norte.

Em Escala Sinótica há a predominância dos anticiclones (giro anti-horário no hemisfério sul) e ciclones extratropicais (giro horário no hemisfério sul), que provocam mudança nas condições do tempo (nebulosidade, precipitação, tempestades e oscilações bruscas de temperatura) e variações nas intensidades e direções dos ventos nos altos e baixos níveis atmosféricos.

Custódio (2009) destaca que a combinação do ciclone extratropical (zona de baixa pressão) situado sobre o Chaco (29S e 66W) e o anticiclone tropical sul situado sobre o Atlântico Sul (zona de alta pressão), associada à circulação global (Escala Planetária) resulta numa importante corrente de vento da zona de alta pressão para a zona de baixa pressão, formando o vento predominante do interior do Uruguai e do extremo sul do Brasil, circulação de sudeste e leste, conhecido como vento Aragano.

O autor também destaca os ventos Norte e Minuano, formados pelo encontro da massa de ar polar continental e da massa de ar tropical, que produz um anticiclone tropical.

Em micro e mesoescala encontram-se os ventos de circulação local. Custódio (2009) exemplifica com: a) brisas marítimas e terrestres, b) ventos em vales e montanhas, c) nevoeiros, d) temporais, e) tornados.

De acordo com o Atlas do Potencial Eólico Brasileiro (2001), no Brasil, entre a Depressão Equatorial ${ }^{42}$ e a latitude de $10^{\circ} S$ predominam os ventos alísios de leste a sudeste. Entre a latitude de $10^{\circ} \mathrm{S}$ e o extremo sul brasileiro prevalecem os efeitos da Escala Sinótica.

\footnotetext{
42 A posição média da Depressão Equatorial estende-se de oeste a leste ao longo da região Norte do Brasil e sobre o Oceano Atlântico adjacente. Ela coincide com a localização e orientação da Bacia Amazônica, no centro da qual existe uma faixa persistente de baixas pressões. A Depressão Equatorial é geralmente uma zona de pequenos gradientes de pressão e ventos fracos. (ATLAS do Potencial Eólico Brasileiro, 2001).
} 
Martins, Guarnieri e Pereira (2008) afirmam que os movimentos observados na atmosfera terrestre são uma sobreposição de todas as escalas de tempo e espaço, de modo que, eventualmente, circulações locais podem predominar sobre os movimentos de Escala Planetária, determinando as condições do vento em regiões específicas.

Nesse sentido, o Atlas do Potencial Eólico Brasileiro (2001) apresenta uma síntese das características em menores escalas sobre a distribuição dos regimes de vento organizada em 7 regiões geográficas: (1) Bacia Amazônica Ocidental e Central; (2) Bacia Amazônica Oriental; (3) Zona Litorânea Norte-Nordeste; (4) Zona Litorânea Nordeste-Sudeste; (5) Elevações Nordeste-Sudeste; (6) Planalto Central; (7) Planaltos do Sul.

Fadigas (2011) destaca a importância de se conhecer os diversos tipos de variações temporais da velocidade dos ventos para a previsão de geração de longo prazo, dimensionamento dos equipamentos e para a operação de curto prazo.

As variações interanuais são variações lentas na velocidade dos ventos (escala maior que um ano) provocadas por fenômenos de mesoescala ${ }^{43}$. As variações sazonais decorrem da sazonalidade anual da radiação solar na Terra. As variações diárias são provadas pela variação diária da radiação solar. As variações de curta duração estão associadas a pequenas flutuações e a rajadas de ventos.

\subsection{DADOS DE VELOCIDADE DO VENTO}

O vento apresenta variações de curto, médio e longo prazo (no segundo e minuto, no dia, no mês, no ano e ao longo dos anos). De acordo com Custódio (2009), as variações ao longo do ano possuem um comportamento sazonal, porém já foram registradas diferenças de até $18 \%$ entre a média de longo prazo e a média anual, de tal forma que o autor recomenda considerar no projeto variações plurianuais de até $10 \%$.

Pinto et al (2011) alertam que a periodicidade de eventos significativos (como Niños e Niñas) é normalmente igual a cinco ou seis anos e eventos extremos costumam ocorrer a cada onze anos.

43 Dimensões entre $1 \mathrm{~km}$ a $100 \mathrm{~km}$, segundo classificação fornecida em Pinto (2013) e Lutgens e Tarbuck apud Martins, Guarnierl \& Pereira (2008). 
O conhecimento detalhado do regime de ventos é fundamental, uma vez que os erros de medição irão impactar no dimensionamento do projeto, na estimativa da geração de curto (risco na operação) e longo prazo (risco na comercialização).

Para o setor eólico, a base de dados de velocidade de vento tem por objetivo: i) identificar as regiões com maior disponibilidade energética e ii) realizar a previsão da geração de energia de curto, médio e longo prazos.

De acordo com Fadigas (2011), somente há duas décadas é que se passou a realizar campanhas de medição de vento com a finalidade de avaliar o potencial eólico. No Brasil, campanha de medição destinada a avaliar recursos eólicos, é ainda mais recente.

Pinto et al (2011) asseveram que para minimizar as incertezas no desenvolvimento de um projeto eólico, idealmente, seria necessário um período de medições de algumas décadas. Para Custódio (2009), o período necessário seria de 5 a 10 anos, com medição de qualidade e instalada no local.

A ausência de dados histórico de longo prazo confiáveis para dimensionamento de empreendimentos eólicos fez com que a ANEEL e a Empresa de Pesquisa Energética flexibilizassem suas exigências numa primeira fase.

Até 31.12.2012, a ANEEL exigiu um histórico de dados de vento de 12 meses para emitir a outorga de empreendimento eólico. A partir dessa data, a Resolução Normativa ANEEL 391/2009 passou a exigir um histórico de 3 anos para o ato de outorga. Por sua vez, até o ano 2010, a Empresa de Pesquisa Energética exigiu do interessado um histórico de 12 meses para a participação nos leilões regulados. A Portaria MME 21/2008 passou a exigir um histórico de 2 anos para participação dos leilões regulados a partir de 2011 e prevê exigência de histórico de 3 anos a partir do ano 2017.

Com o objetivo de constituir uma base de dados histórica para estudos de geração eólica, a partir de 2009, os Editais dos Leilões de Energia Nova passaram a exigir a instalação de torres de medição anemométricas e climatológicas no local dos parques eólicos vencedores do leilão, durante todo o período do contrato de energia.

De acordo com a EPE ${ }^{44}$, os primeiros registros ocorreram em fevereiro de 2011 e em maio de 2014 havia 220 estações de medições instaladas, sendo que 8 estações com histórico superior a 3 anos, 61 estações com histórico superior a 2 anos e as

\footnotetext{
${ }^{44}$ Informações disponíveis em https://sistemas.epe.gov.br/AMADVP.
} 
demais, com histórico superior a 1 ano. Os dados são disponibilizados pela EPE, porém consolidados por Estados (Bahia, Ceará, Rio Grande do Norte e Rio Grande do Sul) 45 .

Ao contrário do longo histórico de vazão dos rios (hidrometria), a série histórica de medição de velocidade do vento disponível é bastante limitada, o que em certa medida, compromete com as estimativas de geração de energia. Em decorrência dessa limitação, tem-se utilizado séries históricas oriundas de modelos meteorológicos.

Séries de vento apropriadas para a determinação da energia gerada são dados escassos e com pouquíssima disponibilidade. Como será mostrado adiante, alguns órgãos brasileiros dispõem de séries de velocidade de vento, porém não podem ser utilizadas para o dimensionamento de projetos eólicos por serem medidas em baixas altitudes. Outras limitações estão em falhas nos dados, grandes escalas temporais (e.g. apenas dados mensais) e má distribuição geográfica dos pontos de medição.

O Instituto Nacional de Pesquisas Espaciais (INPE) disponibiliza gratuitamente dados relacionados ao projeto SONDA (Sistema de Organização Nacional de Dados Ambientais). São medições de velocidade e direção de vento e temperatura do ar, realizadas com a amostragem de 10 minutos $^{46}$, em altitudes de 25 e 50 metros, para torres instaladas em 7 localidades, sendo 3 no Estado do Pernambuco ${ }^{47}$, conforme ilustrado na Figura 4.

O INPE valida os dados obtidos considerando metodologias robustas, entretanto isso não impede que falhas nas medições ocorram. Caso algum problema aconteça com os aparelhos medidores, não é aplicado nenhum tipo de preenchimento e os zeros permanecem nas séries. Além disso, os dados considerados suspeitos não são corrigidos e apenas ganham uma sinalização para que sejam avaliados pelos usuários.

Além de poucas estações anemométricas existentes no projeto SONDA, existem muitos períodos sem dados. Ressalta-se que depois de 2011 não são disponibilizados registros de vento.

\footnotetext{
45 Últimos dados disponíveis no site são de junho de 2015. (https://sistemas.epe.gov.br/AMADVP/, acessado em 20 de fevereiro de 2016).

${ }^{46}$ São consideradas as médias das medições a cada intervalo.

47 De acordo com o sitio http://sonda.ccst.inpe.br/infos/index.html, acessado em 17/10/2015, as torres estão instaladas em Belo Jardim (PE), Triunfo (PE), Petrolina (PE), São João do Cariri (PB), São Martinho da Serra (RS), Ourinhos (SP) e Brasília (DF).
} 
Figura 4 - Localização das Estações SONDA.

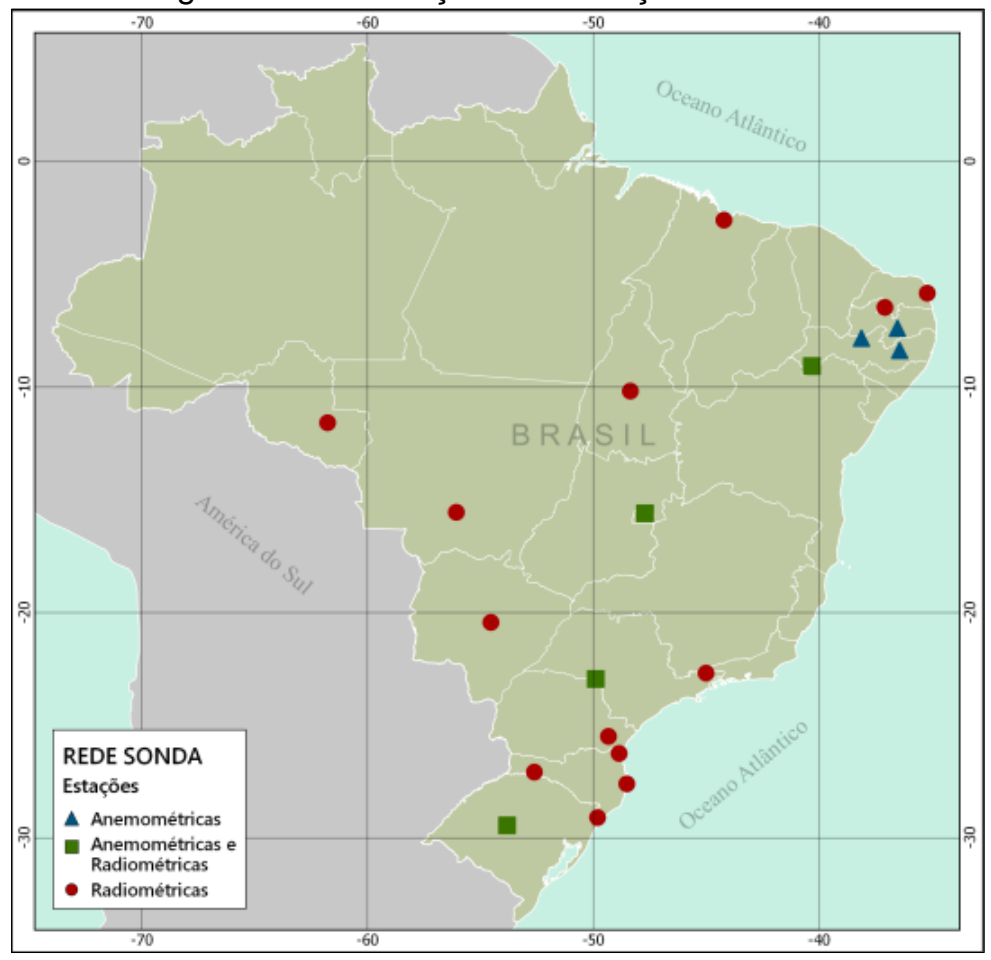

Fonte: SONDA (2015)

Outra fonte de dados de velocidade e direção do vento é o Instituto de Controle do Espaço Aéreo (ICEA) ${ }^{48}$, que reúne informações coletadas nos principais aeroportos brasileiros através do Sistema de Controle do Espaço Aéreo Brasileiro. Especificamente para medições anemométricas, os registros são disponibilizados em termos de frequências de ocorrências horárias, mensais e anuais. Para cada tipo de escala temporal, deve ser fornecida um valor específico de tempo, seja hora, mês ou ano. A título de exemplo, a Figura 5 mostra as frequências de ocorrências de velocidade e direção do vento para a hora 09:00 durante o ano de 1951, no aeroporto Afonso Pena, em São José dos Pinhais (Paraná).

Há de se destacar a boa extensão do banco de dados que, em geral, coincide com a inauguração dos respectivos aeroportos. No entanto, nota-se que os dados disponibilizados não são séries temporais propriamente ditas, mas diagramas de frequência. Além disso, todas as informações disponibilizadas se referem a medições feitas em superfície.

48 Informações obtidas do sitio http://clima.icea.gov.br/clima/, acessado em: 01/07/2015. 
Figura 5 - Rosa dos Ventos (Aeroporto Afonso Pena, em São José dos Pinhais - PR), ano de 1951, hora 09:00).

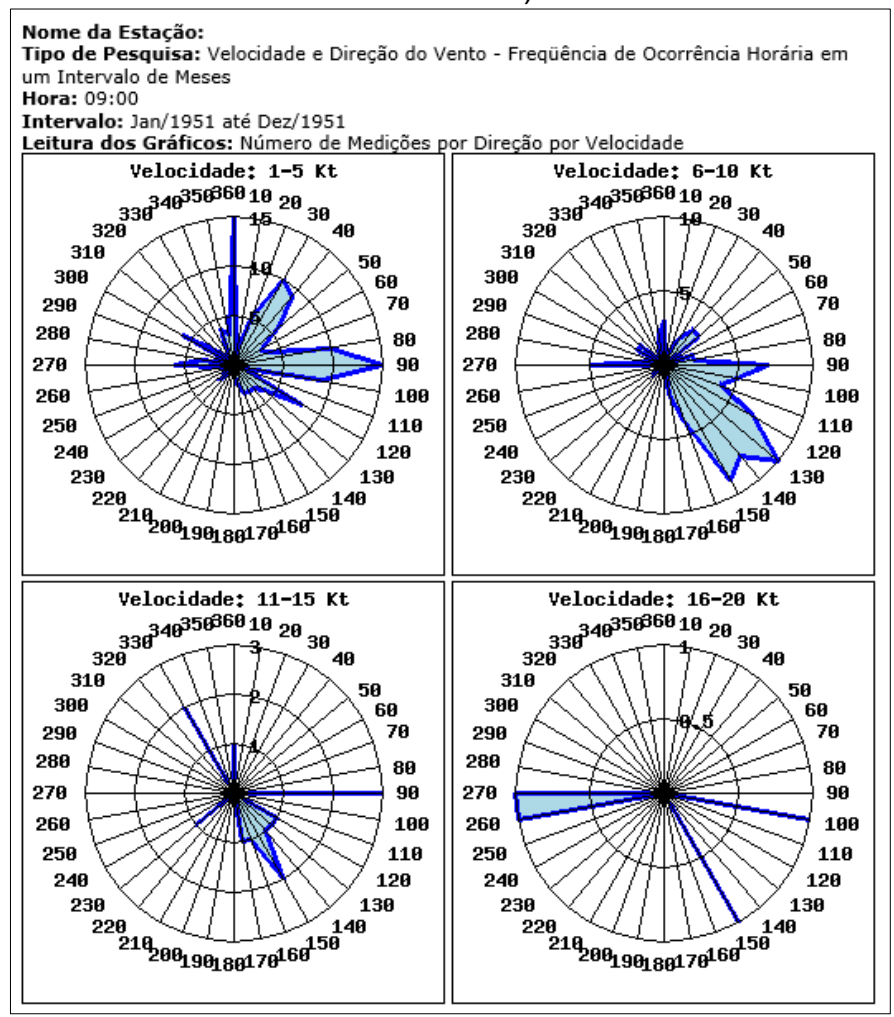

Fonte: ICEA (2015).

O Instituto Nacional de Meteorologia (INMET) ${ }^{49}$ possui extensa rede de estações meteorológicas distribuídas pelo país, conforme se observa na Figura 6 . 0 INMET opera equipamentos convencionais e automáticos, sendo que os registros ficam disponíveis para livre consulta. Uma visualização rápida dos dados pode ser feita através do próprio mapa. Nessa opção são oferecidos dados horários de no máximo 90 dias da data de consulta. Temperatura do ar, unidade relativa, ponto de orvalho, pressão, velocidade do vento, radiação e chuva são as variáveis exibidas; contudo o órgão ressalta que nenhuma série possui tratamento ou análise de consistência.

Apesar da rede do INMET cobrir uma vasta área do território nacional, a grande limitação de seu uso está na altitude de medição. Todas as estações estão instaladas a 10 metros da superfície, fazendo com que sua utilização para determinação da energia gerada seja inviável.

49 Informações obtidas do sitio http://www.inmet.gov.br/ portal/index.php?r=bdmep/bdmep, acessado em: 01. jul. 2015. 
Figura 6 - Rede de Estações Meteorológicas do INMET.

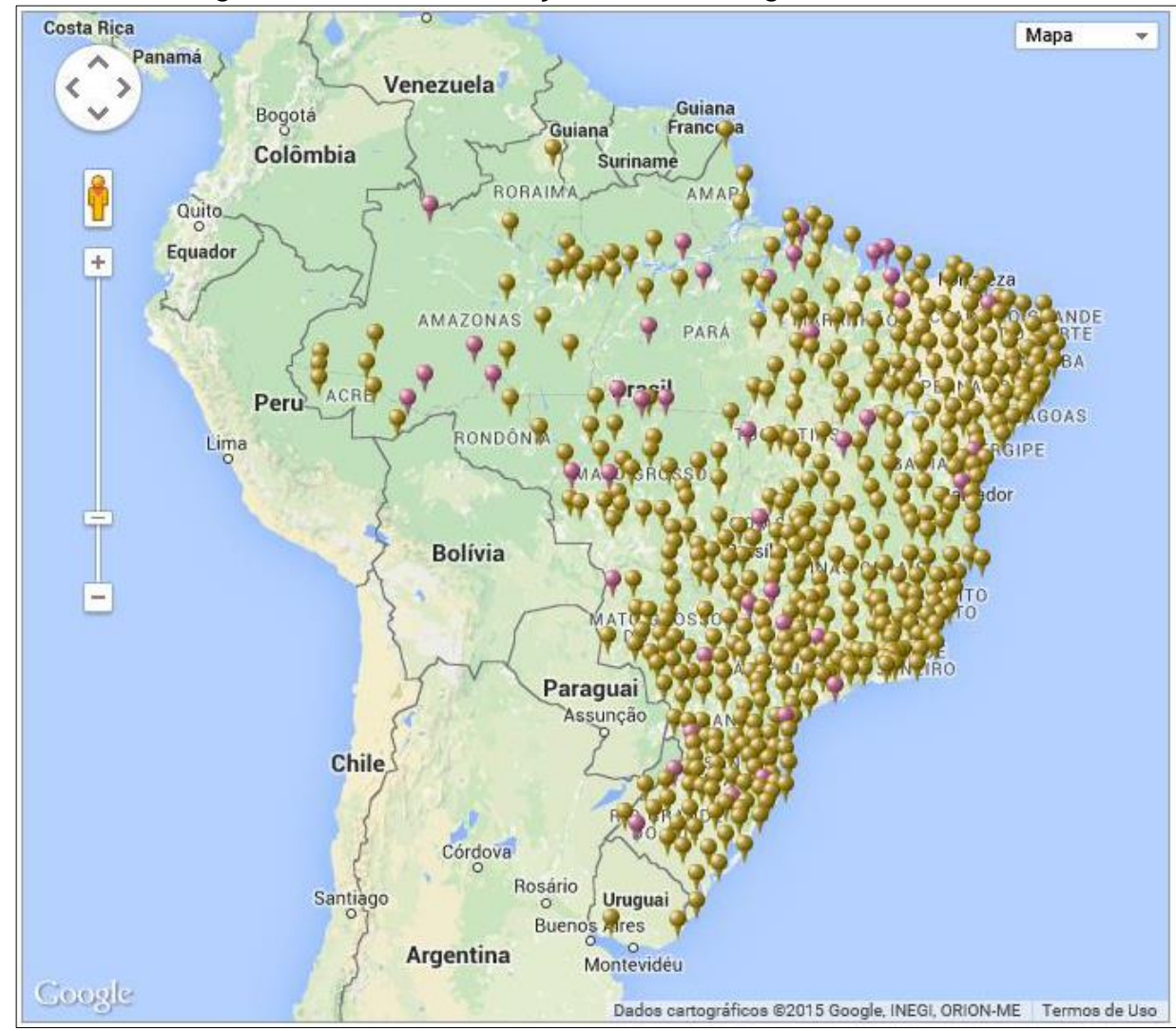

Fonte: adaptado de Instituto Nacional de Meteorologia (2015).

Registros históricos mais completos podem ser coletados através do Banco de Dados Meteorológicos para Ensino e Pesquisa (BDMEP), que oferece séries históricas de variáveis medidas através de estações convencionais. Grande parte dessas séries tem início em 1961 e são oferecidas em três horários distintos: 00:00, 12:00 e 18:00. Entretanto, algumas séries possuem dados com falhas, o que exige atenção para sua utilização.

A organização norte americana National Centers for Environmental Prediction $\left(\right.$ NCEP) ${ }^{50}$ e National Center for Atmospheric Research (NCEAR) ${ }^{51}$ dispõe de dados climáticos para diversos locais do mundo. A consulta pode ser feita diretamente através do portal do Climate Data Online ${ }^{52}$, podendo ser definida por diversos critérios como região geográfica mundial, país, ou código da estação meteorológica. A Figura 7 exibe a distribuição de estações de medição em território nacional. Os dados históricos de vento disponíveis estão referenciados à altura de 10 metros do nível do mar e intervalo de amostragem de 6 horas, a partir do ano 1948.

\footnotetext{
50 Detalhes em http://www.ncep.noaa.gov. Acessado em 10/02/2015.

51 Detalhes em http://ncar.ucar.edu. Acessado em 10/02/2015.

52 Disponível em: <http://www7.ncdc.noaa.gov/CDO/ cdoselect.cmd>. Acesso em: 15/07/2015.
} 
No entanto, os dados dessa fonte sofrem de limitações semelhantes às do INMET: os dados possuem muitas falhas, não são consistidos e são medidos em baixas altitudes.

Figura 7 - Estações Meteorológicas com Dados de Vento Disponibilizadas pelo NOAA.

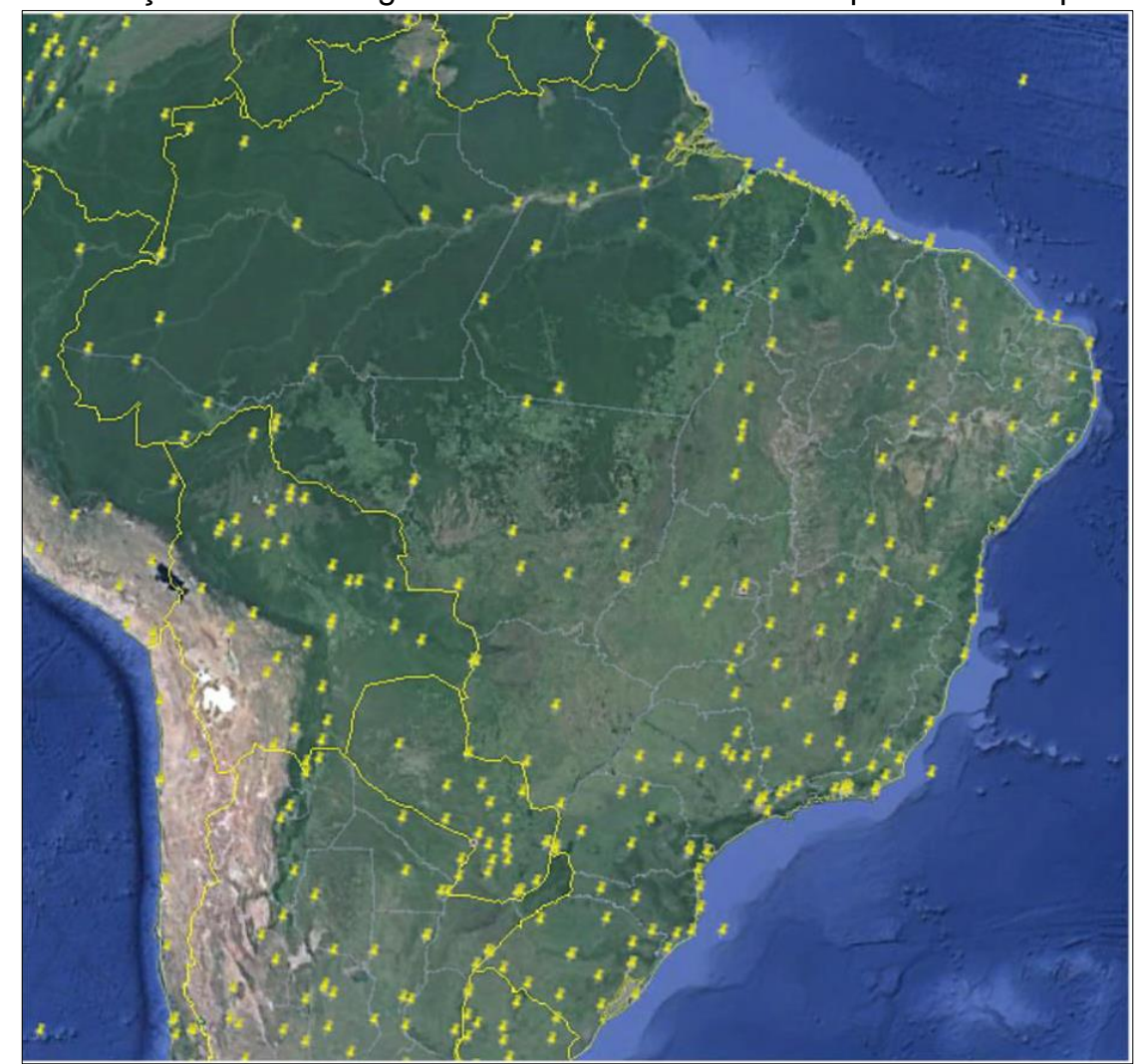

Fonte: NOAA - Climate Data Online.

Há empresas que comercializam dados meteorológico para a aplicação em energia. Vortex é uma empresa sediada em Barcelona, na Espanha, que comercializa soluções de suporte relacionadas a tecnologias eólicas, solar e offshore para diversos fins. Particularmente para dados de vento, a empresa trabalha com um portfólio de produtos como sistemas específicos para o posicionamento de torres meteorológicas, projetos de fazendas eólicas e séries históricas de dados.

Skamarock et al (2008) ressaltam que todos os dados fornecidos pela Vortex não são provenientes de medições diretas, mas de modelos matemáticos, o que reduz enormemente a possibilidade de erros humanos ou de equipamentos medidores.

De acordo com os autores, as séries de vento provenientes da Vortex são obtidas com o modelo climatológico The Weather Research \& Forecast Model (WRF), 
conhecido e utilizado em mais de 150 países, sendo que, no ano 2008, havia mais de 6.000 usuários registrados no WRF em todo o mundo.

Tal ferramenta foi desenvolvida para fins de previsão e simulação atmosférica em mesoescala ${ }^{53}$ num esforço conjunto de diversas agências norte americanas, dentre elas o National Center for Atmosperic Research (NCAR) e o National Oceanic and Atmospheric Administration (NOAA).

O principal desafio de modelos atmosféricos como esse (WRF) é aliar um apropriado equacionamento de processos que governam as dinâmicas atmosféricas com métodos para sua solução. Sucintamente, os processos físicos considerados são (SKAMAROCK et al, 2008):

a) Microfísica: processos de vapor de água, precipitação e evaporação;

b) Parametrização cumulus: efeitos de nuvens de origem convectiva;

c) Camada superficial: temperatura da superfície da Terra e fluxos de umidade junto ao solo;

d) Modelo de superfície do solo: usa as informações do processo anterior para determinar temperaturas e fluxos de umidade no interior dos solos (incluindo superfícies congeladas) e oceanos;

e) Camada limite planetária: fluxos verticais devidos a transportes turbulentos considerando toda a camada atmosférica.

Os modelos climáticos dependem de um conjunto de dados para poder ser inicializados. Estes dados se referem às condições físicas no início da simulação, estabelecidas de acordo com o período histórico que se pretende representar.

Um modelo de previsão climática depende, evidentemente, de condições recentes para possibilitar as projeções. Por outro lado, um modelo para obtenção de séries históricas depende de condições climáticas passadas. Em ambos os casos, os dados utilizados são provenientes dos chamados processos de reanálise, ou de assimilação de dados (tradução livre do termo data assimilation).

Martins, Guarnieri e Pereira (2008) explicam que as bases de dados de reanálise permitem uma visão geral dos ventos globais, sem falhas no histórico de dados, porém com baixa resolução espacial.

53 Dimensões entre $1 \mathrm{~km}$ a $100 \mathrm{~km}$, segundo classificação fornecida em Pinto (2013) e Lutgens e Tarbuck apud Martins, Guarnieri e Pereira (2008). 
Projetos de reanálise são desenvolvidos pelo National Centers for Environmental Prediction e National Center for Atmospheric Research ${ }^{54}$ e pelo European Centre for Medium Range Weather Forecasting 55.

Modelos numéricos globais ou regionais (mesoescala ${ }^{56}$ ) simulam 0 escoamento atmosférico, representando razoavelmente bem a circulação geral da atmosfera (Escala Planetária) e fenômenos de Escala Sinótica.

Essencialmente, o produto da reanálise é um excepcional conglomerado de dados climáticos capazes de descrever os diversos estados da atmosfera e em diferentes períodos. Esses dados podem ser adquiridos a partir de medições ou através de modelos de circulação global. Não raro, os dois são considerados no processo. No caso dos dados da Vortex, é utilizada a terceira geração da reanálise elaborada pelos centros norte-americanos National Centers for Environmental Prediction (NCEP), denominada Climate Forecast System Reanalysis (CFSR), que cobre o período a partir de 1979 (SAHA et al, 2010).

Os dados observados são coletados de múltiplas fontes e/ou dispositivos, tais como radiossondas, aeronaves, satélites, radares e medições diretas em terra e sobre a superfície do mar. Uma vez consolidados, essas informações servem como ponto de partida para um modelo de circulação global cujas saídas são direcionadas ao modelo WRF.

Ribeiro (2013) sintetiza uma série histórica de longo prazo a partir da série histórica obtida do National Centers for Environmental Prediction e do National Center for Atmospheric Research (modelos numéricos de mesoescala ${ }^{57}$ ) na coordenada mais próxima da torre de medição instalada para os estudos de micrositing. De acordo com a autora, os dados horários e diários obtidos do National Centers for Environmental Prediction e do National Center for Atmospheric Research apresentam baixa correlação com os dados da torre de medição, contudo, na base mensal a correlação é significativa.

Para as projeções de energia, há necessidade de projeções de velocidade de vento de curto prazo e de longo prazo.

\footnotetext{
${ }^{54}$ Ver detalhes em www.cdc.noaa.gov/cdc/reanalysis, acessado em 17/05/2015.

55 Ver detalhes em www.ecmwf.int/research/era/, acessado em 17/05/2015.

56 Dimensões entre $1 \mathrm{~km}$ a $100 \mathrm{~km}$, segundo classificação fornecida em Pinto (2013) e Lutgens e Tarbuck apud Martins, Guarnieri e Pereira (2008).

57 Dimensões entre $1 \mathrm{~km}$ a $100 \mathrm{~km}$, segundo classificação fornecida em Pinto (2013) e Lutgens e Tarbuck apud Martins, Guarnieri e Pereira (2008).
} 
Erros na medição da velocidade do vento durante a fase exploratória, resultam em problemas no dimensionamento do parque eólico e na estimativa da produção de energia, com impacto na modelagem econômica financeira do projeto.

Fadigas (2011) leciona que previsões de curto prazo utilizam técnicas estatísticas de extrapolação dos dados históricos, tais como: método da persistência, modelo auto regressivo de ordem n, ARMA (Modelo Auto Regressivo e de Média Móvel), ARMAX (Modelo Auto Regressivo e de Média Móvel com Entrada Exógena), rede neural, lógica fuzzy, dentre outros e, os métodos meteorológicos são mais adequados para previsões de longo prazo.

Custódio (2009) cita os modelos MesoMap ${ }^{58}$ e o Mesoscale Modeling System - 5th Generation (MM5) como ferramentas de mesoescala59. FADIGAS (2011) acrescenta a essa lista os modelos ETA ${ }^{60}$, HIRLAM ${ }^{61}$ (High Resolution Limited Area Model) e o KAMM 62 (Karlsruher Atmospharisches Mesoskaliges Modell).

Para aumentar a confiabilidade pode-se utilizar o método físico ou método estatístico. No método estatístico, medições de vento locais são associadas aos resultados das simulações dos modelos numéricos globais ou regionais por meio de equações empíricas ajustadas. No método físico, o vento geostrófico (resultado dos modelos numéricos globais ou regionais) alimenta um modelo dinâmico que leva em conta as relações físicas de camada limite para ajuste do perfil de vento, e as condições fisiográficas locais.

No entanto, a ausência de informações sobre a rugosidade, obstáculos e orografia resultam em erros na estimativa do vento na altura de geradores, atendendo precariamente o segmento de geração de energia. Esses aspectos devem ser levados em conta no estudo de micrositing, cujo objetivo é quantificar a volatilidade da velocidade do vento na área do projeto.

\footnotetext{
58 De acordo com o Atlas do Potencial Eólico Brasileiro (2001), o núcleo do Sistema MesoMap é o MASS (Mesoscale Atmospheric Simulation System), um modelo numérico de previsão de tempo, estado-da-arte no setor, desenvolvido desde o início dos anos 1980 pela empresa MESO Inc., que integra a joint-venture TrueWind Solutions e LLC.

59 Dimensões entre $1 \mathrm{~km}$ a $100 \mathrm{~km}$, segundo classificação fornecida em Pinto (2013) e Lutgens e Tarbuck apud Martins, Guarnieri e Pereira (2008).

$60 \mathrm{O}$ modelo de área limitada Eta, foi desenvolvido pela Universidade de Belgrado em conjunto com o Instituto de Hidrometeorologia da lugoslávia, e se tornou operacional no National Centers for Environmental Prediction (NCEP).

${ }^{61} \mathrm{O}$ modelo de área limitada de alta resolução HIRLAM foi desenvolvido por um consórcio de institutos de meteorologia da Europa.

62 Modelo meteorológico desenvolvido na Alemanha denominado de Karlsruher Atmospharisches Mesoskaliges Modell.
} 
Custódio (2009) e Fadigas (2011) citam o WASP® (Wind Atlas Analysis Application Program) ${ }^{63}$, Wind-Pro ${ }^{64}$, WindMap ${ }^{65}$ e Windfarm ${ }^{66}$ como modelos disponíveis para estudo local.

\subsection{FUNÇÃO DENSIDADE DE PROBABILIDADE}

A velocidade do vento é uma variável aleatória, sendo que a frequência da distribuição da velocidade do vento pode ser representada por uma função densidade de probabilidade. Fadigas (2011) elenca as principais funções de distribuição de probabilidade aplicadas na engenharia eólica: (i) distribuição normal, (ii) distribuição normal bivariável, (iii) distribuição exponencial, (iv) distribuição de Rayleigh, (v) distribuição de Weibull.

A função densidade de probabilidade de Rayleigh fica definida apenas com o conhecimento da velocidade média do vento e, para Silva et al (1999) e Fadigas (2011) representa bem os regimes de vento que apresentam velocidades moderadas. A função densidade de probabilidade de Rayleigh é dada pela expressão da Equação (5).

$$
f(v)=\frac{\pi}{2} \cdot \frac{v}{V^{2}} \cdot e^{-\left(\frac{\pi}{4}\right) \cdot\left(\frac{v}{V}\right)^{2}}
$$

Onde:

$f(v)$ é a função densidade de probabilidade de Rayleigh;

$v$ é a velocidade do vento $(\mathrm{m} / \mathrm{s})$;

$V$ é a velocidade média do vento $(\mathrm{m} / \mathrm{s})$.

\footnotetext{
63 O WASP $\AA$ é um modelo computacional que estima a velocidade do vento em um determinado volume baseando-se em uma medição pontual.

${ }^{64} \mathrm{O}$ programa Wind-PRO foi desenvolvido pela empresa dinamarquesa EMD International.

${ }^{65}$ De acordo com o Atlas do Potencial Eólico Brasileiro (2001), o WindMap é um modelo de simulação de camada-limite atmosférica de microescala, fundamentado na equação da continuidade (conservação de massa ou escoamento não divergente).

${ }^{66}$ Openwind é um novo programa computacional desenvolvido pela AWS TruePower, LLC, para a concepção, otimização e avaliação de projetos de energia eólica.
} 
O Gráfico 22 apresenta a função densidade de probabilidade de Rayleigh para 3 velocidades médias de vento.

Gráfico 22 - Função Densidade de Probabilidade de Rayleigh (V=7, 10 e 12 m/s).

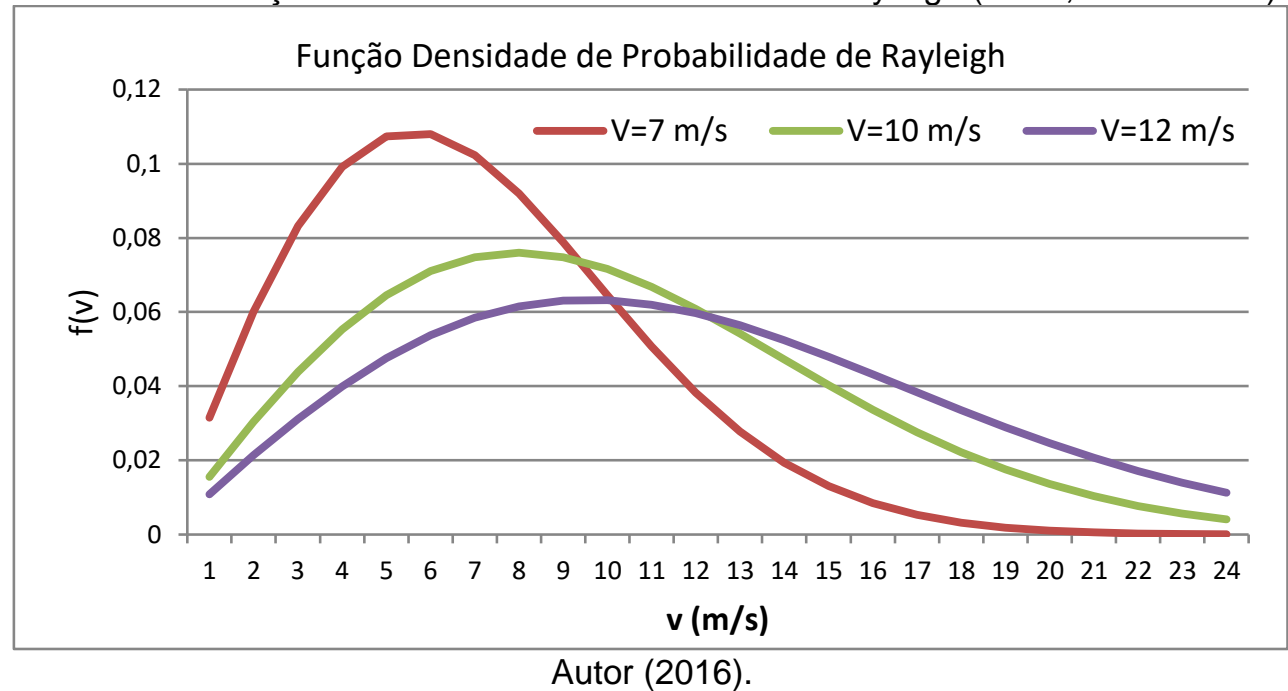

Para Custódio (2009), a função densidade de probabilidade de Rayleigh normalmente é utilizada em estudos preliminares, onde ainda não se conhece o perfil da velocidade do vento. No entanto, essa função não permite representar muitas situações práticas de interesse, especialmente quando as velocidades de vento são altas (SILVA et al 1999).

A função densidade de probabilidade de Weibull apresenta melhores resultados do que aqueles fornecidos pela função densidade de probabilidade de Rayleigh, sendo um caso especial da distribuição Gama. Trata-se de uma função biparamétrica (parâmetros c e k), exigindo para sua definição, o conhecimento da velocidade média e do desvio padrão. A Equação (6) apresenta a função de Weibull.

$$
f(v)=\frac{k}{c} \cdot\left(\frac{v}{c}\right)^{k-1} \cdot e^{-\left(\frac{v}{c}\right)^{k}}
$$

Onde:

$f(v)$ é a função densidade de probabilidade de Weibull;

$v$ é a velocidade do vento $(\mathrm{m} / \mathrm{s})$;

$c$ é o fator de escala $(\mathrm{m} / \mathrm{s})$.

$k$ é o fator de forma (adimensional). 
De acordo com Custódio (2009), o fator de escala (c) está relacionado com a velocidade média do vento, por sua vez, o fator de forma $(k)$ está relacionado com a variância da velocidade do vento, representando a forma da função de distribuição da velocidade do vento.

Araújo (1989) leciona que vários métodos podem ser utilizados para estimar os parâmetros c e k da função de Weibull, dependendo dos dados de vento disponíveis e do rigor requerido na análise. Nesse sentido, a autora relaciona 5 métodos paramétricos e 2 métodos gráficos para estimar os parâmetros c e $k$ da função de Weibull. Silva et al (1999) utilizam conceitos de algoritmos genéticos para estimar os parâmetros c e k. Fadigas (2011) e Araújo (1989) propõem a Equação (7) e a Equação (8) para obter parâmetros k e c da função de Weibull, respectivamente.

$$
k=\left(\frac{\sigma_{v}}{V}\right)^{-1,086}
$$

Onde:

$\sigma_{v}$ é o desvio padrão da velocidade do vento;

$V$ é a velocidade média do vento $(\mathrm{m} / \mathrm{s})$.

$$
c=\frac{V}{\Gamma(1+1 / k)}
$$

Onde:

$\Gamma$ é a função Gama de argumento $(1+1 / k)$

O Gráfico 23 apresenta a função densidade de probabilidade de Weibull para 4 valores diferentes para o parâmetro c (escala). 
Gráfico 23 - Função Densidade de Probabilidade de Weibull (Variando c).

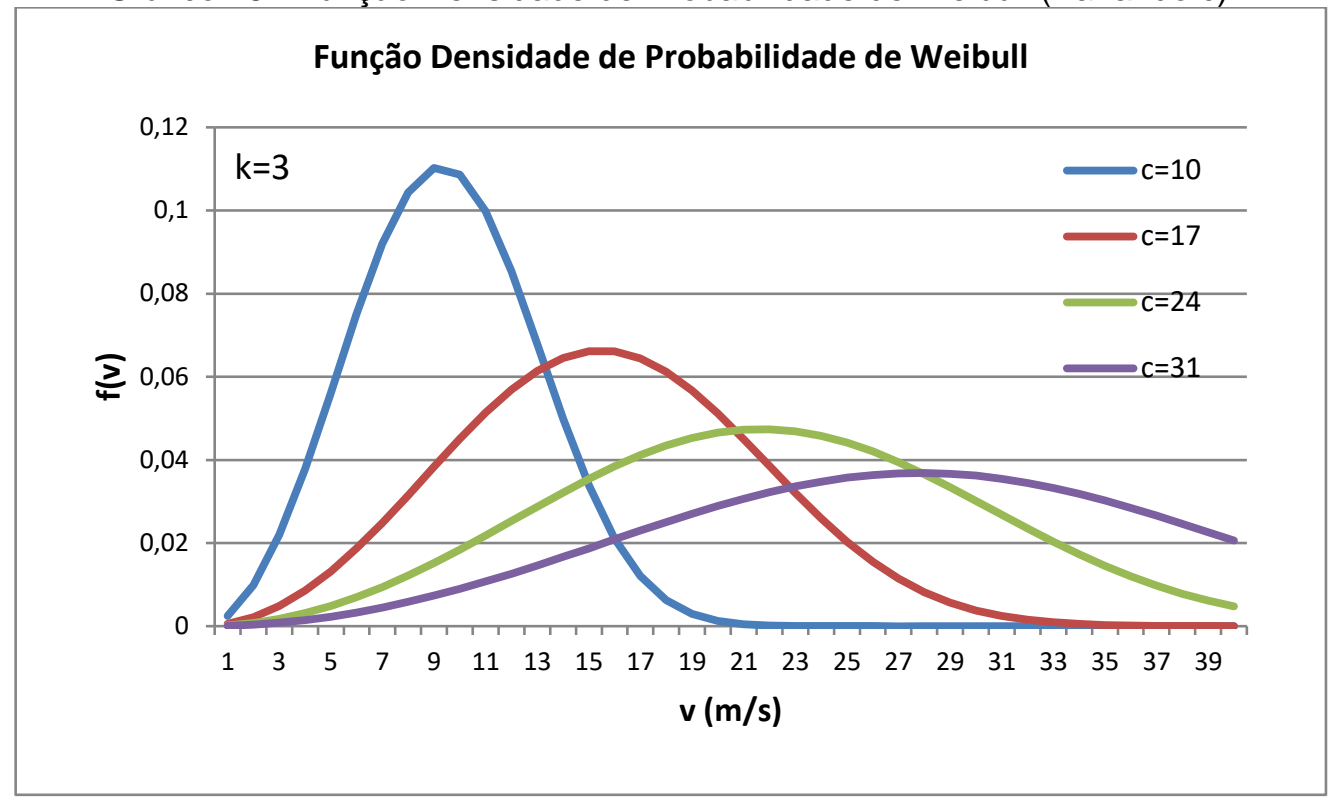

Autor (2016).

O Gráfico 24 apresenta a função densidade de probabilidade de Weibull para 5 valores diferentes para o parâmetro k (forma).

Gráfico 24 - Função Densidade de Probabilidade de Weibull (Variando k).

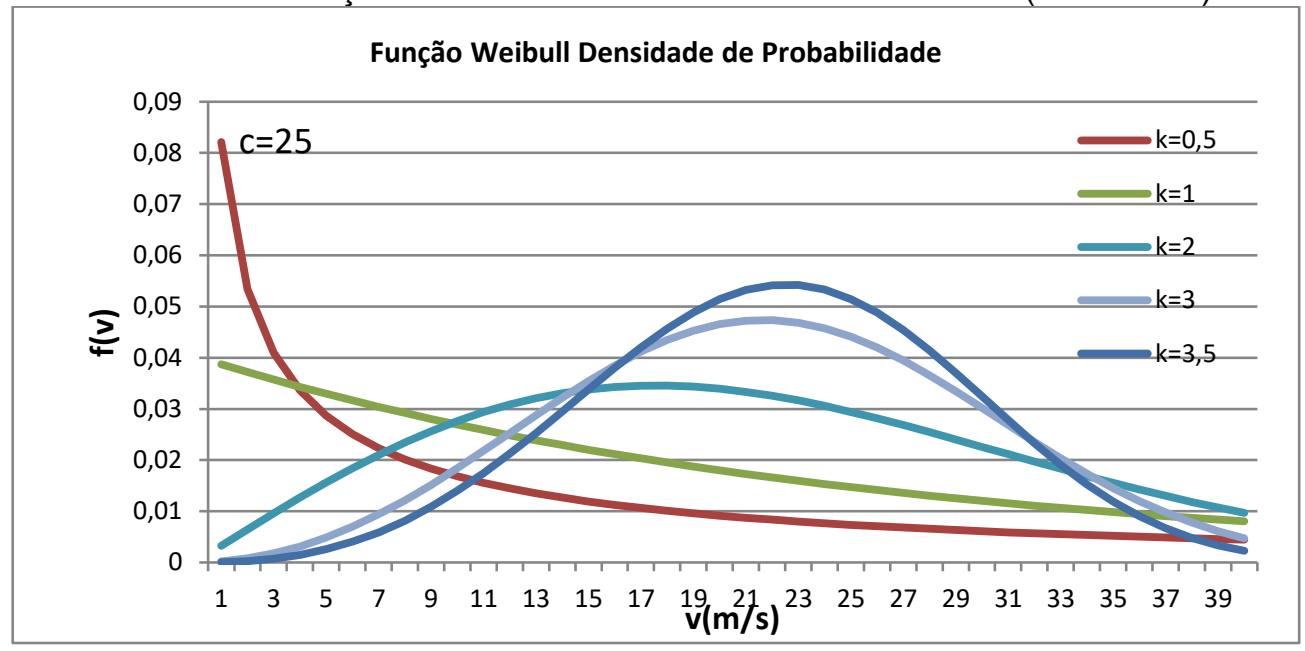

Autor (2016).

A função densidade de probabilidade de Weibull consegue retratar um grande número de padrões de comportamento da velocidade do vento, uma vez que incorpora a distribuição exponencial (quando $k=1$ ) e a distribuição de Rayleigh (quando $k=2$ ), além de fornecer uma boa aproximação da distribuição normal (quando $k=3,5$ ) (FADIGAS, 2011). 


\subsection{FUNDAMENTOS DA GERAÇÃO DE ENERGIA EÓLICA}

A partir do conhecimento da velocidade do vento de uma determinada área, pode-se calcular o potencial eólico do lugar e o dimensionamento de um parque eólico. A potência eólica é dada pela Equação (9) (CUSTÓDIO, 2009).

$$
P=1 / 2 \cdot \rho \cdot v^{3} \cdot A
$$

Onde:

$P$ é a potência do vento $(\mathrm{W})$;

$\rho$ é a massa específica do ar $\left(\mathrm{kg} / \mathrm{m}^{3}\right)$;

$A$ é a área de seção transversal $\left(\mathrm{m}^{2}\right)$;

$v$ é a velocidade livre do vento $(\mathrm{m} / \mathrm{s})$.

Para fins comparativos do potencial eólico nas diversas áreas, adota-se a Equação (10), definida a seguir.

$$
\frac{P}{A}=1 / 2 \cdot \rho \cdot v^{3}
$$

Observa-se pelas equações anteriores que a potência é diretamente proporcional ao cubo da velocidade. Sendo assim, pequenas variações na velocidade do vento provocam elevadas variações na potência. Caso a velocidade seja reduzida pela metade a potência é reduzida em $1 / 8$.

Quando o vento atinge um conversor eólico, parte da potência eólica calculada pela Equação (10) é convertida em potência mecânica, conforme demonstração realizada em Fadigas (2011), a partir da lei de continuidade de fluxo, que resulta na Equação (11).

$$
P_{m}=1 / 2 \cdot \rho \cdot A \cdot v_{1}{ }^{3} \cdot \frac{\left(1+\frac{v_{2}}{v_{1}}\right) \cdot\left(1-\left(\frac{v_{2}}{v_{1}}\right)^{2}\right)}{2}
$$


Onde:

$P_{m}$ é a potência mecânica extraída pelo conversor eólico (W);

$v_{1}$ é a velocidade do vento antes do conversor eólico $(\mathrm{m} / \mathrm{s})$;

$v_{2}$ é a velocidade do vento após o conversor eólico $(\mathrm{m} / \mathrm{s})$.

O termo $\frac{\left(1+\frac{v_{2}}{v_{1}}\right) \cdot\left(1-\left(\frac{v_{2}}{v_{1}}\right)^{2}\right)}{2}$ é denominado de coeficiente de potência ou coeficiente de $B e t z^{67}\left(C_{B}\right)$, e traduz a relação entre a potência mecânica do conversor e a potência eólica contida no vento. A máxima transferência de potência ocorre quando a relação entre as velocidades $v_{2} / v_{1}$ é igual a 1/3. Assim, a Equação (11) pode ser reescrita pela Equação (12).

$$
P_{m}=1 / 2 \cdot \rho \cdot A \cdot v_{1}^{3} \cdot c_{B}
$$

Onde:

$c_{B}$ é o coeficiente de Betz, adimensional e igual a $16 / 27$, para $v_{2} / v_{1}=1 / 3$.

Desta forma, a máxima potência mecânica que pode ser extraída pelo conversor eólico é dada pela Equação (13).

$$
P_{m_{\max }}=16 / 27 \cdot P_{m}
$$

O Gráfico 25 representa a potência disponível do vento Equação (10) e a máxima potência mecânica extraída por uma turbina eólica por área Equação (13), em ambos os casos, considerando massa específica do ar $(\rho)$ igual a 1,225 kg/m .

${ }^{67}$ Físico que demonstrou o coeficiente de potência ideal. 
Gráfico 25 - Potência Eólica e Máxima Potência Mecânica.

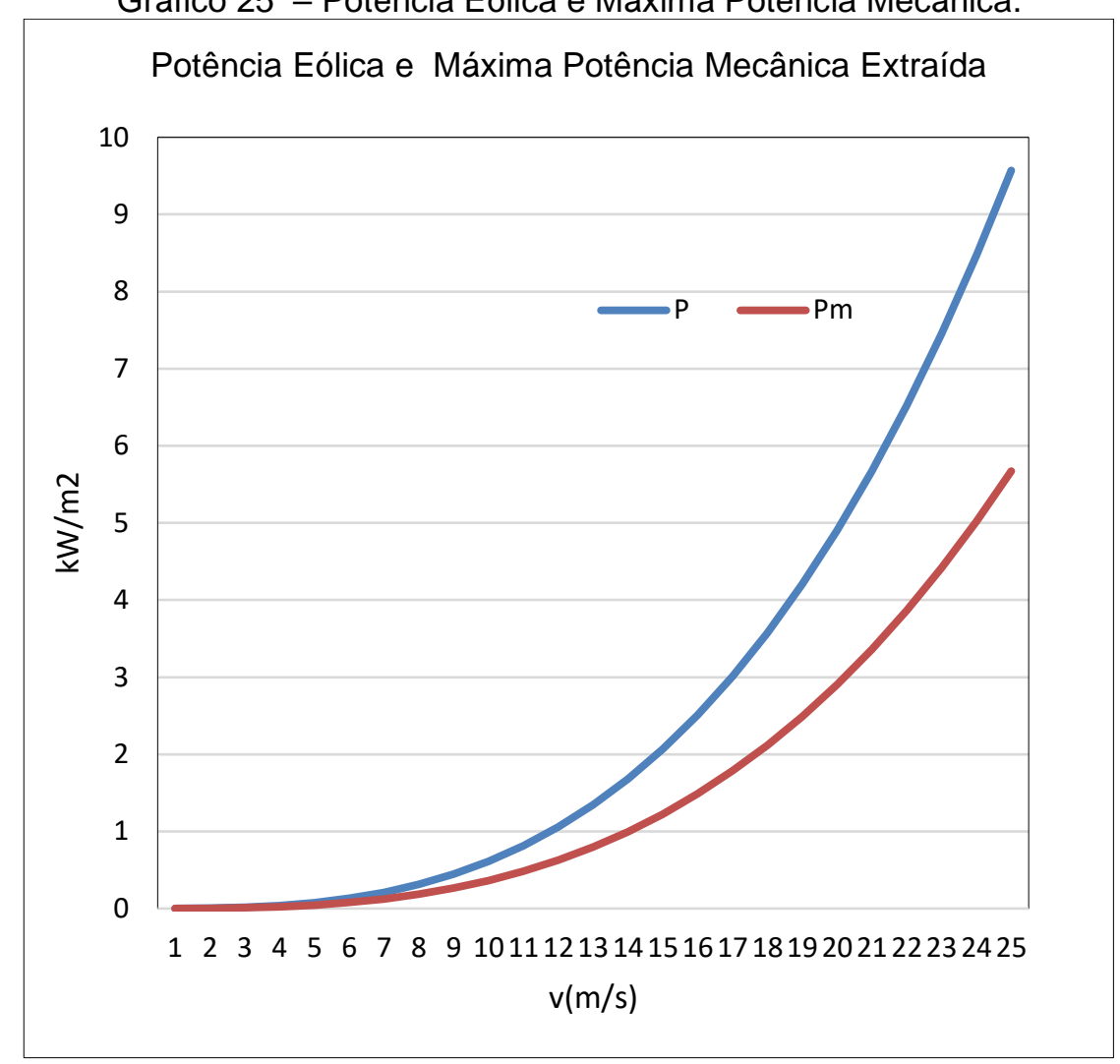

Autor (2016).

A potência elétrica extraída do conversor eólico é menor que a potência mecânica máxima devido às perdas aerodinâmicas, elétricas e mecânicas do processo de conversão, que são expressas pelo coeficiente de potência $\left(\mathrm{C}_{p}\right)$, este por sua vez, varia com a velocidade do vento, em razão da variação da eficiência aerodinâmica das pás do rotor com a velocidade do vento. A Equação (14) indica a relação entre a potência elétrica real extraída do vento por uma turbina eólica e a potência eólica disponível $\left(\mathrm{C}_{\mathrm{p}}\right)$.

$$
C_{p}=\frac{P_{e}}{\frac{1}{2} \cdot \rho \cdot A \cdot v^{3}}
$$

Onde:

$P_{e}$ é a potência elétrica extraída pelo conversor eólico (W). 
Para calcular a energia gerada pelas turbinas eólicas, é necessário obter informações acerca das curvas de potência dos equipamentos (potência e coeficiente de potência). Estas curvas representam o quanto de energia um aerogerador é capaz de gerar em uma determinada faixa de velocidade de vento, face o comportamento do coeficiente de potência em função da velocidade do vento. O Gráfico 26, reproduzido do catálogo do fabricante, representa a curva de potência e curva do coeficiente de potência do aerogerador E126 da Enercon, de 7.580 kW de potência nominal.

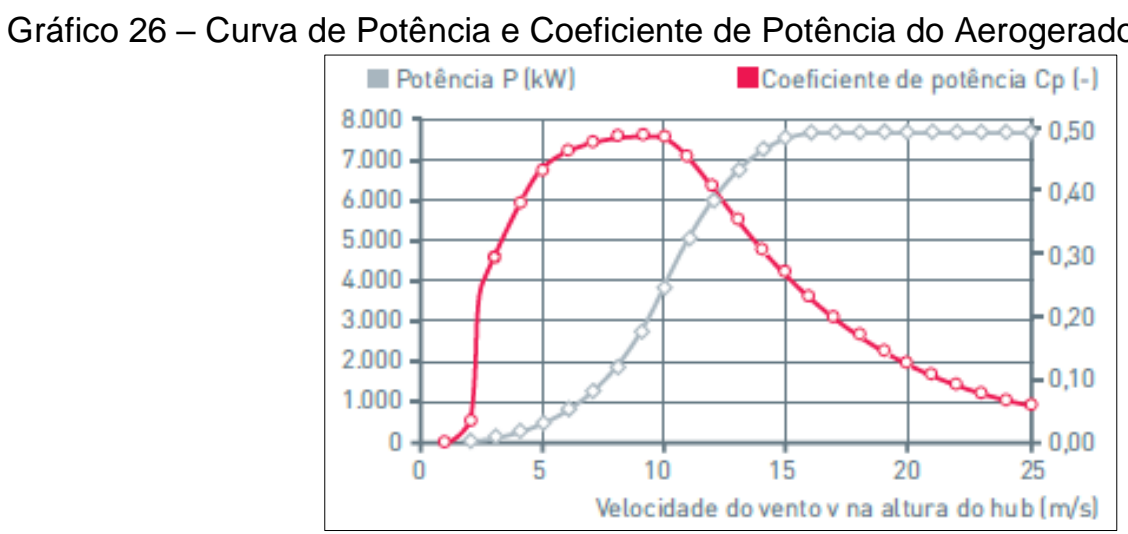

Fonte: Catálogo do Fabricante Enercon.

A potência elétrica média produzida por um aerogerador pode ser calculada a partir da função densidade de probabilidade da velocidade do vento e pela curva de potência elétrica fornecida pelo fabricante, conforme Equação (15).

$$
\bar{P}_{e}=\int_{0}^{\infty} P_{e}(v) \cdot p(v) d v
$$

Onde:

$\bar{P}_{e}$ é a potência elétrica média extraída do aerogerador $(\bar{W})$;

$P_{e}(v)$ é a curva (função) de potência elétrica fornecida pelo fabricante;

$p(v)$ é a função densidade de probabilidade da velocidade do vento.

Conforme item 4.3, a função de densidade de probabilidade da velocidade do vento pode ser representada pela função de Rayleigh (Equação (5)) ou pela função de Weibull (Equação (6)). 
Alternativamente, a potência elétrica média produzida por um aerogerador pode ser calculada a partir de medições de velocidade de vento e pela curva de potência elétrica fornecida pelo fabricante, conforme Equação (16).

$$
\overline{P_{e}}=\frac{1}{N} \cdot \sum_{i=1}^{N} P_{e}\left(v_{i}\right)
$$

Onde:

$P_{e}\left(v_{i}\right)$ é potência elétrica fornecida pelo fabricante para a velocidade $v_{i}$;

$N$ é o número total de medições realizadas da velocidade do vento.

Outra forma de calcular a potência elétrica média produzida por um aerogerador a partir de medições de velocidade de vento, consiste em usar a frequência das observações, conforme Equação (17).

$$
\bar{P}_{e}=\sum_{j=1}^{K} P_{e}\left(v_{j}\right) \cdot f_{v j}
$$

Onde:

$P_{e}\left(v_{k}\right)$ é potência elétrica fornecida pelo fabricante para a velocidade $v_{j}$;

$f_{v j}$ é o percentual de ocorrência (frequência) da velocidade $v_{j}$;

$K$ é o número total de intervalos de ocorrência da velocidade do vento.

A partir da Equação (15) pode-se obter a energia anual gerada por um aerogerador, considerando o número de horas no ano, conforme Equação (18).

$$
E A G=8760 \cdot \int_{0}^{\infty} P_{e}(v) \cdot p(v) d v
$$

Onde: $E A G$ é a estimativa da energia anual gerada pelo aerogerador (Wh). 
Alternativamente, conforme Equação (16) e Equação (17), a estimativa da energia anual gerada pelo aerogerador também pode ser calculada a partir do histograma da velocidade do vento.

A TABELA 12 ilustra um exemplo do cálculo da energia anual gerada para o aerogerador E126 da Enercon, de potência nominal de 7.580 kW e curva de potência apresentada no Gráfico 26, supondo que os dados de medição da velocidade de vento, tenham resultado na função Weibull com o parâmetro de forma (k) igual a 3,5 e o parâmetro de escala (c) igual a $25 \mathrm{~m} / \mathrm{s}$ (representada pela curva azul no Gráfico 23).

TABELA 12- Estimativa da Energia Anual Gerada pelo Aerogerador E126 da Enercon com Função

\begin{tabular}{|c|c|c|c|c|c|c|}
\hline $\begin{array}{c}\text { Classe da } \\
\text { Velocidade } \\
(\mathrm{m} / \mathrm{s})\end{array}$ & $\begin{array}{l}\text { Frequência de } \\
\text { ocorrência } \\
{[p(v)]}\end{array}$ & $\begin{array}{l}\text { Frequência } \\
\text { Acumulada }\end{array}$ & Duração & $\begin{array}{l}\text { Potência } \\
\text { Aerogerador } \\
{[\mathrm{Pe}(\mathrm{v})](\mathrm{kW})}\end{array}$ & $p(v) \cdot \operatorname{Pe}(v)$ & $\begin{array}{c}\text { Curva de } \\
\text { Pernanência }\end{array}$ \\
\hline 1 & $0,00 \%$ & $0,00 \%$ & $100,00 \%$ & - & - & - \\
\hline 2 & $0,03 \%$ & $0,03 \%$ & $99,97 \%$ & - & - & - \\
\hline 3 & $0,07 \%$ & $0,10 \%$ & $99,90 \%$ & 55,00 & 0,04 & 0,04 \\
\hline 4 & $0,15 \%$ & $0,25 \%$ & $99,75 \%$ & 175,00 & 0,26 & 0,30 \\
\hline 5 & $0,26 \%$ & $0,51 \%$ & $99,49 \%$ & 410,00 & 1,05 & 1,35 \\
\hline 6 & $0,40 \%$ & $0,91 \%$ & $99,09 \%$ & 760,00 & 3,06 & 4,41 \\
\hline 7 & $0,59 \%$ & $1,50 \%$ & $98,50 \%$ & $1.250,00$ & 7,37 & 11,78 \\
\hline 8 & $0,82 \%$ & $2,32 \%$ & $97,68 \%$ & $1.900,00$ & 15,53 & 27,31 \\
\hline 9 & $1,09 \%$ & $3,40 \%$ & $96,60 \%$ & $2.700,00$ & 29,34 & 56,65 \\
\hline 10 & $1,40 \%$ & $4,80 \%$ & $95,20 \%$ & $3.750,00$ & 52,36 & 109,01 \\
\hline 11 & $1,74 \%$ & $6,54 \%$ & $93,46 \%$ & $4.850,00$ & 84,53 & 193,54 \\
\hline 12 & $2,12 \%$ & $8,66 \%$ & $91,34 \%$ & $5.750,00$ & 122,02 & 315,56 \\
\hline 13 & $2,53 \%$ & $11,19 \%$ & $88,81 \%$ & $6.500,00$ & 164,26 & 479,81 \\
\hline 14 & $2,95 \%$ & $14,14 \%$ & $85,86 \%$ & $7.000,00$ & 206,43 & 686,25 \\
\hline 15 & $3,38 \%$ & $17,52 \%$ & $82,48 \%$ & $7.350,00$ & 248,23 & 934,48 \\
\hline 16 & $3,80 \%$ & $21,32 \%$ & $78,68 \%$ & $7.500,00$ & 284,96 & $1.219,44$ \\
\hline 17 & $4,20 \%$ & $25,52 \%$ & $74,48 \%$ & $7.580,00$ & 318,49 & $1.537,93$ \\
\hline 18 & $4,57 \%$ & $30,09 \%$ & $69,91 \%$ & $7.580,00$ & 346,37 & $1.884,30$ \\
\hline 19 & $4,89 \%$ & $34,98 \%$ & $65,02 \%$ & $7.580,00$ & 370,51 & $2.254,81$ \\
\hline 20 & $5,14 \%$ & $40,12 \%$ & $59,88 \%$ & $7.580,00$ & 389,87 & $2.644,68$ \\
\hline 21 & $5,32 \%$ & $45,44 \%$ & $54,56 \%$ & $7.580,00$ & 403,50 & $3.048,18$ \\
\hline 22 & $5,42 \%$ & $50,86 \%$ & $49,14 \%$ & $7.580,00$ & 410,67 & $3.458,85$ \\
\hline 23 & $5,42 \%$ & $56,28 \%$ & $43,72 \%$ & $7.580,00$ & 410,91 & $3.869,75$ \\
\hline 24 & $5,33 \%$ & $61,61 \%$ & $38,39 \%$ & $7.580,00$ & 404,04 & $4.273,79$ \\
\hline 25 & $5,15 \%$ & $66,76 \%$ & $33,24 \%$ & $7.580,00$ & 390,25 & $4.664,04$ \\
\hline 26 & $4,88 \%$ & $71,64 \%$ & $28,36 \%$ & $7.581,00$ & 370,11 & $5.034,15$ \\
\hline 27 & $4,54 \%$ & $76,18 \%$ & $23,82 \%$ & $7.500,00$ & 340,70 & $5.374,85$ \\
\hline 28 & $4,14 \%$ & $80,33 \%$ & $19,67 \%$ & $7.350,00$ & 304,65 & $5.679,50$ \\
\hline 29 & $3,71 \%$ & $84,04 \%$ & $15,96 \%$ & $7.000,00$ & 259,43 & $5.938,93$ \\
\hline 30 & $3,25 \%$ & $87,28 \%$ & $12,72 \%$ & $6.500,00$ & 210,93 & $6.149,86$ \\
\hline 31 & $2,78 \%$ & $90,06 \%$ & $9,94 \%$ & $5.750,00$ & 159,88 & $6.309,74$ \\
\hline 32 & $2,33 \%$ & $92,39 \%$ & $7,61 \%$ & $4.850,00$ & 112,98 & $6.422,72$ \\
\hline 33 & $1,91 \%$ & $94,30 \%$ & $5,70 \%$ & $3.750,00$ & 71,50 & $6.494,22$ \\
\hline
\end{tabular}




\begin{tabular}{ccccccc}
\hline $\begin{array}{c}\text { Classe da } \\
\text { Velocidade } \\
(\mathbf{m} / \mathbf{s})\end{array}$ & $\begin{array}{c}\text { Frequência de } \\
\text { ocorrência } \\
{[\mathbf{p}(\mathbf{v})]}\end{array}$ & $\begin{array}{c}\text { Frequência } \\
\text { Acumulada }\end{array}$ & Duração & $\begin{array}{c}\text { Potência } \\
\text { Aerogerador } \\
{[\mathbf{P e}(\mathbf{v}) \mathbf{~} \mathbf{( k W})}\end{array}$ & $\mathbf{p}(\mathbf{v}) \cdot \mathbf{P e}(\mathbf{v})$ & $\begin{array}{c}\text { Curva de } \\
\text { Pernanência }\end{array}$ \\
\hline 34 & $1,52 \%$ & $95,82 \%$ & $4,18 \%$ & $2.700,00$ & 41,14 & $6.535,36$ \\
35 & $1,19 \%$ & $97,01 \%$ & $2,99 \%$ & $1.900,00$ & 22,56 & $6.557,92$ \\
36 & $0,90 \%$ & $97,91 \%$ & $2,09 \%$ & $1.250,00$ & 11,27 & $6.569,19$ \\
37 & $0,67 \%$ & $98,58 \%$ & $1,42 \%$ & 760,00 & 5,07 & $6.574,25$ \\
38 & $0,48 \%$ & $99,06 \%$ & $0,94 \%$ & 410,00 & 1,97 & $6.576,22$ \\
39 & $0,34 \%$ & $99,39 \%$ & $0,61 \%$ & 175,00 & 0,59 & $6.576,80$ \\
40 & $0,23 \%$ & $99,62 \%$ & $0,38 \%$ & 55,00 & 0,12 & $6.576,93$ \\
41 & $0,00 \%$ & $99,62 \%$ & $0,38 \%$ & - & - & \\
\hline
\end{tabular}

Autor (2016).

A primeira coluna da tabela representa as classes da velocidade do vento observadas. No caso, as classes foram divididas em intervalos de $1 \mathrm{~m} / \mathrm{s}$. A segunda coluna representa o percentual de ocorrência de determinada classe de velocidade de vento, dentro das observações de medição realizadas $(p(v))$.

A velocidade média do vento nesse exemplo foi calculada em 22,16 m/s. A terceira coluna representa a frequência acumulada, ou a curva de permanência da velocidade do vento. A quarta coluna representa a curva de potência do aerogerador E126 da Enercon, de potência nominal de $7.580 \mathrm{~kW}\left(P_{e}(v)\right)$. A última coluna é o cálculo da energia gerada para cada classe da velocidade do vento, sendo obtida pela multiplicação da coluna $p(v)$ pela coluna $P_{e}(v)$. O total de energia gerada é o resultado do somatório da energia gerada para cada classe da velocidade do vento, totalizando $6.576,93 \mathrm{kWmédios,} \mathrm{equivalente} \mathrm{a} 87 \%$ de fator de capacidade. Trata-se de um exemplo didático, onde adotou-se a velocidade média do vento bem acima dos valores encontrados nos projetos reais.

O histograma da velocidade do vento (função densidade de probabilidade) e a curva de potência do aerogerador E126 da Enercon estão apresentados na Figura 8. 
Figura 8 - Frequência de Ocorrência da Velocidade do Vento, Curva de Potência do Aerogerador E126 da Enercon e Estimativa da Energia Média Gerada.

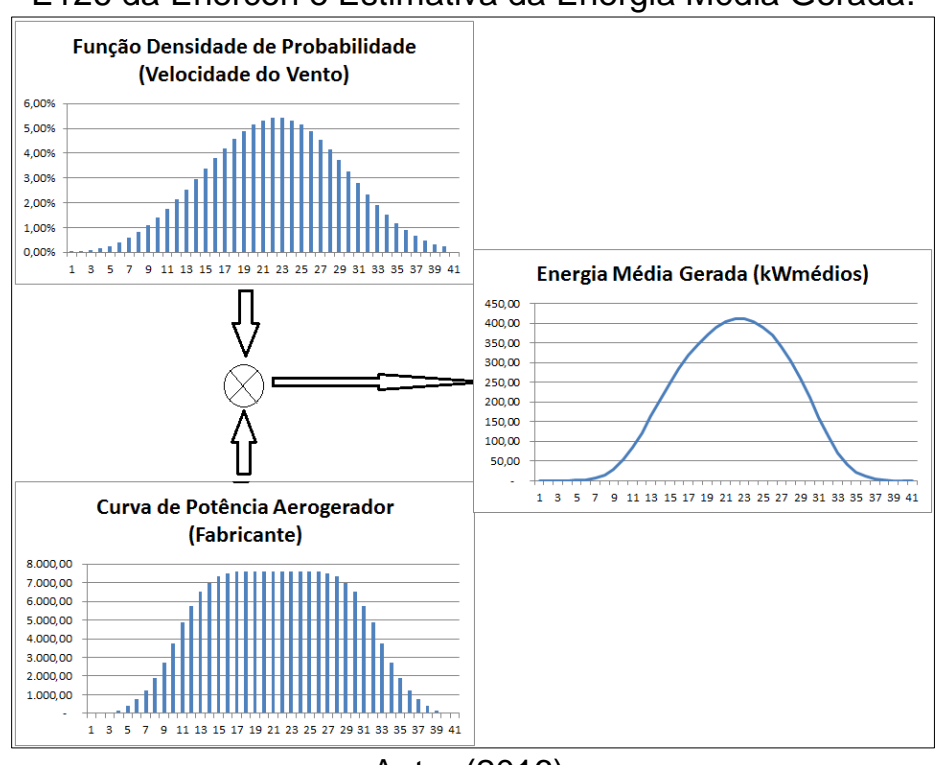

Autor (2016).

A quantidade de energia gerada é estimada pela intersecção da curva de potência do aerogerador com a curva densidade de probabilidade de Weibull da velocidade do vento. A Figura 9, reproduzida de Carvalho (2003), ilustra a representação gráfica do cálculo da quantidade de energia gerada (Ei (kWh)).

Figura 9 - Curva de Potência do Aerogerador, Curva Densidade de Probabilidade de Weibull para a Velocidade do Vento e Curva da Energia Gerada.

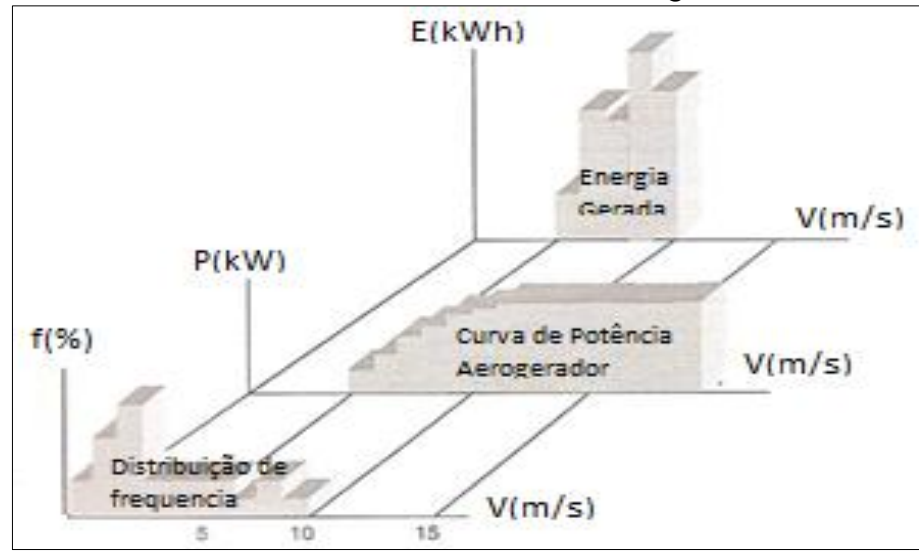

Fonte: adaptado de Carvalho (2003). 


\subsection{GARANTIA FÍSICA DAS USINAS EÓLICAS}

A garantia física é o certificado fornecido pelo poder concedente que define o montante máximo de energia elétrica que pode ser comercializada pela usina por meio de contratos bilaterais, a partir de seu próprio recurso, isto é, sem considerar eventuais contratos de compra de energia. Simplificadamente, a garantia física deve refletir a quantidade de energia possível de ser produzida pelo empreendimento ao longo da sua outorga, com um determinado nível de confiabilidade.

A Portaria MME 258/2008 estabelece a metodologia de cálculo da garantia física de novos empreendimentos de geração de energia elétrica ${ }^{68}$. De acordo com a referida Portaria, a garantia física "é definida como aquela correspondente à máxima quantidade de energia que este sistema pode suprir a um dado critério de garantia de suprimento", ou confiabilidade.

Para UHEs e UTEs, o cálculo da garantia física é realizado pelos modelos NEWAVE e MSUI e considera como critério de garantia de suprimento a igualdade entre o Custo Marginal de Operação médio anual (CMO) e o Custo Marginal de Expansão (CME), admitida uma tolerância e respeitado o limite do risco de déficit de $5 \%$ em cada submercado.

Para os empreendimentos eólicos, a Portaria estabelece que "as usinas cuja inflexibilidade é igual à disponibilidade declarada pelo agente gerador, ou ainda, que possuam CVU nulo, como é o caso das usinas de fonte eólica - UEE e das termelétricas movidas à biomassa, terão a sua GF, definida como a máxima quantidade de energia que a usina pode vender no SIN". Nestes casos, a garantia física é calculada e declarada pelo próprio investidor e certificada por uma empresa independente.

Ao contrário das UHEs e UTEs, a garantia física das usinas eólicas não é obtida por simulações estocásticas da geração eólica, integrada ao sistema interligado hidrotérmico nacional, com o modelo NEWAVE, tampouco leva em consideração a ponderação da energia gerada pelo $\mathrm{CMO}$.

Enquanto a garantia física de UHEs e UTEs é calculada por um critério econômico, a garantia física das usinas eólicas é calculada por um critério físico, associado diretamente à expectativa de produção física do parque no longo prazo.

68 Para os empreendimentos de geração em operação comercial antes da publicação desse Portaria, vale a definição constante da Portaria MME 303/2004. 
A garantia física das usinas eólicas é calculada com base na estimativa de produção de energia, que utiliza os resultados do mapeamento do regime de ventos (histórico de dados de ventos decorrente de medições locais) e curvas de desempenho calculadas e garantidas pelos fabricantes dos aerogeradores.

Até abril de 2013, a estimativa da produção de energia das usinas eólicas (garantia física) considerou um nível de confiança de 50\% (denominado de P50). A partir da publicação da Portaria MME 131/2013 ${ }^{69}$, a estimativa de produção de energia passou a considerar o nível de confiança de 90\% (denominado de P90), que, de acordo com a Nota Técnica EPE-DEE-NT-072/2013-r0, refere ao "valor de energia anual que é excedido com uma probabilidade de ocorrência igual ou maior a $90 \%$ para um período de variabilidade futura de 20 anos". A garantia física das usinas eólicas é calculada de acordo com a Equação (19).

$$
G F=\frac{\left[P 90_{a c} x(1-T E I F) x(1-I P)-\Delta P\right]}{8760}
$$

Onde:

$P 90_{a c}$ é a produção anual de energia certificada, em MWh, referente ao valor de energia anual com uma probabilidade de ocorrência igual ou maior a $90 \%$, constante da Certificação de Medições Anemométricas e de Produção Anual de Energia;

TEIF é a Taxa Equivalente de Indisponibilidade Forçada;

$I P$ é a Indisponibilidade Programada;

$\Delta P$ é a estimativa anual do consumo interno e perdas elétricas até o ponto de conexão da usina eólica com o sistema elétrico, em MWh.

A estimativa da produção anual de energia certificada deve considerar o abatimento das perdas por conta da disposição dos aerogeradores, das condições

\footnotetext{
${ }^{69}$ A Portaria MME no 131/2013 alterou a metodologia de cálculo de garantia física de empreendimentos eólicos para os Leilões de Reserva, que antes era baseada na produção certifica a P50, passando a considerar a produção referente ao valor de energia anual com uma probabilidade de ocorrência igual ou maior a noventa por cento, conhecido como P90. A Portaria MME n 226/2013 de julho de 2013, por sua vez, estendeu a metodologia de garantia física a P90 para os Leilões de Energia Nova e de Fontes Alternativas. Como consequência, a partir de 2013, a garantia física de empreendimentos eólicos que participarem dos leilões do ambiente regulado ou dos leilões de energia de reserva será calculada considerando o critério do P90. A metodologia de cálculo de Garantia Física com P50 para os empreendimentos eólicos futuros ficou restrita ao ACL.
} 
meteorológicas locais, da densidade do ar, da degradação das pás e das perdas aerodinâmicas do próprio parque e dos efeitos esteira e turbulência de outros parques, entre outras.

A importância da qualidade da medição da velocidade do vento para a estimativa da produção anual de energia foi apresentada por Alé, Simionl e Hack (2008). De acordo com os autores, a incerteza na estimativa da produção anual de energia é aproximadamente igual a 3 vezes a incerteza total do sistema de medição (sistema anemométrico), dividida pela velocidade média medida. Por exemplo, supondo a velocidade média medida de $6 \mathrm{~m} / \mathrm{s}$ e um sistema anemométrico de incerteza igual a $\pm 0,5 \mathrm{~m} / \mathrm{s}$ (representa $\pm 8,33 \%$ de incerteza), a incerteza na estimativa da produção anual de energia é aproximadamente igual a $\pm 25 \%$.

A incerteza na estimativa da produção anual de energia decorre das incertezas na velocidade do vento (medição, extrapolação vertical/horizontal, e climatologia), da incerteza na curva de potência da turbina eólica, e da incerteza no cálculo das perdas aerodinâmicas do parque.

Sendo assim, além da estimativa da produção anual de energia, a Certificação de Medições Anemométricas e de Produção Anual de Energia também deve conter a análise e quantificação das principais fontes de incertezas na geração de energia, composta pela contribuição das incertezas na velocidade do vento (medição, extrapolações vertical e horizontal, e climatológica), na curva de potência da turbina e no cálculo da eficiência aerodinâmica do parque eólico. De acordo com o Lactec (2007), as incertezas na velocidade do vento resultam da contribuição dos seguintes fatores:

a) medição do vento: incertezas de calibração dos anemômetros; inclinação e assimetria do escoamento incidente (shear) no anemômetro; distorção do escoamento devido às estruturas da torre, fixações, hastes de suporte, cabos, etc.; sobre velocidade (overspeeding); incertezas do sistema e instrumentação; incerteza estatística no próprio cálculo da velocidade média a partir das séries temporais de vento;

b) extrapolação vertical: incerteza na extrapolação da velocidade do vento medida na altura do anemômetro para a altura de rotor das turbinas eólicas;

c) extrapolação horizontal: incerteza na extrapolação dos dados medidos no local das torres dos anemômetros para a posição das turbinas eólicas, 
resultante do modelo de cálculo utilizado na simulação dos ventos na área da usina (modelo de mesoescala ${ }^{70}$ );

d) climatologia: incerteza associada à representatividade do período de medições no sítio em relação ao ano climatológico médio, abrangência do período de medições e qualidade da correlação com a referência de longo prazo (NCAR/NCEP Reanalysis Project).

A TABELA 13 apresenta a contribuição de cada fator de incerteza na estimativa da velocidade do vento.

\begin{tabular}{|c|c|}
\hline Incerteza da Velocidade do Vento & Contribuição (\%) \\
\hline Incertezas de Medição e Extrapolação Vertical & $1,8 \%$ \\
\hline Incerteza de Extrapolação Horizontal & $3,1 \%$ \\
\hline Incertezas de Correlação e Climatologia & $2,5 \%$ \\
\hline Incertezas na Velocidade do Vento & $7,5 \%$ \\
\hline
\end{tabular}

Fonte: Silva e Amarante (2013).

Silva e Amarante (2013) asseveram que a contribuição decorrente das incertezas na curva de potência deve ser calculada a partir de resultados de ensaios de medição realizados conforme procedimentos da IEC 61400-12 (International Eletrotechnical Commission) e MEASNET, e executados por instituições acreditadas internacionalmente e com credenciamento ISO/IEC 17025. De acordo com os autores, para a faixa de velocidade média anual do vento de 7 a $9 \mathrm{~m} / \mathrm{s}$ na altura do eixo do rotor, a incerteza padrão típica resultante do ensaio de medição da curva de potência situa-se entre $4 \%$ e $6 \%$, quando realizada estritamente conforme os procedimentos IEC e MEASNET. No entanto, a incerteza na curva de potência pode ser reduzida contratualmente com o fornecedor do aerogerador.

For fim, segundo Silva e Amarante (2013), a incerteza no cálculo das perdas aerodinâmicas decorre do modelo de interferência entre turbinas utilizado na estimativa, e da sua sensibilidade a parâmetros como a curva do coeficiente de tração (Ct) e a constante de decaimento da esteira. A TABELA 14 apresenta a contribuição de cada fator de incerteza no cálculo da Produção Anual de Energia.

\footnotetext{
70 Dimensões entre $1 \mathrm{~km}$ a $100 \mathrm{~km}$, segundo classificação fornecida em Pinto (2013) e Lutgens e Tarbuck apud Martins, Guarnierl e Pereira (2008).
} 
TABELA 14 - Incertezas na Produção Anual de Energia.

\begin{tabular}{lc}
\hline \multicolumn{1}{c}{ Incerteza da Produção Anual de Energia } & Contribuição (\%) \\
\hline Incertezas na Velocidade do Vento (medição, extrapolaçães e climatologia) & $7,5 \%$ \\
Incertezas na Curva de Potência do Aerogerador & $7,0 \%$ \\
Incertezas no Cálculo das Perdas Aerodinâmicas do Parque Eólico & $0,8 \%$ \\
Incerteza Resultante na Produção Anual de Energia & $10,3 \%$ \\
\hline
\end{tabular}

Autor (2016).

Fonte: Silva e Amarante (2013).

A Incerteza Resultante na Produção Anual de Energia é calculada pela raiz quadrada da soma dos quadrados de cada contribuição da incerteza. Assume-se que estas contribuições sejam estatisticamente não correlacionadas ou independentes, e normalmente distribuídas (Distribuição Normal ou Gaussiana). As incertezas devem ser expressas como incertezas padrão ${ }^{71}$, possibilitando a aplicação de elementos de inferência e análise estatística (DANIEL, 2013). Custódio (2009) apresenta faixas típicas de incertezas para diversos fatores, cujos valores são semelhantes aos apresentados por Silva e Amarante (2013), conforme apresentado na TABELA 15.

TABELA 15 - Incertezas Típicas na Produção Anual de Energia.

\begin{tabular}{lc}
\hline \multicolumn{1}{c}{ Componente de Incerteza } & Faixa Típica de Incerteza (\%) \\
\hline Calibração do anemômetro em túnel de vento & $0,5-3$ \\
Seleção do anemômetro (influência do fluxo vertical e da turbulência) & $0,5-4$ \\
Montagem do anemômetro & $0,2-3$ \\
Seleção do local de medição & $0,5-5$ \\
Seleção do período de medição & $0,3-3$ \\
Coleta e avaliação dos dados & 0,2 \\
Correlação com os dados de longo termo (extrapolação climatológica) & $0,5-5$ \\
Extrapolações vertical e horizontal & $1-10$ \\
Total - Incerteza na Velocidade do Vento & $\mathbf{1 , 5 - 1 4}$ \\
\hline Total - Incerteza na Produção Anual de Energia & $\mathbf{3 - 3 0}$ \\
\hline \multicolumn{2}{c}{ Autor (2016). } \\
\multicolumn{2}{c}{ Fonte: Custódio (2009). }
\end{tabular}

A partir dos resultados da análise de incertezas na produção de energia, considerando uma Distribuição Normal ou Gaussiana, podem ser calculados os níveis de energia excedida com uma dada probabilidade de ocorrência ou nível de confiança, os denominados P50, P75 e P90.

Na Certificação de Medições Anemométricas e Certificação de Produção de Energia, elaborada por Silva e Amarante (2013) para um determinado parque eólico,

\footnotetext{
${ }^{71}$ As incertezas expressas como incertezas padrão, considera um intervalo de confiança de $68,3 \%$, equivalente a 1 (um) desvio padrão em relação à média $(x \pm s$, fator de abrangência unitário, que corresponde a um intervalo de confiança de $68.3 \%$ ).
} 
foi estimada a Produção Anual de Energia no valor médio igual a 142,7 GWh.ano (equivalente a uma Garantia Física de 16,3 MWmédios, com uma probabilidade de ocorrência igual ou maior a 50\%). A Incerteza Resultante na Produção Anual de Energia foi calculada em 10,3\% (TABELA 14), equivalente a um desvio padrão de 14,7 GWh.ano, que corresponde a um intervalo de confiança de $68.3 \%$. O Gráfico 27 ilustra os parâmetros estimados.

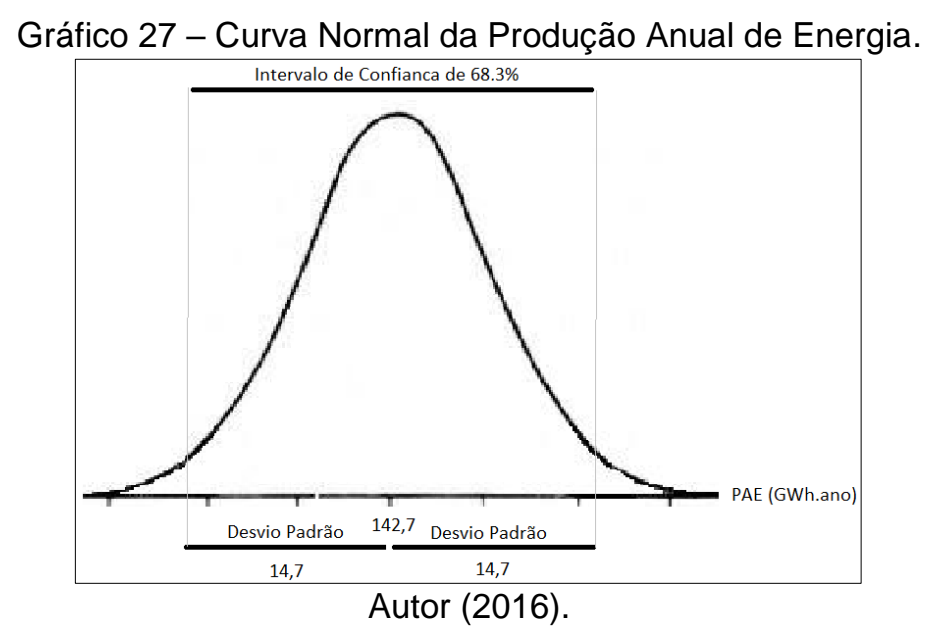

O Gráfico 28 apresenta o comportamento da estimativa da Produção Anual de Energia para vários intervalos de confiança (probabilidades), calculado a partir dos parâmetros de média e desvio padrão representados no Gráfico 27.

Gráfico 28 - Estimativa da Produção Anual de Energia para Vários Níveis de Confiança.

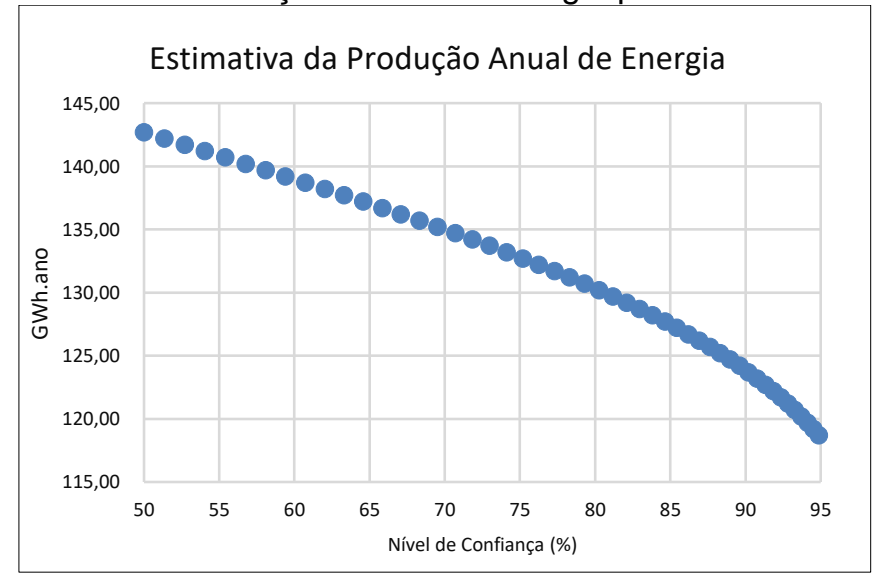

Autor (2016).

A Produção Anual de Energia para cada uma das probabilidades P50, P75, P90 e P95 (nível de confiança) é apresentada na TABELA 16. 
TABELA 16 - Produção Anual de Energia e Níveis de Confiança

\begin{tabular}{cc}
\hline Probabilidade (Nível de Confiança) & Produção Anual de Energia (GWh.ano) \\
\hline P50 & 142,7 \\
P75 & 132,8 \\
P90 & 123,9 \\
P95 & 118,4 \\
\hline
\end{tabular}

Autor (2016).

Fonte: Silva e Amarante (2013).

Verifica-se que no caso em tela, a garantia física calculada pelo critério do P90 é $87 \%$ da garantia física calculada pelo critério do P50. A relação entre a garantia física calculada pelo P90 e pelo P50 depende do valor da Incerteza Padrão, ou seja, depende do desvio padrão da estimativa da Produção Anual de Energia média, sendo que quanto menor esse parâmetro, mais próximos os valores.

De acordo com a Nota Técnica EPE-DEE-NT-072/2013-r0 elaborada pela EPE, a relação entre a produção anual de energia certificada, referente ao valor de energia anual que é excedido com uma probabilidade de ocorrência igual ou maior a $90 \%$ (P90) e o que é excedido com uma probabilidade de ocorrência igual ou maior a $50 \%$ (P50) é dada pela Equação (20).

$$
P 90_{a c}=P 50_{a c} x\left(1-\left(1,28155 x \frac{\text { Incerteza Padrão }}{100}\right)\right)
$$

Onde:

$P 90_{a c}$ é a produção anual de energia certificada, em MWh, referente ao valor de energia anual com uma probabilidade de ocorrência igual ou maior a $90 \%$, constante da Certificação de Medições Anemométricas e de Produção Anual de Energia; $P 50_{a c}$ é a produção anual de energia certificada, em $\mathrm{MWh}$, referente ao valor de energia anual com uma probabilidade de ocorrência igual ou maior a $50 \%$, constante da Certificação de Medições Anemométricas e de Produção Anual de Energia; Incerteza Padrão é o valor em percentual da Incerteza na Produção Anual de Energia obtida da Certificação de Medições Anemométricas Certificação de Produção de Energia;

1,28155 é a variável padronizada da distribuição normal, considerando a probabilidade de ocorrência de 0,1 . 


\subsection{TEORIA DE PORTFÓLIO DE MARKOWITZ}

Para Markowitz (1952), o processo de selecionar uma carteira de ações pode ser dividido em duas etapas. A primeira tem início na observação e experiência do investidor e é finalizada com expectativas sobre o desempenho futuro dos títulos analisados e disponíveis para investimento. A segunda etapa, da qual trata o trabalho de Markowitz, inicia-se com as opiniões sobre o futuro e termina com a escolha de uma carteira de ações. A teoria de seleção de portfólios foi desenvolvida por Markowitz para aplicação em títulos financeiros.

Markowitz parte da simples ideia de que todo investidor lida com duas incertezas no processo decisório de investimento: o retorno e o risco, que seria explicado pela variância (ou o desvio padrão) deste retorno. Neste sentido, o retorno é o fator desejável pelo investidor e a variância o fator indesejável. Sendo assim, o investidor racional ansiaria maximizar o fator desejável e minimizar o indesejável.

Quando postos a escolher entre dois portfólios de mesmo risco, os investidores sempre escolheriam o de maior retorno. Por seu turno, quando postos a escolher entre dois portfólios de mesmo retorno, os investidores sempre escolheriam o de menor risco.

Neste trabalho, como medida de dispersão será utilizada a variância ou desvio padrão, sendo esse último a raiz quadrada da variância. No mesmo sentido, como medida de tendência, será adotada a média simples ou em algumas situações a média ponderada pela probabilidade.

Portanto, de acordo com Markowitz, os investidores avaliariam portfólios apenas com base no valor esperado e na variância das taxas de retorno sobre um período. As únicas informações relevantes para a análise de investimentos seriam o valor esperado (média) e a variância (desvio padrão) dos retornos.

Markowitz analisou os riscos e retornos dos ativos, considerando a variância e o desvio-padrão como representantes do risco e a média (valor esperado) como proxy do retorno. Para tal, utilizou medidas simétricas de risco, assumindo que os investidores apresentam um comportamento compatível com o conceito de simetria de risco e, considerou que os retornos seguem uma distribuição normal, assumindo que os investidores possuem uma função de utilidade quadrática (função muito utilizada para os investidores avessos ao risco). 
Markowitz revolucionou os meios acadêmicos de sua época. O pensamento dominante na ocasião defendia a concentração dos investimentos nos ativos que ofereciam os maiores retornos esperados como a melhor situação para a alocação de recursos. Para Keynes (1939) apud Bruni, Fuentes e Famá (1998), a diversificação seria um equívoco:

Sou a favor de concentrar meus investimentos tanto quanto o mercado permita [...] Supor que segurança consiste em se fazer pequenas apostas num grande número de companhias sobre as quais eu não tenho informações para fazer um bom julgamento, comparada a uma posição substancial numa companhia sobre a qual eu tenho uma informação adequada, parece-me uma paródia. [KEYNES, 1939, apud BERNSTEIN 1992, p. 48).

No mesmo sentido, Loeb (1935) apud Macedo (2003) defendia a atitude especulativa e que o investidor deveria encontrar opções de investimentos que rendessem acima da média do mercado. Para tal, postulava que o investidor deveria concentrar seus recursos em dois ou três e no máximo quatro diferentes ativos. Em sua obra, The Battle for Investment Survival, Loeb (1935) afirmou que:

Uma vez que você obtenha confiança, a diversificação é indesejável. Diversificação é uma admissão de quem não sabe o que fazer e um esforço para ter uma performance média. (LOEB apud MACEDO, 2003).

As conclusões de Markowitz (1952) ressaltaram a importância da diversificação, conceito, até então, contestado pelos pensadores dominantes. Markowitz demonstrou que seria possível obter combinações mais eficientes de alocação de recursos, com melhor relação retorno esperado versus risco incorrido.

A partir de dados estatísticos individuais dos ativos (retorno esperado, desvio padrão e correlação), Markowitz estabeleceu uma carteira ótima de ativos que, dado um determinado risco (desvio padrão), maximiza o retorno esperado, ou dado o retorno esperado, minimiza o risco da carteira. Em razão dos parâmetros utilizados por Markowitz, é comum encontrar na literatura a denominação da sua teoria como teoria de MVP. 


\subsubsection{Formulação Matemática para Dois Ativos}

Para Markowitz, o retorno esperado para um conjunto de ativos é calculado pela média ponderada dos retornos esperados para cada ativo individual. Diversamente do intuitivo, o risco deste conjunto de ativos não é calculado pela média dos riscos dos ativos individuais. O risco desta carteira é depende das variâncias (desvio padrão) individuais de cada ativo e de uma parcela das covariâncias entre os ativos (correlação entre os retornos), calculadas dois a dois.

Supondo dois ativos financeiros, A e B, cujo retorno é uma variável aleatória, pode-se expressar, para cada ativo, o retorno esperado pela média dos seus retornos e o risco pelo desvio padrão dos seus retornos. Matematicamente:

\section{Ativo A}

$$
\begin{aligned}
& \text { Média }_{\mathrm{A}}=\mathrm{E}\left(\widetilde{\mathrm{R}}_{\mathrm{A}}\right)=\overline{\mathrm{R}}_{\mathrm{A}} \\
& \operatorname{Risco}_{\mathrm{A}}=\mathrm{S}\left(\widetilde{\mathrm{R}}_{\mathrm{A}}\right)=\mathrm{S}_{\mathrm{A}}
\end{aligned}
$$

Ativo B

$$
\begin{aligned}
& \text { Média }_{B}=E\left(\widetilde{R}_{B}\right)=\bar{R}_{B} \\
& \operatorname{Risco}_{B}=S\left(\widetilde{R}_{B}\right)=S_{B}
\end{aligned}
$$

Onde:

$\tilde{R}_{A}$ é a variável aleatória do retorno do Ativo $A$;

$\tilde{R}_{B}$ é a variável aleatória do retorno do Ativo $\mathrm{B}$;

$E\left(\widetilde{R}_{A}\right)$ e $\bar{R}_{A}$ é o valor esperado da variável aleatória do retorno do Ativo A;

$E\left(\tilde{R}_{B}\right)$ e $\bar{R}_{B}$ é o valor esperado da variável aleatória do retorno do Ativo $\mathrm{B}$;

$S\left(\tilde{R}_{A}\right)$ e $S_{A}$ é a variância da variável aleatória do retorno do Ativo A;

$S\left(\widetilde{R}_{B}\right)$ e $S_{B}$ é a variância da variável aleatória do retorno do Ativo B. 
Supondo uma carteira composta pela composição $w_{1}$ do ativo $\mathrm{A}$ e $w_{2}$ do ativo $\mathrm{B}$, onde a soma de $w_{1}$ e $w_{2}$ é igual a unidade e $w_{1}$ e $w_{2}$ maiores que zero (carteira não alavancada), tem-se:

$$
\begin{aligned}
& \tilde{R}_{C}=w_{1} \cdot \tilde{R}_{A}+w_{2} \cdot \tilde{R}_{B} \\
& w_{1}+w_{2}=1
\end{aligned}
$$

Onde:

$\tilde{R}_{C}$ é a variável aleatória da carteira formada pelos Ativos $\mathrm{A}$ e $\mathrm{B}$;

$w_{1}$ e $w_{2}$ é a quantidade percentual do Ativo A e do Ativo B (peso dos ativos na carteira), respectivamente, na carteira ( $\mathrm{w}_{1}$ e $\mathrm{w}_{2}$ são maiores ou iguais a zero).

O retorno esperado da carteira é calculado pela esperança matemática da variável aleatória $\widetilde{R}_{C}$, conforme Equação (27), a seguir:

$$
E\left[\tilde{R}_{C}\right]=E\left[w_{1} \cdot \tilde{R}_{A}+w_{2} \cdot \tilde{R}_{B}\right]
$$

O valor esperado de uma combinação linear de variáveis aleatórias é a combinação linear dos seus valores esperados conforme a Equação (28) e a Equação (29), a seguir:

$$
\begin{aligned}
& E(\tilde{X}+\tilde{Y})=E(\tilde{X})+E(\tilde{Y}) \\
& E(k . \tilde{X})=k \cdot E(\tilde{X})
\end{aligned}
$$

Aplicando as propriedades da esperança matemática (Equação (28) e (29)) na Equação (27), obtém-se o retorno esperado da carteira $E\left[\tilde{R}_{C}\right]$ como a média ponderada dos retornos esperados dos ativos individuais, conforme a Equação (30), a seguir:

$$
E\left[\tilde{R}_{C}\right]=w_{1} \cdot E\left[\tilde{R}_{A}\right]+w_{2} \cdot E\left[\tilde{R}_{B}\right]
$$


Por sua vez, o risco da carteira $S\left[\tilde{R}_{C}\right]$ é calculado, conforme a seguir:

$$
\begin{aligned}
& S\left[\tilde{R}_{C}\right]=S\left[w_{1} \cdot \tilde{R}_{A}+w_{2} \cdot \tilde{R}_{B}\right] \\
& S^{2}\left[\tilde{R}_{C}\right]=S^{2}\left[w_{1} \cdot \tilde{R}_{A}+w_{2} \cdot \tilde{R}_{B}\right]=E\left[R_{C}-\tilde{R}_{C}\right]^{2} \\
& E\left[R_{C}-\tilde{R}_{C}\right]^{2}=E\left[\left(w_{1} \cdot R_{A}+w_{2} \cdot R_{B}\right)-\left(w_{1} \cdot \tilde{R}_{A}+w_{2} \cdot \tilde{R}_{B}\right)\right]^{2} \\
& E\left[R_{C}-\tilde{R}_{C}\right]^{2}=E\left[w_{1} \cdot\left(R_{A}-\tilde{R}_{A}\right)+w_{2} \cdot\left(R_{B}-\tilde{R}_{B}\right)\right]^{2}
\end{aligned}
$$

Resolvendo o quadrado da soma e aplicando as propriedades: (i) valor esperado da soma de uma série de retornos é igual à soma dos valores esperados de cada retorno (Equação (28)), e; (ii) valor esperado de uma constante multiplicada por um retorno é igual à constante multiplicada pelo retorno esperado (Equação (29)), obtém-se a Equação (35).

$$
S^{2}\left[\tilde{R}_{C}\right]=E\left[R_{C}-\tilde{R}_{C}\right]^{2}=S^{2}\left(w_{1} \cdot \tilde{R}_{A}\right)+S^{2}\left(w_{2} \cdot \tilde{R}_{B}\right)+2 \cdot w 1 \cdot w 2 \cdot E\left[\left(R_{A}-\tilde{R}_{A}\right) \cdot\left(R_{B}-\tilde{R}_{B}\right)\right]
$$

A covariância é calculada pela Equação (36).

$$
\operatorname{cov}\left(\tilde{R}_{A}, \tilde{R}_{B}\right)=E\left[\left(R_{A}-\tilde{R}_{A}\right) \cdot\left(R_{B}-\tilde{R}_{B}\right)\right]
$$

Substituindo a Equação (36) da covariância na Equação (35), obtém-se a Equação (37).

$$
S^{2}\left[\tilde{R}_{C}\right]=S^{2}\left(w_{1} \cdot \tilde{R}_{A}\right)+S^{2}\left(w_{2} \cdot \tilde{R}_{B}\right)+2 \cdot w_{1} \cdot w_{2} \cdot \operatorname{cov}\left(\tilde{R}_{A}, \tilde{R}_{B}\right)
$$

Finalmente, sabendo que a covariância de uma variável aleatória multiplicada por uma constante é igual à constante multiplicada pela covariância da variável aleatória, obtém-se a Equação (38) e a Equação (39).

$$
S^{2}\left[\tilde{R}_{C}\right]=w_{1}{ }^{2} \cdot S^{2}\left(\tilde{R}_{A}\right)+w_{2}{ }^{2} \cdot S^{2}\left(\tilde{R}_{B}\right)+2 \cdot w_{1} \cdot w_{2} \cdot \operatorname{cov}\left(\tilde{R}_{A}, \tilde{R}_{B}\right)
$$


Ou:

$$
S^{2}\left[\tilde{R}_{C}\right]=\left(w_{1} \cdot S\left(\tilde{R}_{A}\right)\right)^{2}+\left(w_{2} \cdot S\left(\tilde{R}_{B}\right)\right)^{2}+2 \cdot w_{1} \cdot S\left(\tilde{R}_{A}\right) \cdot w_{2} \cdot S\left(\tilde{R}_{B}\right) \cdot \rho_{A, B}
$$

Observa-se pela Equação (38) que o risco da carteira (variância) é dado pela soma das variâncias dos ativos $A$ e $B$ mais uma parcela que é função da correlação (covariância) dos ativos $\mathrm{A}$ e $\mathrm{B}$.

Note-se que a covariância é o valor esperado do produto de dois desvios: (i) os desvios dos retornos do ativo $\mathrm{A}$ em relação a sua média $\left(R_{A}-\widetilde{R}_{A}\right)$; e, (ii) os desvios dos retornos do ativo $\mathrm{B}$ em relação a sua média $\left(R_{B}-\tilde{R}_{B}\right)$. Portanto, a covariância pode ser positiva ou negativa, e explica como os retornos dos ativos $A$ e $B$, variam entre si. Para variações simultâneas, positivas ou negativas $\left(\left(R_{A}-\tilde{R}_{A}\right)\right.$ e $\left.\left(R_{B}-\tilde{R}_{B}\right)\right)$, a covariância é um número positivo elevado. Por outro lado, se o movimento dos desvios positivos e negativos ocorrem em momentos distintos, a covariância é negativa. Por fim, se não houver relação alguma entre os desvios (variáveis independentes), a covariância tenderá a zero.

Por sua vez, a correlação indica a força (grau da correlação) e a direção (positiva ou negativa) do relacionamento linear entre duas variáveis aleatórias, para o caso do coeficiente de correlação de Pearson, como na Equação (39) anterior.

\subsubsection{Formulação Matemática para N Ativos}

Considerando uma carteira composta por $\mathrm{N}$ ativos, a formulação matemática do retorno e da variância pode ser escrita pela Equação (41) e Equação (43) ou Equação (44), conforme a seguir.

$$
\begin{aligned}
& E\left[\tilde{R}_{C}\right]=w_{1} \cdot E\left[\tilde{R}_{1}\right]+w_{2} \cdot E\left[\tilde{R}_{2}\right]+w_{3} \cdot E\left[\tilde{R}_{3}\right]+\cdots+w_{N} \cdot E\left[\tilde{R}_{N}\right] \\
& \tilde{R}_{C}=E\left[\tilde{R}_{C}\right]=\sum_{i=1}^{N} w_{i} \cdot E\left[\tilde{R}_{i}\right]
\end{aligned}
$$




$$
\begin{aligned}
S_{C}^{2}=S^{2}\left[\tilde{R}_{C}\right]= & \left(w_{1} \cdot S\left(\tilde{R}_{1}\right)\right)^{2}+\left(w_{2} \cdot S\left(\tilde{R}_{2}\right)\right)^{2}+\cdots+\left(w_{N} \cdot S\left(\tilde{R}_{N}\right)\right)^{2} \\
& +2 \cdot w_{1} \cdot S\left(\tilde{R}_{1}\right) \cdot w_{2} \cdot S\left(\tilde{R}_{2}\right) \cdot \rho_{1,2}+\cdots \\
& +2 \cdot w_{1} \cdot S\left(\tilde{R}_{1}\right) \cdot w_{N} \cdot S\left(\tilde{R}_{N}\right) \cdot \rho_{1, N}+\cdots \\
& +2 \cdot w_{2} \cdot S\left(\tilde{R}_{2}\right) \cdot w_{N} \cdot S\left(\tilde{R}_{N}\right) \cdot \rho_{2, N}+\cdots \\
& +2 \cdot w_{N-1} \cdot S\left(\tilde{R}_{N-1}\right) \cdot w_{N} \cdot S\left(\tilde{R}_{N}\right) \cdot \rho_{N-1, N} \\
S^{2}\left[\tilde{R}_{C}\right]=\sum_{i=1}^{N} & \left(w_{i} \cdot S\left(\tilde{R}_{i}\right)\right)^{2}+\sum_{i=1}^{N} \sum_{j=1}^{N} S\left(\tilde{R}_{i}\right) \cdot S\left(\tilde{R}_{j}\right) \cdot w_{i} \cdot w_{j} \cdot \rho_{i, j}
\end{aligned}
$$

Ou, usando a covariância:

$$
S^{2}\left[\tilde{R}_{C}\right]=\sum_{i=1}^{N}\left(w_{i} \cdot S\left(\tilde{R}_{i}\right)\right)^{2}+\sum_{i=1}^{N} \sum_{\substack{j=1 \\ j \neq i}}^{N} w_{i} \cdot w_{j} \cdot \operatorname{cov}\left(\tilde{R}_{i}, \tilde{R}_{j}\right)
$$

A Equação (41) e a Equação (44) podem ser reescritas em formas de matrizes, conforme a seguir:

$$
\begin{aligned}
& \tilde{R}_{C}=\left[\begin{array}{llllll}
w_{1} & w_{2} & \ldots & w_{i} & \ldots & w_{N}
\end{array}\right] \cdot\left[\begin{array}{lllllll}
\tilde{R}_{1} & \tilde{R}_{2} & \ldots & \tilde{R}_{i} & \ldots & w \tilde{R}_{N}
\end{array}\right]^{T}
\end{aligned}
$$

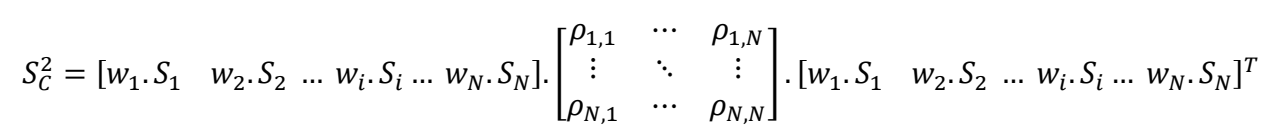

Ou, usando a covariância:

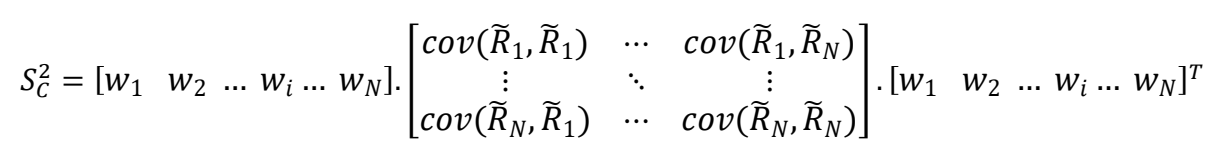

As Equações (45), (46) e (47) são genéricas e aplicadas para uma carteira contendo $\mathrm{N}$ ativos. 


\subsubsection{Casos Particulares de Carteiras para N Ativos Independentes}

Algumas carteiras merecem a atenção, em razão dos seus resultados e conclusões. É caso de uma carteira formada por $\mathrm{N}$ ativos, todos eles independentes, de modo que a covariância entre eles é igual a zero $\left(\operatorname{cov}\left(\tilde{R}_{i}, \tilde{R}_{j}\right)=0\right)$. Ainda, considera-se que a quantidade de cada ativo da carteira seja a mesma. Desta forma, a Equação (44) pode ser reescrita e simplificada, conforme a seguir.

$$
S^{2}\left[\tilde{R}_{C}\right]=\sum_{i=1}^{N}\left(w_{i} \cdot S\left(\tilde{R}_{i}\right)\right)^{2}+\sum_{i=1}^{N} \sum_{\substack{j=1 \\ j \neq i}}^{N} w_{i} \cdot w_{j} \cdot \operatorname{cov}\left(\tilde{R}_{i}, \tilde{R}_{j}\right)
$$

Onde:

$\sum_{i=1}^{N} \sum_{\substack{j=1 \\ j \neq i}}^{N} w_{i} \cdot w_{j} \cdot \operatorname{cov}\left(\tilde{R}_{i}, \tilde{R}_{j}\right)=0$

Desta forma:

$$
\begin{aligned}
& S^{2}\left[\tilde{R}_{C}\right]=\sum_{i=1}^{N}\left(w_{i} \cdot S\left(\tilde{R}_{i}\right)\right)^{2}=\sum_{i=1}^{N}\left(\frac{1}{N} \cdot S\left(\tilde{R}_{i}\right)\right)^{2}, \text { que pode ser reescrita como: } \\
& S^{2}\left[\tilde{R}_{C}\right]=\frac{1}{N} \cdot \sum_{i=1}^{N} \frac{\left(S\left(\tilde{R}_{i}\right)\right)^{2}}{N}
\end{aligned}
$$

O termo $\sum_{i=1}^{N} \frac{\left(S\left(\tilde{R}_{i}\right)\right)^{2}}{N}$ da Equação (48) é uma média, que represente a variância média dos ativos contidos na carteira. À medida que $\mathrm{N}$ (número de ativos) aumenta, a variância da carteira reduz. No limite, quando $\mathrm{N}$ tende a infinito, o risco da carteira reduz para zero. Assim, se for possível agrupar em uma carteira um número significativo de ativos não correlacionados (retornos independentes), o resultado seria uma carteira de baixo risco. 
Evidente que no mundo real, os ativos possuem correlações entre si, e, portanto, o risco zero da carteira é teórico, contudo, seu valor pode ser bem inferior à variância do retorno de um ativo individual.

\subsubsection{Casos Particulares de Carteiras para N Ativos Distribuídos Uniformemente}

Outra carteira que merece a atenção é aquela que possui $\mathrm{N}$ ativos distribuídos de maneira uniforme (a quantidade de cada ativo da carteira é a mesma), com covariância entre os mesmos. Desta forma, a Equação (44) pode ser reescrita da seguinte forma:

$$
S^{2}\left[\tilde{R}_{C}\right]=\frac{1}{N} \cdot \sum_{i=1}^{N} \frac{\left(S\left(\tilde{R}_{i}\right)\right)^{2}}{N}+\frac{(N-1)}{N} \cdot \sum_{i=1}^{N} \sum_{\substack{j=1 \\ j \neq i}}^{N} \frac{\operatorname{cov}\left(\tilde{R}_{i}, \tilde{R}_{j}\right)}{N-(N-1)}
$$

Consoante já demonstrado, o termo $\sum_{i=1}^{N} \frac{\left(S\left(\widetilde{R}_{i}\right)\right)^{2}}{N}$ da Equação (49) representa a variância média dos ativos contidos na carteira. Da mesma forma, o termo $\sum_{i=1}^{N} \sum_{\substack{j=1 \\ j \neq i}}^{N} \frac{\operatorname{cov}\left(\tilde{R}_{i}, \tilde{R}_{j}\right)}{N .(N-1)}$ da Equação (49) representa a soma das covariâncias dividida pela quantidade de covariâncias existentes, portanto, representa a média das covariâncias.

Quando $\mathrm{N}$ tende a infinito (número elevado de ativos), o primeiro termo da Equação (49) tende a zero, portanto, a variância dos ativos é irrelevante para a variância da carteira. Nesta hipótese, o segundo termo da Equação (49) tende à média das covariâncias, portanto, o risco da carteira tende à média das covariâncias. Assim, quanto maior o número de ativos em uma carteira, o risco individual de cada ativo (variância) reduz a importância, passando a ter relevância a inter-relação dos ativos, dado pela covariância, que é o risco sistêmico, conjuntural, comum a todos os ativos do mesmo mercado.

Desta forma, a medida que se aumenta a diversificação de uma carteira, os riscos individuais perdem importância frente a covariância média dos retornos. Em síntese, para elevado grau de diversificação (número elevado de ativos) o risco 
individual dos ativos é minimizado, resultando no risco da carteira igual à média das covariâncias.

\subsubsection{Efeito da Diversificação no Risco da Carteira}

As equações apresentadas no tópico 4.6.3 demonstram que o risco de uma carteira de ativos é função da quantidade de ativos. O aumento do número de ativos da carteira reduz o seu risco. Existe uma relação assintótica decrescente entre o número de ativos de uma carteira e o desvio-padrão da mesma. No entanto, verificase que a partir de uma determinada quantidade de ativos, o risco praticamente se estabiliza.

Segundo Securato (1996), o risco total a que está sujeito um ativo (ou uma carteira de investimentos) pode ser dividido em risco sistêmico (conjuntural ou não diversificável) e risco não sistêmico (próprio ou diversificável).

O risco sistêmico decorre dos sistemas econômico, político e social, sendo proporcional às possibilidades de variações da conjuntura, facilitadas por regras mal definidas ou mal aplicadas, pelos desmandos, pelos escândalos, pela insegurança jurídica e regulatória, enfim, por todo um processo que passa pela credibilidade institucional como um todo. Nesse sentido, o Estado é um dos maiores responsáveis pelo risco sistêmico, o qual impacta em todos os ativos simultaneamente.

O risco não sistêmico é intrínseco ao ativo e ao subsistema em que ele está inserido. O risco não sistêmico é gerado por fatos que atingem diretamente o ativo em consideração ou o seu subsistema, não atingindo os demais ativos.

A diversificação dos ativos permite reduzir apenas o risco não sistêmico (diversificável), isto porque, eventuais fatos que impactam em um subsistema de ativos, podem não impactar na mesma proporção ou sentido outro subsistema de ativos. Por sua vez, o risco sistêmico não pode ser diversificado, uma vez que tem impacto sobre todo o conjunto dos ativos.

Evans e Archer (1968) analisaram o comportamento de 470 ações relacionadas no índice Standard and Poor's, no período compreendido entre 1958 e 1967, montando carteiras aleatórias contendo de 1 a 40 ações. Os autores evidenciaram que o risco da carteira varia com o número de ativos de acordo com a Equação (50), a seguir. 


$$
y=B \cdot\left(\frac{1}{x}\right)+A
$$

Onde: y é o risco médio da carteira de x ações e x é a quantidade de ações da carteira.

De acordo com a formulação proposta, para um elevado número de ativos, o risco tende ao parâmetro "A", podendo ser interpretado como o risco mínimo ou o risco sistêmico (risco não diversificável). Evans e Archer (1968) demonstraram que uma carteira contendo 8 (oito) ativos consegue eliminar a parte mais significativa do risco não sistêmico, levantando dúvidas de carteiras com mais de 10 (dez) ativos em sua composição.

Elton e Gruber (1977), utilizando retornos semanais de aproximadamente 3.500 ativos no período compreendido entre 1971 e 1974, demonstram que $51 \%$ do risco poderia ser eliminado aumento o número de ativos da carteira de 1 para 10 ativos. Para uma carteira com 20 ativos, é possível eliminar $56 \%$ de seu risco, ou seja, apenas 5 pontos percentuais a mais que a carteira com 10 ativos. No entanto, passando $o$ número de ativos para 30 , o risco seria reduzido em apenas $2 \%$. Praticamente o mesmo risco de uma carteira com 1000 ativos.

Brito (1981) utilizou a mesma metodologia proposta por Evans e Archer (1968), tendo concluído que os ganhos da diversificação ocorreram com carteiras compostas por 8 a 10 ações e, que carteiras com mais de 15 ações apresentam ganhos desprezíveis.

Dos estudos de Evans e Archer (1968), Elton e Gruber (1977) e Brito (1981) verificou-se que uma parcela do risco pode ser total ou parcialmente eliminada pela diversificação da carteira, denominado de risco diversificável (risco não sistêmico), que compreende o parâmetro "B" da Equação (50).

No entanto, existe uma parcela do risco que não pode ser eliminado (ou reduzido), sendo insensível a diversificação, denominado de risco não diversificável (risco sistêmico), que tem origem nas flutuações a que está sujeito o sistema econômico como um todo, sendo suas principais fontes as variações nas taxas de juros, a inflação e a situação política. 
O Gráfico 29 demonstra o comportamento do risco em função do número de ativos na carteira e ilustra o risco diversificável e o risco não diversificável (risco sistêmico) (ver item 5.1.6).

Gráfico 29 - Comportamento do Risco em Função da Diversificação.

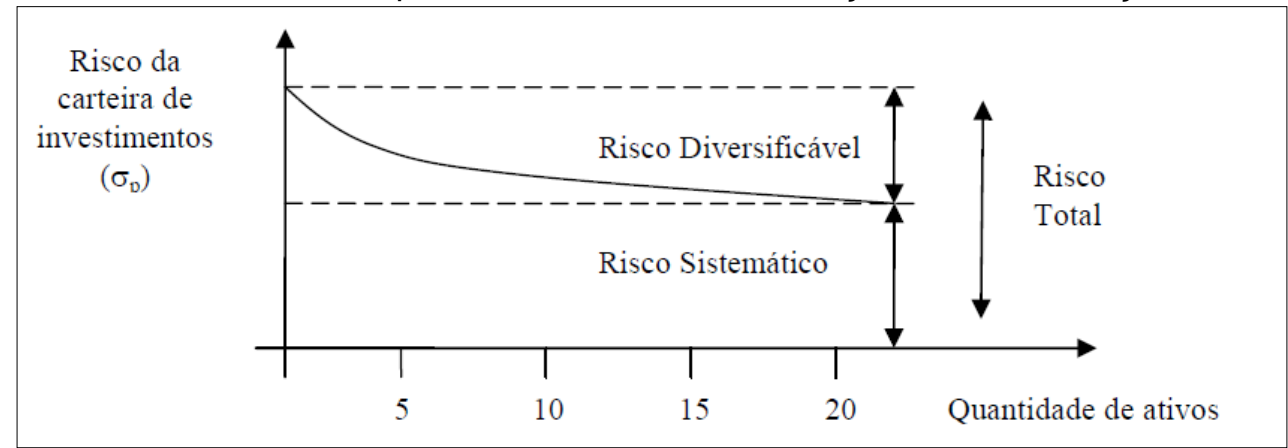

Fonte: Assaf Neto (2001).

Elton et al (2004) ${ }^{72}$ apresentaram o comportamento do risco em função do número de ativos para os Estados Unidos e Reino Unido. O Gráfico 30 e o Gráfico 31 apresentam o comportamento do risco da carteira como percentagem do risco de um título individual para diversos números de ativos da carteira. Segundo o estudo, nos Estados Unidos, com a diversificação da carteira o risco de um ativo individual pode reduzir em $73 \%$, enquanto no Reino Unido a redução é da ordem de $65,5 \%$.

Gráfico 30 - Efeito do Número de Títulos Sobre o Risco da Carteira nos EUA.

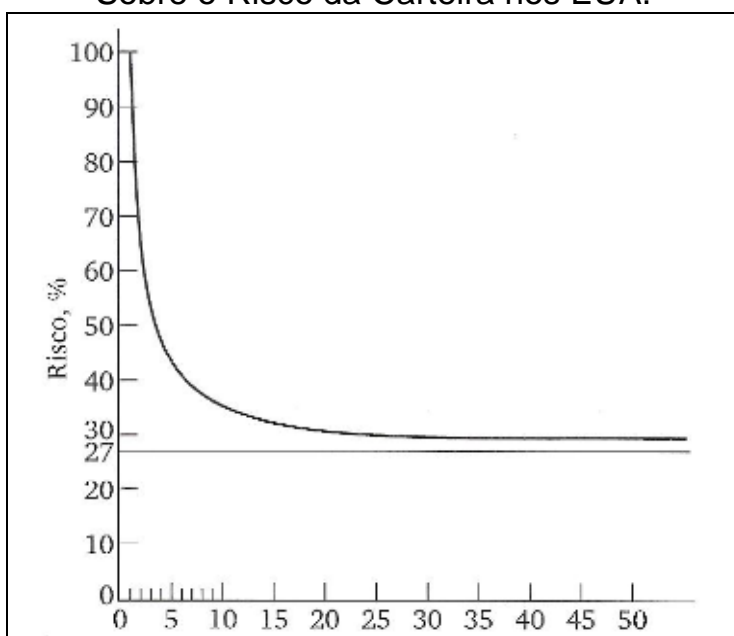

Fonte: Elton et al (2004).
Gráfico 31 - Efeito do Número de Títulos Sobre o Risco da Carteira no Reino Unido.

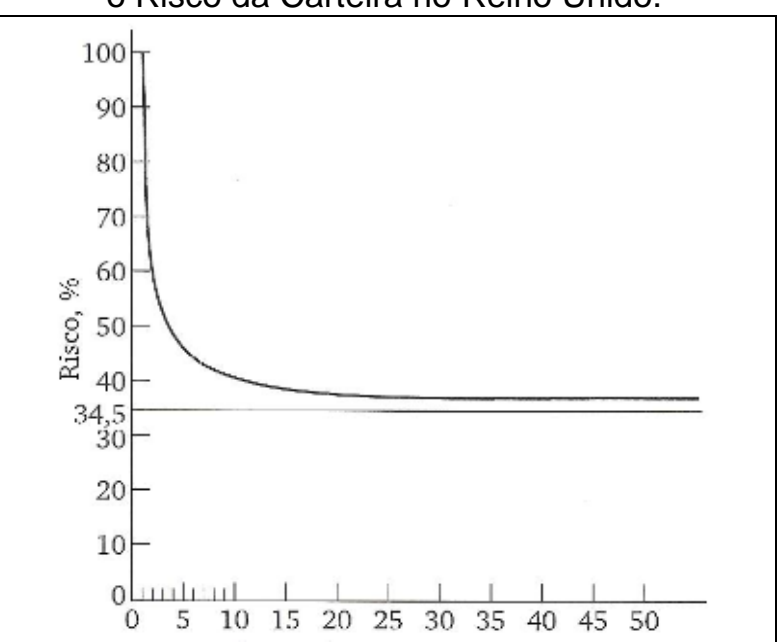

Fonte: Elton et al (2004). 
Existe uma quantidade de ativos na carteira, a partir da qual, satura a redução do risco. Este risco mínimo da carteira é denominado de risco não diversificável ou risco sistemático, sendo intrínseco ao mercado.

A metodologia utilizada para encontrar o número de ativos da carteira que proporciona a redução do risco será empregada para a determinação do risco mínimo de geração do conjunto de parques eólicos, cujo detalhamento será apresentado oportunamente.

\subsubsection{Importância Da Correlação para a Teoria De Portfólio De Markowitz}

O impacto da correlação dos ativos sobre o risco da carteira foi evidenciado pelas Equações (47) e (48). Para ativos sem nenhuma correlação ( $\rho$ igual a 0 ), o risco da carteira é a própria soma do risco de cada ativo. Para ativos fortemente correlacionados ( $\rho$ igual a 1, por exemplo), o risco da carteira é maior que a soma dos riscos de cada ativo. Por outro lado, para ativos com correlação negativa, o risco da carteira é menor que a soma do risco individual de cada ativo.

A importância da correlação (ou da covariância) no postulado de Markowitz foi destacada por Securato (1997), asseverando que antes do trabalho pioneiro de Markowitz, o raciocínio intuitivo associava a relação entre risco e retorno a uma reta, como se os ativos fossem perfeitamente correlacionados:

\footnotetext{
Esse tipo de raciocínio do nosso investidor é bastante 'intuitivo'. Tão intuitivo quanto afirmar que 'um peso de dez quilos cai dez vezes mais depressa que o peso de um quilo'. Então, dizem, Galileu subiu no alto da Torre de Pizza e soltou, junto, um peso de dez e outro de um quilo, que caíram juntos ao solo. Bem, lá se foi a intuição. O Galileu das Finanças foi Markowitz, o qual provou que o raciocínio 'intuitivo' de nosso investidor estava errado. O gráfico correto da relação risco versus retorno não é, no caso geral, uma reta, mas, sim, uma hipérbole. (SECURATO, 1997, p. 64).
}

O impacto da diversificação decorre da constatação de que os preços dos ativos financeiros não se movem de modo exatamente conjunto. As diversas combinações dos ativos da carteira que maximizam o retorno para vários níveis de risco, resultam na fronteira de eficiência. A variância de uma carteira é reduzida pelo fato de que a variação no preço individual de um ativo é compensada por variações opostas no outro. 
Tal comportamento pode ser ilustrado, por exemplo, com uma carteira composta por um ativo lastreado no índice IBOVESPA e outro em Títulos Públicos. Quando o Banco Central aumenta a taxa de juros dos Títulos Públicos, a economia tende a desacelerar, consequentemente diminui o nível de produção das empresas, com impacto negativo no IBOVESPA. Por outro lado, uma redução na taxa de juros dos Títulos Públicos facilita o acesso ao crédito, aumentando o nível de produção e o IBOVESPA.

Para ilustrar o efeito das covariâncias, suponham-se os ativos $A 1$ e A2 com três possíveis retornos, em função da ocorrência dos eventos $A, B$ e $C$, e o ativo $A 3$ (carteira), composto pela combinação de $60 \%$ do ativo $A 1$ e $40 \%$ do ativo $A 2$, conforme ilustrado na TABELA 17.

\begin{tabular}{|c|c|c|c|}
\hline Evento & Ativo $A 1(R \$))$ & Ativo A2 $(\mathrm{R} \$))$ & Ativo A3 $(\mathrm{R} \$))$ \\
\hline$A$ & 1,3 & 0,8 & 1,1 \\
\hline B & 1,1 & 1,1 & 1,1 \\
\hline C & 0,6 & 1,8 & 1,1 \\
\hline
\end{tabular}

Por simplificação, será adotado que os Ativos A1 e A2 custem no instante decisório do investimento $R$ \$1,00 (um Real). Caso o investidor tenha selecionado o ativo A1 para alocar todo o seu fundo, na ocorrência do evento "C", haverá uma perda de $\mathrm{R} \$ 0,40$ (quarenta centavos). Na escolha do ativo $\mathrm{A} 2$ e ocorrência do evento "C", haverá um lucro de $R \$ 0,80$ (oitenta centavos). Da mesma forma, se o investidor escolher o ativo $A 2$ e o evento "A" tenha ocorrido, implicará em uma perda de $R \$ 0,20$ (vinte centavos). A opção pelo ativo $A 1$ e a ocorrência do evento "A", resulta em um lucro de $R \$ 0,30$ (trinta centavos).

Observa-se na TABELA 17 que o maior retorno do ativo A1 ocorre simultaneamente no pior retorno do ativo $A 2$, quando da realização do evento " $A$ ". Da mesma forma, o maior retorno do ativo A2 ocorre quando 0 ativo $A 1$ tem o pior desempenho, na realização do evento "C". Conclui-se que os ativos A1 e A2 apresentam retornos máximos e mínimos em eventos opostos. Sendo assim, uma combinação entre os dois ativos, conforme proposto pelo ativo A3 (carteira composta por $60 \%$ do ativo $A 1$ e $40 \%$ do ativo A2), possibilita explorar o efeito da covariância 
dos ativos $\mathrm{A} 1$ a $\mathrm{A} 2$, gerando uma carteira com retorno esperado com menor variância (menor risco) que o risco individual de cada ativo (A1 e A2).

Genericamente, supondo dois ativos, sendo o ativo $A 1$, com retorno médio igual a $6 \%$ e volatilidade (risco) igual a $2 \%$ e, o ativo $\mathrm{A} 2$, com retorno médio igual a $10 \%$ e volatilidade igual a 10\%, o impacto da covariância na carteira para diversos valores de correlação pode ser ilustrado no Gráfico 32.

\section{Gráfico 32 - Otimização do Risco e Retorno para uma Carteira Teórica com Diversos Valores de} Correlação.

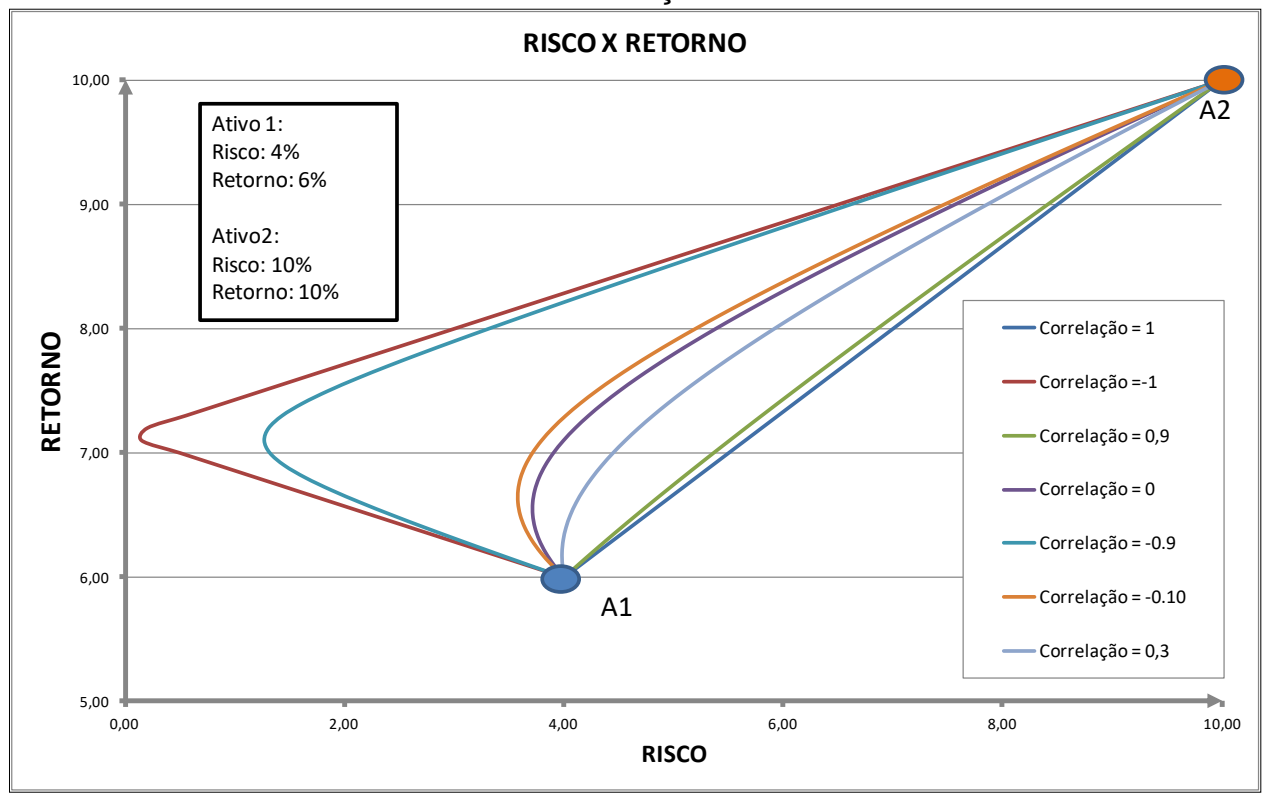

Fonte: Autor (2016).

Conforme se verifica no Gráfico 32, para uma correlação próxima da unidade, para as diversas possibilidades de composição da carteira, a função (retorno $=f$ (risco)) tende a uma reta que passa pelos dois ativos. À medida que a correlação vai se aproximando do zero, surge uma concavidade para a direita da abscissa (para o lado do eixo do retorno). E, quando a correlação se torna negativa, a concavidade vai se acentuando. Nas duas últimas hipóteses, é possível obter uma carteira composta pelos ativos $\mathrm{A} 1$ e $\mathrm{A} 2$, com retorno maior, para um determinado risco, que o somatório do retorno individual dos ativos. No caso particular idealizado, onde a correlação dos ativos da carteira é unitária e negativa, é possível obter o ponto ótimo teórico de risco zero, com um determinado retorno.

Portanto, verifica-se que o retorno esperado da carteira é igual ao somatório do retorno esperado dos ativos, enquanto que o desvio padrão da carteira depende do 
coeficiente de correção $(\rho)$ dos ativos, que pode ser negativo e, portanto, resultar em uma carteira com desvio padrão (risco) inferior ao somatório dos desvios dos ativos.

\subsubsection{Cálculo da Fronteira Eficiente}

Para obter a curva da fronteira eficiente, Elton, Gruber, Brown e Goetzmann (2004) propõem especificar o retorno e minimizar o risco da carteira, sujeita as restrições de que a soma dos percentuais de participação dos ativos na carteira seja igual a um e que todos os títulos tenham percentuais positivos ou nulos.

A formulação proposta é a seguinte:

$$
\operatorname{Minimizar} \sum_{i=1}^{N}\left(w_{i} \cdot S\left(\tilde{R}_{i}\right)\right)^{2}+\sum_{i=1}^{N} \sum_{\substack{j=1 \\ j \neq i}}^{N} w_{i} \cdot w_{j} \cdot \operatorname{cov}\left(\tilde{R}_{i}, \tilde{R}_{j}\right)
$$

Sujeita às seguintes restrições:

$\sum_{i=1}^{N} w_{i}=1$

$0 \leq w_{i} \leq 1$, para i variando de 1 até $\mathrm{N}$;

$\tilde{R}_{C}=E\left[\tilde{R}_{C}\right]=\sum_{i=1}^{N} w_{i} \cdot E\left[\tilde{R}_{i}\right]=\tilde{R}$

De acordo com os autores, variando $\tilde{R}$ entre o retorno da carteira de mínima variância e o retorno da carteira de máximo retorno, produz-se a curva da fronteira eficiente. A dificuldade dessa proposta é conhecer o retorno da carteira para as duas situações extremas.

Securato (1996) parte do plano variância x retorno e supõe que a curva C' representa a fronteira eficiente de uma carteira de ativos com risco, para demonstrar cálculo da fronteira eficiente, conforme ilustrado no Gráfico 33. 


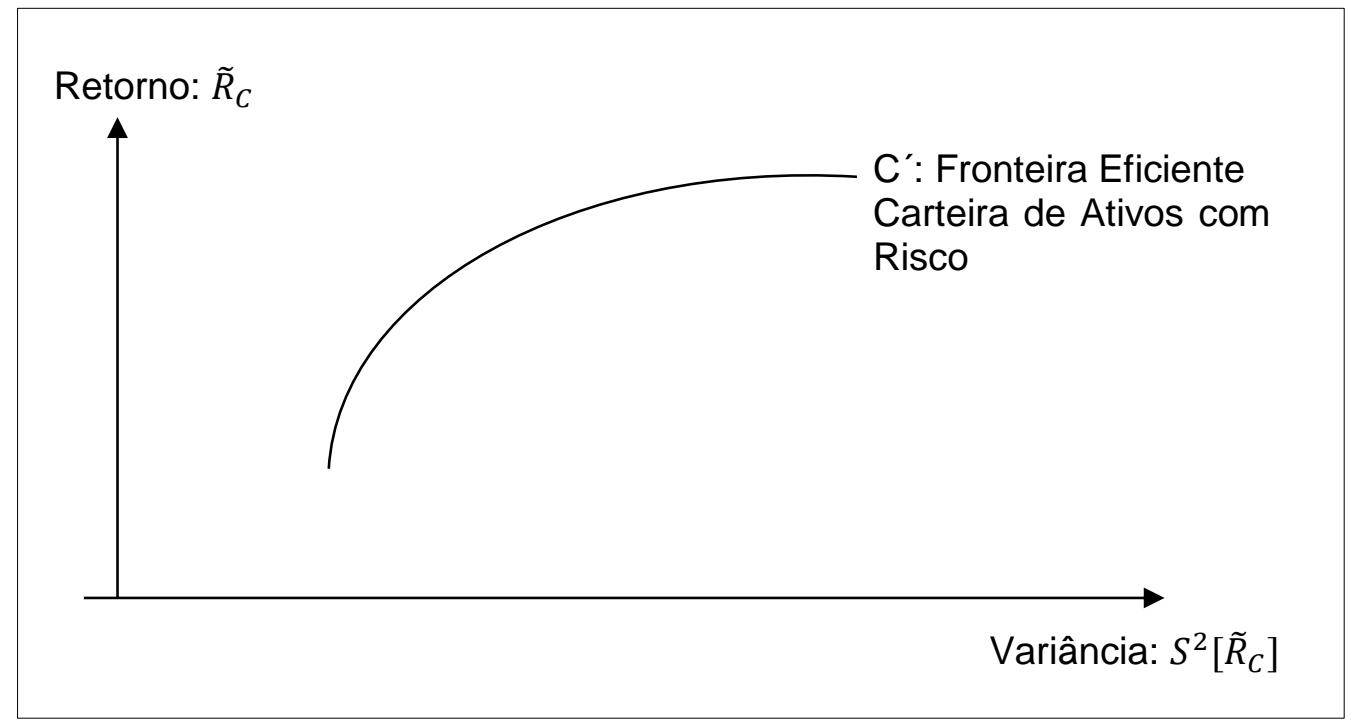

Autor (2016).

Fonte: Securato (1996)

Fixando o ponto $\mathrm{P}$ na Curva $\mathrm{C}^{\prime}$ e fazendo retas passarem pelo ponto $\mathrm{e}$ cruzarem o eixo das ordenadas (retorno), serão obtidas retas secantes e tangentes à Curva, conforme ilustrado no Gráfico 34.

Gráfico 34 - Plano Variância x Retorno - Retas Secantes e Tangentes.

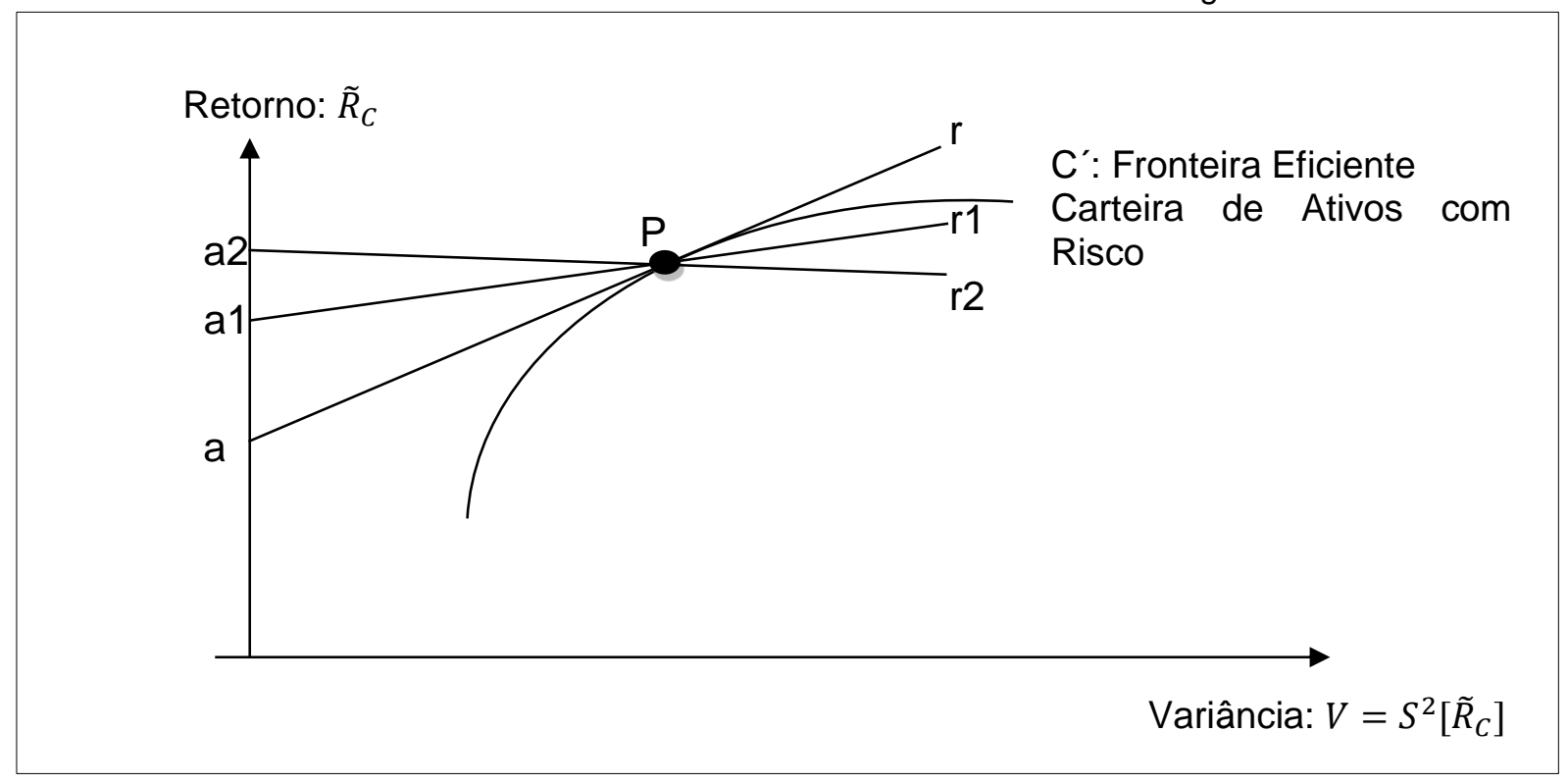

Autor (2016).

Fonte: Securato (1996).

A reta tangente à Curva $C^{\prime}$, comparada às demais retas secantes, possui o menor termo independente (ponto a, no eixo das ordenadas). As equações das retas que passam pelo ponto $P$ podem ser escritas da seguinte forma: 


$$
\tilde{R}_{c}=a_{j}+b_{j} . V
$$

Reescrevendo:

$$
a_{j}=\tilde{R}_{c}-b_{j} . V
$$

Desta forma, a reta tangente (reta $r$ ) à Curva $C^{\prime}$, que passa pelo ponto $P$, deve atender a seguinte condição:

$$
a=\min \left(a_{j}\right)=\min \left(\tilde{R}_{c}-b \cdot V\right)
$$

Onde:

$$
\begin{aligned}
& \tilde{R}_{C}=E\left[\tilde{R}_{C}\right]=\sum_{i=1}^{N} w_{i} \cdot E\left[\tilde{R}_{i}\right] \\
& V=S^{2}\left[\tilde{R}_{C}\right]=\sum_{i=1}^{N}\left(w_{i} \cdot S\left(\tilde{R}_{i}\right)\right)^{2}+\sum_{i=1}^{N} \sum_{\substack{j=1 \\
j \neq i}}^{N} w_{i} \cdot w_{j} \cdot \operatorname{cov}\left(\tilde{R}_{i}, \tilde{R}_{j}\right)
\end{aligned}
$$

Sujeita às seguintes restrições:

$\sum_{i=1}^{N} w_{i}=1, \mathrm{e} ;$

$0 \leq w_{i} \leq 1$

Destaca-se que outras restrições podem ser incluídas no problema, tais como limites mínimos de pagamento de dividendos, limites de participação (superior e inferior) de um ativo na carteira, bem como outras. No presente caso, será apresentada formulação do problema, apenas com as restrições detalhadas anteriormente, que impedem que a proporção de um ativo seja inferior a zero e superior a 1, ou seja, impedem que a solução seja uma carteira alavancada. 
Para obter a composição da carteira que resulta na fronteira eficiente (Curva $\mathrm{C}^{\prime}$ ) é necessário encontrar a quantidade de cada ativo da carteira ( $\left.\mathrm{w}_{\mathrm{i}}\right)$. Trata-se de um problema de minimização de uma função objetivo, sujeita às restrições, que pode ser solucionado pelo método do multiplicador de Lagrange, somando $f(w)$ com $g(w)$, conforme a seguinte formulação. Fazendo:

$$
a=f\left(w_{1}, w_{2} \ldots w_{i} \ldots w_{N}\right)=\tilde{R}_{c}-b . V
$$

E:

$$
g\left(w_{1}, w_{2} \ldots w_{i} \ldots w_{N}\right)=w_{1}+w_{2}+\cdots+w_{i}+\cdots+w_{N}-1=0
$$

Obtém-se a Equação (59), conforme a seguir:

$$
F\left(w_{1}, w_{2} \ldots w_{i} \ldots w_{N}, \lambda\right)=f\left(w_{1}, w_{2} \ldots w_{i} \ldots w_{N}\right)+\lambda . g\left(w_{1}, w_{2} \ldots w_{i} \ldots w_{N}\right)
$$

Substituindo-se a Equação (55) e Equação (56) na Equação (59), obtém-se a Equação (60):

$$
F\left(w_{1}, w_{2} \ldots w_{i} \ldots w_{N}, \lambda\right)=\sum_{i=1}^{N} w_{i} \cdot E\left[\tilde{R}_{i}\right]-b\left(\sum_{i=1}^{N}\left(w_{i} \cdot S\left(\tilde{R}_{i}\right)\right)^{2}+\sum_{\substack{i=1 \\ j}}^{N} \sum_{\substack{j=1 \\ j \neq i}}^{N} w_{i} \cdot w_{j} \cdot \operatorname{cov}\left(\tilde{R}_{i}, \tilde{R}_{j}\right)\right)+\lambda \cdot\left(w_{1}+w_{2}+\cdots+w_{i}+\cdots+w_{N}-1\right)
$$

O ponto de mínimo da função $F$ é obtido derivando em relação às suas variáveis e fazendo igual a zero, conforme a seguir:

$$
\frac{\partial F}{\partial w_{i}}=0
$$

Para i variando de 1 até $\mathrm{N}, \mathrm{e}$ :

$$
\frac{\partial F}{\partial \lambda}=0
$$


Derivando e escrevendo em forma de sistema de equações, obtém-se, em forma matricial:

$$
\left[\begin{array}{ccccc}
2 \cdot S\left(\tilde{R}_{1}\right)^{2} & 2 \cdot \operatorname{cov}\left(\tilde{R}_{2}, \tilde{R}_{1}\right) & & 2 \cdot \operatorname{cov}\left(\tilde{R}_{N}, \tilde{R}_{1}\right) & 1 \\
2 \cdot \operatorname{cov}\left(\tilde{R}_{1}, \tilde{R}_{2}\right) & 2 \cdot S\left(\tilde{R}_{2}\right)^{2} & & 2 \cdot \operatorname{cov}\left(\tilde{R}_{N}, \tilde{R}_{2}\right) & 1 \\
& \vdots & \ddots & \vdots \\
2 \cdot \operatorname{cov}\left(\tilde{R}_{1}, \tilde{R}_{N}\right) & 2 \cdot \operatorname{cov}\left(\tilde{R}_{2}, \tilde{R}_{N}\right) & \ldots & 2 \cdot S\left(\tilde{R}_{N}\right)^{2} & 1 \\
1 & 1 & & 1 & 0
\end{array}\right] \cdot\left[\begin{array}{c}
w_{1} \\
w_{2} \\
\vdots \\
w_{N} \\
\lambda / b
\end{array}\right]=\left[\begin{array}{c}
\tilde{R}_{1} / b \\
\tilde{R}_{2} / b \\
\vdots \\
\tilde{R}_{N} / b \\
1
\end{array}\right]
$$

Sendo assim:

$$
\left[\begin{array}{c}
w_{1} \\
w_{2} \\
\vdots \\
w_{N} \\
\lambda / b
\end{array}\right]=\left[\begin{array}{ccccc}
2 \cdot S\left(\tilde{R}_{1}\right)^{2} & 2 \cdot \operatorname{cov}\left(\tilde{R}_{2}, \tilde{R}_{1}\right) & \ldots & 2 \cdot \operatorname{cov}\left(\tilde{R}_{N}, \tilde{R}_{1}\right) & 1 \\
2 \cdot \operatorname{cov}\left(\tilde{R}_{1}, \tilde{R}_{2}\right) & 2 \cdot S\left(\tilde{R}_{2}\right)^{2} & & 2 \cdot \operatorname{cov}\left(\tilde{R}_{N}, \tilde{R}_{2}\right) & 1 \\
& \vdots & & \ddots & \vdots \\
2 \cdot \operatorname{cov}\left(\tilde{R}_{1}, \tilde{R}_{N}\right) & 2 \cdot \operatorname{cov}\left(\tilde{R}_{2}, \tilde{R}_{N}\right) & \ldots & 2 \cdot S\left(\tilde{R}_{N}\right)^{2} & 1 \\
1 & 1 & & 1 & 0
\end{array}\right]^{-1} \cdot\left[\begin{array}{c}
\tilde{R}_{1} / b \\
\tilde{R}_{2} / b \\
\vdots \\
\tilde{R}_{N} / b \\
1
\end{array}\right]
$$

De forma simplificada:

$$
W=M^{-1} \cdot U
$$

Variando o valor de b (coeficiente linear da reta tangente à Curva $C^{\prime}$ ), obtémse os valores de $w_{i}$. Ressalta-se que a restrição $0 \leq w_{i} \leq 1$ não foi considerada na solução do problema, portanto, deve-se verificar se essa condição está satisfeita para os valores de b, caso não sejam desejadas carteiras de composição alavancadas. Esquematicamente, a curva da fronteira eficiente, supondo uma carteira formada por 3 ativos, é encontrada, conforme Gráfico 35. 
Gráfico 35 - Esquema para obter a Curva da Fronteira Eficiente.

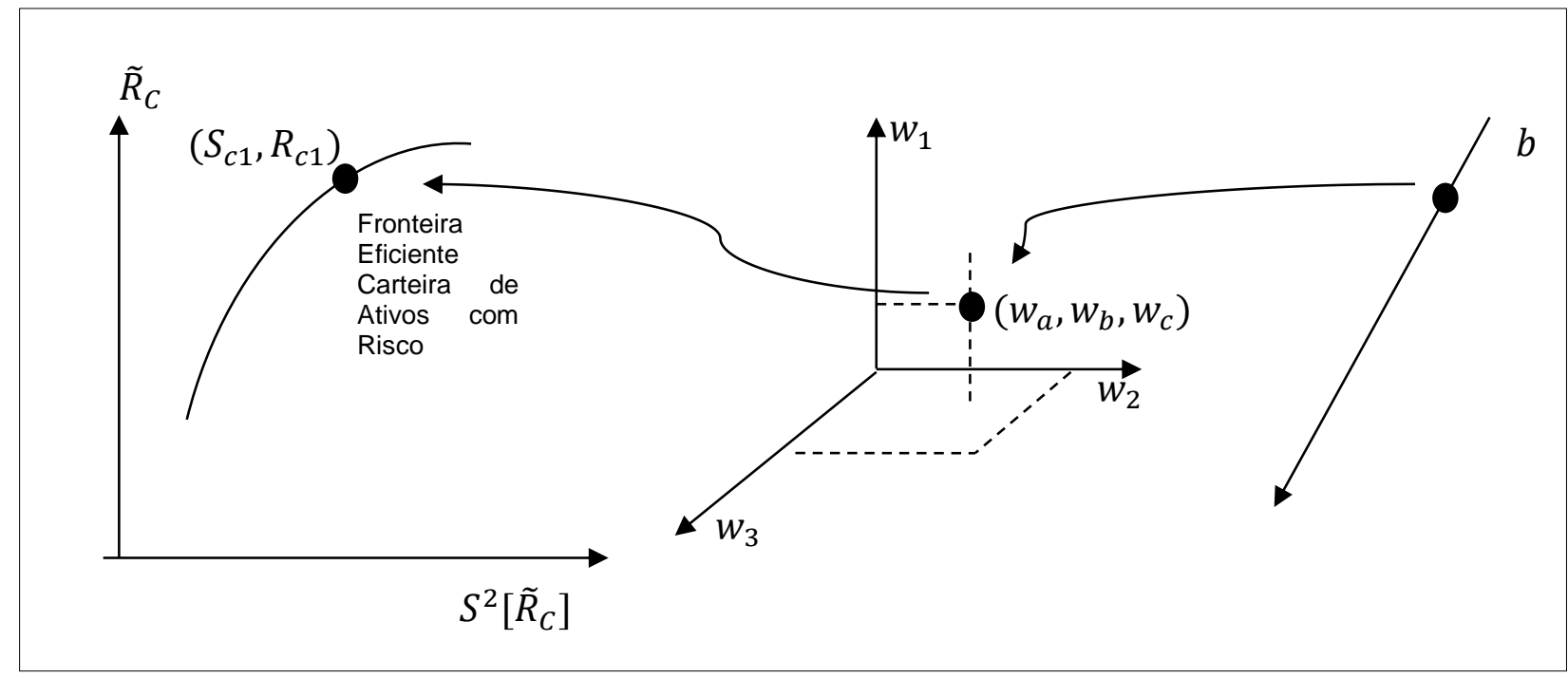

Autor (2016).

Fonte: Securato (1996).

Tendo em vista que o parâmetro b é o coeficiente linear da reta tangente à Curva C', o risco mínimo da carteira pode ser obtido fazendo o valor de b tender ao infinito (vértice da curva da fronteira eficiente).

Securato (1996) demonstra que a solução da matriz resulta na equação geral da hipérbole, conforme a seguir:

$$
\frac{\left(S\left[\tilde{R}_{C}\right]-0\right)^{2}}{\left(S_{\min }\left[\tilde{R}_{C}\right]\right)^{2}}-\frac{\left(\tilde{R}_{C}-\tilde{R}_{C \min }\right)^{2}}{A^{2}}=1
$$

Onde:

$S_{\min }\left[\tilde{R}_{C}\right]$ é o valor do risco mínimo da carteira, e;

$\tilde{R}_{C m i n}$ é o valor do retorno da carteira para o risco mínimo.

Em ambas as proposições, trata-se de um problema de programação quadrática, uma vez a presença dos termos $w_{i}^{2}$ e $w_{i} \cdot w_{j}$. 


\subsection{TEORIA DE PORTFÓLIO - MODELO SHARPE}

Sharpe (1964) simplificou o modelo de Markowitz, apresentando o modelo de índice único, com redução no volume e tipos de dados necessários para a análise de carteiras.

De acordo com o modelo de Markowitz, o risco da carteira depende das variâncias (desvio padrão) individuais de cada ativo e de uma parcela das covariâncias entre os ativos (correlação entre os retornos), calculadas dois a dois. Sendo assim, supondo $\mathrm{N}$ o número de ativos a serem analisados, são necessários estimar $\mathrm{Nx}(\mathrm{N}-1) / 2$ correlações entre os retornos. Para 150 ativos, devem ser estimados 11.175 coeficientes de correlações e 11.475 parâmetros totais.

Sharpe (1964) propôs usar um ativo padrão para calcular a correlação com os demais ativos. Assim, no lugar de calcular a correlação de cada par de ativo, a correlação passa a ser calculada entre 0 ativo e o ativo padrão.

A ideia consiste na observação do comportamento do preço das ações. Quando o mercado sobe (refletido pelo índice do IBOVESPA, por exemplo), a maioria das ações tende a subir. Da mesma forma, quando o mercado cai, o preço da maioria das ações também reduz. Sendo assim, como ativo padrão, Sharpe adotou a carteira formada por todos os ativos de risco da economia e denominou de carteira de mercado. A propósito, essa é a hipótese chave do modelo de Sharpe. O único motivo pelo qual as ações variam em conjunto, de forma sistemática, é devido a variação conjunta comum com o mercado. Não existem efeitos setoriais que podem justificar a variação conjunta dos títulos. Formalmente, isso significa que ei é independente de ej, onde "e" é a variável aleatória da componente do retorno do ativo que é independente do desempenho do mercado.

Fazendo a regressão linear entre os retornos de um ativo $\left(R_{i}\right)$ e os retornos da carteira de mercado $\left(R_{m}\right)$, obtêm-se a Equação (67). O Gráfico 36 ilustra o Plano $R_{i} x$ $\mathrm{R}_{\mathrm{m}}$.

$$
R_{i}=a_{i}+\beta_{i} \cdot R_{m}
$$

Onde:

$R_{i}$ é o retorno do ativo "i” (variável aleatória); 
$a_{i}$ é a componente do retorno do ativo "i" que é independente do desempenho do mercado (variável aleatória que pode ser decomposta em $a_{i}=\alpha_{i}+e_{i}$, onde $\alpha_{i}$ é o valor esperado de $a_{i}$ e $e_{i}$, a variável aleatória);

$\beta_{i}$. é uma constante que mede a variação do retorno do ativo "i" dada uma variação do retorno do mercado;

$R_{m}$ é o retorno do mercado (variável aleatória).

Gráfico 36 - Plano $R_{i} \times R_{m}$

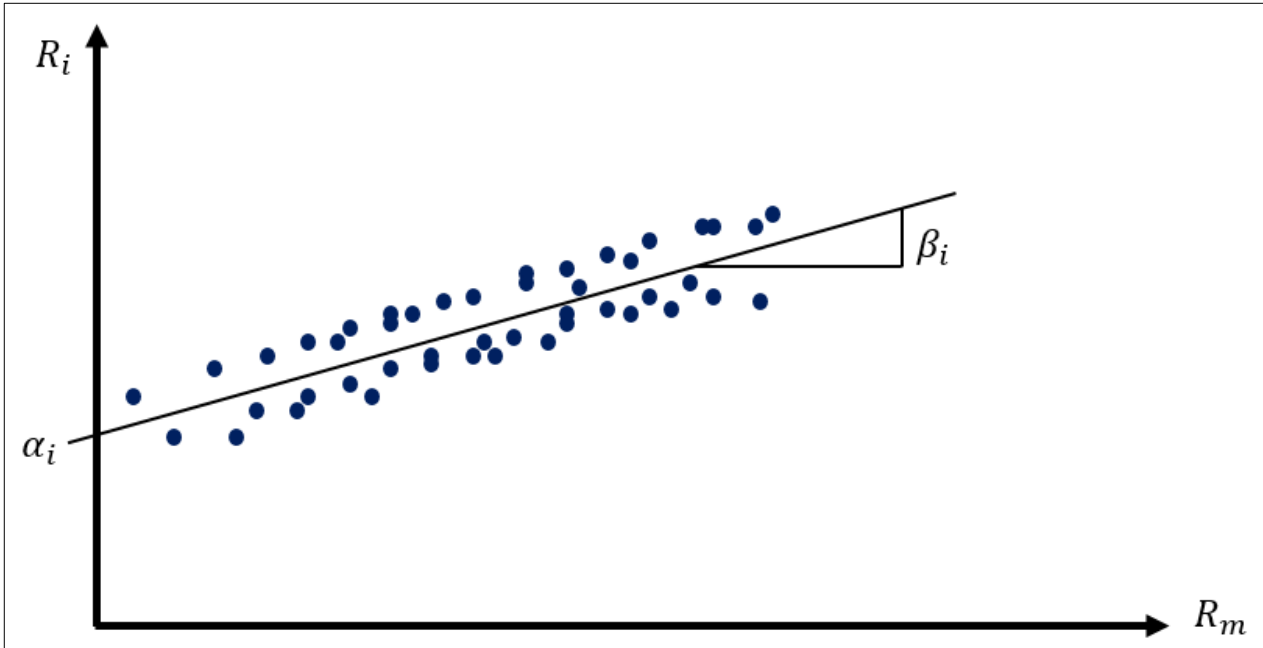

Autor (2016).

Securato (1996) e Elton et al (2004) apresentam a formulação matemática do retorno esperado, desvio padrão e covariância quando o modelo de índice único é utilizado para representar o movimento conjunto dos ativos, formulado por Sharpe (1964), cujos resultados estão nas Equações (68), (69) e (70).

$$
\begin{aligned}
& \bar{R}_{\iota}=\alpha_{i}+\beta_{i} \cdot \overline{R_{m}} \\
& \sigma_{i}^{2}=\beta_{i}^{2} \cdot \sigma_{m}^{2}+\sigma_{e i}^{2} \\
& \sigma_{i j}=\beta_{i} \cdot \beta_{j} \cdot \sigma_{m}^{2}
\end{aligned}
$$

Onde:

$\bar{R}_{l}$ é o valor esperado do retorno do ativo "i"; 
$\alpha_{i}$ é o valor esperado da componente do retorno do ativo "i" que é independente do desempenho do mercado;

$\beta_{i}$.e $\beta_{j}$ é uma constante que mede a variação do retorno do ativo "i" (ou ativo “j") dada uma variação do retorno do mercado;

$\overline{R_{m}}$ é o valor esperado do retorno do mercado;

$\sigma_{i}^{2}$ é a variância do retorno do ativo "i";

$\sigma_{m}^{2}$ é a variância do retorno do mercado;

$\sigma_{e i}^{2}$ é a variância da componente do retorno do ativo "i" que é independente do desempenho do mercado;

$\sigma_{i j}$ é a covariância entre os retornos dos ativos "i" e “j”.

Nota-se pela na Equação (68) que o valor esperado do retorno do ativo $\left(\bar{R}_{l}\right)$ é composto por duas parcelas, sendo uma parte específica $\left(\alpha_{i}\right)$, que independe do desempenho do mercado e a outra associada ao comportamento do mercado $\left(\beta_{i} \cdot \overline{R_{m}}\right)$. O valor de $\beta_{i}$ irá explicar o comportamento do retorno do ativo $\left(\bar{R}_{l}\right)$ em relação ao retorno do mercado.

Valores de $\beta_{i}$ acima de "1" resultam em uma variação maior do retorno do ativo em relação ao mercado. Valores de $\beta_{i}$ abaixo de "1" resultam em uma variação menor do retorno do ativo em relação ao mercado. Para $\beta_{i}$ igual a 1 , o valor do retorno do ativo tem a mesma variação do mercado.

$\mathrm{Na}$ Equação (69) é possível observar que a variância do retorno do ativo $\left(\sigma_{i}^{2}\right)$ é explicada pelo risco específico $\left(\sigma_{e i}^{2}\right)$, que independe do desempenho do mercado, e pelo risco sistemático (ou risco de mercado), associado ao comportamento do mercado $\left(\beta_{i}^{2} \cdot \sigma_{m}^{2}\right)$.

Por sua vez, na Equação (70) verifica-se que a covariância entre os dois ativos depende apenas do risco do mercado.

Elton et al (2004) apresentam a formulação do retorno esperado e a variância para uma carteira genérica, utilizando o modelo de índice único de Sharpe, reproduzidas nas Equações (71) e (72).

$$
\tilde{R}_{C}=E\left[\tilde{R}_{C}\right]=\sum_{i=1}^{N} w_{i} \cdot \alpha_{i}+\sum_{i=1}^{N} w_{i} \cdot \beta_{i} \cdot \overline{R_{m}}
$$




$$
S^{2}\left[\tilde{R}_{C}\right]=\sum_{i=1}^{N}\left(w_{i} \cdot \beta_{i} \cdot S\left(\tilde{R}_{m}\right)\right)^{2}+\sum_{i=1}^{N} \sum_{\substack{j=1 \\ j \neq i}}^{N} w_{i} \cdot w_{j} \cdot \beta_{i} \cdot \beta_{j} \cdot S^{2}\left(\tilde{R}_{m}\right)+\sum_{i=1}^{N} w_{i}^{2} \cdot \sigma_{e i}^{2}
$$

Desta forma, para calcular o retorno esperado e a variância para uma carteira genérica Equação (71) e Equação (72) é necessário estimar $\alpha_{i}, \beta_{i}$ e o $\sigma_{e i}^{2}$ de cada ação, além dos parâmetros do mercado $\overline{R_{m}}$ e a $S^{2}\left(\tilde{R}_{m}\right)$, totalizando $3 . \mathrm{N}+2$ estimativas. Assim, para 150 ativos, devem ser estimadas 452 variáveis, número bem menor que as 11.175 estimativas de coeficientes de correlações, indispensáveis para aplicação de Markowitz.

É possível simplificar a Equação (71) e a Equação (72), fazendo:

$$
\begin{aligned}
& \alpha_{c}=\sum_{i=1}^{N} w_{i} \cdot \alpha_{i} \\
& \beta_{c}=\sum_{i=1}^{N} w_{i} \cdot \beta_{i}
\end{aligned}
$$

Substituindo a Equação (73) e a Equação (74) na Equação (71) e na Equação (72), obtém-se:

$$
\begin{aligned}
& \tilde{R}_{C}=E\left[\tilde{R}_{C}\right]=\alpha_{c}+\beta_{c} \cdot \overline{R_{m}} \\
& S^{2}\left[\tilde{R}_{C}\right]=\left(\beta_{c} \cdot S\left(\tilde{R}_{m}\right)\right)^{2}+\sum_{i=1}^{N} w_{i}^{2} \cdot \sigma_{e i}^{2}
\end{aligned}
$$

No item 4.6.3 foi analisada uma carteira especial, que possui $\mathrm{N}$ ativos distribuídos de maneira uniforme (a quantidade de cada ativo da carteira é a mesma). De acordo com a Equação (49), quando $\mathrm{N}$ tende a infinito (número elevado de ativos), o risco da carteira tende à média das covariâncias. 
Fazendo o mesmo exercício do item 4.6.3, supondo uma carteira que possui $\mathrm{N}$ ativos distribuídos de maneira uniforme, a Equação (76) pode ser simplificada e reescrita pela Equação (77).

$$
S^{2}\left[\tilde{R}_{C}\right]=\left(\beta_{c} \cdot S\left(\tilde{R}_{m}\right)\right)^{2}+\frac{1}{N} \cdot \sum_{i=1}^{N} \frac{1}{N} \cdot \sigma_{e i}^{2}
$$

Para valores elevados de $\mathrm{N}$ (elevado número de ativos na carteira), o segundo termo da Equação (77) perde a importância no cálculo do risco da carteira. Sendo assim, os riscos individuais perdem importância frente ao risco do mercado.

Em síntese, para elevado grau de diversificação (número elevado de ativos) o risco individual dos ativos é suprimido (risco diversificável). No entanto, a parcela $\left(\beta_{c} \cdot S\left(\tilde{R}_{m}\right)\right)^{2}$ não se altera com o aumento do número de ativos. Como $S^{2}\left(\tilde{R}_{m}\right)$ é constante para qualquer ativo, $\beta_{i}$ é a medida do risco não diversificável do ativo.

Para obter a curva da fronteira eficiente no plano retorno $x$ risco (retorno=f(risco)), a partir do modelo de Sharpe, Securato (1996) propõe obter a composição da carteira $\left(\mathrm{w}_{\mathrm{i}}\right)$ que minimize $S^{2}\left(\tilde{R}_{m}\right)$.

$$
\operatorname{Minimizar}\left(S^{2}\left[\tilde{R}_{C}\right]\right)=\operatorname{Minimizar}\left[\left(\beta_{c} . S\left(\tilde{R}_{m}\right)\right)^{2}+\sum_{i=1}^{N} w_{i}^{2} \cdot \sigma_{e i}^{2}\right]
$$

Sujeita às seguintes restrições:

$\sum_{i=1}^{N} w_{i}=1$

$0 \leq w_{i} \leq 1$, para i variando de 1 até $\mathrm{N}$;

$\tilde{R}_{C}=E\left[\tilde{R}_{C}\right]=\alpha_{c}+\beta_{c} \cdot \overline{R_{m}}$.

Esta formulação é semelhante a formulação apresentada na Equação (51). 
Markowitiz foi pioneiro em apresentar uma ferramenta para otimização de carteiras. Sharpe simplificou o modelo apresentado por Markowitiz. No entanto, Treynor (1962) e Lintner (1965) também apresentaram suas teorias sobre a otimização de carteiras.

Neste trabalho será utilizado apenas o modelo de Markowitz para encontrar as carteiras otimizadas e a fronteira eficiente. Para um trabalho futuro sugere-se aplicar o modelo de Sharpe, Treynor (1962) e Lintner (1965) e comparar os resultados.

\subsection{TEORIA DE PORTFÓLIO DE MARKOWITZ APLICADA AO PLANEJAMENTO DO SETOR ELÉTRICO - ESTADO DA ARTE}

Bar-Lev e Katz (1976) foram os pioneiros em aplicar a teoria portfólio em ativos de energia. Eles analisaram a aquisição de combustíveis fósseis na indústria de energia elétrica dos EUA. O objetivo do estudo foi determinar em que medida as concessionárias de serviço público de energia elétrica vinham adquirindo os combustíveis primários (gás natural, carvão e óleo) de forma eficiente. Para tal, foram construídas fronteiras eficientes de aquisição de combustível para diferentes regiões dentro dos EUA e comparadas com o desempenho real das concessionárias de serviço público regionais. Os autores descobriram que, embora a compra de combustíveis das concessionárias de serviço público fosse diversificada, suas carteiras eram caracterizadas por altos riscos e altos retornos. Os autores sugeriram que o posicionamento das concessionárias de serviço público decorria do próprio regulamento, que não incentivava a redução do preço de aquisição e a redução do risco.

Mais recentemente, Drake e Hubacek (2007) estudaram dois cenários para a instalação de 2,75 GW de capacidade instalada eólica, equivalente a 1,75\% da demanda de eletricidade do Reino Unido para o ano 2005. O cenário 1 consistia de uma única fazenda eólica enquanto que o cenário 2 distribuía o recurso energético em quatro fazendas eólicas offshore, localizadas em quatro diferentes regiões do Reino Unido, com combinações eficientes da capacidade instalada de cada fazenda, aplicando a teoria de portfólio de Markowitz.

Os autores compararam o resultado da volatilidade e da geração esperada, considerando que toda a geração eólica está concentrada em uma única fazenda, 
com o caso em que os parques eólicos estão dispersos em quatro fazendas, localizadas em diferentes regiões, apresentando as vantagens numéricas do segundo caso. A fraca correlação entre as fazendas justifica a redução na volatilidade da geração total.

No referido estudo, foi utilizado o histórico de velocidade de vento das torres de medição meteorológicas, relativo ao ano 2004, com frequência horária. Para o cálculo da energia gerada, utilizou-se a curva de potência da turbina eólica V90-3.0MW, do fabricante Vestas.

O cenário 2 apresentou uma geração média 9,2\% inferior ao cenário 1, porém com uma redução na volatilidade de $36 \%$, resultante do baixo fator de correlação da geração entre os parques. O estudo também calculou as perdas no sistema de transmissão para os dois cenários sem, no entanto, utilizá-las na otimização das combinações eficientes da capacidade instalada de cada fazenda.

Os autores apontaram que a utilização de histórico de intervalo de amostragem entre 5 a 10 minutos teria sido mais apropriado para capturar com maior precisão o comportamento da velocidade do vento no curto prazo. Além disso, os autores sugerem a adoção de um intervalo histórico de 3 anos. A altura dos medidores e a posição geográfica também podem ter prejudicado a precisão dos estudos.

Roques, Hiroux e Saguan (2009), partindo de dados históricos da energia gerada por usinas eólicas localizadas na Áustria, Dinamarca, França, Alemanha e Espanha, aplicaram a teoria de MVP e obtiveram o portfólio ótimo, demonstrando que a projeção da expansão eólica realizada pela Tradewind, para 2020, está fora da curva de eficiência encontrada, com um fator de capacidade $6 \%$ inferior.

De acordo com o artigo, os países Dinamarca, Alemanha e Espanha são pioneiros na geração de energia eólica, por sua vez a França e a Áustria possuem planos ambiciosos para a expansão dessa fonte. Os autores utilizaram dados horários de energia gerada, referente ao período de 2006 e 2007, normalizados pela potência instalada, obtendo o histórico do fator de capacidade horário para cada país.

Neste artigo, a aplicação da teoria de portfólio de Markowitz deu-se de duas formas: i) sobre os dados do histórico de todas as horas do dia; ii) sobre os dados do histórico das horas do período da ponta do dia.

Em ambas as situações a função objetivo é a otimização da energia gerada (minimizar a volatilidade ou maximizar a geração de energia), sendo que no segundo 
caso, os autores buscam otimizar a confiabilidade do sistema ${ }^{73}$. Os autores introduziram restrições de disponibilidade eólica e restrições de transmissão para ambas situações.

Os autores constataram que os históricos de medição de países vizinhos possuem correlação positiva, enquanto que os históricos de países distantes (Espanha e Alemanha) possuem correlação baixa ou negativa.

De acordo com a Lei do Estado de Illinois (Public Act 095-0481), no ano 2025, o percentual de $25 \%$ da demanda de energia elétrica deverá ser suprido com energia renovável (Renewable Portfólio Standard - RPS), sendo que 75\% do RPS será suprido com energia eólica.

Tendo em vista esse requisito, Chupp, Hickey e Loomis (2012) aplicaram a teoria de MVP para definir o portfólio eólico no Estado de Illinois (EUA). Os autores destacam a necessidade que os dados para esse tipo de estudo devem: (i) ser provenientes de medidores instalados em torres específicos para a estimativa de geração eólica, (ii) ter histórico superior a 3 (três) anos, (iii) ter alta frequência de amostragem, (iv) medidos em altura superior a 80 metros (altura típica de uma turbina eólica).

Em seus estudos, os autores usaram os dados de velocidade vento do National Renewable Energy Laboratory, obtidos em medidores apropriados, fixados a 80 metros (ou mais) do solo, frequência de amostragem de 10 minutos e histórico de 3 (três) anos, de 2004 a 2006.

Foram selecionados 79 sítios (potenciais fazendas eólicas), com fatores de capacidade que variam de $26,1 \%$ a $37,33 \%$, e recurso eólico disponível para projetos entre 203.2 MW a 1.290.6 MW.

A partir dos dados estatísticos dos 79 ativos (79 sítios eólicos), os autores encontram 3 (três) curvas de fronteira eficiente: (i) cenário sem restrição, (ii) cenário com restrição de potência instalada e (iii) cenário com restrição de horário de pico.

Apesar da disponibilidade de 79 ativos (79 sítios eólicos), as simulações demonstraram que, para os 3 (três) cenários, as carteiras otimizadas (sobre a fronteira) utilizam uma quantidade bem reduzida de ativos (sítios eólicos).

No caso do cenário sem restrição, apenas 18 ativos (fazendas) são necessários para otimizar a carteira. Esse resultado é coerente com a teoria de MVP, uma vez que

${ }^{73}$ LOLP (Loss of Load Probability). 
foi evidenciado no tópico 4.6.5 que a partir de um determinado número de ativos na carteira, a diversificação deixa de produzir resultados eficientes.

Os autores destacaram a importância do estudo, que pode ser utilizado pelas autoridades governamentais como um mapa para a expansão ótima.

Nos artigos analisados, a série histórica utilizada é bastante representativa, sendo a menor delas, anual, com amostragem horária. Adicionalmente, destaca-se que os artigos apresentaram correlações baixas entre as fazendas eólicas, sendo algumas negativas, condição favorável para a aplicação da teoria de MVP com êxito.

Há diversos trabalhos publicados demonstrando que o aumento da distância entre os parques eólicos faz diminuir a correlação da velocidade do vento (e da geração eólica) entre eles e, consequentemente diminuir a volatilidade da geração eólica total. Sinden (2007) analisou o histórico de 66 estações de medição meteorológicas espelhadas por todo o Reino Unido, referente ao período de 1970 a 2003, com uma frequência de amostragem horária. O autor encontrou a função da correlação entre pares de parques eólicos com a distância entre os parques. A partir da combinação de 2080 pares de parques eólicos, foram obtidos os pontos da função (distância e correlação dos parques). $O$ autor demonstrou que o fator de correlação entre os parques eólicos do Reino Unido diminui aproximadamente 0,1 para distâncias entre eles, superiores a $100 \mathrm{~km}$.

Miguel, Ramos e Securato (2012) utilizaram a teoria de MVP para avaliar se a carteira de usinas eólicas do PROINFA está sobre a fronteira eficiente. Para tal, os autores somaram a energia gerada das usinas eólicas dentro do mesmo Estado e normalizaram pela potência instalada, obtendo o histórico do fator de capacidade para usinas eólicas equivalentes por Estado. A base de dados utilizada pelos autores foi de 3 anos, com amostragem mensal, o que pode ter comprometido os resultados, em razão da pouca quantidade de dados. No entanto, esse foi o primeiro trabalho que aplicou a teoria de MVP no segmento eólico brasileiro.

A complementaridade da geração eólica também foi estudada por Ramos, Guarnier e Wizler (2012) que propuseram um mecanismo de compartilhamento de risco entre os agentes de geração eólica, semelhante ao que existe para os geradores hidroelétricos (Mecanismo de Realocação da Energia).

Os autores utilizaram o CVaR como medida de risco para avaliar o nível de contratação considerando a usina individual e um conjunto de usinas eólicas. 
Ramos et al (2013) avaliaram a complementaridade da fonte eólica e da hidroelétrica. Os autores propuseram um modelo para analisar a complementaridade hídrica-eólica e o efeito do portfólio sobre os lucros financeiros e exposições ao risco. O modelo tem como objetivo encontrar a carteira ótima e a quantidade de alocação de volume de energia em contratos. O CVaR foi utilizado como medida de risco. Os resultados obtidos mostram um forte benefício para alguns produtores de energia eólica, quando associado com os produtores hídricos, uma vez que seus perfis de risco são minimizados.

Em Ortiz (2014) foi realizada uma análise espacial-temporal sobre a complementariedade de fontes eólicas e fotovoltaicas em três regiões do Brasil. Para o estudo foram usados dados de vento, radiação solar e temperatura. Com a consideração do custo de implementação das fontes, foi possível realizar uma análise técnico-econômica além da análise financeira e de risco no mercado de curto prazo através da implementação de algoritmo baseado na metodologia desenvolvida por Ramos, Guarnier, Witzler (2012). Foram consideradas três simulações. Na primeira foi realizado um dimensionamento das fontes complementares e foram simuladas as séries de velocidade do vento, irradiância solar e temperatura em um modelo de estimativa de geração de energia. Buscou-se maximizar a energia com menor variabilidade, contudo com o alto investimento e baixa capacidade de geração a energia fotovoltaica se mostrou ineficiente e inviabilizou sua inserção em um portfólio. Na segunda otimização, foi considerada a minimização da diferença na produção de energia, a fim de estudar o grau de complementaridade entre as fontes. Por fim, considerou-se a sensibilidade do custo de implementação da fonte fotovoltaica para avaliar sua inserção em um portfólio. Logo, obteve-se uma avaliação da composição de um portfólio por energia solar em ambientes de contratação do setor elétrico brasileiro.

Gunn (2012) discute a proporção de energia que deve ser comercializada nas diferentes regras contratuais de energia elétrica. A partir disso, usa a teoria de MVP e simula quatro cenários, nos quais os três primeiros tratam das fontes eólicas, biomassa e $\mathrm{PCH}$ individualmente, e no quarto trata das quatro fontes em conjunto.

Através dos dados foi constatado que para todas as usinas os portfolios de menor risco foram firmados com metade da energia alocada em contratos feitos através de leilões públicos e a outra metade no mercado livre. Porém os resultados 
obtidos dependem do preço da energia no mercado de curto prazo para se ter uma boa estimativa.

Pereira (2014) fez uma análise de investimento de um conjunto de projetos de geração de energia renovável através da teoria de MVP e fluxo de caixa. A rentabilidade é mensurada pela taxa interna de retorno (TIR) e a minimização do risco foi considerada pelo CVaR. Assim, o trabalho sugere uma metodologia para consolidar a estratégia de investimento de uma empresa em um portfólio de matrizes energéticas com restrições de investimentos da empresa. Esta técnica visa estabelecer metas de investimento por matriz, especificar as usinas que irão participar ou modificar o portfólio e avaliar o comportamento da usina em um portfólio. Com isso foi demonstrado que se pode fazer uso de estratégias de mitigação de risco de acordo com o comportamento de aversão ao risco e capacidade de investimento do empreendedor. Logo, para um parâmetro de aversão ao risco de 0,0 a rentabilidade foi de $16,39 \%$ e risco de $6,5 \%$; considerando aversão ao risco de 0,20 a rentabilidade e risco foi de $15,76 \%$ e $2,88 \%$ respectivamente. Assim, reduzindo a rentabilidade em 0,63\%, obteve-se uma diminuição do risco de 4,07\%.

Soares (2008) aborda um estudo sobre a melhor maneira de se alocar o investimento e selecionar a carteira eficiente dentro de um conjunto de projetos de geração, evidenciando quais seriam os mais rentáveis do pondo de vista do investidor.

A metodologia segue três etapas: cálculo da distribuição de probabilidade dos retornos dos projetos; construção do conjunto eficiente das alternativas de investimento; e seleção da carteira de projetos.

A teoria de portfólio foi abordada por três modelos diferentes: média-variância, minimax e CVaR. Com o objetivo de desenvolver uma metodologia que faça a avaliação econômico-financeira de novos empreendimentos de geração de energia, precificação de riscos e seleção de carteiras de projetos, foi escolhido o critério CVaR, que permite controlar a maior perda admitida pelo investidor, para um determinado nível de confiança.

A distribuição de retornos foi estimada em função do mapeamento e modelagem de fatores de risco diferentes usando simulação de Monte Carlo. Assim, com a metodologia desenvolvida é possível comparar a competividade de diferente tecnologia de geração de energia. Para isto usou-se um cenário com 13 alternativas de investimentos com diferentes tecnologias de geração e distribuídas nos quatro subsistemas nacionais. 
Maués (2008) avalia o binômio risco-retorno do estudo de matriz enérgica feito pela EPE para 2030, publicado no ano de 2006. Após a comparação dos dados se constatou que a matriz não está otimizada para risco-retorno em 2030. Porém, com o aumento da inserção de matrizes eólicas e resíduos da plantação de cana de açúcar o risco é reduzido significativamente, bem como o custo médio por quilowatt hora.

Isto também é constatado quando se modifica os dados de entrada para determinação da fronteira eficiente mostrando que as participações destas duas fontes de energia resultam em portfólios robustos com grande aversão ao risco. Observou-se que o estudo feito pela EPE para 2030 ficou situado abaixo e à direita da fronteira eficiente, mostrando que com o uso da teoria de MVP se encontram melhores resultados de alocação de matriz energética, atingindo uma redução de 5\% no risco. Foram apresentadas também diferenças e substituições de matrizes energéticas quando usada a teoria de MVP, sinalizando uma mudança da geração térmica a carvão por eólicas, cogeração a gás e a base de resíduos de cana de açúcar.

Boro (2014) pesquisou o comportamento energético entre fontes renováveis não convencionais, cujo objetivo central foi a identificação dos ganhos advindos da complementariedade existente entre os diferentes processos de geração. O resultado é a indicação para o investidor de uma carteira composta por diferentes fontes que the traga mais competitividade por meio da diminuição do risco. Foram realizadas simulações envolvendo a sazonalidade na produção e características de cada fonte.

As simulações foram divididas em três etapas: (i) aferição da complementaridade através de séries históricas - considera um portfólio composto pelas fontes $\mathrm{PCH}$, Biomassa, Eólica e Solar e contrato de longo prazo; (ii) incremento do modelo de complementariedade utilizando séries de vento reconstituídas e critérios de risco - avalia a sinergia entre uma PCH participante do MRE com quatro diferentes parques eólicos; (iii) acoplamento de fontes renováveis não convencionais a um bloco existente de fonte hidráulica - analisa o comportamento da receita e do risco quando fontes complementares são combinadas separadamente a uma usina hidrelétrica existente.

Boro e Ramos (2014) discutiram o comportamento da complementariedade entre as fontes energéticas, eólica e hidráulica, utilizando simulação envolvendo a sazonalidade na produção energética e otimização do CVaR. Entre os resultados alcançados os atores citam a sinergia entre as fontes. A análise de sensibilidade ao risco indicou que os ganhos com a mitigação dessa variável foram mais importantes 
do que a perda de receita e que o comprometimento total da garantia física não significa uma blindagem à perda de receita.

A aplicação da teoria de MVP no planejamento da expansão da geração eólica permite encontrar um portfólio ótimo que maximiza a geração esperada, para uma dada volatilidade ou, minimiza a volatilidade, para uma dada geração esperada. A ferramenta pode ser usada pelo órgão planejador, indicando o portfólio de usinas devem entrar em operação, de modo a minimizar a volatilidade, para uma quantidade de energia gerada esperada. Para o investidor, a ferramenta pode ser utilizada de apoio para a decisão da escolha do sítio mais apropriado, com o objetivo de construir uma carteira otimizada de investimentos. 


\section{APLICAÇÃO DA METODOLOGIA E RESULTADOS}

\subsection{MODELO PROPOSTO APLICADO À SÉRIE DE ENERGIA GERADA DAS USINAS DO PROINFA}

As usinas eólicas foram consideradas como um ativo financeiro. A partir do histórico de energia gerada mensal, foram obtidos os parâmetros de média, desvio padrão e covariância, dos ativos. A série histórica de energia gerada mensal foi convertida em fator de capacidade e obtidos os mesmos parâmetros.

O objetivo principal do modelo é obter a curva da fronteira eficiente, composta pelas carteiras otimizadas (item 4.6.7), por meio da aplicação da teoria de portfólio de Markowitz descrita na Equação (51), com e sem restrições. Para tal, foram obtidas carteiras otimizadas e ajustada a curva da fronteira eficiente sobre os respectivos pontos.

De acordo com o item 4.6.7, para obter a curva da fronteira eficiente é arbitrado o retorno e encontrada a carteira de menor risco, sujeita as restrições de que a soma dos percentuais de participação dos ativos na carteira seja igual a um e que todos os títulos tenham percentuais positivos ou nulos (Equação (51)).

A formulação foi proposta por Elton et al (2004), que ensinam que variando o retorno da carteira $(\tilde{R})$, entre o retorno da carteira de mínima variância e o retorno da carteira de máximo retorno, produz-se a curva da fronteira eficiente.

Cada carteira otimizada contém a proporção do ativo na composição da carteira, que equivale a proporção da potência instalada da usina eólica na carteira otimizada. A Figura 10 representa o modelo proposto básico.

Figura 10 - Modelo Proposto Básico.

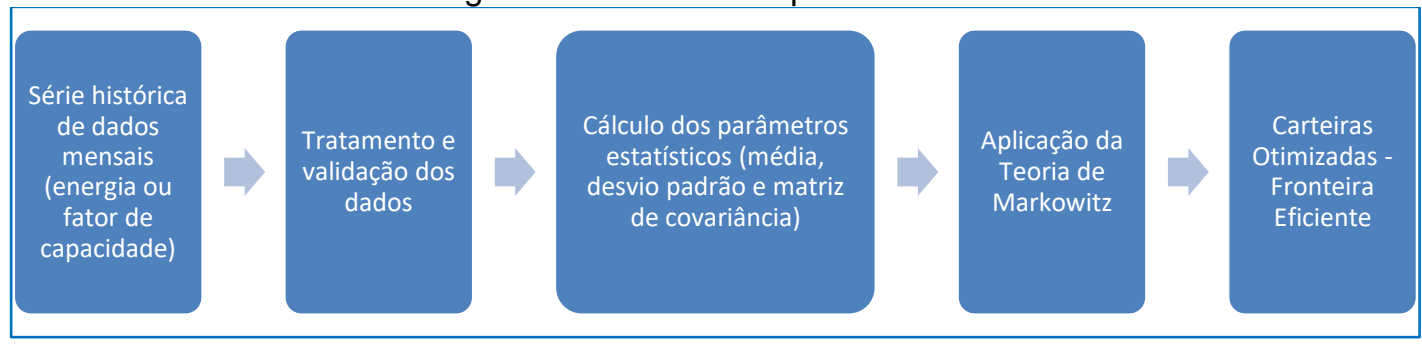

Autor (2016). 
O modelo proposto foi aplicado na série histórica de energia gerada mensal das usinas do PROINFA para validação da metodologia e na sequência, na série histórica de velocidade de vento (mensal e horária), obtida do Vortex.

O modelo foi inicialmente aplicado sem restrições incorporadas ao problema de otimização, com o histórico de dados de energia gerada, em base mensal, das usinas do PROINFA (usinas eólicas, usinas termoelétricas à biomassa e PCHs) e por meio da função disponível no Matlab ${ }^{74}$. A função "portopt" do Matlab calcula o risco, retorno e os pesos das carteiras otimizadas, tendo como entrada, o vetor das médias e a matriz de covariância, obtidos das séries históricas de energia gerada (ou fator de capacidade).

Como as usinas contratadas pelo PROINFA entraram em operação comercial em diversas datas, nas otimizações considerando as usinas individualizadas, foram selecionadas apenas as usinas que entraram em operação comercial até junho de 2011, abrangendo uma vasta quantidade de usinas com simultaneidade de dados ${ }^{75} \mathrm{e}$ dispersidade geográfica. A TABELA 18 apresenta a quantidade de usinas e a potência instalada por Estado e por tipo de fonte, que foram utilizadas nas simulações individualizadas por usina, que representam $69 \%$ da potência total contratada pelo PROINFA.

Ao total, a amostra compreende 104 usinas, das quais, 39 são $\mathrm{PCH}$ e estão localizadas em 10 Estados da Federação, 20 são usinas termoelétricas a biomassa, localizadas em 8 Estados e por fim, 45 são usinas eólicas, localizadas em 8 Estados e utilizando os aerogeradores dos fabricantes Vestas, Wobben/Enercon, Impsa e Suzlon.

Nas otimizações onde as usinas foram agregadas por Estado (usina equivalentes), foi utilizada a série histórica do fator de capacidade, assim foi possível o uso do período de janeiro de 2009 a novembro de 2015. Como a série de dados está normalizada (fator de capacidade), a entrada em operação comercial das usinas ao longo do período não compromete a série, na medida em que é ajustada pela soma da potência das usinas que entram em operação comercial.

\footnotetext{
74 [PortRisk, PortReturn, PortWts] = portopt(m,c,n). Onde: i) Parâmetros de Entrada: (m - vetor unitário das médias dos ativos; $\mathrm{C}$ - matriz de covariância dos ativos; $\mathrm{n}$ - número de carteiras otimizadas); ii) Parâmetros de Saída: (PortRisk - vetor do desvio padrão das carteiras otimizadas; PortReturn - vetor do retorno das carteiras otimizadas; PortWts - vetor dos pesos dos ativos das carteiras otimizadas).

${ }^{75}$ Série histórica de junho de 2011 a novembro de 2015, totalizando 53 meses.
} 
TABELA 18 - Usinas do PROINFA Utilizadas na Otimização.

\begin{tabular}{|c|c|c|c|}
\hline Fonte & Estado & $\begin{array}{c}\text { Quantidade de } \\
\text { Usinas }\end{array}$ & Potência (MW) \\
\hline \multirow{9}{*}{ Biomassa } & AL & 2 & 31,00 \\
\hline & GO & 2 & 54,52 \\
\hline & $M G$ & 1 & 30,00 \\
\hline & PB & 1 & 20,00 \\
\hline & PE & 1 & 33,20 \\
\hline & PR & 3 & 88,10 \\
\hline & SE & 1 & 5,00 \\
\hline & SP & 9 & 271,52 \\
\hline & Subtotal & 20 & 533,34 \\
\hline \multirow{9}{*}{ Eólica } & CE & 17 & 500,53 \\
\hline & PB & 13 & 63,70 \\
\hline & PE & 4 & 17,00 \\
\hline & $\mathrm{PI}$ & 1 & 17,85 \\
\hline & RJ & 1 & 28,05 \\
\hline & $\mathrm{RN}$ & 3 & 100,30 \\
\hline & RS & 4 & 157,56 \\
\hline & SC & 2 & 79,00 \\
\hline & Subtotal & 45 & 963,99 \\
\hline \multirow{11}{*}{$\mathrm{PCH}$} & BA & 3 & 41,80 \\
\hline & ES & 2 & 25,50 \\
\hline & $\mathrm{GO}$ & 5 & 120,00 \\
\hline & $M G$ & 3 & 56,50 \\
\hline & MS & 4 & 76,20 \\
\hline & MT & 4 & 84,24 \\
\hline & RJ & 3 & 79,00 \\
\hline & RS & 7 & 141,5 \\
\hline & SC & 5 & 94,70 \\
\hline & TO & 3 & 46,80 \\
\hline & Subtotal & 39 & 766,24 \\
\hline Total & & 104 & $2.263,57$ \\
\hline
\end{tabular}

Nos itens seguintes, foram obtidas carteiras otimizadas e as curvas de fronteira eficiente para as usinas do PROINFA, considerando os: i) dados históricos da energia gerada das usinas eólicas individualizadas; ii) dados históricos do fator de capacidade das usinas eólicas individualizadas; iii) dados históricos do fator de capacidade das usinas eólicas agregados por Estado (usinas eólicas equivalentes); iv) dados históricos do fator de capacidade de todos os tipos de usinas (fonte eólica, pequenas centrais e biomassa); v) dados históricos do fator de capacidade das usinas agregados por Estado e por fonte. 
Por fim, encontrou-se o risco mínimo da carteira, considerando os dados históricos do fator de capacidade das usinas eólicas individualizadas e agregados por Estado (usinas eólicas equivalentes).

\subsubsection{Otimização 01 - Usinas Eólicas Individualizadas do PROINFA - Energia Gerada}

Nesta otimização, para a aplicação da teoria de portfólio de Markowitz, foram utilizados os dados históricos de energia gerada das 45 usinas eólicas do PROINFA referente ao período de junho de 2011 a novembro de 2015, totalizando 53 meses.

Neste caso, para cada usina eólica foi calculada a média e o desvio padrão da energia gerada mensal (em MWh), sendo que a média de geração foi considerada como o retorno (Equação (21)) e, o desvio padrão da energia gerada foi considerado o risco (Equação (22)), para fins de aplicação da teoria de portfólio de Markowitz. A TABELA 19 resume os parâmetros de média e desvio padrão.

A média e o desvio padrão da carteira atual PROINFA ${ }^{76}$ foram obtidos a partir da média e do desvio padrão de cada usina eólica, ponderados pela potência instalada da referida usina sobre a potência instalada das usinas do PROINFA da amostra, conforme Equações (41) e (44), onde o quociente da potência da usina pela potência total das usinas do PROINFA foi considerado como o peso do ativo da carteira $\left(w_{i}\right)^{77}$. Ressalta-se que a média e o desvio padrão da energia gerada pela totalidade das usinas do PROINFA é maior que a média e o desvio padrão calculados pelo método descrito. $O$ cálculo da média e do desvio padrão da carteira atual proporcionalizado pelas potências de cada usina é necessário na medida em que os parâmetros (média e desvio padrão) individualmente são influenciados pela potência das usinas ${ }^{78}$. Alternativamente, para compatibilizar a dimensão dos parâmetros da carteira atual com a dimensão dos parâmetros das usinas consideradas individualmente, poderia ter sido multiplicada a média e o desvio padrão de cada usina eólica pela relação entre a potência total da carteira atual do PROINFA e a potência da usina.

\footnotetext{
${ }^{76} \mathrm{~A}$ carteira atual PROINFA representa uma carteira de ativos, considerando as usinas em operação comercial do PROINFA.

77 O parâmetro w (peso do ativo na carteira) é obtido pelo quoeficiente da potência da usina sobre a potência total da amostra.

${ }^{78}$ A teoria de Markowitz foi desenvolvida para aplicação sobre os índices dos ativos financeiros e não sobre os valores absolutos.
} 
TABELA 19 - Média e Desvio Padrão da Energia Gerada das Usinas Eólicas do PROINFA.

\begin{tabular}{|c|c|c|c|c|}
\hline \multirow{2}{*}{ Usina Eólica } & \multirow{2}{*}{ Potência (MW) } & \multirow{2}{*}{ Estado } & \multicolumn{2}{|c|}{ Energia Gerada Mensal (MWh) } \\
\hline & & & Média & Desvio Padrão \\
\hline Beberibe & 25,20 & $\mathrm{CE}$ & $7.240,24$ & $2.290,56$ \\
\hline Bons Ventos & 50,00 & $\mathrm{CE}$ & $15.179,86$ & $4.684,97$ \\
\hline Canoa Quebrada & 57,00 & $\mathrm{CE}$ & $18.302,92$ & $5.543,47$ \\
\hline Canoa Quebrada (Rv) & 10,50 & $\mathrm{CE}$ & $3.589,61$ & 982,59 \\
\hline Enacel & 31,50 & $\mathrm{CE}$ & $9.353,41$ & $2.876,23$ \\
\hline Foz Do Rio Choró & 25,20 & CE & $6.977,27$ & $2.321,77$ \\
\hline Icaraizinho & 54,00 & $\mathrm{CE}$ & $19.814,70$ & $7.365,42$ \\
\hline Lagoa Do Mato & 3,23 & $\mathrm{CE}$ & $1.296,68$ & 339,46 \\
\hline Paracuru & 23,40 & $\mathrm{CE}$ & $9.388,01$ & $3.291,92$ \\
\hline Praia Do Morgado & 28,80 & CE & $8.412,94$ & $3.447,99$ \\
\hline Praia Formosa & 6,60 & CE & $1.569,12$ & 652,32 \\
\hline Praia Formosa & 5,40 & $\mathrm{CE}$ & $1.283,85$ & 533,73 \\
\hline Praia Formosa & 13,80 & $\mathrm{CE}$ & $3.280,90$ & $1.363,95$ \\
\hline Praia Formosa & 78,60 & CE & $18.687,02$ & $7.768,64$ \\
\hline Praias De Parajuru & 28,80 & $\mathrm{CE}$ & $7.177,12$ & $2.336,86$ \\
\hline Taiba Albatroz & 16,50 & $\mathrm{CE}$ & $5.207,31$ & $2.226,01$ \\
\hline Volta Do Rio & 42,00 & CE & $12.239,00$ & $5.942,69$ \\
\hline Albatroz & 4,50 & PB & 970,99 & 284,84 \\
\hline Atlântica & 4,50 & PB & $1.004,75$ & 256,34 \\
\hline Camurim & 4,50 & PB & $1.038,60$ & 265,66 \\
\hline Caravela & 4,50 & PB & 960,81 & 290,93 \\
\hline Coelhos I & 4,50 & PB & $1.017,19$ & 279,95 \\
\hline Coelhos II & 4,50 & PB & $1.127,21$ & 311,93 \\
\hline Coelhos III & 4,50 & PB & 738,08 & 202,05 \\
\hline Coelhos IV & 4,50 & PB & 916,44 & 231,26 \\
\hline Mataraca & 4,50 & PB & 767,99 & 210,46 \\
\hline Millennium & 10,20 & PB & $2.434,94$ & 610,98 \\
\hline Pirauá & 4,25 & PB & $1.319,72$ & 250,24 \\
\hline Presidente & 4,50 & PB & 736,56 & 195,51 \\
\hline Vitória & 4,25 & PB & 895,70 & 262,86 \\
\hline Gravatá Fruitrade & 4,25 & PE & $1.265,15$ & 321,46 \\
\hline Mandacaru & 4,25 & PE & $1.130,00$ & 287,17 \\
\hline Santa Maria & 4,25 & $\mathrm{PE}$ & 887,05 & 295,44 \\
\hline Xavante & 4,25 & PE & 886,26 & 278,19 \\
\hline Pedra Do Sal & 17,85 & $\mathrm{PI}$ & $5.499,40$ & $2.204,81$ \\
\hline Gargaú & 28,05 & RJ & $5.969,63$ & $2.567,09$ \\
\hline Alegria I & 19,92 & RN & $4.843,89$ & $1.611,02$ \\
\hline Alegria II & 31,08 & RN & $7.558,09$ & $2.513,74$ \\
\hline RN $15-R$ io Do Fogo & 49,30 & RN & $12.290,95$ & $3.373,39$ \\
\hline Dos Índios & 50,00 & RS & $9.554,38$ & $2.848,68$ \\
\hline Osório & 50,00 & RS & $9.557,59$ & $2.866,68$ \\
\hline Palmares & 7,56 & RS & $2.247,54$ & 540,58 \\
\hline Sangradouro & 50,00 & RS & $10.382,34$ & $2.997,51$ \\
\hline Água Doce & 9,00 & SC & $1.610,61$ & 425,60 \\
\hline Elebras Cidreira & 70,00 & SC & $17.321,27$ & $4.085,58$ \\
\hline Carteira Atual PROINFA & 963,99 & BR & $10.770,24$ & $3.083,49$ \\
\hline
\end{tabular}

Autor (2016)

Fonte: BRASIL. Eletrobrás (2016).

A covariância foi calculada para cada par de usina eólica da TABELA 19 a partir da série histórica de energia gerada, obtendo-se a matriz de covariância.

A partir dos parâmetros estatísticos calculados para cada usina eólica (desvio padrão e matriz de covariância) foram obtidas 30 carteiras otimizadas (item 4.6.7) e ajustada a curva da fronteira eficiente, por meio da aplicação da teoria de portfólio de Markowitz (Equação (51)). Os resultados estão apresentados no Gráfico 37. 
Gráfico 37 - Fronteira Eficiente das Usinas Eólicas do PROINFA (Dados em Energia).

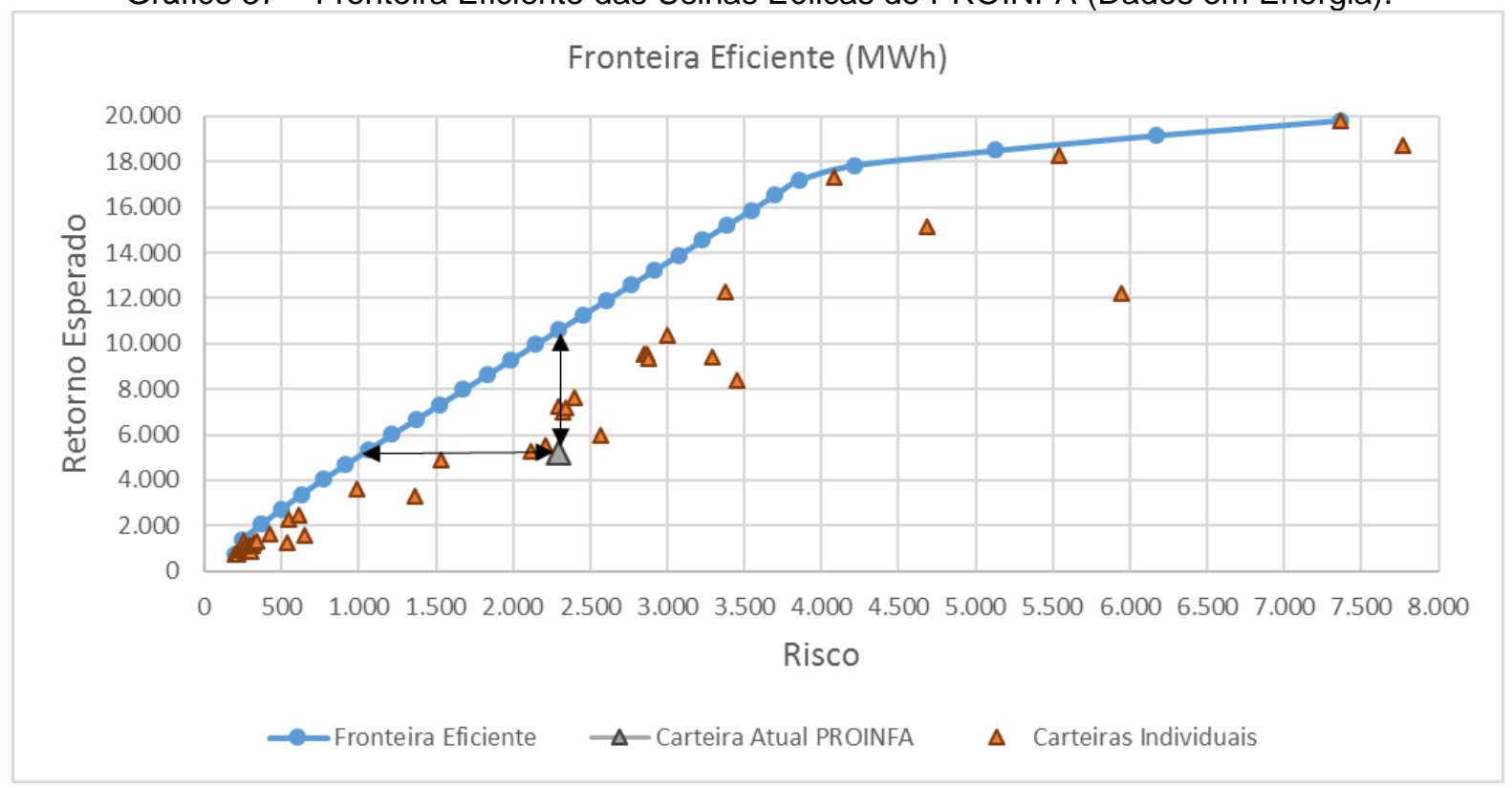

Autor (2016).

Os ativos individuais, caracterizados pela média e pelo desvio padrão da energia gerada de cada usina, estão representados pelos pontos (triângulos) de cor laranja. A carteira atual, calculada pelo somatório das médias e dos desvios padrões da energia gerada de cada usina, ponderadas pelas respectivas potências, está representada pelo triângulo de cor cinza. As carteiras otimizadas, que estão sobre a curva da fronteira eficiente, estão ilustradas pelos pontos em cor azul.

Alguns ativos individuais estão próximos da fronteira eficiente, como as usinas eólicas dos Estados da Paraíba e do Pernambuco, além da usina Elebras Cidreira, do Estado de Santa Catarina. As usinas eólicas dos Estados do Ceará, Rio Grande do Norte e Rio de Janeiro estão mais afastadas da fronteira eficiente.

Ressalta-se que esse resultado está sendo influenciado pela potência instalada de cada usina, uma vez que as usinas que ficaram mais próximas da fronteira eficiente são as de menores potência, com exceção da usina Elebras Cidreira. Da mesma forma, as usinas mais distantes da fronteira são aquelas de maior potência. É natural que quanto maior a potência da usina, maior é o valor da média e, possivelmente, do desvio padrão da energia gerada (em valores absolutos).

Observa-se que a carteira atual está distante da fronteira eficiente, sinalizando que a regra de contratação do PROINFA, que limitou a potência instalada dos empreendimentos por Estado, não foi suficiente para resultar em uma carteira otimizada. 
Na TABELA 20 são apresentados 10 exemplos de carteiras otimizadas (sobre a curva da fronteira eficiente) e a carteira atual, com o peso da participação de cada usina na carteira, assim como os respectivos desvios e retornos.

Observa-se que o somatório de participação das usinas para a carteira atual não é igual a 100\%, pois na TABELA 20 estão sendo apresentadas apenas as usinas eólicas que foram selecionadas pelo modelo para compor as carteiras ótimas. Assim, verifica-se que a carteira atual é formada por apenas $31,75 \%$ de usinas utilizadas na composição das carteiras otimizadas e o restante por usinas não selecionadas.

\begin{tabular}{|c|c|c|c|c|c|c|c|c|c|c|c|c|}
\hline \multirow[b]{2}{*}{$\begin{array}{c}\text { Carteira } \\
\text { Ótima }\end{array}$} & \multirow[b]{2}{*}{$\begin{array}{l}\text { DP } \\
\text { (1) }\end{array}$} & \multirow[b]{2}{*}{$\begin{array}{c}R \\
(2)\end{array}$} & \multicolumn{10}{|c|}{ Participação das Usinas nas Carteiras Otimizadas } \\
\hline & & & $\begin{array}{l}\text { Canoa } \\
\text { Quebrada }\end{array}$ & Enacel & $\begin{array}{c}\text { RN } 15- \\
\text { Rio Do } \\
\text { Fogo }\end{array}$ & $\begin{array}{l}\text { Elebras } \\
\text { Cidreira }\end{array}$ & $\begin{array}{c}\text { Preside } \\
\text { nte }\end{array}$ & Gargaú & $\begin{array}{c}\text { Xa- } \\
\text { vante }\end{array}$ & $\begin{array}{c}\text { Gravatá } \\
\text { Fruitra- } \\
\text { de }\end{array}$ & $\begin{array}{l}\text { Icaraiz } \\
\text { inho }\end{array}$ & $\begin{array}{c}\text { Lagoa } \\
\text { Do } \\
\text { Mato }\end{array}$ \\
\hline 1 & 194 & 755 & $0,00 \%$ & $0,00 \%$ & $0,00 \%$ & $0,00 \%$ & $87,73 \%$ & $0,00 \%$ & $12,27 \%$ & $0,00 \%$ & $0,00 \%$ & $0,00 \%$ \\
\hline 2 & 480 & 2.661 & $0,00 \%$ & $3,79 \%$ & $0,00 \%$ & $6,39 \%$ & $0,00 \%$ & $1,25 \%$ & $0,00 \%$ & $76,44 \%$ & $0,00 \%$ & $12,12 \%$ \\
\hline 3 & 883 & 4.567 & $0,00 \%$ & $10,06 \%$ & $0,00 \%$ & $15,18 \%$ & $0,00 \%$ & $1,07 \%$ & $0,00 \%$ & $73,69 \%$ & $0,00 \%$ & $0,00 \%$ \\
\hline 4 & 1.063 & 5.355 & $0,00 \%$ & $12,17 \%$ & $0,00 \%$ & $19,07 \%$ & $0,00 \%$ & $0,93 \%$ & $0,00 \%$ & $67,82 \%$ & $0,00 \%$ & $0,00 \%$ \\
\hline 5 & 1.771 & 8.379 & $4,17 \%$ & $9,43 \%$ & $4,11 \%$ & $32,30 \%$ & $0,00 \%$ & $0,02 \%$ & $0,00 \%$ & $49,97 \%$ & $0,00 \%$ & $0,00 \%$ \\
\hline 6 & 2.220 & 10.285 & $9,02 \%$ & $3,78 \%$ & $6,18 \%$ & $40,45 \%$ & $0,00 \%$ & $0,00 \%$ & $0,00 \%$ & $40,56 \%$ & $0,00 \%$ & $0,00 \%$ \\
\hline 7 & 2.670 & 12.191 & $12,96 \%$ & $0,00 \%$ & $8,18 \%$ & $48,68 \%$ & $0,00 \%$ & $0,00 \%$ & $0,00 \%$ & $30,18 \%$ & $0,00 \%$ & $0,00 \%$ \\
\hline 8 & 3.121 & 14.097 & $15,01 \%$ & $0,00 \%$ & $10,06 \%$ & $57,08 \%$ & $0,00 \%$ & $0,00 \%$ & $0,00 \%$ & $17,85 \%$ & $0,00 \%$ & $0,00 \%$ \\
\hline 9 & 3.573 & 16.003 & $17,07 \%$ & $0,00 \%$ & $11,93 \%$ & $65,48 \%$ & $0,00 \%$ & $0,00 \%$ & $0,00 \%$ & $5,52 \%$ & $0,00 \%$ & $0,00 \%$ \\
\hline 10 & 4.299 & 17.909 & $34,05 \%$ & $0,00 \%$ & $0,00 \%$ & $55,79 \%$ & $0,00 \%$ & $0,00 \%$ & $0,00 \%$ & $0,00 \%$ & $10,15 \%$ & $0,00 \%$ \\
\hline $\begin{array}{c}\text { Carteira } \\
\text { Atual }\end{array}$ & 2.294 & 5.217 & $5,91 \%$ & $3,27 \%$ & $5,11 \%$ & $7,26 \%$ & $0,47 \%$ & $2,91 \%$ & $0,44 \%$ & $0,44 \%$ & $5,60 \%$ & $0,34 \%$ \\
\hline
\end{tabular}

(1) DP: Desvio Padrão em MWh.mês. (2) R: Retorno em MWh.mês.

Autor (2016).

A carteira 6 (em azul) possui praticamente o mesmo desvio padrão da carteira atual (2.294 MWh.mês). Desta forma, uma mudança na composição da carteira atual poderia aumentar a expectativa de geração de 5.217 MWh.mês para 10.285 MWh.mês, para o mesmo risco. No mesmo sentido, uma mudança na composição da carteira atual poderia reduzir a volatilidade de 2.294 MWh.mês para 1.063 MWh.mês, mantendo praticamente a mesma energia gerada (carteira 4, destacada em verde).

Os resultados obtidos possuem uma faixa de expectativa de geração entre 755 MWh.mês (carteira de risco mínimo) a 19.814 MWh.mês (carteira de maior retorno), enquanto a carteira atual possui uma expectativa de geração igual a 5.217 MWh.mês. As carteiras otimizadas com expectativa de geração inferior à carteira atual exigirão maior investimento para atendimento da mesma demanda. 
Ao contrário, as carteiras otimizadas com expectativa de geração superior à carteira atual exigirão menor investimento para atendimento da mesma demanda.

A média e o desvio padrão das carteiras otimizadas foram calculadas a partir da média e do desvio padrão das usinas que compõe a carteira. Desta forma, se for considerada a potência de 963,99 MW (potência da amostra) para as carteiras otimizadas, os parâmetros de média e desvio padrão deverão ser proporcionalizados pela relação entre a potência da amostra pelo somatório das potências das usinas selecionadas para a respectiva carteira.

A carteira 1 (carteira de risco mínimo) tem uma expectativa de geração de 755 MWh.mês com uma composição de $88 \%$ de participação da usina Presidente $(7,7$ $\mathrm{MW}$ ) e $12 \%$ da usina Xavante ( $1,05 \mathrm{MW}$ ), totalizando $8,75 \mathrm{MW}$ de potência instalada ${ }^{79}$. Desta forma, supondo que se deseje que a carteira 1 tenha uma potência de 963,99 MW (igual a potência da amostra), a usina Presidente teria uma potência ajustada para 845,74 MW e a usina Xavante uma potência ajustada para 118,25 MW. Assim, os parâmetros de média e desvio padrão da carteira 1 seriam ajustados pela relação entre a potência de 963,99 MW (potência da amostra) pela soma das potências das usinas da carteira $(8,75 \mathrm{MW})$, resultando em uma expectativa de geração igual a 83.170,45 MWh.mês, equivalente a um fator de capacidade de 0,12. Mesmo raciocínio aplica-se as demais carteiras otimizadas.

Outro resultado interessante é que as carteiras otimizadas utilizam apenas 10 usinas eólicas (Canoa Quebrada, Enacel, RN 15 - Rio Do Fogo, Elebras Cidreira, Presidente, Gargaú, Xavante, Gravatá Fruitrade, Icaraizinho, Lagoa Do Mato). As demais 35 usinas eólicas são descartadas em todas as carteiras otimizadas. Chupp, Hickey e Loomis (2012) já haviam obtido resultado semelhante em seus estudos.

No Gráfico 38 é apresentada a frequência de uso das usinas eólicas para as 10 carteiras otimizadas selecionadas, com destaque para a usina Elebras Cidreira, que foi utilizada em $90 \%$ das carteiras.

\footnotetext{
${ }^{79} \mathrm{~A}$ usina Presidente tem 4,5 MW de potência instalada, enquanto a usina Xavante possui uma potência instalada de 4,25 MW (ver TABELA 19 - Média e Desvio Padrão da Energia Gerada das Usinas Eólicas do PROINFA.)
} 
Gráfico 38 - Frequencia de Uso das Usinas Eólicas do PROINFA nas 10 Carteiras Otimizadas (Dados em Energia Gerada).

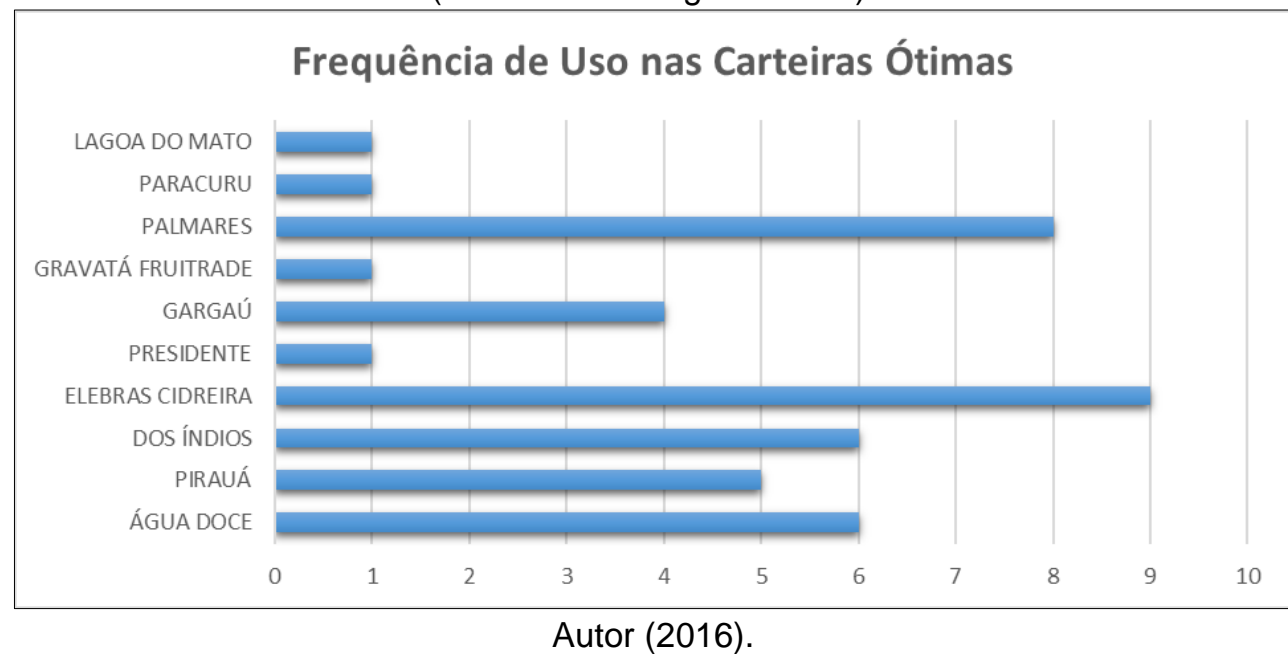

Apesar dos parâmetros média e do desvio padrão poderem ser ajustados pela multiplicação da razão entre a potência total do PROINFA pela potência individual da usina, a covariância entre as séries da energia gerada é afetada pelo tamanho da usina. Assim, usar valores absolutos para aplicar a teoria de portfólio de Markowitz tem como inconveniente a influência do valor da capacidade instalada dos parques eólicos sobre os resultados (matriz de covariância). Para eliminar o impacto do valor da potência instalada, nos demais itens, será adotada a energia gerada normalizada pela potência, isto é, será utilizado o histórico do fator de capacidade das usinas como parâmetro de entrada para a teoria de portfólio de Markowitz.

\subsubsection{Otimização 02 - Usinas Eólicas Individualizadas do PROINFA - Fator de Capacidade}

Nesta otimização foi utilizada a mesma série histórica da energia gerada mensal do item 5.1.1 normalizada pela potência, obtendo-se a série histórica mensal do fator de capacidade, de junho de 2011 a novembro de 2015, totalizando 53 meses, conforme o Gráfico 39, que ilustra adicionalmente, o histórico dos máximos, mínimos e das médias mensais das usinas eólicas do PROINFA. Note-se que, Roques, Hiroux e Saguan (2009) também normalizaram a energia gerada pela potência instalada em seus estudos. 
Gráfico 39 - Histórico do Fator de Capacidade das 45 Usinas Eólicas do PROINFA.

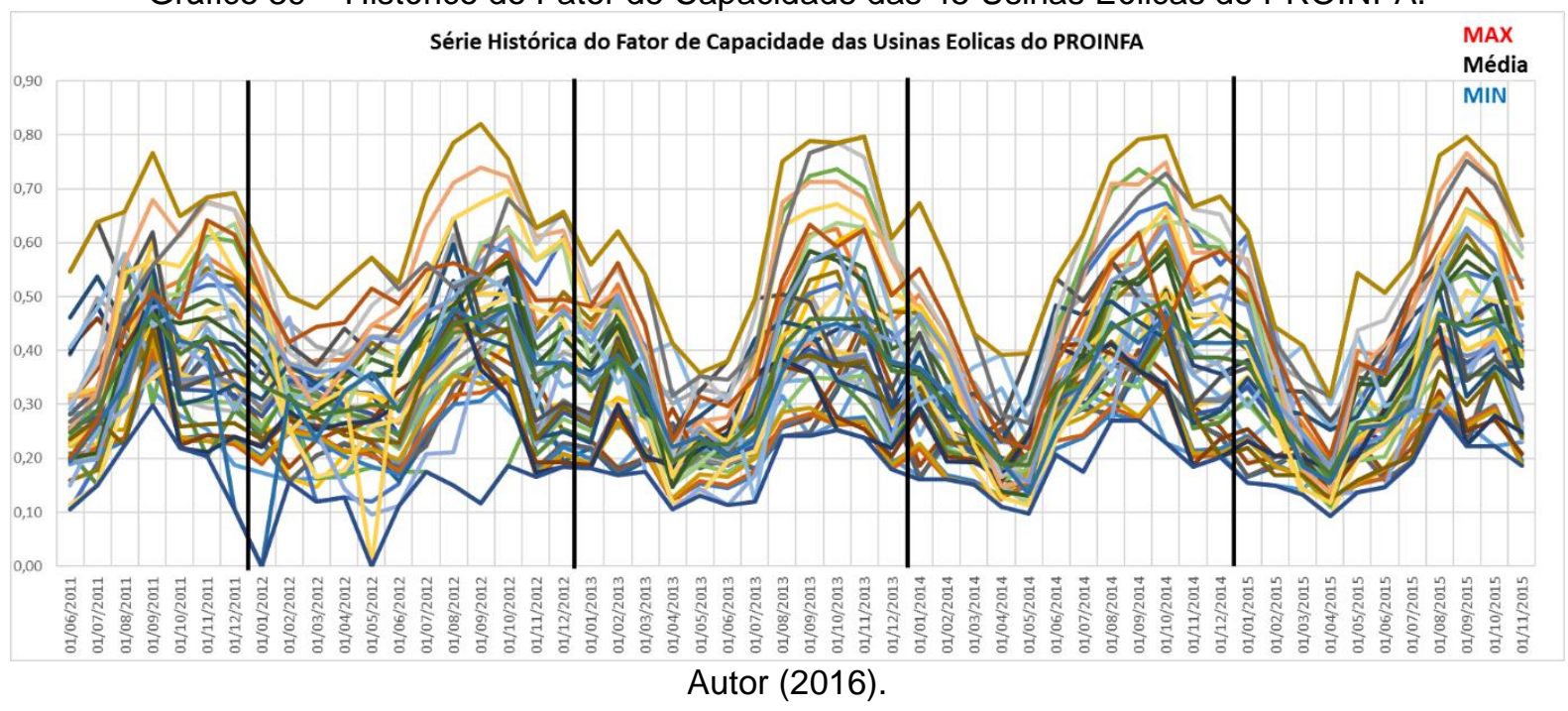

Neste caso, para cada usina eólica, foi calculada a média e o desvio padrão do fator de capacidade, sendo que a média do fator de capacidade foi considerada como o retorno (Equação (21)) e, o desvio padrão do fator de capacidade foi considerado o risco (Equação (22)), para fins de aplicação da teoria de portfólio de Markowitz. A TABELA 21 resume os parâmetros de entrada do modelo.

TABELA 21 - Média e Desvio Padrão do Fator de Capacidade das Usinas Eólicas do PROINFA.

\begin{tabular}{|c|c|c|c|c|}
\hline \multirow[t]{2}{*}{ Usina Eólica } & \multirow[t]{2}{*}{ Potência (MW) } & \multirow[t]{2}{*}{ Estado } & \multicolumn{2}{|c|}{$\begin{array}{l}\text { Fator de Capacidade } \\
\text { Energia Gerada/Potência }\end{array}$} \\
\hline & & & Média & Desvio Padrão \\
\hline Beberibe & 25,20 & CE & 0,39 & 0,12 \\
\hline Bons Ventos & 50,00 & CE & 0,42 & 0,13 \\
\hline Canoa Quebrada & 57,00 & $\mathrm{CE}$ & 0,44 & 0,13 \\
\hline Canoa Quebrada (Rv) & 10,50 & CE & 0,47 & 0,13 \\
\hline Enacel & 31,50 & CE & 0,41 & 0,12 \\
\hline Foz Do Rio Choró & 25,20 & $\mathrm{CE}$ & 0,38 & 0,13 \\
\hline Icaraizinho & 54,00 & CE & 0,50 & 0,19 \\
\hline Lagoa Do Mato & 3,23 & CE & 0,55 & 0,14 \\
\hline Paracuru & 23,40 & CE & 0,55 & 0,19 \\
\hline Praia Do Morgado & 28,80 & CE & 0,40 & 0,16 \\
\hline Praia Formosa & 6,60 & CE & 0,33 & 0,13 \\
\hline Praia Formosa & 5,40 & CE & 0,33 & 0,13 \\
\hline Praia Formosa & 13,80 & CE & 0,33 & 0,13 \\
\hline Praia Formosa & 78,60 & CE & 0,33 & 0,13 \\
\hline Praias De Parajuru & 28,80 & CE & 0,34 & 0,11 \\
\hline Taiba Albatroz & 16,50 & CE & 0,43 & 0,18 \\
\hline Volta Do Rio & 42,00 & $\mathrm{CE}$ & 0,40 & 0,19 \\
\hline Albatroz & 4,50 & PB & 0,30 & 0,09 \\
\hline Atlântica & 4,50 & PB & 0,31 & 0,08 \\
\hline Camurim & 4,50 & PB & 0,32 & 0,08 \\
\hline Caravela & 4,50 & PB & 0,29 & 0,09 \\
\hline Coelhos I & 4,50 & PB & 0,31 & 0,09 \\
\hline Coelhos II & 4,50 & PB & 0,34 & 0,10 \\
\hline Coelhos III & 4,50 & PB & 0,22 & 0,06 \\
\hline Coelhos IV & 4,50 & PB & 0,28 & 0,07 \\
\hline Mataraca & 4,50 & PB & 0,23 & 0,06 \\
\hline Millennium & 10,20 & PB & 0,33 & 0,08 \\
\hline Pirauá & 4,25 & PB & 0,43 & 0,08 \\
\hline Presidente & 4,50 & PB & 0,22 & 0,06 \\
\hline Vitória & 4,25 & PB & 0,29 & 0,09 \\
\hline Gravatá Fruitrade & 4,25 & PE & 0,41 & 0,11 \\
\hline
\end{tabular}




\begin{tabular}{|c|c|c|c|c|}
\hline \multirow[t]{2}{*}{ Usina Eólica } & \multirow{2}{*}{ Potência (MW) } & \multirow[t]{2}{*}{ Estado } & \multicolumn{2}{|c|}{$\begin{array}{l}\text { Fator de Capacidade } \\
\text { Energia Gerada/Potência }\end{array}$} \\
\hline & & & Média & Desvio Padrão \\
\hline Mandacaru & 4,25 & $\mathrm{PE}$ & 0,37 & 0,10 \\
\hline Santa Maria & 4,25 & PE & 0,29 & 0,10 \\
\hline Xavante & 4,25 & PE & 0,29 & 0,09 \\
\hline Pedra Do Sal & 17,85 & $\mathrm{PI}$ & 0,42 & 0,17 \\
\hline Gargaú & 28,05 & RJ & 0,29 & 0,12 \\
\hline Alegria I & 19,92 & $\mathrm{RN}$ & 0,33 & 0,11 \\
\hline Alegria II & 31,08 & $\mathrm{RN}$ & 0,33 & 0,11 \\
\hline RN $15-R$ io Do Fogo & 49,30 & $\mathrm{RN}$ & 0,34 & 0,09 \\
\hline Dos Índios & 50,00 & RS & 0,26 & 0,08 \\
\hline Osório & 50,00 & RS & 0,26 & 0,08 \\
\hline Palmares & 7,56 & RS & 0,41 & 0,10 \\
\hline Sangradouro & 50,00 & RS & 0,28 & 0,08 \\
\hline Água Doce & 9,00 & SC & 0,25 & 0,07 \\
\hline Elebras Cidreira & 70,00 & SC & 0,34 & 0,08 \\
\hline Carteira Atual PROINFA & 963,99 & BR & 0,345 & 0,092 \\
\hline
\end{tabular}

Fonte: BRASIL. Eletrobrás (2016).

A média e o desvio padrão da carteira atual foram obtidos a partir da média e do desvio padrão de cada usina eólica, ponderados pela potência instalada da referida usina sobre a potência instalada das usinas do PROINFA.

A matriz de covariância foi obtida a partir do cálculo da covariância para cada par de usina eólica considerando a série histórica mensal do fator de capacidade.

A partir dos parâmetros estatísticos (desvio padrão e matriz de covariância), foram obtidas as carteiras otimizadas (item 4.6.7) e ajusta da curva da fronteira eficiente, por meio da aplicação da teoria de portfólio de Markowitz (Equação (51)). Os resultados estão apresentados no Gráfico 40.

Gráfico 40 - Fronteira Eficiente das Usinas Eólicas do PROINFA (Dados em Fator de Capacidade).

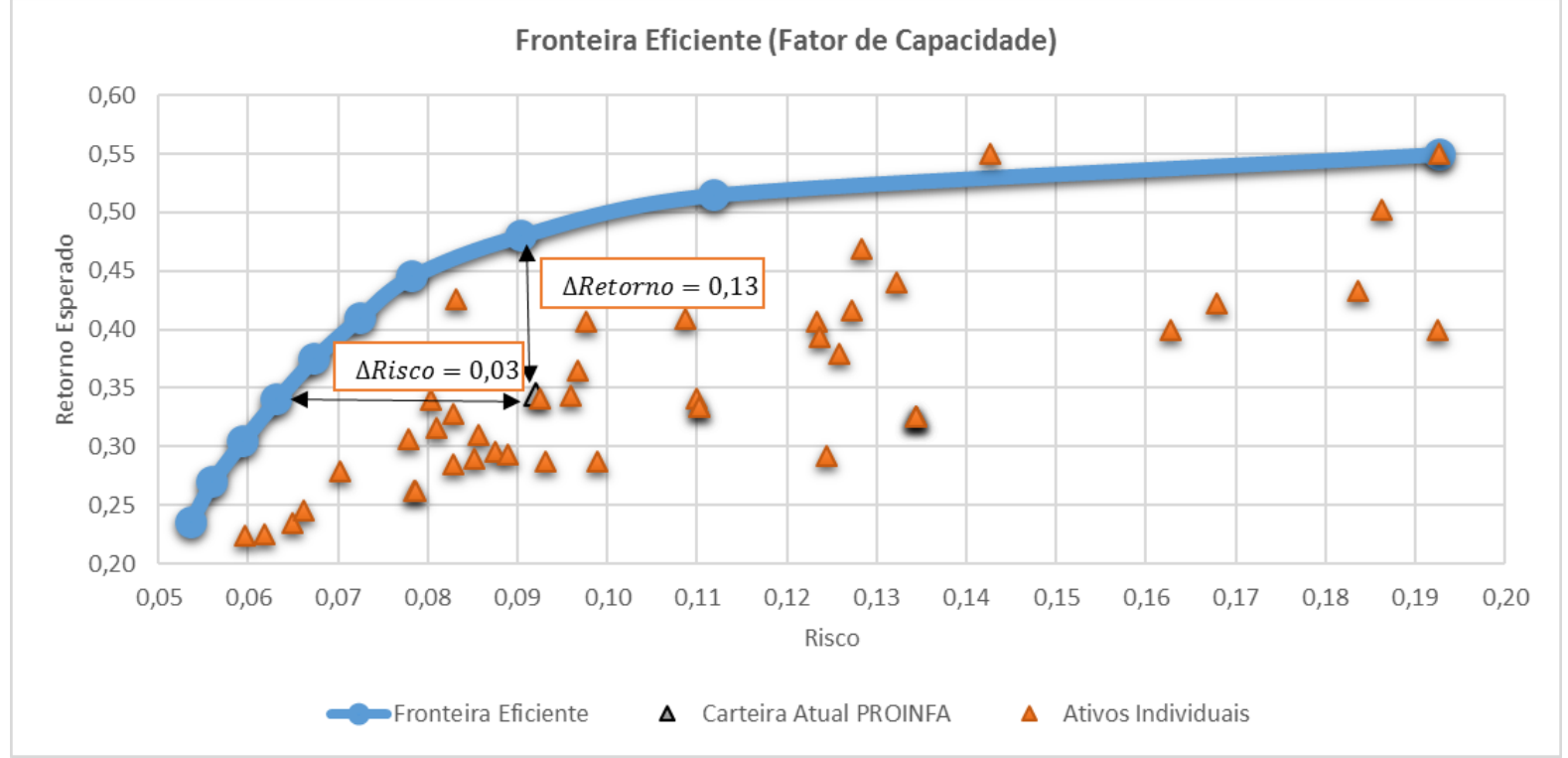

Autor (2016). 
Os ativos individuais, caraterizados pela média e pelo desvio padrão do histórico do fator de capacidade de cada usina, estão representados pelos pontos de cor laranja (triângulo) ${ }^{80}$. A carteira atual, calculada pela média e desvio padrão do fator de capacidade de cada usina, ponderados pelo quociente da respectiva potência sobre a potência total, está representada pelo ponto (triângulo) de cor cinza. As carteiras otimizadas, que estão sobre a curva da fronteira eficiente, estão ilustradas pelos pontos em cor azul. Os resultados obtidos com a utilização do fator de capacidade são semelhantes aos obtidos com a energia gerada, demonstrando que a carteira atual está distante da fronteira eficiente e que, portanto, a regra de contratação do PROINFA, que limitou a potência instalada dos empreendimentos por Estado, não foi suficiente para resultar em uma carteira otimizada.

Na TABELA 22 são apresentados 10 exemplos de carteiras otimizadas (sobre a curva da fronteira eficiente) e a carteira atual, com os respectivos desvios e retornos.

TABELA 22 - Exemplos de Carteiras Otimizadas das Usinas Eólicas do PROINFA (Parâmetros em Fator de Capacidade).

\begin{tabular}{|c|c|c|c|c|c|c|c|c|c|c|c|c|}
\hline \multirow{2}{*}{$\begin{array}{c}\text { Carteira } \\
\text { Ótima }\end{array}$} & \multirow{2}{*}{$\begin{array}{l}\text { DP } \\
\text { (1) }\end{array}$} & \multirow{2}{*}{$\begin{array}{c}R \\
(2)\end{array}$} & \multicolumn{10}{|c|}{ Potência Instalada (MW) } \\
\hline & & & $\begin{array}{l}\text { Água } \\
\text { Doce }\end{array}$ & Pirauá & $\begin{array}{l}\text { Dos } \\
\text { Índios }\end{array}$ & $\begin{array}{l}\text { Elebras } \\
\text { Cidreira } \\
\end{array}$ & $\begin{array}{l}\text { Presi- } \\
\text { Dente }\end{array}$ & Gargaú & $\begin{array}{c}\text { Gravatá } \\
\text { Fruitrade } \\
\end{array}$ & $\begin{array}{c}\text { Palma- } \\
\text { res }\end{array}$ & $\begin{array}{c}\text { Para- } \\
\text { curu }\end{array}$ & $\begin{array}{c}\text { Lagoa Do } \\
\text { Mato }\end{array}$ \\
\hline 1 & 0,05 & 0,24 & 385,64 & 0,00 & 20,20 & 0,00 & 538,76 & 19,39 & 0,00 & 0,00 & 0,00 & 0,00 \\
\hline 2 & 0,06 & 0,27 & 345,31 & 0,00 & 0,00 & 143,43 & 346,77 & 56,56 & 47,38 & 2,46 & 0,00 & 22,10 \\
\hline 3 & 0,06 & 0,31 & 333,45 & 75,62 & 0,00 & 136,68 & 196,40 & 67,90 & 70,73 & 35,03 & 0,00 & 48,17 \\
\hline 4 & 0,06 & 0,34 & 324,97 & 167,73 & 0,00 & 130,28 & 42,09 & 79,12 & 84,30 & 64,49 & 0,00 & 71,01 \\
\hline 5 & 0,07 & 0,38 & 232,55 & 165,18 & 0,00 & 104,27 & 0,00 & 57,13 & 154,12 & 132,58 & 0,00 & 118,15 \\
\hline 6 & 0,07 & 0,41 & 108,66 & 127,13 & 0,00 & 70,92 & 0,00 & 22,68 & 245,04 & 215,16 & 0,00 & 174,41 \\
\hline 7 & 0,08 & 0,45 & 0,00 & 53,06 & 0,00 & 0,00 & 0,00 & 0,00 & 351,98 & 314,84 & 0,00 & 244,12 \\
\hline 8 & 0,09 & 0,48 & 0,00 & 0,00 & 0,00 & 0,00 & 0,00 & 0,00 & 354,70 & 121,90 & 0,00 & 487,39 \\
\hline 9 & 0,11 & 0,52 & 0,00 & 0,00 & 0,00 & 0,00 & 0,00 & 0,00 & 238,86 & 0,00 & 0,00 & 725,13 \\
\hline 10 & 0,19 & 0,55 & 0,00 & 0,00 & 0,00 & 0,00 & 0,00 & 0,00 & 0,00 & 0,00 & 963,99 & 0,00 \\
\hline $\begin{array}{c}\text { Carteira } \\
\text { Atual } \\
\text { PROINFA }\end{array}$ & 0,09 & 0,34 & 9,00 & 4,25 & 50,00 & 70,00 & 4,50 & 28,05 & 4,25 & 7,56 & 23,40 & 3,23 \\
\hline
\end{tabular}

(1) DP: Desvio Padrão; (2) R: Retorno Autor (2016).

A potência instalada de cada usina eólica também é apresentada para cada carteira ótima, que foi considerada com uma potência total igual a 963,99 MW (potência da carteira atual) ${ }^{81}$.

${ }^{80}$ Aparentemente há um ativo individual que está fora da curva da fronteira eficiente. No entanto, o ativo não viola a restrição e essa aparente violação é decorrente do ajuste da curva que une os pontos dos ativos otimizados.

${ }^{81}$ Observa-se que o somatório da potência da linha "Carteira Atual" não é igual a 963,99 MW, pois na TABELA 22 estão sendo apresentadas apenas as usinas eólicas que foram selecionadas pelo modelo para compor as carteiras ótimas. 
Assim, verifica-se que a potência da Carteira Atual é formada por apenas $21,19 \%$ de usinas utilizadas na composição das carteiras otimizadas e o restante por usinas não selecionadas.

A carteira atual possui o mesmo desvio padrão da carteira 8 (destacada em azul). Assim, uma mudança na composição da carteira atual poderia aumentar a expectativa do fator de capacidade de 0,34 para 0,48 , mantendo o mesmo risco $(0,09)$.

Da mesma forma, uma mudança na composição da carteira atual poderia reduzir a volatilidade do fator de capacidade de 0,09 para 0,06, mantendo praticamente a mesma expectativa do fator de capacidade (carteira 4, destacada em verde).

Os resultados obtidos possuem uma faixa de expectativa de fator de capacidade entre 0,24 (carteira de risco mínimo) a 0,55 (carteira de maior retorno), enquanto a carteira atual possui uma expectativa igual a 0,34 . As carteiras otimizadas com menor expectativa de fator de capacidade (geração) que a carteira atual, exigirão maior investimento para atendimento da mesma demanda. Ao contrário, para atender a mesma quantidade de demanda da carteira atual, com investimento igual ou menor, deve-se selecionar as carteiras com maior expectativa de fator de capacidade (geração).

A carteira 1, de risco mínimo (desvio padrão de 0,05357), é composta pelas usinas de Água Doce (386 MW de potência instalada), Presidente (539 MW), Dos Índios (20 MW) e Gargáu (19 MW). Ressalta-se que essa usina tem o menor fator de capacidade $(0,24)$, portanto, eventual seleção dessa carteira para atender a atual demanda do PROINFA (fator de capacidade de 0,34 ) exigiria investimentos adicionais (necessidade de $42 \%$ potência instalada adicional).

No Gráfico 41 é apresentada a frequência de uso das usinas eólicas para 10 carteiras otimizadas, com destaque para as usinas Lagoa do Mato e Gravatá Fruitrade, que foram utilizadas em $80 \%$ das carteiras. No item 5.1.1, a usina Elebras Cidreira foi utilizada em $90 \%$ das carteiras.

O resultado é semelhante ao item 5.1.1 (dados em energia), uma vez que aqui, as carteiras otimizadas também utilizam apenas 10 usinas eólicas, algumas que haviam sido selecionadas no item 5.1.1, outras novas. 
Gráfico 41 - Frequência de Uso das Usinas Eólicas nas 10 Carteiras Otimizadas (Dados em Fator de Capacidade) - Usinas Eólicas do PROINFA.

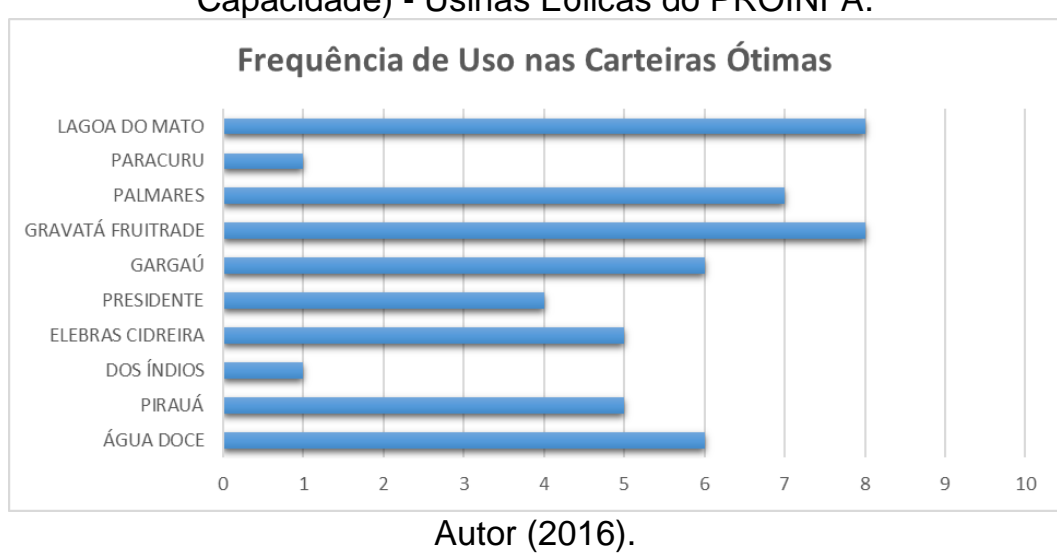

A TABELA 23 relaciona as usinas selecionas no modelo. Em verde, estão listadas as usinas selecionadas no item 5.1.1 e nesse item. Em azul, estão listadas as usinas selecionadas apenas nesse item. Em amarelo, estão listadas as usinas selecionadas somente no item 5.1.1.

TABELA 23 - Usinas Eólicas Selecionadas pelo Modelo.

\begin{tabular}{ccc}
\hline Usina & Estado & Potência (MW) \\
\hline Canoa Quebrada & CE & 57,00 \\
Enacel & CE & 31,50 \\
Icaraizinho & CE & 54,00 \\
Lagoa Do Mato & CE & 3,23 \\
Paracuru & CE & 23,40 \\
Pirauá & PB & 4,25 \\
Presidente & PB & 4,50 \\
Gravatá Fruitrade & PE & 4,25 \\
Xavante & PE & 4,25 \\
Gargaú & RJ & 28,05 \\
RN 15 Orio Do Fogo & RN & 49,30 \\
Dos Índios & RS & 50,00 \\
Palmares & RS & 7,56 \\
Água Doce & SC & 9,00 \\
Elebras Cidreira & SC & 70,00 \\
\hline
\end{tabular}

Autor (2016).

A divergência entre a composição das carteiras é justificada pela influência dos diversos valores de potência instalada no cálculo da matriz de covariância. Para eliminar o impacto do valor da capacidade instalada, será utilizada a série histórica do fator de capacidade nas simulações seguintes. 


\subsubsection{Otimização 03 - Usinas Eólicas Equivalentes do PROINFA - Fator de Capacidade}

Verifica-se que as usinas eólicas que estão localizadas dentro do mesmo Estado possuem fator de correlação elevado. O Gráfico 42, Gráfico 43 e o Gráfico 44 ilustram a forte correlação entre o fator de capacidade das usinas eólicas Dos Índios, Sangradouro e Osório, localizadas no Estado do Rio Grande do Sul.

Gráfico 42 - Correlação entre as Usinas Eólicas Osório e Sangradouro - Estado do Rio Grande do Sul (Parâmetros adimensionais - Fator de Capacidade).

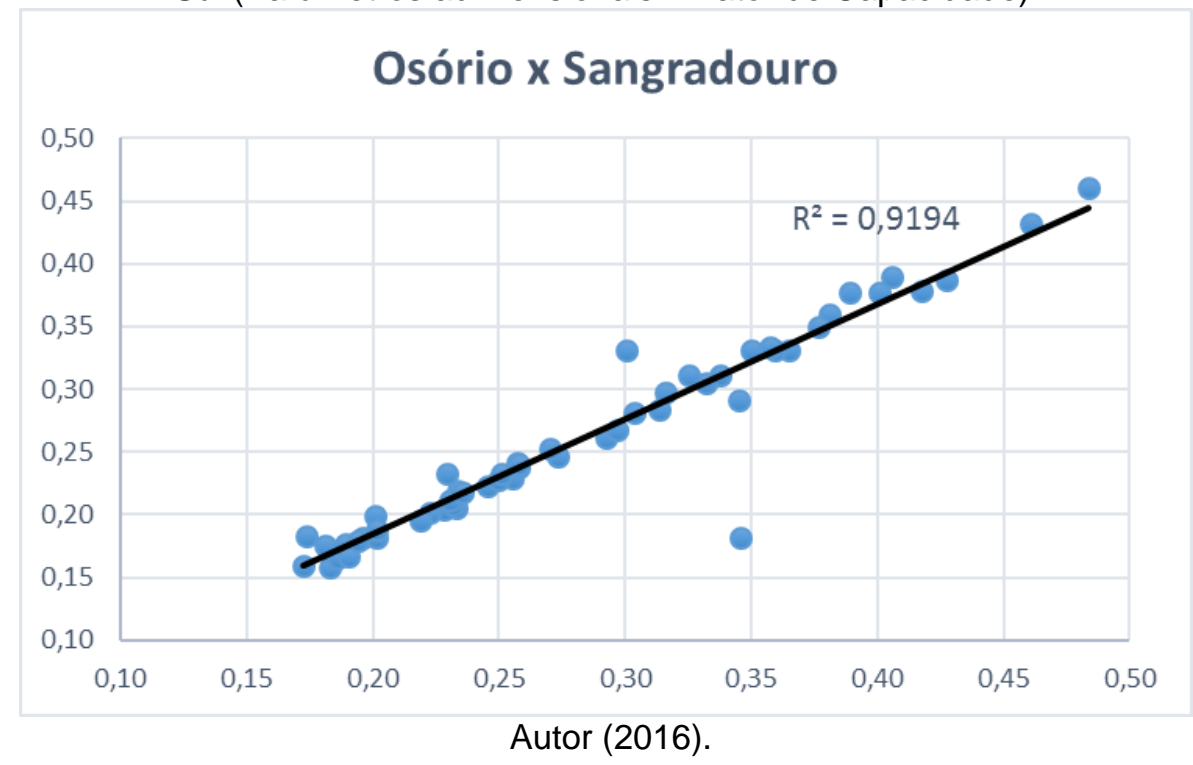

Gráfico 43 - Correlação entre as Usinas Eólicas Dos Índios e Sangradouro - Estado do Rio Grande do Sul (Parâmetros adimensionais - Fator de Capacidade).

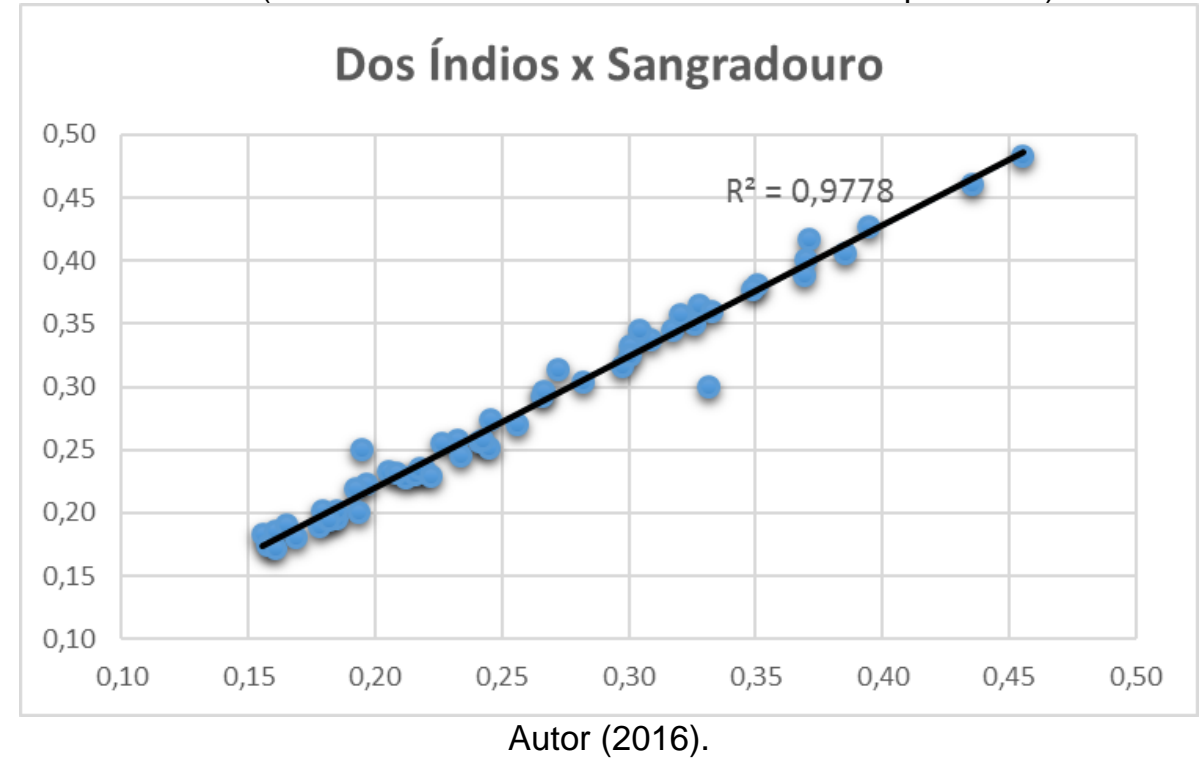

Autor (2016). 
Gráfico 44 - Correlação entre as Usinas Eólicas Dos Índios e Osório - Estado do Rio Grande do Sul (Parâmetros adimensionais - Fator de Capacidade).

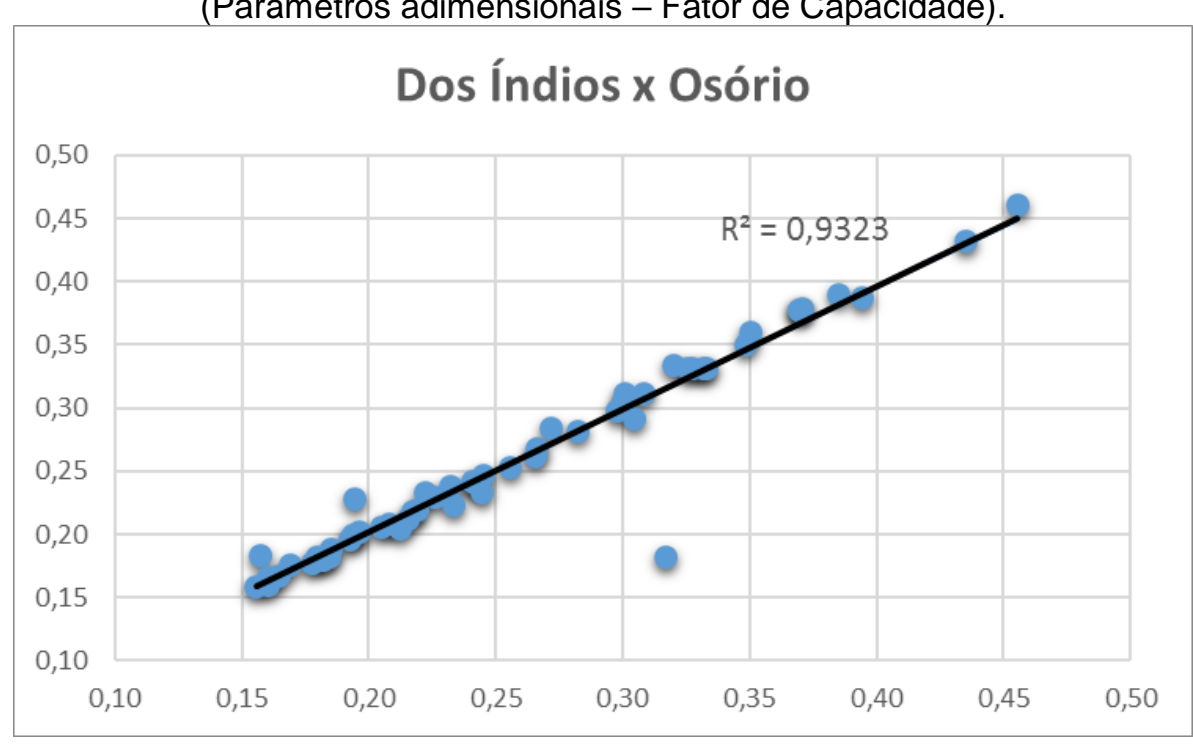

Autor (2016).

Pelo Gráfico 45 é possível observar o comportamento bem sincronizado do fator de capacidade das usinas eólicas Dos Índios, Sangradouro e Osório.

Gráfico 45 - Histórico do Fator de Capacidade das Usinas Eólicas do Estado do Rio Grande do Sul.

Fator de Capacidade - Usinas Rio Grande do Sul

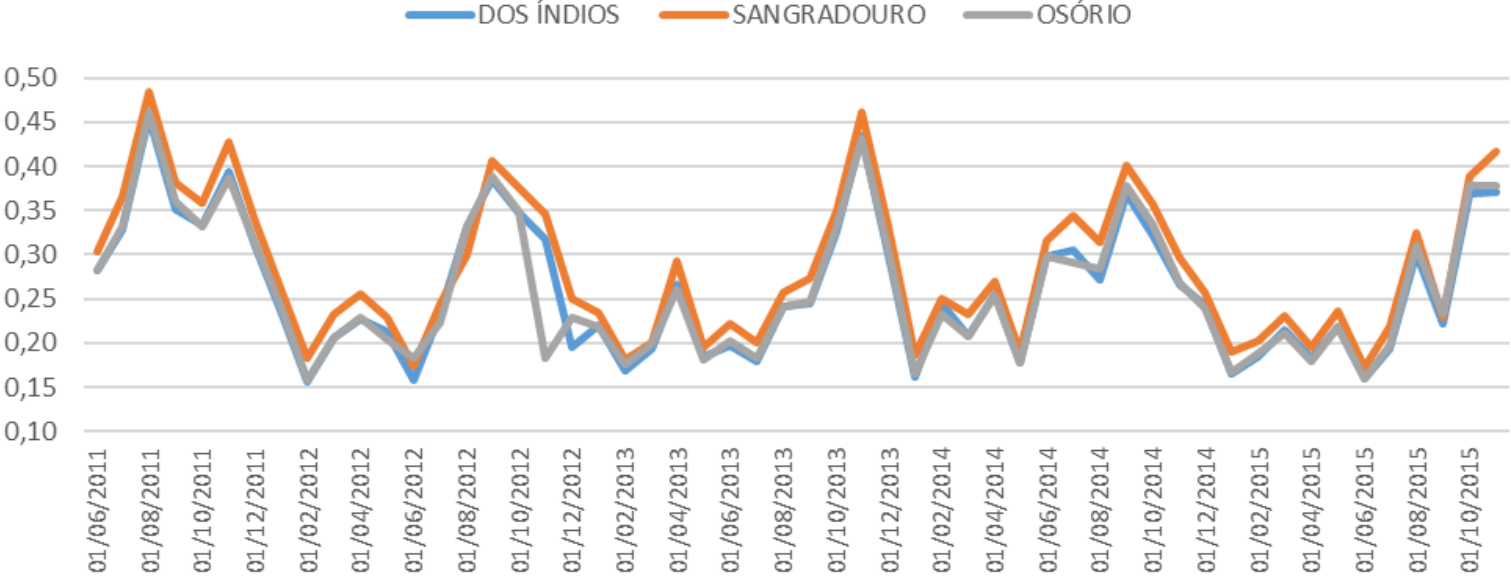

Autor (2016).

O Gráfico 46 apresenta ilustra a fraca correlação entre o fator de capacidade da usina eólica Água Doce e a usina eólica Canoa Quebrada, localizadas no Estado de Santa Catarina e Ceará, respectivamente. 
Gráfico 46 - Correlação entre a Usina Eólica Água Doce e a Usina Eólica Canoa Quebrada, localizadas no Estado de Santa Catarina e Ceará (Parâmetros adimensionais - Fator de Capacidade).

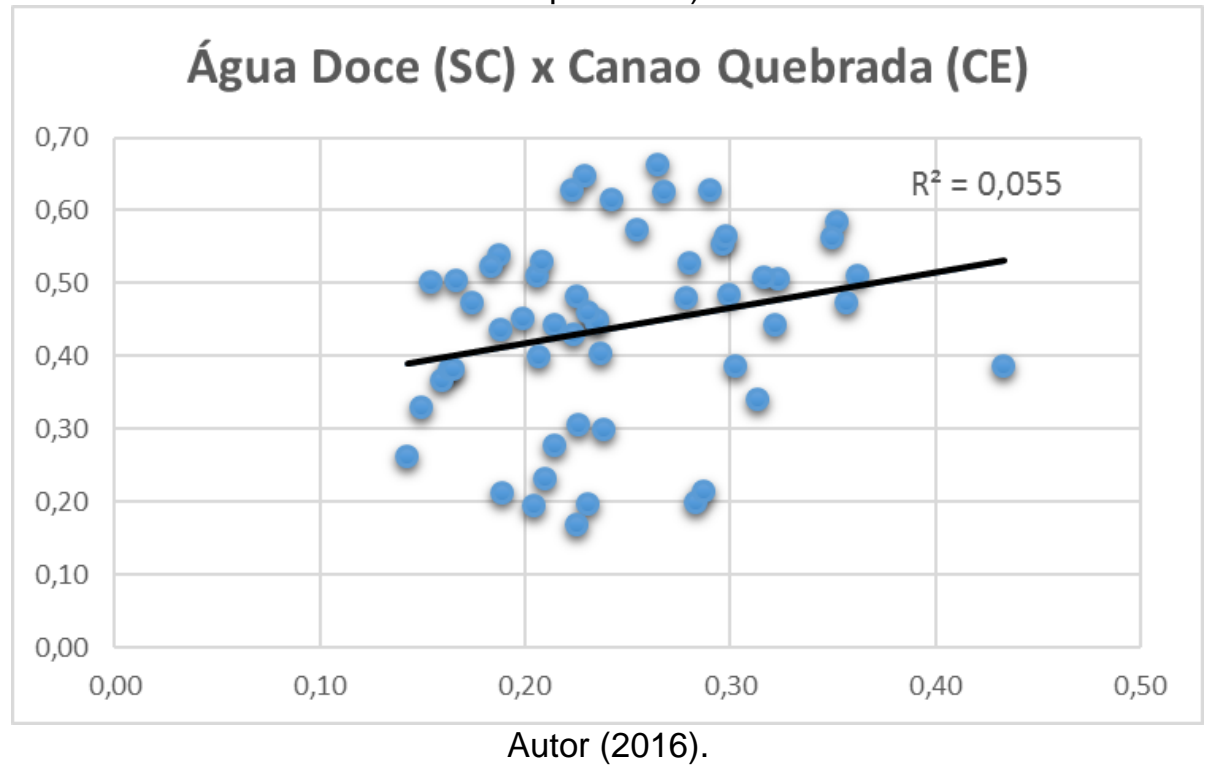

A TABELA 24 apresenta o fator de correlação do fator de capacidade de algumas usinas eólicas, com destaque para correlações superior a 0,9, na cor verde mais escura, que na maioria das vezes, corresponde àquelas usinas dentro do mesmo Estado. Esse é o caso das 3 usinas localizadas no Rio Grande do Sul, das 11 usinas do Paraíba. No Ceará, algumas usinas possuem correlação acima de 0,9, outras, contudo possuem correlação entre 0,6 a 0,9, o que ainda é bastante significativo.

TABELA 24 - Fator de Correlação do Fator de Capacidade das Usinas Eólicas.

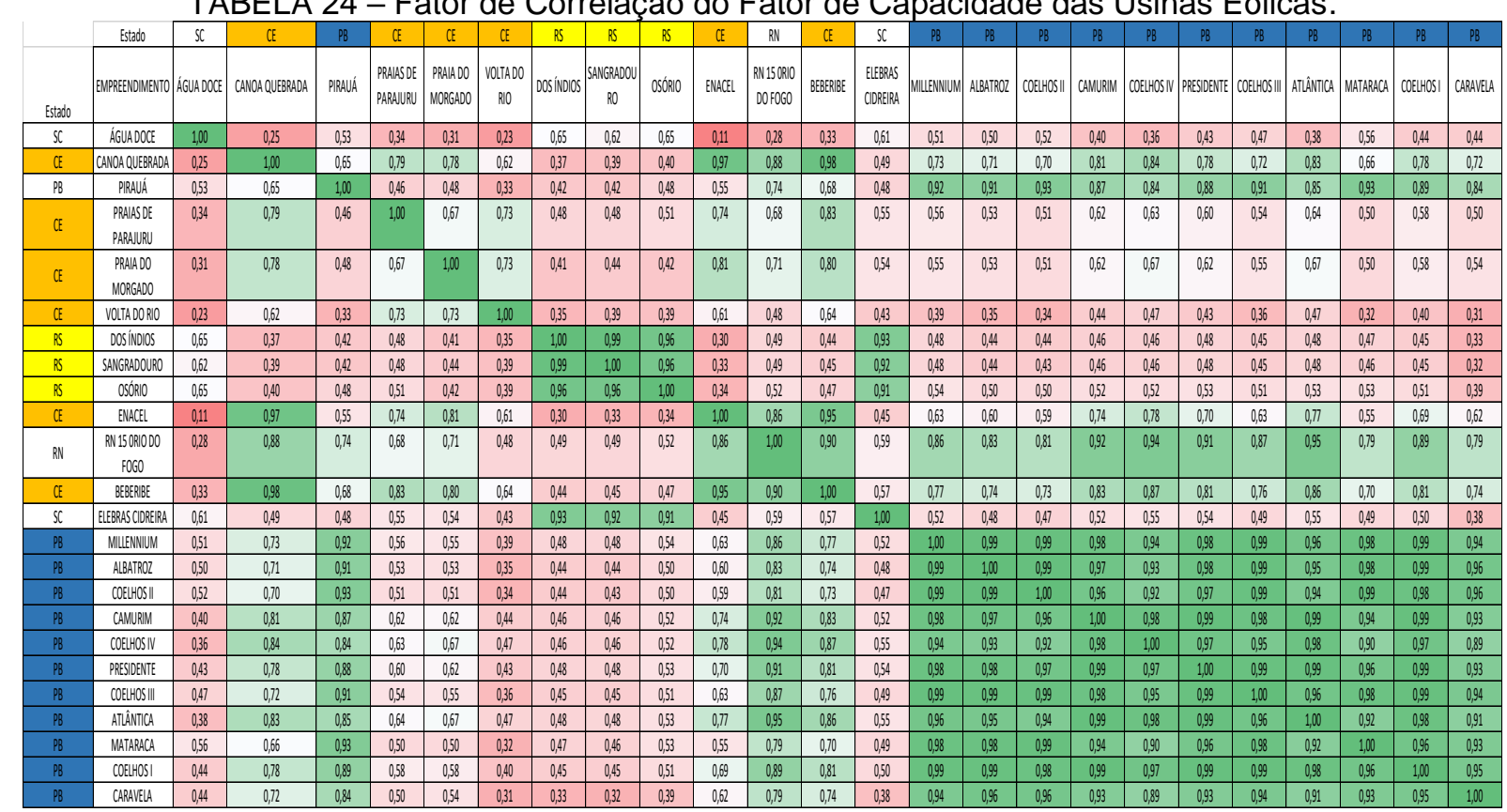

Autor (2016). 
Correlações negativas ou positivas de baixos valores produzem um resultado melhor na aplicação da teoria de portfólio de Markowitz, conforme apresentado no item 4.6.6.

Tendo sido evidenciado que as usinas localizadas dentro do mesmo Estado possuem correlação elevada, nesta otimização as usinas foram reunidas por Estado, passando a ser denominadas de usinas equivalentes. Para a aplicação da teoria de portfólio de Markowitz, foram utilizados os dados históricos do fator de capacidade das usinas equivalentes.

Para cada Estado, o somatório da energia gerada é normalizado pelo somatório da potência instalada das usinas, na medida em que tais usinas entram em operação comercial. Desta forma, a potência instalada de cada usina equivalente aumenta com a entrada em operação comercial de alguma usina individualizada, possibilitando o uso do histórico de todas as usinas individualizadas, cuja data de entrada em operação comercial esteja entre janeiro de 2009 a dezembro de 2015 ${ }^{82}$. O comportamento do fator de capacidade para cada usina eólica equivalente está apresentado no Gráfico 47 ao Gráfico 54.

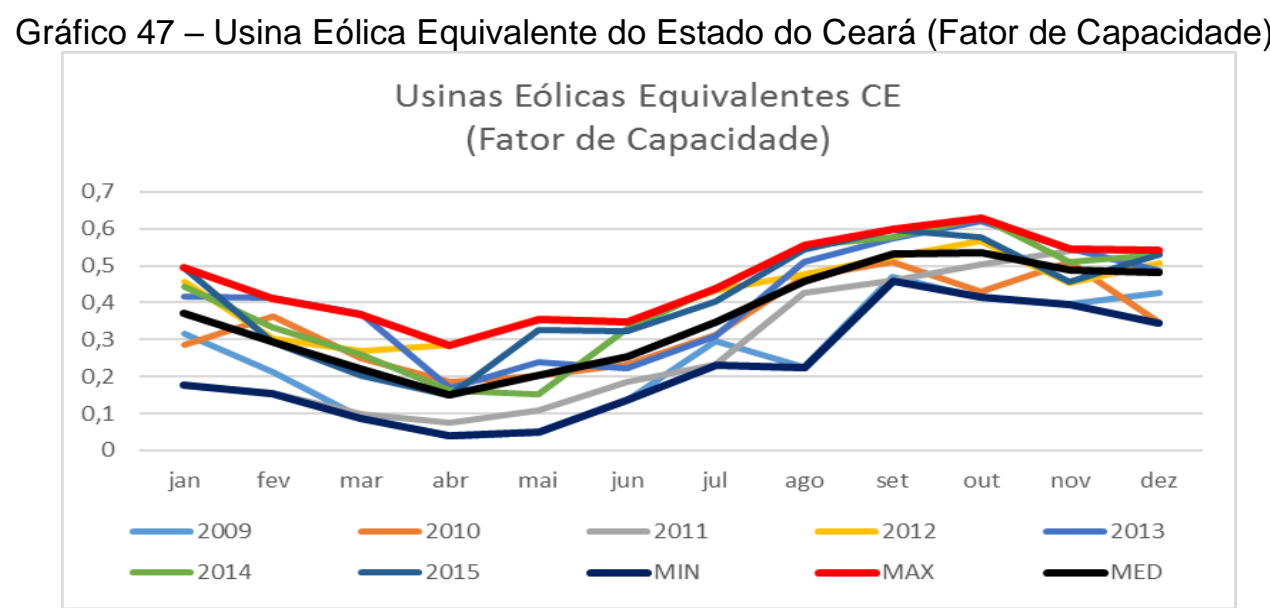

Autor (2016).

${ }^{82}$ Adotou-se que o comportamento da energia gerada para o mês de dezembro de 2015 foi igual ao mês de dezembro de 2014, ante a ausência daquele dado. 
Gráfico 48 - Usina Eólica Equivalente do Estado da Paraíba (Fator de Capacidade).

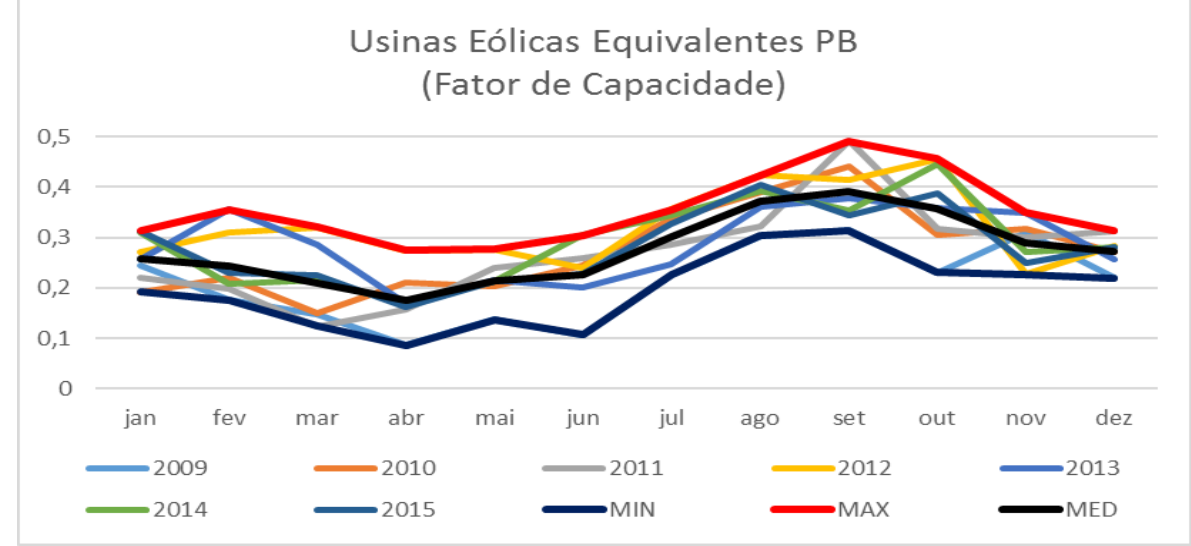

Autor (2016).

Gráfico 49 - Usina Eólica Equivalente do Estado do Piauí (Fator de Capacidade).

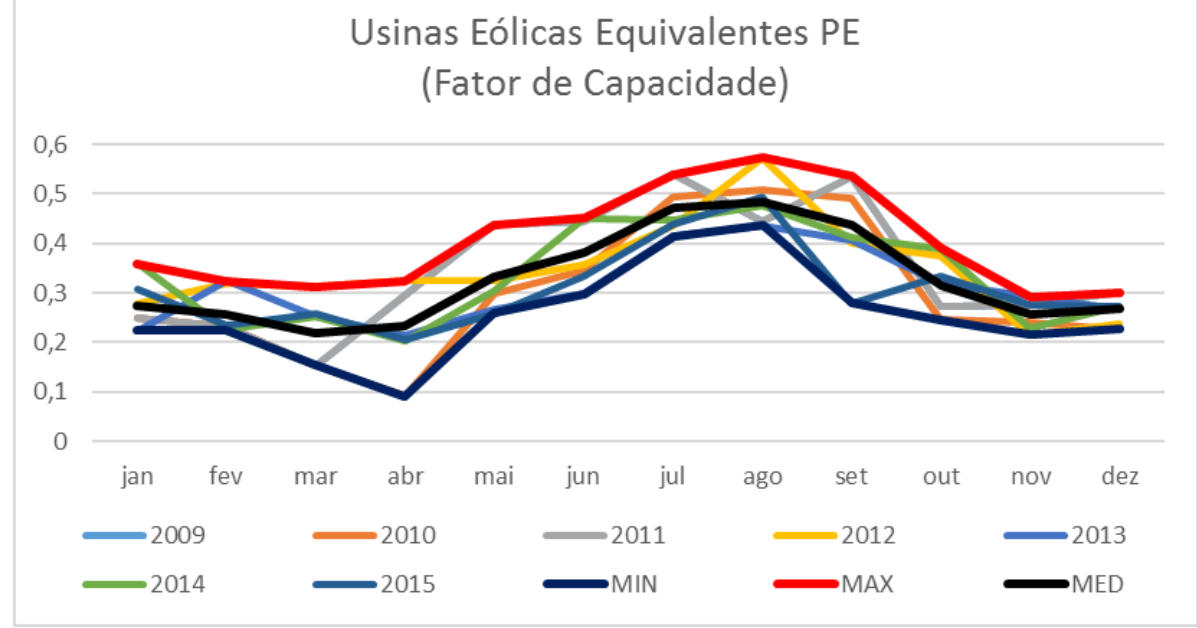

Autor (2016).

Gráfico 50 - Usina Eólica Equivalente do Estado do Rio Grande do Norte (Fator de Capacidade).

Usinas Eólicas Equivalentes PI

(Fator de Capacidade)

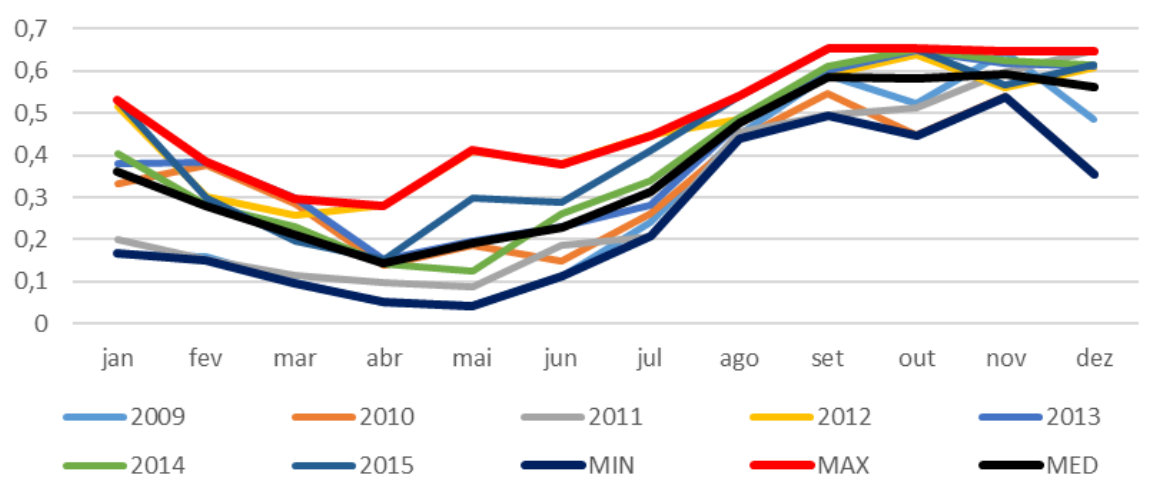

Autor (2016). 
Gráfico 51 - Usina Eólica Equivalente do Estado do Rio de Janeiro (Fator de Capacidade).

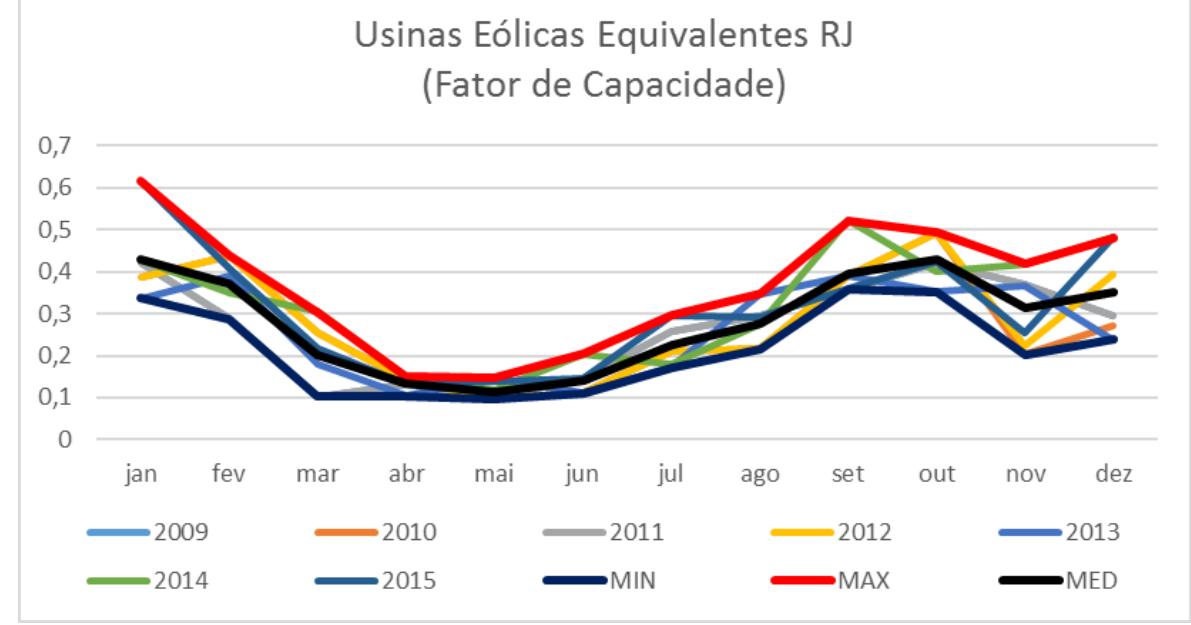

Autor (2016).

Gráfico 52 - Usina Eólica Equivalente do Estado do Rio Grande do Norte (Fator de Capacidade).

Usinas Eólicas Equivalentes RN

(Fator de Capacidade)

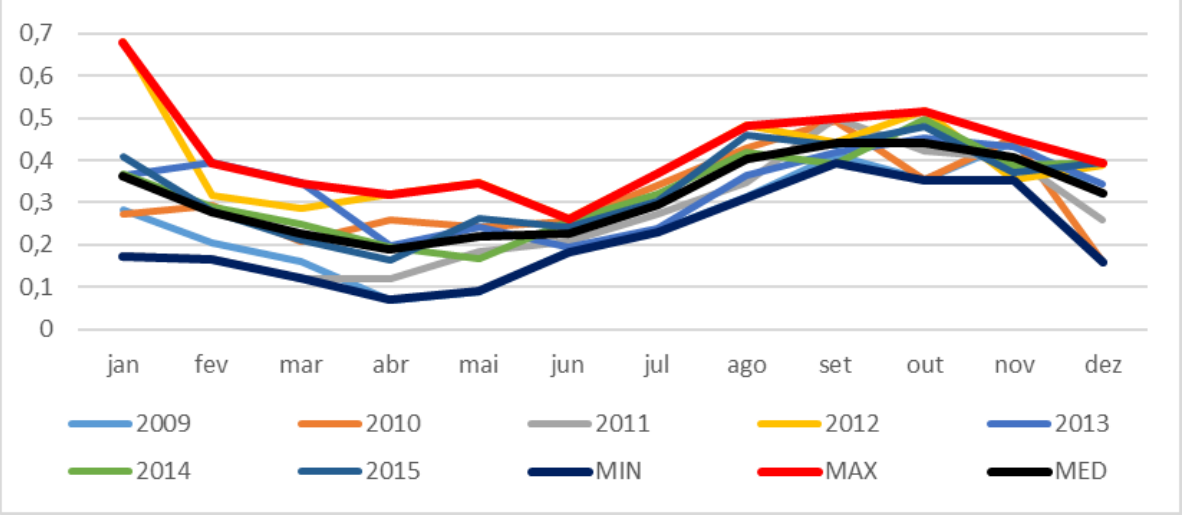

Autor (2016).

Gráfico 53- Usina Eólica Equivalente do Estado do Rio Grande do Sul (Fator de Capacidade).

Usinas Eólicas Equivalentes RS

(Fator de Capacidade)

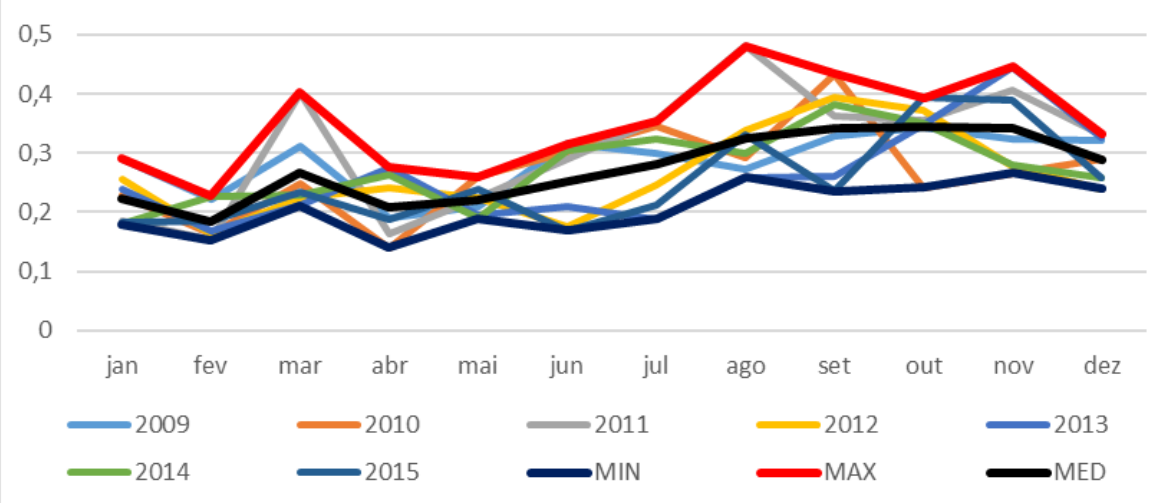

Autor (2016). 
Gráfico 54 - Usina Eólica Equivalente do Estado de Santa Catarina (Fator de Capacidade).

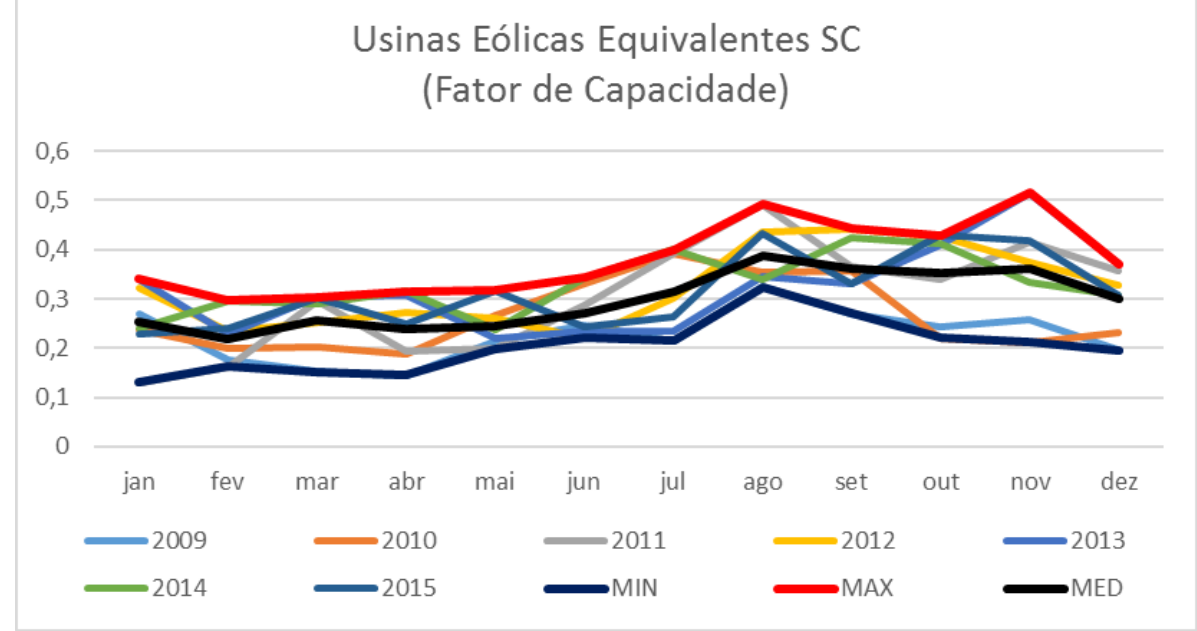

Autor (2016).

O Gráfico 55 apresenta o comportamento da média mensal do fator de capacidade para cada usina eólica equivalente, referente ao período de janeiro de 2009 a dezembro de 2015, onde pode-se observar a complementariedade entre alguns Estados.

Gráfico 55 - Usina Eólica Equivalente - Fator de Capacidade Médio.

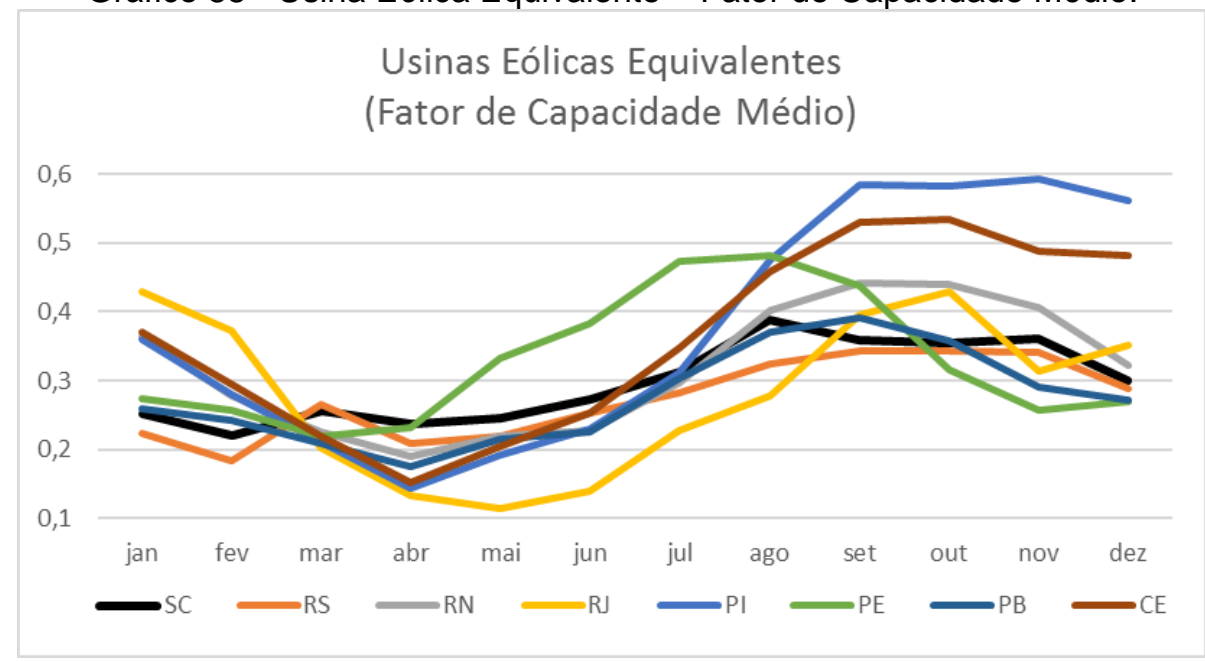

Autor (2016).

Para cada par de usinas eólicas equivalentes foi calculada a covariância do histórico do fator de capacidade, obtendo-se a matriz de covariância. A TABELA 25 resume os parâmetros de entrada do modelo (média e desvio padrão) para cada usina eólica equivalente, bem como a identificação das usinas eólicas individuais que compõem a usina eólica equivalente. 
TABELA 25 - Média e Desvio Padrão do Fator de Capacidade das Usinas Eólicas Equivalentes.

\begin{tabular}{|c|c|c|c|c|}
\hline \multirow{2}{*}{$\begin{array}{l}\text { Usina Eólica } \\
\text { Equivalente }\end{array}$} & \multirow{2}{*}{$\begin{array}{c}\text { Potência } \\
\text { (MW) }\end{array}$} & \multirow{2}{*}{ Usinas Eólicas Individuais } & \multicolumn{2}{|c|}{$\begin{array}{c}\text { Fator de } \\
\text { Capacidade }\end{array}$} \\
\hline & & & Média & $\begin{array}{l}\text { Desvio } \\
\text { Padrão }\end{array}$ \\
\hline CE & 500,53 & $\begin{array}{c}\text { Beberibe, Bons Ventos, Canoa Quebrada, Canoa Quebrada (RV), } \\
\text { Enacel, Foz Do Rio Choró, Icaraizinho, Lagoa Do Mato, Paracuru, Praia } \\
\text { Do Morgado, Praia Formosa I, Praia Formosa II, Praia Formosa III e Praia } \\
\text { Formosa IV, Praias De Parajuru, Taiba Albatroz, Volta Do Rio }\end{array}$ & 0,36 & 0,15 \\
\hline PB & 63,7 & $\begin{array}{c}\text { Albatroz, Atlântica, Camurim, Caravela, Coelhos I, Coelhos II, Coelhos III, } \\
\text { Coelhos IV, Mataraca, Millennium, Pirauá, Presidente, Vitória }\end{array}$ & 0,28 & 0,08 \\
\hline PE & 17,00 & Gravatá Fruitrade, Mandacaru, Santa Maria, Xavante & 0,27 & 0,16 \\
\hline $\mathrm{PI}$ & 17,85 & Pedra Do Sal ${ }^{83}$ & 0,37 & 0,18 \\
\hline RJ & 28,05 & Gargaú 84 & 0,21 & 0,17 \\
\hline $\mathrm{RN}$ & 100,30 & Alegria I, Alegria II, RN 15 -Rio Do Fogo & 0,31 & 0,11 \\
\hline RS & 157,56 & Osório, Sangradouro, Dos Índios, Palmares & 0,27 & 0,08 \\
\hline SC & 79,00 & Água Doce, Elebras Cidereira & 0,30 & 0,08 \\
\hline $\begin{array}{l}\text { Carteira Atual } \\
\text { PROINFA }\end{array}$ & 963,99 & Todas & 0,32 & 0,10 \\
\hline
\end{tabular}

Fonte: BRASIL. Eletrobrás (2016).

A partir dos parâmetros estatísticos (desvio padrão e matriz de covariância), foram obtidas dez carteiras otimizadas (item 4.6.7) e ajustada a curva da fronteira eficiente, por meio da aplicação da teoria de portfólio de Markowitz (Equação (51)). A fronteira eficiente e as carteiras individualizadas estão representadas no Gráfico 56.

Gráfico 56 - Fronteira Eficiente e Carteira Atual para as Usinas Eólicas Equivalentes do PROINFA (Parâmetros adimensionais - Fator de Capacidade).

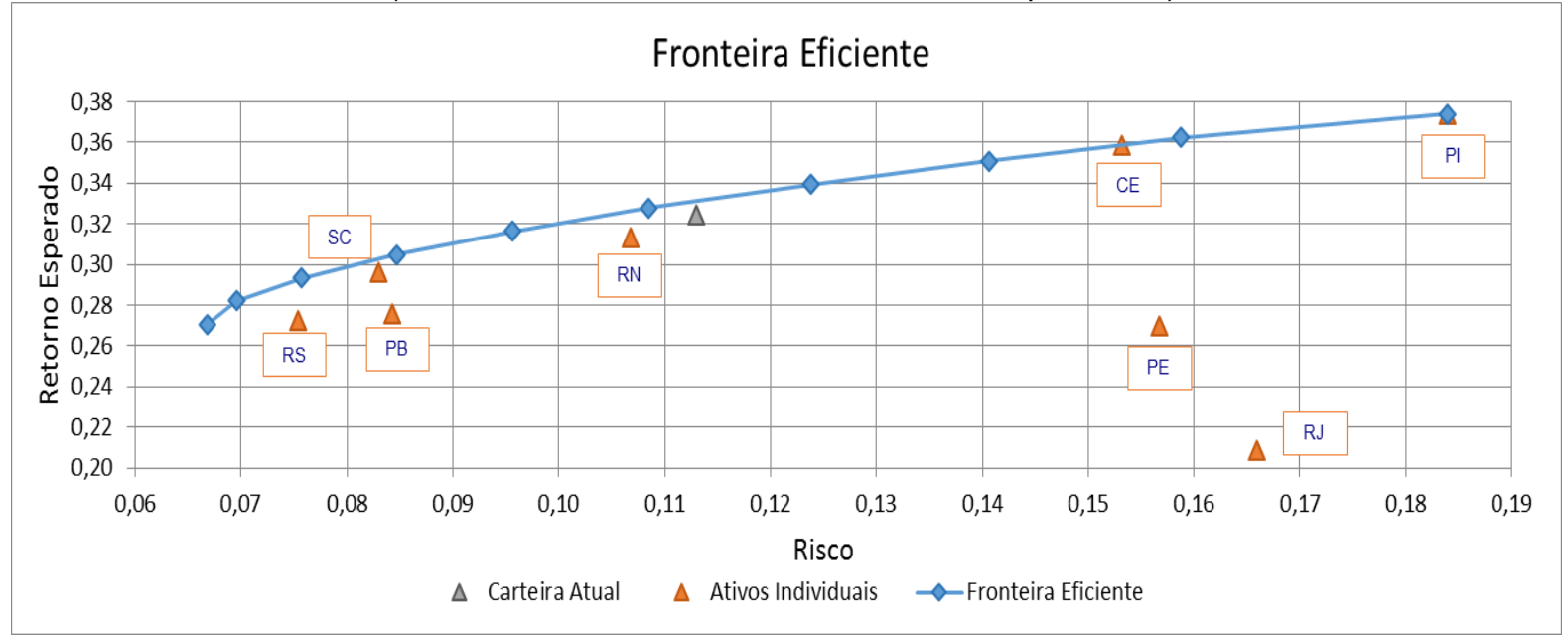

Autor (2016).

${ }^{83}$ Ante a ausência de histórico de energia gerada desde janeiro de 2009, os dados faltantes da usina equivalente do Estado do Piauí foram preenchidos com os dados do mesmo mês a partir do ano em que a usina entrou em operação comercial. Esse artifício foi necessário, na medida em que nesse Estado existe apenas uma usina eólica do PROINFA.

${ }^{84}$ Para a usina equivalente do Estado do Rio de Janeiro adotou-se o mesmo procedimento usado para a usina equivalente do Estado do Piauí. 
As carteiras individuais (usinas equivalentes) estão representadas pelos pontos de cor laranja (triângulo), enquanto as carteiras otimizadas, que estão sobre a curva da fronteira eficiente, estão ilustradas pelos pontos em cor azul. A carteira atual PROINFA está identificada pela cor cinza.

Conforme se evidencionou na TABELA 24, o fator de correlação do fator de capacidade de algumas usinas eólicas dentro do mesmo Estado nem sempre possuem valores acima de 0,9 . No Ceará, algumas usinas possuem correlação acima de 0,9 , outras, contudo possuem correlação entre 0,6 a 0,9 , o que afetou o resultado na composição de algumas usinas equivalentes, na medida em que as volatidades individuais foram compensadas, resultando em uma usina com característica diversa das suas usinas individuais. Em decorrência, ao contrário do que se observou no item 5.1.2, a carteira atual ficou próxima da fronteira eficiente.

Apenas a usina equivalente do Estado de Pernambuco não foi selecionada para compor as 10 carteiras otimizadas. A carteira de risco mínimo (desvio padrão de 0,0668 e média igual a 0,2705 ) é composta por usinas com $61 \%$ de potência instalada no Rio Grande do Sul, 34\% na Paraíba e 5\% no Rio de Janeiro.

\subsubsection{Otimização 04 - Todas as Usinas Individualizadas do PROINFA - Fator de Capacidade}

Nesta otimização, para a aplicação da teoria de portfólio de Markowitz, foram utilizados os dados históricos do fator de capacidade das usinas do PROINFA (fonte eólica, pequenas centrais e biomassa). Foram consideradas apenas as usinas que entraram em operação comercial até julho de 2011. O histórico do fator de capacidade de junho de 2011 a novembro de 2015, totalizando 53 meses, é apresentado no Gráfico 57. Ao total, a amostra compreende 104 usinas, das quais, 39 são PCHs, 20 são usinas termoelétricas à biomassa, e por fim, 45 são usinas eólicas (TABELA 18). 
Gráfico 57 - Histórico do Fator de Capacidade das Usinas do PROINFA.

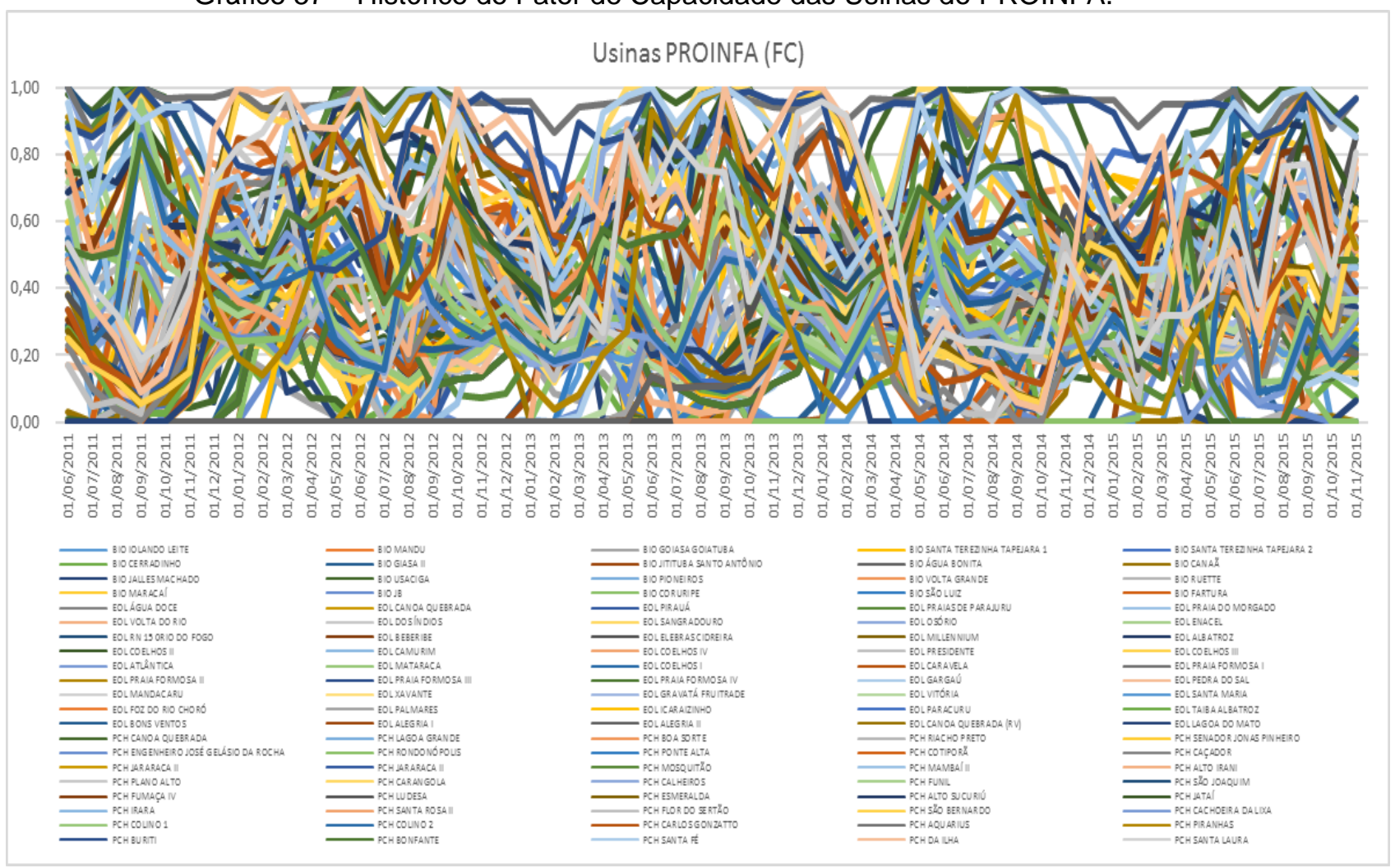

Autor (2016).

Neste caso, pretende-se investigar o impacto da diversificação das fontes e da região geográfica dos empreendimentos do PROINFA. A TABELA 26 resume os parâmetros de média e desvio padrão de cada usina.

A partir dos parâmetros estatísticos (média e matriz de covariância) foram obtidas as carteiras otimizadas (item 4.6.7) e ajustada a curva da fronteira eficiente, por meio da aplicação da teoria de portfólio de Markowitz (Equação(51)), primeiramente para as usinas agrupadas por fonte e, por último, considerando todas as usinas.

A fronteira eficiente e as carteiras individualizadas para as usinas eólicas estão representadas no Gráfico 58. A fronteira eficiente e as carteiras individualizadas para as usinas termoelétricas biomassa estão representadas no Gráfico 59.

A fronteira eficiente e as carteiras individualizadas para as usinas PCHs estão representadas no Gráfico 60. Por fim, o Gráfico 61 ilustra a fronteira eficiente considerando todas as usinas do PROINFA e as fronteiras considerando as usinas eólicas, UTEs biomassa e as PCHs. 
TABELA 26 - Média e Desvio Padrão do Fator de Capacidade das Usinas do PROINFA.

\begin{tabular}{|c|c|c|c|c|c|}
\hline \multirow[b]{2}{*}{ Usina } & \multirow[b]{2}{*}{ Fonte } & \multirow[b]{2}{*}{ Estado } & \multirow{2}{*}{$\begin{array}{c}\text { Potencia } \\
\text { (MW) }\end{array}$} & \multicolumn{2}{|c|}{ Fator de Capacidade } \\
\hline & & & & Média & $\begin{array}{l}\text { Desvio } \\
\text { Padrão }\end{array}$ \\
\hline Iolando Leite & Biomassa & SE & 5,00 & 0,26 & 0,27 \\
\hline Mandu & Biomassa & SP & 20,20 & 0,28 & 0,24 \\
\hline Goiasa Goiatuba & Biomassa & GO & 42,52 & 0,20 & 0,14 \\
\hline Santa Terezinha Tapejara 1 & Biomassa & PR & 27,54 & 0,43 & 0,26 \\
\hline Santa Terezinha Tapejara 2 & Biomassa & PR & 20,56 & 0,24 & 0,15 \\
\hline Cerradinho & Biomassa & SP & 50,00 & 0,10 & 0,08 \\
\hline Giasa II & Biomassa & PB & 20,00 & 0,20 & 0,18 \\
\hline Jitituba Santo Antônio & Biomassa & $\mathrm{AL}$ & 15,00 & 0,37 & 0,30 \\
\hline Água Bonita & Biomassa & SP & 15,80 & 0,34 & 0,22 \\
\hline Canaã & Biomassa & SP & 30,00 & 0,11 & 0,20 \\
\hline Jalles Machado & Biomassa & GO & 12,00 & 0,13 & 0,17 \\
\hline Usaciga & Biomassa & PR & 40,00 & 0,23 & 0,16 \\
\hline Pioneiros & Biomassa & SP & 28,40 & 0,27 & 0,24 \\
\hline Volta Grande & Biomassa & MG & 30,00 & 0,38 & 0,29 \\
\hline Ruette & Biomassa & SP & 24,40 & 0,21 & 0,14 \\
\hline Maracaí & Biomassa & SP & 36,82 & 0,30 & 0,22 \\
\hline JB & Biomassa & PE & 33,20 & 0,09 & 0,09 \\
\hline Coruripe & Biomassa & $\mathrm{AL}$ & 16,00 & 0,26 & 0,27 \\
\hline São Luiz & Biomassa & SP & 36,00 & 0,19 & 0,13 \\
\hline Fartura & Biomassa & SP & 29,90 & 0,32 & 0,22 \\
\hline Água Doce & Eólica & SC & 9,00 & 0,24 & 0,06 \\
\hline Canoa Quebrada & Eólica & CE & 57,00 & 0,44 & 0,13 \\
\hline Pirauá & Eólica & PB & 4,25 & 0,42 & 0,08 \\
\hline Praias De Parajuru & Eólica & CE & 28,80 & 0,34 & 0,11 \\
\hline Praia Do Morgado & Eólica & CE & 28,80 & 0,40 & 0,16 \\
\hline Volta Do Rio & Eólica & CE & 42,00 & 0,40 & 0,19 \\
\hline Dos Índios & Eólica & RS & 50,00 & 0,26 & 0,08 \\
\hline Sangradouro & Eólica & RS & 50,00 & 0,28 & 0,08 \\
\hline Osório & Eólica & RS & 50,00 & 0,26 & 0,08 \\
\hline Enacel & Eólica & CE & 31,50 & 0,41 & 0,12 \\
\hline RN 15 Orio Do Fogo & Eólica & $\mathrm{RN}$ & 49,30 & 0,34 & 0,09 \\
\hline Beberibe & Eólica & CE & 25,20 & 0,39 & 0,12 \\
\hline Elebras Cidreira & Eólica & SC & 70,00 & 0,34 & 0,08 \\
\hline Millennium & Eólica & PB & 10,20 & 0,33 & 0,08 \\
\hline Albatroz & Eólica & PB & 4,50 & 0,30 & 0,09 \\
\hline Coelhos II & Eólica & PB & 4,50 & 0,34 & 0,09 \\
\hline Camurim & Eólica & PB & 4,50 & 0,32 & 0,08 \\
\hline Coelhos IV & Eólica & PB & 4,50 & 0,28 & 0,07 \\
\hline Presidente & Eólica & PB & 4,50 & 0,22 & 0,06 \\
\hline Coelhos III & Eólica & PB & 4,50 & 0,22 & 0,06 \\
\hline Atlântica & Eólica & PB & 4,50 & 0,31 & 0,08 \\
\hline Mataraca & Eólica & PB & 4,50 & 0,23 & 0,06 \\
\hline Coelhos I & Eólica & PB & 4,50 & 0,31 & 0,08 \\
\hline Caravela & Eólica & PB & 4,50 & 0,29 & 0,09 \\
\hline Praia Formosa I & Eólica & CE & 6,60 & 0,33 & 0,13 \\
\hline Praia Formosa II & Eólica & $\mathrm{CE}$ & 5,40 & 0,33 & 0,13 \\
\hline Praia Formosa IIII & Eólica & CE & 13,80 & 0,33 & 0,13 \\
\hline Praia Formosa IV & Eólica & CE & 78,60 & 0,33 & 0,13 \\
\hline Gargaú & Eólica & RJ & 28,05 & 0,29 & 0,13 \\
\hline Pedra Do Sal & Eólica & $\mathrm{PI}$ & 17,85 & 0,42 & 0,17 \\
\hline Mandacaru & Eólica & PE & 4,25 & 0,36 & 0,09 \\
\hline Xavante & Eólica & PE & 4,25 & 0,29 & 0,09 \\
\hline Gravatá Fruitrade & Eólica & PE & 4,25 & 0,41 & 0,10 \\
\hline Vitória & Eólica & PB & 4,25 & 0,29 & 0,08 \\
\hline Santa Maria & Eólica & PE & 4,25 & 0,29 & 0,09 \\
\hline Foz Do Rio Choró & Eólica & $\mathrm{CE}$ & 25,20 & 0,38 & 0,12 \\
\hline Palmares & Eólica & RS & 7,56 & 0,41 & 0,10 \\
\hline Icaraizinho & Eólica & CE & 54,00 & 0,50 & 0,18 \\
\hline Paracuru & Eólica & CE & 23,40 & 0,55 & 0,19 \\
\hline Taiba Albatroz & Eólica & CE & 16,50 & 0,43 & 0,18 \\
\hline Bons Ventos & Eólica & $\mathrm{CE}$ & 50,00 & 0,42 & 0,13 \\
\hline Alegria I & Eólica & $\mathrm{RN}$ & 19,92 & 0,33 & 0,11 \\
\hline Alegria II & Eólica & RN & 31,08 & 0,33 & 0,11 \\
\hline Canoa Quebrada (RV) & Eólica & CE & 10,50 & 0,47 & 0,13 \\
\hline Lagoa do Mato & Eólica & $\mathrm{CE}$ & 3,23 & 0,55 & 0,14 \\
\hline Canoa Quebrada & $\mathrm{PCH}$ & MT & 28,00 & 0,15 & 0,86 \\
\hline
\end{tabular}




\begin{tabular}{|c|c|c|c|c|c|}
\hline \multirow[b]{2}{*}{ Usina } & \multirow[b]{2}{*}{ Fonte } & \multirow[b]{2}{*}{ Estado } & \multirow[b]{2}{*}{$\begin{array}{l}\text { Potencia } \\
\text { (MW) }\end{array}$} & \multicolumn{2}{|c|}{ Fator de Capacidade } \\
\hline & & & & Média & $\begin{array}{l}\text { Desvio } \\
\text { Padrão }\end{array}$ \\
\hline Lagoa Grande & $\mathrm{PCH}$ & TO & 21,50 & 0,11 & 0,59 \\
\hline Boa Sorte & $\mathrm{PCH}$ & TO & 16,00 & 0,09 & 0,48 \\
\hline Riacho Preto & $\mathrm{PCH}$ & TO & 9,30 & 0,06 & 0,34 \\
\hline Senador Jonas Pinheiro & $\mathrm{PCH}$ & MT & 5,94 & 0,18 & 0,54 \\
\hline $\begin{array}{c}\text { Engenheiro José Gelásio Da } \\
\text { Rocha }\end{array}$ & $\mathrm{PCH}$ & MT & 23,70 & 0,15 & 0,38 \\
\hline Rondonópolis & $\mathrm{PCH}$ & MT & 26,60 & 0,15 & 0,38 \\
\hline Ponte Alta & $\mathrm{PCH}$ & MS & 13,00 & 0,09 & 0,44 \\
\hline Cotiporã & $\mathrm{PCH}$ & RS & 19,50 & 0,25 & 0,45 \\
\hline Caçador & $\mathrm{PCH}$ & RS & 22,50 & 0,24 & 0,44 \\
\hline Jararaca & $\mathrm{PCH}$ & RS & 27,30 & 0,27 & 0,63 \\
\hline Mosquitão & $\mathrm{PCH}$ & $\mathrm{GO}$ & 30,00 & 0,34 & 0,32 \\
\hline Mambaí II & $\mathrm{PCH}$ & GO & 12,00 & 0,18 & 0,57 \\
\hline Alto Irani & $\mathrm{PCH}$ & SC & 21,00 & 0,27 & 0,49 \\
\hline Plano Alto & $\mathrm{PCH}$ & SC & 16,00 & 0,26 & 0,49 \\
\hline Carangola & $\mathrm{PCH}$ & MG & 15,00 & 0,29 & 0,47 \\
\hline Calheiros & $\mathrm{PCH}$ & RJ & 19,00 & 0,24 & 0,40 \\
\hline Funil & $\mathrm{PCH}$ & MG & 22,50 & 0,23 & 0,37 \\
\hline São Joaquim & $\mathrm{PCH}$ & ES & 21,00 & 0,20 & 0,48 \\
\hline Fumaça IV & $\mathrm{PCH}$ & $\mathrm{ES}$ & 4,50 & 0,21 & 0,40 \\
\hline Ludesa & $\mathrm{PCH}$ & $\mathrm{SC}$ & 26,20 & 0,21 & 0,59 \\
\hline Esmeralda & $\mathrm{PCH}$ & RS & 22,20 & 0,24 & 0,55 \\
\hline Alto Sucuriú & $\mathrm{PCH}$ & MS & 29,00 & 0,12 & 0,65 \\
\hline Jataí & $\mathrm{PCH}$ & $\mathrm{GO}$ & 30,00 & 0,22 & 0,56 \\
\hline Irara & $\mathrm{PCH}$ & $\mathrm{GO}$ & 30,00 & 0,18 & 0,47 \\
\hline Santa Rosa II & $\mathrm{PCH}$ & RJ & 30,00 & 0,23 & 0,45 \\
\hline Flor Do Sertão & $\mathrm{PCH}$ & $\mathrm{SC}$ & 16,50 & 0,20 & 0,39 \\
\hline São Bernardo & $\mathrm{PCH}$ & RS & 15,00 & 0,24 & 0,53 \\
\hline Cachoeira Da Lixa & $\mathrm{PCH}$ & BA & 14,80 & 0,14 & 0,32 \\
\hline Colino 1 & $\mathrm{PCH}$ & BA & 11,00 & 0,17 & 0,32 \\
\hline Colino 2 & $\mathrm{PCH}$ & $\mathrm{BA}$ & 16,00 & 0,15 & 0,25 \\
\hline Carlos Gonzatto & $\mathrm{PCH}$ & RS & 9,00 & 0,21 & 0,56 \\
\hline Aquarius & $\mathrm{PCH}$ & MS & 4,20 & 0,06 & 0,94 \\
\hline Piranhas & $\mathrm{PCH}$ & GO & 18,00 & 0,33 & 0,43 \\
\hline Buriti & $\mathrm{PCH}$ & MS & 30,00 & 0,07 & 0,89 \\
\hline Bonfante & $\mathrm{PCH}$ & MG & 19,00 & 0,20 & 0,39 \\
\hline Santa Fé & $\mathrm{PCH}$ & RJ & 30,00 & 0,22 & 0,66 \\
\hline Da Ilha & $\mathrm{PCH}$ & RS & 26,00 & 0,28 & 0,68 \\
\hline Santa Laura & $\mathrm{PCH}$ & SC & 15,00 & 0,24 & 0,56 \\
\hline Carteira Atual (PROINFA) & & & $2.263,57$ & 0,38 & 0,05 \\
\hline
\end{tabular}

Autor (2016).

Fonte: BRASIL. Eletrobrás (2016).

Gráfico 58 - Fronteira Eficiente e Carteira Atual para as Usinas Eólicas do PROINFA (Parâmetros adimensionais - Fator de Capacidade).

Fronteira Eficiente - Usinas Eólicas

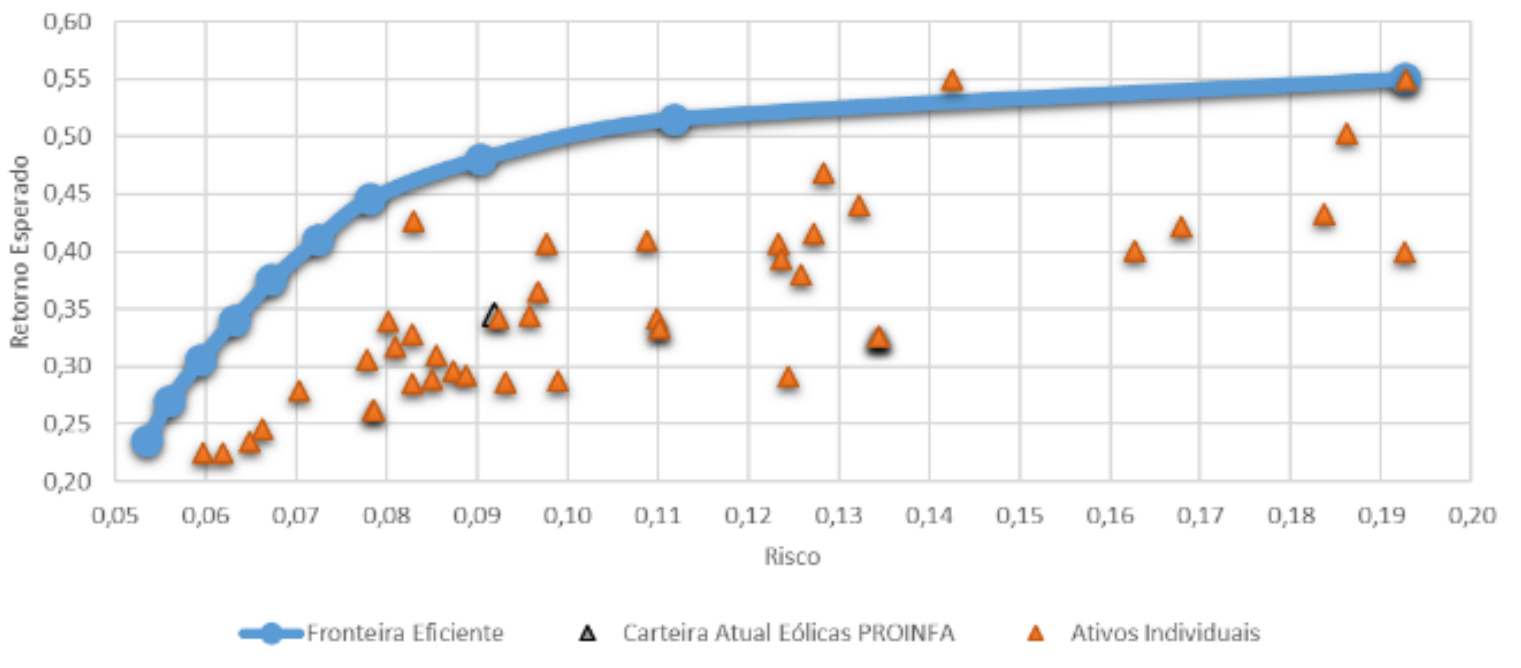

Autor (2016). 
Gráfico 59 - Fronteira Eficiente e Carteira Atual para as UTEs Biomassa do PROINFA (Parâmetros adimensionais - Fator de Capacidade).

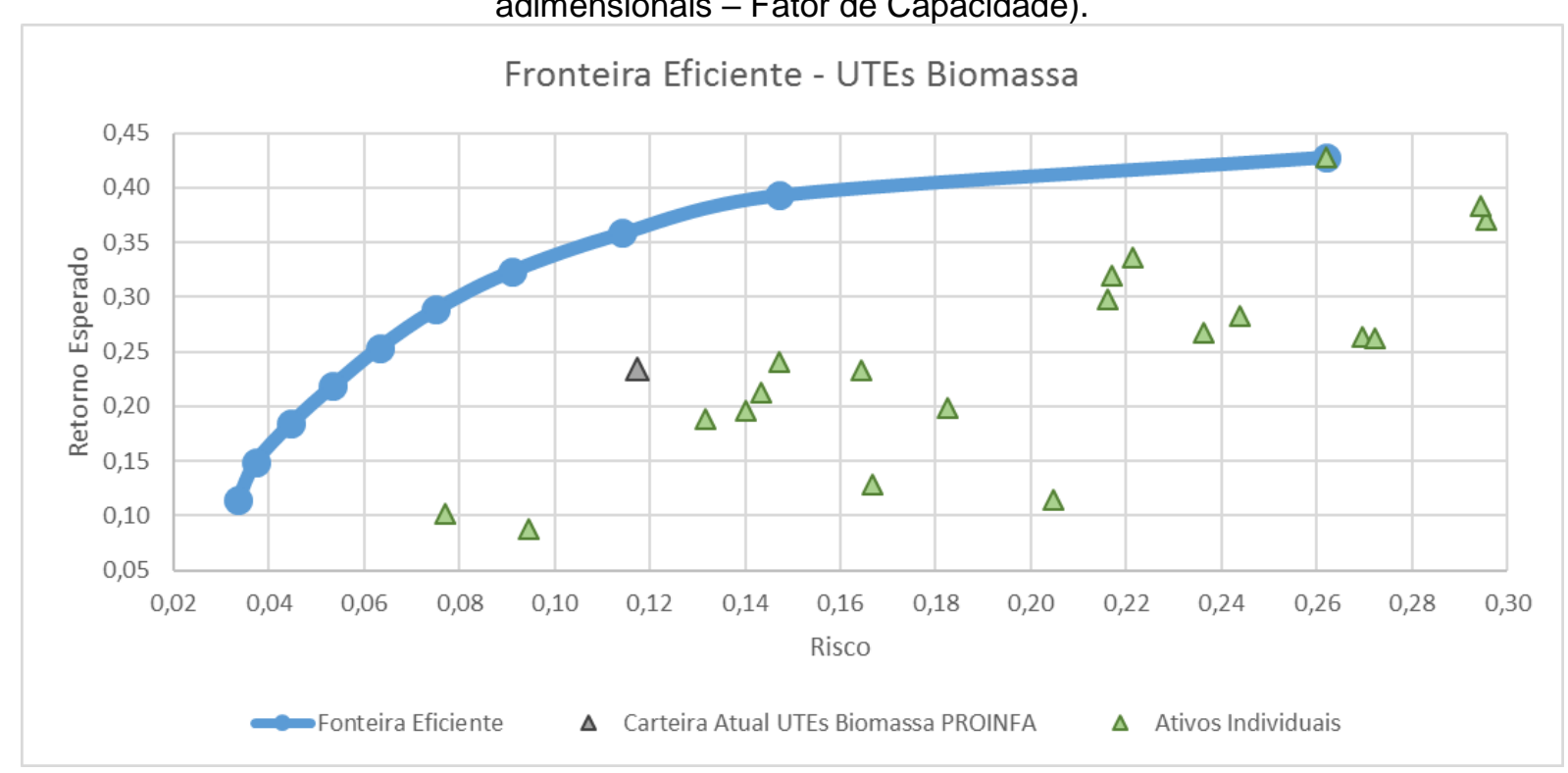

Autor (2016)

Gráfico 60 - Fronteira Eficiente e Carteira Atual para as PCHs do PROINFA (Parâmetros adimensionais - Fator de Capacidade).

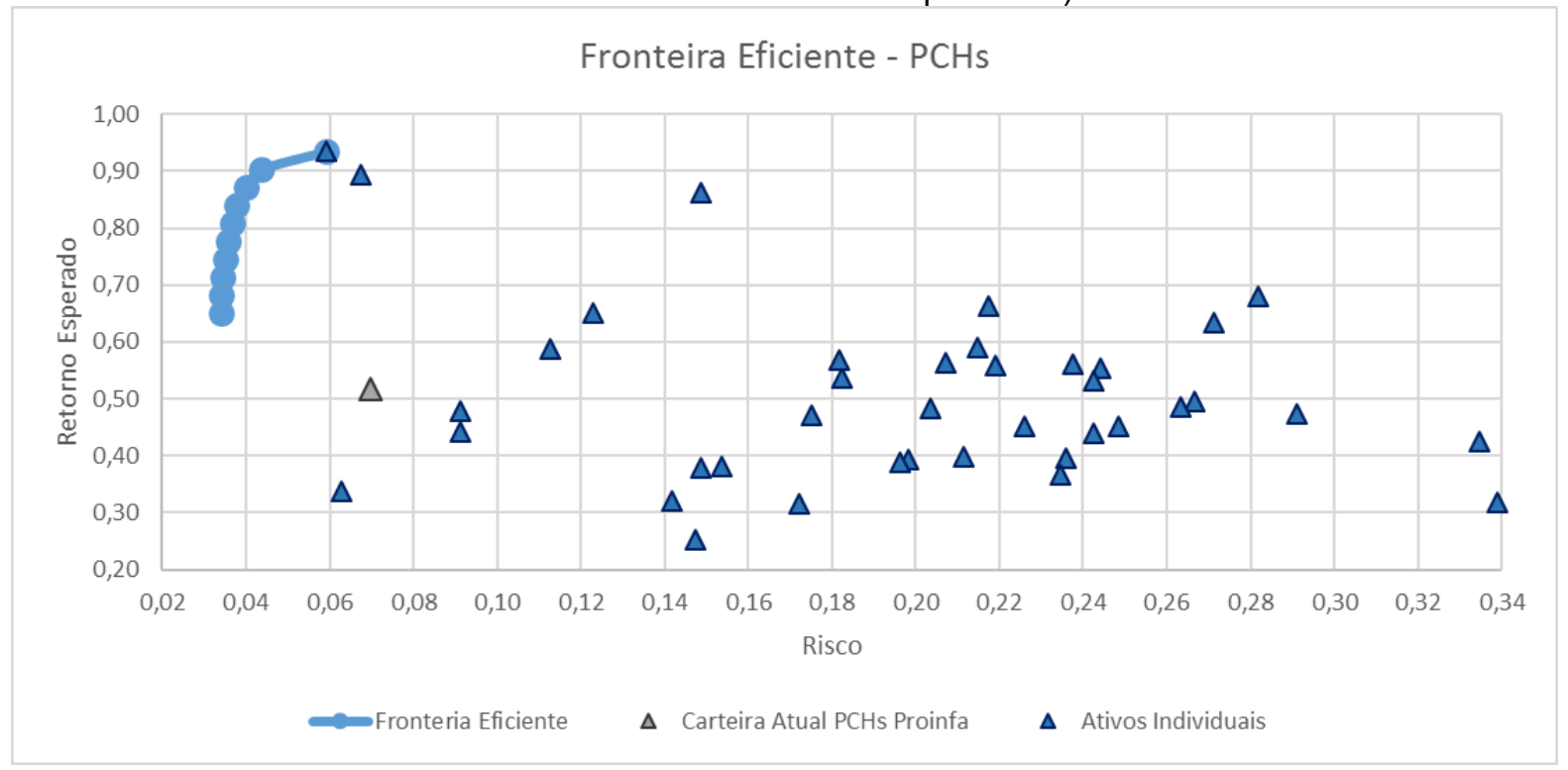

Autor (2016) 
Gráfico 61 - Fronteira Eficiente e Carteira Atual para as Usinas do PROINFA (Parâmetros adimensionais - Fator de Capacidade).

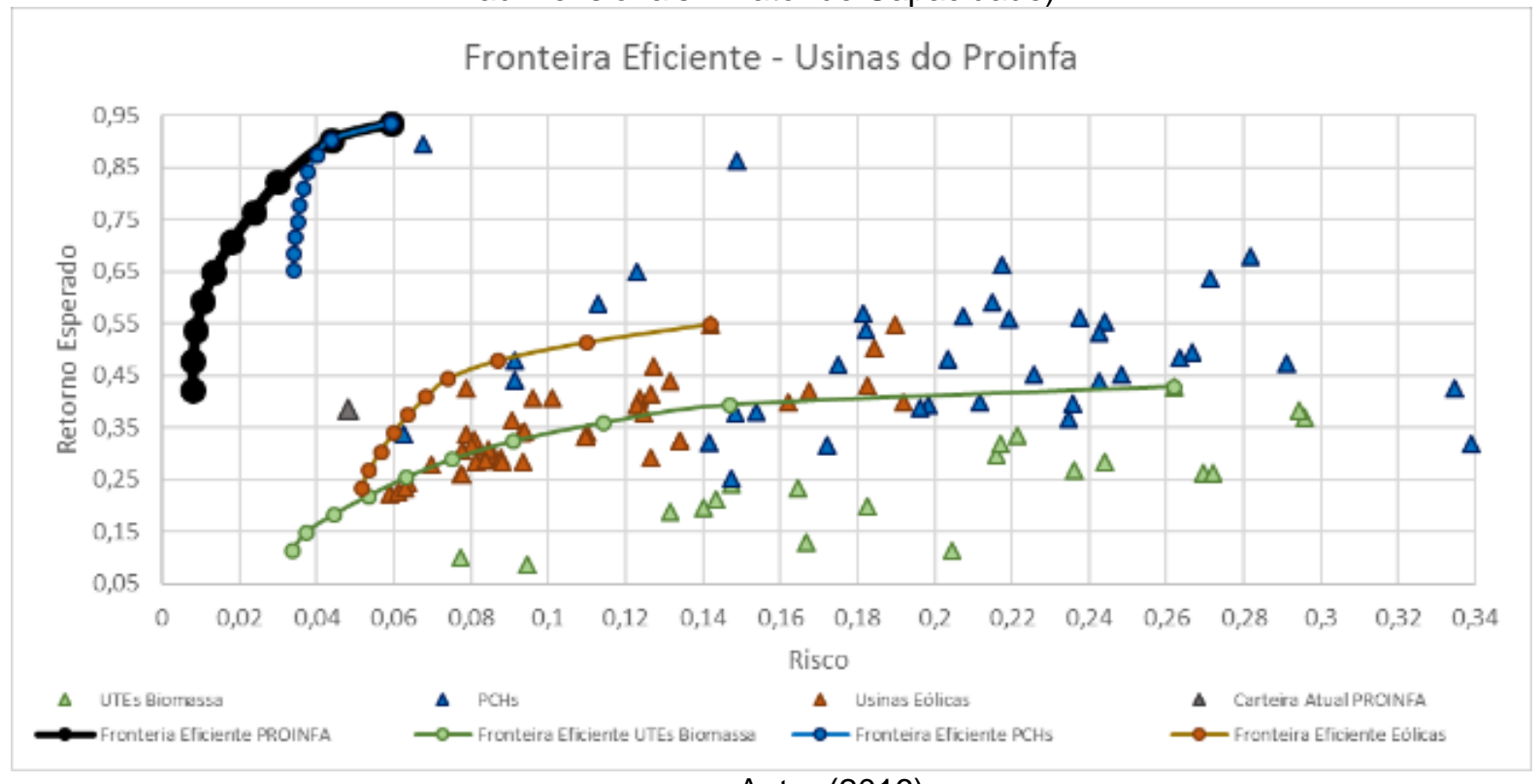

Autor (2016)

As carteiras individuais estão representadas pelos pontos (triângulos) de cor azul para as PCHs, verde para as usinas termoelétricas à biomassa e laranja, para as usinas eólica. As carteiras otimizadas, que estão sobre a curva da fronteira eficiente, estão ilustradas pelos pontos quadrados em cor azul. A carteira atual está identificada pelo ponto de cor cinza. Cabe ressaltar que a carteira atual das usinas eólicas, considerou apenas as usinas eólicas do PROINFA. O mesmo procedimento foi adotado para calcular a carteira atual para as UTEs Biomassa e PCHs. A carteira atual do Gráfico 61 considerou todas as usinas do PROINFA.

Observa-se pelos gráficos que a diversificação das fontes possibilita obter uma fronteira eficiente de menor risco. O Gráfico 61 permite verificar que a curva da fronteira eficiente, considerando todas as usinas está mais à esquerda das demais (menor risco) e acima das demais (maior retorno).

Apesar da carteira atual não estar sobre a fronteira eficiente, a diversificação de fontes, resultado das regras de contratação do PROINFA, possibilitou uma carteira atual de menor risco que as carteiras considerando apenas um tipo de fonte. A TABELA 27 apresenta os parâmetros das carteiras atuais, demonstrando a redução do risco com a diversificação das fontes. 
TABELA 27 - Risco e Retorno das Carteiras Atuais.

\begin{tabular}{ccc}
\hline Carteiras Atuais & Risco & Retorno \\
\hline Usinas Eólicas & 0,10 & 0,36 \\
UTEs Biomassa & 0,12 & 0,23 \\
PCHs & 0,07 & 0,52 \\
\hline Todas as Usinas & 0,05 & 0,38 \\
\hline
\end{tabular}

Autor (2016).

A TABELA 28 apresenta os parâmetros das carteiras de menor risco, para as 4 hipóteses (apenas as usinas eólicas, as UTEs biomassa e as PCHs e com todas as usinas). A carteira de risco mínimo considerando todas as usinas é a que apresentou o menor desvio padrão.

TABELA 28 - Risco e Retorno das Carteiras de Menor Risco.

\begin{tabular}{ccc}
\hline Tipos de Carteiras & Risco & Retorno \\
\hline Usinas Eólicas & 0,05 & 0,24 \\
UTEs Biomassa & 0,03 & 0,11 \\
PCHs & 0,03 & 0,65 \\
\hline Todas as Usinas & 0,01 & 0,42 \\
\hline
\end{tabular}

Autor (2016).

No Gráfico 62 é possível verificar que a carteira atual, mesmo considerando a diversificação das fontes e da localização, está distante da fronteira eficiente e que, portanto, a regra de contratação do PROINFA, que limitou a potência instalada dos empreendimentos por Estado e por fonte, não foi suficiente para resultar em uma carteira otimizada.

Gráfico 62 - Fronteira Eficiente e Carteira Atual para as Usinas do PROINFA (Parâmetros adimensionais - Fator de Capacidade).

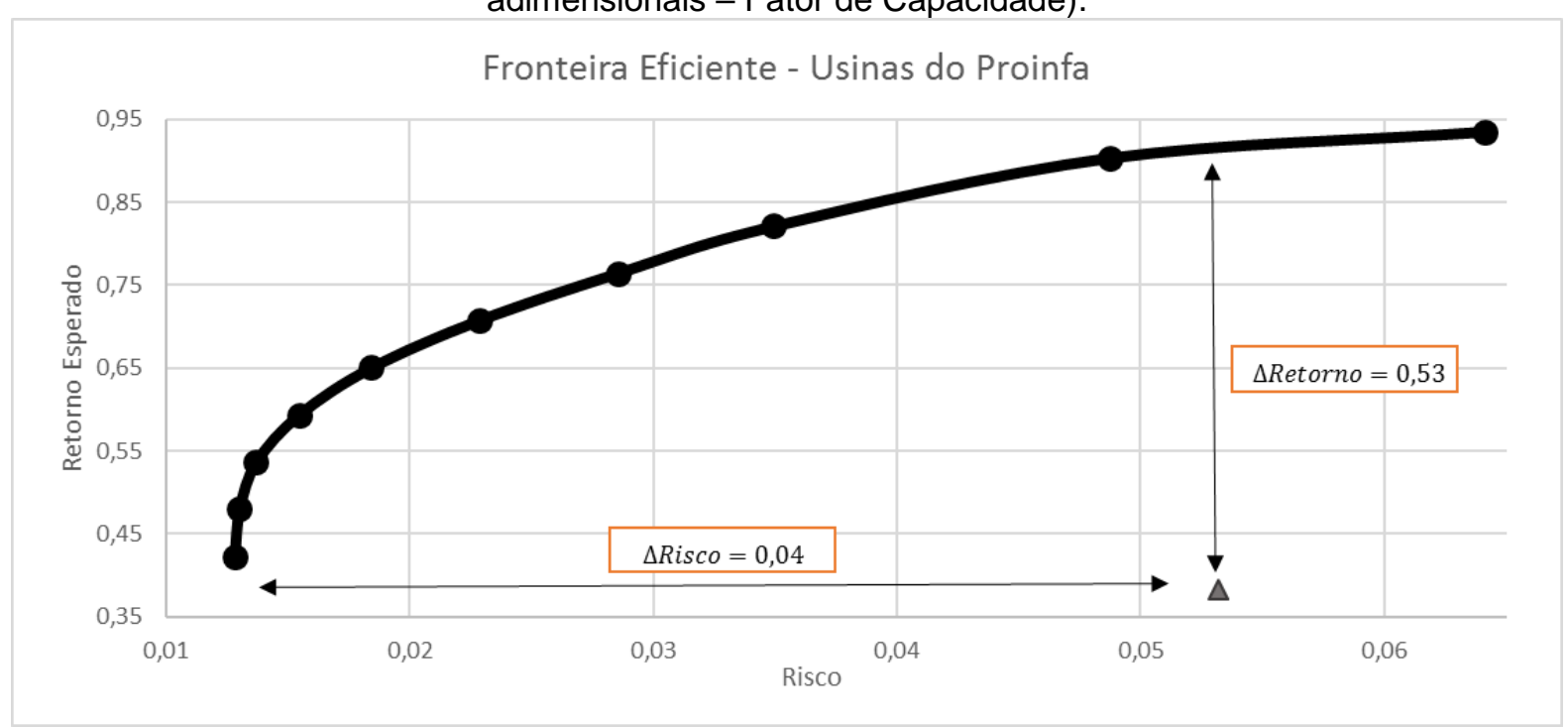

Autor (2016). 
Os resultados obtidos possuem uma faixa de expectativa de fator de capacidade entre 0,42 (carteira de risco mínimo) a 0,94 (carteira de maior retorno), enquanto a carteira atual possui uma expectativa de fator de capacidade igual a 0,38.

Em 10 carteiras otimizadas, foram descartados 59 ativos individuais e apenas 25 ativos foram selecionados (9 usinas biomassa, 12 usinas eólicas e 4 PCHs).

A carteira de risco mínimo $(0,01)$ possui uma expectativa de geração maior que a carteira atual e utiliza apenas 33 usinas (a carteira atual conta com 104 usinas).

$O$ retorno da carteira atual pode ser majorado de 0,38 para 0,91 mantendo o mesmo risco, com ajustes na sua composição. Em outras palavras, com o mesmo investimento em capacidade instalada, pode-se aumentar a expectativa de geração.

\subsubsection{Otimização 05 - Todas as Usinas Equivalentes do PROINFA - Fator de Capacidade}

Tendo em vista a forte correlação das usinas do mesmo tipo de fonte e dentro do mesmo Estado, nessa otimização foram utilizadas as usinas equivalentes por estado e por fonte e os parâmetros do histórico do fator de capacidade do período de janeiro de 2009 a dezembro de $2015^{85}$. O comportamento da série histórica, por fonte e por Estado, está apresentado nos Gráfico 63 a Gráfico 66.

Para cada par de usina eólica equivalente foi calculada a covariância do histórico do fator de capacidade, obtendo-se a matriz de covariância.

A TABELA 29 resume os parâmetros da média e desvio padrão para cada usina eólica equivalente, bem como a quantidade de usinas individuais que compõem a usina equivalente e a potência instalada equivalente.

A fronteira eficiente e as carteiras individualizadas para as usinas eólicas equivalentes estão representadas no Gráfico 67. A fronteira eficiente e as carteiras individualizadas para as usinas termoelétricas biomassa equivalentes estão representadas no Gráfico 68. A fronteira eficiente e as carteiras individualizadas para as usinas PCHs equivalentes estão representadas no Gráfico 69. Por fim, o Gráfico 70 ilustra a fronteira eficiente considerando todas as usinas equivalentes do PROINFA e as fronteiras considerando as usinas eólicas, UTEs biomassa e as PCHs.

${ }^{85}$ Adotou-se que o comportamento da energia gerada para o mês de dezembro de 2015 foi igual ao mês de dezembro de 2014, ante a ausência daquele dado. 
Gráfico 63 - Série Histórica do Fator de Capacidade - Usinas Eólicas Equivalentes.

Usinas Eólicas (FC)

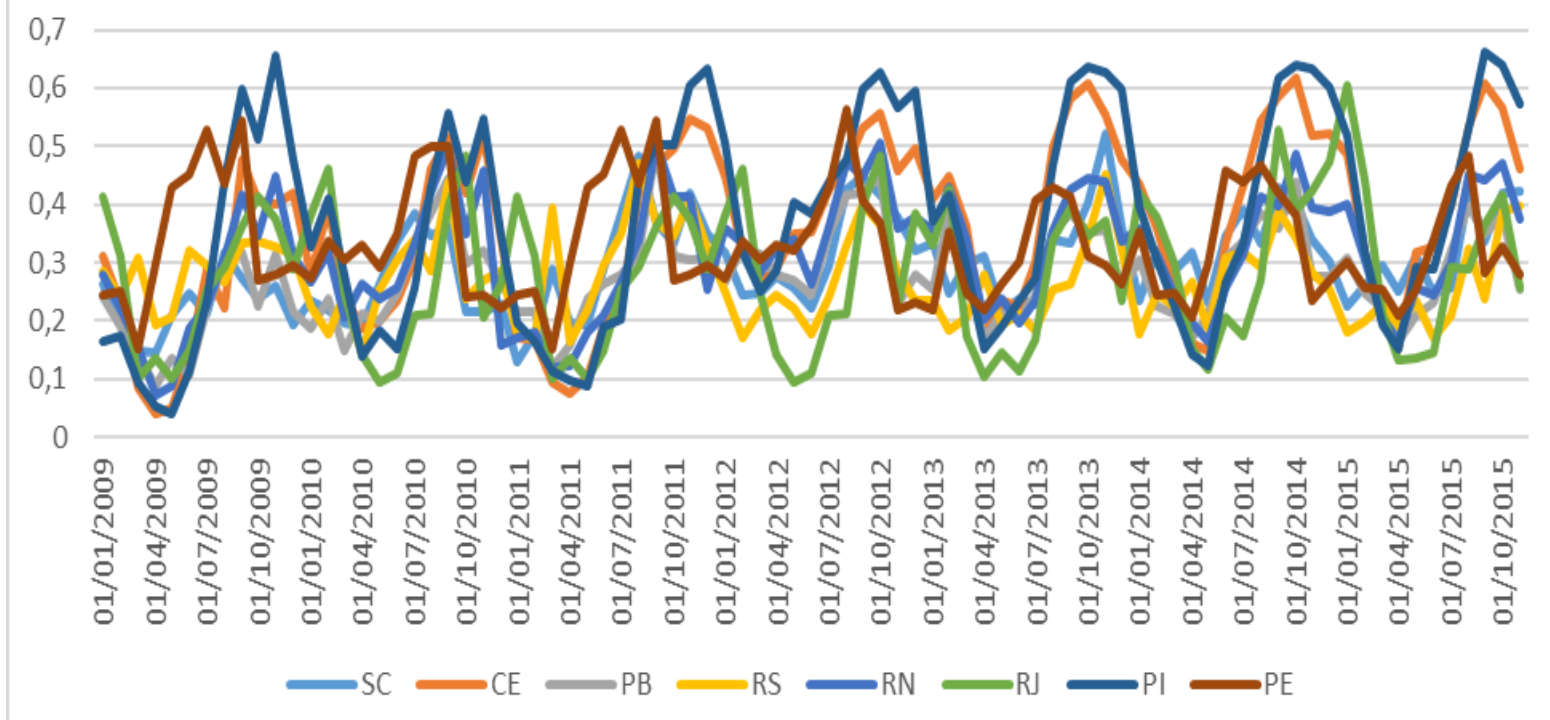

Autor (2016).

Gráfico 64 - Série Histórica do Fator de Capacidade - Usinas Biomassa Equivalentes.

Usinas Biomassa (FC)

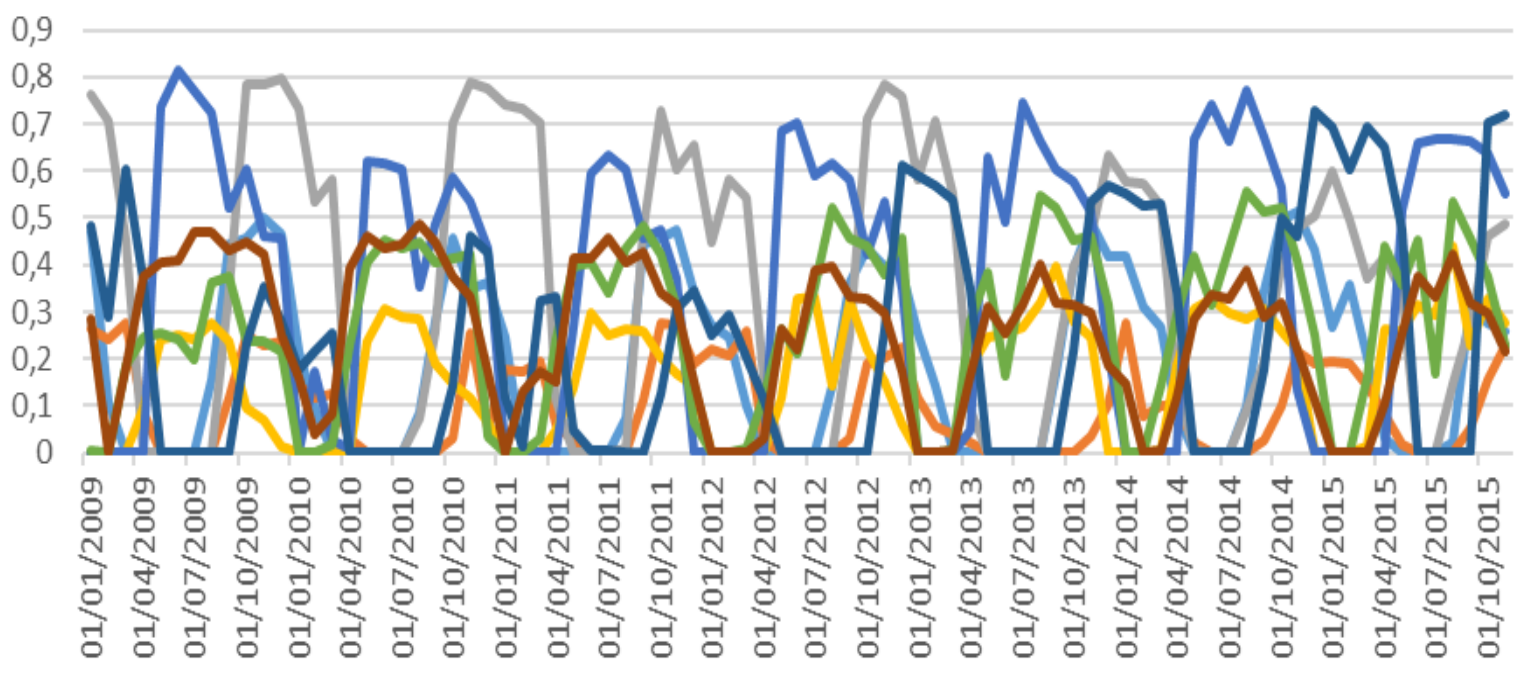

$\longrightarrow \mathrm{PB} \longrightarrow \mathrm{PE} \longrightarrow \mathrm{AL} \longrightarrow \mathrm{GO} \longrightarrow \mathrm{MG} \longrightarrow \mathrm{PR} \longrightarrow \mathrm{SE} \longrightarrow \mathrm{SP}$

Autor (2016). 
Gráfico 65 - Série Histórica do Fator de Capacidade - Usinas PCHs Equivalentes.

Usinas PCHs (FC)

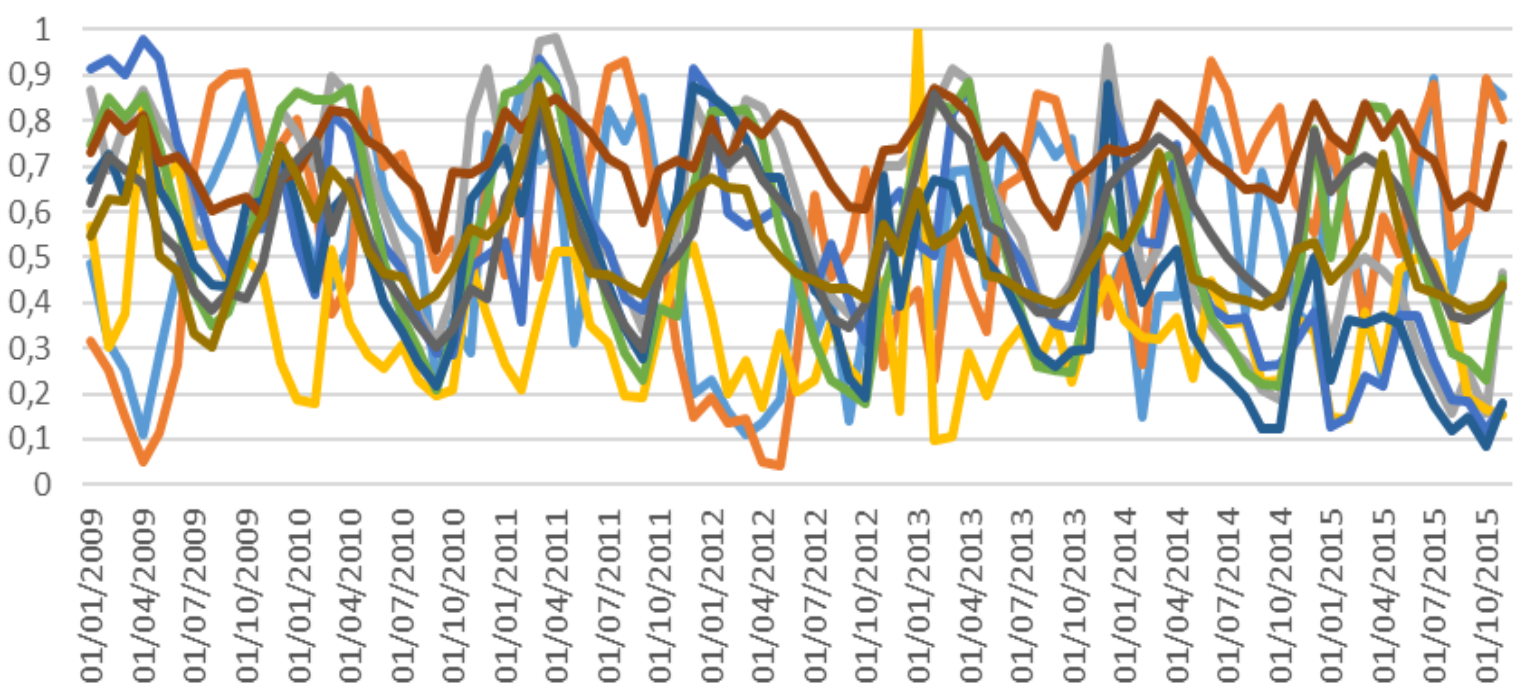

$\longrightarrow \mathrm{SC} \longrightarrow \mathrm{RS} \longrightarrow \mathrm{RJ} \longrightarrow \mathrm{BA} \longrightarrow \mathrm{ES} \longrightarrow \mathrm{GO} \longrightarrow \mathrm{MG} \longrightarrow \mathrm{MS} \longrightarrow \mathrm{MT} \longrightarrow \mathrm{TO}$

Autor (2016).

Gráfico 66 - Série Histórica do Fator de Capacidade - Usinas Equivalentes.

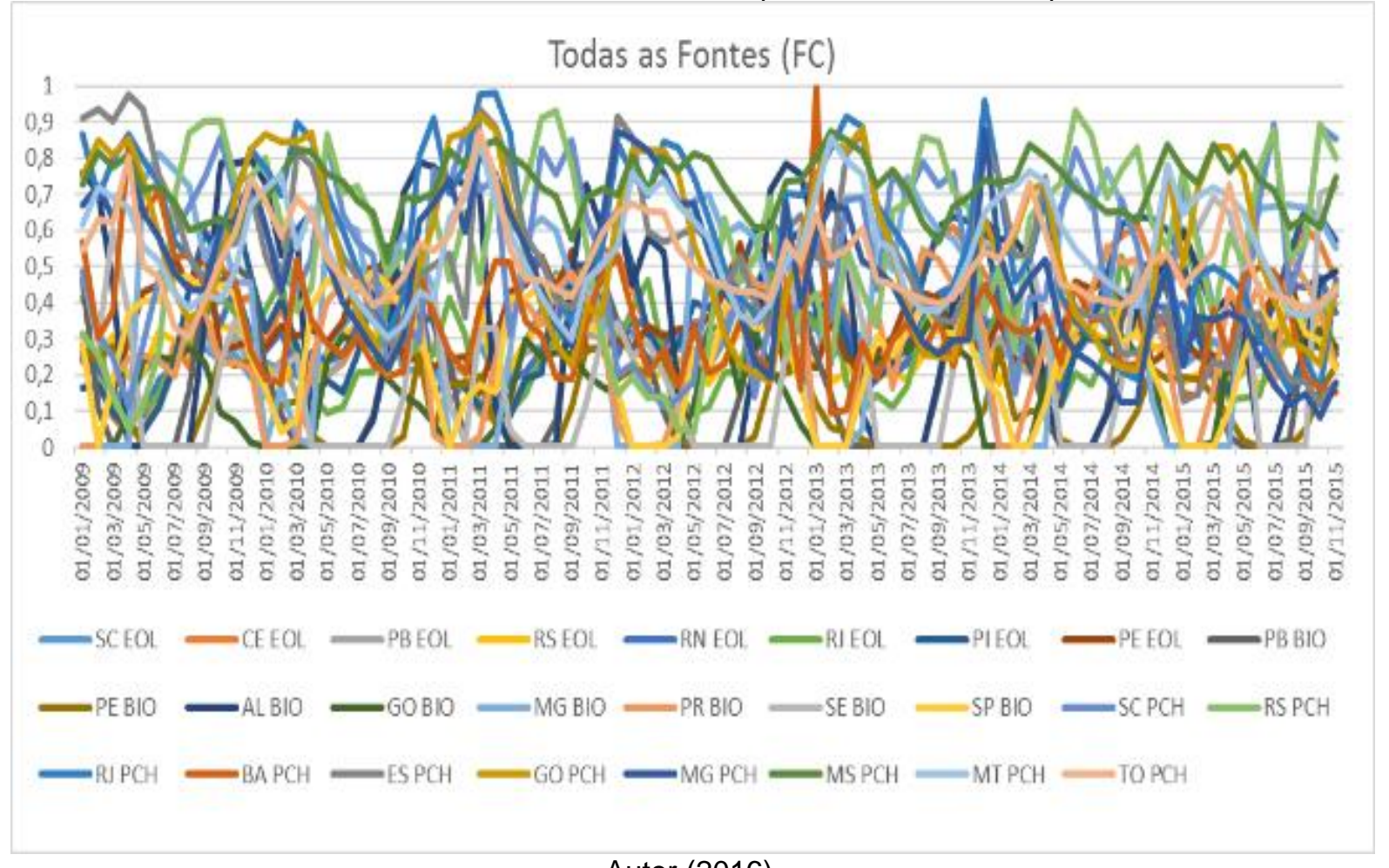

Autor (2016). 
TABELA 29 - Média e Desvio Padrão do Fator de Capacidade das Usinas Equivalentes.

\begin{tabular}{|c|c|c|c|c|c|}
\hline \multirow{2}{*}{ Fonte } & \multirow{2}{*}{ Estado } & \multirow{2}{*}{$\begin{array}{l}\text { Quantidade } \\
\text { de Usinas }\end{array}$} & \multirow{2}{*}{$\begin{array}{l}\text { Potência Instalada } \\
\text { (MW) }\end{array}$} & \multicolumn{2}{|c|}{ Fator de Capacidade } \\
\hline & & & & Média & Desvio Padrão \\
\hline Biomassa & $\mathrm{AL}$ & 2 & 31,00 & 0,35 & 0,30 \\
\hline Biomassa & GO & 2 & 54,52 & 0,16 & 0,13 \\
\hline Biomassa & $M G$ & 1 & 30,00 & 0,37 & 0,29 \\
\hline Biomassa & PB & 1 & 20,00 & 0,19 & 0,19 \\
\hline Biomassa & PE & 1 & 33,20 & 0,09 & 0,10 \\
\hline Biomassa & $\mathrm{PR}$ & 3 & 88,10 & 0,27 & 0,18 \\
\hline Biomassa & SE & 1 & 5,00 & 0,23 & 0,25 \\
\hline Biomassa & SP & 9 & 271,52 & 0,26 & 0,15 \\
\hline Eólica & CE & 17 & 500,53 & 0,36 & 0,15 \\
\hline Eólica & PB & 13 & 63,70 & 0,28 & 0,08 \\
\hline Eólica & PE & 4 & 17,00 & 0,27 & 0,16 \\
\hline Eólica & $\mathrm{PI}$ & 1 & 17,85 & 0,37 & 0,18 \\
\hline Eólica & RJ & 1 & 28,05 & 0,21 & 0,17 \\
\hline Eólica & $\mathrm{RN}$ & 3 & 100,30 & 0,31 & 0,11 \\
\hline Eólica & RS & 4 & 157,56 & 0,27 & 0,08 \\
\hline Eólica & SC & 2 & 79,00 & 0,30 & 0,08 \\
\hline $\mathrm{PCH}$ & BA & 3 & 41,80 & 0,34 & 0,17 \\
\hline $\mathrm{PCH}$ & ES & 2 & 25,50 & 0,53 & 0,22 \\
\hline $\mathrm{PCH}$ & GO & 5 & 120,00 & 0,55 & 0,23 \\
\hline $\mathrm{PCH}$ & MG & 3 & 56,50 & 0,47 & 0,21 \\
\hline $\mathrm{PCH}$ & MS & 4 & 76,20 & 0,73 & 0,08 \\
\hline $\mathrm{PCH}$ & MT & 4 & 84,24 & 0,55 & 0,15 \\
\hline $\mathrm{PCH}$ & RJ & 3 & 79,00 & 0,59 & 0,22 \\
\hline $\mathrm{PCH}$ & RS & 8 & 142,20 & 0,56 & 0,24 \\
\hline $\mathrm{PCH}$ & SC & 5 & 94,70 & 0,52 & 0,22 \\
\hline $\mathrm{PCH}$ & TO & 3 & 46,80 & 0,52 & 0,11 \\
\hline $\begin{array}{c}\text { Carteira Atual } \\
\text { (PROINFA) }\end{array}$ & & & $2.264,27$ & 0,3828 & 0,0489 \\
\hline
\end{tabular}

Autor (2016).

Fonte: BRASIL. Eletrobrás (2015).

Gráfico 67 - Fronteira Eficiente e Carteira Atual - Usinas Eólicas Equivalentes (Parâmetros adimensionais - Fator de Capacidade).

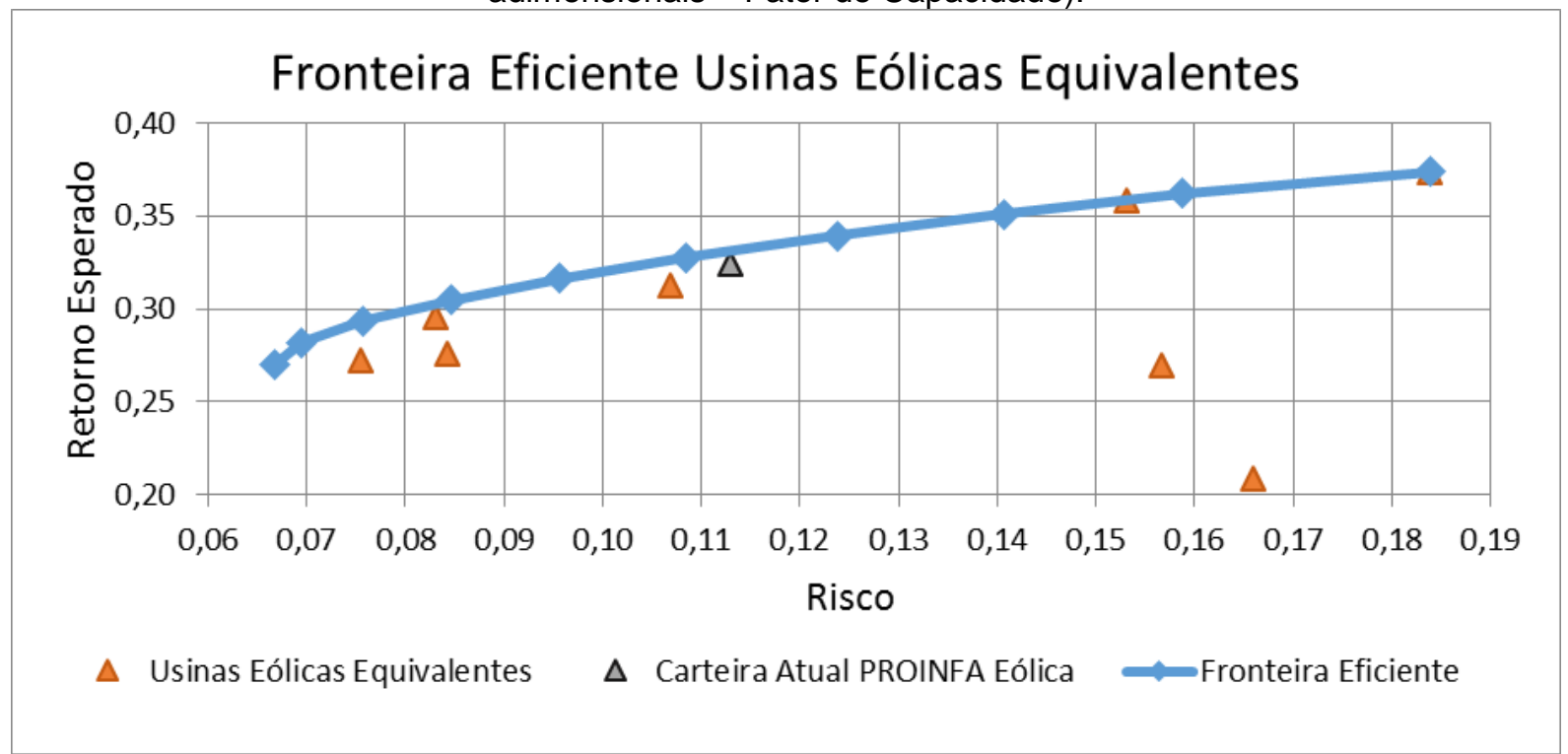

Autor (2016). 
Gráfico 68 - Fronteira Eficiente e Carteira Atual - UTEs Biomassa Equivalentes (Parâmetros adimensionais - Fator de Capacidade).

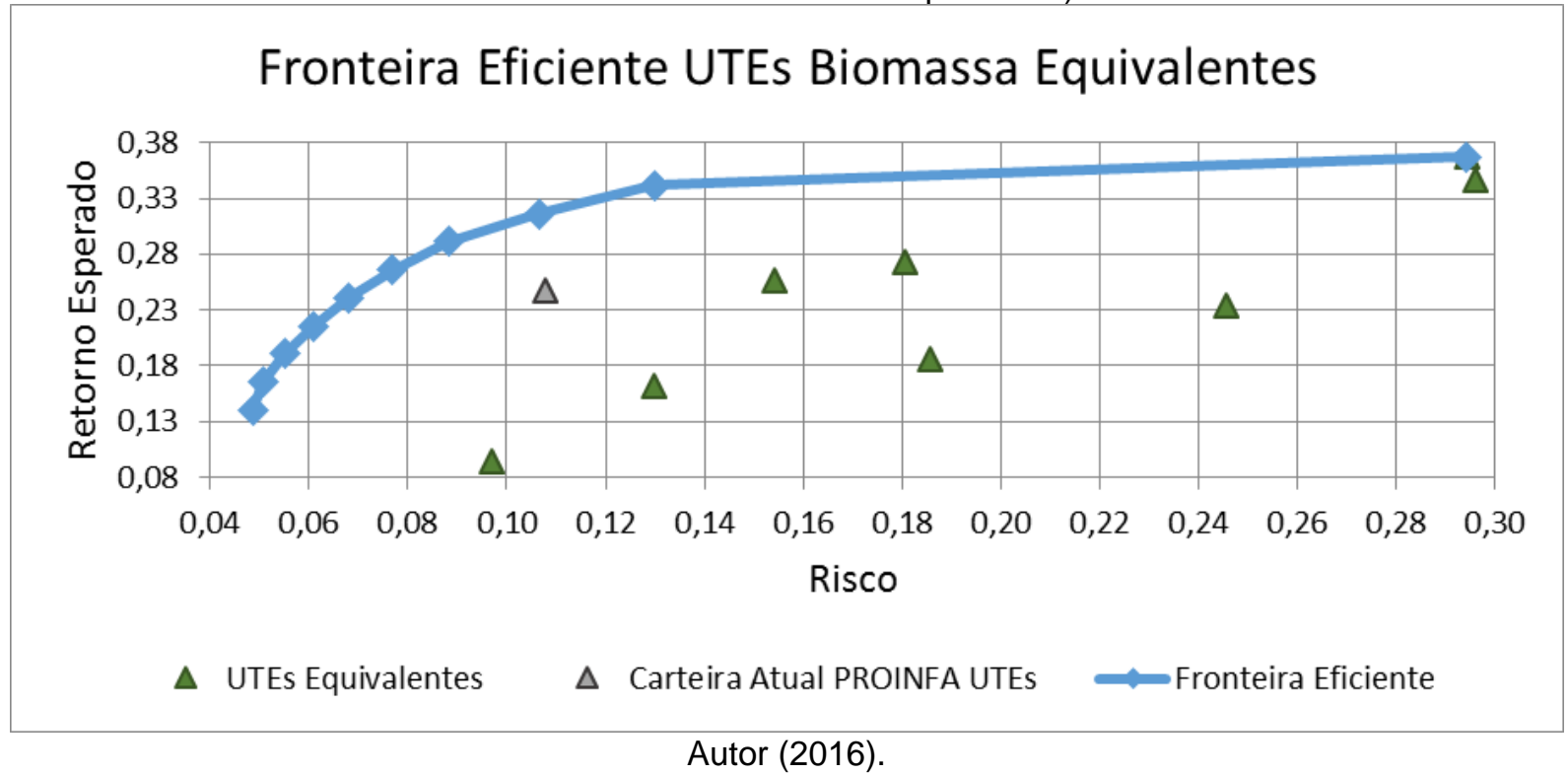

Gráfico 69 - Fronteira Eficiente e Carteira Atual - PCHs Equivalentes (Parâmetros adimensionais Fator de Capacidade).

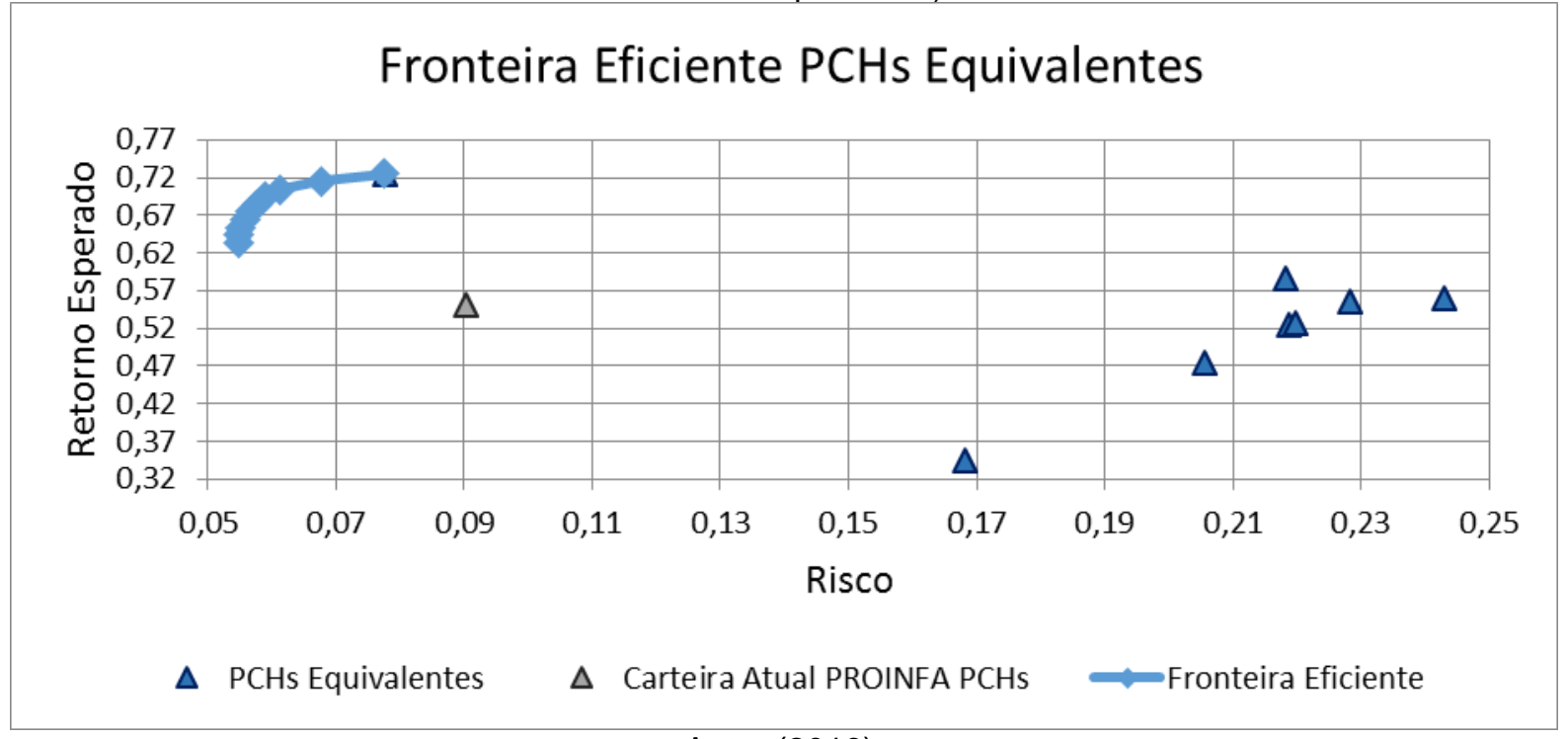

Autor (2016). 
Gráfico 70 - Fronteira Eficiente e Carteira Atual - Usinas Equivalentes (Parâmetros adimensionais Fator de Capacidade).

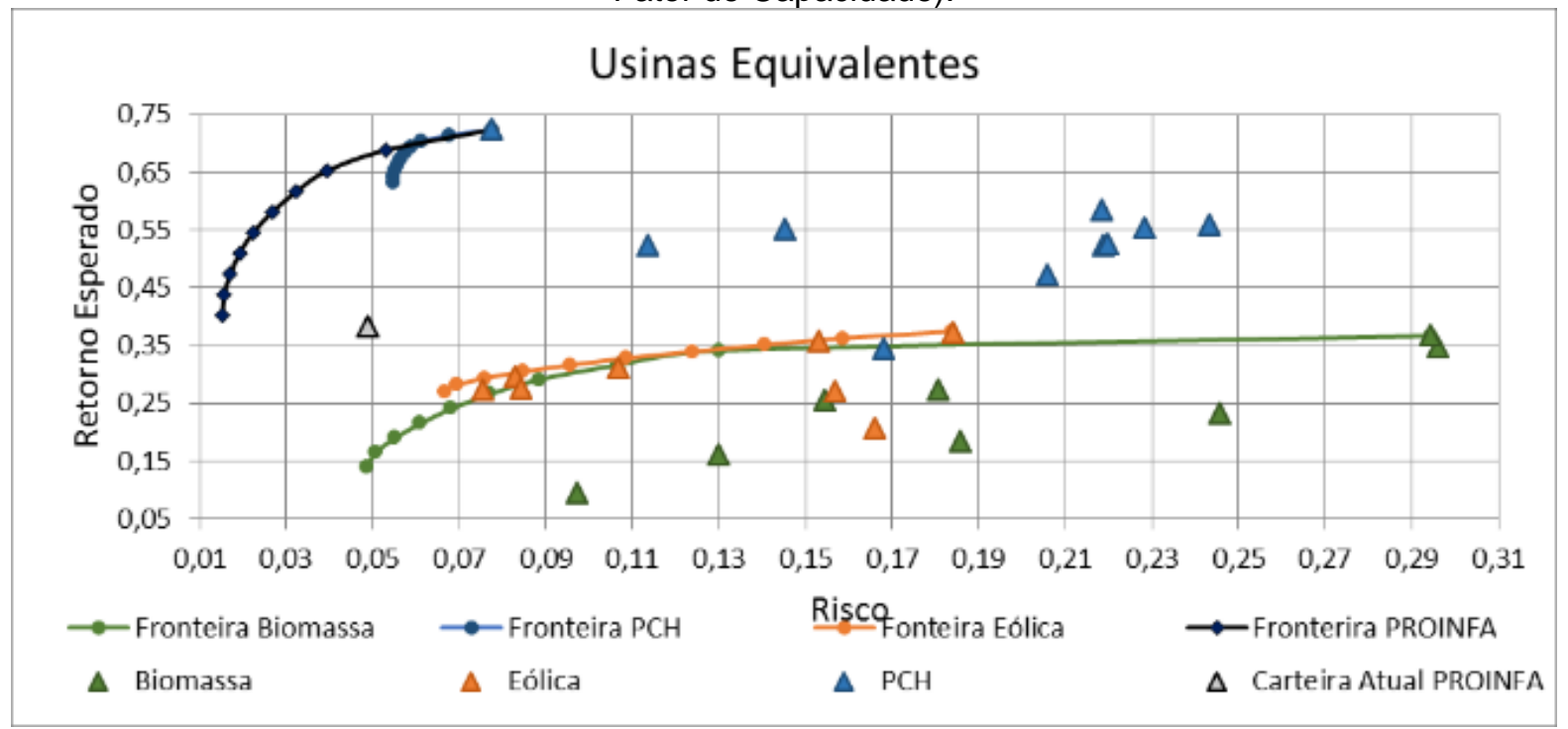

Autor (2016).

As carteiras individuais equivalentes estão representadas pelos pontos triangulares de cor azul para as $\mathrm{PCHs}$, verde para as usinas termoelétricas à biomassa e laranja, para as usinas eólica. As carteiras otimizadas, que estão sobre a curva da fronteira eficiente, estão ilustradas pelos pontos quadrados em cor azul. A carteira atual está identificada pela cor cinza. Cabe ressaltar que a carteira atual das usinas eólicas, considerou apenas as usinas eólicas do PROINFA. O mesmo procedimento foi adotado para calcular a carteira atual para as UTEs Biomassa e PCHs. A carteira atual do Gráfico 70 considerou todas as usinas do PROINFA.

Observa-se pelos gráficos que a diversificação das fontes possibilita uma fronteira eficiente de menor risco. O Gráfico 70 permite verificar que a curva da fronteira eficiente, considerando todas as usinas está mais à esquerda das demais (menor risco) e acima das demais (maior retorno).

No Gráfico 70 é possível observar que a carteira atual, mesmo considerando a diversificação das fontes e da localização, está distante da fronteira eficiente e que, portanto, a regra de contratação do PROINFA, que limitou a potência instalada dos empreendimentos por Estado e por fonte, não foi suficiente para resultar em uma carteira otimizada.

A TABELA 30 apresenta os parâmetros das carteiras atuais, demonstrando a redução do risco com a diversificação das fontes. 
TABELA 30 - Risco e Retorno das Carteiras Atuais Equivalentes.

\begin{tabular}{ccc}
\hline Carteiras Equivalentes Atuais & Risco & Retorno \\
\hline Usinas Eólicas & 0,11 & 0,32 \\
UTEs Biomassa & 0,11 & 0,25 \\
PCHs & 0,09 & 0,55 \\
\hline Todas as Usinas & 0,05 & 0,38 \\
\hline
\end{tabular}

A TABELA 31 apresenta os parâmetros das carteiras de menor risco, para as 4 hipóteses (apenas as usinas eólicas, as UTEs biomassa e as PCHs e com todas as usinas). A carteira de risco mínimo considerando todas as usinas equivalentes é a que apresentou o menor desvio padrão.

TABELA 31 - Risco e Retorno das Carteiras Equivalentes de Menor Risco.

\begin{tabular}{ccc}
\hline Tipos de Carteiras & Risco & Retorno \\
\hline Usinas Eólicas & 0,07 & 0,27 \\
UTEs Biomassa & 0,05 & 0,14 \\
PCHs & 0,05 & 0,63 \\
\hline Todas as Usinas & 0,02 & 0,40 \\
\hline
\end{tabular}

Os resultados obtidos possuem uma faixa de expectativa de fator de capacidade entre 0,40 (carteira de risco mínimo) a 0,73 (carteira de maior retorno), enquanto a carteira atual possui uma expectativa de fator de capacidade igual a 0,38. Em 10 carteiras otimizadas, foram selecionados apenas 18 ativos (6 usinas biomassa, 4 usinas eólicas e $8 \mathrm{PCHs}$ ).

Destaca-se que, uma mudança na composição da carteira atual poderia reduzir a volatilidade de 0,05 para 0,02, mantendo a mesma média do fator de capacidade, alternativamente, seria possível aumentar a expectativa de geração de 0,38 para 0,65, para o mesmo risco.

\subsubsection{Cálculo do Risco Mínimo}

No item 3.1 foi abordado o limite regulatório de contratação das usinas do PROINFA, por Estado e por fonte. Os resultados das simulações demonstram que essa restrição regulatória de contratação não implicou em uma carteira otimizada de ativos de geração. Como tal, foi verificado que a carteira atual dos ativos do PROINFA não está sobre a fronteira eficiente, para as diversas curvas obtidas. 
Os resultados apresentados até o momento confirmam que não existe necessidade de um grande número de ativos para otimizar a carteira. Em todas as simulações realizadas para os casos analisados, as carteiras otimizadas utilizaram uma quantidade de ativos sempre inferior à quantidade de ativos disponíveis para a otimização.

Nesta otimização, pretende-se calcular o risco sistêmico de uma carteira de projetos eólicos, ou seja, o risco mínimo de geração, bem como a quantidade de ativos (usinas eólicas) necessários para se obter o risco mínimo. Para tal, serão utilizados os parâmetros do histórico do fator de capacidade, considerando as usinas eólicas individualizadas e as usinas eólicas equivalentes (agrupadas por Estado), obtendo-se os resultados para os dois cenários.

Para obter a relação entre o risco e a quantidade de ativos na carteira, foram consideradas todas as combinações possíveis de carteiras, agrupando os ativos em carteiras de um, dois, três, quatro ativos, e assim sucessivamente, desconsiderando as combinações que somente alteram a posição dos ativos na carteira.

Para cada carteira obtida com as combinações possíveis, foi aplicada a teoria de Markowitz e calculado o risco mínimo. Para todas as carteiras com o mesmo número de ativos, foi obtido o risco mínimo. A Figura 11 ilustra o procedimento adotado.

Figura 11 - Procedimento para Obter o Risco Sistêmico.

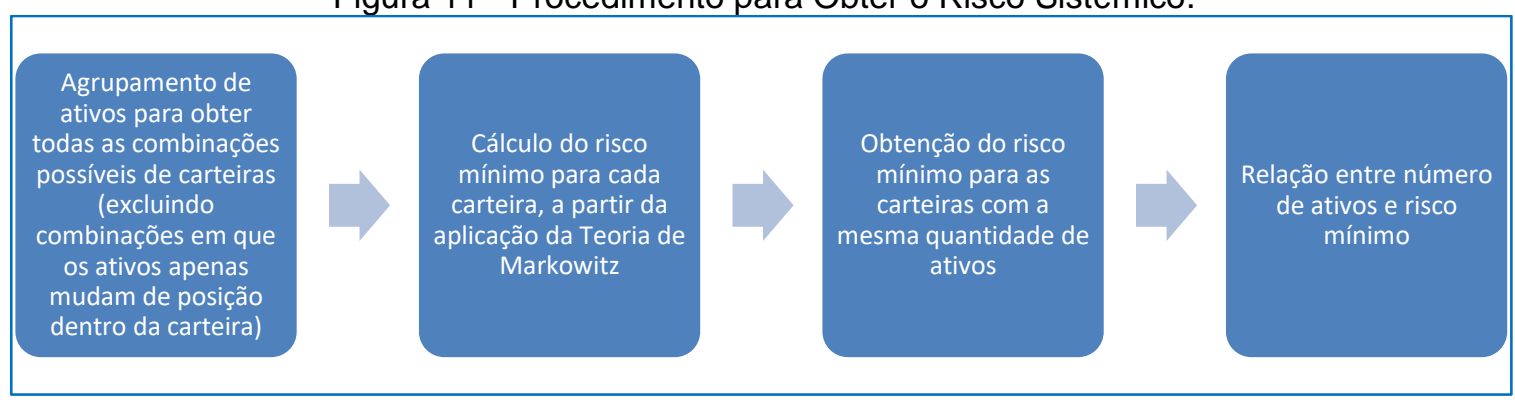

Autor (2016).

Como já foi demonstrado que as carteiras otimizadas não utilizam a totalidade dos ativos, tendo em vista as diversas combinações e o número de simulações, foram sorteados 16 (dezesseis) ativos individuais da lista das 45 usinas eólicas da TABELA 21 e considerada a série histórica do período de junho de 2011 a novembro de 2015 para obter o risco mínimo. Para a otimização por usinas equivalentes, foram 
considerados os 8 (oito) ativos da TABELA 25 (usinas eólicas equivalentes), no período de janeiro de 2009 a dezembro de 2015.

A função do risco da carteira pela quantidade de ativos, considerando as 16 usinas eólicas individualizadas, está representa no Gráfico 71.

Gráfico 71 - Variação do Risco pelo Número de Ativos para as Usinas Eólicas Individualizadas (Parâmetros adimensionais - Fator de Capacidade).

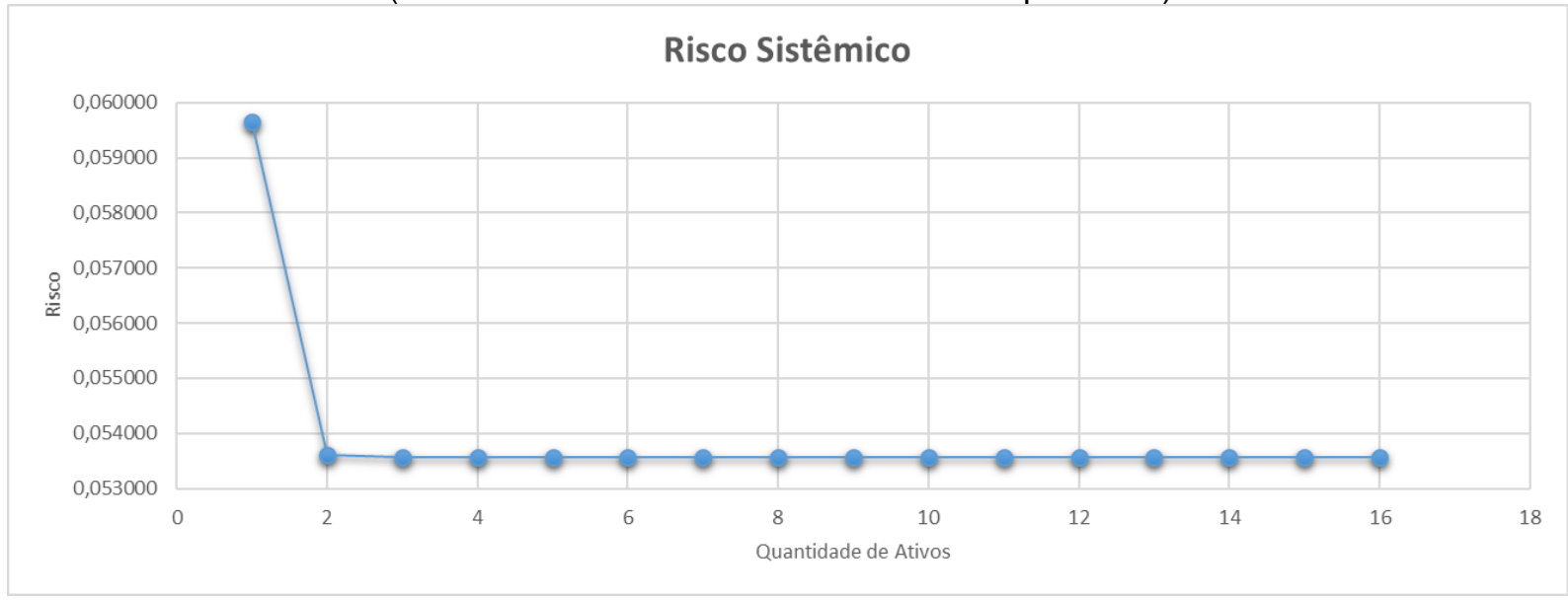

Autor (2016).

Os resultados estão coerentes com o referencial teórico, pois comprovam que uma carteira com poucos ativos é suficiente para eliminar a parte mais significativa do risco não sistêmico (diversificável), contudo, não se consegue reduzir o risco sistêmico independente do número de ativos.

O resultado também está coerente com o obtido no item 5.1.2, onde foi evidenciado que com 4 (quatro) usinas eólicas é possível obter a carteira otimizada de risco mínimo (TABELA 22) com valor de aproximadamente 0,053566 (fator de capacidade), o mesmo valor do risco mínimo do Gráfico 71 .

A função do risco da carteira pela quantidade de ativos, considerando as usinas eólicas equivalentes, está representa no Gráfico 72.

O resultado está coerente com o obtido no item 5.1.3, onde foi evidenciado que com 3 usinas eólicas equivalentes ( 3 Estados) é possível obter uma carteira otimizada de risco mínimo (TABELA 31) com valor aproximado de 0,0668 (fator de capacidade), o mesmo do Gráfico 72. 
Gráfico 72 - Variação do Risco pelo Número de Ativos para as Usinas Eólicas Equivalentes (Parâmetros adimensionais - Fator de Capacidade).

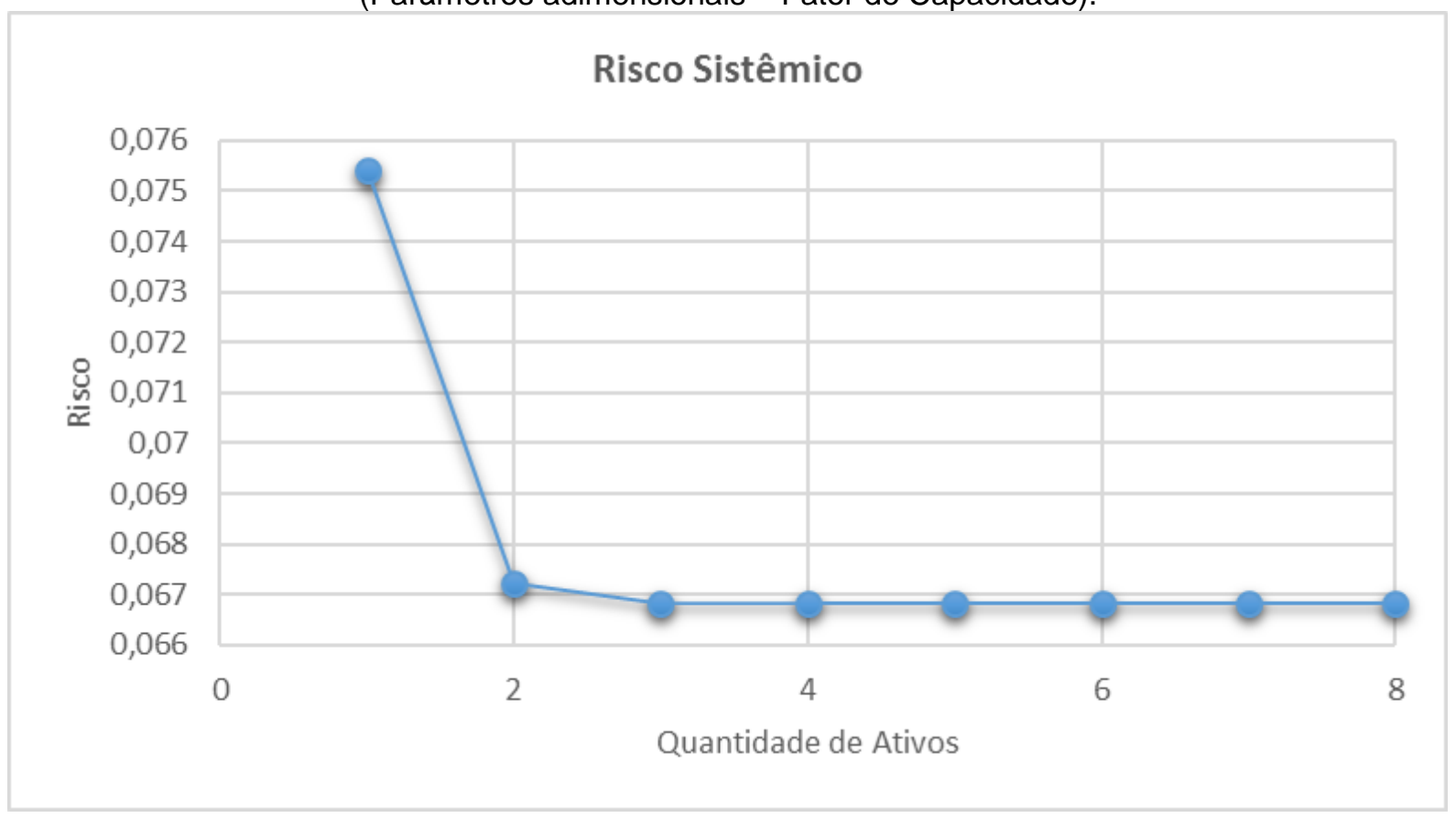

Autor (2016).

A definição do risco mínimo é de grande importância para o ambiente da comercialização e para o ambiente operativo, pois permite calcular a geração eólica mínima da carteira. No caso, o risco mínimo calculado, como utilizou dados históricos mensais, são úteis para avaliações sobre contratos de energia e exposição ao mercado curto prazo. Para o ambiente de operação, o cálculo do risco mínimo deve utilizar um histórico em base horária, porém considerar as restrições de transmissão. No item 5.2 serão utilizadas séries históricas de velocidade de vento de 1994 a 2014, em escala horária, possibilitando incorporar os limites de transmissão.

\subsection{MODELO PROPOSTO APLICADO À SÉRIE DE DADOS DO VORTEX}

As usinas do PROINFA possuem uma base de dados (temporal e geográfica) reduzida, com impacto nos resultados obtidos. O tamanho da série histórica influencia o cálculo da fronteira eficiente. Séries maiores tendem a resultados mais confiáveis, na medida em que capturam os efeitos da sazonalidade e de variação interanual da velocidade do vento. Da mesma forma, uma maior quantidade de pontos geograficamente dispersos, permite ao modelo definir com melhor precisão a fronteira eficiente, uma vez que abrange um maior número de correlações entre os ativos. 
Além disso, o uso dos dados das usinas do PROINFA sofre a influência da curva de potencia do aerogerador instalado, bem como da altura da torre. Por fim, o uso da energia gerada provoca a influência da potência do aerogerador sobre os resultados e, o uso de uma base de dados mensal, não possibilita inserir restrições de transmissão ao modelo de otimização.

Com o objetivo de melhorar a qualidade dos resultados, foi utilizada a base de dados disponibilizada pela Vortex. O modelo climatológico The Weather Research and Forecasting (WRF), utilizado pela Vortex para gerar as séries de vento, foi apresentado no item 4.2 .

Os pontos de medição foram selecionados a partir da análise gráfica cruzada utilizando o Atlas do Potencial Eólico Brasileiro (2001), elaborado pelo CEPEL, e as principais linhas de transmissão existentes, estas fornecidas pelo ONS e disponibilizadas pela ANEEL através da plataforma SIGEL ${ }^{86}$. Como resultado, foram selecionados dados de 22 coordenadas geográficas, distribuídas nas áreas de maior potencial eólico e próximas ao sistema de transmissão existente. A Figura 12 exibe a distribuição espacial das coordenadas (séries coletadas).

Os pontos de dados foram concentrados na região litorânea do Nordeste e na porção sul do Brasil, em concordância com a disponibilidade do recurso eólico, conforme consta no Atlas do Potencial Eólico Brasileiro (2001).

A Figura 13 e a Figura 14 ilustram a localização dos pontos escolhidos com a sobreposição do mapa de potencial eólico (Atlas do Potencial Eólico Brasileiro (2001)) e da rede de transmissão (obtida da plataforma SIGEL), para as porções Nordeste e Sul da área de estudo, respectivamente. A escala de cores do mapa de potencial eólico indica tons mais escuros para regiões com as maiores velocidades médias de vento.

Para cada coordenada, a Vortex fornece séries com registros nas altitudes entre 50 a 150 metros, variando em escala de 10 metros ${ }^{87}$. Para o estudo, foram selecionadas as séries de dados para a altura de 100 metros, pois é a altura da torre em que os aerogeradores vem sendo instalados na sua maioria.

\footnotetext{
${ }^{86}$ www.aneel.gov.br

${ }^{87}$ Esse é um fator importante, pois permite que a modelagem utilize séries com velocidades de vento nas mesmas alturas das torres dos aerogeradores, dispensando a necessidade de extrapolações verticais.
} 
Figura 12 - Distribuição Espacial das Coordenadas Selecionadas do Vortex.

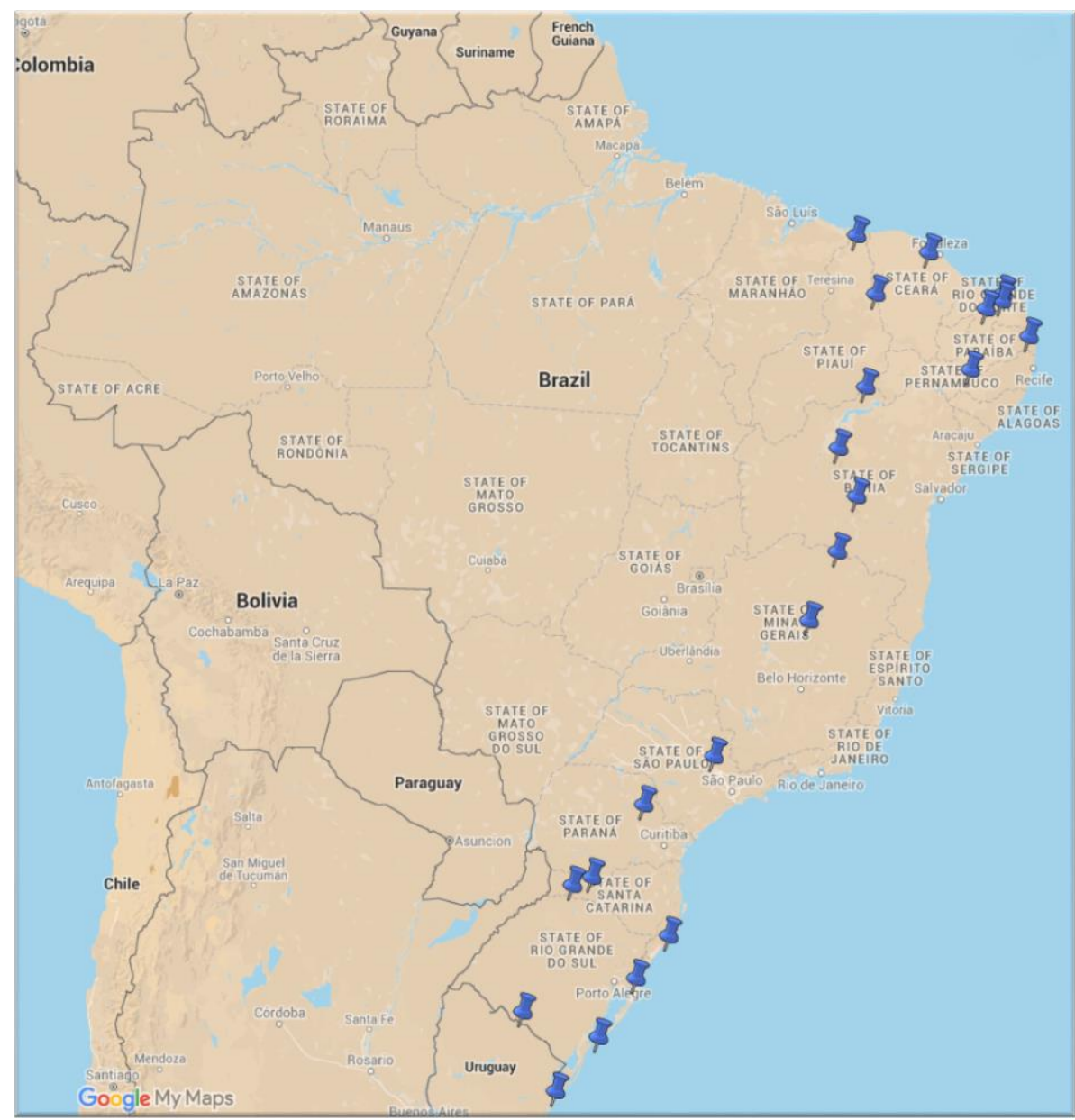

Autor (2016).

Fonte: Google Maps (2015).

Figura 13 - Potencial Eólico, Sistema de Transmissão e Pontos Adquiridos para a Porção Norte da Área de Estudo.

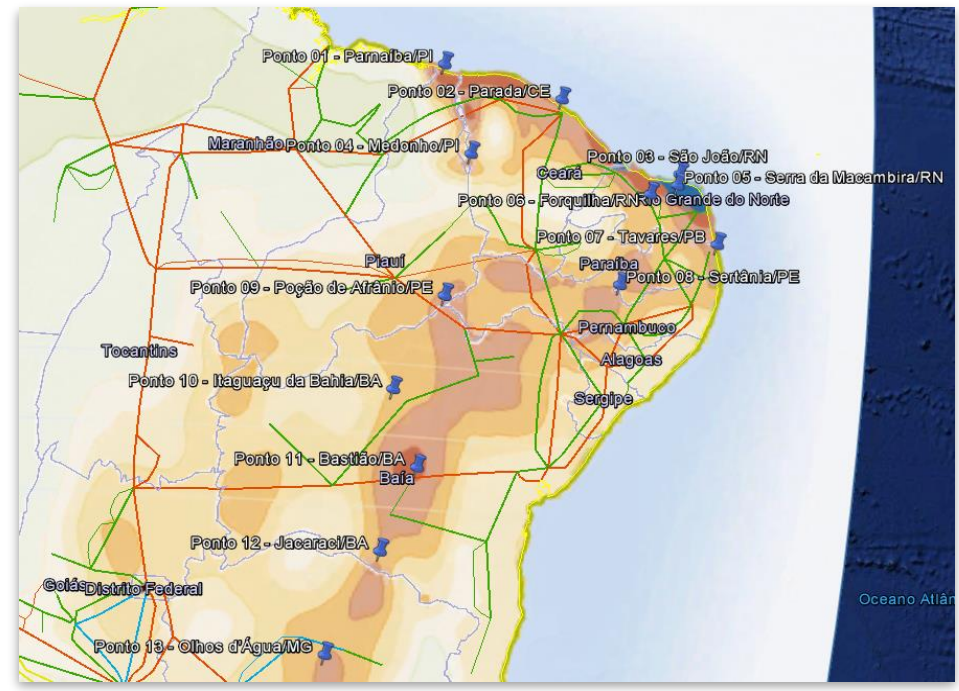

Autor (2016)

Fonte: Atlas do Potencial Eólico Brasileiro (2001) e SIGEL (2015). 
Figura 14 - Potencial Eólico, Sistema de Transmissão e Pontos Adquiridos para a Porção Sul da Área de Estudo.

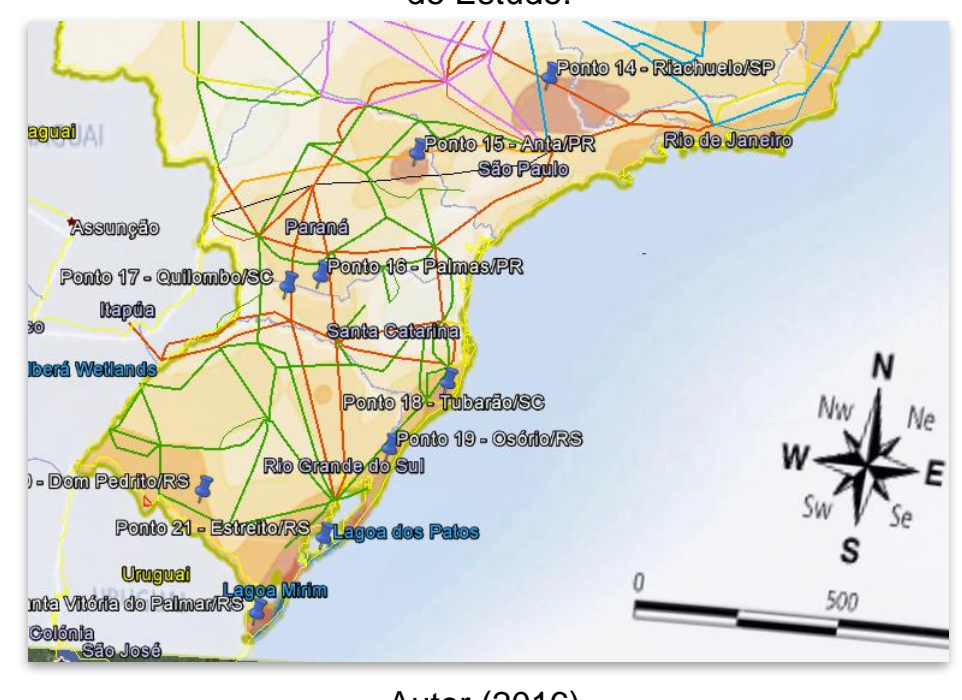

Fonte: Atlas do Potencial Eólico Brasileiro (2001) e SIGEL (2015).

A série de dados de velocidade do vento é fornecida em base horária, tendo sido escolhido para o estudo, o período de 01/01/1994 a 31/12/2014 (21 anos). Por fim, a Vortex também fornece a série de densidade do ar, o que permite calcular a geração de energia elétrica horária de um modo mais preciso (Equação(9)). Não raro utiliza-se um valor padrão de densidade do ar de 1,225 Kg/m³, contudo deve-se lembrar que esse valor é válido somente ao nível do mar e para uma temperatura de $15^{\circ} \mathrm{C}$.

O modelo proposto na Figura 10 foi adaptado para incorporar a conversão dos dados de velocidade de vento em energia (ou fator de capacidade), em base horária e mensal, conforme Figura 15. Para a conversão dos dados de velocidade de vento em séries de energia gerada, foram utilizadas as curvas de potência dos fabricantes com o maior número de aerogeradores instalados no Brasil, conforme adiante apresentado (item 5.2.2).

Figura 15 - Modelo Proposto Completo.

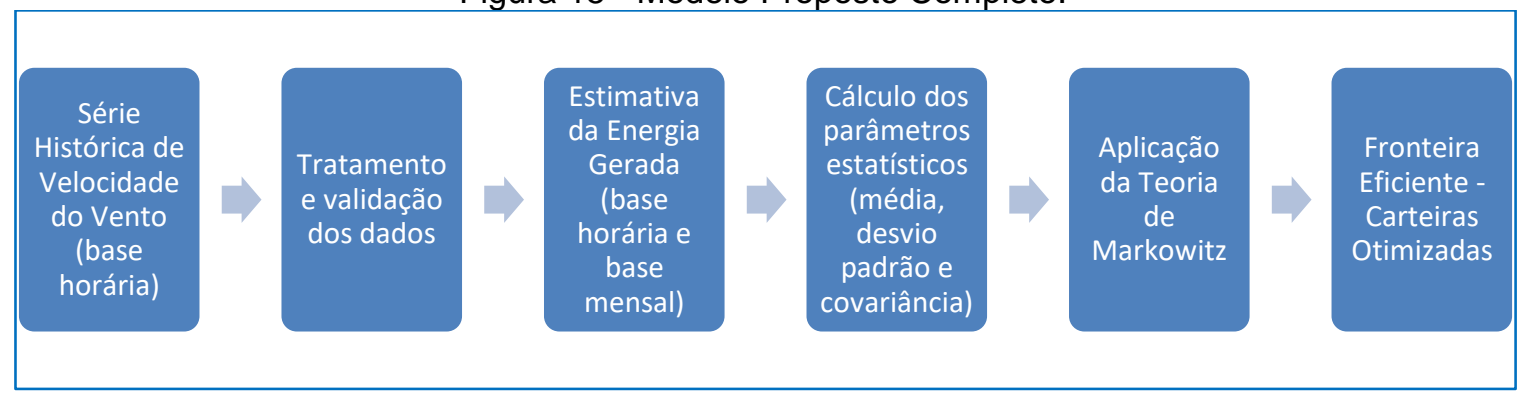

Autor (2016). 


\subsubsection{Tratamento dos Dados de Velocidade de Vento}

Analisando-se uma série temporal, é natural esperar que o comportamento de seus elementos siga um padrão condizente com o fenômeno que the deu origem. Elementos que fogem a esse padrão sendo, portanto, discrepantes em relação às demais variáveis da série são denominados outliers. De acordo com SEO (2006), em geral, esses valores são muito baixos ou muito altos em comparação com o restante da série, sendo gerados por erros de medição ou modelagem, dependendo da origem da série temporal.

As séries temporais de vento utilizadas no presente estudo são resultados de modelos matemáticos (The Weather Research and Forecasting Model - WRF), o que elimina a ocorrência de erros humanos ou de equipamentos medidores (ver item 4.2), porém não exclui a possibilidade de ocorrer algum dado outlier.

A Vortex inclui relatórios de consistência individuais para cada uma das coordenadas. Em resumo, são sete os tipos de análise aplicados às séries:

1. Homogeneidade na média da velocidade do vento;

2. Homogeneidade na variância da velocidade do vento;

3. Presença de tendências (lineares) de longo termo na velocidade do vento;

4. Análises cruzadas considerando desvios em relação ao valor médio (velocidade do vento versus temperatura e velocidade do vento versus pressão);

5. Análise cruzada velocidade do vento versus índice ENSO Niño 3.4;

6. Influência dos ventos de maior velocidade sobre a variabilidade total da série de velocidade do vento;

7. Análise sobre a incerteza de longo termo.

Análises na homogeneidade das séries de velocidade do vento (tipos 1 e 2) são utilizadas para identificar distinções na evolução da média e variância no decorrer da série histórica. De acordo com Naghettini e Pinto (2007), uma série homogênea é aquela na qual todos os seus elementos advêm de uma única e idêntica população. Nesse sentido, eventos extremos de ocorrência climáticas podem gerar elementos distintos do restante da série, caracterizando uma não homogeneidade. Alterações não pontuais, como períodos mais severos de fenômenos El Niño ou La Niña, também podem gerar não homogeneidades. 
A verificação da presença de tendências de longo termo (tipo 3) está, de certo modo, relacionada com a questão da homogeneidade da série. Entretanto, as tendências são associadas a eventos mais abrangentes, como variabilidades e mudanças climáticas. Pode-se dizer, dessa maneira, que a presença de não homogeneidades nos dados pode induzir o aparecimento de tendências de longo termo. Para essa análise, a Vortex emprega métodos que verificam aumentos (ou decrescimentos) lineares nas séries.

As verificações 1 a 3 são efetuadas sobre médias móveis de 12 meses, calculadas a partir dos dados horários. A título de melhor conhecer as séries em questão, a TABELA 32 agrupa os resultados das verificações de homogeneidade e tendências de longo termo para todas as coordenadas. Em cada caso são mostrados os períodos (em anos) nos quais as séries são consideradas homogêneas e/ou com tendências.

Nota-se que todas as séries apresentam homogeneidade na média em todo o período considerado. Por outro lado, diversas não homogeneidades na variância foram identificadas. Por exemplo, para a série Parnaíba, somente os períodos entre 1994-2001, 2001-2008 e 2008-2014 apresentam homogeneidade na variância. A mesma interpretação é feita com relação às tendências de longo termo. Para Parnaíba, diferentes tendências foram identificadas nos períodos de 1994-2001, 20012006 e 2006-2014. Nas otimizações não foram consideradas as diferentes tendências identificadas, na medida em que se utilizou a série histórica de cada coordenada como dado de entrada para o cálculo da média e da covariância entre as coordenadas.

Prosseguindo com as análises oferecidas no relatório de consistência da Vortex, as avaliações cruzadas entre velocidade do vento, temperatura e pressão (tipo 4) são exibidas por serem úteis em evidenciar sinais climáticos característicos, principalmente em termos de variabilidade intra-anual.

A avaliação cruzada entre velocidade do vento e ENSO Niño 3.4 (tipo 5) tenta mostrar a relação entre eventos El Niño e as velocidades de vento. ENSO é a sigla para El Niño Southern Oscilation, índice que revela variabilidades na temperatura da superfície do oceano Pacífico. Estas, quando presentes, podem indicar a ocorrência de eventos El Niño. Trata-se de uma análise interessante, pois pode explicar determinados períodos extremos de velocidade do vento presentes no histórico. 
TABELA 32 - Resultados das Análises de Homogeneidade e Tendência Disponíveis no Vortex.

\begin{tabular}{|c|c|c|c|c|}
\hline Código & Nome & $\begin{array}{l}\text { Homogeneidade na } \\
\text { Média }\end{array}$ & $\begin{array}{l}\text { Homogeneidade na } \\
\text { Variância }\end{array}$ & $\begin{array}{l}\text { Tendência de Longo } \\
\text { Termo }\end{array}$ \\
\hline 1 & Parnaíba & $1994-2014$ & $\begin{array}{l}1994-2001 \mid 2001-2008 \\
2008-2014\end{array}$ & $\begin{array}{l}1994-2001 \mid 2001-2006 \\
2006-2014\end{array}$ \\
\hline 2 & Parada & $1994-2014$ & \begin{tabular}{l|l}
$1994-1999$ & $1999-2001$ \\
$2001-2004$ & $2004-2008$ \\
$2008-2013$ & $2013-2014$
\end{tabular} & $\begin{array}{l}1994-2001 \mid 2001-2007 \\
2007-2014\end{array}$ \\
\hline 3 & Sao João & $1994-2014$ & $\begin{array}{l}1994-2000 \mid 2000-2008 \\
2008-2014\end{array}$ & $\begin{array}{l}1994-2001 \mid 2001-2007 \\
2007-2014\end{array}$ \\
\hline 4 & Medonho & $1994-2014$ & $1994-2013$ | 2013-2014 & 1994-2005 | 2005-2014 \\
\hline 5 & Macambira & $1994-2014$ & \begin{tabular}{l|l}
$1994-1997$ & $1997-2000$ \\
$2000-2006$ & $2006-2008$ \\
$2008-2013$ & $2013-2014$
\end{tabular} & Sem tendência \\
\hline 6 & Forquilha & $1994-2014$ & \begin{tabular}{l|l}
$1994-1996$ & $1996-1999$ \\
$1999-2008$ & $2008-2014$
\end{tabular} & 1994-2001 | 2001-2014 \\
\hline 7 & Tavares & $1994-2014$ & \begin{tabular}{l|l}
$1994-1997$ & $1997-1999$ \\
$1999-2000$ & $2000-2008$ \\
$2008-2010$ & $2010-2014$
\end{tabular} & $1994-2014$ \\
\hline 8 & Sertania & 1994-2014 & $\begin{array}{l}1994-1996 \mid 1996-1999 \\
1999-2000 \mid 2000-2009 \\
2009-2014\end{array}$ & $1994-2014$ \\
\hline 9 & Afranio & 1994-2014 & $1994-2012$ | 2012-2014 & 1994-2004 | 2004-2014 \\
\hline 10 & Itaguaçu & $1994-2014$ & $1994-2012$ | 2012-2014 & Sem tendência \\
\hline 11 & Boninal & $1994-2014$ & \begin{tabular}{l|l}
$1994-1997$ & $1997-1999$ \\
$1999-2007$ & $2007-2009$ \\
$2009-2012$ & $2012-2014$
\end{tabular} & $1994-2014$ \\
\hline 12 & Jacaraci & $1994-2014$ & \begin{tabular}{l|l}
$1994-1995$ & $1995-1998$ \\
$1998-2009$ & $2009-2014$
\end{tabular} & $1994-2014$ \\
\hline 13 & Olhos d'Água & $1994-2014$ & \begin{tabular}{l|l}
$1994-1995$ & $1995-1998$ \\
$1998-2000$ & $2000-2006$ \\
$2006-2012$ & $2012-2014$
\end{tabular} & $1994-2014$ \\
\hline 14 & Riachuelo & 1994-2014 & $\begin{array}{l}1994-2000 \mid 2000-2012 \\
2012-2014\end{array}$ & 1994-2014 \\
\hline 15 & Anta & 1994-2014 & 1994-2003 | 2003-2014 & Sem tendência \\
\hline 16 & Palmas & $1994-2014$ & $1994-2013$ | 2013-2014 & $\begin{array}{l}1994-2001 \mid 2001-2006 \\
2006-2014\end{array}$ \\
\hline 17 & Quilombo & $1994-2014$ & 1994-1998 | 1998-2014 & 1994-2008 | 2008-2014 \\
\hline 18 & Tubarão & $1994-2014$ & \begin{tabular}{l|l}
$1994-1998$ & $1998-2000$ \\
$2000-2011 \mid$ & $2011-2014$
\end{tabular} & $1994-2002$ | 2002-2014 \\
\hline 19 & Osório & $1994-2014$ & \begin{tabular}{l|l}
$1994-1998$ & $1998-2001$ \\
$2001-2004$ & $2004-2014$
\end{tabular} & 2006-2014 \\
\hline 20 & Dom Pedrito & $1994-2014$ & 1994-1995 | 1995-2014 & 1994-2001|2001-2014 \\
\hline 21 & Estreito & $1994-2014$ & $\begin{array}{l}1994-1995 \mid 1995-1997 \\
1997-2001 \mid 2001-2013 \\
2013-2014\end{array}$ & $1994-2014$ \\
\hline 22 & Palmar & 1994-2014 & $\begin{array}{l}\text { 1994-1996 | 1996-2000 } \\
2000-2014\end{array}$ & Sem tendência \\
\hline
\end{tabular}

Autor (2016).

Fonte: Vortex (2015).

A influência dos ventos de maior velocidade sobre a série total (tipo 6) é avaliada observando-se o comportamento das séries originais e de ventos com velocidades acima do percentil $75 \%$. Segundo essa métrica, somente os ventos que ocorreram $25 \%$ ou mais no histórico são considerados episódios intensos. Ainda de acordo com o relatório, diferenças nas duas curvas (original e percentil 75\%) podem evidenciar o impacto da variabilidade climática nos ventos de maior velocidade. 
Por fim, as análises sobre a incerteza no longo termo (tipo 7) são elaboradas com base no cálculo do desvio padrão das séries. Considerando a série histórica completa (no caso, com 21 anos de duração), são montadas diversas sub amostras de 1 a 21 anos de duração. A intenção é avaliar o grau de incerteza quando se utilizam amostras de tamanhos inferiores ao total. Naturalmente, quanto menor o tamanho da amostra, maior a incerteza associada a ela.

Com o intuito de validar a qualidade dos dados que compõem a série temporal de vento, primeiramente foi executada uma varredura nas séries com o objetivo de identificar dados faltantes e, em seguida, identificaram-se os dados zerados. É importante mencionar que os zeros nas séries de vento têm significado físico e, portanto, são aceitáveis. Assim, de posse das ocorrências de dados de vento iguais a zero, desenvolveu-se a analise nos dados sucessores e antecessores a essas observações. Dessa maneira, conseguiu-se constatar se o dado zerado era originado por algum tipo de erro ou se realmente naquele momento a ocorrência de vento era nula.

De acordo com a Vortex, os dados fornecidos são considerados validados, ou seja, isento de erros e outliers. Ainda assim, as séries de dados de vento de cada coordenada foram submetidas ao método de detecção de outliers Z-Score Modificado (IGLEZWICZ; HOAGLIN, 1994).

A fundamentação teórica desse método tem como princípio o método Z-Score, que é baseado na propriedade da distribuição Normal que se $X \sim N\left(\mu, \sigma^{2}\right)$ então $Z=(X-\mu) / \sigma \sim N(0,1)$ (SHIFFLER, 1988).

O método Z-Score é muito utilizado na identificação de outliers e de implementação muito variada. Geralmente o Z-Score é definido como:

$$
Z S_{i}=\frac{x_{i}-\hat{\mu}}{\hat{\sigma}}
$$

Onde:

$x_{i}$ é a observação no instante $i=1,2, \ldots, n$, sendo $n$ o tamanho da amostra; $\hat{\mu}$ é a média amostral, e; $\hat{\sigma}$ representa o desvio padrão amostral. 
São calculados tantos ZSi quanto for o tamanho da série. Uma regra geral considera outliers as observações com $|Z S i|$ maior que 3. Este valor pode mudar, dependendo do conjunto de dados ou do critério de decisão adotado. No entanto, de acordo com Shiffler (1988), esse critério também tem seus problemas já que o máximo valor de $|Z S i|$ é $(n-1) / \sqrt{ } n$ e ainda é possível que nenhum $|Z S i|$ dos outliers seja maior que esse limite, especialmente para um conjunto pequeno de dados.

O problema com o método do Z-Score é que $\hat{\mu}$ e $\hat{\sigma}$ podem ser muito afetados por outliers. Uma alternativa é substituí-los por estimadores mais robustos, ou seja, substituir a média amostral $(\mu)$ pela mediana amostral $(\tilde{\mu})$, conforme Equação (80), e o desvio padrão amostral $(\sigma)$ pelo desvio absoluto da mediana (MAD), conforme Equação (81).

$$
\begin{aligned}
& \tilde{\mu}=\left\{\begin{array}{c}
x_{i}\left(\frac{n-1}{2}\right), \text { para } n \text { par } \\
\frac{x_{i}\left(\frac{n}{2}\right)+x_{i}\left(\frac{n}{2}+1\right)}{2}, \text { para } n \text { impar }
\end{array}\right\} \\
& \mathrm{MAD}=\operatorname{mediana}\left\{\left|x_{i}-\tilde{\mu}\right|\right\}
\end{aligned}
$$

Por sua vez, o Z-Score Modificado é determinado por:

$$
\mathrm{ZSM}_{i}=\frac{0,6745 \cdot\left(x_{i}-\tilde{\mu}\right)}{M A D}
$$

Onde: o valor 0,6745 é devido ao valor esperado do $M A D$, ou $E(M A D)=0,6745 \hat{\sigma}$, para um valor $n$ elevado e dados com distribuição Normal.

As observações são identificadas como outliers se $|Z S M i|>3,5$. Ressalta-se que para a aplicação do procedimento de detecção de outliers os eventuais valores nulos foram removidos das séries, para não influir no cálculo das estatísticas.

A TABELA 33 contém dados estatísticos referentes a velocidade do vento para cada uma das 22 coordenadas. Na primeira coluna tem-se a velocidade média amostral, na segunda coluna o desvio padrão amostral e na terceira a mediana amostral desses dados. $\mathrm{O}$ desvio padrão e a mediana foram empregadas no cálculo 
do Z-Score Modificado, método implementado em linguagem Matlab. Os resultados são exibidos em termos de percentuais de outliers na quarta coluna. Por fim, a última coluna exibe o percentual de dados zerados em cada uma das coordenadas no período estudado.

O que se observa é que as coordenadas mais ao Sul e afastadas do litoral apresentam as menores velocidades médias. A exceção é a estação Medonho (na tríplice divisa entre os Estados do Piauí, Pernambuco e Bahia) que, mesmo estando no interior do continente, apresenta velocidades de vento elevadas. De um modo geral, o litoral Nordeste apresenta as maiores velocidades médias, seguido do litoral do Estado do Rio Grande do Sul.

TABELA 33 - Resultado da Aplicação do Método Z-Score Modificado.

\begin{tabular}{|c|c|c|c|c|c|c|}
\hline Série & Estado & $\begin{array}{c}\text { Velocidade Média } \\
(\mathrm{m} / \mathrm{s})\end{array}$ & $\begin{array}{c}\text { Desvio Padrão } \\
(\mathrm{m} / \mathrm{s})\end{array}$ & Mediana $(\mathrm{m} / \mathrm{s})$ & Outliers (\%) & $\begin{array}{c}\text { Zeros } \\
\text { (\%) }\end{array}$ \\
\hline Parnaiba & $\mathrm{PI}$ & 9,45 & 2,22 & 9,50 & 7,95 & 0,00 \\
\hline Parada & CE & 7,66 & 1,93 & 7,80 & 16,00 & 0,00 \\
\hline São João & RN & 8,72 & 1,82 & 8,80 & 22,62 & 0,00 \\
\hline Medonho & $\mathrm{PI}$ & 8,67 & 2,41 & 8,70 & 2,33 & 0,00 \\
\hline Macambira & RN & 8,76 & 1,85 & 8,80 & 7,14 & 0,00 \\
\hline Forquilha & RN & 7,62 & 1,93 & 7,60 & 2,62 & 0,00 \\
\hline Tavares & PB & 6,25 & 1,57 & 6,30 & 5,29 & 0,05 \\
\hline Sertania & PE & 6,50 & 1,77 & 6,50 & 2,14 & 0,00 \\
\hline Afranio & PE & 8,75 & 3,23 & 9,20 & 0,00 & 0,14 \\
\hline Palmas & PR & 6,87 & 3,00 & 5,10 & 1,14 & 0,33 \\
\hline Quilombo & SC & 5,38 & 3,06 & 4,70 & 16,81 & 0,81 \\
\hline Tubarão & SC & 5,89 & 3,06 & 6,80 & 0,57 & 0,48 \\
\hline Osório & RS & 7,08 & 3,59 & 5,00 & 38,67 & 0,24 \\
\hline Dom Pedrito & RS & 6,51 & 2,83 & 5,60 & 0,90 & 0,90 \\
\hline Estreito & RS & 7,71 & 3,15 & 6,80 & 16,33 & 0,14 \\
\hline Palmar & RS & 7,50 & 2,92 & 7,50 & 23,90 & 0,14 \\
\hline Itaguaçu & BA & 5,37 & 2,28 & 5,30 & 0,00 & 0,57 \\
\hline Boninal & BA & 6,98 & 2,13 & 7,00 & 0,05 & 0,05 \\
\hline Jacaraci & BA & 6,63 & 2,05 & 3,80 & 5,14 & 0,05 \\
\hline Olho D'agua & MG & 3,90 & 1,83 & 3,60 & 3,48 & 0,86 \\
\hline Riachuelo & SP & 3,79 & 1,81 & 5,50 & 13,86 & 0,86 \\
\hline Anta & PR & 3,89 & 2,55 & 3,40 & 43,52 & 2,81 \\
\hline
\end{tabular}

Os dados zerados podem significar tanto outliers como períodos sem ventos. Isso pode ficar mais evidente na coordenada de Afranio, onde não foram detectados 
outliers e, ainda assim, $0,14 \%$ da série é formada por zeros. Itaguaçu é outro exemplo de um caso semelhante.

Naturalmente, a quantidade de zeros está diretamente relacionada com a magnitude das velocidades médias em cada coordenada. Quanto mais baixa a velocidade, maior o percentual de zeros.

O método Z-Score Modificado foi aplicado para cada coordenada geográfica e elaborado o seguinte conjunto de gráficos:

a) dados horários de velocidade de vento $(\mathrm{m} / \mathrm{s})$, com destaque para os dados zerados e os dados considerados outliers;

b) velocidade média mensal para o período, representada pela linha central (em azul). São também apresentados um desvio padrão abaixo e acima (em vermelho).

c) histograma de frequências absolutas da velocidade, considerando todos os valores da série histórica.

A seguir, apresenta-se a aplicação do método para a série temporal da coordenada Anta. A série temporal de dados de vento na coordenada Anta, tem $43,52 \%$ de dados detectados como outliers e $2,81 \%$ de dados zerados (TABELA 33). Apesar do valor representativo de outliers, essas ocorrências não são consideradas dados atípicos, pois analisando a série percebe-se que a velocidade do vento cresce gradativamente até atingir um ponto máximo e em seguida decresce também gradualmente. $\mathrm{O}$ mesmo ocorre nos dados iguais a zero, levando a acreditar que naquele momento as ocorrências de vento se caracterizavam por valores de velocidade praticamente nulos. Naturalmente, a quantidade de zeros está diretamente relacionada com a magnitude das velocidades médias em cada posto. No geral, quanto mais baixa a velocidade, maior o percentual de zeros, como no caso série da coordenada Anta. Os dados zerados podem significar tanto outliers como períodos sem ventos.

A elevada quantidade de outliers também pode ser explicada teoricamente. $\mathrm{O}$ método Z-Score Modificado foi desenvolvido para amostras com distribuição aproximadamente Normal (e.g. Gaussiana), como o próprio equacionamento evidencia.

Ao analisar os histogramas da série de Anta, nota-se claramente que os dados possuem uma distribuição assimétrica, cujo ajuste poderia ser representado por 
distribuições das famílias de Valores Extremos Generalizados (Generalized Extreme Values - GEV, como as distribuições Weibull e Gumbel), Pearson (como as distribuições Beta e Gama) e a distribuição Log-Normal. De fato, consoante item 4.1, a distribuição de Weibull é muito empregada na modelagem de dados de velocidade de vento.

O Gráfico 73 apresenta os dados horários de velocidade de vento da coordenada Anta, com destaque para os dados zerados (em verde) e os dados considerados outliers (em vermelho).

O Gráfico 74 apresenta a velocidade média mensal da coordenada Anta representada pela linha central (em azul) e um desvio padrão abaixo e acima (em vermelho). O Gráfico 75 apresenta o histograma de frequências absolutas no qual o eixo das abcissas representa as velocidades médias de vento e o eixo das ordenadas o número de vezes que uma dada velocidade ocorreu na coordenada Anta. Para a realização deste gráfico, foram considerados todos os valores da série histórica.

Gráfico 73 - Série Histórica da Velocidade Horária do Vento da Coordenada Anta para o Período de 1994 a 2014.

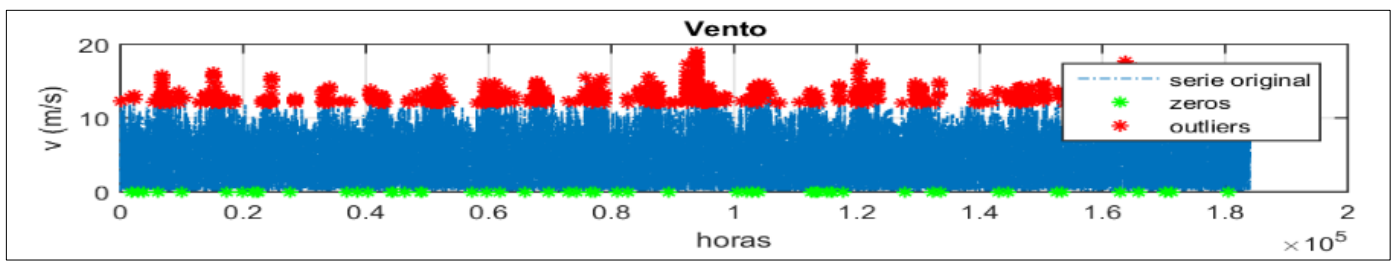

Autor (2016).

Gráfico 74 - Série Histórica da Velocidade Média Mensal da Coordenada Anta para o Período de 1994 a 2014.

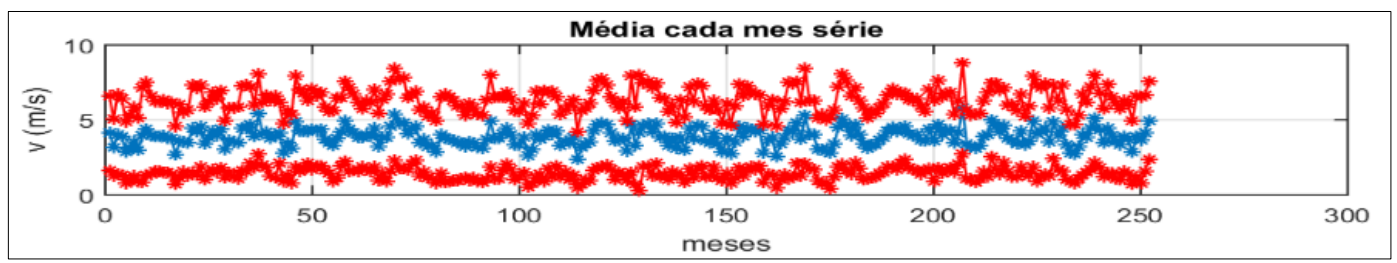

Autor (2016).

Gráfico 75 - Histograma da Velocidade do Vento da Coordenada Anta para o Período de 1994 a 2014.

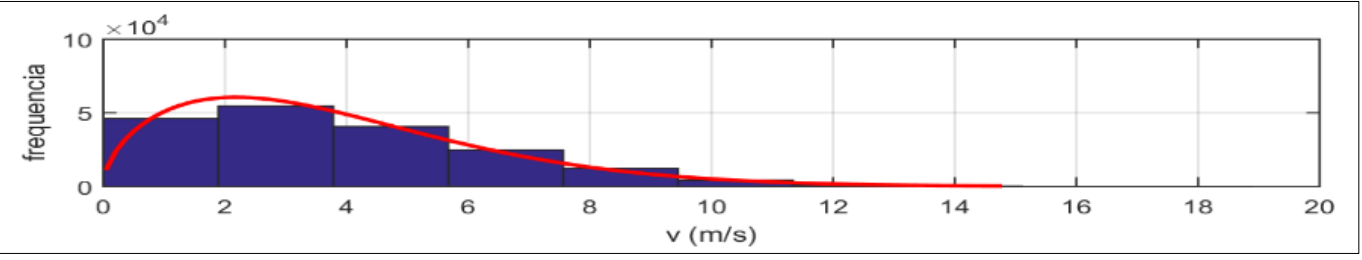

Autor (2016). 
Validados os dados das séries de vento, o próximo passo do modelo proposto é a estimativa da energia gerada, em base mensal e em base horária, conforme detalhado no tópico seguinte.

\subsubsection{Aerogeradores Comerciais Instalados no Brasil}

A série histórica de energia gerada foi obtida a partir da fundamentação apresentada no item 4.4. Inicialmente foi necessária a escolha da curva de potência do aerogerador. Para tal, foi realizado a pesquisa dos fabricantes com o maior número de equipamentos instalados no Brasil.

De acordo com o levantamento realizado em dezembro de 2015 pela ABEEólica, 11 (onze) fabricantes possuem equipamentos aerogeradores instalados no Brasil, de forma que 7 (sete) deles detêm 89\% do mercado (Gráfico 76). As empresas GE, Gamesa e Alstom ${ }^{88}$ possuem as maiores participações, somando 56\%. As empresas Wobben/Enercon, Impsa ${ }^{89}$, Acciona e Vestas somam outros $33 \%$ de participação.

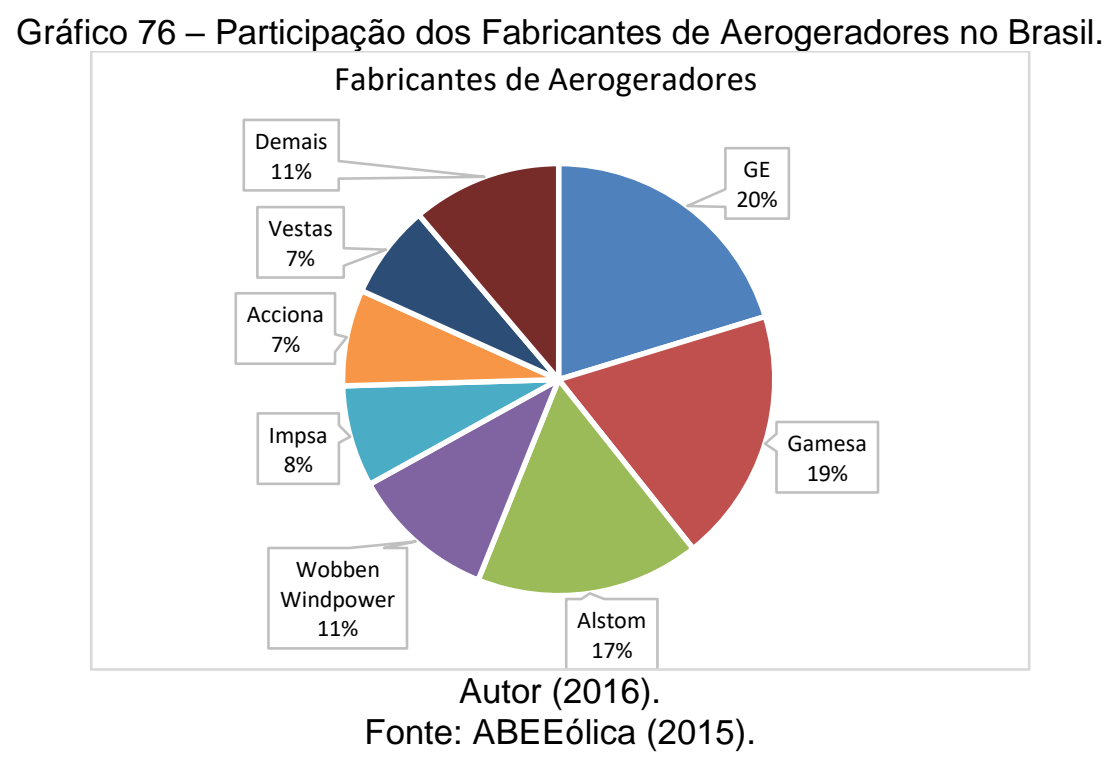

${ }^{88}$ EM 2014 a GE anunciou a compra dos ativos da Alstom.

89 A Wind Power, subsidiária da argentina Impsa e uma das empresas âncoras do Complexo Industrial e Portuário de Suape, na Região Metropolitana do Recife, teve sua falência decretada pelo Tribunal de Justiça de Pernambuco em 2014. 
Selecionou-se os aerogeradores dos 6 (seis) fabricantes de maior participação no mercado nacional, limitando a potência de cada turbina para a faixa entre 2.000 KW e $3.000 \mathrm{KW}$, novamente em concordância com os tipos de equipamentos instalados nos parques eólicos brasileiros. As características de cada aerogerador utilizados são fornecidas na TABELA 34.

TABELA 34 - Características Gerais dos Aerogeradores Selecionados.

\begin{tabular}{llll}
\hline Empresa & Equipamento & Potência nominal (KW) & Diâmetro do rotor (m) \\
\hline GE Wind Energy & GE 2.5/88 & 2500 & 88 \\
GE Wind Energy & GE 2.5/100 & 2500 & 100 \\
Gamesa & G87 & 2000 & 87 \\
Gamesa & G90 & 2000 & 90 \\
Gamesa & G97 & 2000 & 97 \\
Vestas & V80 & 2000 & 80 \\
Vestas & V90 & 2000 & 90 \\
Wobben/Enercon & E-115 & 2500 & 115,7 \\
Alstom & ECO 110 & 3000 & 110 \\
Alstom & ECO 100 & 3000 & 100 \\
IMPSA & IWP 83 & 2100 & 83 \\
IMPSA & IWP 100 & 2000 & 100 \\
\hline \multicolumn{4}{c}{ Autor (2016). } \\
& \multicolumn{2}{c}{ Fonte: Suisse Éole (2015). }
\end{tabular}

As curvas dos aerogeradores foram coletadas da Suisse Éole (2015), uma associação suíça de produtores de energia eólica e que dispõe de site com diversas informações relacionadas. Dentre estas, há uma seção específica para curva de potência de aerogeradores, que guarda grande parte dos dados dos fabricantes selecionados. Alstom e IMPSA não possuem dados nessa fonte e suas curvas foram obtidas diretamente dos catálogos dos fabricantes. O Gráfico 77 exibe as curvas dos aerogeradores relacionados na TABELA 34 .

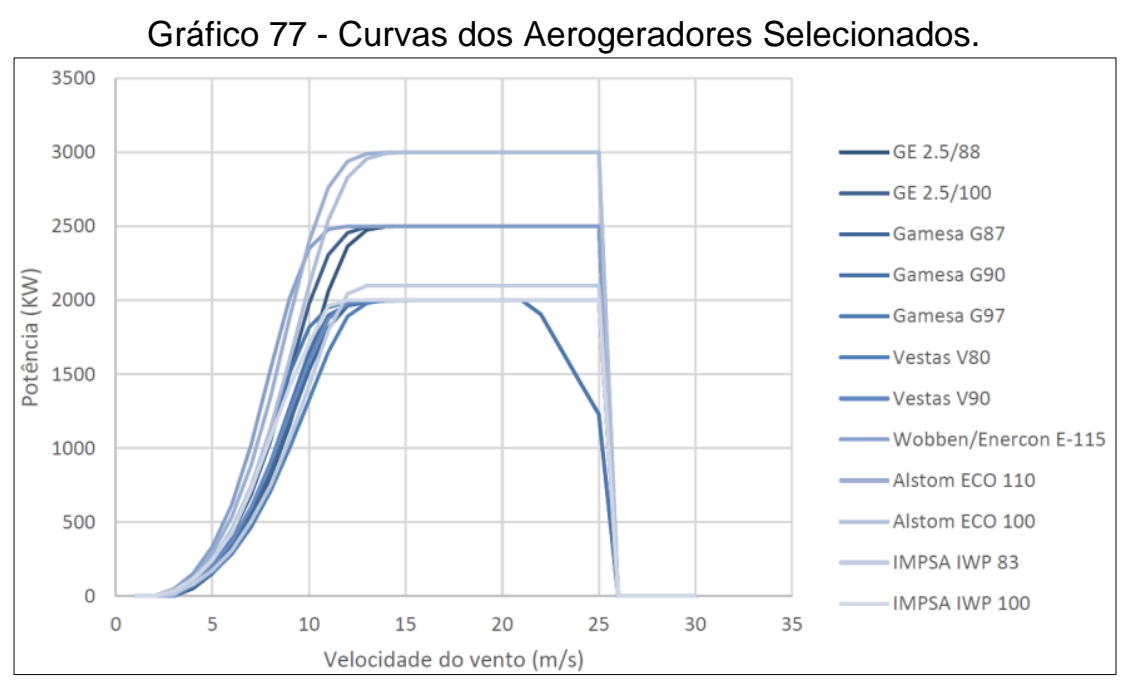

Autor (2016).

Fonte: Suisse Éole, (2015) e Catálogo dos Fabricantes Alstom e IMPSA. 
Todos os equipamentos trabalham com uma velocidade de corte (cut off) de 25 $\mathrm{m} / \mathrm{s}$. Isso significa que quando os ventos atingem esse patamar de velocidade, a geração de energia é interrompida por motivos de segurança das estruturas. Nota-se que, além da potência máxima gerada, a grande distinção entre as curvas se dá na faixa de ventos entre 5 e $15 \mathrm{~m} / \mathrm{s}$. Isso é importante porque esse intervalo concentra a maioria dos registros de velocidade.

\subsubsection{Estimativa da Energia Gerada}

Nos próximos itens são descritas as formas de obtenção das séries históricas de energia gerada, base para a aplicação da metodologia de seleção dos portfólios. Trata-se da conversão das séries de velocidade de vento $(\mathrm{m} / \mathrm{s})$ em energia (MWh ou MWmédio, dependendo da escala temporal considerada). A divisão de escalas temporais está baseada na escala original dos dados de vento (base horária, obtida da Vortex) e nas curvas dos aerogeradores selecionados (item 5.2.2 - Aerogeradores Comerciais Instalados no Brasil).

\subsubsection{Estimativa da Energia Gerada - Base Horária}

A relação entre velocidade de vento e potência eólica foi apresentada no item 4.4, e é explicada pela Equação (9) (CUSTÓDIO, 2009). Em termos de energia, a referida equação pode ser reescrita pela Equação (83).

$$
\frac{E}{t}=\frac{1}{2} \rho A v^{3}
$$

Onde: $E$ é a energia gerada em um intervalo de tempo $t$ e $v$ um valor de velocidade que se admite praticamente constante no intervalo de tempo $t$.

Considerando que as séries históricas de vento utilizadas no projeto são de base horária (e.g. $t=1$ hora), a Equação (83) pode ser utilizada para expressar diretamente a energia em MWh em base horária. 
No entanto, os aerogeradores não são capazes de transformar toda a energia potencial do vento em energia mecânica devido a perdas aerodinâmicas, elétricas e mecânicas presentes em todo o processo, que são expressas pelo coeficiente de potência $\left(C_{p}\right)$, este por sua vez, varia com a velocidade do vento, em razão da variação da eficiência aerodinâmica das pás do rotor com a velocidade do vento (ver Equação (14) no item 4.4 e Gráfico 78). Desta forma, a Equação (83) é reescrita para se incluir no equacionamento, coeficiente de potência $\left(C_{p}\right)$.

$$
E=\frac{1}{2} \rho A v^{3} c_{p}
$$

Onde:

$c_{p}$ é o coeficiente de potência, que represente o rendimento do aerogerador e, $t=1$ hora.

Os diversos fabricantes de aerogeradores fornecem curvas de potência que já consideram o coeficiente de potência. Por exemplo, o Gráfico 78 exibe a curva do aerogerador Enercon E-115, com potência nominal de $2.500 \mathrm{~kW}$.

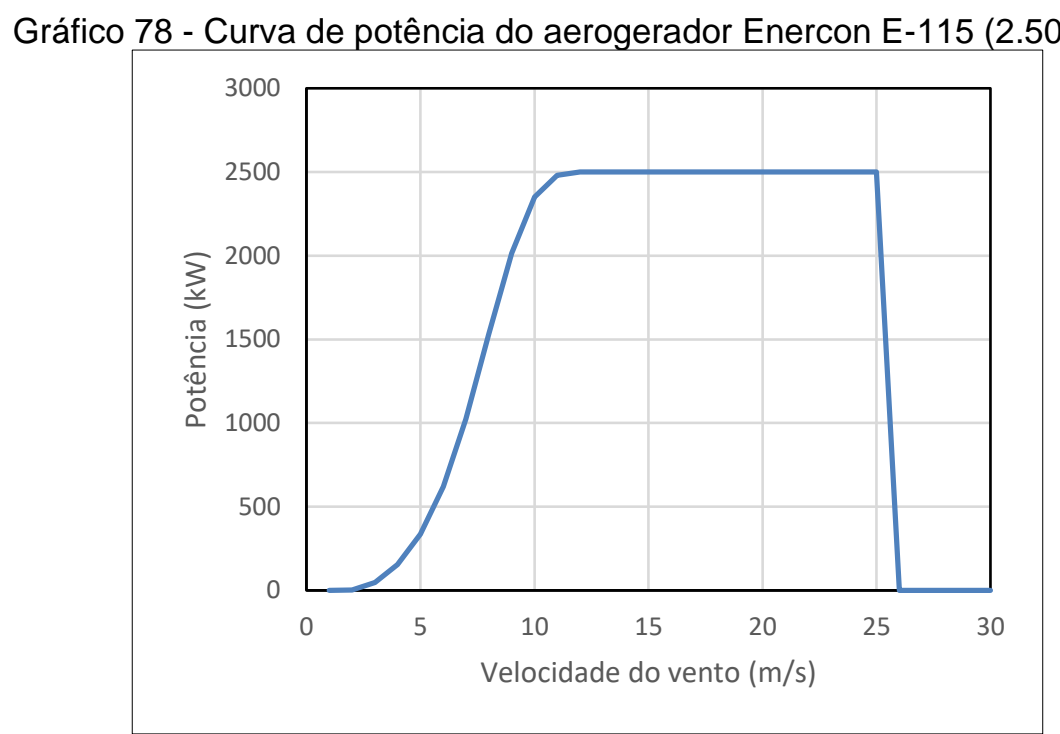

$$
\text { Autor (2016). }
$$

Fonte: Catálogo do fabricante Enercon. 
Há pelo menos duas formas de se obter a série de energia gerada. Uma forma de obter as séries horárias de energia gerada seria consultar diretamente a curva do aerogerador para cada valor de velocidade de vento. Todavia, esse processo possui algumas limitações teóricas, pois o coeficiente de potência $\left(c_{p}\right)$ não é constante e varia com a velocidade. Mesmo não sendo significativa, essa variação agrega imprecisões ao processo.

A solução nesse caso, que consiste na outra forma de obter a série de dados, é determinar um valor de $c_{p}$ para cada ponto da curva de potência (e.g. 30 pontos) e, na sequência, aplicar a Equação (84) para encontrar a energia gerada em base horária.

Utilizando-se dos dados adquiridos para o projeto, a determinação das séries de energia gerada foi feita seguindo o segundo método, por se considerar o mais preciso. Além das séries de vento, estão disponíveis também as séries horárias de densidade do ar, o que permite a aplicação das equações anteriormente mostradas.

Os coeficientes $c_{p}$, para cada ponto da curva de potência, foram calculados através de três passos: (i) seleção da curva de potência do aerogerador desejado; (ii) determinação da potência eólica usando a Equação (83) e (iii) divisão dos resultados dos passos (i) e (ii), para obter os coeficientes $c_{p}$.

O cálculo do passo (ii) deve ser realizado para a mesma gama de velocidades de vento utilizadas na curva de potência do aerogerador. Em outras palavras, se a curva contiver valores de energia definidos para 30 pontos (velocidades de 1 a $30 \mathrm{~m} / \mathrm{s}$, como no caso do aerogerador Enercon apresentado no Gráfico 78), a Equação (83) deverá ser aplicada para $v=1, \ldots, 30 \mathrm{~m} / \mathrm{s}$. Ao final do processo, obteve-se a curva de coeficientes de potência, que será utilizada na determinação da energia gerada.

A fim de ilustrar o processo, mostra-se um exemplo de cálculo dos coeficientes de potência para o aerogerador GE 2.5/88, com potência nominal de $2.500 \mathrm{~kW}$ e diâmetro do rotor de $88 \mathrm{~m}$ (área de $6.082 \mathrm{~m}^{2}$ ). Os cálculos dos passos (ii) e (iii) são exibidos na TABELA 35. 
TABELA 35 - Exemplo de Cálculo para Determinação dos Coeficientes de Potência do Aerogerador

\begin{tabular}{cccc}
\multicolumn{4}{c}{ GE 2.5/88. } \\
\hline $\begin{array}{c}\text { Velocidade do } \\
\text { vento }(\mathrm{m} / \mathrm{s})\end{array}$ & $\begin{array}{c}\text { Potência do } \\
\text { aerogerador }(\mathrm{kW})\end{array}$ & $\begin{array}{c}\text { Potência } \\
\text { eólica }(\mathrm{kW})\end{array}$ & $\begin{array}{c}\text { Coeficiente de } \\
\text { potência }\end{array}$ \\
\hline 1 & 0 & 4 & 0 \\
2 & 0 & 28 & 0 \\
3 & 0 & 95 & 0 \\
4 & 53 & 226 & 0,234 \\
5 & 153 & 442 & 0,346 \\
6 & 304 & 764 & 0,398 \\
7 & 517 & 1.213 & 0,426 \\
8 & 800 & 1.810 & 0,442 \\
9 & 1.156 & 2.577 & 0,449 \\
10 & 1.616 & 3.535 & 0,457 \\
11 & 2.061 & 4.705 & 0,438 \\
12 & 2.366 & 6.109 & 0,387 \\
13 & 2.477 & 7.767 & 0,319 \\
14 & 2498 & 9.701 & 0,258 \\
15 & 2.500 & 11.931 & 0,210 \\
16 & 2.500 & 14.480 & 0,173 \\
17 & 2.500 & 17.368 & 0,144 \\
18 & 2.500 & 20.617 & 0,121 \\
19 & 2.500 & 24.248 & 0,103 \\
20 & 2.500 & 28.281 & 0,088 \\
21 & 2.500 & 32.739 & 0,076 \\
22 & 2.500 & 37.643 & 0,066 \\
23 & 2.500 & 43.012 & 0,058 \\
24 & 2.500 & 48.870 & 0,051 \\
25 & 2.500 & 55.237 & 0,045 \\
26 & 0 & 62.134 & 0 \\
27 & 0 & 69.583 & 0 \\
28 & 0 & 77.604 & 0 \\
29 & 0 & 86.219 & 0 \\
30 & 0 & 95.450 & 0 \\
\hline & Autor & &
\end{tabular}

Autor (2016).

A segunda coluna da TABELA 35 exibe a curva do aerogerador fornecida pelo fabricante. A terceira coluna, por sua vez, é o resultado do passo (ii) através da aplicação da Equação (83). Evidentemente, os valores da potência eólica crescem com o aumento da velocidade e não contam com as limitações de funcionamento do aerogerador. Por fim, a quarta coluna é o resultado do passo (iii), ou seja, corresponde à razão entre os valores das colunas dois e três. Para melhor visualização, o Gráfico 79 confronta a curva de potência do aerogerador com a série de coeficientes de potência calculados. 
Gráfico 79 - Comparativo entre as Curvas de Potência e Coeficientes de Potência para o Aerogerador GE 2.5/88.

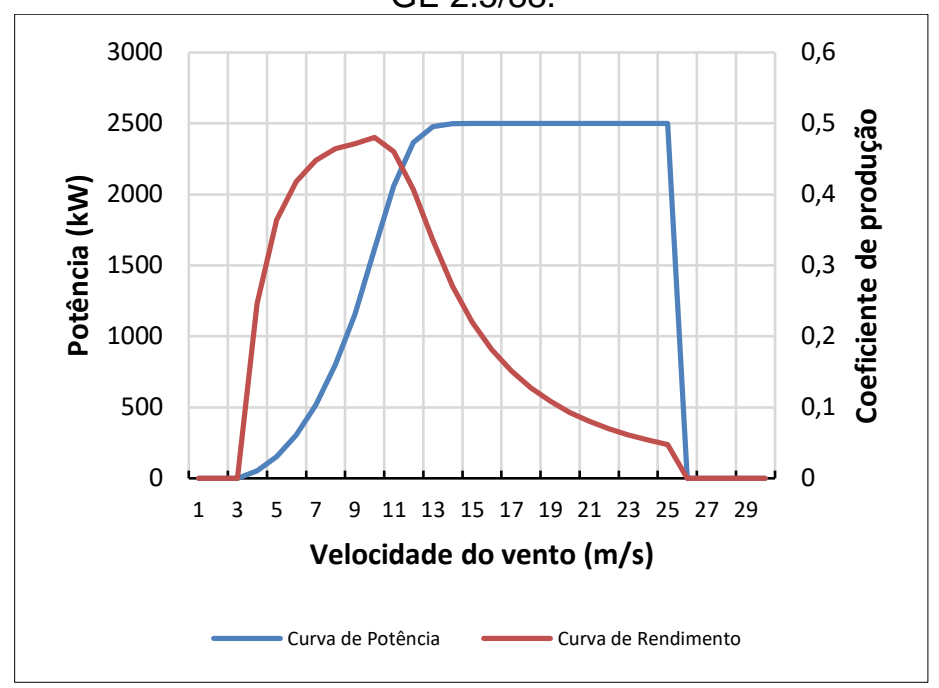

Autor (2016).

É interessante notar as evidentes diferenças entre as curvas. A faixa na qual o rendimento do aerogerador é maior se situa nas velocidades intermediárias (entre $5 \mathrm{e}$ $13 \mathrm{~m} / \mathrm{s}$ ), decaindo com o aumento da velocidade. Nesse sentido, velocidades maiores de vento geram mais energia, entretanto com menores rendimentos do equipamento aerogerador.

A curva de rendimento resultante desse processo é, finalmente, utilizada na Equação (83) para a determinação da energia gerada. Nesse caso, utilizam-se as séries históricas de vento na consulta aos coeficientes de produção. Para velocidades não inteiras, uma interpolação linear simples é aplicada.

Continuando o exemplo anterior, selecionou-se a coordenada Parnaíba (TO) e calculou-se a série de energia horária. Porém, a título de comparação, calculou-se também a geração horária utilizando diretamente a curva do aerogerador. Os resultados são mostrados no Gráfico 80 para um período de 24 horas, para facilitar a interpretação. Plotaram-se também as diferenças percentuais entre as duas metodologias de cálculo. 
Gráfico 80 - Diferenças entre a Energia Gerada quando Calculada e Interpolada Diretamente da Curva do Aerogerador (cálculos para Parnaíba - TO).

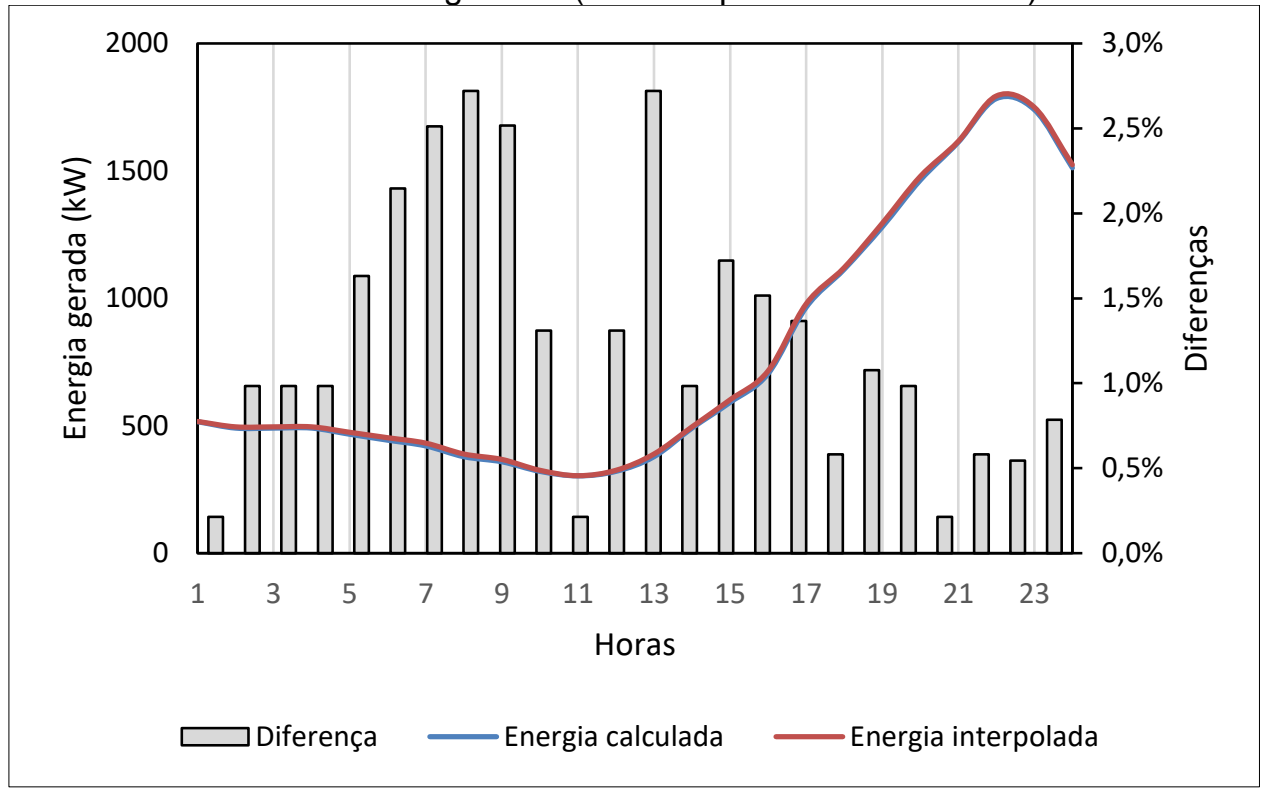

Autor (2016).

Através das curvas é difícil perceber distinções entre as energias calculadas pelos dois métodos. Entretanto, as diferenças ficam mais evidentes através das barras verticais que chegam a superar a marca dos $2,5 \%$.

Vale mencionar que as diferenças foram determinadas com base na energia interpolada diretamente da curva do aerogerador. Por terem resultado todas positivas, é possível concluir que a geração oferecida na curva do fabricante é ligeiramente maior do que a calculada. O mesmo padrão foi observado para os demais aerogeradores e coordenadas.

O Gráfico 81 e o Gráfico 82 ilustram o resultado do processo para as séries de energia gerada horária para as coordenadas Dom Pedrito (RS) e Afrânio (PE), respectivamente, para o aerogerador Enercon E-115 (2.500 kW). Para todos os meses de janeiro da série histórica foi plotado o pior, melhor e o mês que representa a média. No caso da coordenada Dom Pedrito, o pior mês de janeiro ocorreu em 2014, o melhor em 2004 e o que representa a média foi o mês de janeiro de 2002. No caso da coordenada Afrânio, o pior mês de janeiro ocorreu em 1994, o melhor em 2006 e o que representa a média foi o mês de janeiro de 2011. 
Gráfico 81 - Séries de Energia Gerada Horária para a Coordenada Dom Pedrito (RS) - Aerogerador Enercon E-115 (2.500 kW) - Janeiro de 2002, 2004 e 2014.

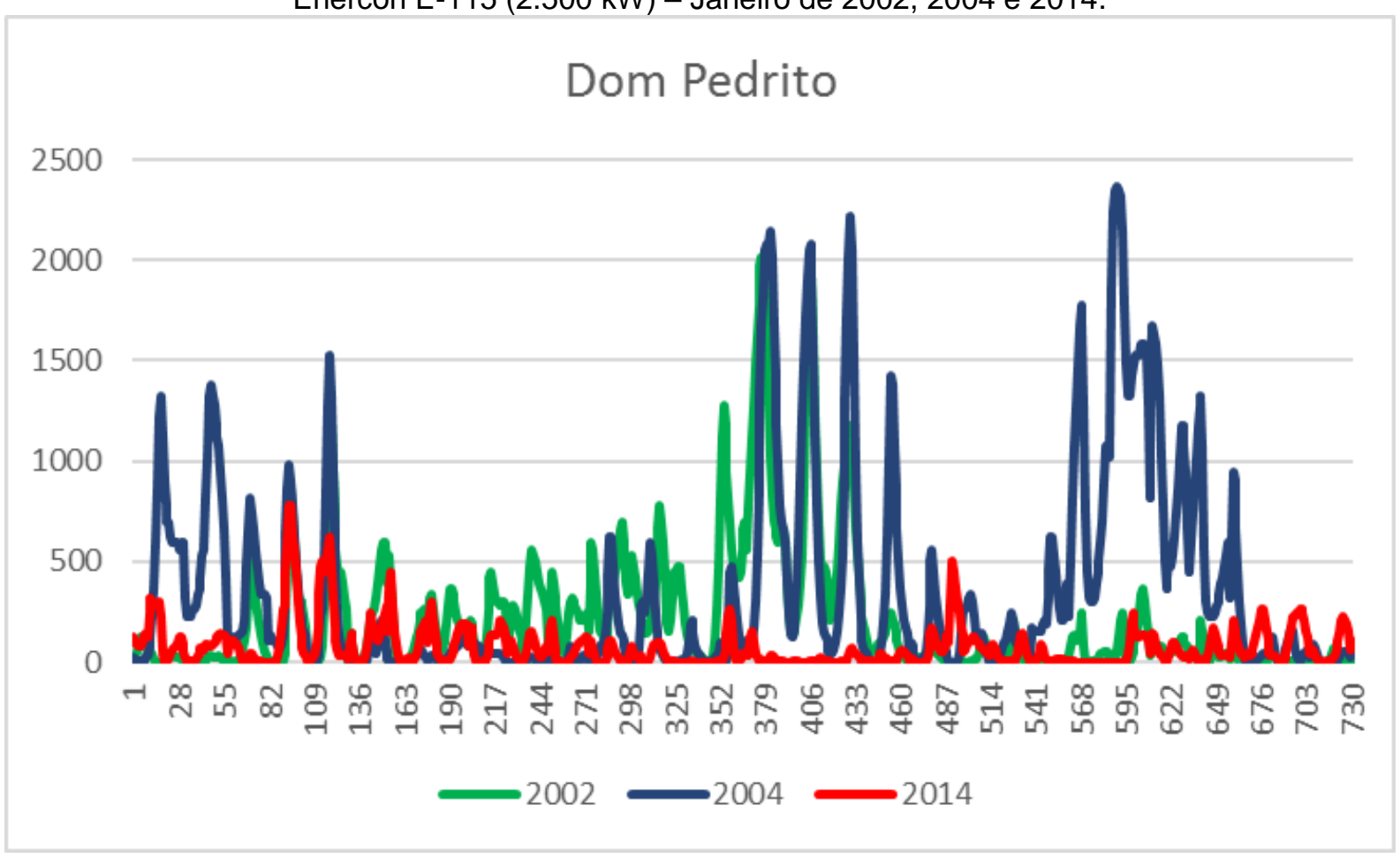

Autor (2016).

Gráfico 82 - Séries de Energia Gerada Horária para a Coordenada Afrânio (PE) - Aerogerador Enercon E-115 (2.500 kW) - Janeiro de 1994, 2006 e 2011.

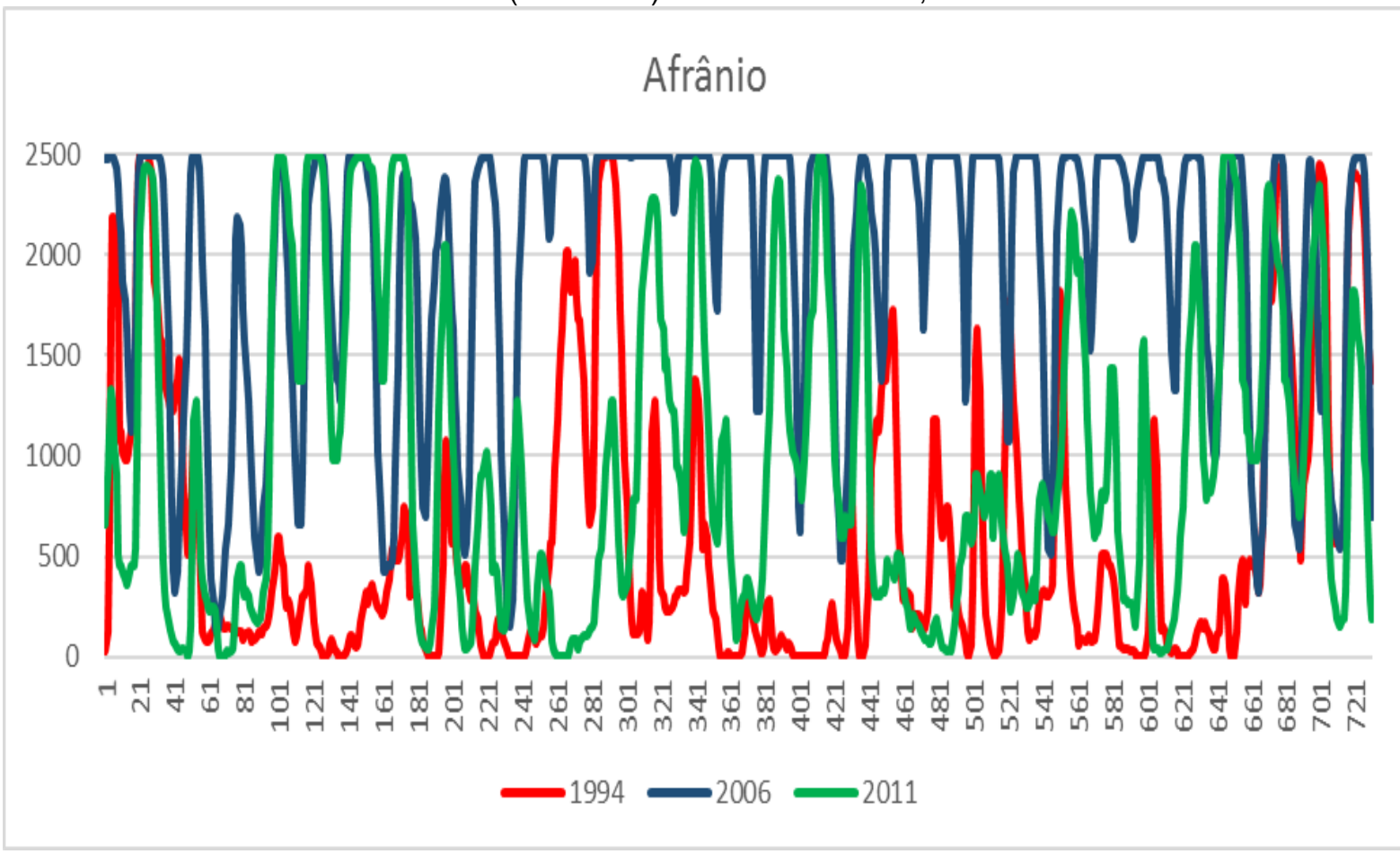

Autor (2016).

O método selecionado foi repetido para todas as 22 coordenadas e para os 12 aerogeradores selecionados (TABELA 34), obtendo-se 264 séries de energia gerada 
horária para o período de 01/01/1994 a 31/12/2014 (cada série com 183.960 pontos, resultado do produto do número de anos pela quantidade de horas no ano). Para cada coordenada foram obtidas 12 séries (uma série para cada modelo de aerogerador).

\subsubsection{Estimativa da Energia Gerada - Base Mensal}

A energia gerada em base mensal é obtida através da integralização da geração em base horária. Uma maneira direta de se obter a energia mensal em $\mathrm{MWh}$ seria somar, mês a mês, as energias horárias calculadas conforme item anterior. Há, no entanto, outra forma de determina-la sem ter que depender do cálculo da energia em base horária, por meio da aplicação da Equação (15).

A função densidade de probabilidade da velocidade do vento $p(v)$ da Equação (15) pode ser determinada de duas maneiras distintas. A primeira, teórica, é através da aplicação de uma função densidade de probabilidades que represente o perfil de velocidades de vento.

Conforme abordado no item 4.3, as distribuições normal, exponencial e de Rayleigh (Equação (5)) podem ser empregadas, no entanto a distribuição de Weibull (Equação (6)) é a mais utilizada para esse fim.

Mesmo que a distribuição de Weibull consiga simular uma boa gama de perfis de vento, a determinação da energia gerada em um mês não é inteiramente precisa. Isso porque a função densidade de probabilidades apenas modela a série de ventos, ou seja, esta é tão somente uma representação da realidade. Além disso, existem incertezas na definição dos parâmetros da distribuição (parâmetros k e c da Equação (6)), mesmo que feitos mês a mês.

Uma melhoria nesse sentido é alcançada através do segundo método para determinação de $p(v)$, baseado em uma técnica empírica. Nesse método, as séries de velocidades de vento são categorizadas em histogramas de frequência relativa que contabilizam o percentual de observações em uma determinada faixa de velocidades. Cada percentual $p(v)$ é, então, diretamente substituído na Equação (15). A energia mensal (em MW médios) será a soma dos resultados em todas as classes. Ressaltase que esse método não considera as séries de densidade do ar, o que não é problemático na medida em que a variação da altitude das coordenadas é pequena. 
O método empírico foi o selecionado para a determinação das energias mensais. Por esse motivo, um exemplo ilustrativo é apresentado a seguir. Considerase a coordenada Parada (no Estado do CE) e o aerogerador Enercon E-115 visando determinar a energia gerada no mês de janeiro de 1994. O primeiro passo é determinar o histograma de frequências relativas da velocidade do vento para o referido mês. Apesar de intuitivo, é importante frisar que o número de classes de velocidades de vento a ser utilizado deve coincidir com o número de faixas da curva de potência do aerogerador para ser possível a aplicação da Equação (15). No caso, o número de classes empregadas é 30 , separadas em intervalos de $1 \mathrm{~m} / \mathrm{s}$. O Gráfico 83 exibe o histograma resultante, juntamente com a curva do aerogerador Enercon E115.

Gráfico 83 - Histograma de Frequências Relativas para Janeiro de 1994 na Coordenada Parada (CE) e Curva de Potência do Aerogerador Enercon E-115 (2.500 kW).

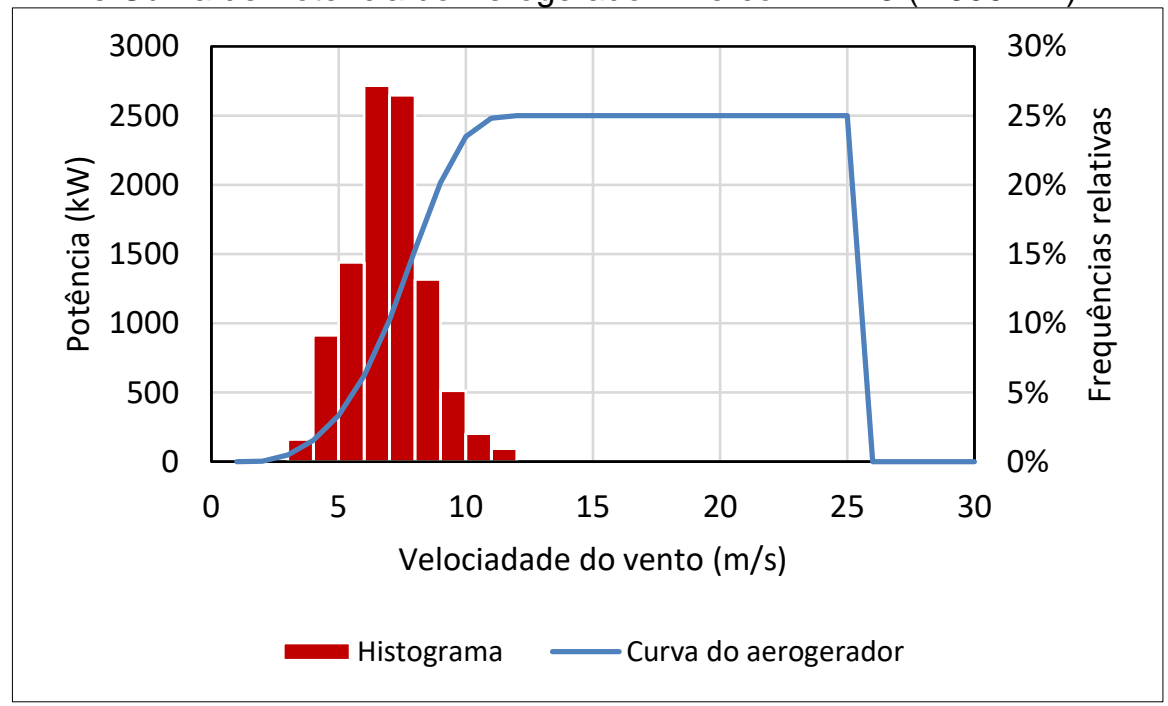

Autor (2016).

A interpretação do histograma é feita da seguinte maneira: o percentual de cada barra representa a frequência com que a velocidade associada ocorreu no período. Assim, por exemplo, em aproximadamente 2\% do tempo no mês de janeiro de 1994 as velocidades do vento ficaram entre 3 e $4 \mathrm{~m} / \mathrm{s}$; em aproximadamente $9 \%$ do tempo as velocidades variaram entre 4 e $5 \mathrm{~m} / \mathrm{s}$ e assim por diante. No caso da coordenada Parada, as velocidades se concentraram entre 3 e 12 m/s não ocorrendo registros inferiores ou superiores a esse intervalo.

Para a determinação da energia gerada nesse mês, foi elaborada a TABELA 36 com o detalhamento do cálculo. 
TABELA 36 - Processo de Cálculo Empírico da Energia Gerada no mês de Janeiro de 1994 para a Coordenada Parada (CE), Utilizando o Aerogerador Enercon E-115.

\begin{tabular}{|c|c|c|c|}
\hline $\begin{array}{l}\text { Faixas de velocidade } \\
\text { do vento }(\mathrm{m} / \mathrm{s})\end{array}$ & $\begin{array}{l}\text { Curva de Potência } \\
\text { do aerogerador } \\
\text { (kW) }\end{array}$ & $\begin{array}{l}\text { Frequências } \\
\text { relativas da } \\
\text { Velocidade }\end{array}$ & $\begin{array}{l}\text { Energia gerada por } \\
\text { faixa (kWmédio) }\end{array}$ \\
\hline 1 & 0 & $0 \%$ & 0 \\
\hline 2 & 3 & $0 \%$ & 0 \\
\hline 3 & 48 & $0 \%$ & 0 \\
\hline 4 & 153 & $1,61 \%$ & 2 \\
\hline 5 & 335 & $9,14 \%$ & 31 \\
\hline 6 & 620 & $14,38 \%$ & 89 \\
\hline 7 & 1023 & $27,15 \%$ & 278 \\
\hline 8 & 1530 & $26,48 \%$ & 405 \\
\hline 9 & 2015 & $13,17 \%$ & 265 \\
\hline 10 & 2350 & $5,11 \%$ & 120 \\
\hline 11 & 2480 & $2,02 \%$ & 50 \\
\hline 12 & 2500 & $0,94 \%$ & 24 \\
\hline 13 & 2500 & $0 \%$ & 0 \\
\hline 14 & 2500 & $0 \%$ & 0 \\
\hline 15 & 2500 & $0 \%$ & 0 \\
\hline 16 & 2500 & $0 \%$ & 0 \\
\hline 17 & 2500 & $0 \%$ & 0 \\
\hline 18 & 2500 & $0 \%$ & 0 \\
\hline 19 & 2500 & $0 \%$ & 0 \\
\hline 20 & 2500 & $0 \%$ & 0 \\
\hline 21 & 2500 & $0 \%$ & 0 \\
\hline 22 & 2500 & $0 \%$ & 0 \\
\hline 23 & 2500 & $0 \%$ & 0 \\
\hline 24 & 2500 & $0 \%$ & 0 \\
\hline 25 & 2500 & $0 \%$ & 0 \\
\hline 26 & 0 & $0 \%$ & 0 \\
\hline 27 & 0 & $0 \%$ & 0 \\
\hline 28 & 0 & $0 \%$ & 0 \\
\hline 29 & 0 & $0 \%$ & 0 \\
\hline 30 & 0 & $0 \%$ & 0 \\
\hline \multicolumn{3}{|c|}{ Energia total no mês (kWmédio) } & 1.264 \\
\hline
\end{tabular}

A segunda coluna da TABELA 36 é a curva de potência do aerogerador. A terceira coluna é o histograma de frequências relativas da velocidade do vento de janeiro de 1994, o mesmo mostrado na Gráfico 83. A última coluna é a energia gerada por faixa de velocidades, obtida a partir da multiplicação entre os elementos da segunda e terceira colunas. Por fim, na base da tabela está a energia gerada no mês (em kWmédios), resultado da soma dos elementos da quarta coluna. Dessa maneira, a energia gerada em janeiro de 1994 foi de 1.264 kWmédios na coordenada Parada 
e com o aerogerador Enercon E-115. Esse processo foi replicado para todos os meses do período de 01/01/1994 a 31/12/2014, obtendo-se a energia gerada para cada mês.

O Gráfico 84 e o Gráfico 85 ilustram o resultado do processo para as séries de energia gerada mensal para as coordenadas Dom Pedrito (RS) e Afrânio (PE), respectivamente, considerando o aerogerador Enercon E-115 (2.500 kW).

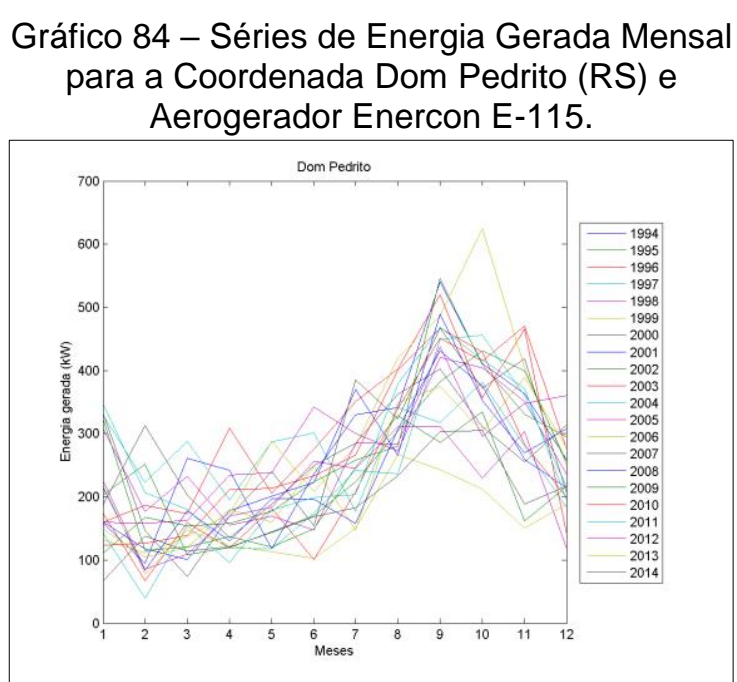

Autor (2016).
Gráfico 85 - Séries de Energia Gerada Mensal para a Coordenada Afrânio (PE) e Aerogerador Enercon E-115.

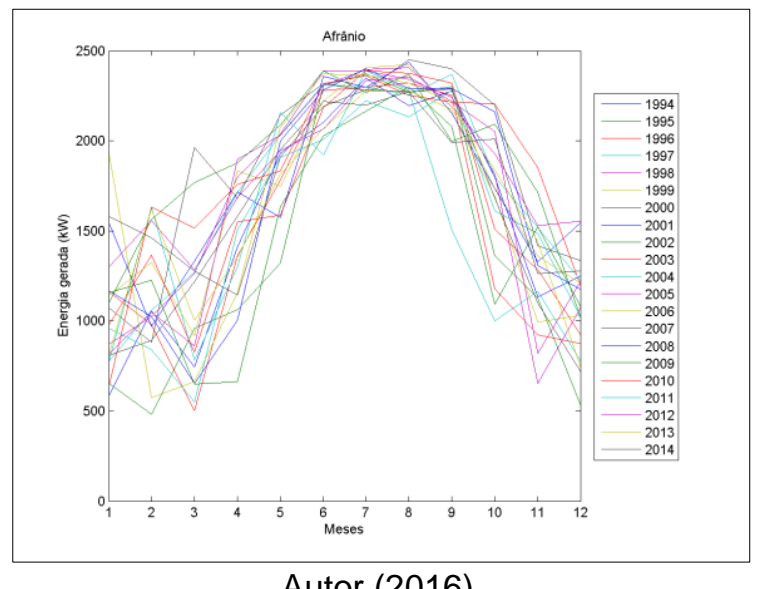

Este processo foi repetido e aplicado para todas as 22 coordenadas e para os 12 aerogeradores selecionados (TABELA 34), obtendo-se 264 séries de energia gerada para o período de 01/01/1994 a 31/12/2014, em base mensal (cada série com 252 pontos, 21 anos $\times 12$ meses).

\subsubsection{Otimizações Realizadas e Resultados - Cálculo da Fronteira Eficiente para Cada Modelo de Aerogerador}

Neste tópico foram realizadas as seguintes otimizações: i) para cada um dos 12 modelos de aerogeradores foi obtida a curva fronteira eficiente considerando as 22 séries (correspondentes às coordenadas geográficas) de energia gerada e do fator de capacidade, em base horária e mensal; ii) foi encontrada a fronteira eficiente considerando todos os 12 modelos de aerogeradores e todas as 22 coordenadas geográficas simultaneamente, obtendo-se 264 séries históricas de energia gerada, em base mensal e horária; iii) foi analisado o impacto na fronteira eficiente considerando todos os 12 modelos de aerogeradores com preços diferenciados e as 22 
coordenadas geográficas simultaneamente, obtendo-se 264 séries históricas de margem líquida (receita menos despesa), em base mensal; iv) para o aerogerador do fabricante Wobben/Enercon foi encontrada a fronteira eficiente, considerando as 22 coordenadas geográficas e restrições de transmissão; v) foi realizado o cálculo do risco mínimo, considerando as 22 séries históricas (correspondentes às coordenadas geográficas) de energia gerada para o aerogerador do fabricante Wobben/Enercon, em base horária e mensal, vi) foi obtida a curva do fator de correlação entre as coordenadas e as respectivas distâncias entre elas.

O detalhamento de cada otimização encontra-se a seguir, em item específico. A Figura 16 ilustra o procedimento básico adotado para a obtenção das fronteiras eficientes.

Figura 16 - Procedimento Básico para Obter a Curva da Fronteira Eficiente.

\begin{tabular}{|c|c|c|c|}
\hline $\begin{array}{l}\text { Seleção do } \\
\text { Modelo do } \\
\text { Aerogerador }\end{array}$ & $\begin{array}{l}\text { Produção } \\
\text { das } 22 \text { Séries } \\
\text { de Energia }\end{array}$ & $\begin{array}{l}\text { Aplicação do } \\
\text { Modelo } \\
\text { MVP }\end{array}$ & $\begin{array}{c}\text { Fronteira } \\
\text { Eficiente e } \\
\text { Carteiras } \\
\text { Otimizadas }\end{array}$ \\
\hline
\end{tabular}

Antes de se apresentar os resultados das otimizações, detalha-se a seguir como foram obtidos os parâmetros de média e desvio padrão para a carteira atual e para a carteira atual PROINFA.

A carteira atual foi considerada como aquela composta por todas as usinas eólicas construídas, em construção e contratadas. Por sua vez, a carteira atual PROINFA foi considerada como aquela composta por todas as usinas eólicas em operação e contratadas pelo PROINFA.

O Boletim Mensal de Dados do Setor Eólico elaborado pela ABEEólica, em novembro de 2015, contabilizou 18,07 GW de capacidade eólica instalada (7,96 GW construída e 10,11 GW em construção ou contratada, conforme detalhado no item 3.2). Cada usina eólica dessa lista foi associada a uma coordenada em função da distância.

A TABELA 37 relaciona as usinas eólicas listadas no Boletim Mensal de Dados do Setor Eólico elaborado pela ABEEólica e que estão próximas da coordenada Boninal. Para essa coordenada foi associada a potência instalada de 424,99 MW. O mesmo procedimento foi adotado para calcular a potência instalada das demais coordenadas. 
TABELA 37 - Usinas Eólicas Próximas da Coordenada Boninal.

\begin{tabular}{|c|c|c|c|c|c|c|c|c|}
\hline Coordenada & Latitude & Longitude & Usina Eólica & $\begin{array}{l}\text { Potência } \\
\text { (MW) }\end{array}$ & Estado & Município & Contratação & $\begin{array}{c}\text { Distância entre } \\
\text { Coordenada e } \\
\text { Usina (Km) }\end{array}$ \\
\hline \multirow{15}{*}{ Boninal } & \multirow{15}{*}{$12^{24859.60^{\circ} \mathrm{s}}$} & \multirow{15}{*}{${ }^{41} \cdot 4251.6^{\circ} \mathrm{O}$} & Esperança & 28 & BA & Bonito & LER 2013 & 104,8 \\
\hline & & & $\begin{array}{l}\text { Ventos da } \\
\text { Bahia II }\end{array}$ & 30 & BA & Bonito & A-5 2013 (DEZ) & 104,8 \\
\hline & & & Macaubas & 35,07 & BA & $\begin{array}{l}\text { Brotas de } \\
\text { Macaúbas }\end{array}$ & LER 2009 & 111,88 \\
\hline & & & Novo Horizonte & 30,06 & BA & $\begin{array}{l}\text { Brotas de } \\
\text { Macaúbas }\end{array}$ & LER 2009 & 111,88 \\
\hline & & & Seabra & 30,06 & BA & $\begin{array}{l}\text { Brotas de } \\
\text { Macaúbas }\end{array}$ & LER 2009 & 111,88 \\
\hline & & & Primavera & 29,9 & BA & Morro do Chapéu & LER 2010 & 146,96 \\
\hline & & & Sao Judas & 29,9 & BA & Morro do Chapéu & LER 2010 & 146,96 \\
\hline & & & $\begin{array}{l}\text { Boa Vista } \\
\text { Lagoinha }\end{array}$ & 30 & BA & Morro do Chapéu & Mercado Livre & 146,96 \\
\hline & & & & 28 & BA & Morro do Chapéu & Mercado Livre & 146,96 \\
\hline & & & $\begin{array}{l}\text { Ventos Da } \\
\text { Santa Dulce }\end{array}$ & 28 & BA & Morro do Chapéu & A-5 2014 & 146,96 \\
\hline & & & $\begin{array}{l}\text { Ventos Da } \\
\text { Santa } \\
\text { Esperança }\end{array}$ & 28 & BA & Morro do Chapéu & A-5 2014 & 146,96 \\
\hline & & & $\begin{array}{l}\text { Ventos Do São } \\
\text { Mario }\end{array}$ & 28 & BA & Morro do Chapéu & A-5 2014 & 146,96 \\
\hline & & & $\begin{array}{l}\text { Ventos Do São } \\
\text { Paulo }\end{array}$ & 28 & BA & Morro do Chapéu & A-5 2014 & 146,96 \\
\hline & & & $\begin{array}{l}\text { Ventos da } \\
\text { Bahia IV }\end{array}$ & 12 & BA & $\begin{array}{l}\text { Mulungu do } \\
\text { Morro }\end{array}$ & A-5 2013 (DEZ) & 87,29 \\
\hline & & & $\begin{array}{l}\text { Ventos da } \\
\text { Bahia VIII }\end{array}$ & 30 & BA & $\begin{array}{c}\text { Mulungu do } \\
\text { Morro }\end{array}$ & A-5 2013 (DEZ) & 87,29 \\
\hline
\end{tabular}

Autor (2016).

Fonte: ABEEólica (2015).

O percentual de participação de cada coordenada na composição da carteira atual e da carteira atual PROINFA foi calculado pela relação entre a potência associada à coordenada e a potência total da carteira (peso da potência instalada para cada coordenada), conforme representado na TABELA 38. 
TABELA 38 - Pesos da Potência na Carteira Atual e na Carteira PROINFA.

\begin{tabular}{ccc} 
Coordenadas & Pesos Carteira Atual & Pesos Carteira PROINFA \\
\hline Parnaiba & $5,52 \%$ & $12,66 \%$ \\
Parada & $11,41 \%$ & $27,38 \%$ \\
São João & $13,95 \%$ & $17,57 \%$ \\
Medonho & $0,32 \%$ & $0,00 \%$ \\
Macambira & $7,89 \%$ & $0,00 \%$ \\
Forquilha & $6,92 \%$ & $0,00 \%$ \\
Tavares & $0,44 \%$ & $6,05 \%$ \\
Sertania & $4,64 \%$ & $1,14 \%$ \\
Afranio & $14,42 \%$ & $0,00 \%$ \\
Palmas & $0,82 \%$ & $10,59 \%$ \\
Tubarao & $0,54 \%$ & $7,13 \%$ \\
Osório & $4,50 \%$ & $17,49 \%$ \\
Dom Pedrito & $1,22 \%$ & $0,00 \%$ \\
Estreito & $1,55 \%$ & $0,00 \%$ \\
Palmar & $4,52 \%$ & $0,00 \%$ \\
Itaguaçu & $7,22 \%$ & $0,00 \%$ \\
Boninal & $2,39 \%$ & $0,00 \%$ \\
Jacaraci & $11,74 \%$ & $0,00 \%$ \\
\hline Total Geral & $100,00 \%$ & $100,00 \%$ \\
\hline & Autor (2016). & \\
\hline & &
\end{tabular}

Os percentuais são equivalentes à relação entre a potência instalada naquela coordenada (calculada conforme exemplificado na TABELA 39) sobre a potência instalada das usinas eólicas construídas, em construção e contratadas no Brasil (carteira atual) ou apenas das usinas eólicas contratadas pelo PROINFA (carteira atual PROINFA).

Desta forma, a média da energia gerada (ou fator de capacidade) da carteira atual e da carteira atual PROINFA foi obtida pela ponderação dos parâmetros de média de cada coordenada geográfica, pelos percentuais de participação da coordenada nas respectivas carteiras, conforme a Equação (41). Por sua vez, o desvio padrão da energia gerada (ou fator de capacidade) da carteira atual e da carteira atual PROINFA foi obtido pela ponderação dos parâmetros de desvio padrão de cada coordenada geográfica, pelos percentuais de participação da coordenada nas respectivas carteiras e, pelo somatório da correlação das coordenadas, conforme a Equação (43). 
5.2.4.1 Otimização 01 - Fronteira Eficiente para Cada Aerogerador - Base Mensal

Nos Gráfico 86 é apresentada a curva da fronteira eficiente para cada modelo do aerogerador, resultado das otimizações realizadas, considerando a série de energia gerada em base mensal. A curva azul representa a fronteira eficiente. Os pontos em azul representam algumas das possíveis carteiras otimizadas. Os pontos em vermelho representam as coordenadas, equivalente a uma carteira composta somente por essa coordenada (carteira não otimizada).

O comportamento das curvas e dos pontos são semelhantes, uma vez que a série da energia gerada foi calculada a partir da mesma base de dados de velocidade do vento, sendo as diferenças decorrentes da curva de potência de cada modelo de aerogerador.

Nesse sentido, há três coordenadas (Riachuelo, Olho da Água e Anta) que estão próximas do ponto de risco mínimo da curva de fronteira eficiente. Parada, Itaguaçu e Afrânio, ao contrário, são as coordenadas mais distantes da fronteira eficiente.

Gráfico 86 - Curvas de Fronteiras Eficientes para cada Modelo de Aerogerador - Série Mensal de Energia Gerada (kWmédios).
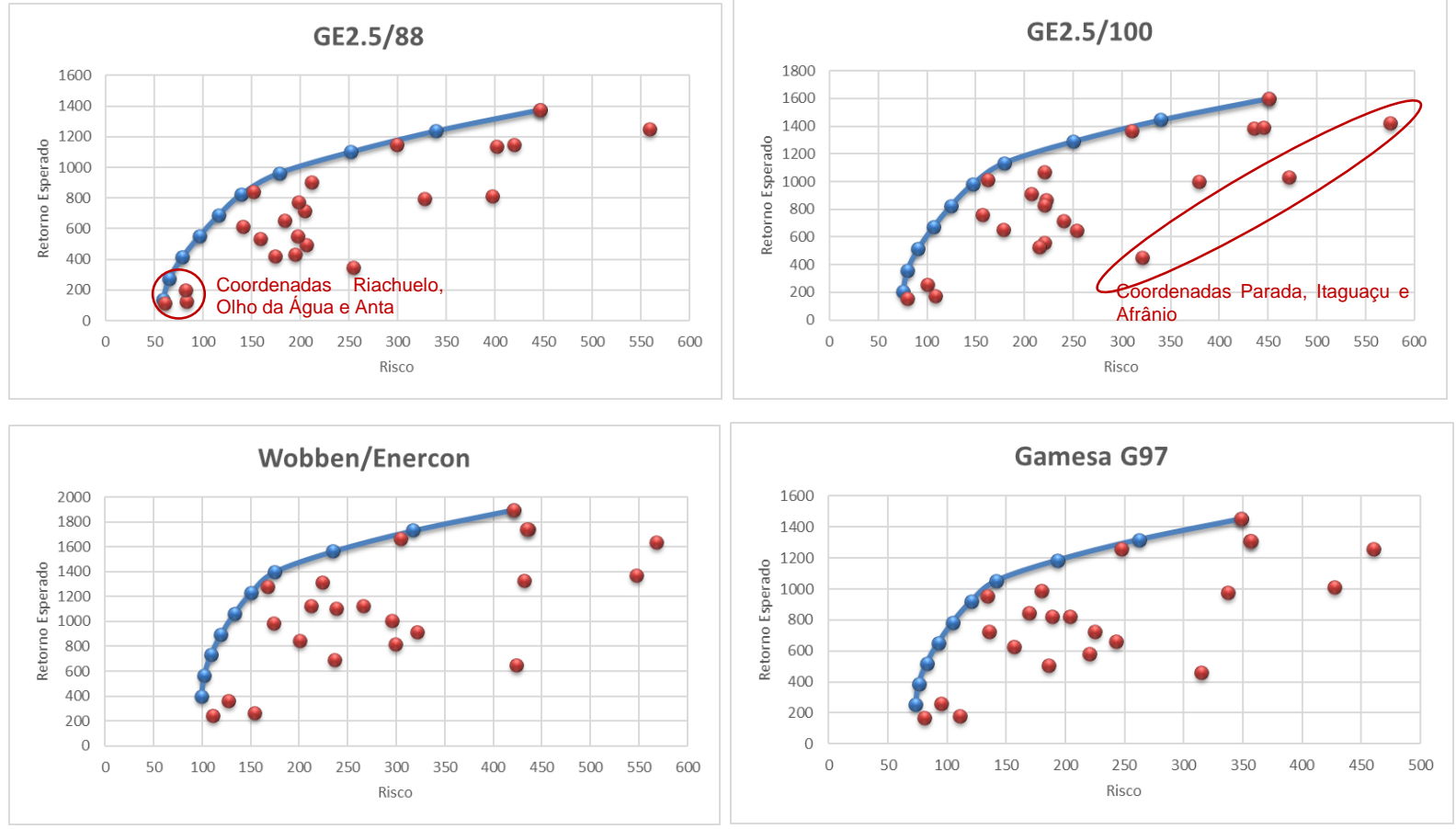

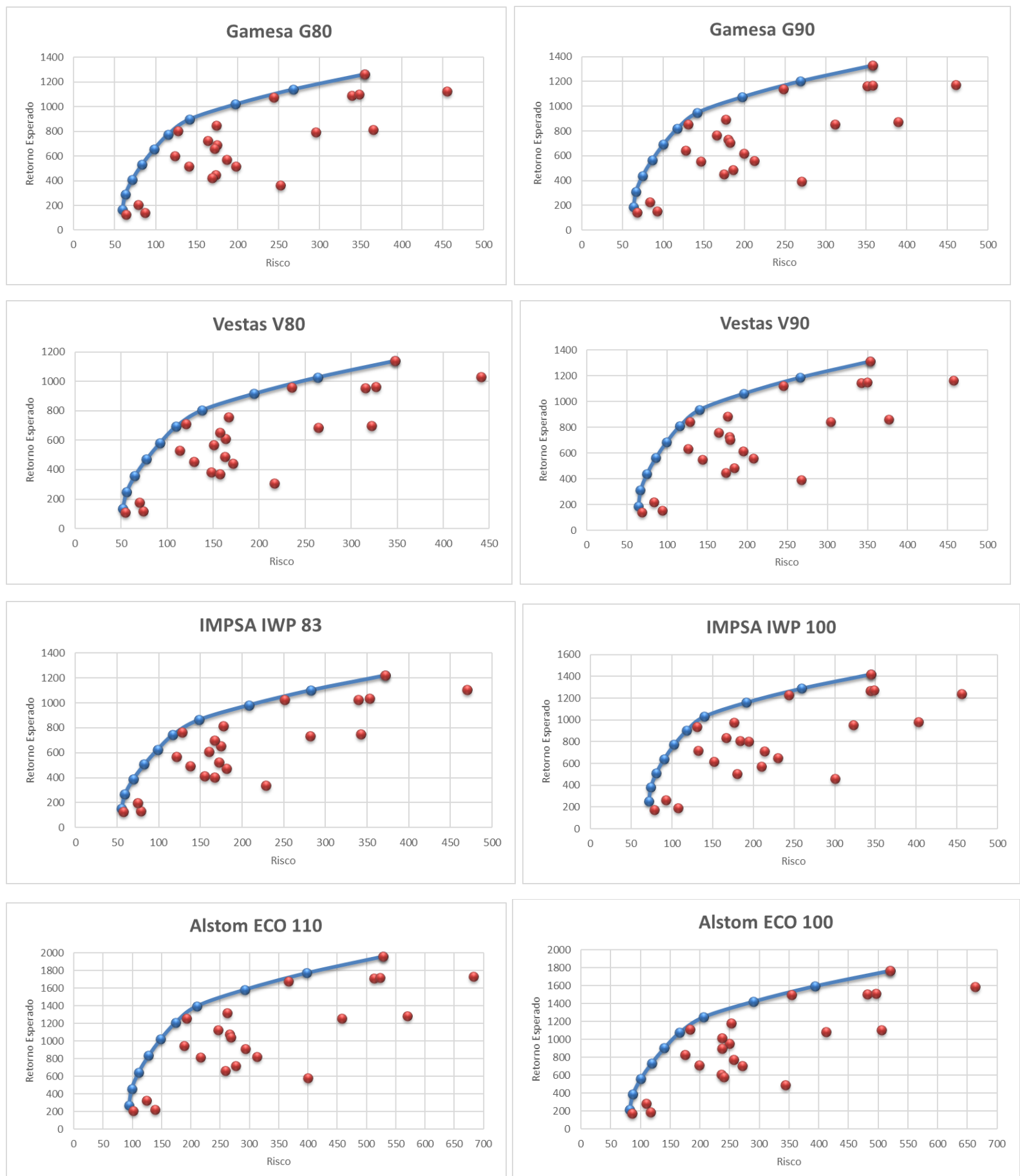

Autor (2016)

Apesar de existirem 22 coordenadas disponíveis para a curva da fronteira eficiente, apenas 12 coordenadas foram utilizadas para compor as carteiras otimizadas. As coordenadas Parada ${ }^{90}$, São João, Mocambira, Forquilha, Tavares,

${ }_{90}$ As coordenadas Parada e Itaguaçu não foram selecionadas para compor as carteiras otimizadas e são as coordenadas mais distantes da curva das fronteiras otimizadas. 
Palmas, Tubarão, Itaguaçu, Jacaraci e Olho da Água ${ }^{91}$ não foram selecionadas no processo de otimização para nenhum modelo de aerogerador. O Gráfico 87 apresenta a frequência da seleção das 22 coordenadas nas carteiras otimizadas para as 12 simulações realizadas (para cada modelo de aerogerador). O resultado está coerente com o item 4.6.5.

A TABELA 39 relaciona o risco mínimo e a geração esperada para cada aerogerador. $\mathrm{O}$ aerogerador Wobben/Enercon possui maior expectativa de geração $\mathrm{e}$ menor relação risco/retorno. Nesse sentido, para o atendimento de uma determinada demanda, o aerogerador Wobben/Enercon exigirá menos potência instalada (investimentos) que os demais. Alternativamente, para um parque eólico com a mesma potência instalada, o parque composto por aerogeradores Wobben/Enercon irão produzir mais energia em média que os demais fabricantes.

Das 22 coordenadas possíveis para compor as carteiras de menor risco, as coordenadas Quilombo, Riachuelo, Anta ${ }^{92}$ e Palmar foram as únicas utilizadas, sendo que as 3 primeiras foram utilizadas nos 12 modelos de aerogeradores e a coordenada Palmar foi utilizada nos 5 modelos com as menores relação risco/retorno (Alstom ECO110, IMPSA IWP100, Vestas V90, Gamesa G97 e Wobben/Enercon).

\footnotetext{
${ }^{91}$ A coordenada Olho da Água está próxima do ponto de risco mínimo da curva da fronteira eficiente, mas não foi selecionada nas carteiras otimizadas.

${ }^{92}$ As coordenadas Riachuelo e Anta estão próximas do ponto de risco mínimo da curva de fronteira eficiente.
} 
Gráfico 87 - Frequencia de Uso das Coordenadas nas Carteiras Otimizadas - Série Mensal de Energia Gerada.

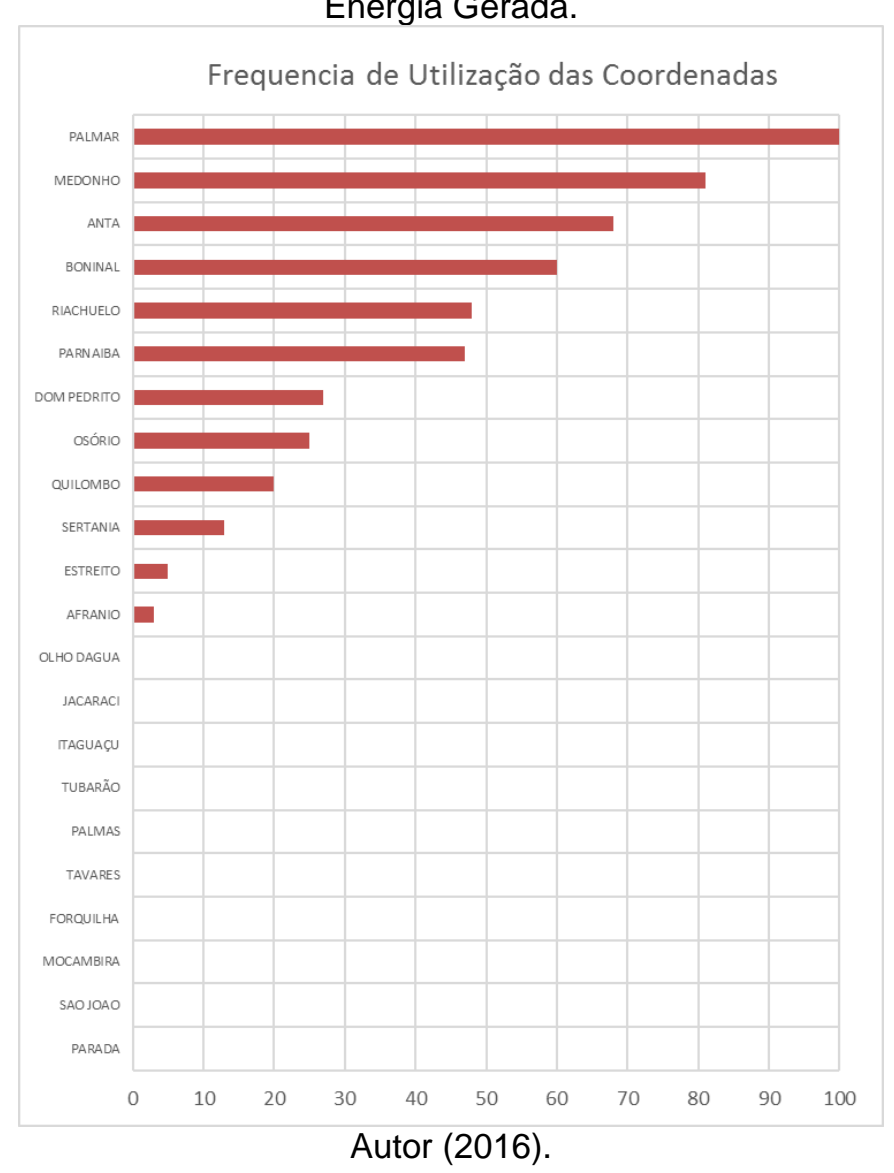

TABELA 39 - Risco Mínimo e Geração Esperada - Série Mensal de Energia Gerada.

\begin{tabular}{cccc}
\hline Tipo do Aerogerador & $\begin{array}{c}\text { Risco Mínimo } \\
\text { (kWmédios) }\end{array}$ & $\begin{array}{c}\text { Geração Esperada } \\
\text { (kWmédios) }\end{array}$ & Risco/Geração \\
\hline Wobben/Enercon & 99,08 & 396,82 & $25 \%$ \\
GE 2.5/88 (2.500kW) & 59,07 & 137,00 & $43 \%$ \\
GE 2.5/100 (2.500kW) & 75,20 & 203,58 & $37 \%$ \\
Gamesa G80 & 59,74 & 165,07 & $36 \%$ \\
Gamesa G90 & 63,59 & 184,66 & $34 \%$ \\
Gamesa G97 & 73,62 & 251,99 & $29 \%$ \\
Vestas V80 & 51,78 & 135,49 & $38 \%$ \\
Vestas V90 & 63,93 & 187,04 & $34 \%$ \\
IMPSA IWP83 & 54,97 & 151,03 & $36 \%$ \\
IMPSA IWP100 & 71,45 & 254,17 & $28 \%$ \\
Alstom ECO110 & 94,43 & 271,24 & $35 \%$ \\
Alstom ECO100 & 81,62 & 219,17 & $37 \%$ \\
\hline
\end{tabular}
Autor (2016).

No item 5.1 foi verificado que o uso de histórico da energia gerada pode ter prejudicado o resultado obtido em razão do impacto da dimensão da potência instalada de cada usina eólica. Evidente que o efeito da dimensão nessa otimização 
é bastante reduzido, na medida em que os aerogeradores possuem potências instaladas semelhantes. Não obstante, foram repetidas as otimizações (otimização por tipo de aerogerador) utilizando-se o mesmo histórico da energia gerada, normalizada pela respectiva potência de cada aerogerador.

O Gráfico 88 apresenta a fronteira eficiente para cada modelo de aerogerador, considerando a série histórica do fator de capacidade. Verifica-se que o resultado é semelhante ao obtido aplicando a série histórica de energia gerada. Diferentemente do item 5.1, as potências dos aerogerador são próximas, desta forma, a influência da dimensão da usina eólica nos resultados é reduzida.

Gráfico 88 - Curvas de Fronteiras Eficientes para cada Modelo de Aerogerador - Série Mensal de Fator de Capacidade.
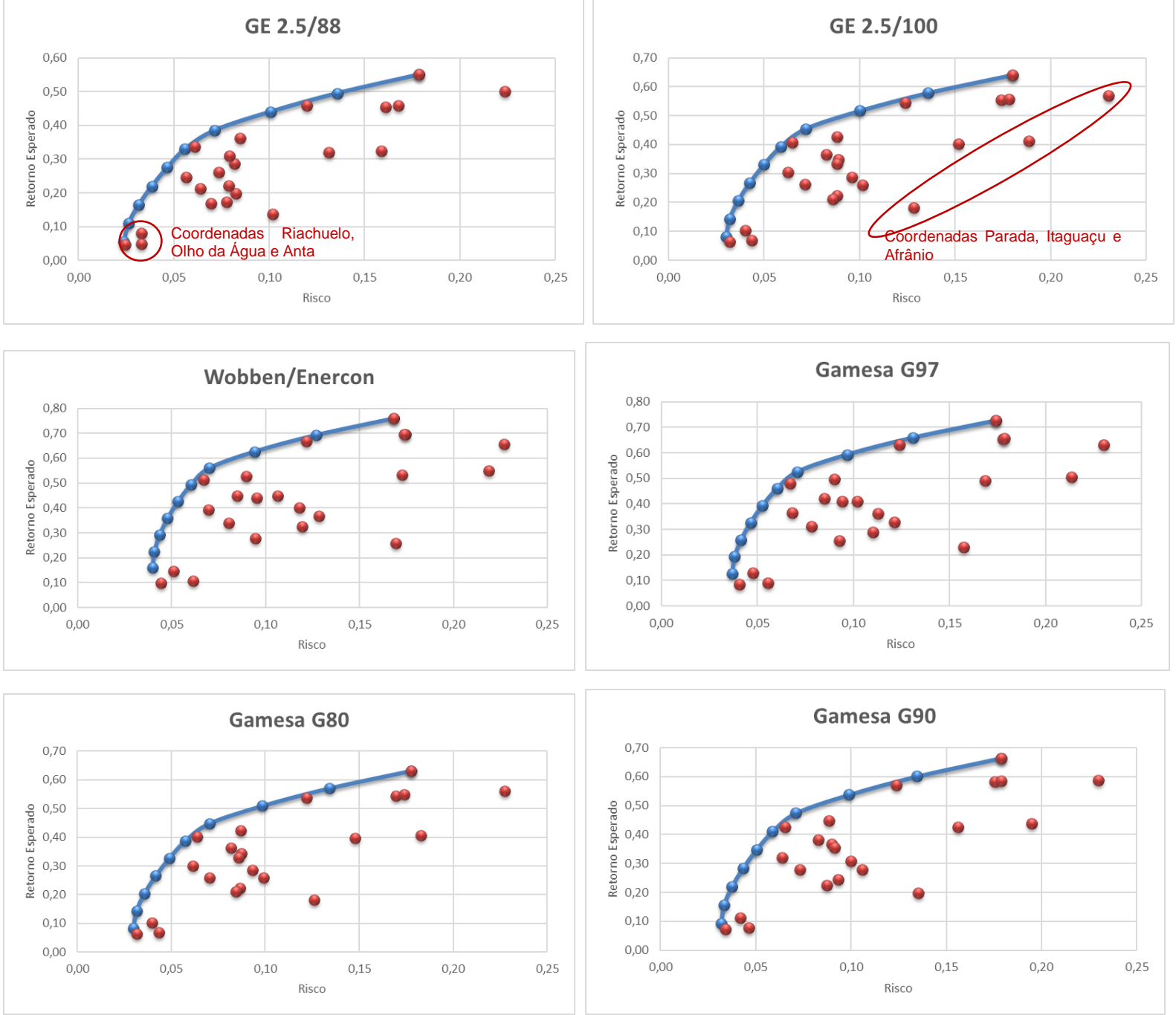

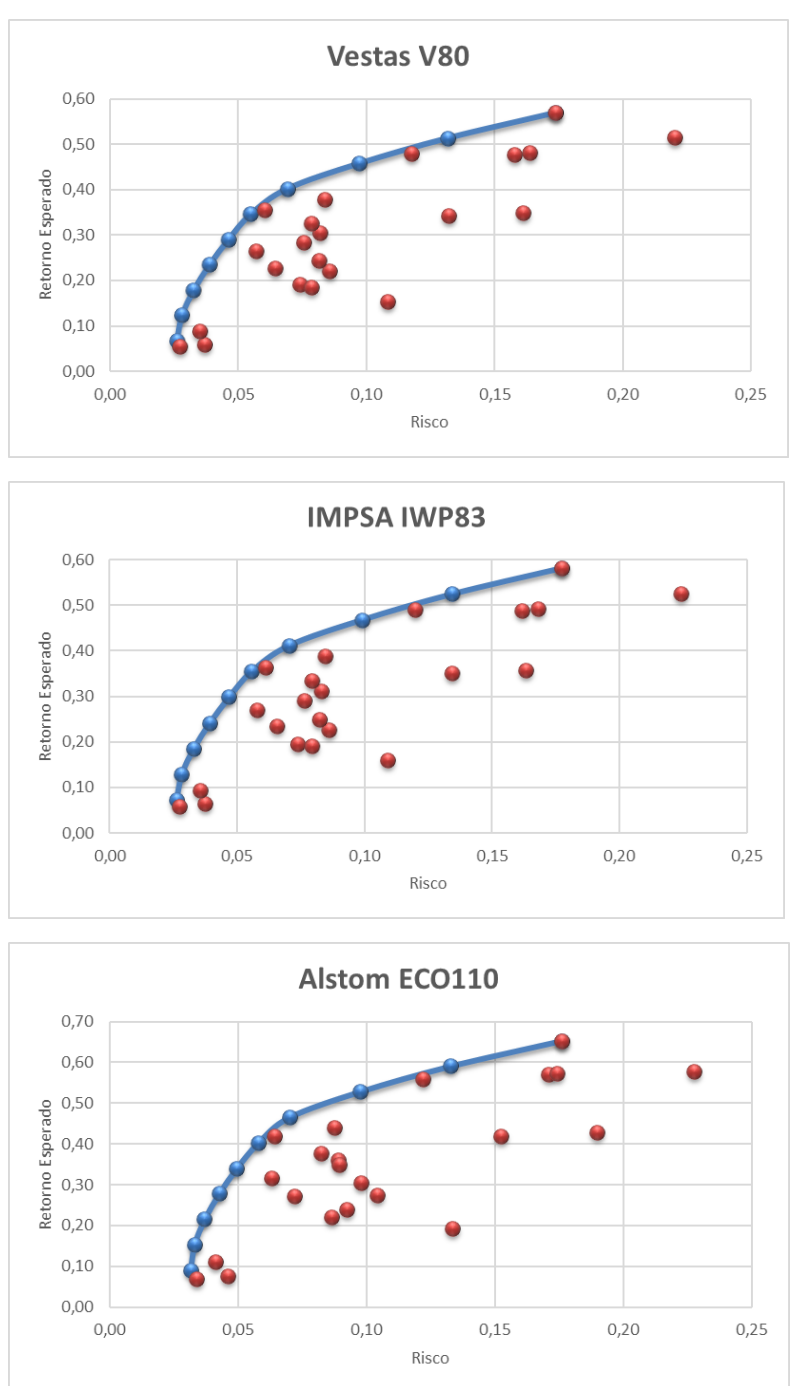
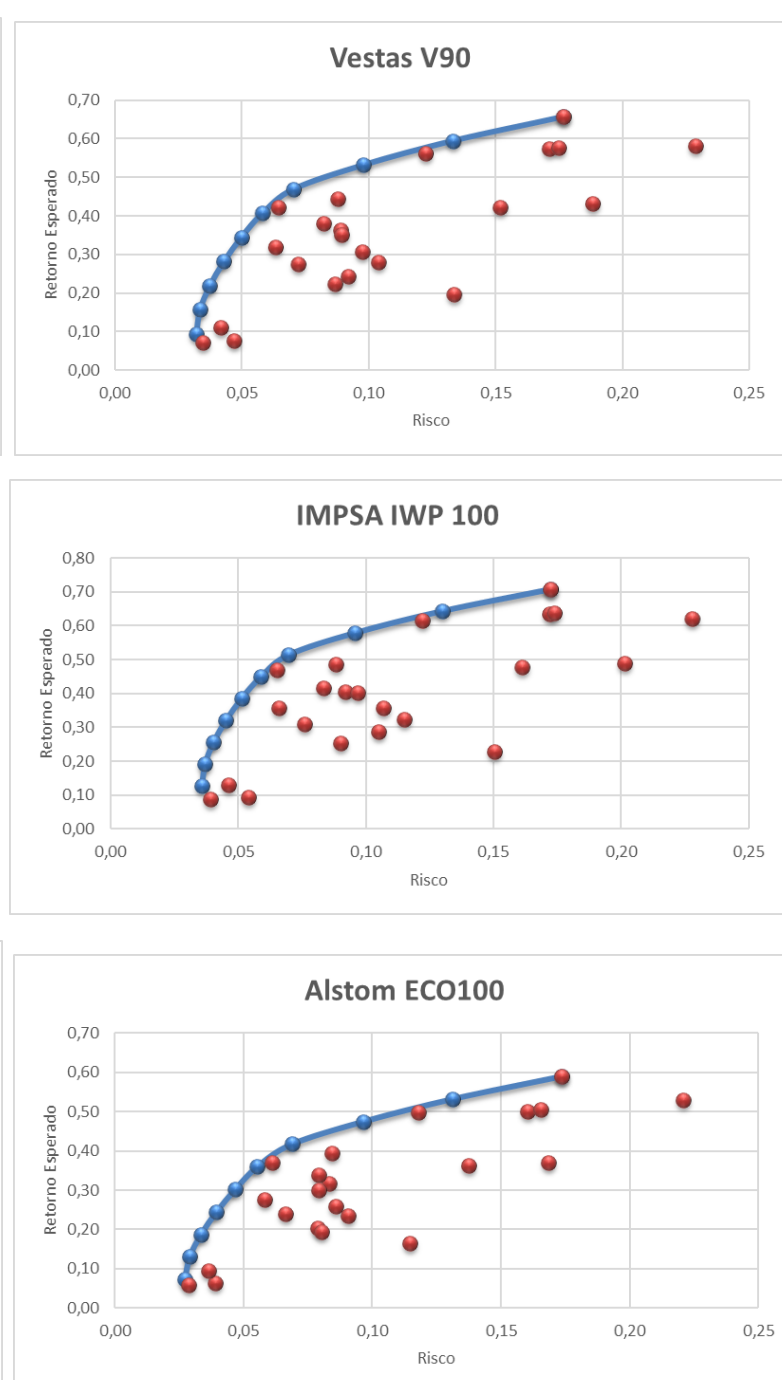

Autor (2016).

O Gráfico 89 e o Gráfico 90 apresentam a curva da fronteira eficiente para cada modelo de aerogerador, considerando a série da energia gerada e a série do fator de capacidade, respectivamente. Os referidos gráficos demonstram que quando se comparam os diversos modelos de aerogeradores entre si, a dimensão da máquina tem influência no resultado.

Para um risco de 300 kWmédios (metade da abscissa), pelo Gráfico 89 é possível observar que os aerogeradores Wobben e Astom Eco 110 apresentam as maiores expectativas de geração.

Por um outro lado, para um risco de 0,1 (metade da abscissa), os aerogeradores Wobben e Gamesa 97 apresentam as maiores expectativas de fator de capacidade, sendo que o aerogerador Astom Eco 110 apresentar apenas a quinta maior expectativa de geração (Gráfico 90 ). 
Gráfico 89 - Fronteiras Eficientes para cada Modelo de Aerogerador (Energia Gerada)

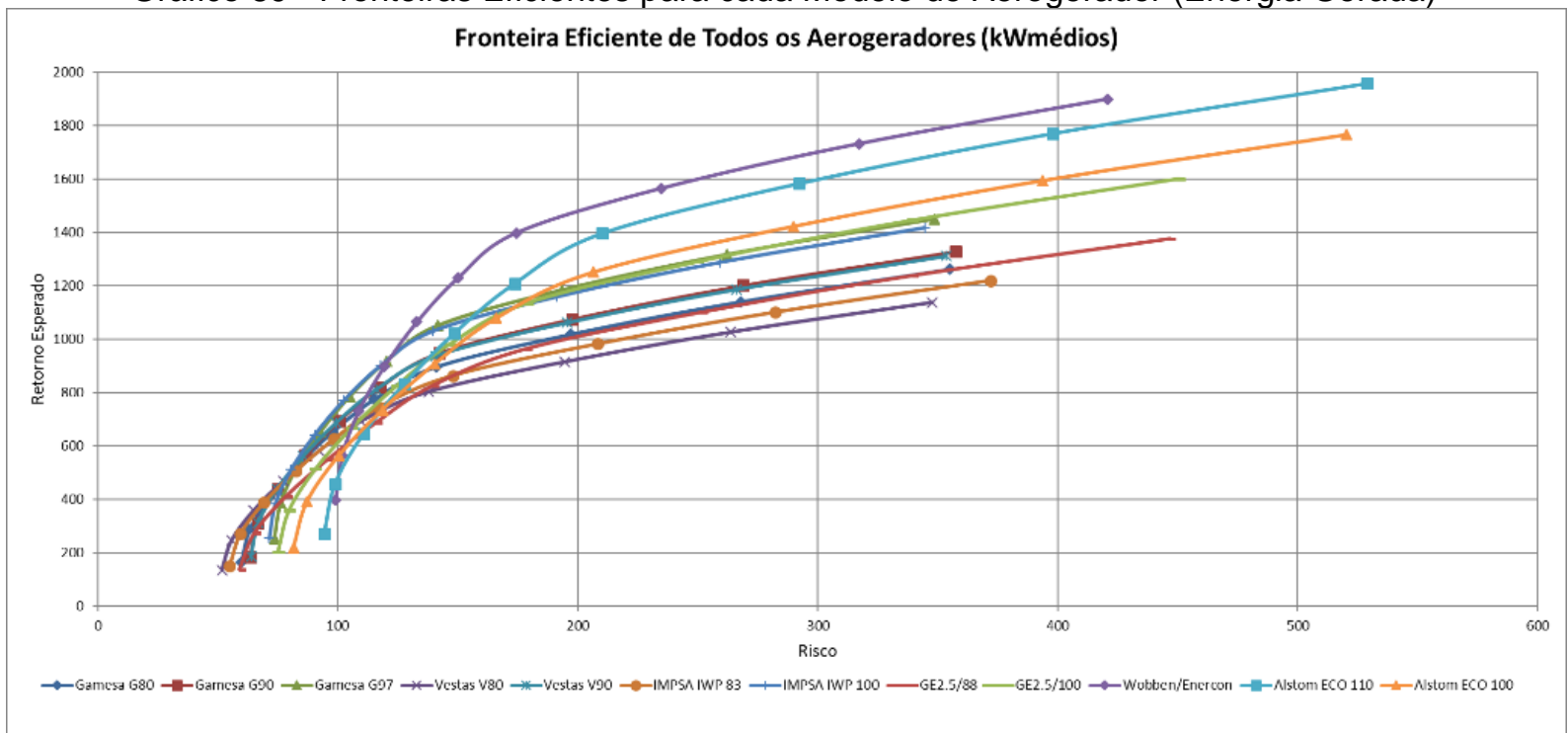

Autor (2016).

Gráfico 90 - Fronteiras Eficientes para cada Modelo de Aerogerador (Fator de Capacidade)

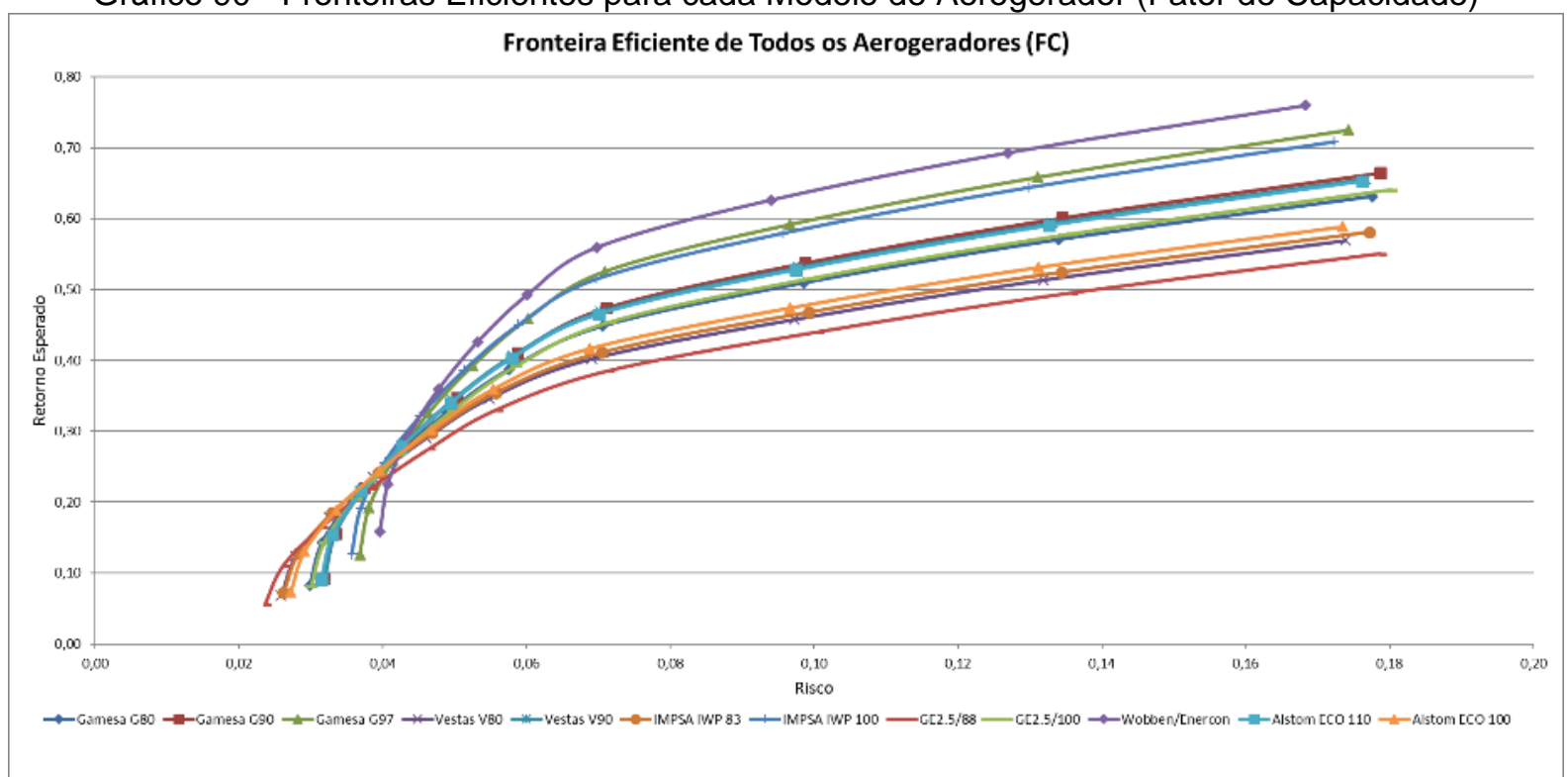

Autor (2016).

O ideal seria um modelo de aerogerador que tivesse o menor risco mínimo e o maior retorno máximo, pois esse modelo ideal estaria melhor adaptado para todas as coordenadas. No entanto, é possível observar que, os aerogeradores que possuem os menores riscos mínimos (parte inicial das curvas), possuem os menores retornos máximos (parte final das curvas) e vice-versa. Nesse sentido, há modelos que possuem um comportamento melhor em determinada faixa da curva em relação a outros. 
No item 5.2.4.3, é apresentado o resultado da otimização, considerando que cada modelo de aerogerador e cada coordenada é um ativo possível para compor a carteira.

O Gráfico 91 ilustra a curva da fronteira eficiente para o aerogerador Wobben/Enercon em conjunto com a carteira atual, carteira PROINFA e carteiras individuais, para a série de dados de energia gerada. A carteira atual é representada pelo triângulo azul e a carteira PROINFA pelo triângulo cinza. Os pontos em vermelho representam as carteiras (coordenadas) individuais. A curva azul e os pontos em azul, representam a fronteira eficiente e 10 exemplos de carteiras eficientes, respectivamente.

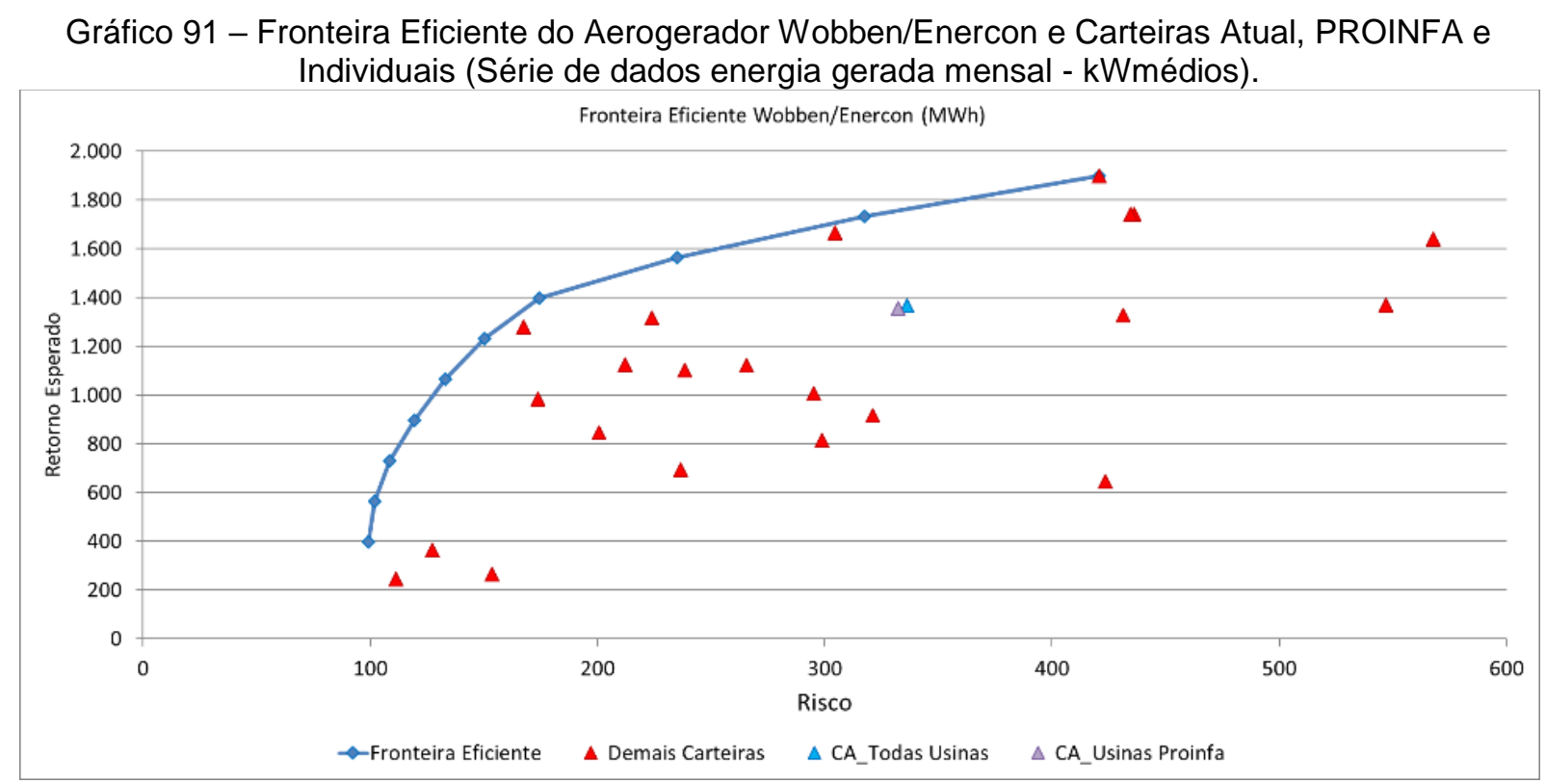

Autor (2016).

A carteira atual e a carteira PROINFA foram calculadas a partir da ponderação dos parâmetros de média e desvio padrão pela potência instalada das usinas listadas no Boletim Mensal de Dados do Setor Eólico elaborado pela ABEEólica, de novembro de 2015, conforme detalhado no item 5.2.4.

Na TABELA 40 são apresentados 10 exemplos de carteiras otimizadas (sobre a curva da fronteira eficiente) e a carteira atual, com os respectivos desvios e retornos. 
TABELA 40 - Exemplos de Carteiras Otimizadas - Aerogerador Wobben/Enercon

\begin{tabular}{|c|c|c|c|c|c|c|c|c|c|c|c|c|}
\hline \multirow{2}{*}{$\begin{array}{c}\text { Carteira } \\
\text { Ótima }\end{array}$} & \multirow{2}{*}{$\begin{array}{l}\text { Risco } \\
(\mathrm{kWm})\end{array}$} & \multirow{2}{*}{$\begin{array}{c}\text { Retorno } \\
(\mathbf{k W m})\end{array}$} & \multicolumn{10}{|c|}{ Percentual da Potência Instalada } \\
\hline & & & Parnaíba & Medonho & Afrânio & Quilombo & Osório & Dom Pedrito & Palmar & Boninal & Riachuelo & Anta \\
\hline 1 & 99,08 & 396,82 & $0,00 \%$ & $0,00 \%$ & $0,00 \%$ & $6,76 \%$ & $0,00 \%$ & $0,00 \%$ & $7,44 \%$ & $0,00 \%$ & $49,43 \%$ & $36,36 \%$ \\
\hline 2 & 101,76 & 563,79 & $0,00 \%$ & $0,95 \%$ & $0,40 \%$ & $2,09 \%$ & $0,00 \%$ & $0,95 \%$ & $21,30 \%$ & $2,43 \%$ & $37,88 \%$ & $34,00 \%$ \\
\hline 3 & 108,67 & 730,76 & $0,00 \%$ & $4,90 \%$ & $0,14 \%$ & $0,00 \%$ & $0,00 \%$ & $0,33 \%$ & $32,65 \%$ & $3,82 \%$ & $25,27 \%$ & $32,88 \%$ \\
\hline 4 & 119,34 & 897,73 & $0,00 \%$ & $8,58 \%$ & $0,00 \%$ & $0,00 \%$ & $0,14 \%$ & $0,00 \%$ & $43,15 \%$ & $4,88 \%$ & $10,38 \%$ & $32,86 \%$ \\
\hline 5 & 132,91 & 1064,70 & $0,00 \%$ & $11,72 \%$ & $0,00 \%$ & $0,00 \%$ & $4,35 \%$ & $0,00 \%$ & $51,44 \%$ & $5,67 \%$ & $0,00 \%$ & $26,82 \%$ \\
\hline 6 & 150,28 & 1231,67 & $0,00 \%$ & $14,93 \%$ & $0,00 \%$ & $0,00 \%$ & $8,78 \%$ & $0,00 \%$ & $61,82 \%$ & $5,21 \%$ & $0,00 \%$ & $9,26 \%$ \\
\hline 7 & 174,40 & 1398,64 & $0,00 \%$ & $30,55 \%$ & $0,00 \%$ & $0,00 \%$ & $0,00 \%$ & $0,00 \%$ & $69,45 \%$ & $0,00 \%$ & $0,00 \%$ & $0,00 \%$ \\
\hline 8 & 234,88 & 1565,61 & $22,28 \%$ & $38,10 \%$ & $0,00 \%$ & $0,00 \%$ & $0,00 \%$ & $0,00 \%$ & $39,62 \%$ & $0,00 \%$ & $0,00 \%$ & $0,00 \%$ \\
\hline 9 & 317,31 & 1732,58 & $44,98 \%$ & $44,97 \%$ & $0,00 \%$ & $0,00 \%$ & $0,00 \%$ & $0,00 \%$ & $10,05 \%$ & $0,00 \%$ & $0,00 \%$ & $0,00 \%$ \\
\hline 10 & 420,72 & 1899,55 & $100,00 \%$ & $0,00 \%$ & $0,00 \%$ & $0,00 \%$ & $0,00 \%$ & $0,00 \%$ & $0,00 \%$ & $0,00 \%$ & $0,00 \%$ & $0,00 \%$ \\
\hline CAtual & 336,16 & 1368,33 & $5,52 \%$ & $0,32 \%$ & $14,42 \%$ & $0,00 \%$ & $4,50 \%$ & $1,22 \%$ & $4,52 \%$ & $2,39 \%$ & $0,00 \%$ & $0,00 \%$ \\
\hline CProinfa & 332,26 & 1354,81 & $12,66 \%$ & $0,00 \%$ & $0,00 \%$ & $0,00 \%$ & $17,49 \%$ & $0,00 \%$ & $0,00 \%$ & $0,00 \%$ & $0,00 \%$ & $0,00 \%$ \\
\hline
\end{tabular}

Verifica-se que a carteira atual e a carteira PROINFA estão próximas entre si e distantes da fronteira eficiente. A regra de contratação das usinas pelo PROINFA e a regra de contratação nos Leilões Regulados não viabilizou (PROINFA) e não está viabilizando (Leilões) a diversificação otimizada da carteira.

Os resultados obtidos possuem uma faixa de expectativa de geração entre 396,82 kWmédios (carteira de risco mínimo) a 1.899,55 kWmédios (carteira de maior retorno), enquanto a carteira atual possui uma expectativa igual a 1.368,33 kWmédios.

As carteiras otimizadas com expectativa de geração menor que a carteira atual, exigirão maior investimento para atendimento da mesma demanda. Ao contrário, para atender a mesma quantidade de demanda da carteira atual, com investimento igual ou menor, deve-se selecionar as carteiras com maior expectativa de geração.

Uma mudança na composição da carteira atual poderia reduzir a volatilidade em 52\% (de 336,16 kWmédios para 174,40 kWmédios), mantendo praticamente a mesma expectativa de geração (carteira 7, destacada em azul), alternativamente, seria possível aumentar em 27\% a expectativa de geração (de 1.368,33 kWmédios para 1.732,58 kWmédios), para praticamente o mesmo risco (carteira 9 , destacada em verde).

O Gráfico 92 ilustra a curva da fronteira eficiente para o aerogerador Wobben/Enercon em conjunto com a carteira atual, carteira PROINFA e carteiras individuais, para a série de dados do fator de capacidade. 
Gráfico 92 - Fronteira Eficiente do Aerogerador Wobben/Enercon e Carteiras Atual, PROINFA e Individuais (Série de dados fator de capacidade mensal).

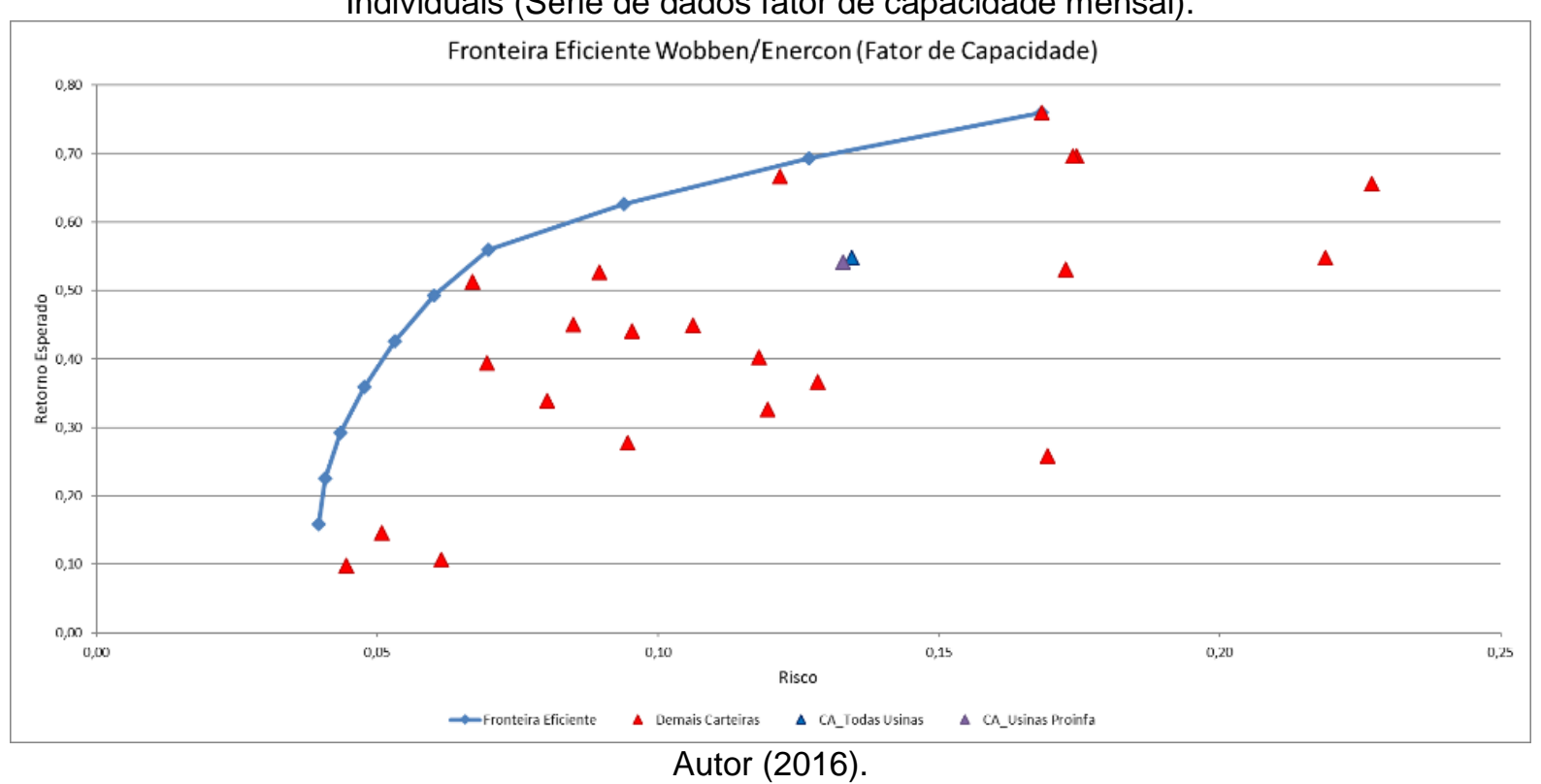

O resultado é semelhante ao obtido pela série de dados da energia gerada. Os ajustes na carteira atual para se obter uma menor volatilidade ou uma maior expectativa de fator de capacidade são os mesmos obtidos anteriormente e com os mesmos resultados.

As otimizações em base mensal são importantes para aplicar nos problemas de comercialização de energia, na medida em que as contabilizações e liquidações contratuais são realizadas em base mensal ${ }^{93}$. No entanto, para fins da operação, as otimizações horárias são mais adequadas ${ }^{94}$. Desta forma, no item seguinte foram realizadas as mesmas otimizações para cada modelo de aerogerador, porém utilizando-se da base de dados horária.

\subsubsection{Otimização 02 - Fronteira Eficiente para Cada Aerogerador - Base Horária}

Nos Gráfico 93 e Gráfico 94 é apresentada a curva da fronteira eficiente para cada modelo do aerogerador, considerando a série histórica em base horária, da energia gerada e do fator de capacidade, respectivamente.

\footnotetext{
${ }^{93}$ Apesar da CCEE usar a base semanal para a contabilização, a liquidação ocorre em base mensal. ${ }_{94}$ Para o problema da operação, quanto menor a amostragem melhor. No presente trabalho, a menor amostragem está em base horária.
} 
Conforme item 5.2.4.1, os resultados para a série histórica com a energia gerada (Gráfico 86) e com o fator de capacidade (Gráfico 88) são semelhantes. A curva azul representa a fronteira eficiente. Os pontos em azul representam algumas das possíveis carteiras otimizadas. Os pontos em vermelho representam as coordenadas, equivalente a uma carteira composta somente por essa coordenada (carteira não otimizada).

Gráfico 93 - Curvas de Fronteiras Eficientes para cada Modelo de Aerogerador - Série Horária de Energia Gerada (kWh).

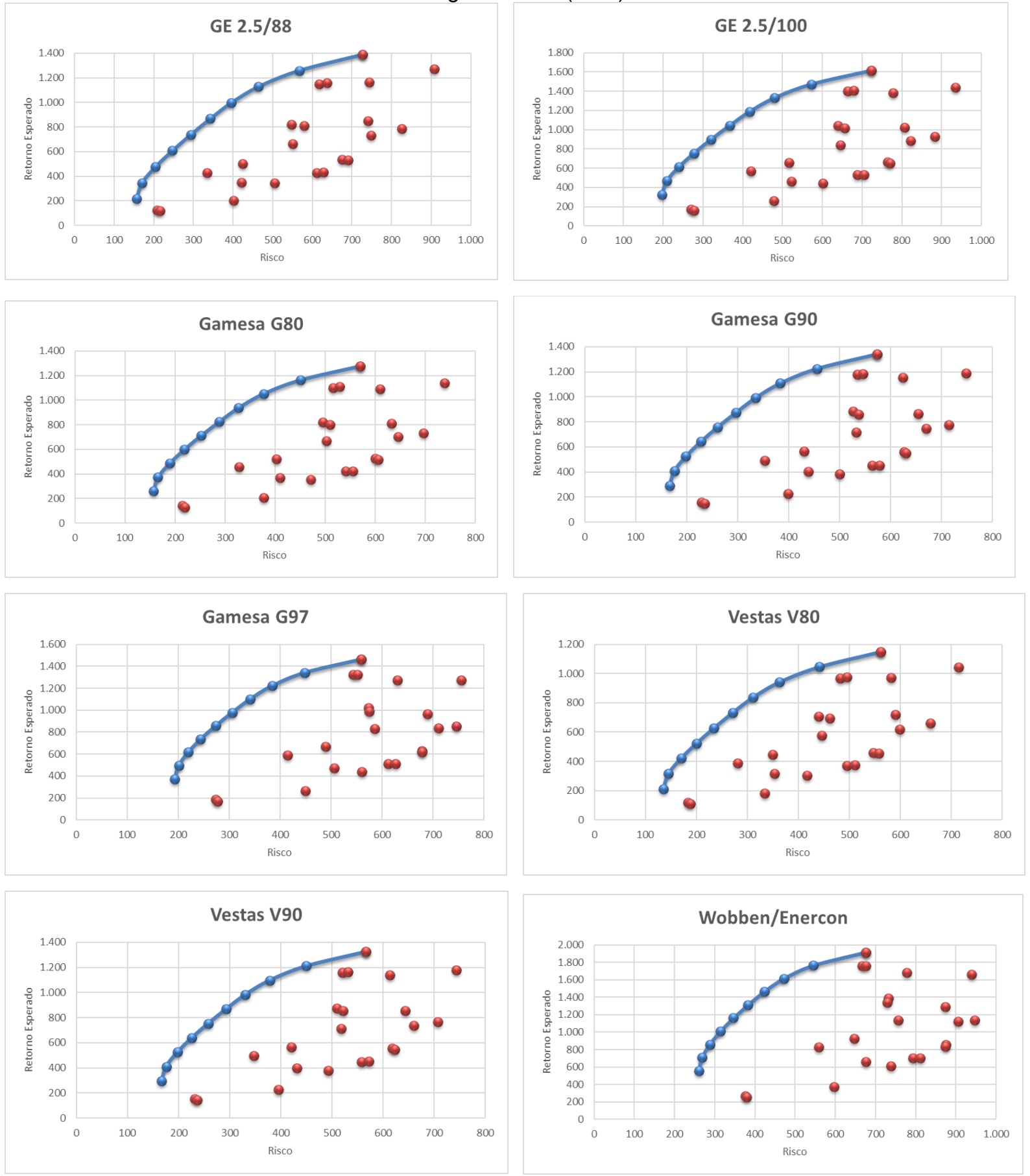



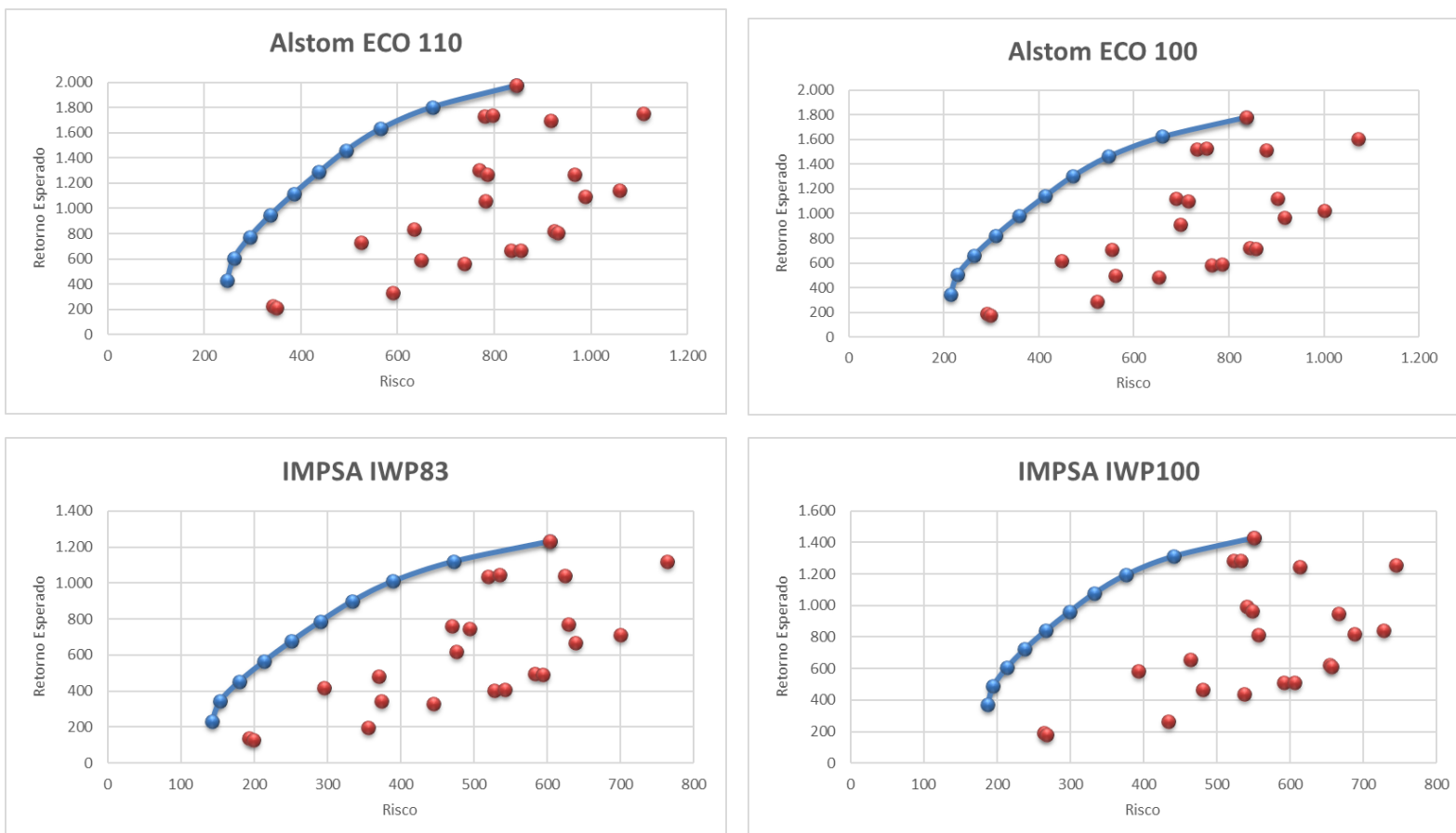

Autor (2016).

Gráfico 94 - Curvas de Fronteiras Eficientes para cada Modelo de Aerogerador - Série Horária do Fator de Capacidade.
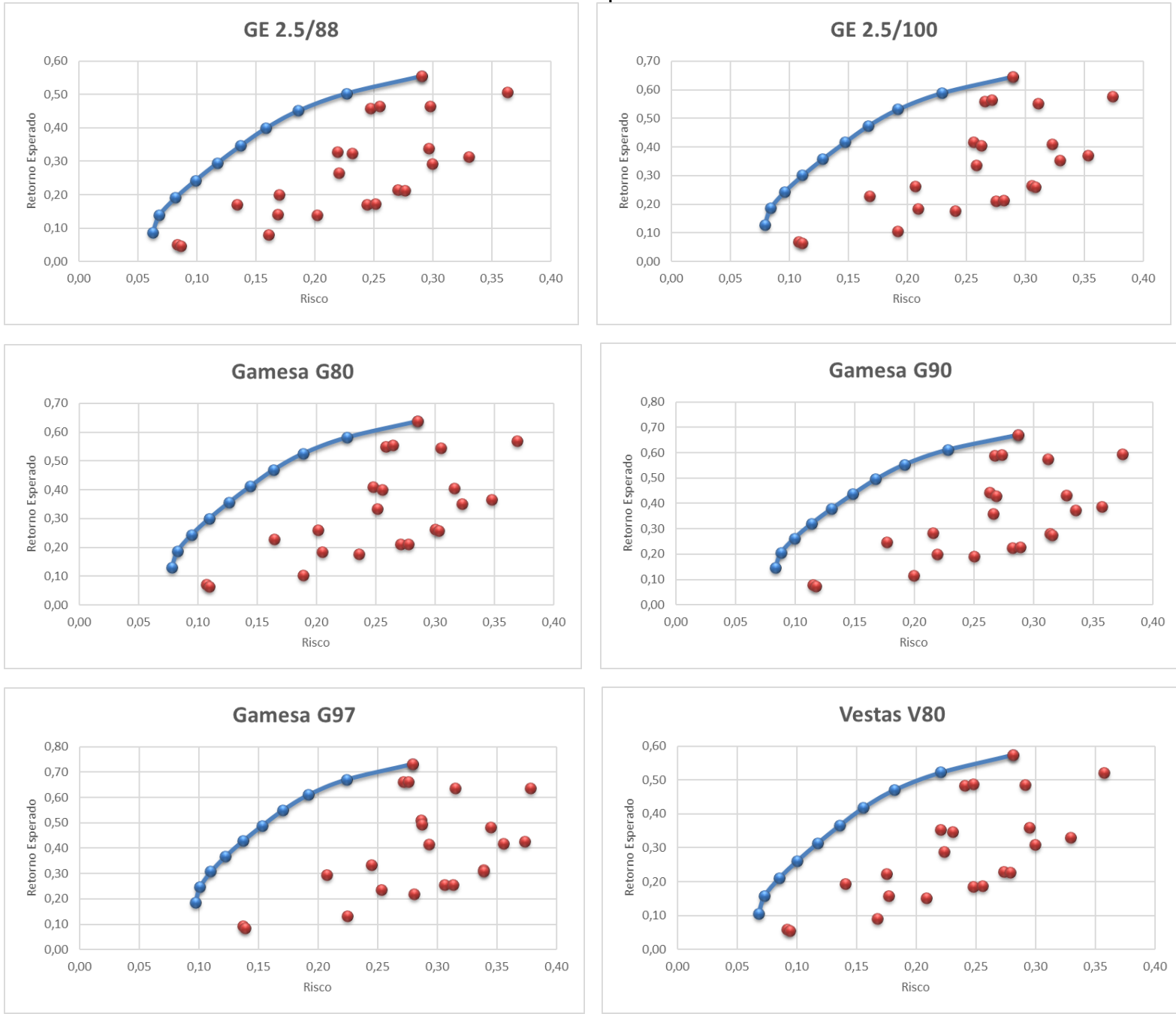

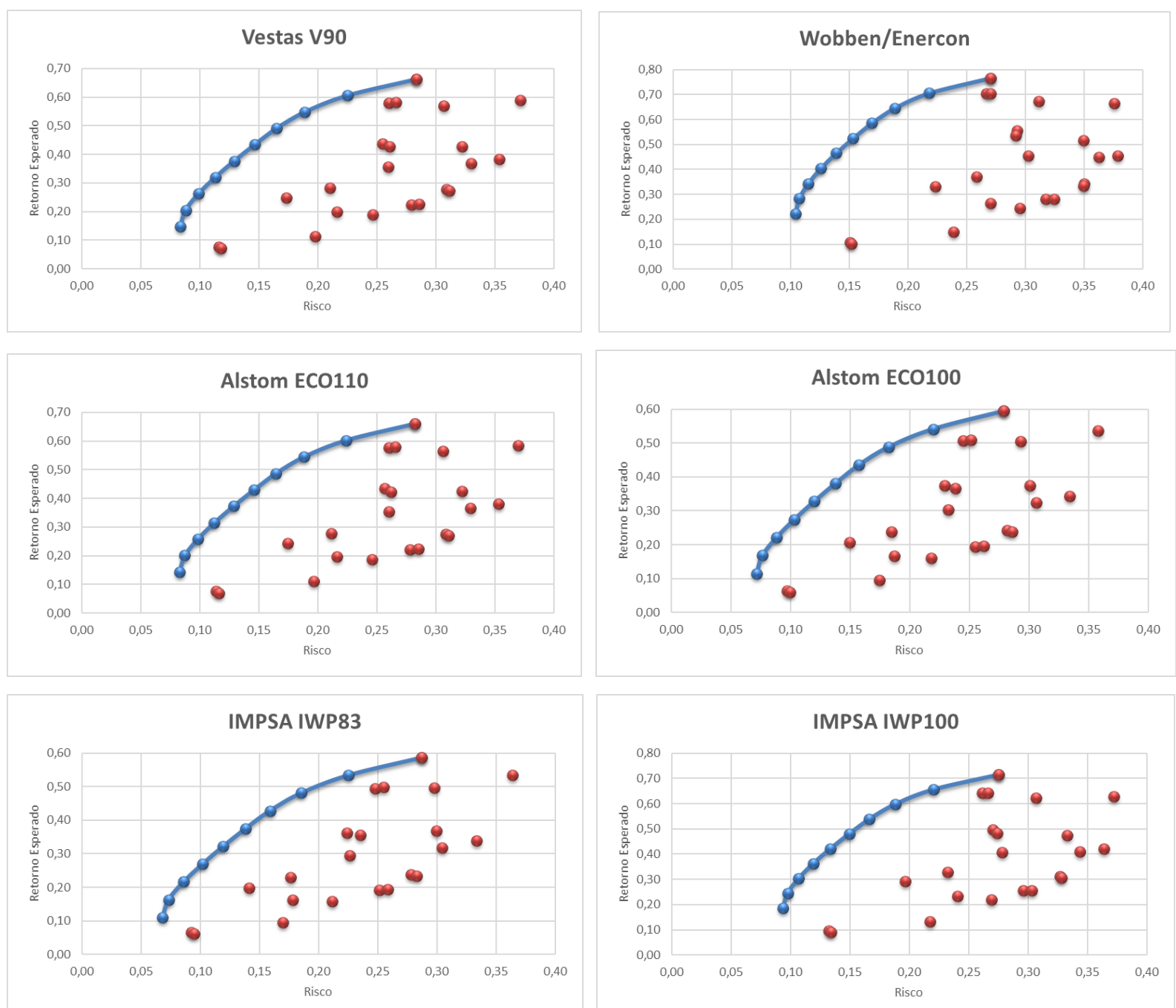

Autor (2016).

Novamente verifica-se semelhanças nas diversas curvas da fronteira, uma vez que a série histórica foi calculada a partir da mesma base de dados de velocidade do vento, sendo as diferenças decorrentes das características de cada modelo de aerogerador.

Nesse sentido, as duas coordenadas mais próximas do ponto de risco mínimo da curva de fronteira eficiente são Jacaraci e Olho D’água. Na otimização mensal (item 5.2.4.1), além da coordenada Olho da Água, as coordenadas Riachuelo e Anta foram as mais próximas do ponto de risco mínimo.

Ao contrário da otimização mensal (item 5.2.4.1), que apontou as coordenadas Parada, Itaguaçu e Afrânio, como as mais distantes da fronteira eficiente, na otimização horária, não há essa predominância. 
O Gráfico 95 e o Gráfico 96 apresentam as 12 fronteiras eficientes (uma para cada modelo de aerogerador), considerando os dados em energia e em fator de capacidade, respectivamente.

Gráfico 95 - Fronteiras Eficientes para cada Modelo de Aerogerador (Energia Gerada).

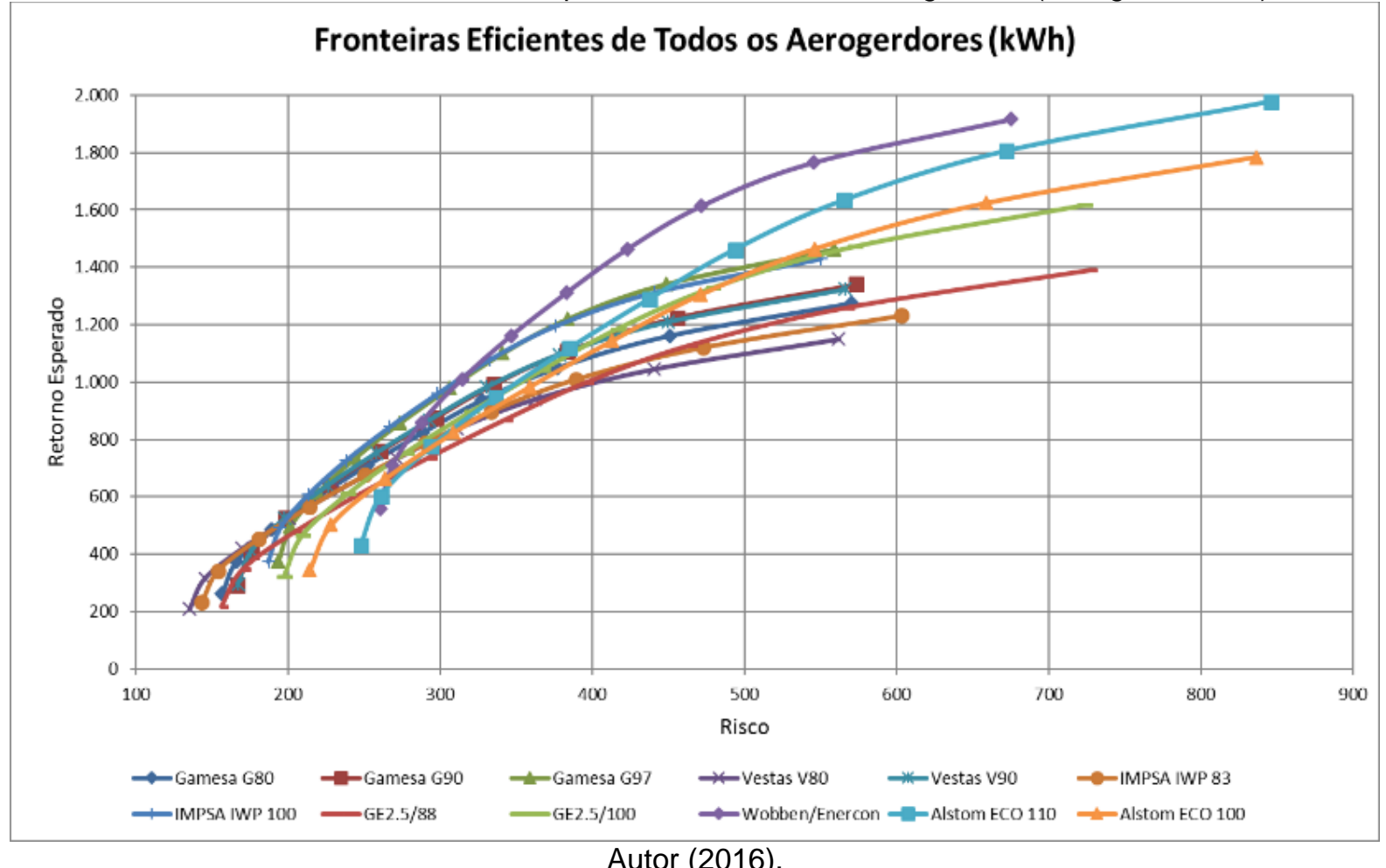

Gráfico 96 - Fronteiras Eficientes para cada Modelo de Aerogerador (Fator de Capacidade).

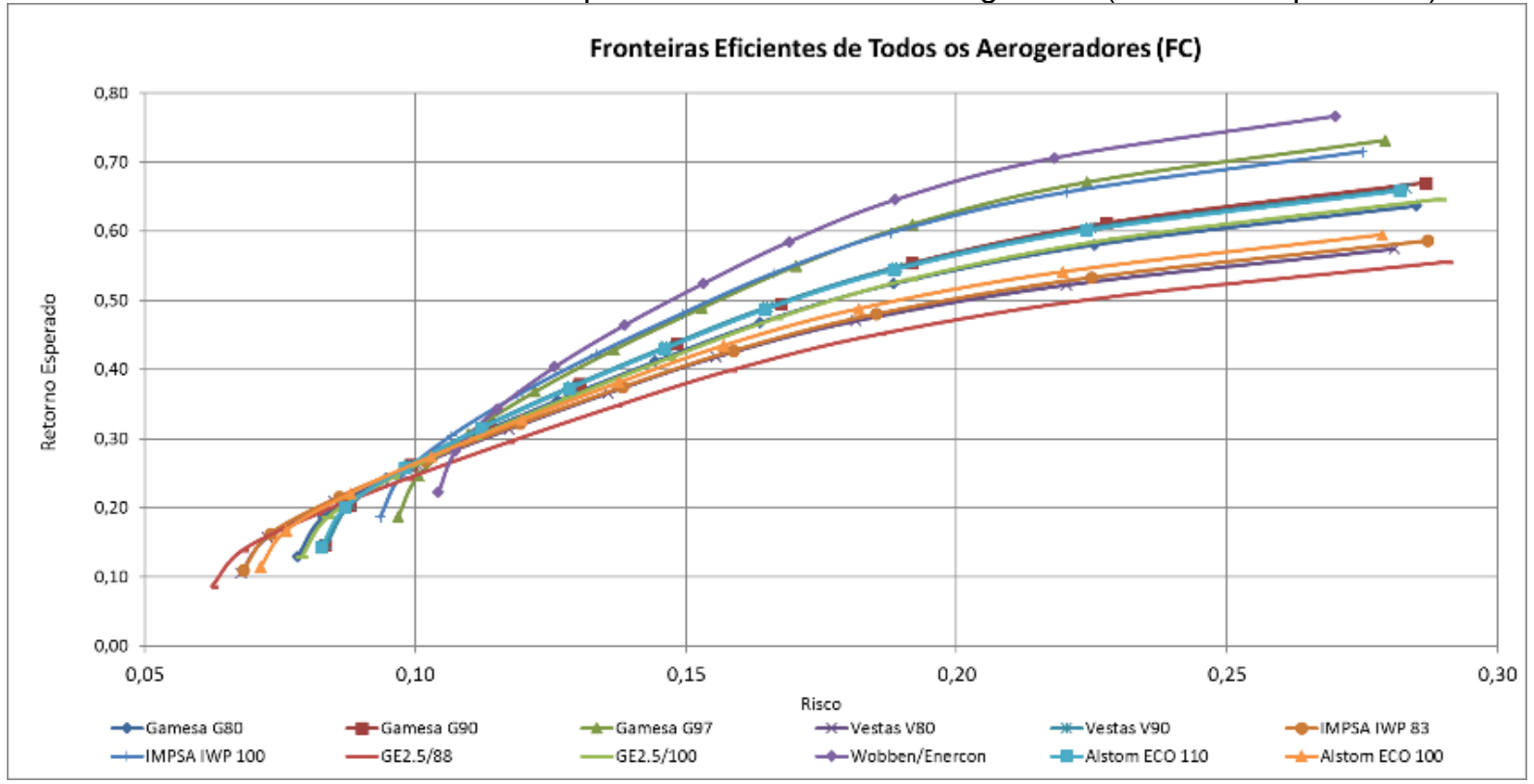

Autor (2016). 
Para um risco de 500 kWh (metade da abscissa), pelo Gráfico 95 é possível observar que os aerogeradores Wobben e Astom Eco 110 apresentam as maiores expectativas de geração (no item 5.2.4.1, esses aerogeradores também apresentaram a maior expectativa de geração em base mensal). Por um outro lado, para um risco de 0,2 (metade da abscissa), pelo Gráfico 96 é possível observar que os aerogeradores Wobben e Gamesa 97 apresentam as maiores expectativas de fator de capacidade, sendo que o aerogerador Astom Eco 110 apresenta apenas a quinta maior expectativa de geração. Esses resultados também foram obtidos no item 5.2.4.1.

Nas 10 carteiras otimizadas simuladas para cada modelo de aerogerador, apenas 5 coordenadas não foram selecionadas (Parada, Mocambira, Forquilha, Quilombo e Itaguaçu) das 22 coordenadas disponíveis. Na otimização em base mensal (item 5.2.4.1), as coordenadas Parada, São João, Mocambira, Forquilha, Tavares, Palmas, Tubarão, Itaguaçu, Jacaraci e Olho da Água não foram selecionadas no processo de otimização para nenhum modelo de aerogerador.

O Gráfico 97 apresenta a frequência da seleção das 22 coordenadas nas carteiras otimizadas para as 12 otimizações realizadas (para cada aerogerador). 0 resultado é coerente com o item 4.6 .5 (efeito da diversificação na carteira), contudo, quando se comparado ao resultado do item 5.2.4.1 (otimização em base mensal), foram necessárias mais coordenadas para a obtenção das carteiras otimizadas.

A TABELA 41 relaciona o risco mínimo e a geração esperada para cada aerogerador. A relação risco/retorno calculada para cada aerogerador na otimização horária é maior que aquela obtida na otimização mensal. Assim como na otimização em base mensal, na otimização horária, o aerogerador Wobben/Enercon possui maior expectativa de geração e menor relação risco/retorno. Assim, para o atendimento de uma determinada demanda, o aerogerador Wobben/Enercon exigirá menos investimento que os demais. 
Gráfico 97 - Frequencia de Uso das Coordenadas nas Carteiras Otimizadas (Fator de Capacidade).

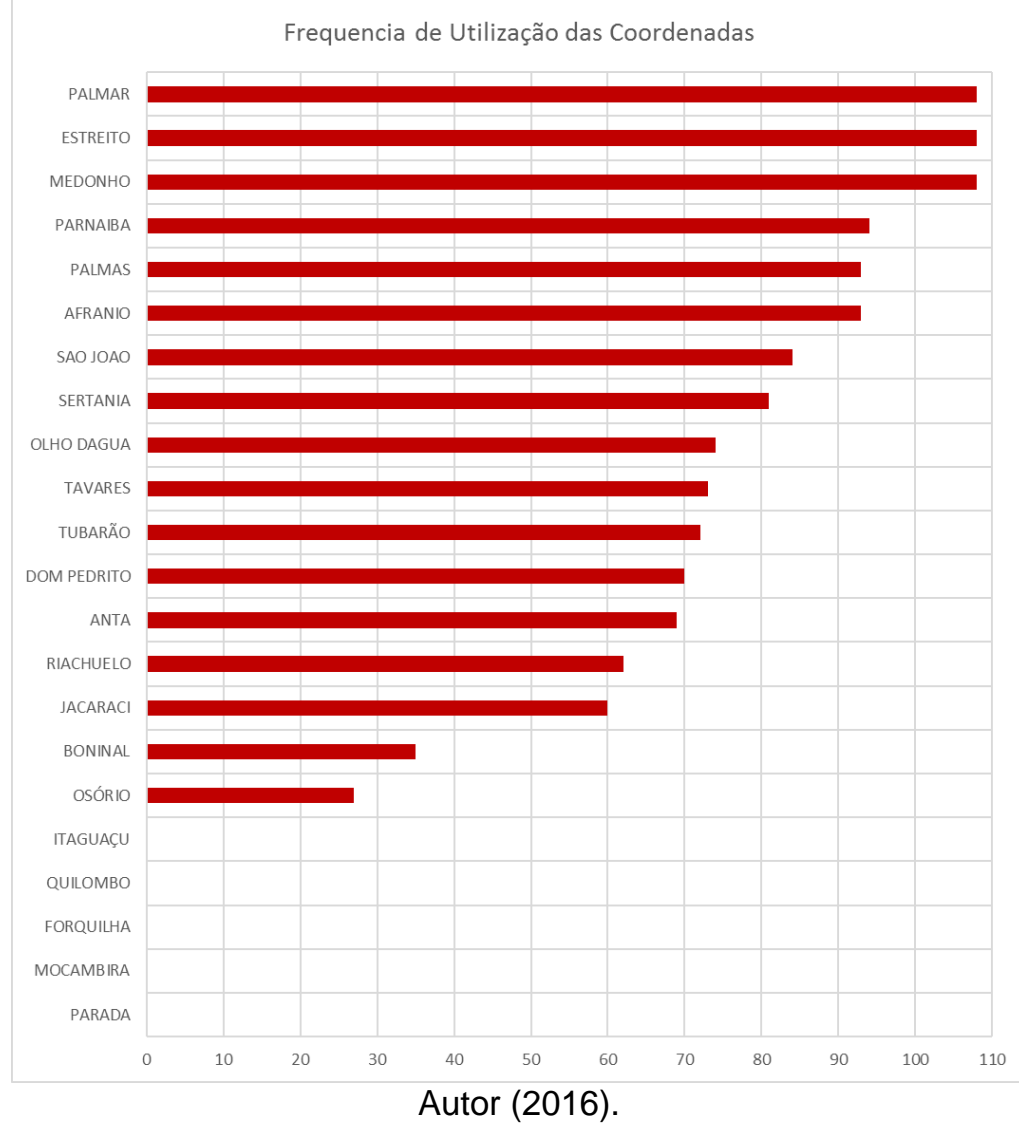

TABELA 41 - Risco Mínimo e Geração Esperada (Energia Gerada)

\begin{tabular}{lccc}
\hline \multicolumn{1}{c}{ Tipo do Aerogerador } & Risco Mínimo (kWh) & Geração Esperada (kWh) & Risco/Geração \\
\hline Wobben/Enercon & 260,41 & 556,98 & $47 \%$ \\
IMPSA IWP100 & 187,05 & 373,82 & $50 \%$ \\
Gamesa G97 & 193,44 & 372,91 & $52 \%$ \\
Gamesa G90 & 166,65 & 291,83 & $57 \%$ \\
Vestas V90 & 167,11 & 295,11 & $57 \%$ \\
Alstom ECO110 & 247,72 & 430,06 & $58 \%$ \\
Gamesa G80 & 156,47 & 260,81 & $60 \%$ \\
GE 2.5/100 & 197,47 & 322,8 & $61 \%$ \\
IMPSA IWP83 & 143,07 & 231,22 & $62 \%$ \\
Alstom ECO100 & 213,87 & 342,99 & $62 \%$ \\
Vestas V80 & 135,32 & 210,9 & $64 \%$ \\
GE 2.5/88 & 155,85 & 215,94 & $72 \%$ \\
\hline
\end{tabular}

Autor (2016).

Das 22 coordenadas possíveis para compor as carteiras de menor risco, as coordenadas Medonho, Tavares, Sertania, Palmas, Osório, Estreito, Palmar, Jacaraci, Olho d'Água95, Dom Pedrito e Anta foram utilizadas. A coordenada Dom Pedrito foi

95 As coordenadas Olho d'Água e Jacaraci estão próximas do ponto de risco mínimo da curva de fronteira eficiente. 
aproveitada apenas na otimização com o modelo do aerogerador Wobben/Enercon. A coordenada Anta foi selecionada para 10 modelos de aerogerador. As demais, foram selecionadas para os 12 modelos.

O Gráfico 98 ilustra a curva da fronteira eficiente para o aerogerador Wobben/Enercon em conjunto com a carteira atual, carteira PROINFA e carteiras individuais, para a série de dados de energia gerada em base horária.

Gráfico 98 - Fronteira Eficiente do Aerogerador Wobben/Enercon e Carteiras Atual, PROINFA e Individuais (Energia Gerada em Base Horária).

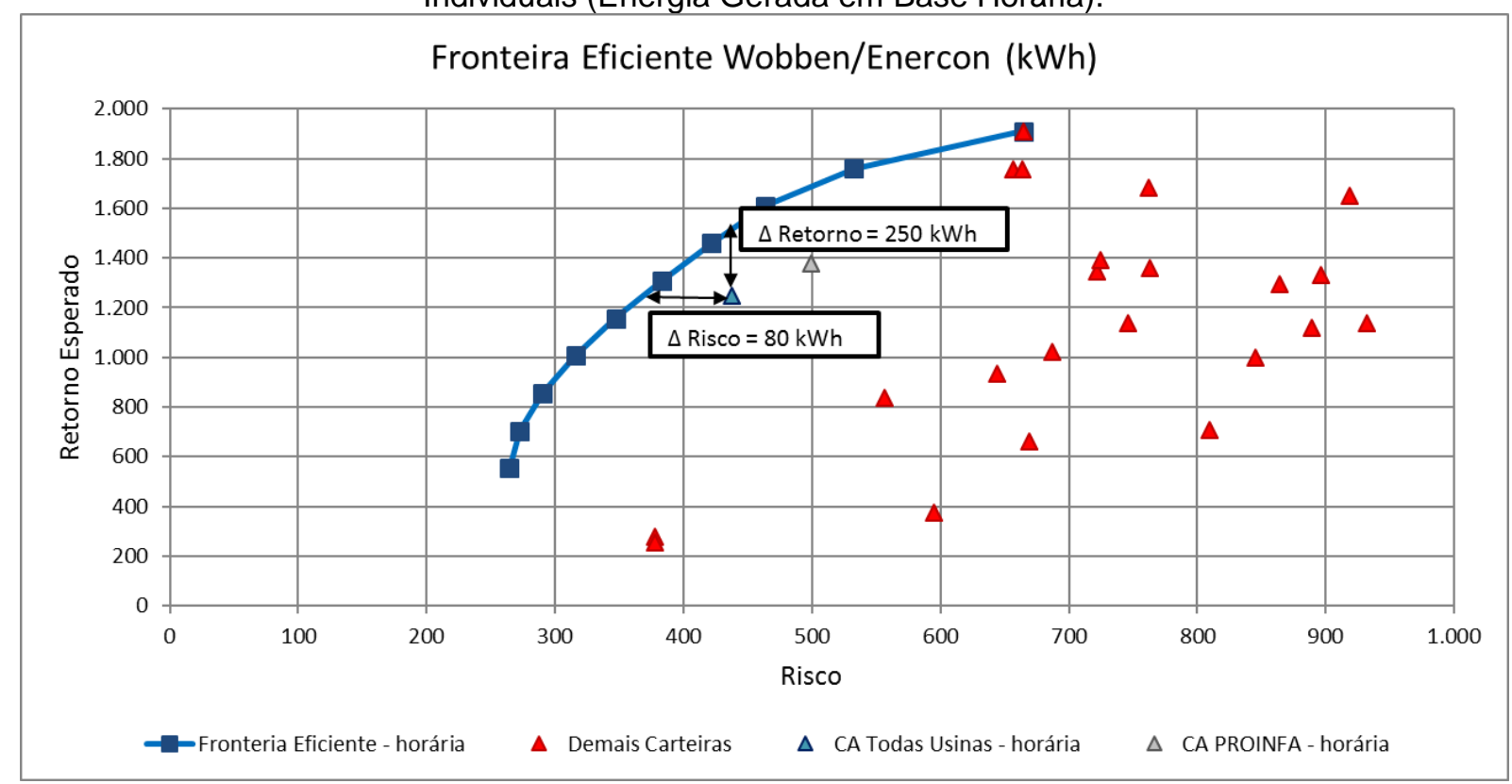

Autor (2016).

A carteira atual e a carteira PROINFA foram calculadas a partir da ponderação dos parâmetros de média e desvio padrão pela potência instalada das usinas listadas no Boletim Mensal de Dados do Setor Eólico elaborado pela ABEEólica, de novembro de 2015, conforme detalhado no item 5.2.4.

Verifica-se que a carteira atual e a carteira PROINFA estão distantes da fronteira eficiente. A regra de contratação das usinas não está obtendo a diversificação otimizada da carteira.

Os resultados obtidos possuem uma faixa de expectativa de geração entre $553,79 \mathrm{kWh}$ (carteira de risco mínimo) a 1.760,48 kWh (carteira de maior retorno), enquanto a carteira atual possui uma expectativa igual a 1.247,82 kWh. As carteiras otimizadas com expectativa de geração menor que a carteira atual, exigirão maior investimento para atendimento da mesma demanda. 
O Gráfico 98 ilustra que uma mudança na composição da carteira atual poderia reduzir a volatilidade em $80 \mathrm{kWh}$ (18\% do valor atual), mantendo praticamente a mesma expectativa de geração. Alternativamente, seria possível aumentar em 250 kWh a expectativa de geração ( $20 \%$ do valor atual), para praticamente o mesmo risco.

No item 5.2.4.1 foi verificado que uma mudança na composição da carteira atual poderia reduzir a volatilidade mensal em 52\% (de 336,16 kWmédios para 174,40 kWmédios), mantendo praticamente a mesma expectativa de geração. Alternativamente, seria possível aumentar em $27 \%$ a expectativa de geração mensal (de 1.368,33 kWmédios para 1.732,58 kWmédios), para praticamente o mesmo risco.

A carteira que reduz a volatilidade mensal em $52 \%$ é composta de $30,55 \%$ da potência instalada em Medonho e $69,45 \%$ da potência instalada na coordenada Palmar. Em base horária, essa carteira apresenta um risco de 647 kWh e uma expectativa de geração de $1.436 \mathrm{kWh}$, ou seja, fora da curva da fronteira eficiente.

O Gráfico 99 apresenta as fronteiras eficientes para a série histórica da energia gerada horária e mensal. Na curva vermelha tem-se a fronteira eficiente para a base mensal. Na curva azul, a fronteira eficiente para a base horária. Os pontos em vermelho são os ativos individuais, em base mensal. Os pontos em azul representam os ativos individuais, em base horária. Todos os resultados foram calculados para o aerogerador Wobben/Enercon.

A volatilidade horária é maior que a volatilidade em base mensal, conforme se verifica no Gráfico 99. Isso se explica, pois dentro de um mês, as variações da energia gerada acabam por se compensarem, resultando no mês, variações menores.

Os pontos em azul, que representam os ativos individuais em base horária, na sua grande maioria, possuem maior desvio padrão (risco) que os ativos individuais em base mensal (pontos em vermelho). Em decorrência, a fronteira eficiente em base horária está mais à direita da abscissa (maior volatilidade). 
Gráfico 99 - Fronteiras Eficientes para o Aerogerador Wobben/Enercon - Série histórica de energia gerada horária (kWh) e mensal (kWmédio).

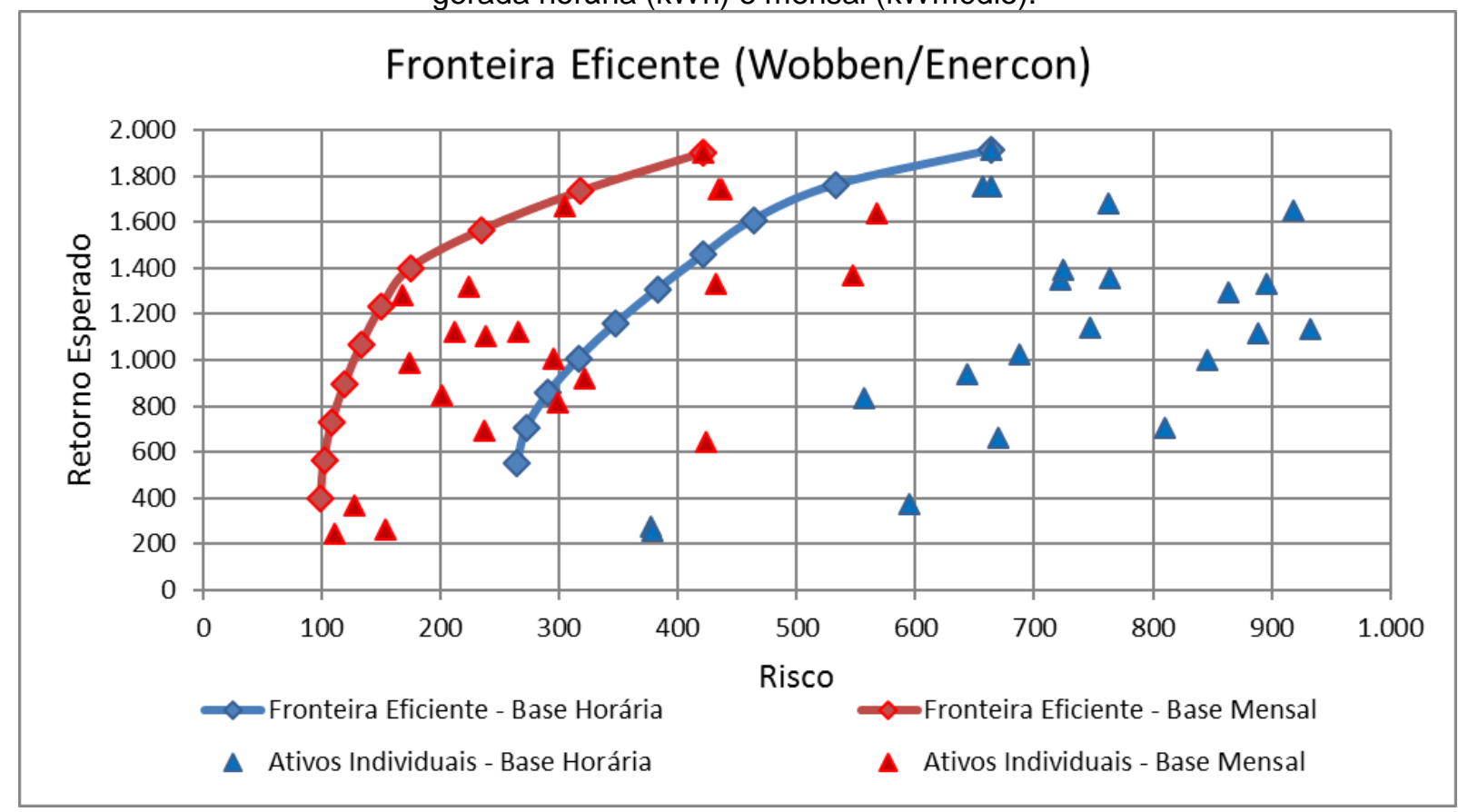

Autor (2016).

As carteiras ótimas sobre a curva da fronteira eficiente mensal não estão sobre a curva da fronteira eficiente horária. A composição das carteiras otimizadas para a base de dados horária diverge da composição das carteiras otimizadas para a base de dados mensal. Em outras palavras, a otimização horária, não resulta em otimização mensal, e vice-versa. Consoante abordado, a otimização mensal é importante para o problema da comercialização de energia, enquanto que a otimização horária é importante para o problema da operação.

5.2.4.3 Otimização 03 - Fronteira Eficiente com Todos os Aerogeradores - Base Mensal e Horária

Nas otimizações anteriores (itens 5.2.4.1 e 5.2.4.2), para cada modelo de aerogerador foi encontrada a fronteira eficiente, considerando as coordenadas como ativos individuais. O Gráfico 89 e o Gráfico 95 apresentaram a curva da fronteira eficiente para cada modelo de aerogerador, considerando a série de energia gerada em base mensal e horária, respectivamente. 
Nos referidos gráficos é possível observar que há aerogeradores que possuem uma melhor relação risco/retorno na primeira parte da curva da fronteira eficiente, enquanto outros possuem um desempenho melhor na segunda parte.

Neste tópico foi obtida a fronteira eficiente, considerando que cada aerogerador e coordenada são ativos possíveis de serem utilizados na otimização.

Sendo assim, tem-se 22 coordenadas e 12 modelos de aerogeradores, que resultam em 264 ativos. Nas otimizações, foi excluído o aerogerador Gamesa G90, pois quando incluído, o modelo de otimização, seja em base mensal, quanto em base horária, não converge ${ }^{96}$. Portanto, foram utilizados no modelo de otimização 22 coordenadas e 11 modelos de aerogeradores, totalizando 242 ativos, período de 01/01/1994 a 31/12/2014, série histórica mensal e horária.

A exclusão do aerogerador Gamesa G90 não implica em prejuízos para o resultado, na medida em que outros dois modelos do mesmo fabricante continuam sendo utilizados nas simulações.

Por uma questão de espaço físico de implementação da usina eólica, adotouse a restrição que para uma determinada coordenada não é possível eleger mais de um modelo de aerogerador. Sendo assim, eventuais carteiras otimizadas com esse tipo de resultado foram descartadas ${ }^{97}$.

O Gráfico 100 apresenta a fronteira eficiente geral (curva azul clara mais espessa) considerando os 242 ativos individuais (22 coordenadas e 11 modelos de aerogeradores), as fronteiras para cada modelo de aerogerador e os ativos individuais (pontos vermelhos). Nesta otimização, foi utilizada a série histórica de energia gerada em base mensal.

A curva da fronteira eficiente geral tangencia as curvas das fronteiras eficientes de cada modelo de aerogerador que possui o maior retorno para o mesmo risco. A parte mais à direita da abscissa tangencia a curva do aerogerador Wobben/Enercon, enquanto a parte mais próxima do eixo das ordenadas, tangencia a curva do aerogerador Vestas V80.

\footnotetext{
${ }^{96}$ Não se conseguiu encontrar o motivo da não convergência.

${ }^{97}$ A restrição de que não seria possível para uma determinada coordenada mais de um modelo de aerogerador se mostrou complexa para a implementação na medida em que o problema de programação linear torna-se um problema de otimização binário misto (mais complexo de se resolver pois envolve variáveis binárias e contínuas), assim optou-se por excluir os resultados que feriam essa restrição.
} 
Gráfico 100 - Fronteira Eficiente Considerando todos os Aerogeradores (Energia Gerada).

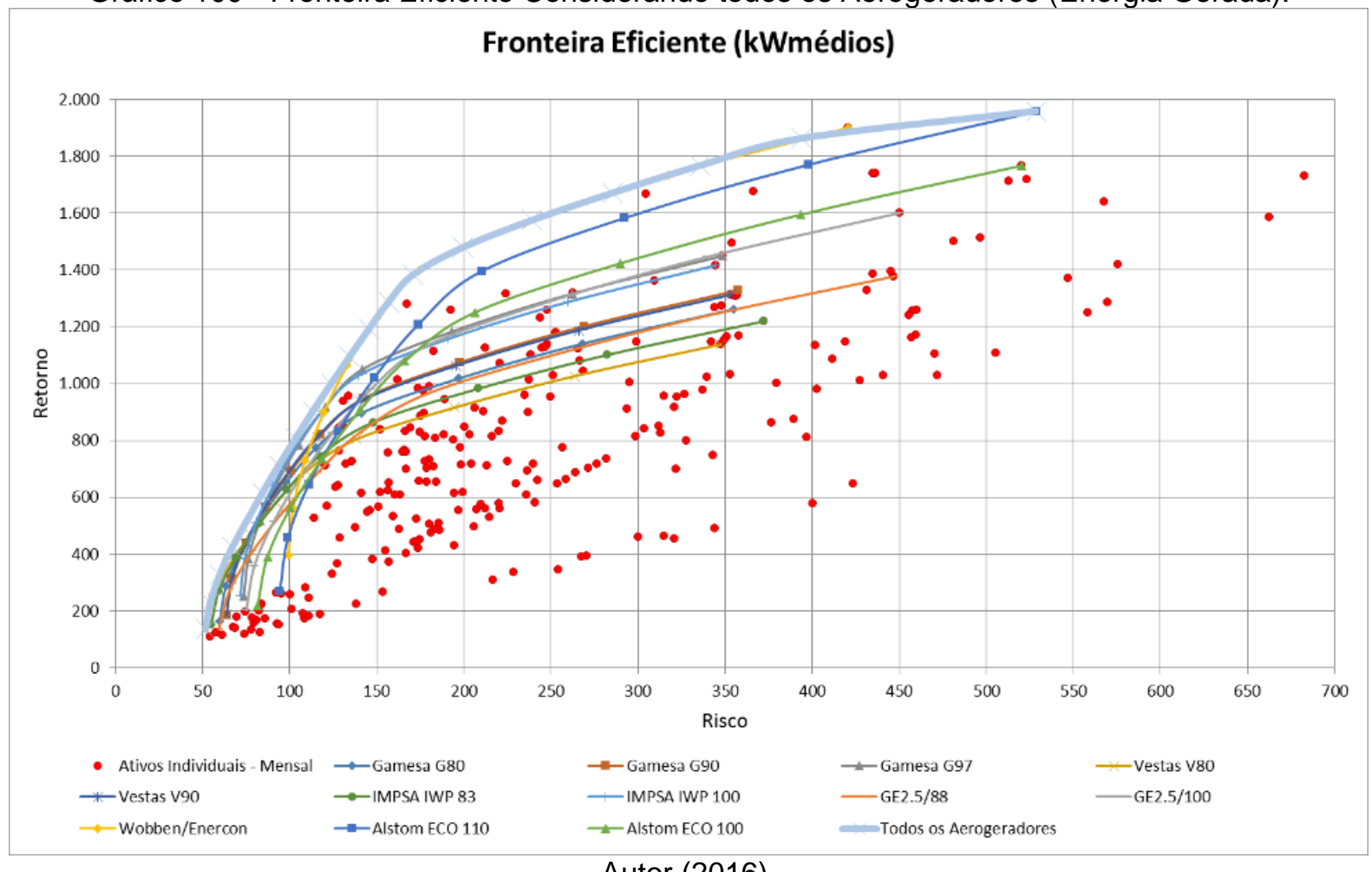

Autor (2016).

O Gráfico 101 apresenta o peso dos modelos dos aerogeradores (percentual de participação do ativo) em 20 carteiras otimizadas. O Gráfico 102 apresenta o peso das coordenadas (percentual de participação do ativo) para as mesmas 20 carteiras otimizadas. Das 20 carteiras otimizadas geradas, apenas 1 carteira foi desconsiderada, pois selecionou o aerogerador Wobben/Enercon e Impsa IWP100 para a coordenada Palmar, muito embora o peso do aerogerador Wobben/Enercon na carteira tenha sido de apenas $1,14 \%$.

Apesar dos 242 ativos individuais disponíveis para a otimização, coerentemente com o que foi apresentado no item 4.6.5, apenas os aerogeradores Wobben/Enercon, Vestas V80, Alstom ECO110 e Impsa IWP100 e as coordenadas Parnaiba, Medonho, Quilombo, Osório, Palmar, Boninal, Riachuelo e Anta foram selecionadas pelo modelo de otimização.

No Gráfico 103 é apresentada a fronteira eficiente geral (que considera os 242 ativos individuais) e as curvas dos aerogeradores Wobben/Enercon, Vestas V80, Alstom ECO110 e Impsa IWP100, que foram selecionados nas carteiras otimizadas. 
Gráfico 101 - Peso dos Modelos dos Aerogeradores nas Carteiras Otimizadas (Série histórica de energia gerada mensal).

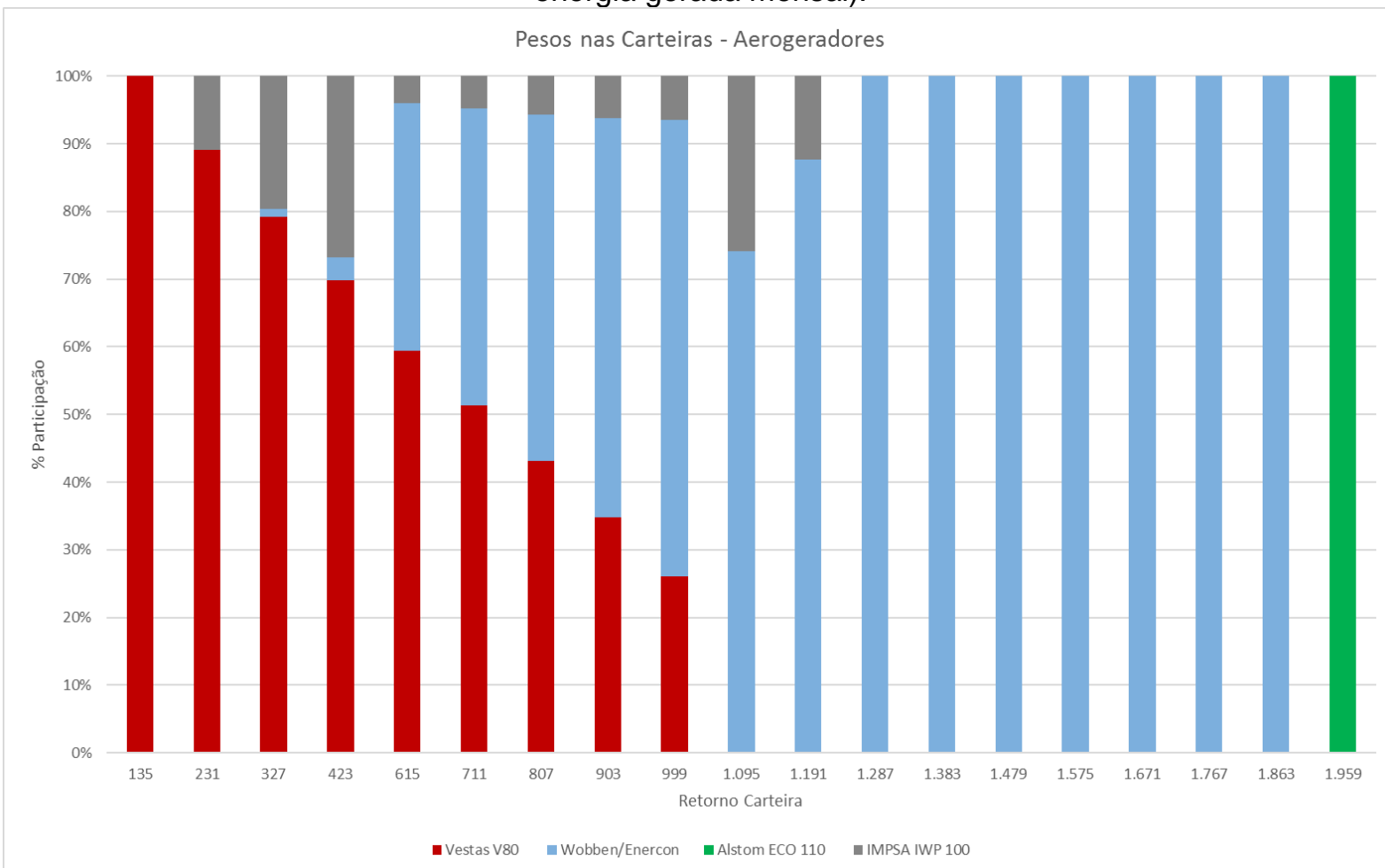

Autor (2016).

Gráfico 102 - Peso das Coordenadas nas Carteiras Otimizadas (Série histórica de energia gerada mensal).

Pesos nas Carteiras - Coordenadas

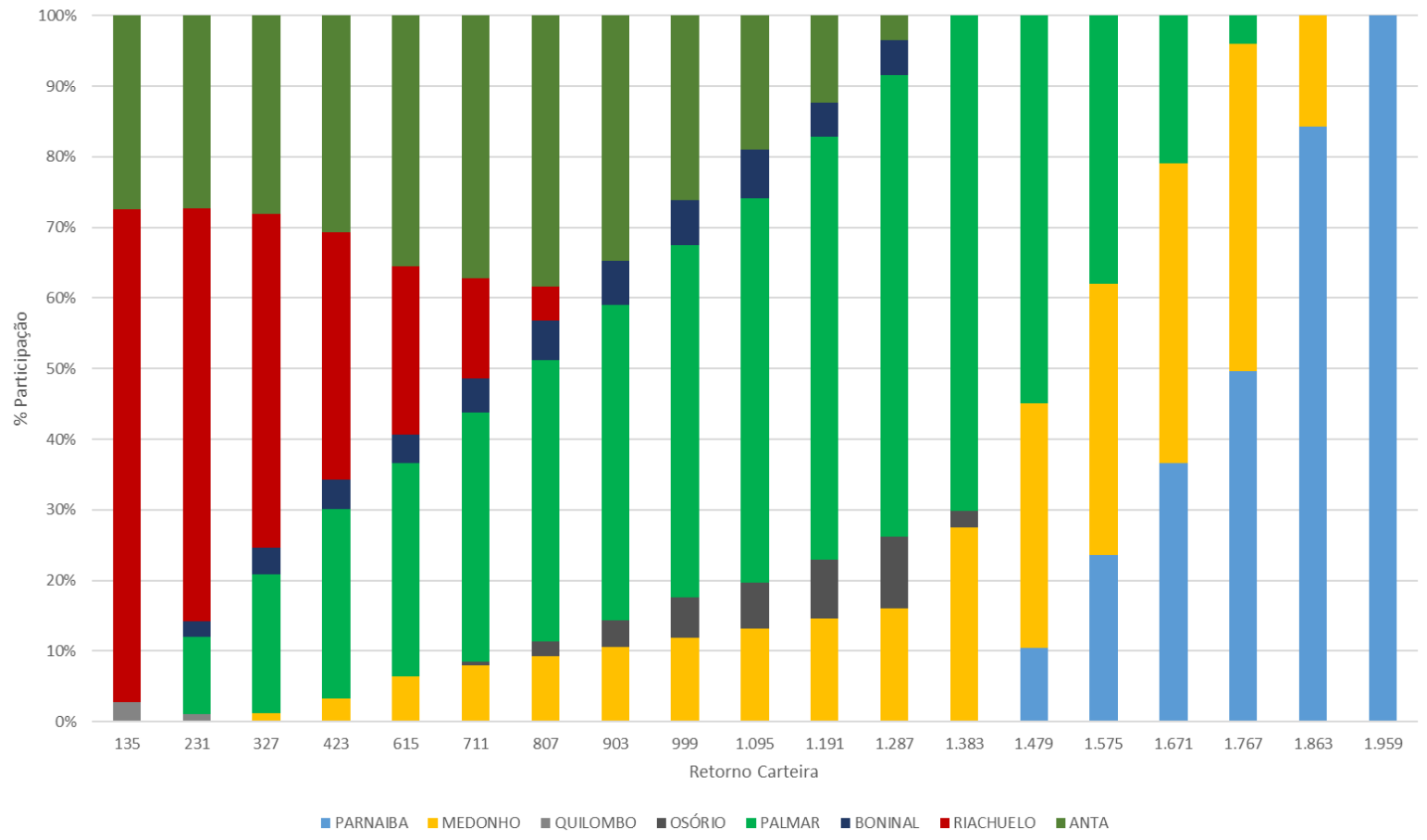

Autor (2016). 
Gráfico 103 - Fronteira Eficiente Considerando todos os Aerogeradores e Curva dos Aerogeradores Selecionados (Série histórica de energia gerada mensal - kWmédios).

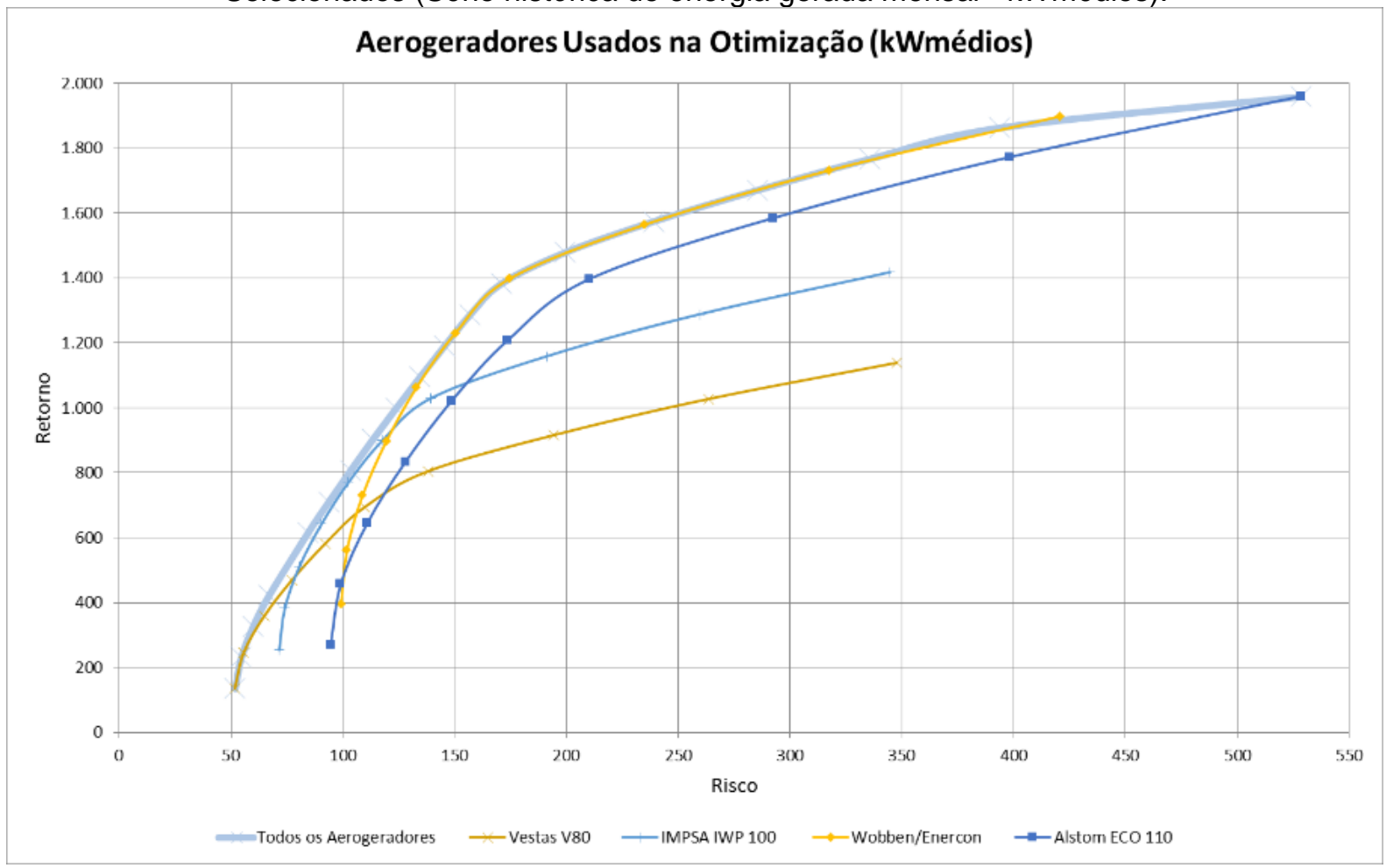

Autor (2016).

Nesse gráfico é possível observar que a curva da fronteira eficiente geral tangencia incialmente a curva do aerogerador Vestas V80, depois a curva do modelo Impsa IWP100, na sequência o aerogerador Wobben/Enercon e ao final o aerogerador AlstoM ECO 110.

A otimização a partir da série histórica de energia gerada em base horária está ilustrada no Gráfico 104, que apresenta a fronteira eficiente geral (curva azul clara mais espessa) considerando os 242 ativos individuais, as fronteiras para cada modelo de aerogerador e os ativos individuais (pontos vermelhos).

$\mathrm{Na}$ otimização horária, também foi adotada a restrição de que para uma determinada coordenada não é possível mais de um modelo de aerogerador. Sendo assim, as carteiras otimizadas com esse tipo de resultado foram descartadas.

Nesse sentido, das 20 carteiras otimizadas geradas, apenas 3 carteiras foram desconsideradas, pois selecionaram dois modelos de aerogerador para a mesma coordenada (Medonho e Palmas). 
Gráfico 104 - Fronteira Eficiente Considerando todos os Aerogeradores (Série histórica de energia gerada horária - kWh).

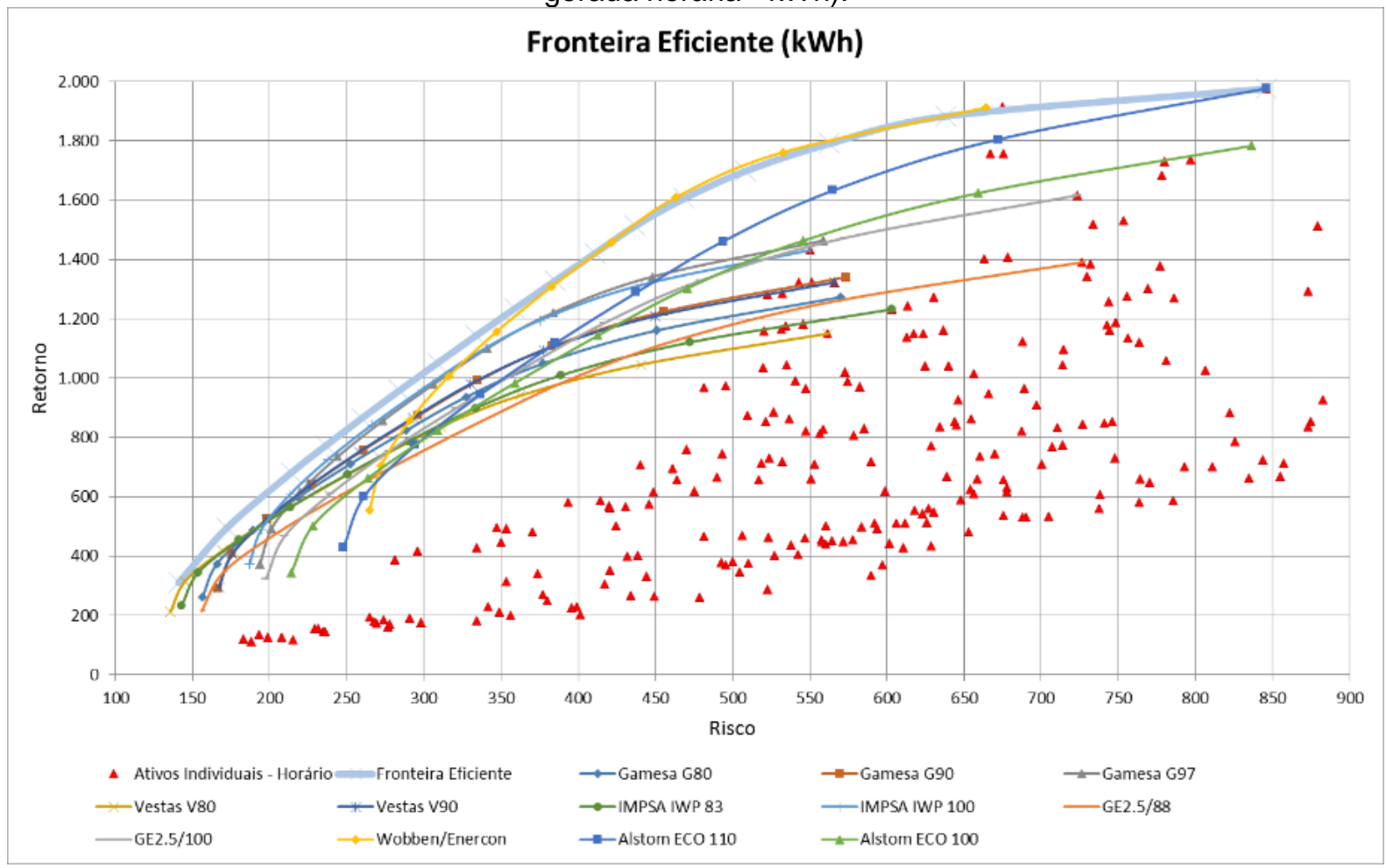

Autor (2016).

No Gráfico 105 é apresentada a fronteira eficiente geral (que considera os 242 ativos individuais) e as curvas dos aerogeradores Wobben/Enercon, Vestas V80, Alstom ECO110, Impsa IWP83 e Impsa IWP100, que foram selecionados nas 20 carteiras otimizadas simuladas. Com exceção do aerogerador Impsa IWP83, os demais já haviam sido selecionados na otimização considerando a série histórica mensal. Nesse gráfico é possível observar que a curva fronteira eficiente geral tangencia incialmente a curva do aerogerador Vestas V80, depois a curva do modelo Impsa IWP83, na sequencia o aerogerador Wobben/Enercon e ao final o aerogerador Alstom ECO 110.

Aparentemente, a curva fronteira eficiente geral não tangencia a curva do modelo Impsa IWP100, contudo as curvas tangenciam-se, mas devido ao reduzido número de pontos (carteiras otimizadas geradas), além das carteiras descartadas, o aparente não tangenciamento é decorrente do ajuste da curva que une os pontos dos ativos otimizados.

O Gráfico 106 apresenta o peso dos modelos dos aerogeradores (percentual de participação do ativo) em 20 carteiras otimizadas (3 foram descartadas). 
Gráfico 105 - Fronteira Eficiente Considerando todos os Aerogeradores e Curva dos Aerogeradores Selecionados (Série histórica de energia gerada horária - kWh).

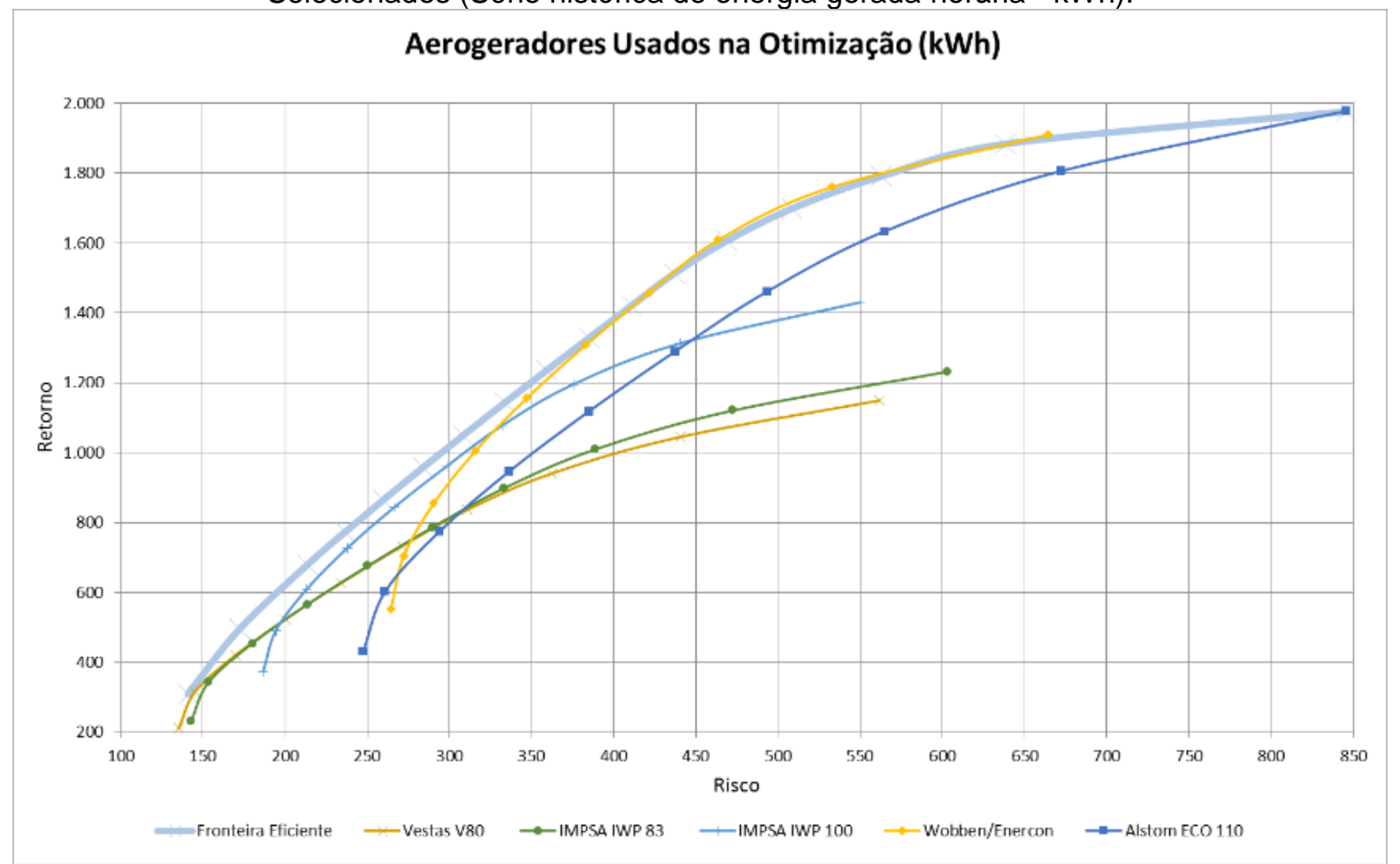

Autor (2016).

Gráfico 106 - Peso dos Modelos dos Aerogeradores nas Carteiras Otimizadas (Série histórica de energia gerada horária).

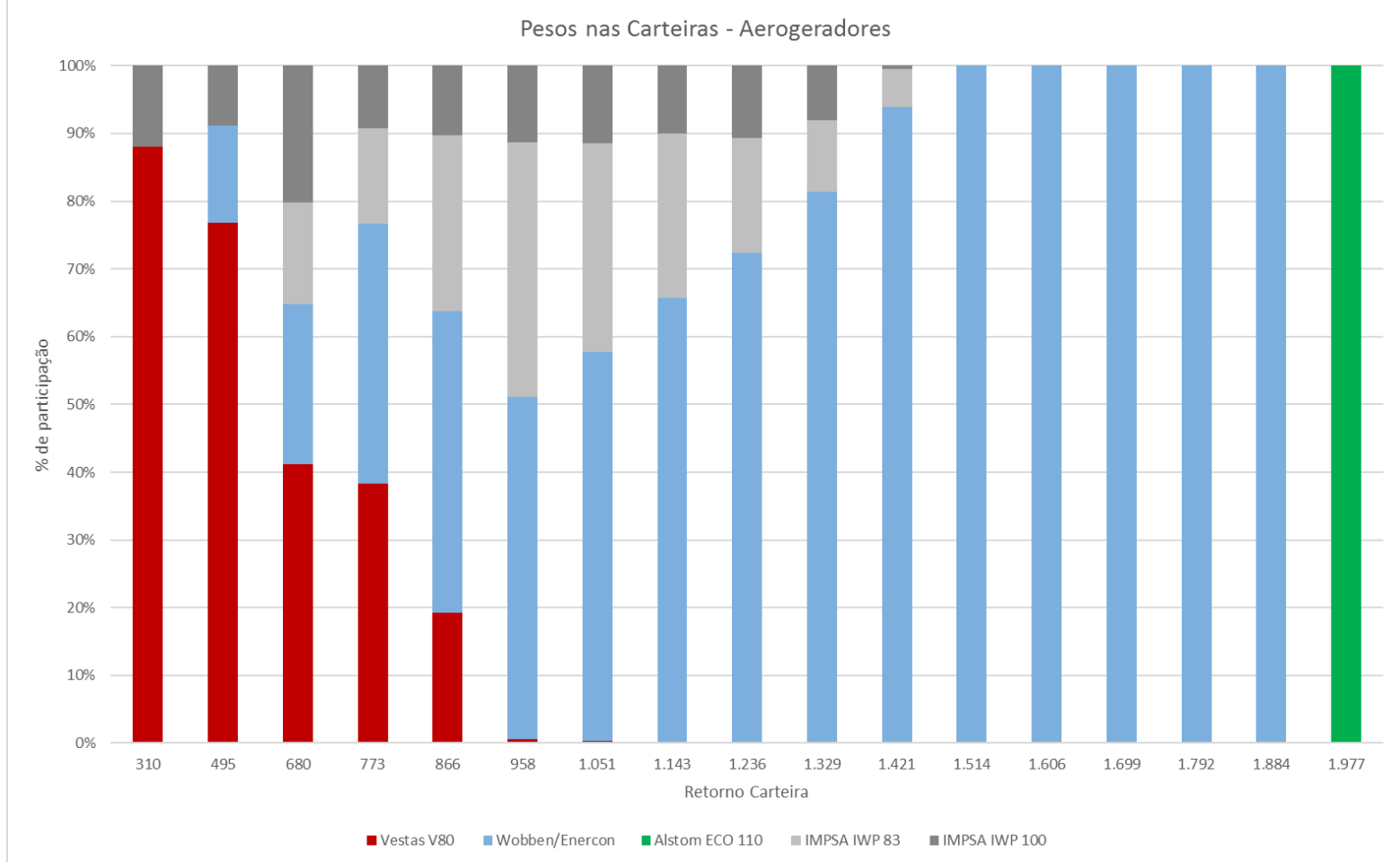

Autor (2016). 
O Gráfico 107 apresenta o peso das coordenadas (percentual de participação do ativo) em 20 carteiras otimizadas (3 foram descartadas).

Gráfico 107 - Peso das Coordenadas nas Carteiras Otimizadas (Série histórica de energia gerada horária).

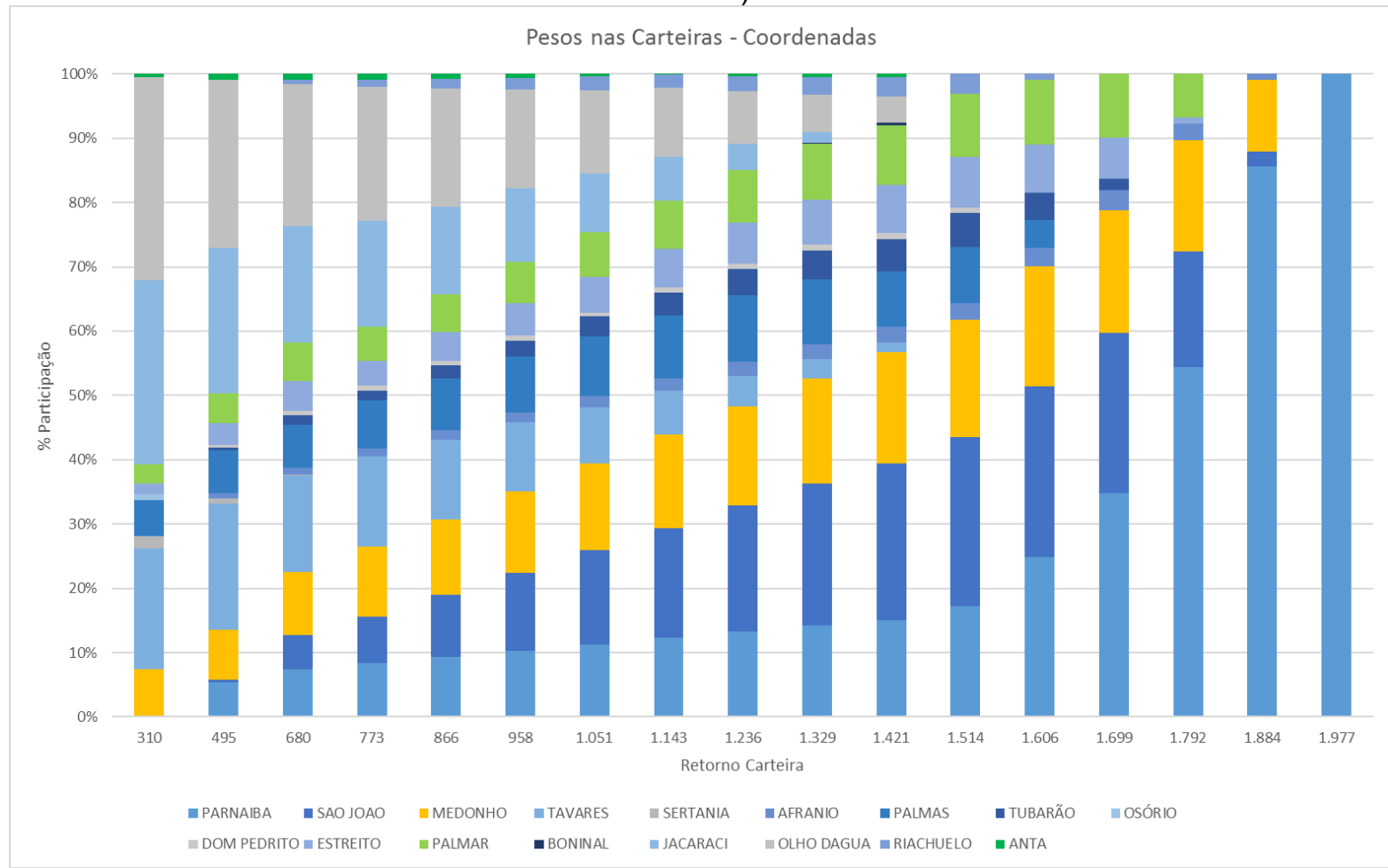

Autor (2016).

Em relação à localização, além das coordenadas Parnaiba, Medonho, Osório, Palmar, Boninal, Riachuelo e Anta, que já haviam sido escolhidas na otimização considerando a série histórica mensal, as coordenadas São João, Tavares, Sertania, Afrânio, Palmas, Tubarão, Dom Pedrito, Estreito, Jucaraci e Olho D’água foram selecionadas entre as 22 disponíveis. A coordenada Quilombo, que havia sido selecionada na otimização considerando a série histórica mensal, não foi selecionada na otimização considerando a série histórica horária.

Verifica-se que as otimizações mensal e horária elegeram praticamente os mesmos aerogeradores. Em relação às coordenadas, a otimização horária selecionou 10 coordenadas a mais que a otimização mensal. Esse resultado já havia sido apresentado nos itens anteriores (5.2.4.1 e 5.2.4.2).

O Gráfico 108 apresenta as fronteiras eficientes para a série histórica da energia gerada horária e mensal. 
Gráfico 108 - Fronteiras Eficientes - Série Histórica de Energia Gerada Horária (kWh) e Mensal (kWmédios).

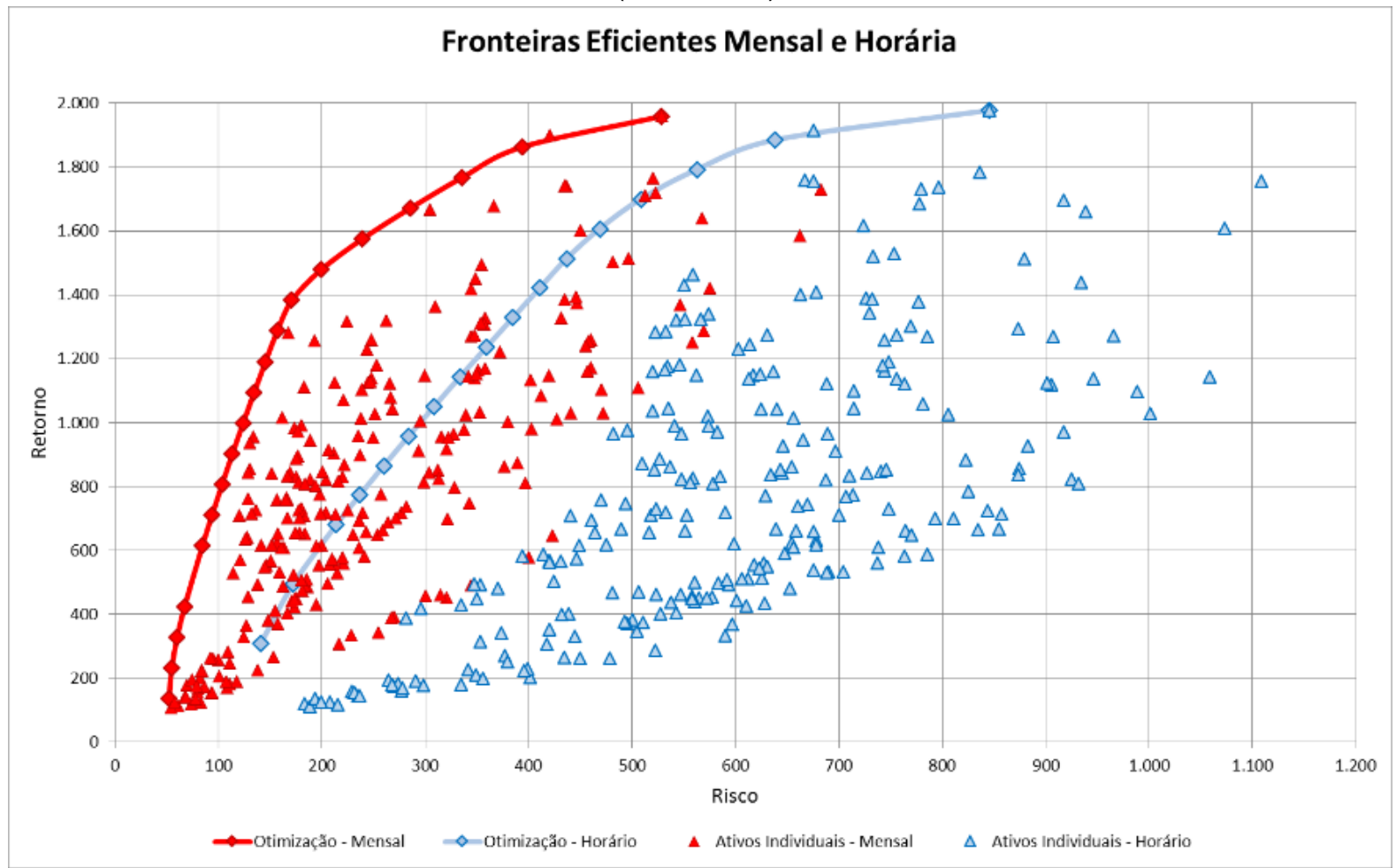

Autor (2016).

$\mathrm{Na}$ curva vermelha tem-se a fronteira eficiente para a base mensal. Na curva azul, a fronteira eficiente para a base horária. Os pontos em vermelho são os ativos individuais, em base mensal. Os pontos em azul representam os ativos individuais, em base horária.

Semelhante ao obtido no Gráfico 99, os pontos em azul, que representam os ativos individuais em base horária, na sua grande maioria, possuem maior desvio padrão (risco) que os ativos individuais em base mensal (pontos em vermelho). Em decorrência, a fronteira eficiente em base horária está mais à direita da abscissa (maior risco).

Da mesma forma que verificado no item 5.2.4.2, as carteiras ótimas sobre a curva da fronteira eficiente mensal não estão sobre a curva da fronteira eficiente horária. Em outras palavras, a otimização horária, não resulta em otimização mensal, e vice-versa. 
5.2.4.4 Otimização 04 - Fronteira Eficiente para Cada Aerogerador - Base Mensal e Horária com Preços Diferenciados para os Aerogeradores

Nos itens 5.2.4.1 e 5.2.4.2 foi verificado que o aerogerador Wobben/Enercon possui a menor relação de risco/retorno para a carteira otimizada de risco mínimo. No mesmo sentido, foi verificado que para a carteira de risco mínimo, o aerogerador Wobben/Enercon possui a maior expectativa de geração (base mensal e horária). Assim, sem considerar o impacto do preço da máquina, esse modelo de aerogerador apresentou-se como o melhor entre os demais para a carteira de risco mínimo.

No entanto, os aerogeradores possuem preços diferenciados entre si. Desta forma, foram realizadas otimizações considerando os preços dos aerogeradores. Todavia, o preço dos aerogeradores não é um dado público, ao contrário, é uma informação que via de regra, encontra-se protegida nos contratos por cláusulas de confidencialidade.

Em razão dessa dificuldade ${ }^{98}$, a partir dos resultados dos Leilões Regulados, estimou-se o valor do investimento por fabricante de aerogerador. Como não foi possível identificar o modelo do aerogerador utilizado pelo empreendedor vencedor do leilão, arbitrou-se o valor do investimento para cada modelo, a partir do valor estimado para o referido fabricante ${ }^{99}$.

A TABELA 42 apresenta os valores dos investimentos estimados para cada modelo e fabricante. A TABELA 43 apresenta valores arbitrados para o valor do investimento, onde foram fixados valores maiores para os aerogeradores selecionados nas otimizações do item 5.2.4.3 (otimização sem preço).

Para avaliar o impacto do valor do investimento na seleção das carteiras, foi considerado que independente da quantidade de energia gerada, o empreendedor tem um custo fixo igual ao valor do investimento (TABELA 42 e TABELA 43) multiplicado pela garantia física do empreendimento (o detalhamento sobre o cálculo da garantia física está descrito no item 5.4.1), que reflete a remuneração do investimento, depreciação e serviço da dívida.

\footnotetext{
98 Conforme já abordado, o fabricante IMPSA está em processo de falência e não tem apresentado cotações de preço para novos projetos. Além disso, o fabricante Alstom foi adquirido pela GE.

99 Usar o resultado dos Leilões Regulados para obter o valor do investimento tem uma série de imprecisões, uma vez que no preço do lance vencedor do Leilão, há outros itens que foram considerados, como a qualidade do vento da região em que o parque eólico está localizado. Não obstante, não se encontrou nenhuma referência de preço por tipo de aerogerador que pudesse ser utilizada no trabalho. Todavia, o que se pretende demonstrar aqui é a influência do preço dos equipamentos no modelo de otimização.
} 
TABELA 42 - Valor do Investimento dos Aerogeradores Considerando o Resultados dos Leilões Regulados e Arbitrado para os Modelos.

\begin{tabular}{cc}
\hline $\begin{array}{c}\text { Modelo } \\
\text { Aerogerador }\end{array}$ & $\begin{array}{c}\text { Valor do Investimento } \\
\text { (R\$/MWh) }\end{array}$ \\
\hline GE2.5/88 & 134,15 \\
GE 2.5/100 & 120,74 \\
Gamesa G80 & 157,49 \\
Gamesa G97 & 149,62 \\
Vestas V80 & 141,74 \\
Vestas V90 & 160,00 \\
Wobben/Enercon & 144,00 \\
Alstom ECO 110 & 150,83 \\
Alstom ECO 100 & 181,46 \\
IMPSA IWP 83 & 199,61 \\
IMPSA IWP 100 & 154,58
\end{tabular}

Autor (2016).
TABELA 43 - Valor do Investimento dos Aerogeradores Arbitrados para Outro Cenário

\begin{tabular}{|c|c|}
\hline $\begin{array}{c}\text { Modelo } \\
\text { Aerogerador }\end{array}$ & $\begin{array}{c}\text { Valor do Investimento } \\
(\mathrm{R} \$ / \mathrm{MWh})\end{array}$ \\
\hline GE2.5/88 & 100,00 \\
\hline GE 2.5/100 & 90,00 \\
\hline Gamesa G80 & 120,00 \\
\hline Gamesa G97 & 110,00 \\
\hline Vestas V80 & 100,00 \\
\hline Vestas V90 & 190,00 \\
\hline Wobben/Enercon & 180,00 \\
\hline Alstom ECO 110 & 200,00 \\
\hline Alstom ECO 100 & 181,46 \\
\hline IMPSA IWP 83 & 199,61 \\
\hline IMPSA IWP 100 & 154,58 \\
\hline
\end{tabular}

Adotou-se como receita da usina, o produto da energia gerada pelo preço de venda (aqui fixado em $\mathrm{R} \$ 210,00 / \mathrm{MWh}$ ), sem nenhuma receita ou despesa com a liquidação da energia no mercado de curto prazo, quando o montante contratado for diferente da energia gerada.

Desta forma, para cada modelo de aerogerador, foi calculada a margem líquida dada pela diferença entre a receita com a energia gerada e o custo fixo do valor do investimento. Nesse sentido, foram geradas as séries históricas mensais de margens líquidas para cada modelo de aerogerador e para as 22 coordenadas e obtidos os parâmetros de média, desvio padrão e matriz de covariância. A partir da aplicação da Equação (51), foram encontradas as carteiras otimizadas sobre a fronteira eficiente.

Assim como no item 5.2.4.3, nesse tópico também foi adotada a restrição de que para uma determinada coordenada não é possível mais de um modelo de aerogerador. Sendo assim, as carteiras otimizadas com esse tipo de resultado foram descartadas.

Para cada cenário de valor do investimento (TABELA 42 e TABELA 43), foram geradas 20 carteiras otimizadas. Na otimização considerando os valores da TABELA 42 foram descartadas ${ }^{100} 5$ carteiras.

${ }^{100}$ A carteira 1 foi descartada pois selecionou para a coordenada Quilombo os aerogeradores GE 2.5/88 e Gamesa G97. A carteira 6 foi descartada pois selecionou para a coordenada Palmar os aerogeradores Gamesa G97 e Wobben/Enercon. As carteiras 7 e 8 foram descartadas pois houve a 
Na otimização considerando os valores da TABELA 43 foram descartadas ${ }^{101} 6$ carteiras. Ressalta-se que o aerogerador Gamesa G90 foi retirado das otimizações para ambos os cenários, pois quando inserido, o modelo não convergiu para nenhuma carteira. Tal situação já havia acontecido no item 5.2.4.3. Ainda, para todos os cenários, para as carteiras 15 a 19 o modelo não encontrou solução. Para o cenário de preços da TABELA 42, o modelo também não encontrou solução para a carteira 14.

O Gráfico 109 apresenta o percentual de participação dos aerogeradores nas 20 carteiras otimizadas para a série histórica de energia gerada mensal, sem considerar o preço dos aerogeradores ${ }^{102}$.

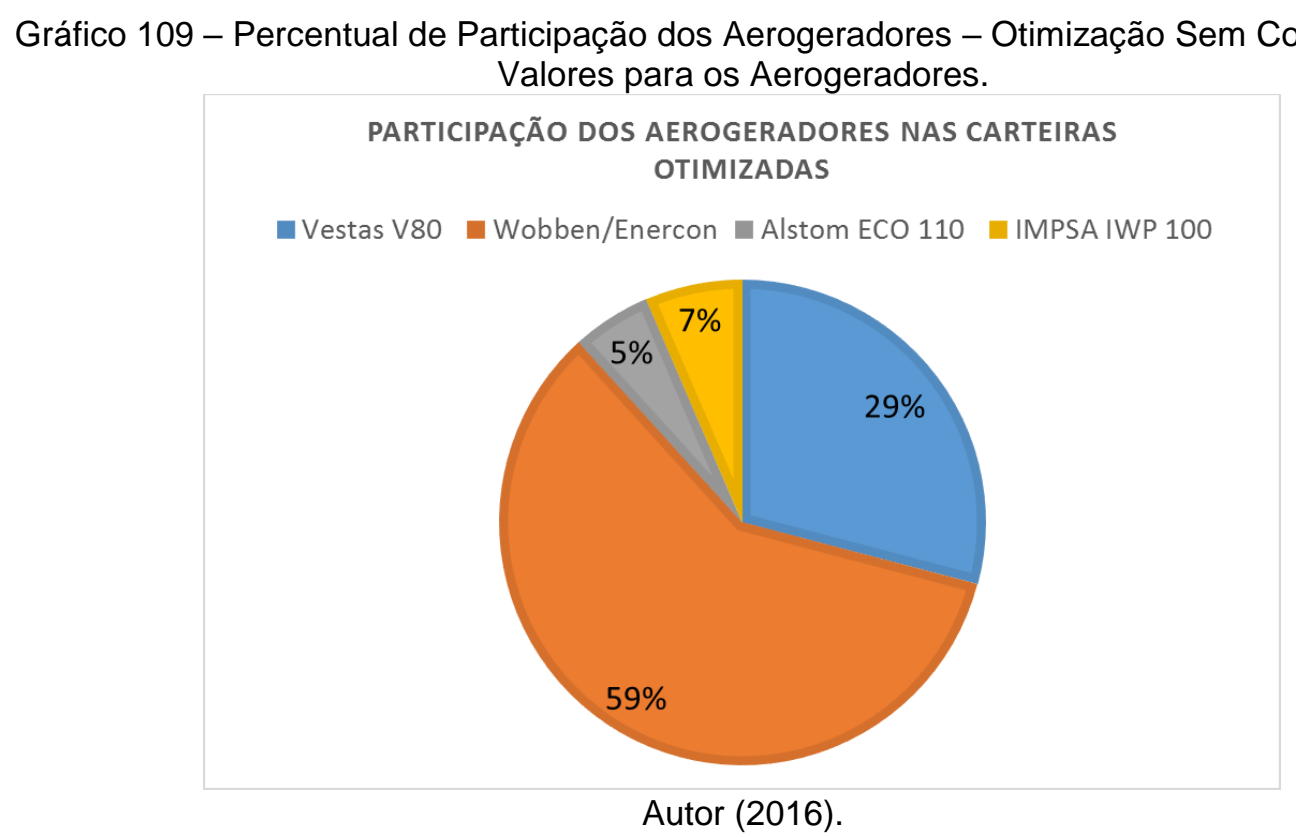

O Gráfico 110 e o Gráfico 111 apresenta o percentual de participação dos aerogeradores nas 20 carteiras otimizadas considerando o preço dos aerogeradores contidos na TABELA 42 e TABELA 43, respectivamente.

seleção de dois aerogeradores para a coordenada Palmar. A carteira 9 foi descartada pois foram selecionados dois aerogeradores para a coordenada Osório.

101 As carteiras 6, 7, 12 e 13 foram descartadas pois foram selecionados dois aerogeradores para essa coordenada. A carteira 10 foi descartada pois selecionou para a coordenada Boninal os aerogeradores Wobben/Enercon e IMPSA IWP 100. A carteira 14 foi descartada pois selecionou para a coordenada Medonho os aerogeradores Wobben/Enercon e Vestas V90.

102 Essa otimização está apresentada no item 5.2.4.3, onde verificou-se que 1 carteira otimizada foi descartada, pois selecionou o aerogerador Wobben/Enercon e Impsa IWP100 para a coordenada Palmar. 
Gráfico 110 - Percentual de Participação dos Aerogeradores - Otimização considerando os valores dos Aerogeradores da TABELA 42.

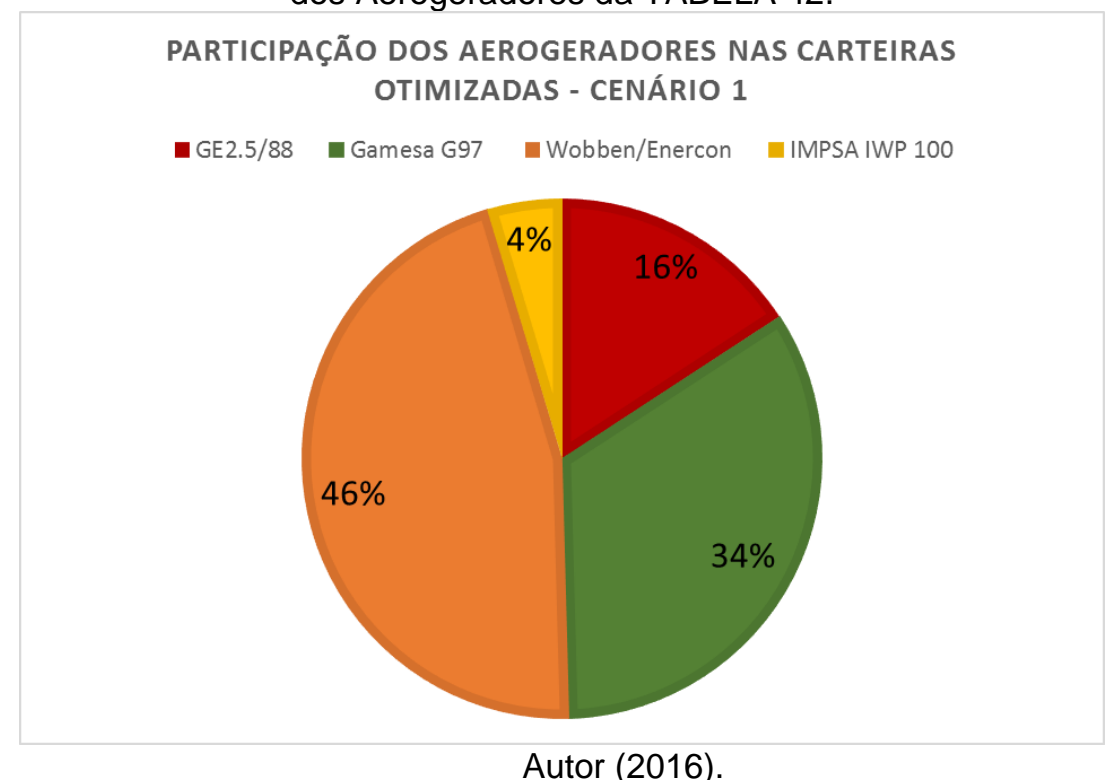

Autor (2016).

Gráfico 111 - Percentual de Participação dos Aerogeradores - Otimização considerando os valores dos Aerogeradores da TABELA 43.

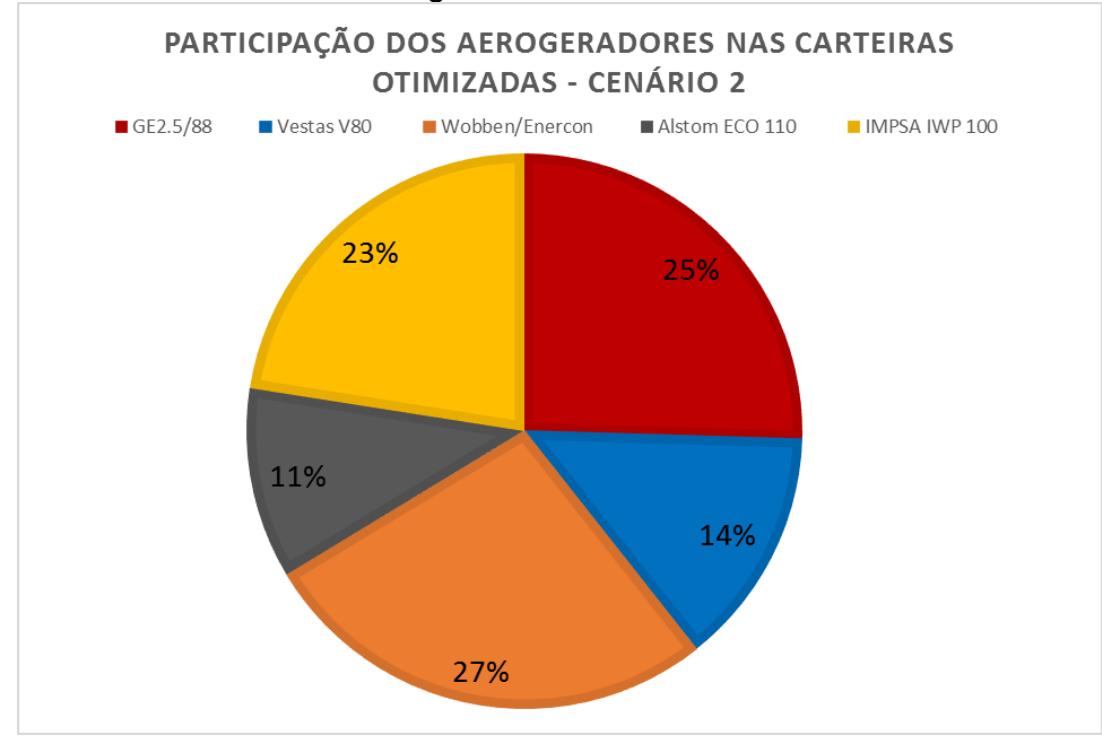

Autor (2016).

Pelo Gráfico 110, no cenário da TABELA 42, verifica-se que os aerogeradores Wobben/Enercon (7ำ preço) e IMPSA IWP 100 (3ำ preço) tiveram redução na participação das 20 carteiras otimizadas. Os aerogeradores Vestas V80 (10 preço) e Alstom ECO 110 (11ํp preço) foram substituídos pelos modelos GE 2.5/88 (2ํㅜ preço) e Gamesa G97 (4º preço), que possuem menor preço. 
Com o cenário de preços da TABELA 43, pelo Gráfico 111 verifica-se que os aerogeradores Wobben/Enercon (12ำ preço) e Vestas V80 (10ำ preço) também tiveram redução na participação das 20 carteiras otimizadas. Por sua vez, os aerogeradores Altom ECO 110 (9º preço) e IMPSA IWP 100 (6º preço) aumentaram a participação. O aerogerador GE 2.5/88 (2ำ preço) passou a ser selecionado.

A introdução do valor do aerogerador no modelo de otimização provoca alterações nas carteiras otimizadas, contudo, verificou-se que mesmo em um cenário extremado de preço, ainda assim o aerogerador Wobben/Enercon é selecionado.

5.2.4.5 Otimização 05 - Fronteira Eficiente para Cada Aerogerador - Base Horária com Restrição de Transmissão

As otimizações anteriores partiram do princípio que não existe restrição de transmissão. No mundo real, o sistema de transmissão é limitado e tem impacto no escoamento da energia e consequentemente na definição da potência da usina eólica.

Nesse sentido, o MME vem estabelecendo que, nos Leilões de Energia, deve ser utilizado o preço do lance como critério de classificação, considerando a capacidade de escoamento do sistema de transmissão (Rede Básica, Demais Instalações de Transmissão - DIT e Instalações de Interesse Exclusivo de Centrais de Geração para Conexão Compartilhada - ICG). A capacidade de escoamento se refere à folga ou margem de capacidade de transmissão existente destinada a acomodar os fluxos de potência provenientes dos novos empreendimentos de geração.

Nesse sentido, para cada Leilão, o ONS conjuntamente com a EPE, vem publicando os valores da capacidade de escoamento para as barras, subáreas e áreas. As barras são as mesmas barras que tiveram empreendimentos de geração cadastrados na EPE para o respectivo Leilão. A subárea é o conjunto de instalações que concorrem pelos mesmos meios de transmissão com alto fator de influência recíproca. Por fim, a área é o conjunto de subáreas que concorrem pelos mesmos recursos de transmissão.

Para cada coordenada geográfica foram traçadas três circunferências de raios 150 km, 200 km e 300 km e foi calculada a capacidade de escoamento para o conjunto de barras, subáreas e áreas, a partir do somatório dos valores da capacidade de 


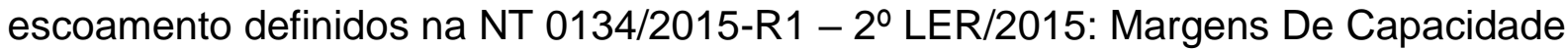
Para Escoamento De Energia Elétrica Pela Rede Básica, DIT E ICG, que estão inseridos dentro das referidas circunferências. A TABELA 44 apresenta as margens de escoamento para cada coordenada e circunferência.

TABELA 44 - Margem de Escoamento para Cada Coordenada.

\begin{tabular}{|c|c|c|c|c|c|c|c|c|c|}
\hline \multirow[t]{2}{*}{ Coordenada } & \multicolumn{3}{|c|}{$\begin{array}{l}\text { Margem de Escoamento (MW) } \\
\text { Raio de } 150 \mathrm{~km}\end{array}$} & \multicolumn{3}{|c|}{$\begin{array}{c}\text { Margem de Escoamento (MW) } \\
\text { Raio de } 200 \text { km }\end{array}$} & \multicolumn{3}{|c|}{$\begin{array}{l}\text { Margem de Escoamento (MW) } \\
\text { Raio de } 300 \text { km }\end{array}$} \\
\hline & Barra & Subárea & Área & Barra & Subárea & Área & Barra & Subárea & Área \\
\hline Parnaiba & 0 & 0 & 0 & 2200 & 2200 & 2200 & 3000 & 3000 & 3000 \\
\hline Parada & 800 & 800 & 800 & 1280 & 1280 & 1280 & 4135 & 3790 & 3790 \\
\hline Sao Joao & 0 & 0 & 0 & 345 & 480 & 480 & 825 & 480 & 480 \\
\hline Medonho & 2510 & 2510 & 2510 & 2510 & 2510 & 2510 & 3490 & 3490 & 3490 \\
\hline Mocambira & 0 & 0 & 0 & 345 & 480 & 480 & 1435 & 800 & 800 \\
\hline Forquilha & 345 & 480 & 480 & 825 & 480 & 480 & 1995 & 1360 & 1360 \\
\hline Tavares & 0 & 0 & 0 & 0 & 0 & 0 & 380 & 380 & 380 \\
\hline Sertania & 990 & 700 & 700 & 4200 & 3400 & 3400 & 4380 & 3580 & 3580 \\
\hline Afranio & 2000 & 1210 & 1210 & 2000 & 1210 & 1210 & 2000 & 1210 & 1210 \\
\hline Palmas & 600 & 550 & 550 & 600 & 550 & 550 & 6510 & 5290 & 5290 \\
\hline Quilombo & 3160 & 2110 & 2110 & 6260 & 4080 & 4080 & 6260 & 4080 & 4080 \\
\hline Tubarão & 2750 & 1000 & 1000 & 4720 & 2970 & 2970 & 5960 & 3830 & 3830 \\
\hline Osório & 300 & 300 & 300 & 850 & 850 & 850 & 850 & 850 & 850 \\
\hline Dom Pedrito & 936 & 2340 & 2340 & 936 & 2340 & 2340 & 936 & 2340 & 2340 \\
\hline Estreito & 0 & 0 & 0 & 0 & 0 & 0 & 0 & 0 & 0 \\
\hline Palmar & 0 & 0 & 0 & 0 & 0 & 0 & 0 & 0 & 0 \\
\hline Itaguaçu & 0 & 0 & 0 & 0 & 0 & 0 & 0 & 0 & 0 \\
\hline Boninal & 0 & 0 & 0 & 0 & 0 & 0 & 0 & 0 & 0 \\
\hline Jacaraci & 0 & 0 & 0 & 0 & 0 & 0 & 900 & 1100 & 1600 \\
\hline Olho Dagua & 2090 & 1920 & 1730 & 2090 & 1920 & 1730 & 2780 & 1920 & 1730 \\
\hline Riachuelo & 1590 & 1100 & 1600 & 1590 & 1100 & 1600 & 4860 & 2850 & 2880 \\
\hline Anta & 1600 & 1350 & 1150 & 1930 & 1800 & 1600 & 3960 & 2850 & 2880 \\
\hline
\end{tabular}

Roques, Hiroux e Saguan (2009) obtiveram o portfólio ótimo para a região compreendida pelos países Áustria, Dinamarca, França, Alemanha e Espanha, considerando as restrições de transmissão.

As otimizações realizadas até o momento aplicaram a função objetiva apresentada na Equação (51). Para a otimização com a restrição de transmissão, na Equação (51) foi introduzida a restrição da margem de escoamento, nos termos da Equação (85).

$$
\operatorname{Minimizar} \sum_{i=1}^{N}\left(w_{i} . S\left(\tilde{R}_{i}\right)\right)^{2}+\sum_{i=1}^{N} \sum_{\substack{j=1 \\ j \neq i}}^{N} w_{i} \cdot w_{j} \cdot \operatorname{cov}\left(\tilde{R}_{i}, \tilde{R}_{j}\right)
$$

Sujeita às seguintes restrições:

$\sum_{i=1}^{N} w_{i}=1$ 
$0 \leq w_{i} \leq 1$, para i variando de 1 até $\mathrm{N}$;

$\tilde{R}_{C}=E\left[\tilde{R}_{C}\right]=\sum_{i=1}^{N} w_{i} \cdot E\left[\tilde{R}_{i}\right]=\tilde{R}$

$w_{i} \leq M E_{i} / 10.000 ; \forall i$ (restrição introduzida)

Onde: $M E_{i}$ é a margem de escoamento para cada coordenada geográfica e 10.000 GWh representa a demanda máxima a ser escoada.

Os valores da TABELA 44 representam o máximo de demanda possível de ser escoada pelo sistema de transmissão. Desta forma, na otimização, foi utilizada a série histórica de geração horária para compatibilizar as grandezas ${ }^{103}$. Adicionalmente, foi adotada a premissa que a demanda máxima a ser escoada é igual a 10 GWh. Essa premissa equivale a dizer que a demanda máxima a ser contratada é igual a $10 \mathrm{GW}$ (potência instalada).

O Gráfico 112 apresenta o comportamento das fronteiras eficientes. A curva cinza não considera a restrição de transmissão ${ }^{104}$. As demais curvas consideram as margens de escoamento nas barras para as circunferências de raios de $150 \mathrm{~km}$, $200 \mathrm{~km}$ e $300 \mathrm{~km}^{105}$.

A medida em que se aumenta a restrição (diminui a margem de escoamento), os resultados são degradados, ou seja, para o mesmo valor de risco, a expectativa de geração é menor.

A TABELA 45 apresenta a composição de 10 carteiras otimizadas para a situação sem restrição e para a situação com restrição de transmissão, representada pela margem de escoamento na barra, para os três raios de circunferência.

As coordenadas Estreito, Palmar, Itaguaçu e Boninal possuem margem de escoamento igual a zero, independente do raio da circunferência (TABELA 44), motivo pelo qual na TABELA 45 essas coordenadas não foram escolhidas no processo de otimização.

${ }^{103}$ Foi utilizado o aerogerador Wobben/Enercon.

${ }^{104}$ A curva sem restrição já havia sido apresentada no Gráfico 93 (Curvas de Fronteiras Eficientes para cada Modelo de Aerogerador - Dados: Série Horária de Energia Gerada).

105 Conforme se observa na TABELA 44, a margem de escoamento aumenta com o aumento da circunferência. 
Gráfico 112 - Fronteira Eficiente com Restrição de Transmissão por Barra.

Fronteira Eficiente (MWh)

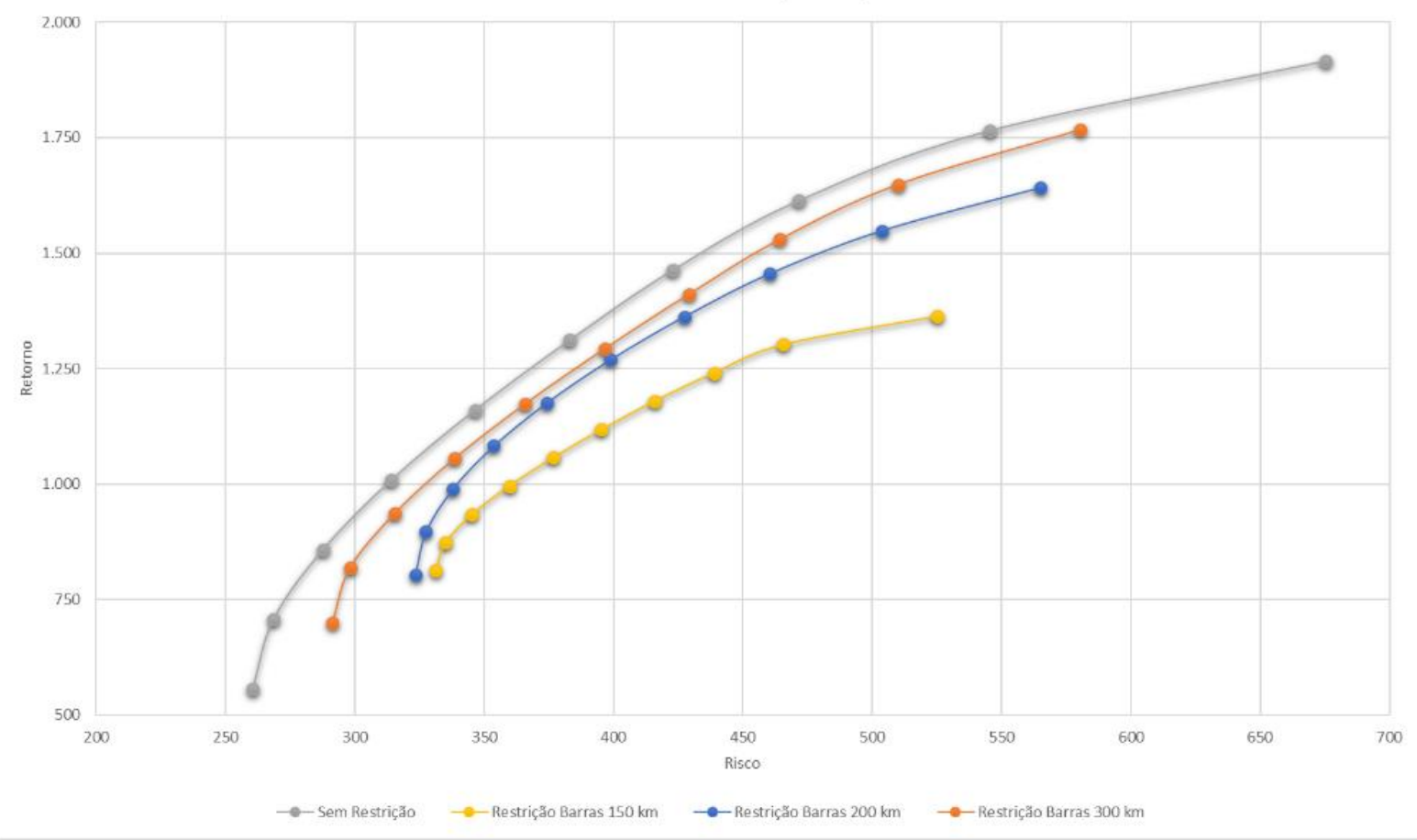

Autor (2016).

TABELA 45 - Exemplos de Carteiras Otimizadas para a Fronteira Eficiente com Restrição de Transmissão por Barra (Risco e retorno em kWh).

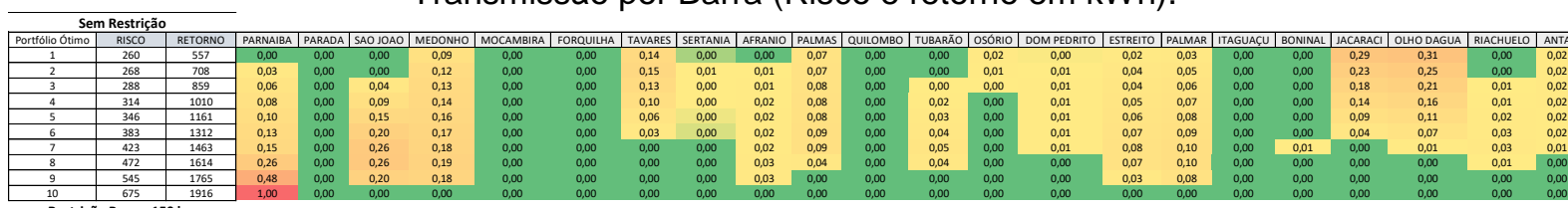

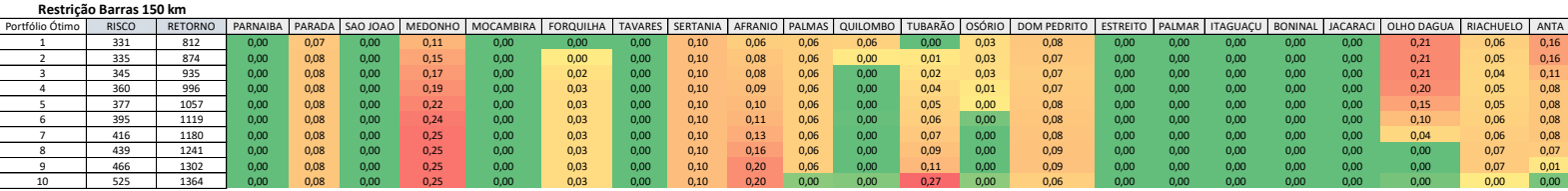

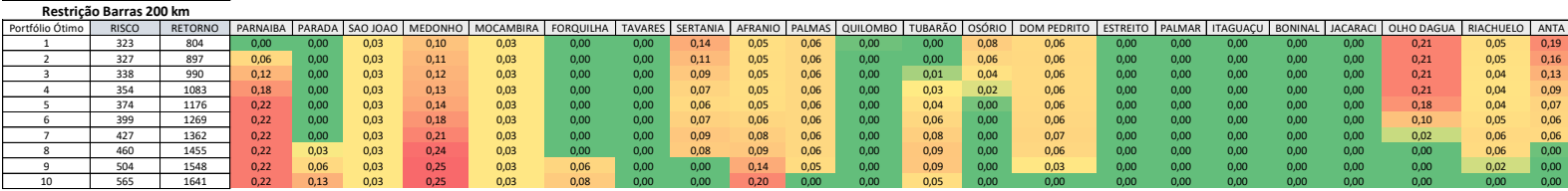

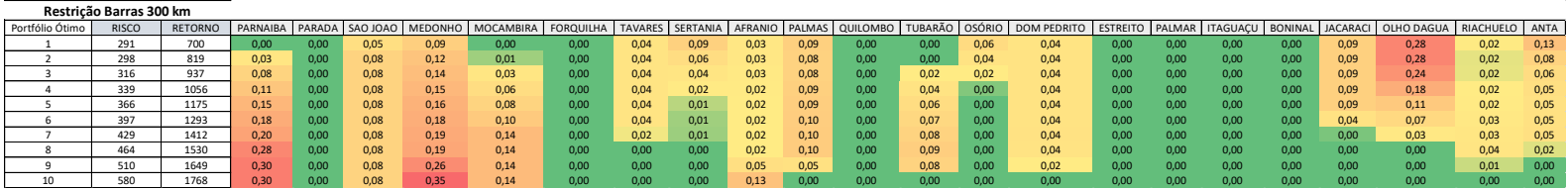
Autor (2016).

Os resultados da otimização considerando as margens de escoamento por subárea e por área estão apresentados no Gráfico 113 e no Gráfico 114 respectivamente. 
Gráfico 113 - Fronteira Eficiente com Restrição de Transmissão por Subárea.

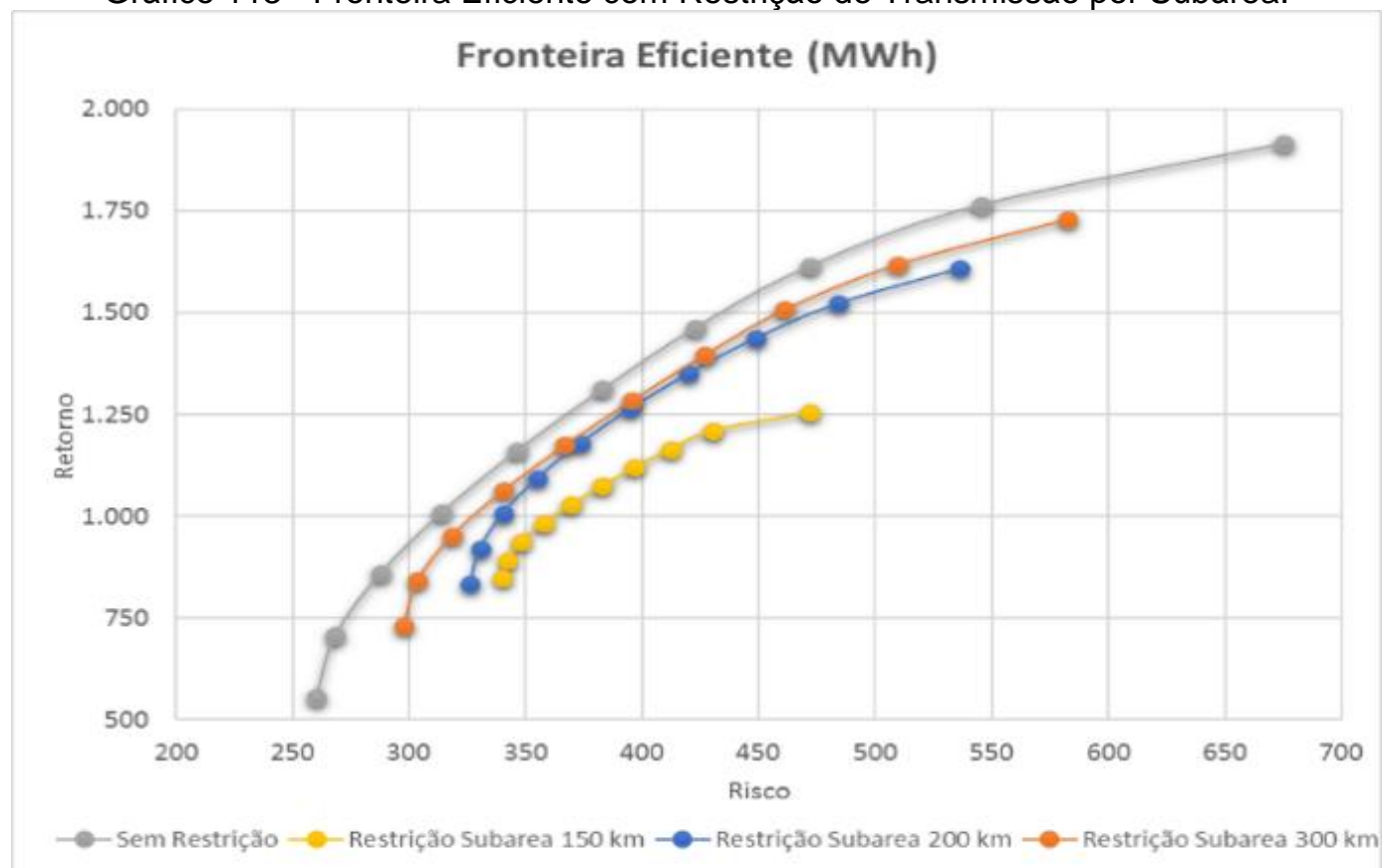

Autor (2016).

Gráfico 114 - Fronteira Eficiente com Restrição de Transmissão por Área.

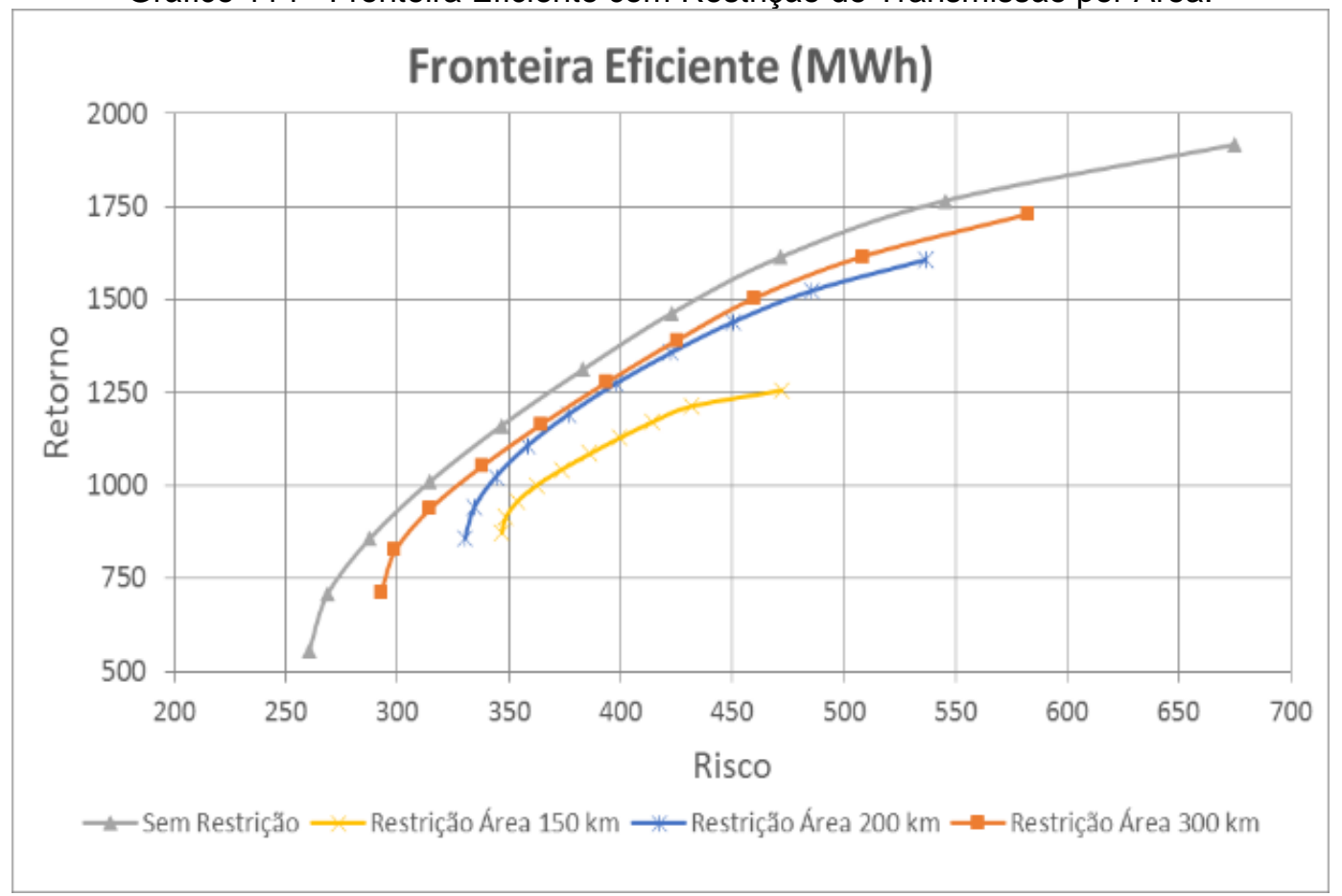

Autor (2016).

A TABELA 46 apresenta a composição de 10 carteiras otimizadas para a situação sem restrição e para a situação com restrição de transmissão, representada pela margem de escoamento na subárea. 
TABELA 46 - Exemplos de Carteiras Otimizadas para a Fronteira Eficiente com Restrição de Transmissão por Subárea (risco e retorno em kWh).

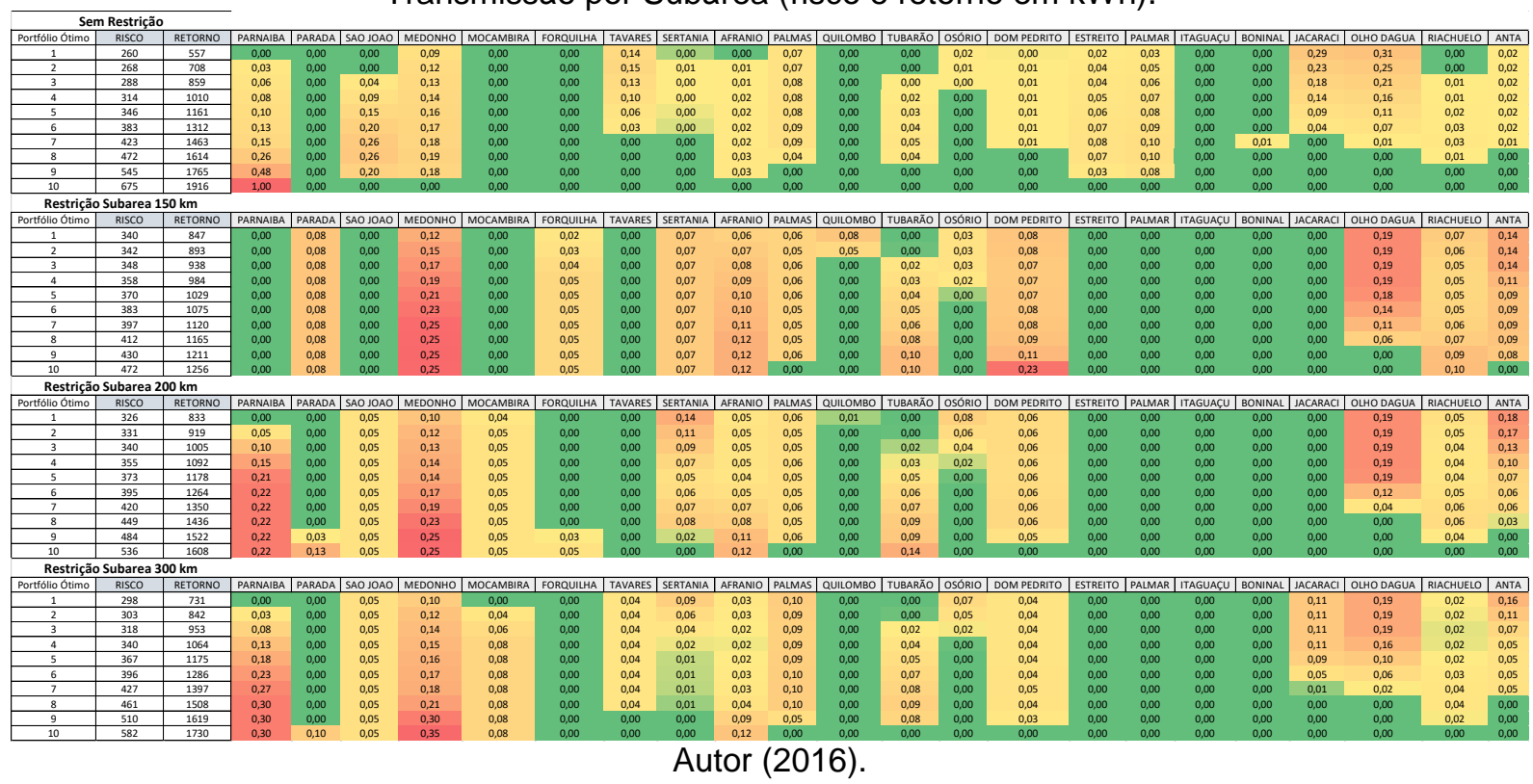

A TABELA 47 apresenta a composição de 10 carteiras otimizadas para a situação com restrição de transmissão, representada pela margem de escoamento na área.

TABELA 47 - Exemplos de Carteiras Otimizadas para a Fronteira Eficiente com Restrição de Transmissão por Área (risco e retorno em kWh).
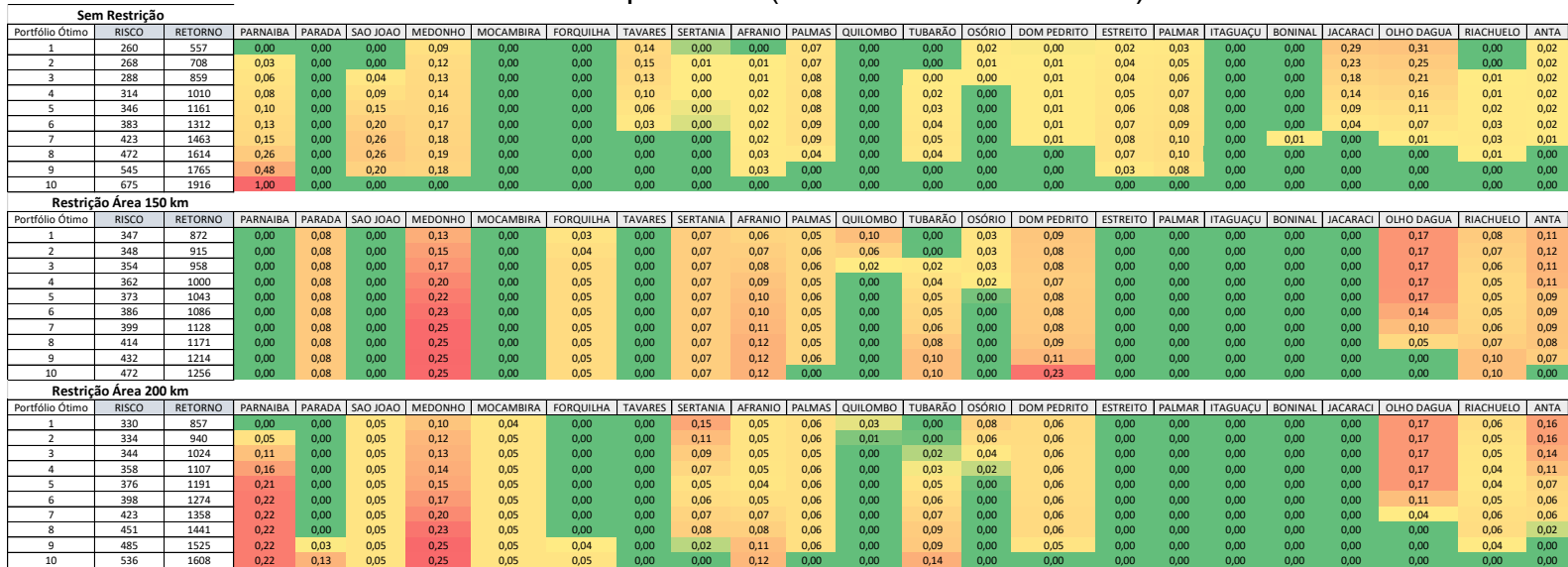
Restrição Área $300 \mathrm{~km}$

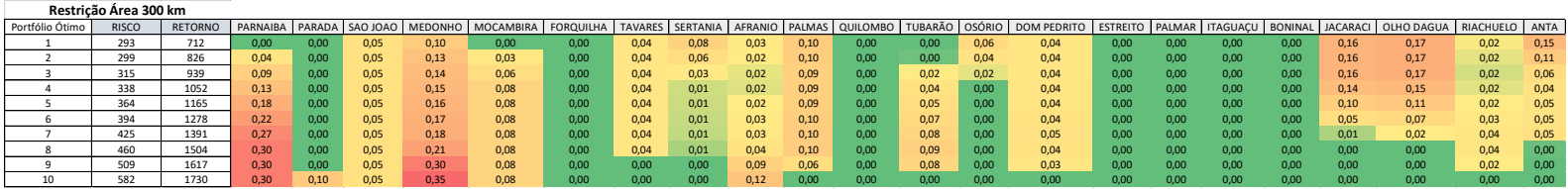
Autor (2016).

O Gráfico 115 e o Gráfico 116 apresentam a fronteira eficiente considerando a restrição na barra, subárea e área, para distância de $150 \mathrm{~km}$ e $300 \mathrm{~km}$, respectivamente. 
Gráfico 115 - Fronteira Eficiente com Restrição de Transmissão no raio de 150km. Fronteira Eficiente com Restrição de Transmissao (MWh)

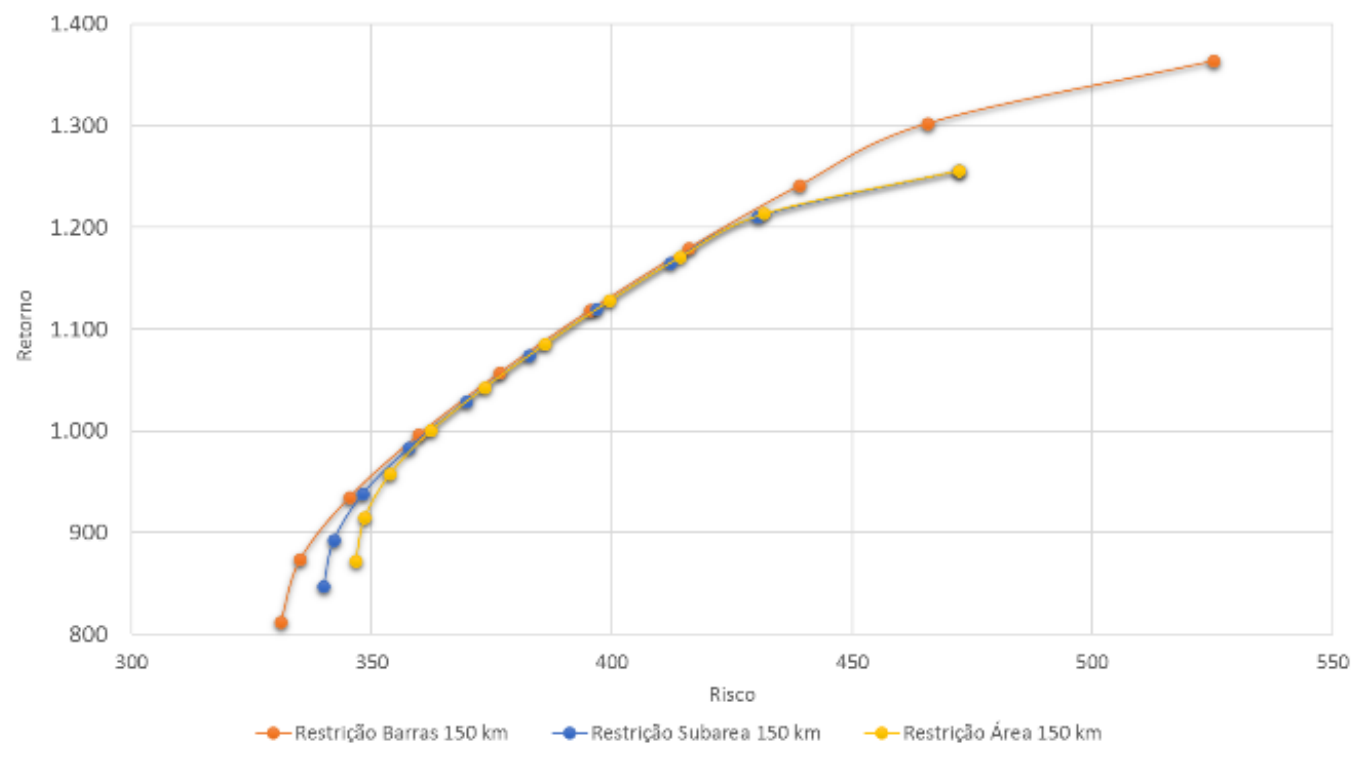

Autor (2016).

Gráfico 116 - Fronteira Eficiente com Restrição de Transmissão no raio de 300km. Fronteira Eficiente com Restrição de Transmissao (MWh)

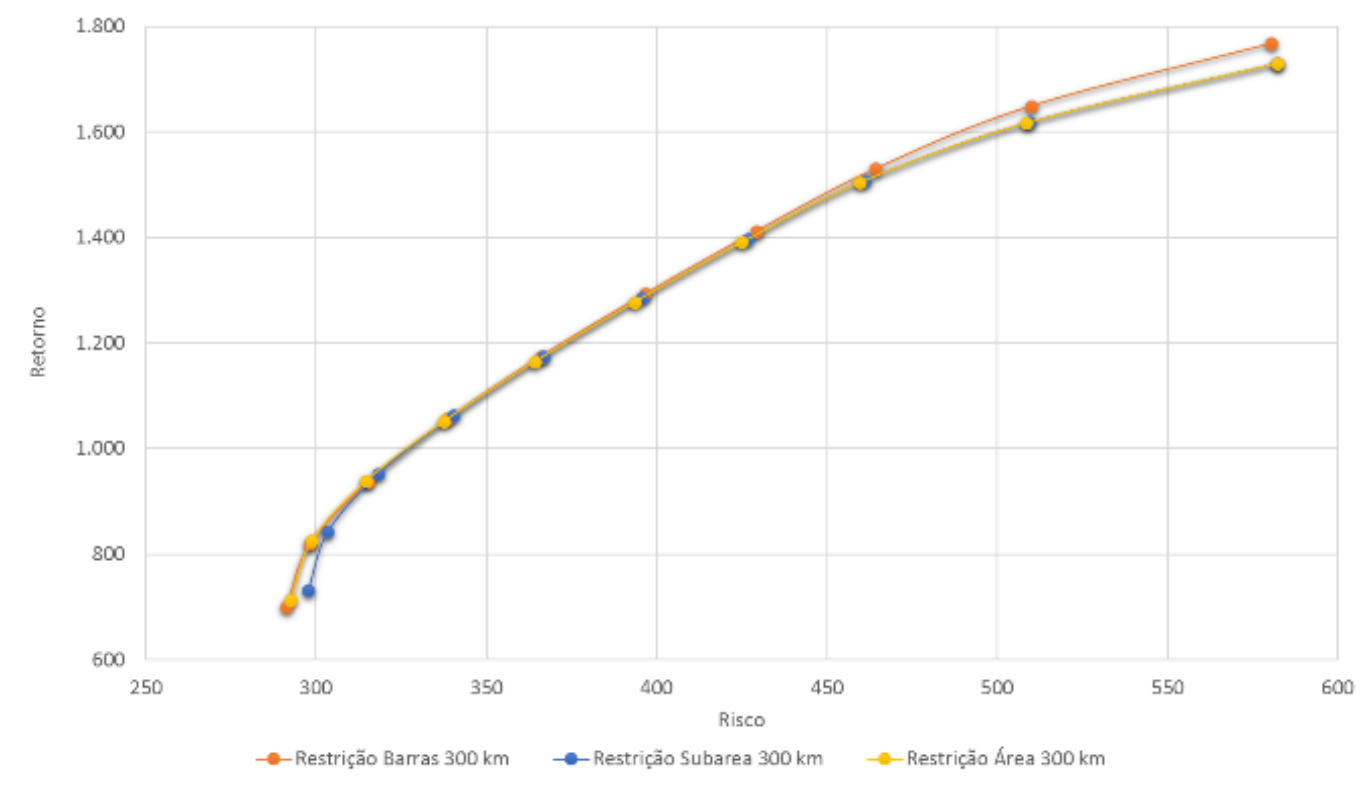

Autor (2016).

As fronteiras são semelhantes dentro da mesma circunferência, na medida em que a margem de escoamento na barra, subárea e área, varia muito pouco dentro do mesmo raio, conforme se observa na TABELA 44.

Os resultados das otimizações sofrem influência do montante contratado, na medida em que a expectativa de retorno das carteiras otimizadas deve respeitar o 
montante contratado e a margem de escoamento. Nesse sentido, verifica-se que as margens de escoamento da TABELA 44 para os diversos cenários e coordenadas são inferiores ao montante contratado.

\subsubsection{Otimização 06 - Cálculo do Risco Mínimo - Base Mensal e Horária}

No item 5.1.6 foi apresentado o resultado do cálculo do risco mínimo para as usinas eólicas do PROINFA. Adotando o mesmo procedimento descrito na Figura 11, foi obtida a função do risco da carteira pela quantidade de ativos, considerando as carteiras formadas pelas 22 coordenadas e para o aerogerador Wobben/Enercon, base horária e mensal.

A função do risco da carteira pela quantidade de ativos, considerando a série histórica em base mensal e horária, está representa no Gráfico 117 e no Gráfico 118, respectivamente.

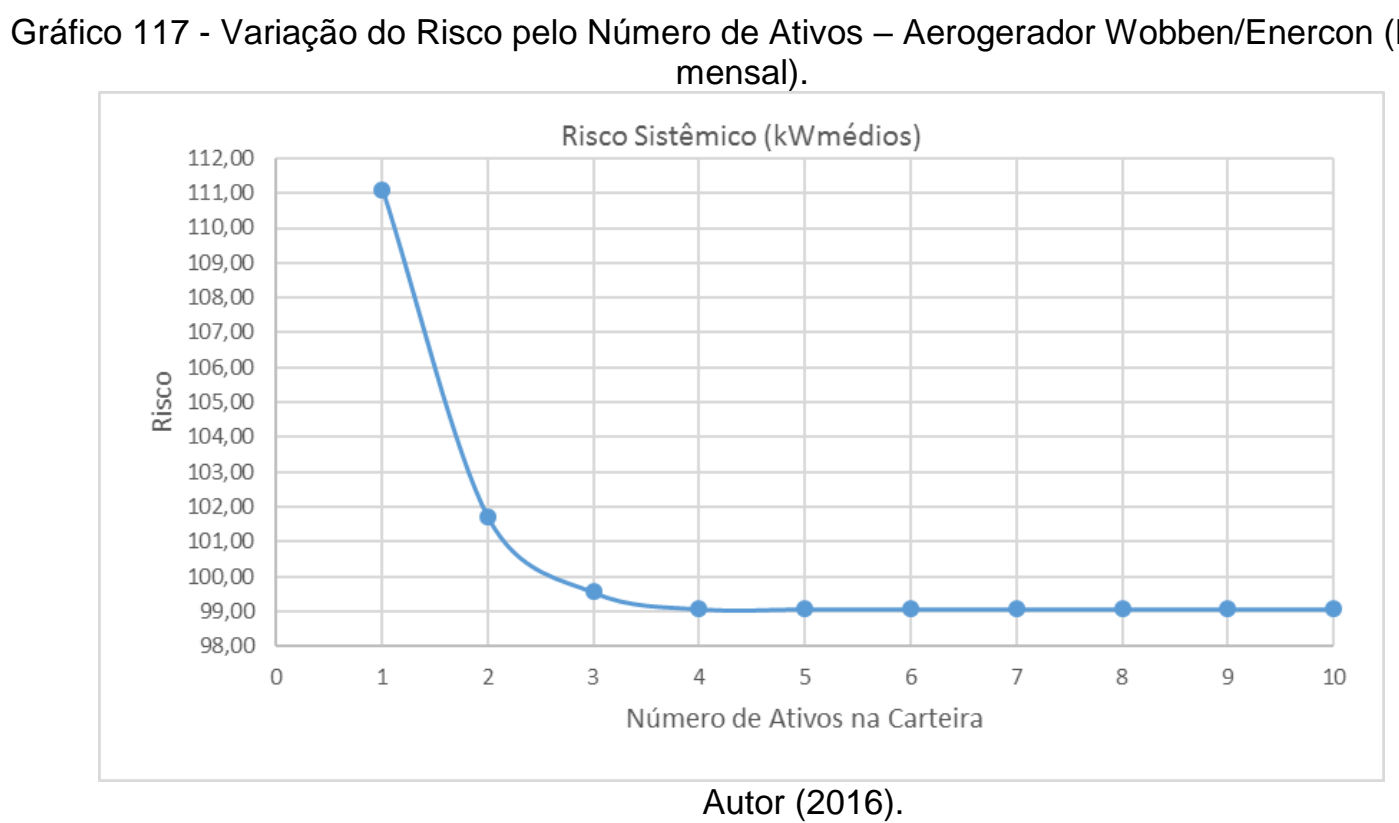


Gráfico 118 - Variação do Risco pelo Número de Ativos - Aerogerador Wobben/Enercon (Base horária).

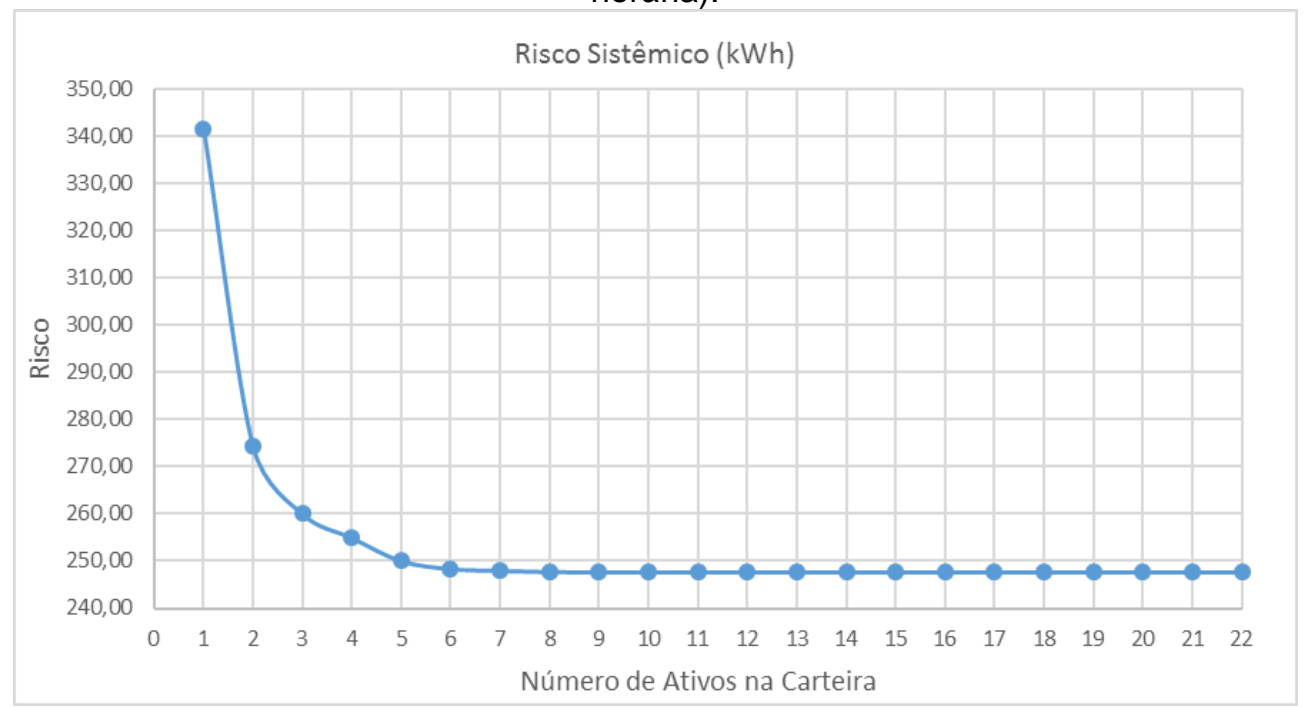

Autor (2016).

O resultado está coerente com o obtido nos itens 5.2.4.1 e 5.2.4.2, onde foi evidenciado que, para a otimização em base mensal, com 4 (quatro) usinas eólicas (coordenadas Quilombo, Palmar, Riachuelo e Anta) é possível obter a carteira de risco mínimo (ver TABELA 40 e Gráfico 91); e, são necessárias 9 (nove) coordenadas (Mocambira, Sertania, Afranio, Tubarão, Osório, Palmar, Olho d'Água, Riachuelo e Anta) para obter a carteira de risco mínimo, em base horária (Gráfico 98 e TABELA 41).

Os resultados estão coerentes com o referencial teórico, pois comprovam que uma carteira com poucos ativos é suficiente para eliminar a parte mais significativa do risco não sistêmico (diversificável), contudo, não se consegue reduzir o risco sistêmico independente do número de ativos.

\subsubsection{Cálculo da Curva do Fator Correlação pela Distância das Usinas}

No item 4.8 foi exposto que Sinden (2007) encontrou a função do fator de correlação com a distância, a partir da combinação de 2080 pares de parques eólicos. O autor demonstrou que o fator de correlação entre os parques eólicos do Reino Unido diminui aproximadamente 0,1 para distâncias superiores a $100 \mathrm{~km}$.

Adotando o mesmo procedimento descrito por Sinden (2007), foi obtida a função do fator de correlação com a distância, considerando a série histórica de 
energia gerada mensal e horária para 27 coordenadas geográficas (composta pelas 22 coordenadas utilizadas até o momento, além de outras 4 coordenadas offshore, nos Estados do Paraná, Ceará, São Paulo e Santa Catarina, e de uma coordenada sobre o reservatório da Usinas Hidroelétrica de Segredo, também no Paraná).

O Gráfico 119 e o Gráfico 120 apresentam a função do fator de correlação com a distância para a série mensal e horaria, respectivamente.

Gráfico 119 - Função do Fator de Correlação da Energia Gerada Mensal pela Distância entre as coordenadas.

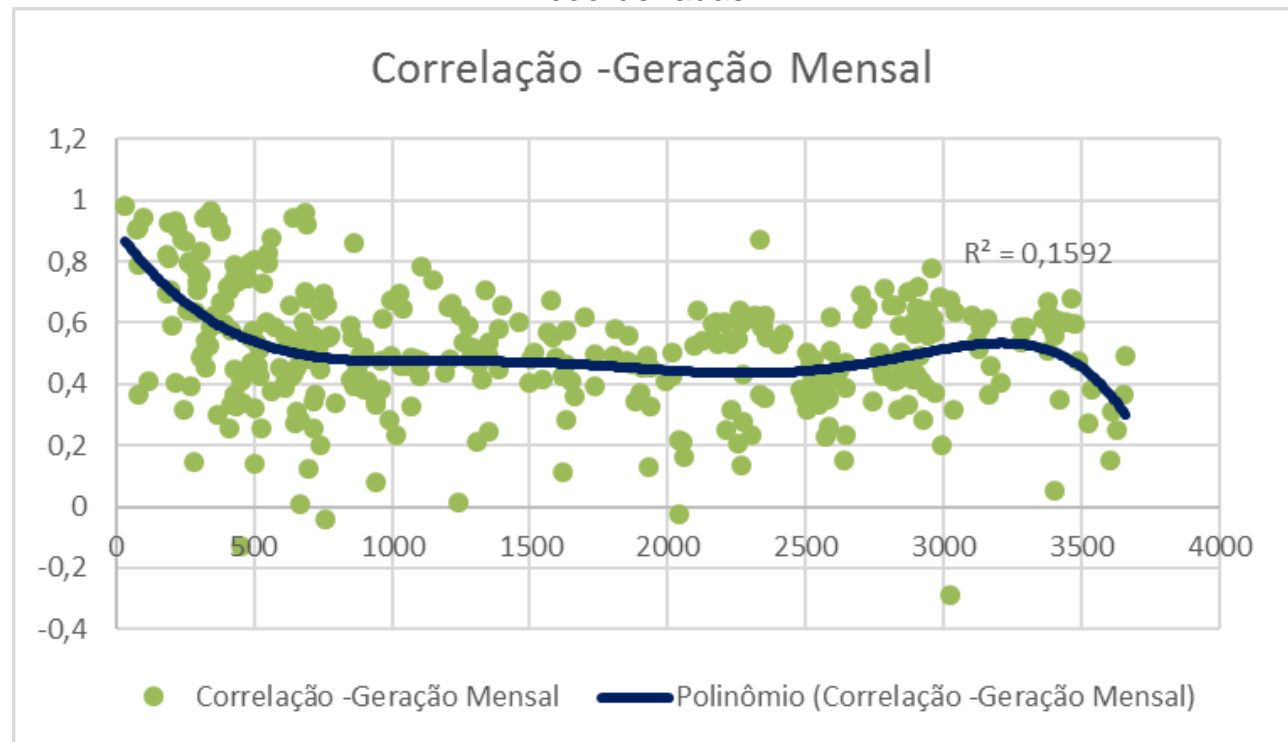

Autor (2016).

Gráfico 120 - Função do Fator de Correlação da Energia Gerada Horária pela Distância entre as coordenadas.

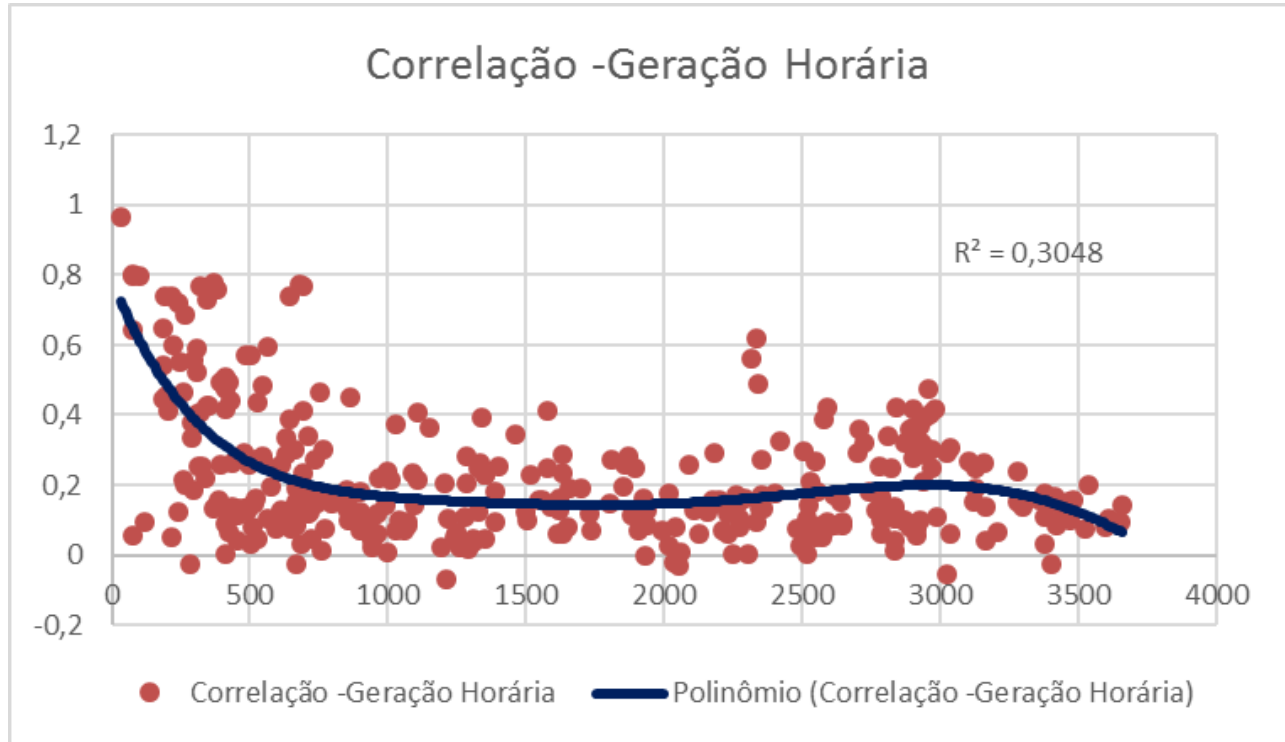

Autor (2016). 
Nos gráficos acima verifica-se que até $500 \mathrm{~km}$, há uma tendência de redução do fator de correlação com a distância. No caso dos dados mensais, o fator de correlação reduz em 0,072 para cada $100 \mathrm{~km}$. Para os dados horários, a redução é de 0,11 para cada $100 \mathrm{~km}$. Nessa faixa, os resultados são semelhantes ao encontrado por SINDEN (2007).

Entre distâncias de $500 \mathrm{~km}$ a $3.000 \mathrm{~km}$, os gráficos demonstram comportamento semelhante, onde o fator de correlação é estável e insensível à variação da distância. No caso, o fator de correlação da série mensal fica estabilizado em 0,5 e, na série horária, em 0,2.

Por fim, para distâncias superiores à $3.000 \mathrm{~km}$, os gráficos apresentam um comportamento de queda no fator de correlação.

Os resultados são qualitativos, na medida em que há uma grande dispersão em relação às curvas ajustadas, que apresentou baixo coeficiente de correlação. Não obstante, os resultados são semelhantes ao obtido por Sinden (2007).

\subsection{MODELO PROPOSTO APLICADO EM PCHS E USINAS EÓLICAS}

No item 5.1 foi aplicada a teoria de Markowitz para obter carteiras otimizadas a partir dos dados de energia gerada das usinas do PROINFA. No item 5.2, a partir da série horária de dados da velocidade do vento do Vortex, foram obtidas séries de energia gerada em base horária e mensal, e aplicou-se a teoria de Markowitz, para obter as fronteiras eficientes para os dados de energia em base horária e mensal.

Nesse item, foi aplicado o modelo de Markowitz sobre as séries de energia gerada mensal obtidas no item 5.2.3.2, ajustadas para usinas eólicas de 25 MW (10 máquinas do aerogerador Wobben/Enercon), e para as séries de energia gerada de 15 PCHs. Desta forma, o modelo proposto na Figura 15 foi adaptado para incluir a série histórica da energia gerada das PCHs, conforme Figura 17. 
Figura 17 - Modelo Proposto para PCHs.

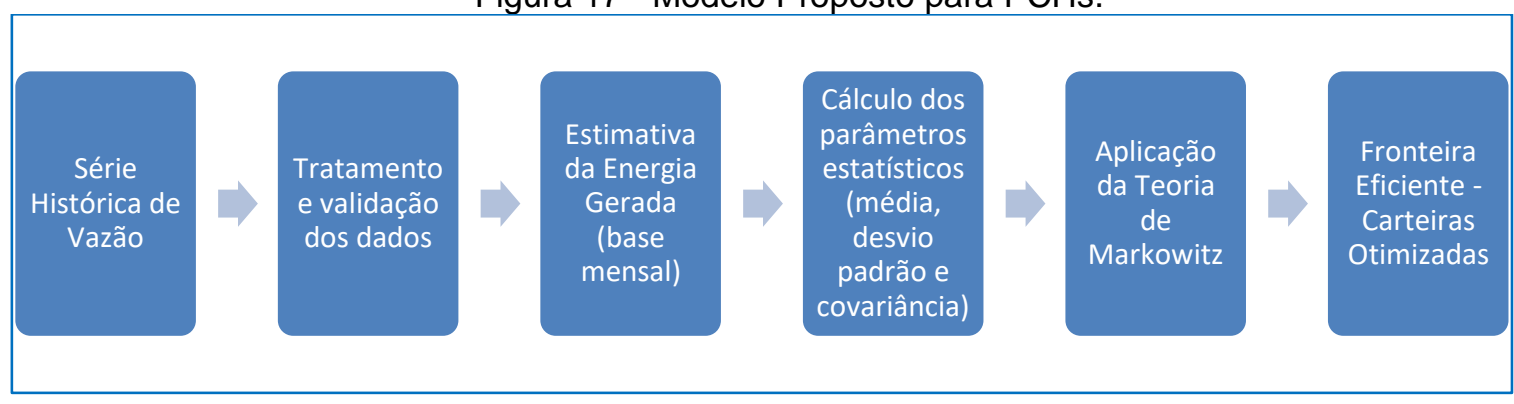

Autor (2016).

O item a seguir demonstra como foram selecionadas as PCHs e como foi realizado o levantamento da série histórica de energia gerada das usinas.

\subsubsection{Levantamento da Série Histórica de Energia Gerada - PCHs}

Diferentemente dos dados de vento, o levantamento inicial das informações de PCHs seguiu o plano de obras para os próximos anos. Isso porque a determinação das séries de geração de energia dessas usinas depende de diversos fatores físicos, o principal deles sendo a altura de queda líquida. Dessa maneira, pôde-se aproveitar o inventário de usinas planejadas para a obtenção dos dados necessários.

A seleção das PCHs foi feita a partir do relatório de fiscalização intitulado Acompanhamento da Expansão da Oferta de Geração de Energia Elétrica (2015), elaborado pela ANEEL. Esse documento traz uma listagem das usinas outorgadas e/ou em fase de implantação, classificadas de acordo com a viabilidade de cada empreendimento, conforme critérios elencados a seguir:

- $\quad$ Viabilidade alta: PCHs sem impedimentos para sua implementação, com obras iniciadas e licença ambiental vigente;

- Viabilidade média: PCHs sem impedimentos para sua implementação, mas com obras não iniciadas ou licença ambiental pendente;

- Viabilidade baixa: PCHs com impedimentos para sua implantação.

No documento consultado, datado de julho de 2015, as PCHs com viabilidade alta ou média possuem data prevista para entrada em operação que se estende até o ano de 2021. 
Por outro lado, as usinas com viabilidade baixa não possuem nenhuma previsão do tipo, o que leva a crer que a regularização de suas situações pode se estender para além desse horizonte. Por esse motivo, optou-se por eliminar da análise as usinas com viabilidade baixa, restando $40 \mathrm{PCHs}$ com viabilidade alta e $107 \mathrm{PCHs}$ com viabilidade média.

Fez-se também uma filtragem das $147 \mathrm{PCHs}$ listadas no relatório Acompanhamento da Expansão da Oferta de Geração de Energia Elétrica, eliminando usinas muito próximas. Ao final, considerando a disponibilidade de dados, chegou-se a um conjunto de $15 \mathrm{PCHs}$.

As informações das PCHs selecionadas foram coletadas no Centro de Documentação da ANEEL, através de sua Biblioteca Virtual. Foram levantados os documentos (Despachos) de aprovação dos projetos básicos de cada usina, os quais contêm as informações necessárias para a estimativa da série de energia gerada. $A$ TABELA 48 reúne os principais dados adquiridos.

Dentre as usinas selecionadas, a PCH Bela Vista possui a maior potência instalada (29 MW), enquanto que a PCH Couro do Cervo possui a menor (1,46 MW). Há predominância de PCHs de significativa capacidade instalada; nove das 15 usinas possuem capacidade superior a $10 \mathrm{MW}$. Com relação às séries históricas, diversas usinas possuem um excelente comprimento, algumas delas com dados disponíveis a partir da década de 1930. O destaque é para a PCH Mata Velha, com histórico variando entre 01/1931 e 12/2011, totalizando 80 anos de dados. Lembra-se que todos os registros estão em escala mensal.

Há de se enfatizar que a presença de dados como rendimento do conjunto turbina/gerador, taxas de indisponibilidade, perdas hidráulicas, níveis de água e altura de queda bruta contribuem para uma maior precisão nas estimativas das séries de energia gerada.

Por fim, exibe-se o Gráfico 121 com o posicionamento das PCHs selecionadas. Para comparação, foram mantidas as coordenadas dos dados de vento adquiridos. 
TABELA 48 - Principais Dados das PCHs Selecionadas.

\begin{tabular}{|c|c|c|c|c|c|c|c|c|}
\hline & $\begin{array}{c}\text { Ado } \\
\text { Popinha } \\
\text { ki }\end{array}$ & $\begin{array}{l}\text { Bela } \\
\text { Vista }\end{array}$ & $\begin{array}{l}\text { Cach. } \\
\text { Cinco } \\
\text { Veados }\end{array}$ & Cantu 2 & $\begin{array}{c}\text { Couro } \\
\text { do } \\
\text { Cervo }\end{array}$ & $\begin{array}{c}\text { Fortuna } \\
\text { II }\end{array}$ & Jacaré & Jambo \\
\hline Despacho ANEEL & $3.005 / 2013$ & $274 / 2014$ & $1.838 / 2012$ & $3.078 / 2014$ & 1.434/2012 & $486 / 2015$ & $485 / 2015$ & $263 / 2015$ \\
\hline Latitude & $27^{2} 27399^{\prime S}$ & $25^{\circ} 48 \cdot 25^{\prime \prime} \mathrm{S}$ & $29255^{20.80 " \mathrm{~s}}$ & $24^{\circ} 44^{\prime} 45^{\prime \prime S}$ & $21^{\circ 20} 0^{\circ} 44^{\prime \prime}$ & $18^{\circ} 54^{\prime} \mathrm{S}$ & $190^{\circ} 8.58 \mathrm{~s}$ & $21^{\circ} 59^{\circ} 0^{\prime \prime S}$ \\
\hline Longitude & $50^{\circ} 31^{1} 122^{\prime \prime}$ & $5253555^{\circ 0}$ & $54^{4} 3^{\prime} 10.80^{\circ} \mathrm{O}$ & $52^{2} 2805^{\prime \prime 0}$ & $45^{\circ} 10^{\prime 19} 19^{\prime \prime}$ & $42^{24410}$ & $42^{\circ 56} 647.86^{\circ} \mathrm{O}$ & $42^{\circ} 07^{\circ} 00^{\prime \prime} \mathrm{W}$ \\
\hline UF & sc & PR & RS & $\mathrm{PR}$ & MG & MG & MG & RJ \\
\hline Rio & Canoas & Chopim & Toropi & Cantú & do Cervo & $\begin{array}{l}\text { Cor. } \\
\text { Grande }\end{array}$ & Guanhães & Grande \\
\hline Potência Instalada Total (MW) & 19,30 & 29,00 & 14,88 & 18,00 & 1,46 & 9,00 & 9,00 & 13,00 \\
\hline Número de unidades & 4 & 2 & 2 & 3 & 2 & 3 & 2 & 2 \\
\hline $\begin{array}{l}\text { Rendimento nominal por turbina } \\
(\%)\end{array}$ & 89,75 & 92,00 & 92,00 & 91,70 & 90,50 & 94,66 & 92,71 & 92,40 \\
\hline $\begin{array}{l}\text { Rendimento nominal por gerador } \\
(\%)\end{array}$ & 97,50 & 96,00 & 96,00 & 97,50 & 97,00 & 97,15 & 97,54 & 97,00 \\
\hline $\begin{array}{l}\text { Taxa equivalente de } \\
\text { indisponibilidade. forçada (\%) }\end{array}$ & 1,26 & 1,26 & 2,50 & 2,00 & 2,50 & 1,26 & 1,26 & 1,26 \\
\hline Indisponibilidade programada (\%) & 4,45 & 3,79 & 2,50 & 3,00 & 2,50 & 0,50 & 0,50 & 2,18 \\
\hline Perdas hidráulicas nominais (m) & 0,34 & 0,47 & 1,92 & 0,52 & 0,92 & 1,25 & 0,60 & 2,90 \\
\hline $\begin{array}{l}\text { N. A. máximo normal de montante } \\
(\mathrm{m})\end{array}$ & 816,7 & 430,0 & 200,0 & 415,0 & 837,4 & 645,0 & 550,0 & 238,5 \\
\hline $\begin{array}{l}\text { N. A. máximo normal de jusante } \\
\text { (m) }\end{array}$ & 803,8 & 414,5 & 161,5 & 373,5 & 819,0 & 593,9 & 525,1 & 180,8 \\
\hline Queda bruta nominal (m) & 12,93 & 15,50 & 38,50 & 41,50 & 18,40 & 51,14 & 24,90 & 57,70 \\
\hline $\begin{array}{l}\text { Área do Reservatório no N.A. } \\
\text { máx. normal }\left(\mathrm{km}^{2}\right)\end{array}$ & 0,30 & 2,36 & 1,34 & 3,55 & 0,01 & 0,94 & 2,24 & 0,42 \\
\hline \multirow[t]{2}{*}{ Série de Vazões Médias Mensais } & $\begin{array}{l}01 / 1943 \\
12 / 2011 \\
\end{array}$ & $\begin{array}{l}01 / 1931 \\
12 / 2002 \\
\end{array}$ & $\begin{array}{l}01 / 1942 \\
12 / 2005 \\
\end{array}$ & $\begin{array}{l}08 / 1967 \\
06 / 2005 \\
\end{array}$ & $\begin{array}{l}01 / 1935 \\
12 / 2009 \\
\end{array}$ & $\begin{array}{l}01 / 1953 \\
12 / 2005 \\
\end{array}$ & $\begin{array}{l}01 / 1946 \\
12 / 2011 \\
\end{array}$ & $\begin{array}{l}01 / 1935 \\
12 / 2006 \\
\end{array}$ \\
\hline & Manopla & $\begin{array}{l}\text { Mata } \\
\text { Velha }\end{array}$ & $\begin{array}{l}\text { Paredão } \\
\text { de Minas }\end{array}$ & \multicolumn{2}{|c|}{$\begin{array}{l}\text { Ponte } \\
\text { Branca }\end{array}$} & Rincão & Rudolf & Saudade \\
\hline Despacho ANEEL & $3.707 / 2014$ & $2.937 / 2013$ & $158 / 2015$ & \multicolumn{2}{|c|}{$1.788 / 2012$} & $2.929 / 2014$ & $1.061 / 2013$ & $863 / 2013$ \\
\hline Latitude & $08^{\circ} 39^{\circ} 05^{\prime \prime} \mathrm{S}$ & $16^{\circ} 12^{\prime} \mathrm{S}$ & $17^{\circ} 07^{\prime 2} 24^{\prime \prime S}$ & \multicolumn{2}{|c|}{ 22052'26.87"S } & $28^{\circ} 25^{\prime} 20^{\prime \prime} \mathrm{S}$ & $27^{\circ} 00 \cdot 51 " \mathrm{~S}$ & $21^{\circ} 53^{\prime} 44.7^{\prime \prime S}$ \\
\hline Longitude & $35^{\circ} 13^{\prime} 03^{\prime \prime} \mathrm{O}$ & $47^{\circ} 10^{\circ} \mathrm{O}$ & $45^{\circ} 26^{\prime} 25^{\prime \prime} \mathrm{O}$ & $49^{\circ} 12$ & $.23 " \mathrm{O}$ & $54^{\circ} 17^{\circ} 599^{\circ} \mathrm{O}$ & $50^{\circ} 09^{\prime 21} 1 \mathrm{O}^{\circ}$ & $43^{\circ} 04^{\prime} 22.1^{\prime \prime O}$ \\
\hline UF & PE & MG & MG & $\varsigma$ & & RS & sc & MG \\
\hline Rio & Sirinhaém & Preto & do Sono & $\mathrm{Pr}$ & & ljuizinho & $\begin{array}{l}\text { Itajaí do } \\
\text { Oeste }\end{array}$ & Cágado \\
\hline Potência Instalada Total (MW) & 5,75 & 24,00 & 26,55 & & & 10,00 & 9,26 & 9,90 \\
\hline Número de unidades & 2 & 2 & 2 & & & 2 & 2 & 3 \\
\hline $\begin{array}{l}\text { Rendimento nominal por turbina } \\
(\%)\end{array}$ & 91,00 & 90,20 & 93,20 & & & 91,00 & 91,15 & 90,20 \\
\hline $\begin{array}{l}\text { Rendimento nominal por gerador } \\
(\%)\end{array}$ & 96,50 & 97,00 & 97,00 & & & 97,00 & 96,00 & 97,00 \\
\hline $\begin{array}{l}\text { Taxa equivalente de } \\
\text { indisponibilidade forçada (\%) }\end{array}$ & 1,00 & 1,26 & 2,07 & & & 1,26 & 1,26 & 1,26 \\
\hline Indisponibilidade programada (\%) & 2,00 & 4,45 & 0,00 & & & 3,73 & 4,45 & 4,45 \\
\hline Perdas hidráulicas nominais (m) & 1,10 & 1,27 & 0,34 & & & 0,48 & 3,48 & 2,05 \\
\hline $\begin{array}{l}\text { N. A. máximo normal de } \\
\text { montante }(\mathrm{m})\end{array}$ & 46,0 & 632,0 & - & & & 213,2 & 457,0 & 425,0 \\
\hline $\begin{array}{l}\text { N. A. máximo normal de jusante } \\
\text { (m) }\end{array}$ & 31,4 & 601,9 & - & & & 201,2 & 399,0 & 364,8 \\
\hline Queda bruta nominal (m) & 14,65 & 30,06 & 29,90 & & & 12,00 & 58,00 & 60,20 \\
\hline $\begin{array}{l}\text { Área do Reservatório no N.A. } \\
\text { máx. normal }\left(\mathrm{km}^{2}\right)\end{array}$ & 0,37 & 2,43 & 6,51 & & & 0,42 & 0,03 & 0,25 \\
\hline Série de Vazões Médias Mensais & $\begin{array}{l}01 / 1963 \\
12 / 2006\end{array}$ & $\begin{array}{l}01 / 1931 \\
12 / 2011\end{array}$ & $\begin{array}{l}01 / 1967 \\
12 / 2012\end{array}$ & $\begin{array}{l}01 / \\
12 /\end{array}$ & & $\begin{array}{l}01 / 1942 \\
12 / 2006\end{array}$ & $\begin{array}{l}01 / 1930 \\
12 / 2005\end{array}$ & $\begin{array}{l}01 / 1957 \\
12 / 2010\end{array}$ \\
\hline
\end{tabular}


Gráfico 121 - Distribuição espacial das PCHs selecionadas juntamente com as coordenadas dos dados de vento (via Google Maps, mapa disponível em http://tinyurl.com/gkoo6oj).

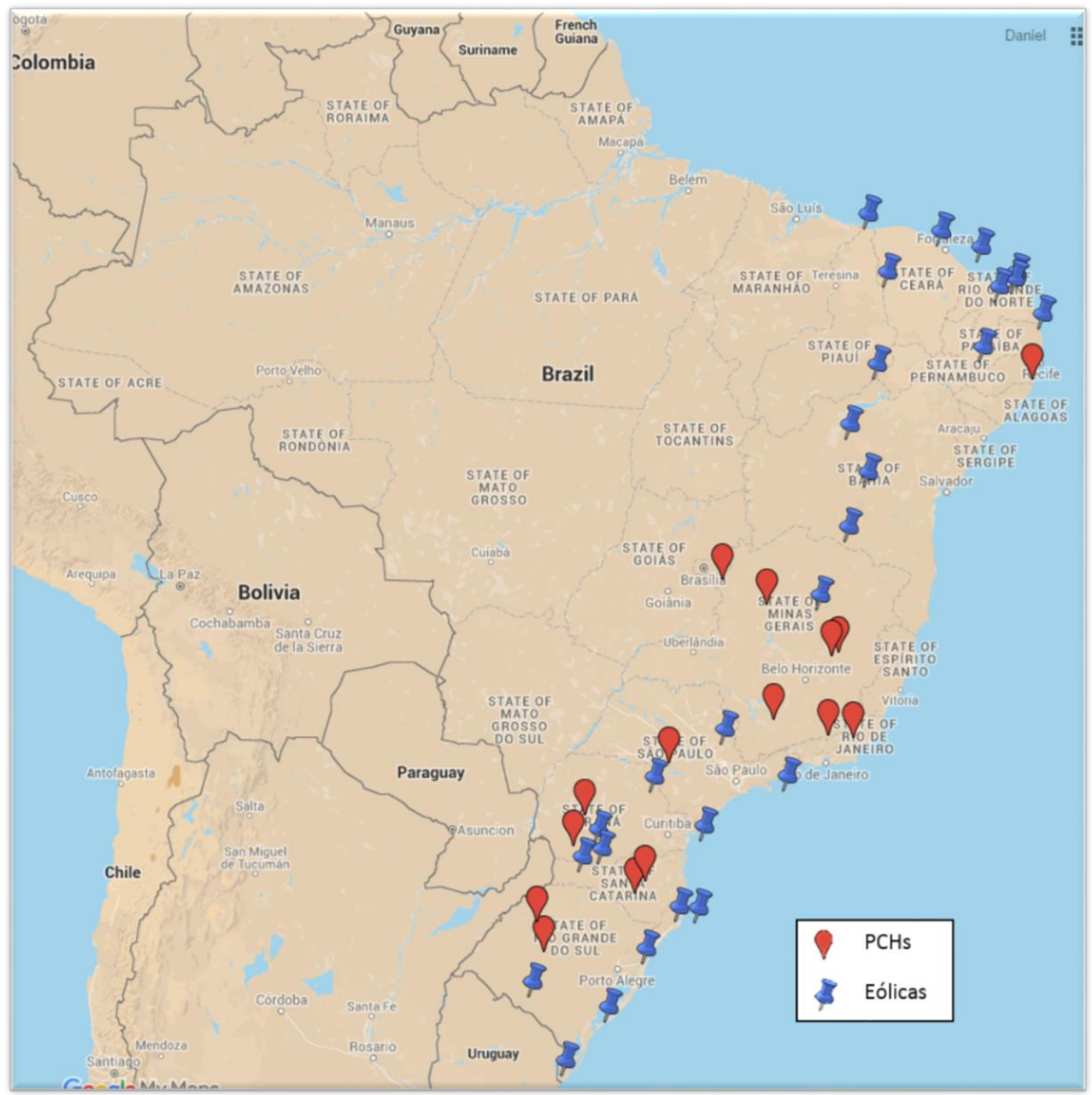

Autor (2016).

Fonte: Google Maps (2015).

O que se observa é uma predominância de PCHs na região Centro-Sul do país, com apenas uma usina prevista para a região Nordeste. De certo modo, essa distribuição contrasta com o potencial eólico brasileiro, o que pode render análises interessantes do ponto de vista dos portfólios de empreendimentos resultantes da metodologia.

De acordo com Pereira (2015), a conversão da energia potencial da água nos reservatórios das usinas em energia elétrica pode ser representada pela Equação (86). 


$$
E=\eta \cdot \rho \cdot g \cdot Q_{T} \cdot H_{L} \cdot \Delta t
$$

Onde:

$\eta$ é o rendimento do conjunto turbina/gerador;

$\rho$ é a massa específica da água $\left(1000 \mathrm{~kg} / \mathrm{m}^{3}\right)$;

$g$ é a constante de aceleração gravitacional $\left(9,81 \mathrm{~m} / \mathrm{s}^{2}\right)$;

$Q_{T}$ é a vazão turbinada pela usina $\left(\mathrm{em} \mathrm{m}^{3} / \mathrm{s}\right)$;

$H_{L}$ é a altura de queda líquida (em $\mathrm{m}$ ), e;

$\Delta t$ é o intervalo de tempo considerado (em h).

A altura de queda líquida se refere à diferença entre os níveis do reservatório e do canal de fuga, descontada das perdas de carga hidráulicas. Nessa configuração, a energia $E$ é expressa em kWh. Ressalta-se que a escala temporal das séries de vazão das PCHs é mensal.

De acordo com o documento Diretrizes para Estudos e Projetos de Pequenas Centrais Hidrelétricas, elaborado pela Eletrobrás (2000), a grande maioria das PCHs contam com reservatórios reduzidos e sem capacidade de regularização, ou seja, operam a fio d'água. Essa é uma informação importante para o cálculo da energia gerada pela usina, pois o processo dispensa a simulação da variação do volume armazenado pelo reservatório. Estando a usina sempre em seu volume de reservação máximo, a altura de queda líquida permanece constante e a única variável passa a ser a vazão turbinada $Q_{T}$. Nesse sentido, é fácil entender que quando a vazão afluente é menor do que a capacidade de turbinamento da $\mathrm{PCH}$, esta gerará a energia correspondente ao volume de água recebido. Por outro lado, quando a vazão afluente é maior do que o engolimento das turbinas, haverá vertimento.

Os valores de vertimento foram obtidos indiretamente através da potência nominal da usina ${ }^{106}$. Foi calculada a energia gerada pela $\mathrm{PCH}$, limitando o resultado ao valor de sua potência instalada, uma vez que o excedente foi considerado vertimento.

106 Os dados levantados para as PCHs não contemplam a capacidade máxima de turbinamento. 
Como forma de demonstrar o procedimento, considera-se a $\mathrm{PCH}$ Ado Popinhaki, localizada no estado de Santa Catarina. São avaliadas as vazões mensais referentes ao ano de 1994, a fim de convertê-las em séries de energia gerada. A TABELA 49 exibe as informações necessárias para o cálculo.

TABELA 49 - Dados da PCH Ado Popinhaki Necessários para a Estimativa da Energia Gerada.

\begin{tabular}{lr}
\hline Parmâmetros & Grandezas \\
\hline Potência Instalada Total (MW) & 19,30 \\
Rendimento nominal por turbina (\%) & 89,75 \\
Rendimento nominal por gerador (\%) & 97,50 \\
Perdas hidráulicas nominais (m) & 0,34 \\
Queda bruta nominal (m) & 12,93 \\
\hline
\end{tabular}

Autor (2016).

O objetivo da obtenção de dados das $\mathrm{PCH}$ é possibilitar uma estimativa da geração de energia. Essa não é uma tarefa simples, pois depende de muitos parâmetros de projeto das usinas. A altura de queda líquida é uma variável de grande interesse por influenciar diretamente a geração de energia da usina. Entretanto, sua correta contabilização depende das perdas de carga decorrentes das diversas estruturas físicas da usina. Outra variável de primordial importância é a vazão afluente ao aproveitamento. Além de um bom histórico, é desejável que as séries históricas estejam consistidas e não contenham dados nulos. O Gráfico 122 mostra a série mensal de afluências para o ano considerado.

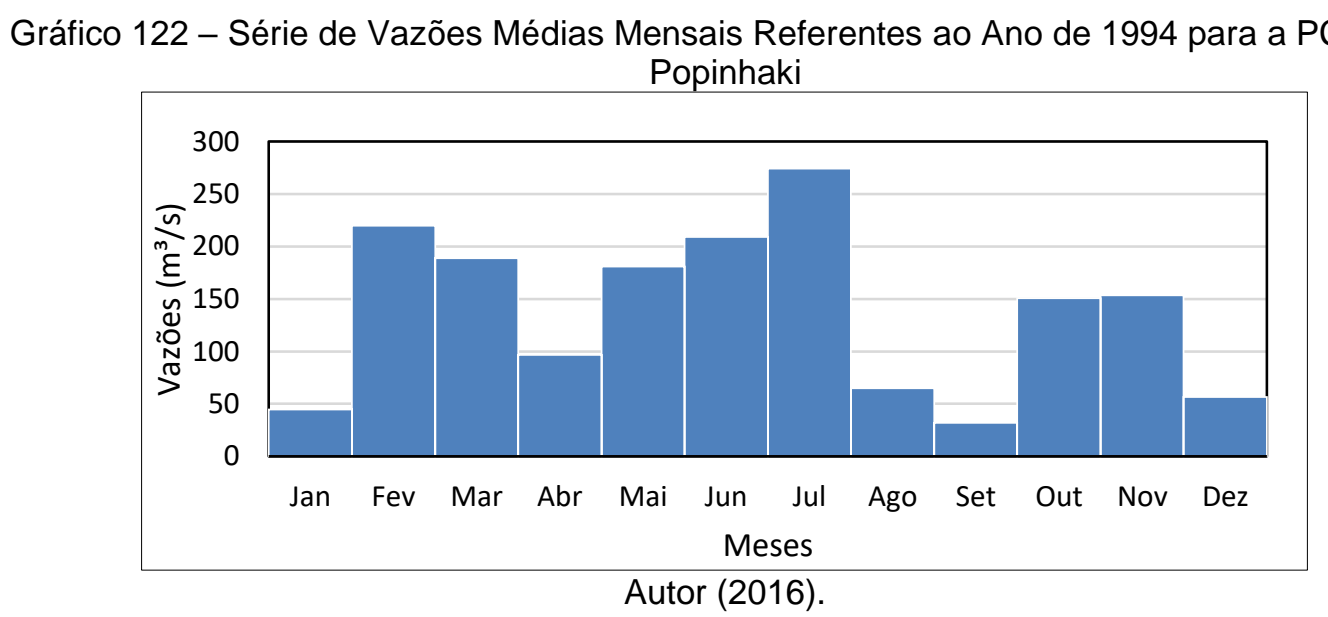

A determinação da energia gerada é feita através da Equação (86), substituindo-se os dados da TABELA 49 e do Gráfico 122. 
O rendimento do conjunto turbina/gerador é o produto entre os rendimentos nominais desses equipamentos, o que resulta em 0,875 . Por sua vez, a queda líquida é obtida subtraindo-se a queda bruta nominal pelas perdas hidráulicas nominais, resultando em 12,59 m. Por fim, considera-se $\Delta t=1$ mês. O cálculo é feito uma vez por mês, chegando-se à série de energia gerada mensal para o ano de 1994, conforme exibido pelo Gráfico 123.

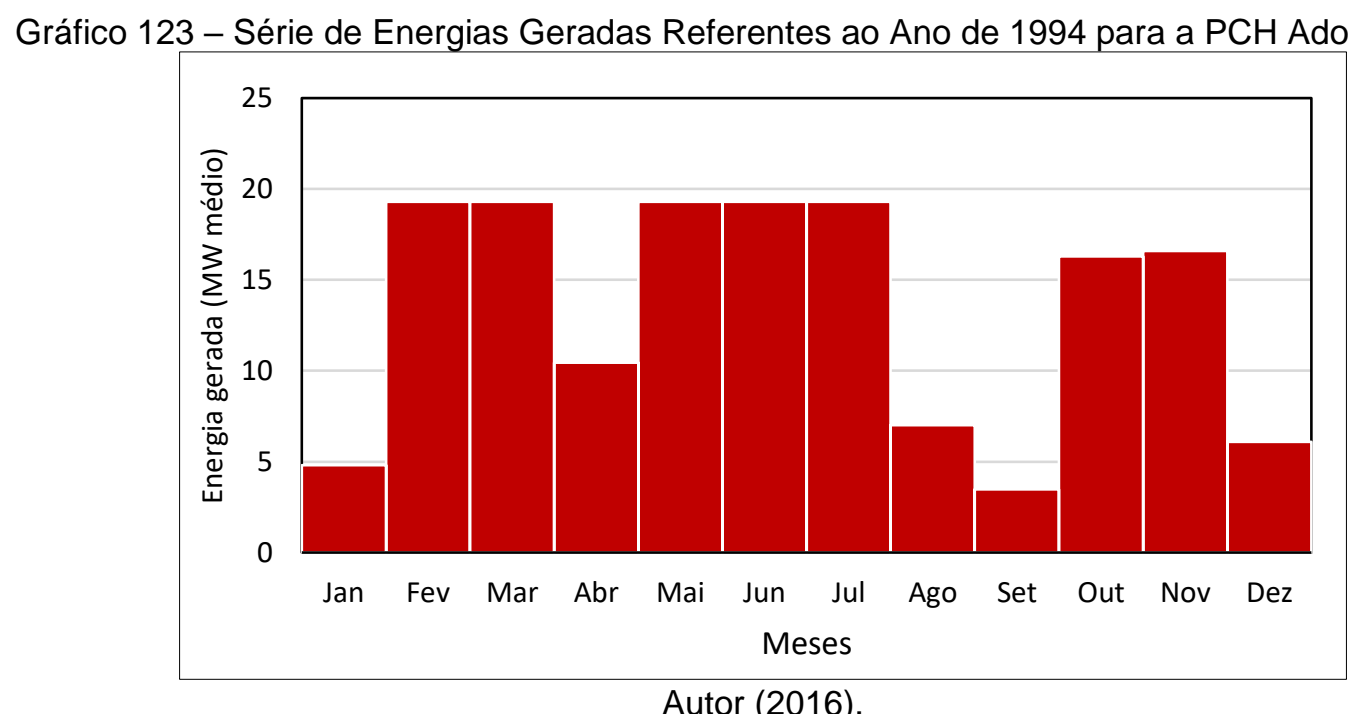

Como se percebe, os meses de fevereiro, março, maio, junho e julho tiveram gerações truncadas no valor da potência instalada dessa usina (19,30 MW). Na simulação, o excedente de vazão para esses meses resultou em vertimentos.

Este processo foi realizado para todos os meses da série histórica de vazão e para todas as PCHs, obtendo-se a série histórica de energia gerada.

\subsubsection{Cálculo da Fronteira Eficiente para PCHs e Usinas Eólicas}

O cálculo da fronteira eficiente foi realizado primeiramente para as usinas eólicas e PCHs separadamente e, na sequencia, em conjunto. Como a ordem de grandeza da potência instalada das usinas é próxima, a otimização foi realizada tão somente com a série de energia gerada.

As séries de energia gerada para as usinas eólicas foram geradas a partir das séries de ventos das 22 coordenadas adquiridas do Vortex e considerando 10 aerogeradores Wobben/Enercon (usinas com potência instalada de $25 \mathrm{MW}$ ). 
Conforme se verifica na TABELA 48, cada PCH possui uma data de início e término das séries de vazões. Assim, para a obtenção da fronteira eficiente das PCHs, foram consideradas as séries históricas de energia gerada mensal, com datas coincidentes, isto é, de 1994 a 2002. Para a obtenção das demais fronteiras eficientes foi utilizado o período comum do histórico, isto é, de 1994 a 2002. A TABELA 50 resume os parâmetros estatísticos de média e desvio padrão para cada usina no referido período.

TABELA 50 - Parâmetros das PCHs e das Usinas Eólicas

\begin{tabular}{|c|c|c|c|}
\hline \multirow{2}{*}{ Nome da Usina/Coordenada } & \multicolumn{3}{|c|}{ Parâmetros (MWmédios) } \\
\hline & Eólica/PCH & Risco & Retorno \\
\hline Parnaiba & & 3,754729 & 19,21691 \\
\hline Parada & & 5,235972 & 13,69826 \\
\hline Sao Joao & & 4,146613 & 17,57625 \\
\hline Medonho & & 2,595675 & 16,49245 \\
\hline Mocambira & & 4,100869 & 17,75879 \\
\hline Forquilha & & 4,081556 & 13,72826 \\
\hline Tavares & & 2,938361 & 8,478652 \\
\hline Sertania & & 3,059305 & 10,0406 \\
\hline Afranio & & 5,929023 & 16,03375 \\
\hline Palmas & & 2,516048 & 10,94408 \\
\hline Quilombo & & 2,419537 & 7,39243 \\
\hline Tubarão & Usınas Eolıcas & 1,98326 & 8,850833 \\
\hline Osório & & 2,11838 & 11,44453 \\
\hline Dom Pedrito & & 1,671428 & 9,998931 \\
\hline Estreito & & 2,087901 & 13,62363 \\
\hline Palmar & & 1,696002 & 12,97143 \\
\hline Itaguaçu & & 4,300643 & 6,301322 \\
\hline Boninal & & 2,563334 & 11,47983 \\
\hline Jacaraci & & 2,843208 & 10,47483 \\
\hline Olho Dagua & & 1,479068 & 2,936223 \\
\hline Riachuelo & & 1,109569 & 2,718132 \\
\hline Anta & & 1,202851 & 3,612755 \\
\hline Ado Popinhaki & & 5,543935 & 13,60508 \\
\hline Bela Vista & & 7,92358 & 21,07018 \\
\hline Cachoeira Cinco Veados & & 5,690897 & 9,754934 \\
\hline Cantú 2 & & 5,744588 & 12,26842 \\
\hline Couro do Cervo & & 0,34241 & 0,767437 \\
\hline Fortuna II & & 2,665664 & 4,573965 \\
\hline Jacaré & & 2,524588 & 3,982344 \\
\hline Jambo & $\mathrm{PCHs}$ & 3,429444 & 8,82612 \\
\hline Manopla & & 1,759148 & 3,078651 \\
\hline Mata Velha & & 5,302895 & 10,71824 \\
\hline Paredão de Minas & & 8,546242 & 10,63053 \\
\hline Ponte Branca & & 2,085932 & 7,226105 \\
\hline Rincão & & 3,123283 & 5,895003 \\
\hline Rudolf & & 2,631919 & 6,829903 \\
\hline Saudade & & 2.41795 & 5,683683 \\
\hline
\end{tabular}

A fronteira eficiente considerando apenas a série histórica de energia gerada das PCHs está apresentada no Gráfico 124. A fronteira eficiente calculada para a série histórica da energia gerada das usinas eólicas está no Gráfico 125. A fronteira eficiente considerando os dados das PCHs e das usinas eólicas está no Gráfico 126. 
Gráfico 124 - Fronteira Eficiente para as Usinas PCHs.

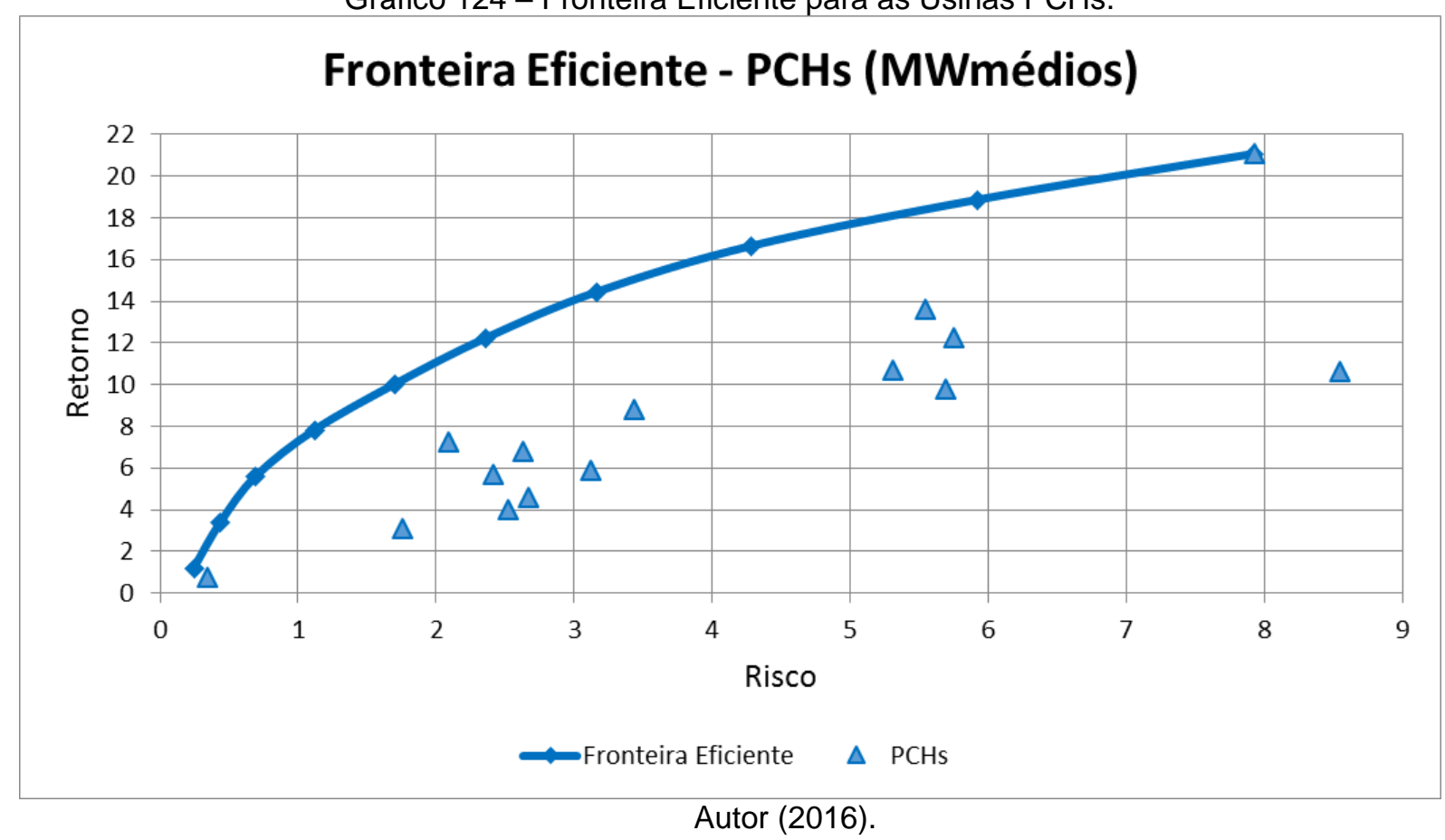

Gráfico 125 - Fronteira Eficiente para as Usinas Eólicas.

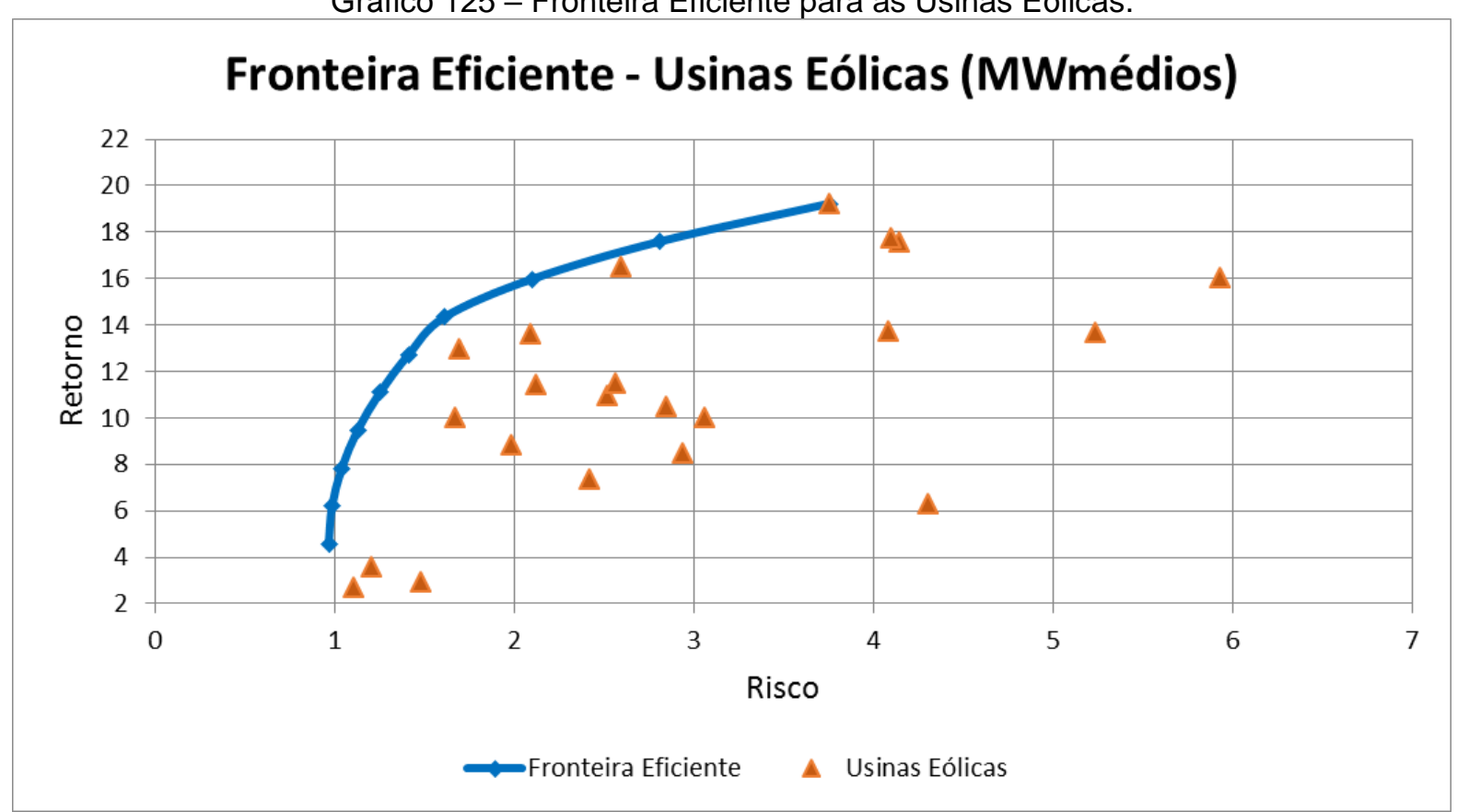

Autor (2016). 
Gráfico 126 - Fronteira Eficiente para as Usinas PCHs e Eólicas.

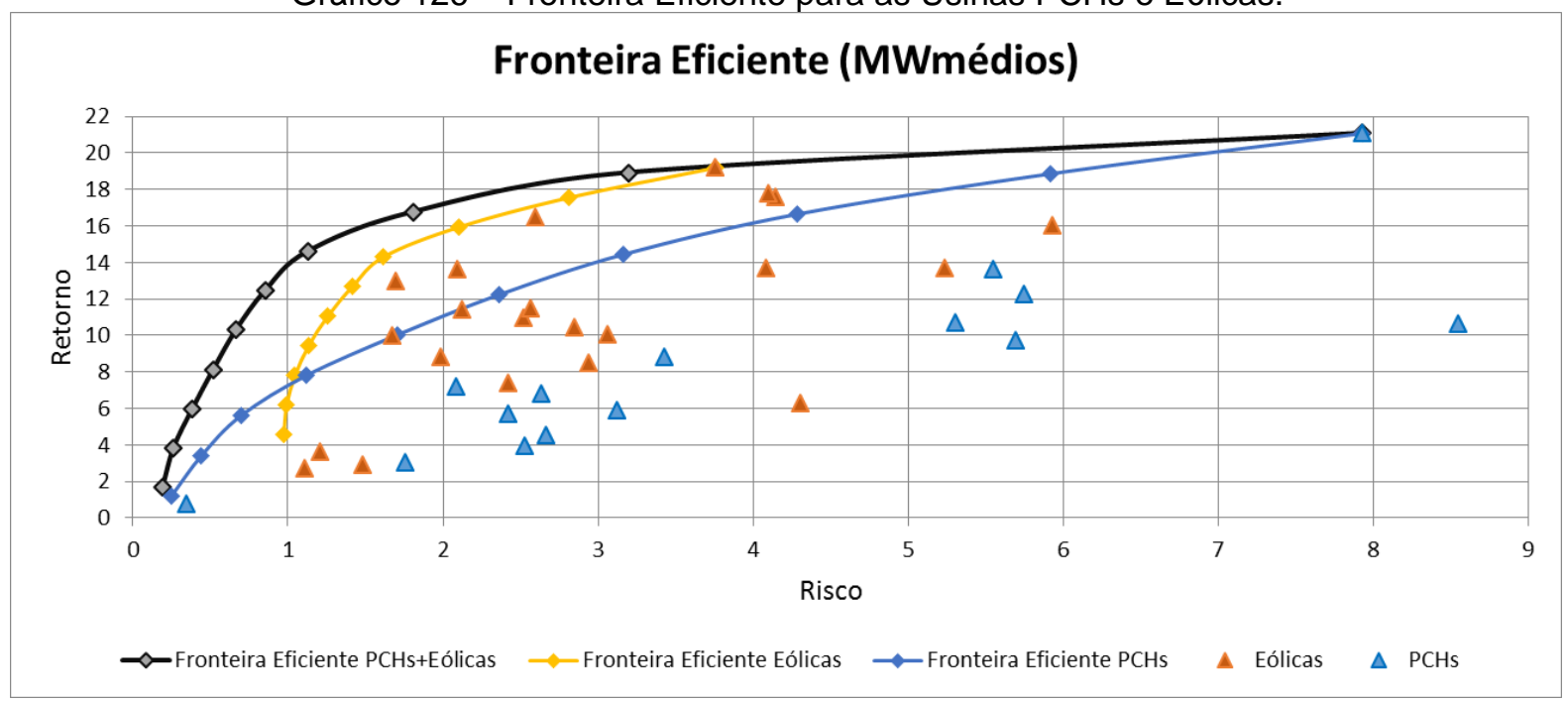

Autor (2016).

$\mathrm{Na}$ cor laranja estão representadas as usinas eólicas individualizadas e na cor azul estão representadas as PCHs. As curvas na cor laranja e azul representam a fronteira eficiente para as usinas eólicas e para as PCHs. As carteiras otimizadas sobre a fronteira eficiente com o portfólio de PCHs e usinas eólicas (curva preta) possuem uma expectativa de geração maior que as demais carteiras da fronteira eficiente obtidas com o mesmo tipo de fonte (curva azul ou curva laranja), para um mesmo risco.

A TABELA 51 apresenta as 3 carteiras otimizadas de risco mínimo. Verifica-se que a carteira formada por PCHs e usinas eólicas possui o menor risco e a menor relação risco/retorno. Esse resultado está coerente com o que foi obtido no item 5.1.5, quando foi otimizado com as usinas do PROINFA.

TABELA 51 - Risco Mínimo e Geração Esperada.

\begin{tabular}{lccc}
\hline Portfólio & $\begin{array}{c}\text { Risco Mínimo } \\
\text { (MWmédios) }\end{array}$ & $\begin{array}{c}\text { Geração Esperada } \\
\text { (MWmédios) }\end{array}$ & Risco/Geração \\
\hline PCHs & 0,25 & 1,21 & $20 \%$ \\
Usinas Eólicas & 0,97 & 4,59 & $21 \%$ \\
PCHs e Usinas & 0,19 & 1,68 & $11 \%$ \\
Eólicas & & &
\end{tabular}

Autor (2016).

Para as carteiras formadas apenas por usinas eólicas, os resultados obtidos possuem uma faixa de expectativa de geração entre 4,59 MWmédios (carteira de risco mínimo) a 19,22 MWmédios (carteira de maior retorno). No caso de carteiras formadas por PCHs, os resultados possuem uma faixa de geração entre 1,21 MWmédios 
(carteira de risco mínimo) a 21,07 MWmédios (carteira de maior retorno). As carteiras de portfólios de usinas eólicas e PCHs possuem uma fronteira eficiente variando de 1,68 MWmédios a 21,07 MWmédios. As carteiras de portfólios de usinas eólicas e $\mathrm{PCHs}$ também possuem risco menor do que as demais.

\subsection{SIMULAÇÕES DE RECEITAS ESPERADAS}

No item 5.2.4 foram otimizadas as carteiras visando minimizar a volatilidade da energia gerada (ou do fator de capacidade), obtendo-se dessa forma a fronteira eficiente, formada por carteiras otimizadas. Para verificar se o resultado da otimização tem melhor efeito econômico para o investidor, foi realizada a comparação da receita da carteira atual com a receita da carteira otimizada. Para tal, as carteiras foram simuladas com Contratos de Energia de Reserva e com contratos bilaterais firmados no mercado livre.

A TABELA 40 apresentou o retorno e o risco para 10 exemplos de carteiras otimizadas e para carteira atual, considerando uma usina eólica com uma máquina do aerogerador Wobben/Enercon $(2.500 \mathrm{~kW})$. A expectativa de geração da carteira atual foi calculada em 1.368,33 kWmédios com um risco de 336,16 kWmédios.

Nas simulações, as séries históricas de energia gerada das carteiras foram obtidas para uma usina eólica de $30 \mathrm{MW}$ de potência instalada, composta por 12 aerogeradores Wobben/Enercon. A TABELA 52 apresenta a composição da carteira atual e da carteira otimizada, ambas com a mesma expectativa de geração. A diferença entre as duas carteiras está no risco. A carteira atual possui o dobro do risco da carteira otimizada. A simulação possibilitará a análise do impacto da volatilidade da energia gerada na receita.

Justifica-se a escolha da simulação do Contrato de Energia de Reserva e do contrato bilateral, pois o primeiro é imune à exposição ao mercado de curto prazo e o segundo sofre exposição ao mercado de curto prazo na medida em que a energia gerada difere da garantia física ${ }^{107}$. As regras de contabilização e liquidação do Contrato de Energia de Reserva foram apresentadas no item 3.5. Para ambos os contratos, foi necessário calcular a garantia física da usina eólica.

${ }^{107}$ Foi considerado que a usina eólica vende em contrato bilateral a totalidade da sua garantia física. 
TABELA 52 - Composição da Carteira Atual e Carteira Otimizada (Usina Eólica 30 MW Aerogerador Wobben/Enercon).

\begin{tabular}{lcc}
\hline & \multicolumn{2}{c}{ Potência (MW) } \\
& Carteira Atual & Carteira Otimizada \\
\hline Parnaiba & 1,66 & 0,00 \\
Parada & 3,42 & 0,00 \\
Sao Joao & 4,19 & 0,00 \\
Medonho & 0,10 & 7,45 \\
Mocambira & 2,37 & 0,00 \\
Forquilha & 2,08 & 0,00 \\
Tavares & 0,13 & 0,00 \\
Sertania & 1,39 & 0,00 \\
Afranio & 4,32 & 0,00 \\
Palmas & 0,25 & 0,00 \\
Quilombo & 0,00 & 0,00 \\
Tubarão & 0,16 & 0,00 \\
Osório & 1,35 & 1,59 \\
Dom Pedrito & 0,36 & 0,00 \\
Estreito & 0,47 & 0,00 \\
Palmar & 1,36 & 20,96 \\
Itaguaçu & 2,17 & 0,00 \\
Boninal & 0,72 & 0,00 \\
Jacaraci & 3,52 & 0,00 \\
Olho Dagua & 0,00 & 0,00 \\
Riachuelo & 0,00 & 0,00 \\
Anta & 0,00 & 0,00 \\
& & \\
\hline Risco (kWmédios) & $\mathbf{4 . 0 3 3 , 8 8}$ & $\mathbf{2 . 0 1 5 , 5 9}$ \\
Retorno (kWmédios) & $\mathbf{1 6 . 4 1 9 , 9 8}$ & $\mathbf{1 6 . 4 1 9 , 9 6}$ \\
\hline & Autor (2016). & \\
\hline
\end{tabular}

A Figura 18 apresenta o modelo utilizado para obter as receitas das carteiras para o Contrato de Energia de Reserva e para o contrato bilateral.

Figura 18 - Modelo Proposto - Simulação das Receitas.

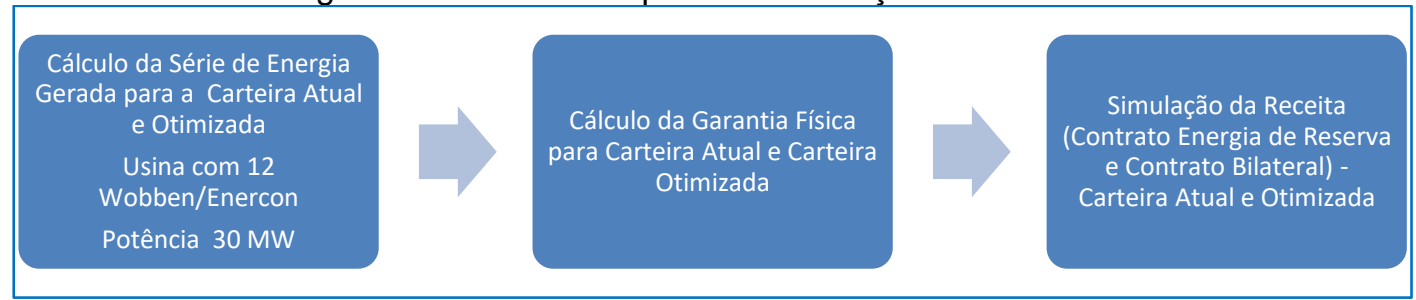

Autor (2016).

Tendo em vista que o cálculo da série de energia gerada mensal para cada carteira já foi demonstrado, os itens seguintes descrevem o cálculo da garantia física e a simulação da receita para cada contrato. 


\subsubsection{Cálculo da Garantia Física}

Conforme apresentado no item 4.5, a garantia física das usinas eólicas é calculada de acordo com a Nota Técnica 072/2013, publicada pela EPE, nos termos da Equação (19).

Evidentemente, por se tratar de uma estimativa futura, o valor considerado para o $P 90_{a c}$ da Equação (19) envolve incertezas. A fim de contabilizá-las, a EPE utiliza a distribuição Normal e recomenda que o cálculo do $P 90_{a c}$ seja feito pela Equação (20), a partir do $P 50_{a c}$.

O $P 50_{a c}$ possui a mesma definição que o $P 90_{a c}$, porém considerando um intervalo de confiança de $50 \%$. Essencialmente, seu valor é substituído pela mediana da série anual de energia, estimada pelo histórico.

A variável $\sigma$ da Equação (20) representa a incerteza padrão (em \%), valor este associado às incertezas na medição da velocidade do vento, estimativa da curva de potência e perdas aerodinâmicas dos parques geradores.

Os valores de TEIF, IP e $\sigma$ foram retirados do trabalho de Santos et al. (2010), no qual os autores expõem dados de algumas usinas eólicas em operação no Brasil. A TABELA 53 mostra os números contidos no estudo e, baseados neles, os valores adotados.

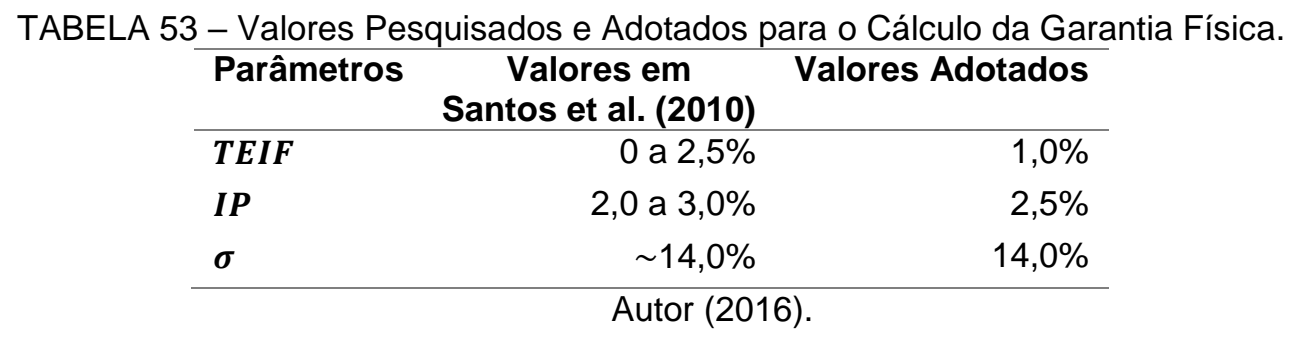

O parâmetro $\Delta P$ foi desconsiderado da formulação devido à ponderação de que se está trabalhando com coordenadas nas quais não existem usinas eólicas; portanto, não há sentido em considerar valores de consumo interno e perdas até o ponto de conexão, pois este não está definido.

Como exemplo do cálculo da garantia física, escolhe-se a coordenada Parnaíba e uma máquina do aerogerador Enercon E-115. O primeiro passo é a determinação do $P 50_{a c}$; como explicado, esse valor se refere à mediana da série de energia gerada na localidade. 
Para obtê-la, aplica-se o procedimento explicado no item 5.2.3.2, com a diferença de que se considera a série histórica de um ano inteiro ao invés de um mês específico. Lembra-se que o exemplo numérico contido no item 5.2.3.2 trata do cálculo da energia gerada para o mês de janeiro de 1994. Aqui é considerada a série de todos os meses de um ano na determinação do histograma e, na sequência, da energia gerada. Feitos os cálculos para todos os anos, basta determinar a mediana da série resultante. $O$ Gráfico 127 exibe as energias anuais e a mediana resultante $\left(P 50_{a c}=1.900,20 \mathrm{~kW}\right.$ médios $)$.

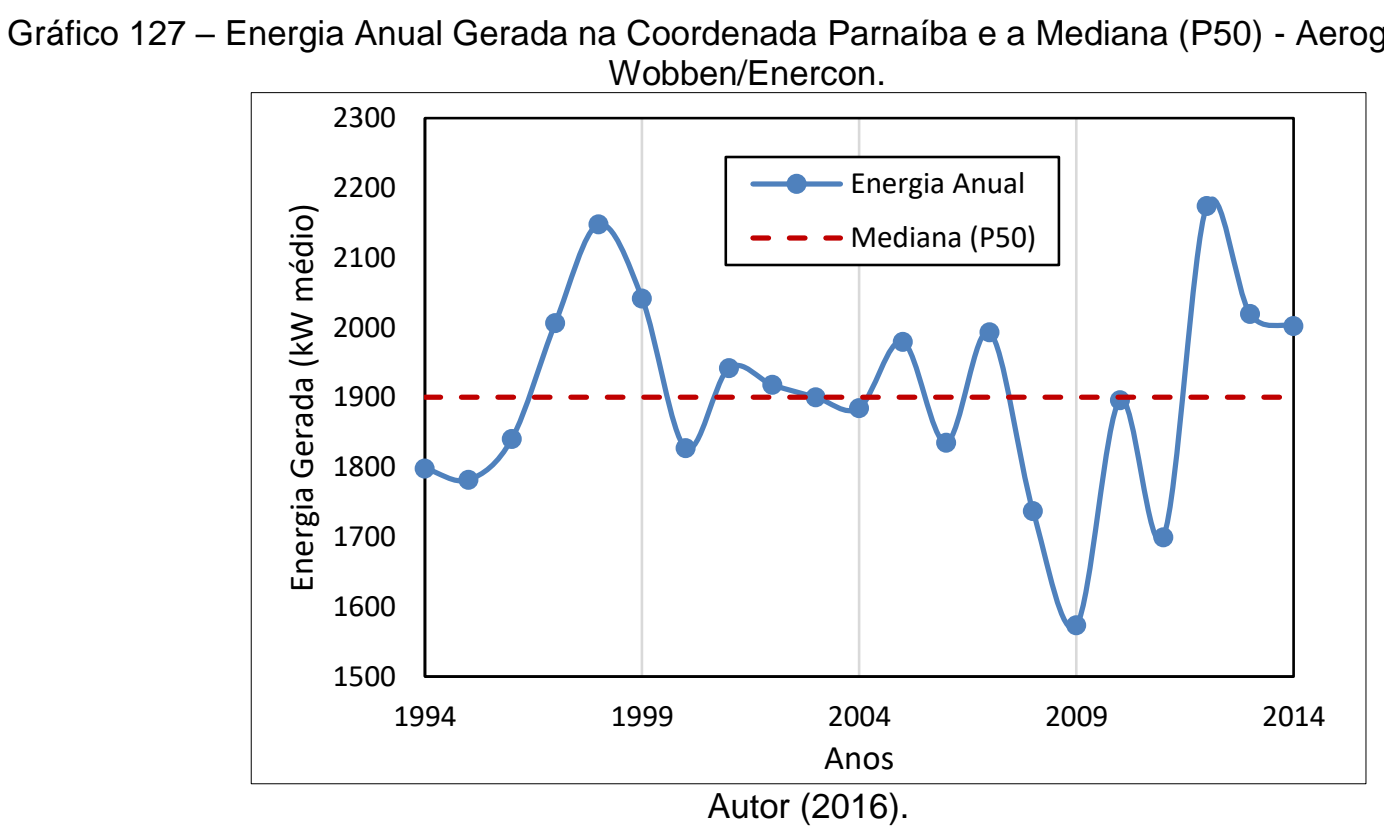

$\mathrm{Na}$ sequência, substitui-se os valores do $P 50_{a c}(1.900,20$ kWmédios) e da incerteza padrão $\sigma(14 \%)$ na Equação (20), chegando-se ao valor de $P 90_{a c}=1.896,80$ kWmédios. Por fim, inserindo-se os valores de $P 90_{a c}, T E I F(0,01)$ e $I P(0,025)$ na Equação (19), obtém-se o resultado da garantia física igual a 1.830,90 kWmédios. Repetindo-se o procedimento para as demais coordenadas ${ }^{108}$, chega-se às garantias físicas ilustradas no Gráfico 128.

108 Além das 22 coordenadas utilizadas no cálculo da Fronteira Eficiente, também foram calculadas as Garantias Físicas das coordenadas offshore nos Estados do Ceará, São Paulo, Paraná e Santa Catarina e a Garantia Física para uma coordenada sobre o reservatório da Usina Hidroelétrica de Segredo, no Estado do Paraná. Essas usinas não foram utilizadas na otimização. 
Gráfico 128 - Garantia Física das Coordenadas.

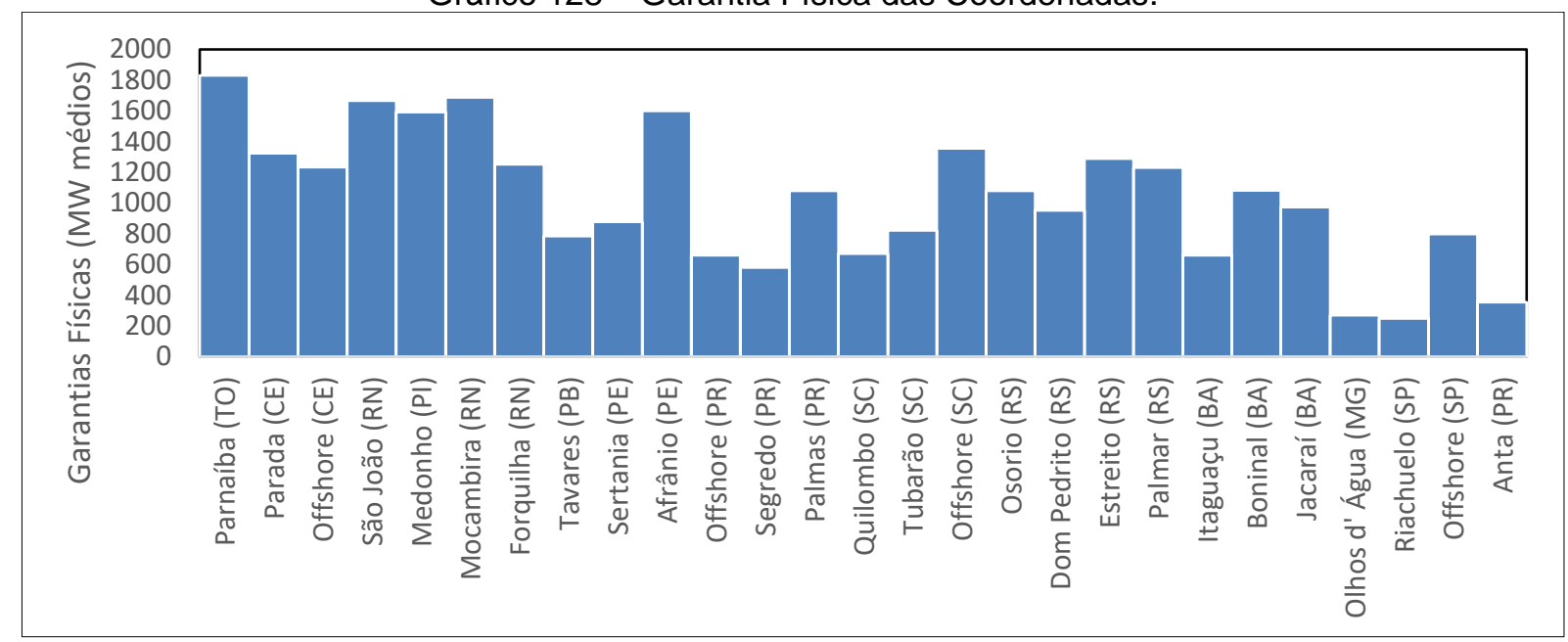

Autor (2016)

Como esperado, os maiores valores de garantias físicas estão localizados nas coordenadas da região nordeste do Brasil. Entretanto, algumas coordenadas localizadas nessa região possuem garantias físicas mais baixas, como Tavares (PB) e Sertania (PE). Por outro lado, coordenadas localizadas na região Sul possuem garantias físicas comparáveis a alguns pontos da região nordeste, como por exemplo Estreito (RS) e Palmar (RS). A maior garantia física dentre as localidades consideradas no projeto foi, justamente, para Parnaíba. A coordenada de menor garantia física foi Riachuelo.

Ressalta-se que os valores contidos no Gráfico 128 consideraram a energia gerada por uma máquina do aerogerador Wobben/Enercon E-115. Para se obter a garantia física de uma usina eólica de $30 \mathrm{MW}$ de potência instalada (12 máquinas do aerogerador Wobben/Enercon E-115), os valores encontrados foram multiplicados por 12 , isto é, foram desconsiderados o efeito esteira de um aerogerador sobre os outros.

Como a carteira atual e a carteira otimizada são constituídas por combinações de usinas em diversas coordenadas, a garantia física dessas carteiras também é uma combinação da garantia física das mesmas coordenadas, conforme consta na TABELA 52. Para a carteira atual, a garantia física resultou em 15.785,00 kWmédios para a carteira otimizada, a garantia física resultou em 15.746,51 kWmédios. A direfença decorre de arredondamentos no processo de seleção do percentual de participação das coordenadas. No cálculo da expectativa de geração, uma pequena diferença entre os valores para cada carteira já havia sido encontrada. 
Evidentemente que não existe previsão regulatória para a fixação de garantia física para uma carteira de usinas. No entanto, na prática, a combinação de várias usinas, com as suas respectivas garantias físicas, resulta na garantia física da própria carteira.

\subsubsection{Simulação da Carteira Considerando o Contrato de Energia de Reserva}

O Contrato de Energia de Reserva foi descrito no item 3.5. Trata-se de um contrato em que o vendedor não fica sujeito ao mercado de curto prazo, caso a energia gerada seja diferente da energia contratada. Além disso, toda a energia gerada da usina deve ser integralmente comercializada no âmbito do contrato. Em decorrência, não existe previsão de uma parte da usina ser comercializada em Leilões de Energia de Reserva e a outra parte e em outra modalidade.

A geração de energia anual acima da margem superior (30\%) do valor contratado implicará em adicional de receita ao investidor (70\% do preço do contrato). Por outro lado, a geração de energia anual abaixo da margem inferior (90\%) do valor contratado resultará em ressarcimento pelo investidor (preço do contrato acrescido de uma penalidade de 15\%). A geração entre a margem superior e a inferior é valorada ao preço do contrato.

O desvio positivo acumulado no quadriênio, contido entre a margem superior e o montante contratado, pode ser parcialmente ou totalmente: (i) cedido para outro investidor que tenha sagrado vencedor do mesmo LER, ou; (ii) transferido para o quadriênio seguinte, ou; (iii) ressarcido ao empreendedor, valorado ao preço contratado. Por sua vez, o desvio negativo acumulado no quadriênio, contido entre a margem inferior e o montante contratado, pode ser compensado por: (i) cessão de energia obtida de outro investidor ou (ii) indenizado pelo investidor, valorado ao preço contratado.

Adicionalmente, o CER prevê a reconciliação contratual a cada período de 4 anos, com base na produção efetivamente verificada desde o início do contrato, limitado ao montante contratado no primeiro quadriênio, sendo que nesse quadriênio o valor contratado é igual ao montante de energia associado ao lance vencedor do certame licitatório. 
Para verificar o resultado financeiro da otimização, o Contrato de Energia de Reserva foi simulado de acordo com as regras citadas e realizada a comparação da receita da carteira atual com a receita da carteira otimizada. As seguintes premissas foram adotadas na simulação:

a) Preço do Contrato igual a $\mathrm{R} \$ 172,60 / \mathrm{MWh}$, que representa o preço médio de venda das usinas eólicas nos leilões regulados;

b) No primeiro quadriênio do contrato, a energia comercializada é igual à garantia física, portanto foram desconsideradas as perdas da Rede Básica;

c) Foram simulados 8 (oito) anos do contrato, ou seja, dois quadriênios;

d) Ao final de cada quadriênio foi considerado que a energia sobrando ou faltando contida dentro da margem superior e inferior, é liquidada ao preço do contrato;

e) No primeiro quadriênio, havendo sobra, a receita adicional é liquidada em 24 parcelas e somadas às receitas mensais no primeiro e segundo ano do segundo quadriênio, em havendo déficit, a despesa é liquidada em 12 parcelas e deduzida das receitas mensais no primeiro ano do segundo quadriênio,

f) No segundo quadriênio, havendo sobra ou déficit, a receita ou despesa é liquidada no último mês desse quadriênio, por isso o valor da receita no último mês ficou bem maior que nos demais.

Tendo em vista a composição da carteira atual e da carteira otimizada com coordenadas localizadas em diversos Estados, foram realizadas duas simulações.

Na primeira simulação, cada carteira foi considerada como uma usina única (30 MW de potência instalada), de tal sorte que a energia gerada em cada coordenada é compensada dentro da própria carteira. Ressalta-se que isso não acontece no mundo real, na medida em que a energia gerada em cada coordenada seria integralmente contabilizada e liquidada no âmbito do seu Contrato de Energia de Reserva, uma vez em as coordenadas estão localizadas em diversos Estados ${ }^{109}$.

$\mathrm{Na}$ segunda simulação, cada coordenada foi considerada como uma usina de potência instalada igual a $30 \mathrm{MW}$. Assim, a energia gerada em cada coordenada foi liquidada dentro das regras do Contrato de Energia de Reserva.

109 Uma usina eólica é composta por diversos aerogeradores e conectada ao Sistema Interligado Nacional por um único sistema de transmissão. 
Nesta simulação, a receita de cada carteira é igual ao somatório da receita em cada coordenada ponderada pela participação da coordenada na respectiva carteira.

Na primeira simulação, onde as carteiras foram consideradas como uma usina única, o comportamento da energia gerada anual para as duas carteiras em comparação com os respectivos montantes contratados (no caso, igual às garantias físicas) está demonstrado no Gráfico 129 e no Gráfico 130.

As linhas pretas representam as margens superior e inferior do contrato. A linha vermelha representa o montante contratado e a linha azul a energia gerada. Para a carteira otimizada, o saldo de energia gerada entre as margens superior e inferior no primeiro quadriênio é positivo, enquanto que para a carteira atual, o saldo é negativo. Como o CER prevê que o montante contratado para o segundo quadriênio é igual ao valor histórico, mas limitado ao montante contratado no primeiro quadriênio, não há variação do montante contratado para a carteira otimizada no quadriênio seguinte, enquanto que para a carteira atual, há uma redução do montante contratado para o segundo quadriênio.

Ambas as carteiras produzem praticamente a mesma quantidade de energia ${ }^{110}$ e estão dentro do limite inferior e superior. A carteira atual apresenta maior disperção em relação à garantia física (maior desvio padrão na energia gerada). Não obstante, conforme será adiante demonstrado, a receita de ambas as carteiras é praticamente a mesma. Isso porque, quando a energia gerada se encontra dentro dos limites inferior e superior, a receita é igual ao preço do contrato multiplicada pela energia gerada.

A regra do CER prevê que saldos positivos são liquidados em 24 parcelas e saldos negativos em 12 parcelas. Desta forma, considerando tão somente os valores acumulados de receita, sem a aplicação da taxa de desconto, não há diferença entre as carteiras.

No primeiro quadriênio, a carteira atual apurou um desvio negativo (geração abaixo do montante contratado) de $2.880,43 \mathrm{MWh}$, enquanto que a carteira otimizada apurou um desvio positivo (geração acima do montante contratado) de $18.770,60$ MWh. O desvio positivo é compensado (ressarcido ao empreendedor) nos 2 primeiros anos do quadriênio seguinte.

${ }^{110} \mathrm{~A}$ expectativa de geração para a carteira atual para ambos os quadriênios é de 1.159.351,92 MWh, enquanto para a carteira otimizada, a expectativa é de 1.156.101,11 MWh. Essa diferença representa 0,28\% e decorre dos arredondamentos e manipulações dos parâmetros intermediários. 
Gráfico 129 - Energia Gerada Anual e Montante Contratado para a Carteira Atual (MWh).

Energia Gerada e Montante Contratado (MWh.ano)

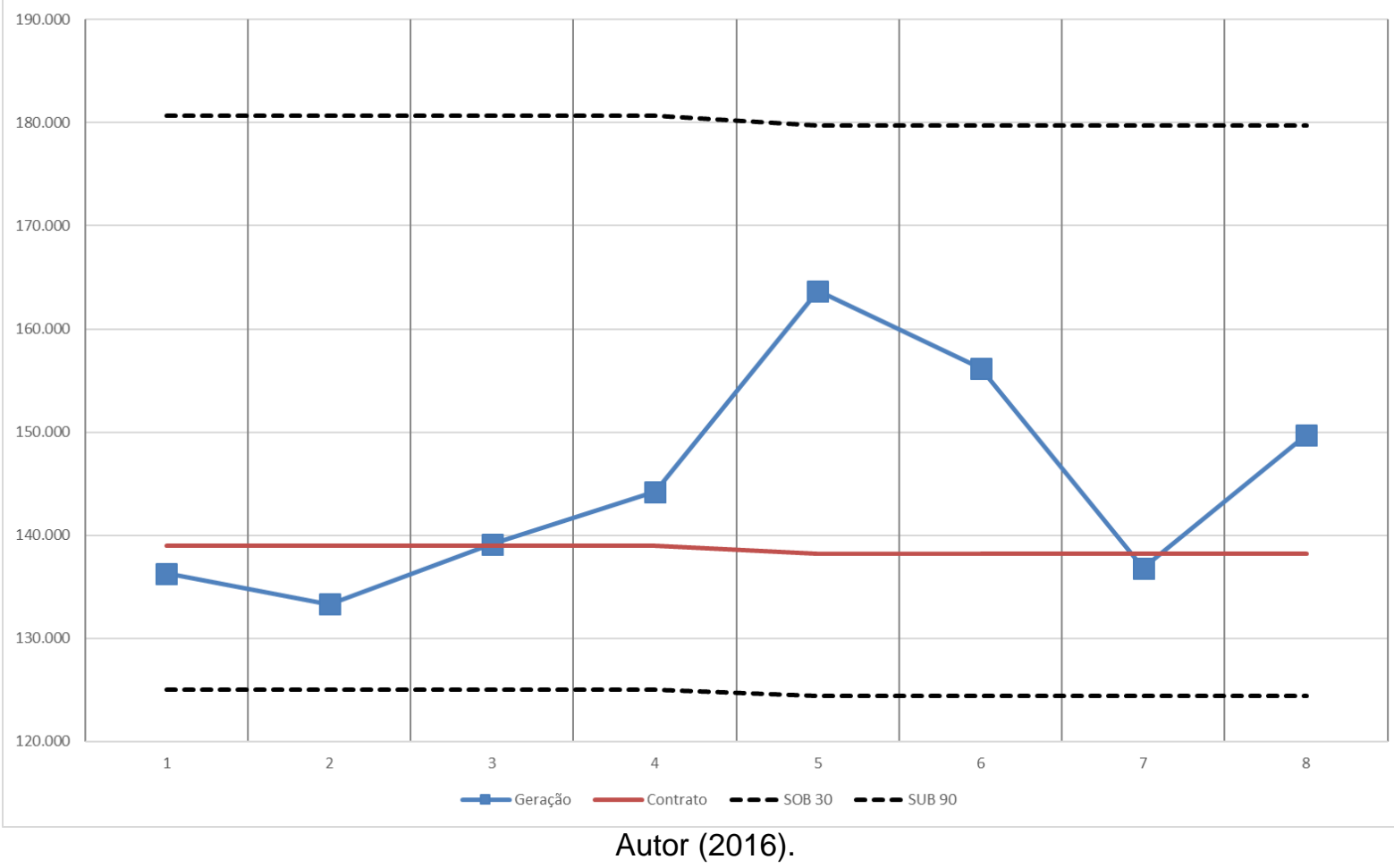

Gráfico 130 - Energia Gerada Anual e Montante Contratado para a Carteira Otimizada (MWh). Energia Gerada e Montante Contratado (MWh.ano)

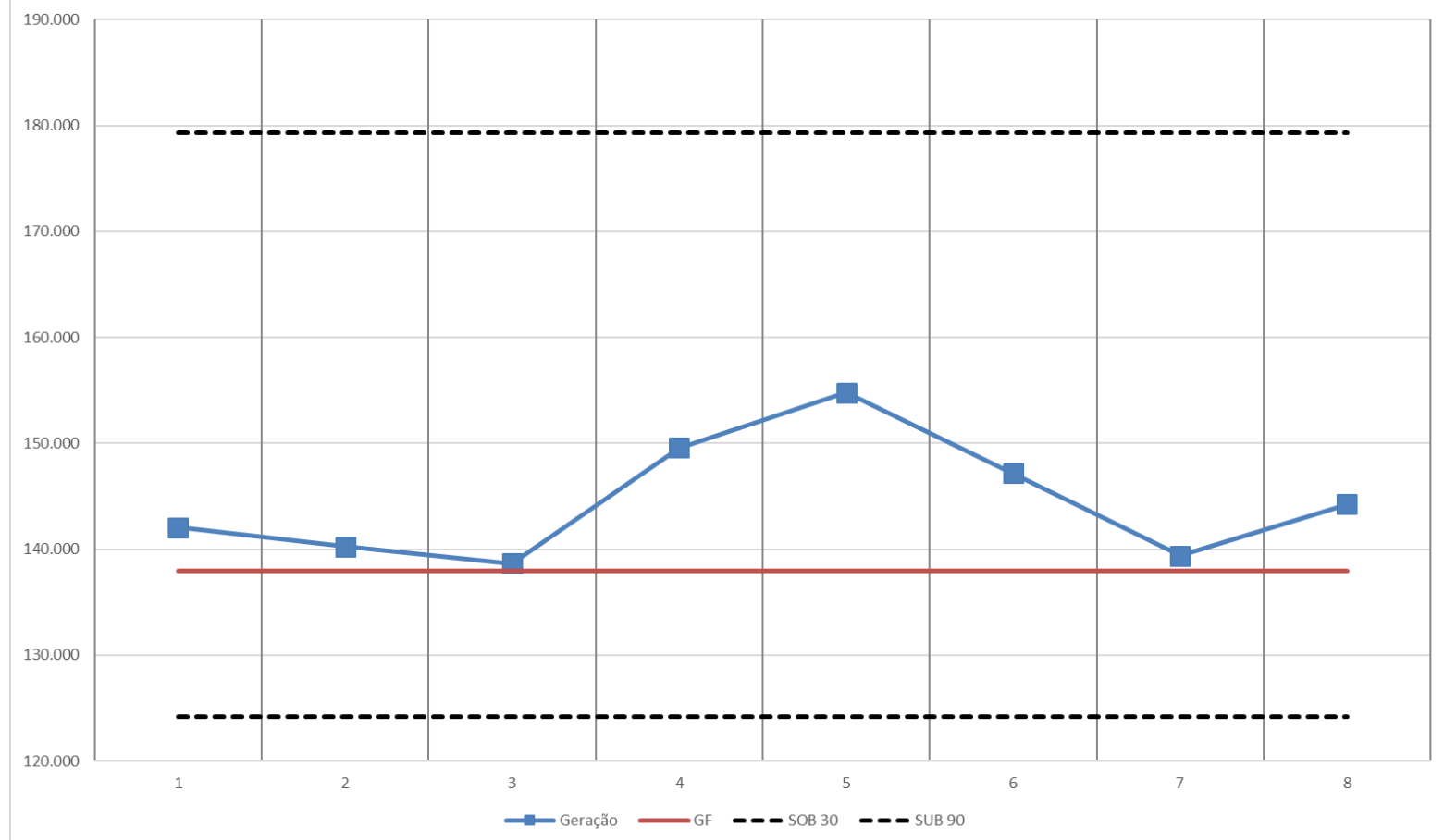

Autor (2016).

O desvio negativo é compensado (indenizado pelo empreendedor) no primeiro ano do quadriênio seguinte. 
No segundo quadriênio, a carteira atual apurou um desvio positivo de 53.492,80 $\mathrm{MWh}$, enquanto que a carteira otimizada apurou um desvio positivo de $33.802,64$ MWh. Os desvios do segundo quadriênio foram liquidados no último ano desse quadriênio. O resultado da liquidação da energia gerada no CER para as duas carteiras está demonstrado no Gráfico 131.

Gráfico 131 - Simulação da Receita do Contrato de Energia de Reserva.

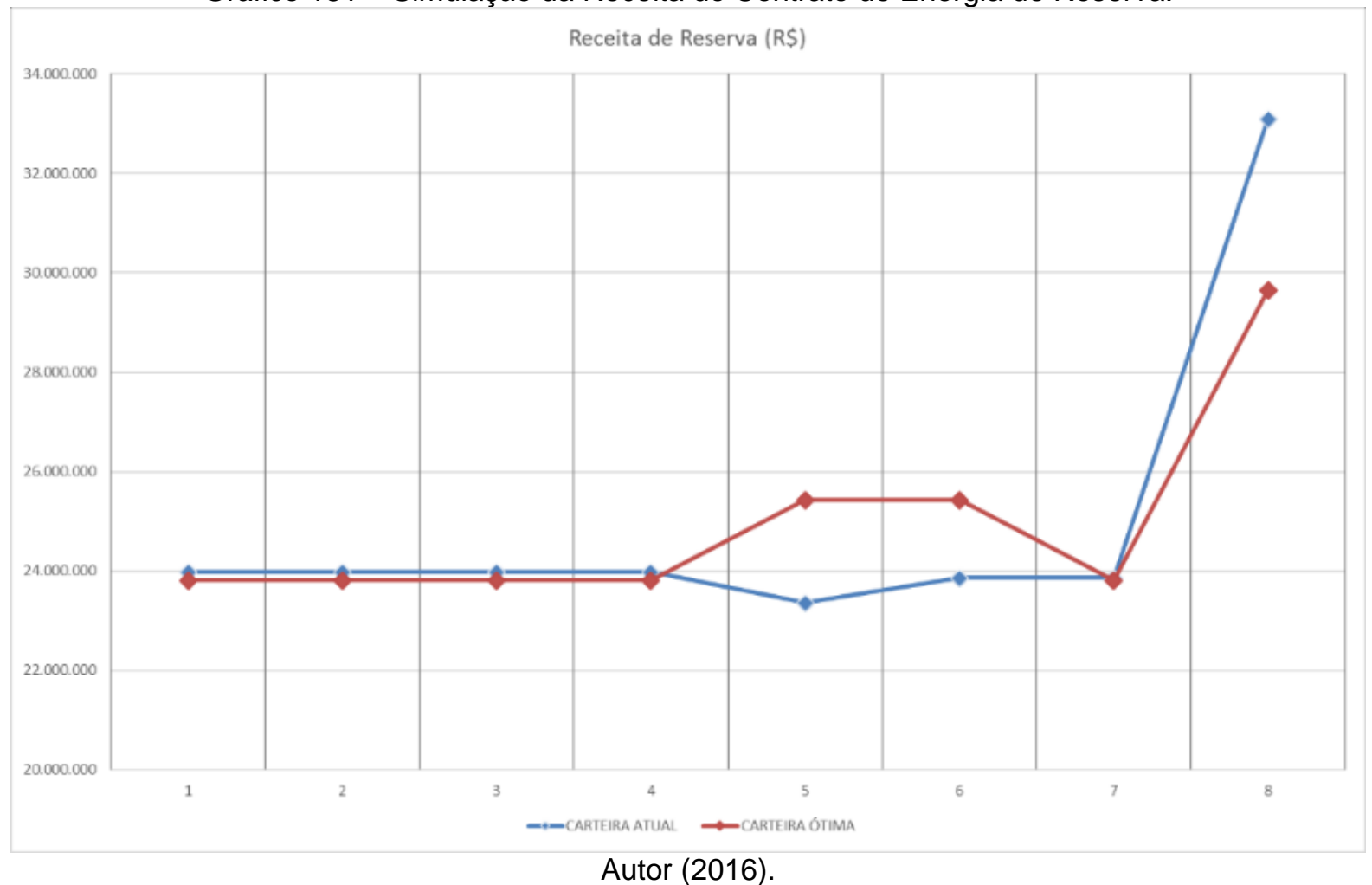

A receita total da carteira ótima é ligeiramente inferior à receita total da carteira atual devido ao processo de cálculo e arredondamento dos percentuais de participação das coordenadas nas carteiras ${ }^{111}$. No último ano da simulação é realizada a compensação do saldo positivo acumulados no $2^{\circ}$ quadriênio. Isso explica a mudança no valor da receita nesse ano, em relação ao anterior.

Para essa simulação, em razão da energia gerada de ambas as carteiras estarem dentro das margens superior e inferior, o processo de otimização da carteira, apesar de ter reduzido a volatilidade de geração, não resultou em aumento de receita.

Na segunda simulação, cada coordenada da carteira foi considerada como uma usina de potência instalada igual a $30 \mathrm{MW}$.

111 Devido aos arredondamentos, a garantia física da carteira atual resultou em 15.785,00 kWmédios, enquanto que para a carteira otimizada, a garantia física resultou em 15.746,51 kWmédios. 
Desta forma, para cada coordenada foi aplicada a regra de liquidação do CER para obter a respectiva receita. A receita de cada carteira foi obtida pelo somatório da receita em cada coordenada ponderada pela participação da coordenada na respectiva carteira.

O comportamento da energia gerada anual e do montante contratado, para cada coordenada (considerada como uma usina de potência instalada igual a $30 \mathrm{MW}$ ) está demonstrado no Gráfico 132.

Gráfico 132 - Energia Gerada e Montante Contratado por Coordenada (MWh)

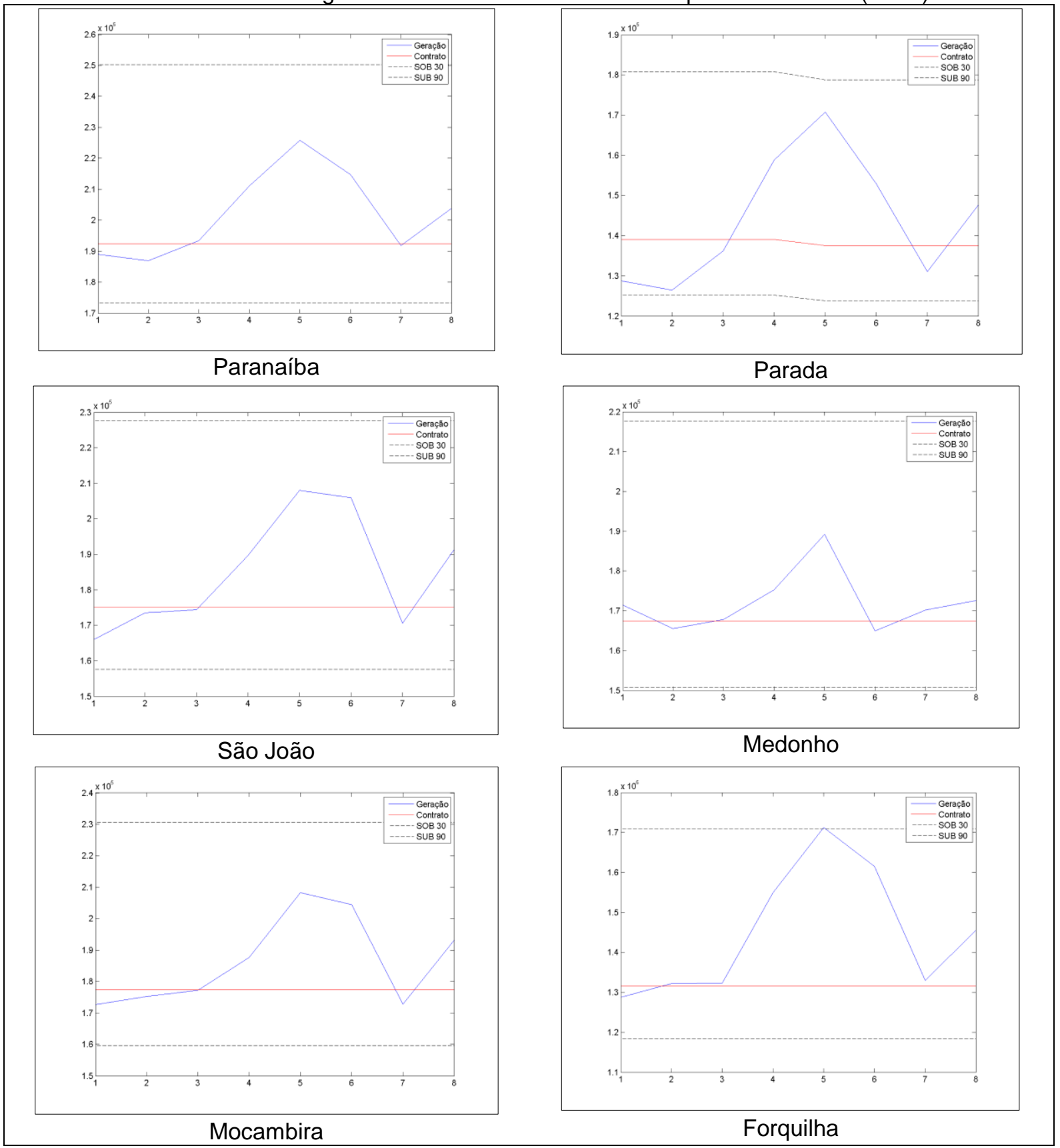



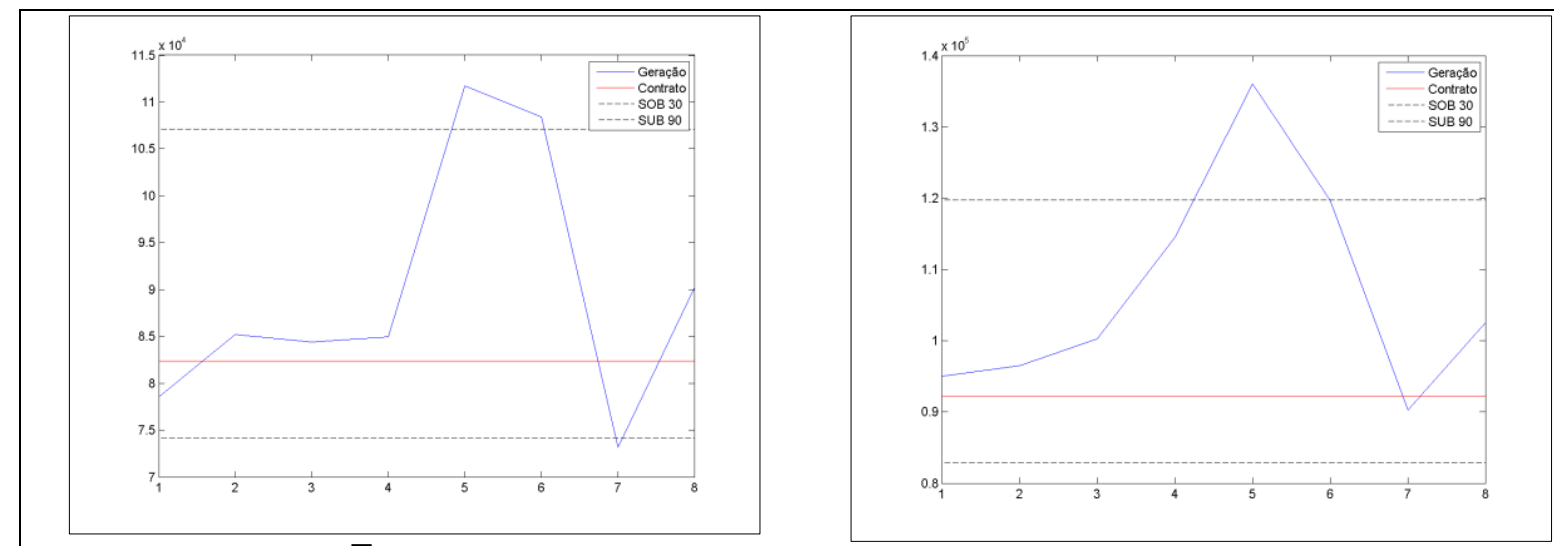

Tavares

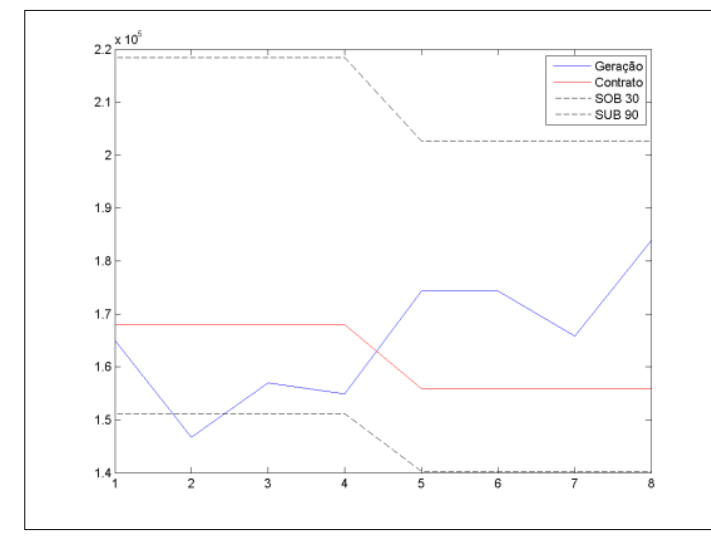

Afrânio

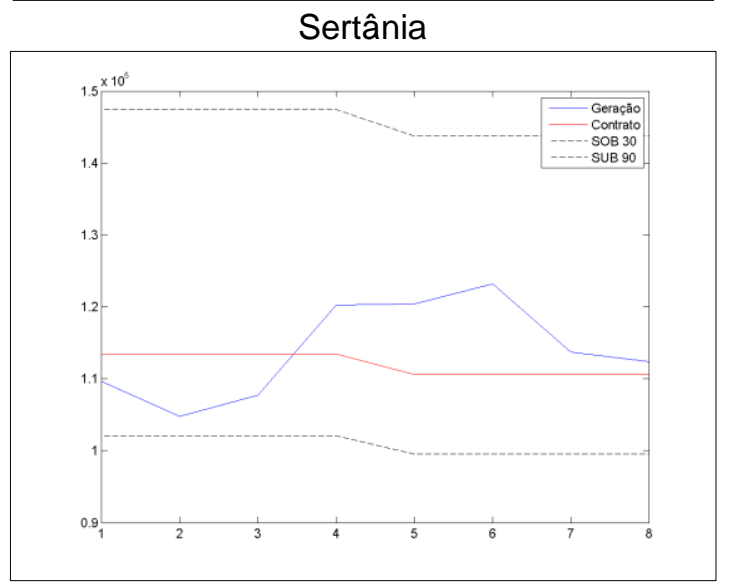

Palmas

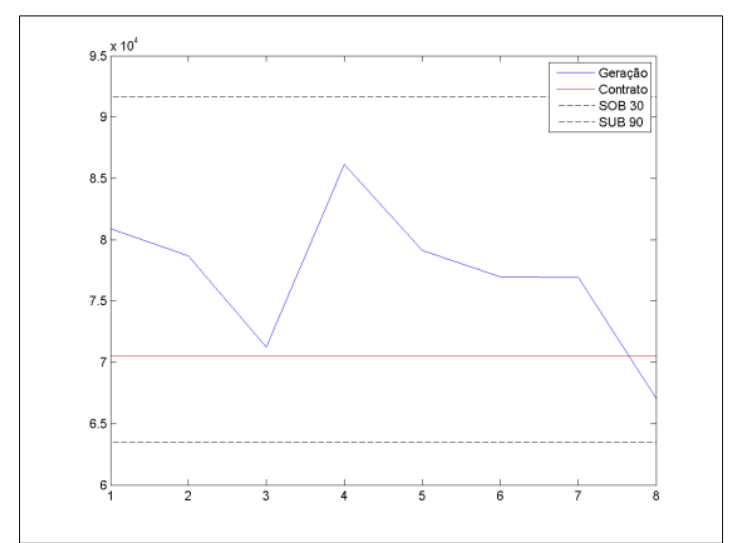

Quilombo

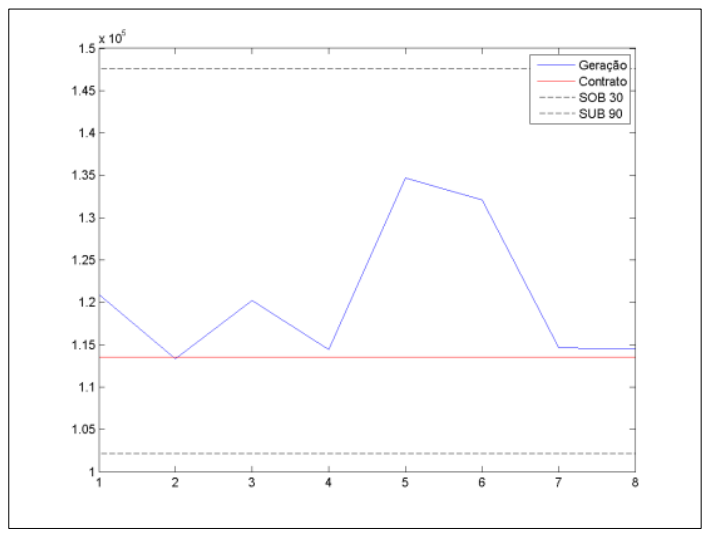

Osório

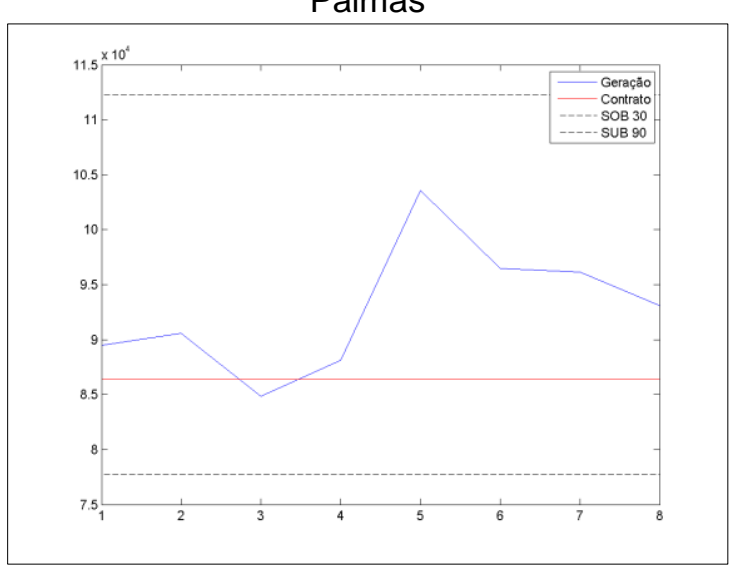

Tubarão

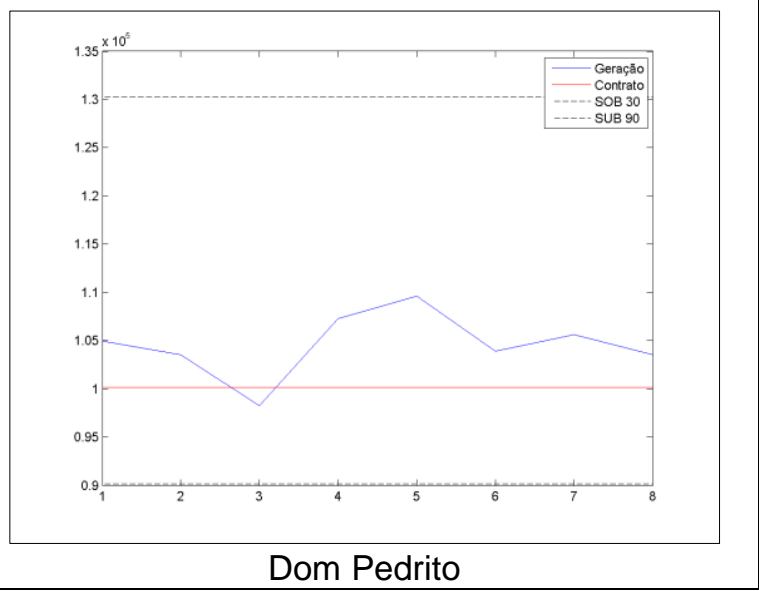



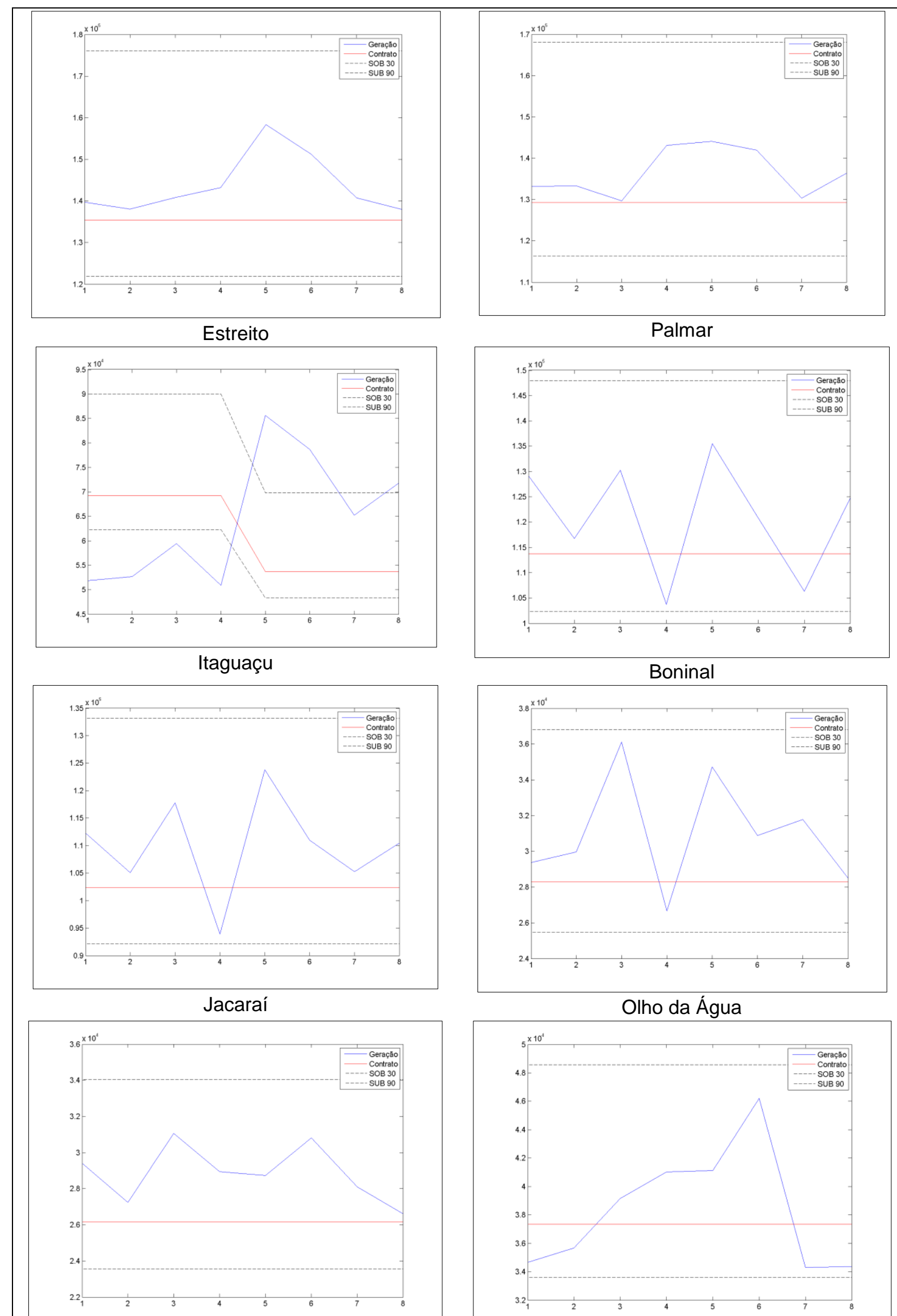

Riachuelo

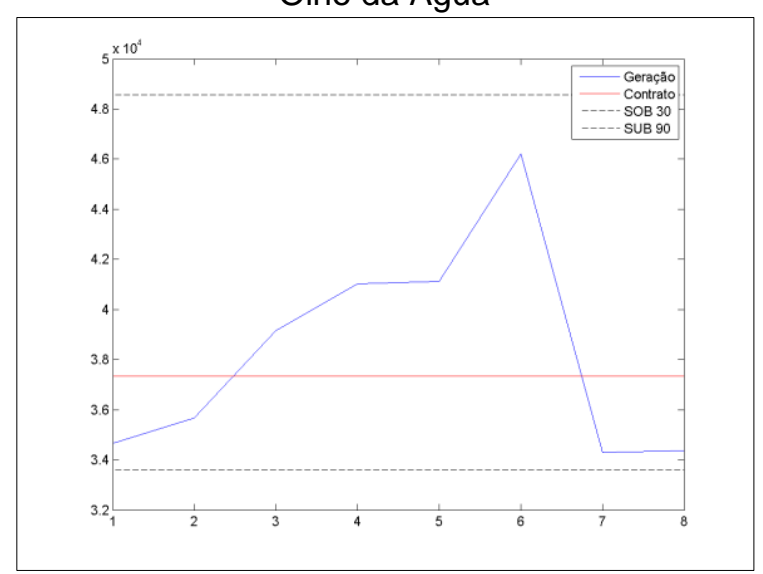

Autor (2016).

Anta 
As linhas pretas representam as margens superior e inferior do contrato. A linha vermelha representa o montante contratado e a linha azul a energia gerada. As coordenadas Tavares, Sertânia, Afrânio e Itaguaçu, que representam $27 \%$ da carteira atual, possuem energia gerada fora da banda (acima do limite superior ou abaixo do limite inferior). Por sua vez, as coordenadas Medonho, Osório e Palmar, que compõem a carteira otimizada, praticamente geram entre o montante contratado e o limite superior. Além disso, as coordenadas Parada, Afrânio, Palmas e Itaguaçu, que representam 34\% da carteira atual, no primeiro quadriênio contabilizaram saldo negativo e, consequentemente, tiveram redução do montante contratado para o segundo quadriênio.

O resultado da liquidação da energia gerada no CER para as duas carteiras está demonstrado no Gráfico 133. Nessa simulação, a receita da carteira atual varia de ano para ano, em razão de algumas coordenadas estarem gerando fora da banda. Isso não acontece para a carteira otimizada, pois as coordenadas geram dentro da banda. A redução da volatilidade na carteira otimizada em relação à carteira atual resulta em um fluxo financeiro mais estável e previsível.

Gráfico 133 - Simulação da Receita do Contrato de Energia de Reserva por Coordenada

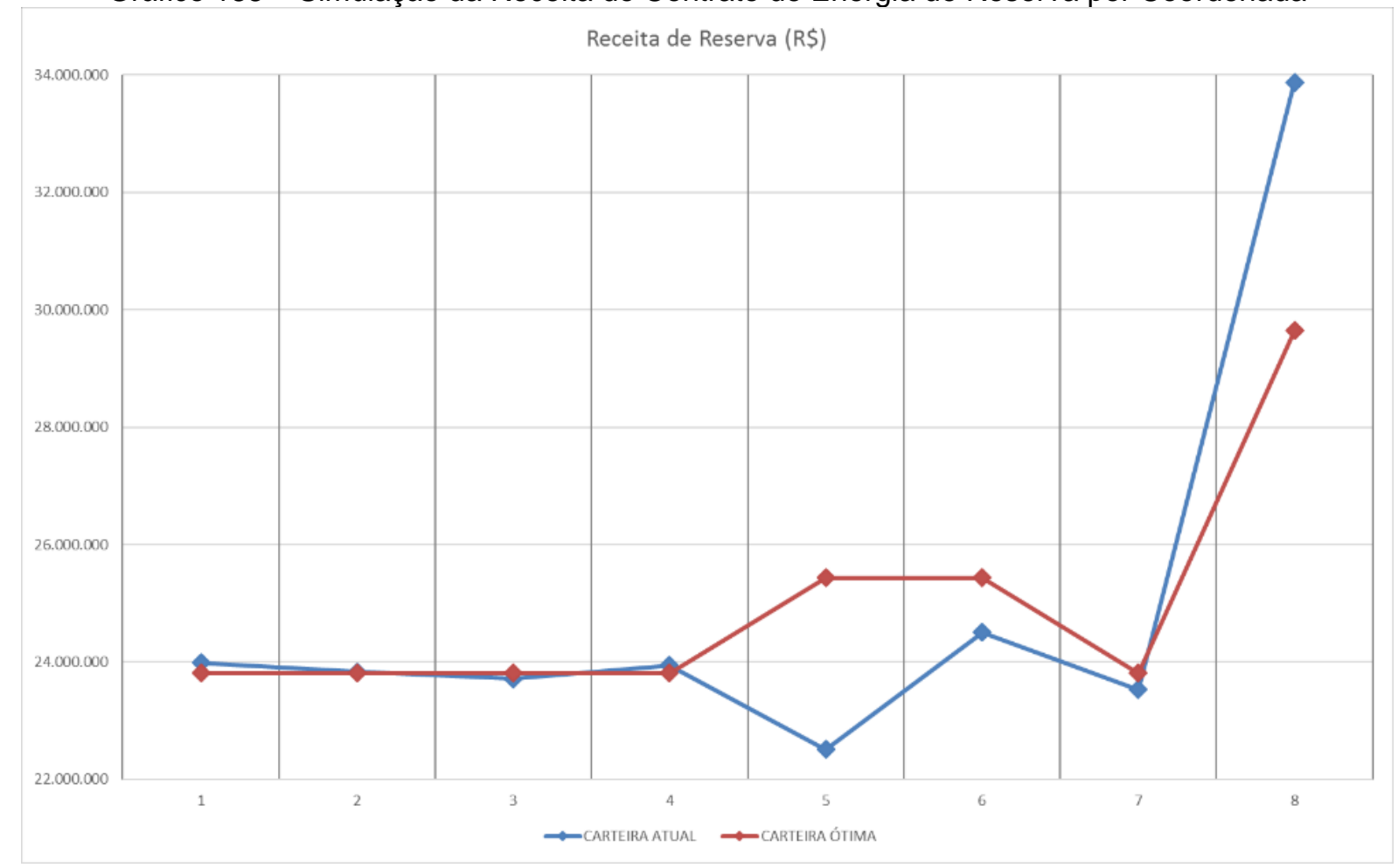

Autor (2016). 
Para essa simulação, o processo de otimização da carteira, apesar de ter reduzido a volatilidade de geração e da receita, não resultou em aumento de receita. Semelhante à simulação anterior, nessa, a receita da carteira ótima é ligeiramente inferior à receita da carteira atual devido ao processo de cálculo e arredondamento dos percentuais de participação das coordenadas nas carteiras ${ }^{112}$. No último ano da simulação é realizada a compensação do saldo positivo acumulado no $2^{\circ}$ quadriênio. Isso explica a mudança no valor da receita nesse ano, em relação ao anterior.

A receita anual da carteira otimizada para as duas simulações foi constante e igual a $R \$ 23,8$ milhões, pois a energia gerada em cada coordenada ficou dentro da margem, onde o faturamento é igual ao montante contratado pelo preço do contrato, sendo os desvios liquidados ao final de cada quadriênio.

Em relação à carteira atual, no período, o total da receita apurada na primeira simulação foi de $R$ \$ 199,9 milhões, enquanto que na segunda foi de $R$ \$ 200,1 milhões. Por sua vez, a receita anual da carteira atual no período para a primeira simulação foi constante e igual a $\mathrm{R} \$ 24$ milhões. No entanto, na segunda simulação, a receita anual da carteira atual variou a cada ano, dentro de uma margem de $\mathrm{R} \$ 1,2$ milhões.

\subsubsection{Simulação da Carteira Considerando a Venda de Energia no Mercado Livre}

Neste ítem, foi analisado o resultado financeito da carteira atual e da carteira otimizada da TABELA 52 no ambiente de contratação livre. A carteira atual tem uma garantia física de 15.785,00 kWmédios e a carteira otimizada de 15.746,51kWmédios. Para a simulação do desempenho das duas carteiras no mercado livre, adotou-se que a garantia física das duas carteiras foi integralmente comercializada em contratos bilaterais. Assim, a diferença entre a energia gerada e a garantia física de cada carteira será liquidada ao PLD, resultando em receita no mercado de curto prazo, quando a energia gerada for maior que a garantia física e, despesa na situação inversa.

\footnotetext{
112 Devido aos arredondamentos, a garantia física da carteira atual resultou em 15.785,00 kWmédios,
} enquanto que para a carteira otimizada, a garantia física resultou em 15.746,51 kWmédios. 
Para tal, adotou-se a premissa de que as variáveis energia eólica gerada e custo marginal de operação são independentes entre si ${ }^{113}$.

Foi utilizada a matriz dos custos marginais de operação do Leilão de Energia A-5/2016, disponibilizada no site da EPE ${ }^{114}$, ajustada para o PLD mínimo e máximo fixado pela ANEEL para o ano $2016^{115}$ (gerando a matriz de PLD). A matriz disponibilizada pela EPE contém 2000 cenários de CMOs para o horizonte de janeiro de 2021 a dezembro de 2025.

Para cada carteira, foi constituída a série histórica de energia gerada mensal, considerando os pesos dos ativos na carteira e as respectivas séries históricas das coordenadas. Por exemplo, a carteira otimizada (TABELA 52) é formada por 5,30\% da coordenada Osório, 24,83\% da coordenada Medonho e 69,87\% da coordenada Palmar. Assim, a série histórica de energia gerada da carteira otimizada é constituída pela média ponderada das coordenadas Osório, Medonho e Palmar. Por sua vez, a série histórica de energia gerada da carteira atual é constituída pela média ponderada das respectivas coordenadas que à compõe.

A série histórica das coordenadas cobre o período de 252 meses (de 01/01/1994 a 31/12/2014). Foi considerado que os anos da série histórica são independentes entre si. Dessa forma, tem-se 21 cenários de energia gerada para cada carteira, todos com a mesma possibilidade de ocorrência em cada ano da matriz do custo marginal de operação.

Desta forma, para cada cenário de energia gerada, foi calculada a exposição na matriz de PLD adotada. Foram realizadas duas simulações. Na primeira simulação, para obter as exposições financeiras, foi considerado o PLD do submercado onde está localizada a coordenada (ativos de cada carteira) ${ }^{116}$.

\footnotetext{
${ }^{113}$ Assim como o custo marginal de operação é influenciado pela energia natural afluente, também sofre a influência da energia produzida pelas usinas eólicas. Não obstante, atualmente a energia gerada eólica é considerada como determinística no modelo de otimização do cálculo do custo marginal de operação.

114 Disponível em http://www.epe.gov.br/leiloes/Paginas/Leil\%C3\%A30\%20de\%20Energia\%20A5\%202016/EPEdivulgaCustosMarginaisdeOpera\%C3\%A7\%C3\%A3odoLeil\%C3\%A3odeEnergiaA52016.aspx. Acessada em 03.04.2016.

115 A Resolução Homologatória ANEEL 2002/2015 fixou em o PLD mínimo em R \$ 30,25/MWh e o PLD máximo em $\mathrm{R} \$ 422,56 / \mathrm{MWh}$.

${ }_{116}$ As coordenadas Parnaíba, Parada, São João, Medonho, Mocambira, Forquilha, Tavares, Sertânia, Afrânio, Itaguaçu, Boninal e Jacaraci estão localizadas no submercado Nordeste, enquanto as coordenadas Palmas, Quilombo, Tubarão, Osório, Dom Pedrito, Estreito e Palmar estão localizadas no submercado Sul.
} 
Na segunda simulação, com o objetivo de excluir o efeito da diferença de preços entre os submercados, e verificar tão somente, o resultado da diversificação, foi considerado que todos os ativos das carteiras estão no submercado Nordeste. Assim para cada célula da matriz foi calculada a exposição financeira no mercado de curto prazo (receita para exposição positiva ou a despesa para a exposição negativa) pela Equação (87).

$$
\text { ExposiçãoMCP } P_{i, j, k, w}=\left(E G_{i, j}-G F\right) x P L D_{k, w}
$$

Onde:

$i$ é o número de cenários da energia gerada, variando de 1 a 21 ;

$j$ é o número de meses de cada cenário de energia gerada, varianao de 1 a 12;

$k$ é o número de meses da matriz do PLD, variando de 1 a 60 ;

$w$ é o número de cenários da matriz do PLD, variando de 1 a 2000.

Para cada carteira (atual e otimizada) e para cada cenário de vento (21 cenários ao total) foi produzida uma matriz de exposição financeira ao mercado de curto prazo de 60 meses por 2.000 cenários. Para obter a matriz de exposição financeira ao mercado de curto prazo para cada carteira e cenários de vento, inicialmente foi calculada a matriz de exposição energética mensal. O Gráfico 134 apresenta a exposição energética mensal para a carteira atual para os 21 cenários de vento e a média da exposição energética.

O Gráfico 135 apresenta a exposição energética mensal para a carteira otimizada para os 21 cenários de vento e a média da exposição energética.

A linha vermelha tracejada representa a média mensal da exposição energética das carteiras. Pelos gráficos, é possível observar que a carteira otimizada possui uma amplitute de exposição energética menor que a carteira atual. As curvas da exposição apresentam uma certa sazonalidade, com exposição negativa no período de dezembro a maio ${ }^{117}$ e exposição positiva no período subsequente.

117 O período seco do submercado sudeste corresponde aos meses maio, junho, julho, agosto, setembro, outubro e novembro. Os meses de dezembro e abril é caracterizado o período úmido. 
Gráfico 134 - Exposição Energética Mensal - Carteira Atual.

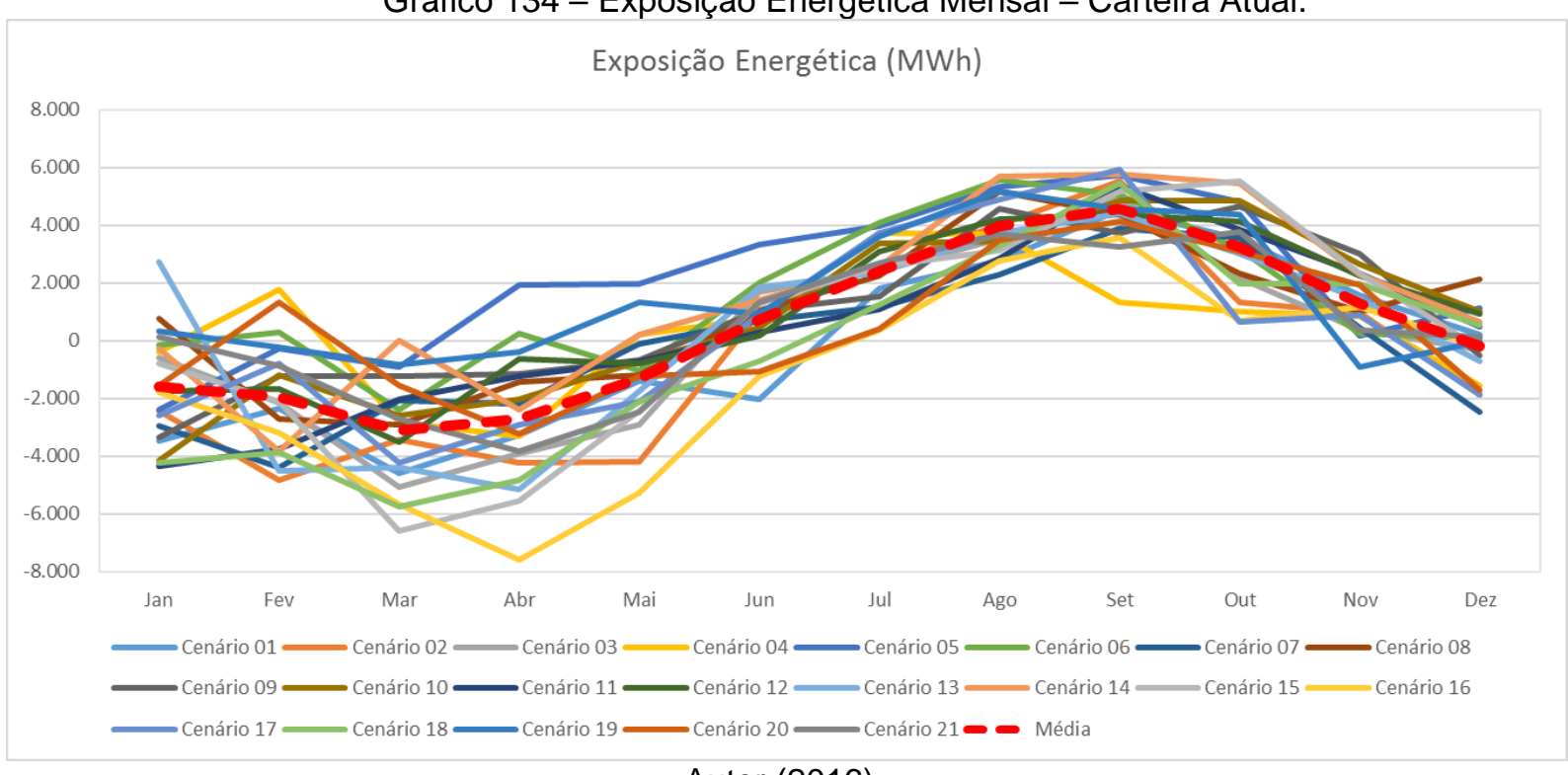

Autor (2016).

Gráfico 135 - Exposição Energética Mensal - Carteira Otimizada.

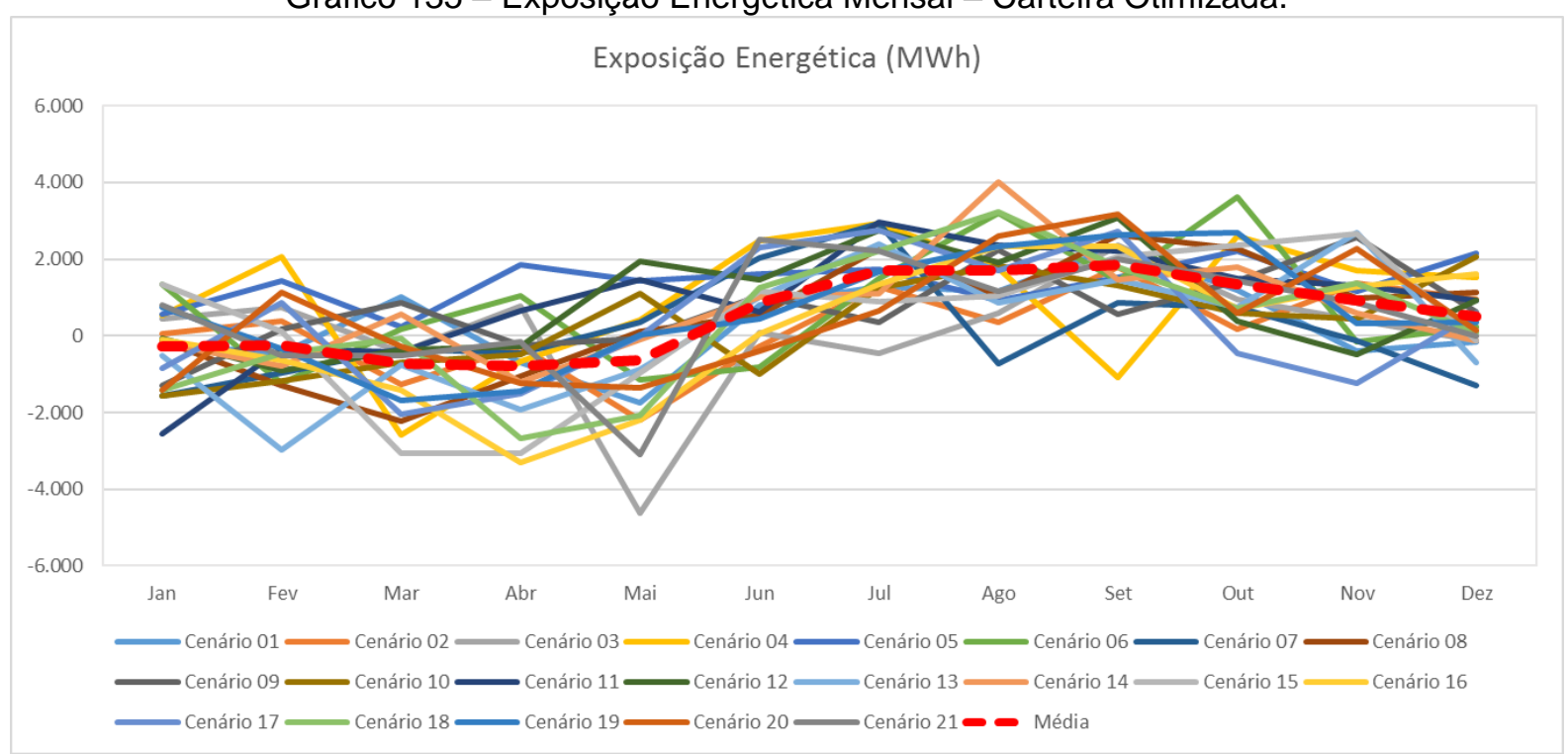

Autor (2016).

A TABELA 54 apresenta um comparativo dos parâmetros estatísticos (média e desvio parão) da exposição energética mensal para as duas carteiras para cada cenário de vento.

A média da exposição para ambas as carteiras é positiva. A carteira otimizada apresenta uma exposição média maior que a carteira atual. Por sua vez, o desvio padrão da carteira otimizada é menor em todos os cenários, evidenciando a redução da volatilidade decorrente do processo de otimização. 
TABELA 54 - Resultado da Exposição Energética Mensal.

\begin{tabular}{rrr|rr}
\hline \multirow{2}{*}{ Cenário } & \multicolumn{2}{c}{ Carteira Atual (MWh) } & \multicolumn{2}{c}{ Carteira Otimizada (MWh) } \\
& \multicolumn{1}{c}{ Média } & Desvio-padrão & Média & Desvio-padrão \\
\hline $\mathbf{1}$ & $-222,82$ & $3.030,20$ & 342,99 & $1.129,64$ \\
$\mathbf{2}$ & $-470,79$ & $3.490,85$ & 191,59 & $1.130,08$ \\
$\mathbf{3}$ & 15,82 & $3.087,09$ & 60,25 & $1.653,38$ \\
$\mathbf{4}$ & 437,77 & $2.215,71$ & 969,97 & $1.690,33$ \\
$\mathbf{5}$ & $2.062,30$ & $2.611,83$ & $1.401,87$ & 602,85 \\
$\mathbf{6}$ & $1.436,00$ & $2.510,71$ & 768,05 & $1.569,75$ \\
$\mathbf{7}$ & $-177,53$ & $2.659,81$ & 120,85 & $1.347,08$ \\
$\mathbf{8}$ & 896,93 & $2.577,98$ & 526,12 & $1.522,78$ \\
$\mathbf{9}$ & 867,89 & $2.634,90$ & 686,11 & $1.060,99$ \\
$\mathbf{1 0}$ & 825,34 & $3.019,37$ & 309,21 & $1.248,06$ \\
$\mathbf{1 1}$ & 351,80 & $2.958,28$ & 895,93 & $1.487,92$ \\
$\mathbf{1 2}$ & 899,12 & $2.673,86$ & 860,61 & $1.344,99$ \\
$\mathbf{1 3}$ & 250,35 & $3.432,25$ & 119,96 & $1.699,06$ \\
$\mathbf{1 4}$ & $1.464,34$ & $3.078,14$ & 679,76 & $1.380,67$ \\
$\mathbf{1 5}$ & 188,89 & $3.876,60$ & 370,25 & $1.910,63$ \\
$\mathbf{1 6}$ & $-1.363,41$ & $3.473,71$ & 172,67 & $1.791,54$ \\
$\mathbf{1 7}$ & 208,17 & $3.247,51$ & 404,00 & $1.682,74$ \\
$\mathbf{1 8}$ & $-581,64$ & $3.567,15$ & 333,18 & $1.779,23$ \\
$\mathbf{1 9}$ & $1.493,36$ & $2.280,97$ & 652,34 & $1.455,31$ \\
$\mathbf{2 0}$ & 340,48 & $2.408,13$ & 492,75 & $1.563,37$ \\
$\mathbf{2 1}$ & 456,51 & $2.590,24$ & 557,71 & $1.552,36$ \\
\hline Média & $\mathbf{4 4 6 , 6 1}$ & $\mathbf{2 . 5 6 5 , 5 4}$ & $\mathbf{5 1 9 , 8 2}$ & $\mathbf{1 . 0 1 8 , 5 1}$ \\
\hline & & Autor $(2016)$ & & \\
& & & &
\end{tabular}

Para os 21 cenários de vento, em 5 cenários, a exposição da carteira atual é negativa. Em todos os cenários a carteira otimizada apresentou exposição positiva. Merece destaque o cenário 5, onde para a carteira otimizada, a média é de 1.401,87 MWh e o desvio padrão de 602,33 MWh. Na ocorrência desse cenário, em nenhuma hipótese haverá exposição financeira negativa no mercado de curto prazo.

As exposições financeiras foram calculadas para cada cenário de vento e para a matriz de PLDs, obtendo-se uma matriz de resultados contendo 60 colunas (60 meses de PLDs) e 42.000 linhas (2000 cenários de PLDs e 21 cenários de vento). Devido ao volume da massa de dados, foram produzidas matrizes da média, desvio padrão e VaR (5\%) dos 2000 cenários de PLD, resultando em matrizes de 21 linhas (cenários de vento) e 60 colunas (meses e PLDs). Na primeira simulação foi considerado o PLD do submercado onde está localizada a coordenada (ativos de cada carteira).

Os resultados da primeira simulação estão dispostos na TABELA 55, que apresenta um comparativo dos parâmetros estatísticos (média, desvio padrão e VaR) 
da exposição ao mercado de curto prazo para as duas carteiras para cada cenário de vento.

TABELA 55 - Resultado da Exposição Financeira ao Mercado de Curto Prazo Considerando a Matriz dos PLDs dos Submercados NE e S.

\begin{tabular}{|c|c|c|c|c|c|c|}
\hline \multirow{2}{*}{$\begin{array}{l}\text { Cenários } \\
\text { de Vento }\end{array}$} & \multicolumn{3}{|c|}{ Carteira Atual (R\$) } & \multicolumn{3}{|c|}{ Carteira Otimizada (R\$) } \\
\hline & Média & Desvio-padrão & VaR 5\% & Média & Desvio-padrão & VaR 5\% \\
\hline 1 & $31.446,53$ & $599.519,27$ & $-987.071,31$ & $82.675,51$ & $243.218,79$ & $-261.930,75$ \\
\hline 2 & $7.090,57$ & $690.858,11$ & $-1.226 .005,27$ & $54.158,67$ & $229.715,70$ & $-365.478,16$ \\
\hline 3 & $84.898,15$ & $616.712,42$ & $-1.019 .195,51$ & $25.305,57$ & $337.679,05$ & $-393.649,43$ \\
\hline 4 & $126.203,83$ & $440.530,52$ & $-601.390,88$ & $200.535,60$ & $349.252,93$ & $-382.646,51$ \\
\hline 5 & $421.702,64$ & $575.785,29$ & $-353.263,99$ & $255.699,74$ & $189.412,58$ & $6.707,24$ \\
\hline 6 & $317.154,24$ & $539.191,05$ & $-290.755,80$ & $159.344,16$ & $345.612,63$ & $-283.577,44$ \\
\hline 7 & $27.413,73$ & $528.515,93$ & $-836.014,49$ & $42.852,56$ & $284.462,01$ & $-373.882,10$ \\
\hline 8 & $224.282,40$ & $521.772,76$ & $-622.532,60$ & $131.988,14$ & $303.036,31$ & $-365.168,65$ \\
\hline 9 & $214.431,88$ & $541.525,28$ & $-511.821,00$ & $138.785,76$ & $223.619,12$ & $-149.719,90$ \\
\hline 10 & $220.199,86$ & $609.012,22$ & $-808.029,74$ & $74.753,33$ & $258.244,73$ & $-355.615,88$ \\
\hline 11 & $126.816,86$ & $588.267,39$ & $-873.031,80$ & $187.814,72$ & $313.822,60$ & $-322.188,69$ \\
\hline 12 & $226.610,64$ & $541.128,47$ & $-504.065,47$ & $179.413,85$ & $295.295,90$ & $-221.677,20$ \\
\hline 13 & $130.079,34$ & $651.834,19$ & $-1.215 .512,95$ & $61.421,74$ & $327.780,27$ & $-492.616,29$ \\
\hline 14 & $335.072,21$ & $633.882,40$ & $-577.857,84$ & $151.524,16$ & $295.897,06$ & $-231.266,57$ \\
\hline 15 & $133.756,35$ & $741.987,19$ & $-1.178 .891,36$ & $108.411,56$ & $352.892,73$ & $-542.969,66$ \\
\hline 16 & $-155.425,56$ & $676.554,79$ & $-1.600 .004,06$ & $74.615,83$ & $333.198,53$ & $-540.377,51$ \\
\hline 17 & $117.476,55$ & $649.283,86$ & $-809.221,26$ & $106.380,72$ & $346.166,63$ & $-409.075,08$ \\
\hline 18 & $-14.556,63$ & $695.196,82$ & $-1.358 .126,95$ & $103.869,25$ & $357.606,47$ & $-498.943,08$ \\
\hline 19 & $315.459,69$ & $503.914,89$ & $-191.610,74$ & $152.356,16$ & $296.878,86$ & $-320.723,84$ \\
\hline 20 & $107.797,38$ & $483.486,59$ & $-497.502,99$ & $116.448,86$ & $318.123,34$ & $-343.203,15$ \\
\hline 21 & $149.899,76$ & $510.980,61$ & $-742.705,42$ & $132.671,24$ & $309.824,02$ & $-323.204,00$ \\
\hline \multirow{2}{*}{$\begin{array}{l}\text { Cenários } \\
\text { de PLD }\end{array}$} & \multicolumn{3}{|c|}{ Carteira Atual $(\mathbf{R} \$)$} & \multicolumn{3}{|c|}{ Carteira Otimizada (R\$) } \\
\hline & Média & Desvio-padrão & VaR 5\% & Média & Desvio-padrão & VaR 5\% \\
\hline Jan/2021 & $-261.564,33$ & $405.044,45$ & $-1.069 .322,72$ & $-47.075,74$ & $213.335,20$ & $-434.407,35$ \\
\hline Jan/2022 & $-259.359,13$ & $395.981,20$ & $-1.037 .397,02$ & $-46.698,91$ & $208.915,06$ & $-426.741,71$ \\
\hline Jan/2023 & $-248.694,24$ & $390.961,24$ & $-1.034 .922,77$ & $-44.761,01$ & $205.440,11$ & $-419.248,00$ \\
\hline Jan/2024 & $-254.888,59$ & $399.678,81$ & $-1.052 .043,81$ & $-45.895,08$ & $210.050,29$ & $-428.631,26$ \\
\hline Jan/2025 & $-252.183,56$ & $393.120,80$ & $-1.033 .370,36$ & $-45.390,62$ & $206.876,59$ & $-421.344,57$ \\
\hline Total & $149.895,73$ & $607.065,55$ & $-825.822,20$ & $121.001,29$ & $309.222,89$ & $-353.881,28$ \\
\hline
\end{tabular}

Os parâmetros foram obtidos a partir da matriz de exposição mensal ao mercado de curto prazo (matriz de exposição ao mercado de curto prazo de 60 meses para 2.000 cenários).

As primeiras 21 linhas contêm o resultado (média, desvio padrão e VaR 5\%) para cada um dos 21 cenários de vento. Por sua vez, as 5 linhas subsequentes, contém o resultado para cada um dos cenários de PLD relativamente ao mês de 
janeiro de cada um dos anos do horizonte ${ }^{118}$. A última linha contém o resultado consolidado de todos os cenários de vento e de PLDs.

Conforme se observa na última linha da tabela, a expectativa de exposição no mercado de curto prazo para a carteira atual é de $R \$ 149.895,73$ enquanto que para a carteira otimizada, a expectativa é de $R \$ 121.001,29$. Embora com receitas semelhantes, o desvio padrão da carteira atual é de $R \$ 607.065,55$ e da carteira otimizada é de $R$ \$309.222,89 (51\% menor). Em consequência, o VaR (5\%) para a carteira atual é de $R \$-825.822,20$, enquanto que para a carteira otimizada o VaR (5\%) é de $R \$$ - 353.881,28 (perda de 43\% inferior). Os resultados demonstram os ganhos da otimização em relação à redução da volatilidade e do risco de perdas.

Em 13 cenários de vento, a carteira atual apresentou uma expectativa de receita no mercado de curto prazo superior à carteira otimizada. No entanto, em todos os cenários de vento o desvio padrão da carteira otimizada é menor. Ressalta-se que para o cenário 19, o VaR da carteira atual é menor que o da carteira otimizada.

Merece atenção o cenário 5 de vento, onde para a carteira otimizada, a expectativa da exposição é de $R \$ 255.699,74$, o desvio padrão de $R \$ 189.412,58$ e o $\operatorname{VaR}(5 \%)$ de $\mathrm{R} \$ 6.707,24$. Na ocorrência desse cenário, para a carteira otimizada em nenhuma hipótese haverá exposição negativa ao mercado de curto prazo. Isto decorre do fato que para essa carteira e cenário, a energia gerada em todos os meses supera a garantia física (montante contratado).

Para os 5 meses de janeiro da matriz de PLDs, a carteira atual apresentou uma expectativa de receita no mercado de curto prazo mais negativa do que carteira otimizada. $O$ valor esperado da exposição financeira no mês de janeiro para a carteira atual é $\mathrm{R} \$ 255.337,97$ (negativo), enquanto que para a carteira otimizada, o valor esperado é $R \$ 45.964,27$ (negativo). Além disso, para todos os meses de janeiro o desvio padrão da carteira otimizada é 50\% menor que a carteira atual. No mesmo sentido, o VaR da carteira otimizada é menos da metade da carteira atual. O Gráfico 136 e o Gráfico 137 apresentam os parâmetros de média, desvio padrão e VaR para a carteira atual e carteira otimizada.

${ }^{118}$ A matriz de resultados contém os resultados para todos os 60 meses. 
Gráfico 136 - Média, Desvio Padrão e VaR da Exposição Financeira da Carteira Atual.

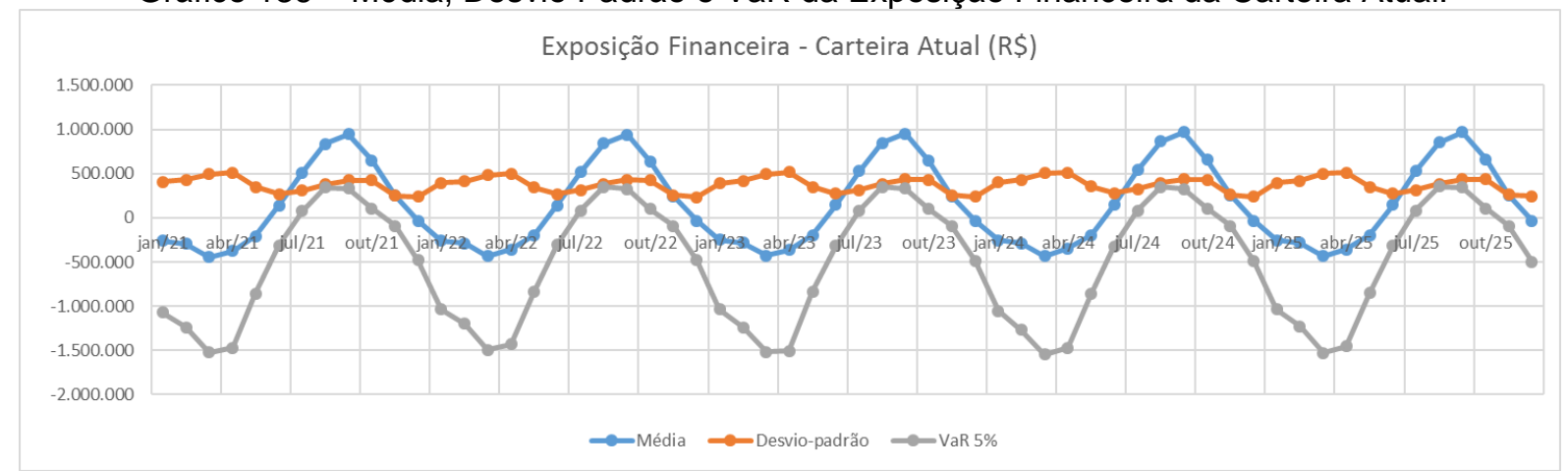

Autor (2016).

Gráfico 137 - Média, Desvio Padrão e VaR da Exposição Financeira da Carteira Otimizada.

Exposição Financeira - Carteira Otimizada (R\$̣)

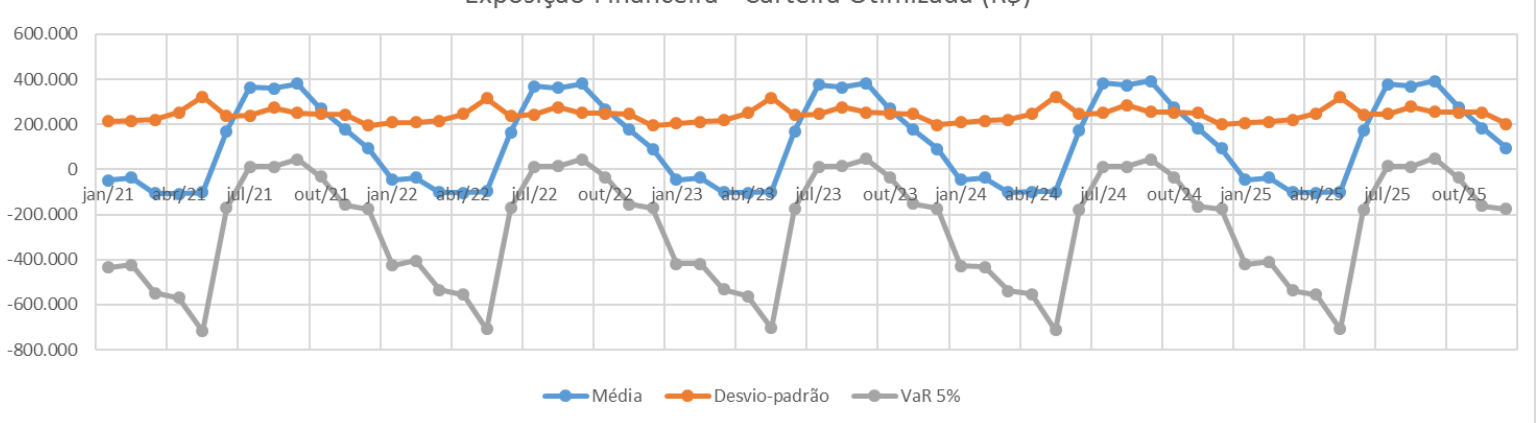

Autor (2016).

A média, desvio padrão e o VaR de cada mês foram calculados considerando os 2000 cenários da matriz de PLD do mês e os 21 cenários de vento do mesmo mês.

O Gráfico 138 contém a distribuição de probabilidade e o histograma da exposição no mercado de curto prazo para a carteira atual e para a carteira otimizada, considerando todas as séries de vento e a matriz de PLDs do submercado onde está localizada cada coordenada da carteira.

Para todos os cenários de vento, o histograma demonstra que a probabilidade de receitas positivas é maior para a carteira otimizada. A carteira atual tem $41 \%$ de chance de incorrer em despesas com a compra de energia no mercado de curto prazo, enquanto que a carteira otimizada tem $35 \%$ de probabilidade dessa ocorrência. 
Gráfico 138 - Distribuição de Probabilidade e Histrograma da Exposição Financeira ao Mercado de Curto Prazo da Carteira Atual e da Carteira Otimizada - Todas Séries de Vento.
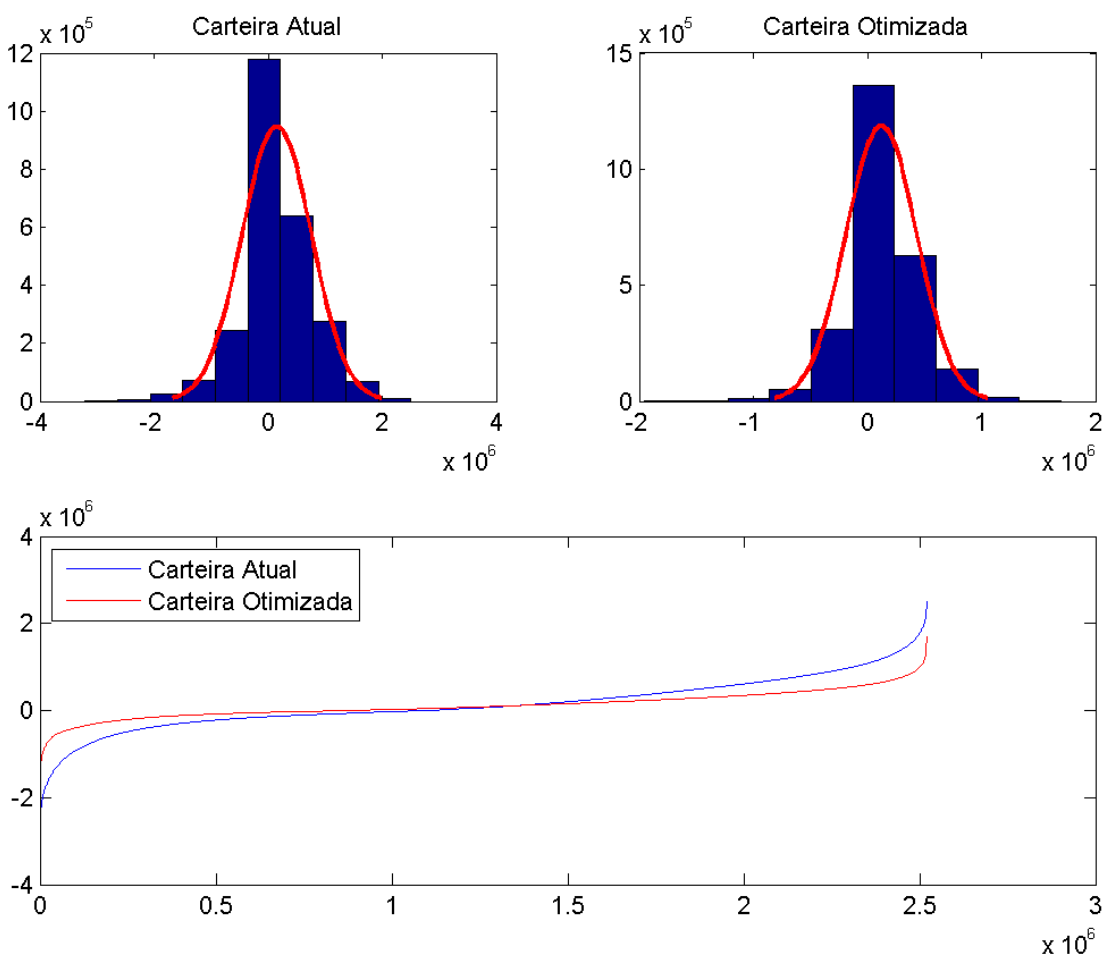

Autor (2016).

Consoante mencionado, ambas as carteiras possuem ativos de geração (coordenadas) em submercados diferentes. Por simplificação, na segunda simulação foi adotado que todos os ativos das carteiras estão no submercado Nordeste. $\mathrm{O}$ objetivo aqui é verificar apenas o efeito da redução da volatilidade da carteira, sem considerar a diferença de preços entre os submercados. Os resultados da segunda simulação estão dispostos na TABELA 56.

A tabela anterior apresenta um comparativo dos parâmetros estatísticos (média, desvio padrão e $\mathrm{VaR}$ ) da exposição ao mercado de curto prazo para as duas carteiras para cada cenário de vento e para a matriz de PLD. Os parâmetros foram obtidos a partir da matriz de exposição mensal ao mercado de curto prazo (matriz de exposição ao mercado de curto prazo de 60 meses para 2.000 cenários). As primeiras 21 linhas contêm o resultado (média, desvio padrão e VaR 5\%) para cada um dos 21 cenários de vento. 
TABELA 56 - Resultado da Exposição Financeira ao Mercado de Curto Prazo considerando a Matriz dos PLDs do Submercado NE.

\begin{tabular}{|c|c|c|c|c|c|c|}
\hline \multirow{2}{*}{$\begin{array}{l}\text { Cenários } \\
\text { de Vento }\end{array}$} & \multicolumn{3}{|c|}{ Carteira Atual (R\$) } & \multicolumn{3}{|c|}{ Carteira Otimizada (R\$) } \\
\hline & Média & Desvio-padrão & VaR 5\% & Média & Desvio-padrão & VaR 5\% \\
\hline 1 & $31.438,51$ & $626.561,26$ & $-1.047 .901,56$ & $82.657,74$ & $239.591,25$ & $-227.631,84$ \\
\hline 2 & $7.088,52$ & $724.632,97$ & $-1.347 .199,91$ & $54.144,49$ & $232.782,92$ & $-381.037,25$ \\
\hline 3 & $84.888,15$ & $630.249,76$ & $-1.093 .673,34$ & $25.305,12$ & $334.150,85$ & $-191.012,30$ \\
\hline 4 & $126.208,86$ & $457.869,33$ & $-648.921,64$ & $200.483,73$ & $368.344,18$ & $-316.284,79$ \\
\hline 5 & $421.675,14$ & $610.580,34$ & $-331.894,88$ & $255.649,18$ & $212.751,60$ & $17.018,94$ \\
\hline 6 & $317.136,25$ & $563.320,68$ & $-294.574,45$ & $159.293,83$ & $347.867,99$ & $-302.171,16$ \\
\hline 7 & $27.411,31$ & $551.041,49$ & $-918.021,95$ & $42.847,14$ & $291.463,23$ & $-368.785,90$ \\
\hline 8 & $224.270,23$ & $544.671,57$ & $-610.899,37$ & $131.957,56$ & $318.556,99$ & $-408.245,17$ \\
\hline 9 & $214.418,31$ & $562.518,94$ & $-519.573,44$ & $138.766,77$ & $238.064,52$ & $-114.001,59$ \\
\hline 10 & $220.182,72$ & $634.075,56$ & $-820.705,94$ & $74.746,10$ & $261.166,71$ & $-354.818,25$ \\
\hline 11 & $126.807,06$ & $614.964,27$ & $-901.247,67$ & $187.780,21$ & $329.664,42$ & $-226.830,92$ \\
\hline 12 & $226.596,86$ & $566.707,74$ & $-601.700,57$ & $179.388,28$ & $305.296,57$ & $-152.678,06$ \\
\hline 13 & $130.069,19$ & $688.436,82$ & $-1.318 .187,60$ & $61.412,31$ & $348.370,71$ & $-505.802,39$ \\
\hline 14 & $335.051,28$ & $666.393,70$ & $-639.598,29$ & $151.511,71$ & $306.357,39$ & $-188.517,70$ \\
\hline 15 & $133.740,84$ & $782.580,98$ & $-1.286 .298,00$ & $108.386,09$ & $380.824,58$ & $-655.505,44$ \\
\hline 16 & $-155.419,33$ & $713.180,84$ & $-1.718 .666,58$ & $74.591,07$ & $360.434,92$ & $-600.292,53$ \\
\hline 17 & $117.470,34$ & $682.438,48$ & $-885.330,21$ & $106.358,24$ & $357.785,89$ & $-442.614,59$ \\
\hline 18 & $-14.559,46$ & $730.567,09$ & $-1.509 .443,63$ & $103.841,97$ & $369.028,90$ & $-569.433,18$ \\
\hline 19 & $315.449,06$ & $525.404,14$ & $-203.473,92$ & $152.331,60$ & $311.386,99$ & $-332.954,45$ \\
\hline 20 & $107.804,44$ & $503.998,67$ & $-617.995,14$ & $116.431,52$ & $334.094,41$ & $-377.160,99$ \\
\hline 21 & $149.900,97$ & $532.563,46$ & $-832.791,02$ & $132.647,26$ & $328.064,77$ & $-217.782,88$ \\
\hline \multirow{2}{*}{$\begin{array}{l}\text { Cenários } \\
\text { de PLD }\end{array}$} & \multicolumn{3}{|c|}{ Carteira Atual (R\$) } & \multicolumn{3}{|c|}{ Carteira Otimizada $(\mathbf{R} \$)$} \\
\hline & Média & Desvio-padrão & VaR 5\% & Média & Desvio-padrão & VaR 5\% \\
\hline Jan/2021 & $-261.515,24$ & $434.313,54$ & $-1.135 .430,79$ & $-47.088,64$ & $218.762,82$ & $-491.071,25$ \\
\hline Jan/2022 & $-259.352,81$ & $423.011,32$ & $-1.092 .853,04$ & $-46.699,27$ & $213.977,64$ & $-475.948,12$ \\
\hline Jan/2023 & $-248.651,17$ & $420.608,48$ & $-1.097 .466,55$ & $-44.772,33$ & $210.970,53$ & $-477.806,02$ \\
\hline Jan/2024 & $-254.887,80$ & $429.758,70$ & $-1.103 .613,99$ & $-45.895,30$ & $215.718,70$ & $-488.589,20$ \\
\hline Jan/2025 & $-252.143,47$ & $422.388,11$ & $-1.094 .635,16$ & $-45.401,15$ & $212.332,03$ & $-477.742,85$ \\
\hline Total & $149.887,11$ & $634.240,91$ & $-889.621,97$ & $120.977,71$ & $321.821,07$ & $-335.623,95$ \\
\hline
\end{tabular}

Por sua vez, as 5 linhas subsequentes, contém o resultado para cada um dos cenários de PLD relativamente ao mês de janeiro de cada um dos anos do horizonte $2021^{119}$. A última linha contém o resultado consolidado de todos os cenários de vento e de PLDs.

A expectativa de exposição no mercado de curto prazo para a carteira atual é de $R \$ 149.887,11$ enquanto que para a carteira otimizada, a expectativa é de $R \$$ 120.977,71. Embora com receitas semelhantes, o desvio padrão da carteira atual é de $R \$ 634.240,91$ e da carteira otimizada é de $R \$ 321.821,07$ (51\% menor).

${ }^{119}$ A matriz de resultados contém os resultados para todos os 60 meses. 
Em consequência, o VaR (5\%) para a carteira atual é de $\mathrm{R} \$-889.621,970$, enquanto que para a carteira otimizada o VaR (5\%) é de $\mathrm{R} \$-335.623,95$ (perda de $38 \%$ inferior). O valor esperado da exposição financeira considerando os 5 meses de janeiro para a carteira atual é $R \$ 255.310,10$ (negativo), enquanto que para a carteira otimizada, o valor esperado é $\mathrm{R} \$ 45.971,34$ (negativo).

Além disso, para todos os meses de janeiro o desvio padrão da carteira otimizada é $50 \%$ menor que a carteira atual. No mesmo sentido, o VaR da carteira otimizada é menos da metadade da carteira atual.

O Gráfico 139 apresenta o comparativo da média da exposição para as duas carteiras. O Gráfico 140 apresenta o comparativo do desvio padrão para as duas carteiras e o Gráfico 141 apresenta o comparativo do VaR para ambas as carteiras.

Entre os meses de julho a outubro, a expectativa de exposição financeira é maior para a carteira atual. Entre os meses de agosto a novembro, o VaR da carteira atual é positivo e ligeiramente superior ao VaR da carteira otimizada. Contudo nos demais meses, o VaR da carteira atual é muito mais negativo que o VaR da carteira otimizada. Por sua vez, o desvio padrão da carteira otimizada é sempre menor que o desvio padrão da carteira atual.

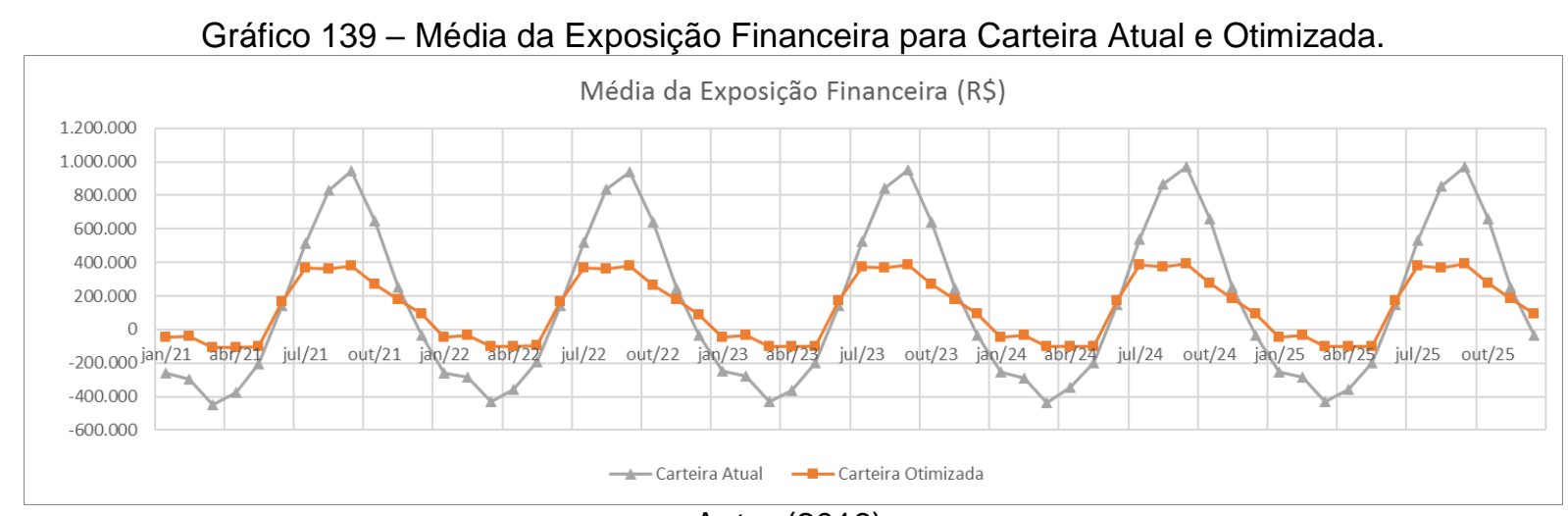

Autor (2016).

Gráfico 140 - Desvio Padrão da Exposição Financeira para Carteira Atual e Otimizada.

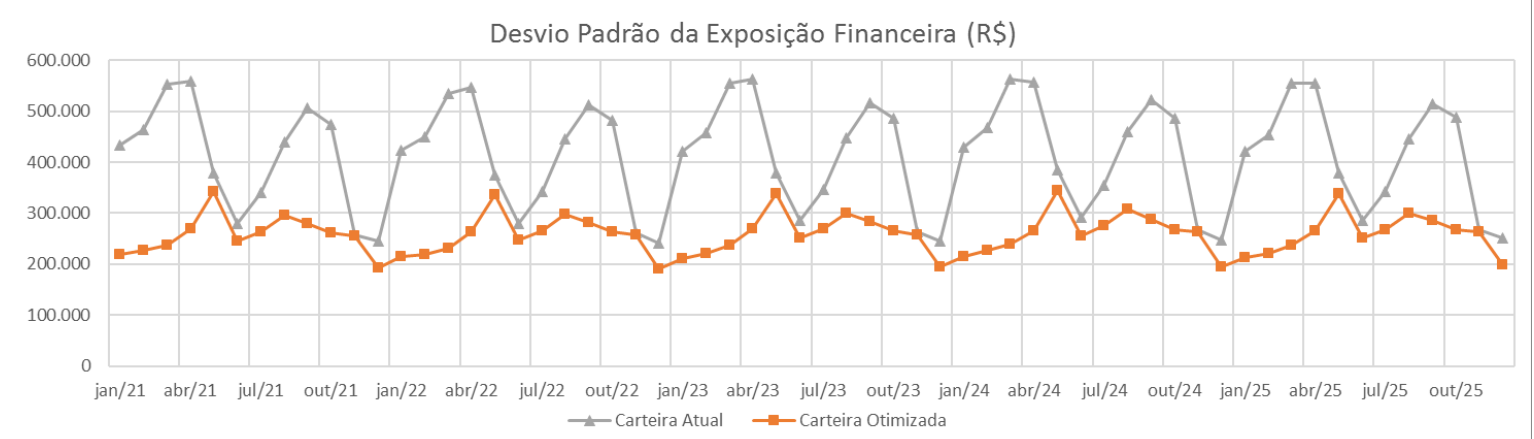

Autor (2016). 
Gráfico 141 - VaR da Exposição Financeira para Carteira Atual e Otimizada.

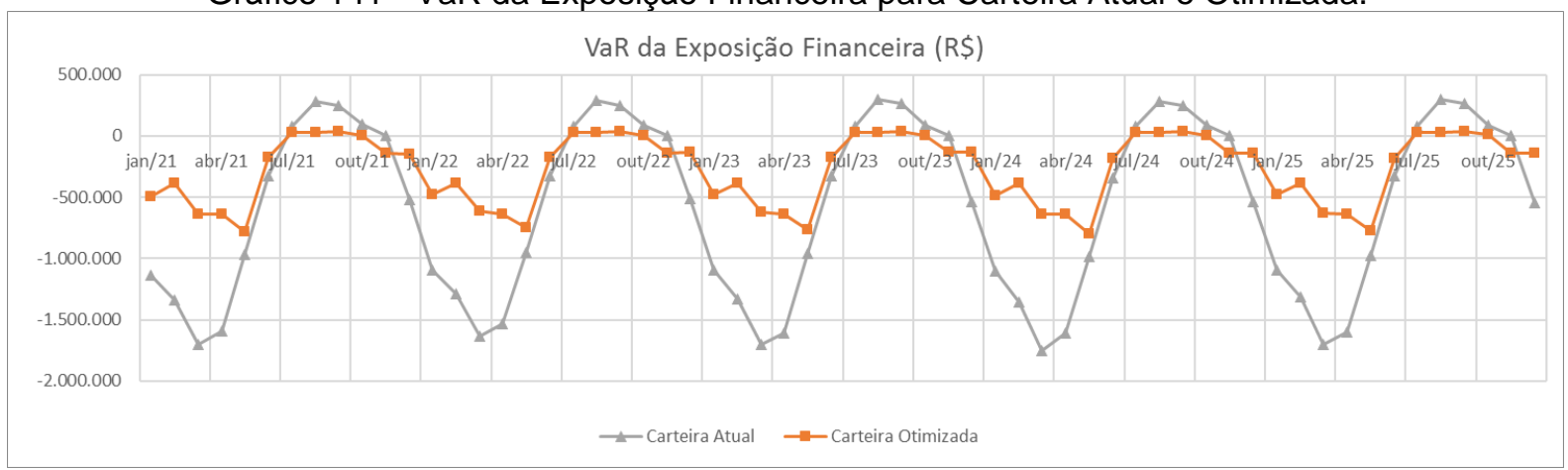

Autor (2016).

O Gráfico 142 contém a distribuição de probalibilidade e o histograma da exposição no mercado de curto prazo para a carteira atual e para a carteira otimizada, considerando todas as séries de vento e os PLDs do submercado NE.

Gráfico 142 - Distribuição de Probabilidade e Histrograma da Exposição Financeira ao Mercado de Curto Prazo da Carteira Atual e da Carteira Otimizada - Todas Séries de Vento.

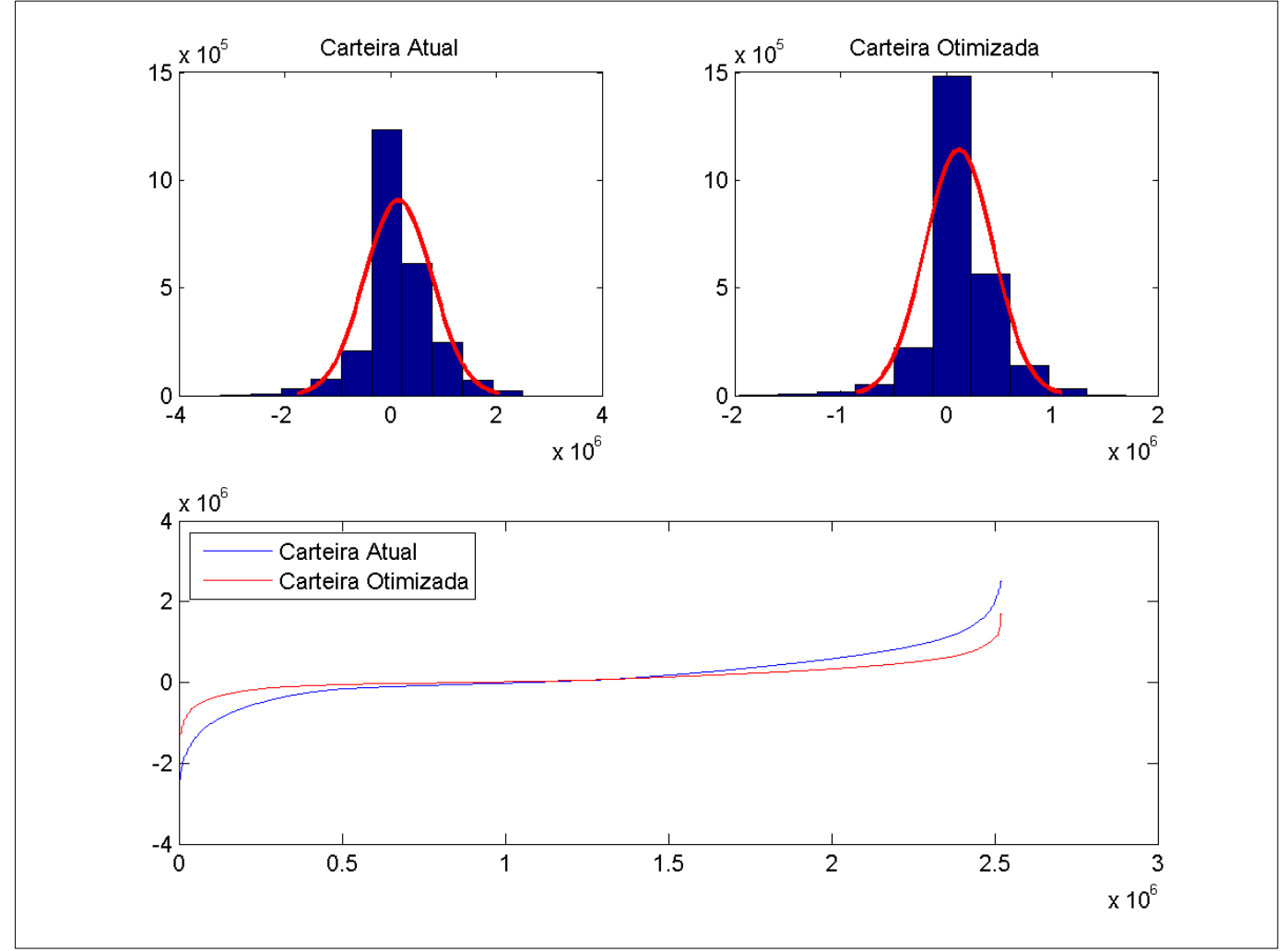

Autor (2016).

Para todos os cenários de vento, o histograma demonstra que a probabilidade de receitas positivas é maior para a carteira otimizada. A carteira atual tem $40 \%$ de chance de incorrer em despesas com a compra de energia no mercado de curto prazo, enquanto que a carteira otimizada tem $35 \%$ de probabilidade dessa ocorrência. 
Os resultados das exposições médias, considerando o PLD dos submercados onde estão localizadas as coordenadas ou considerando o PLD do submercado Nordeste para todas as coordenadas, foram praticamente os mesmos. A exposição média das carteiras para cada cenário teve uma variação inferior a 0,05\%. O desvio padrão considerando o PLD dos submercados onde estão localizadas as coordenadas é menor, embora dentro da margem de 11\%. O VaR apresenta variações maiores, atingindo $100 \%$ de variação entre as duas simulações. Em outras palavras, quando se considera a diferença de preço entre os submercados, a expectativa da receita praticamente não se altera, mas o desvio padrão e o VaR da carteira sofrem mudanças siginificativas, em relação à simulação com o PLD em um único submercado.

A otimização da carteira para a venda da energia eólica no mercado livre se mostrou eficiente, na medida em que para os cenários de vento e matriz de PLD utilizados, conseguiu-se reduzir o risco em relação à carteira atual. 


\section{CONSIDERAÇÕES FINAIS}

A teoria de portfólio de Markowitz já foi utilizada em problemas do setor elétrico em diversos trabalhos, conforme apresentado no item 4.8. No segmento eólico, a técnica foi utilizada para otimização de carteiras no Reino Unido, Europa e EUA, porém até o momento nenhum trabalho havia sido desenvolvido no Brasil sobre o tema.

Nesse trabalho, além da dispersão geográfica das usinas eólicas (22 coordenadas), foram considerados 12 modelos de diferentes fabricantes de aerogeradores para a aplicação da teoria e obtenção da curva da fronteira eficiente. Adotou-se base de dados de energia gerada e fator de capacidade em escala horária e mensal. Foram realizadas otimizações com preços diferenciados para os modelos dos aerogeradores para avaliar o impacto na composição das carteiras. No mesmo sentido, foram introduzidas restrições de transmissão à função objetivo. Por fim, foi realizada a simulação do impacto da otimização na receita com a venda de energia, no ambiente livre e no contrato de energia de reserva.

Em razão do recente surgimento da indústria eólica no Brasil e do seu crescimento na matriz elétrica, a teoria de portfólio de Markowitz passou a ser importante para identificar portfólios otimizados que minimizam o risco de geração, para uma dada meta de energia gerada, ou maximizem a energia gerada para uma dada meta de risco de geração.

O presente trabalho comprovou que a regra de contratação das usinas do PROINFA não levou a um portfólio otimizado, pois a carteira atual PROINFA está distante da curva da fronteira eficiente do plano risco e retorno.

O resultado da otimização utilizando os dados de energia gerada das usinas do PROINFA ficou comprometido, em razão da diversidade da capacidade instalada das usinas. Assim, a aplicação da metodologia em séries de energia gerada deve ficar restrita quando a capacidade instalada das usinas for de porte semelhante. A teoria de MVP é mais indicada para aplicação em índices. Nesse sentido, o resultado da otimização utilizando a série histórica do fator de capacidade das usinas do PROINFA demonstrou que seria possível reduzir a volatilidade da carteira PROINFA em 33\%, com adequação nos pesos dos ativos (potência instalada das usinas). 
Contudo, foi evidenciado a redução do risco da carteira quando há diversidade de fontes, como aconteceu na contratação do PROINFA, ainda que distante da curva da fronteira eficiente.

Por sua vez, a regra de contratação atual, por meio de Leilões Regulados de Energia, também não está resultando em portfólios ótimos. Com ajustes nos pesos dos ativos (potência instalada das usinas) seria possível reduzir a volatidade mensal da carteira atual em 52\%. Da mesma forma, seria possível reduzir a volatilidade horária da carteira atual em 18\%. Destaca-se que a carteira ótima que reduz a volatilidade mensal da carteira atual em $52 \%$ tem uma composição diversa da carteira ótima que reduz a volatilidade horária da carteira atual em 18\%. Foi evidenciado que a otimização em base mensal, visando atender o problema de comercialização de energia, resulta em carteiras diversas das carteiras obtidas na otimização em base horária, visando atender o problema da operação. A otimização do problema de comercialização não resulta em otimização do problema da operação.

Nesse aspecto, a proposta de aplicação da teoria de portfólio de Markowitz pode, por exemplo, ser utilizada pela EPE na alocação da quantidade de energia a ser contratada por fonte e por região, na busca da menor volatilidade horária, visando minimizar os problemas da operação, alternativamente, na busca da menor volatilidade mensal, visando minimizar os problemas da comercialização.

No que se refere à otimização com os 12 modelos de aerogeradores e as 22 coordenadas, verificou-se que determinados modelos de aerogeradores foram selecionados para a fronteira eficiente, enquanto outros modelos, não foram utilizados. Nesse sentido, demonstrou-se que o preço do aerogerador impacta na fronteira eficiente, podendo inclusive compensar eventual vantagem de uma determinada máquina sobre a outra. Porém, mesmo para o cenário estressado de preços, o modelo Wobben/Enercon foi selecionada para a composição das carteiras otimizadas.

Foram obtidas as fronteiras eficientes considerando as restrições de transmissão por barra, subárea e área, onde se verificou que as três curvas são próximas, na medida em que os limites de transmissão por barra, subárea e área são praticamente os mesmos. Os resultados das otimizações sofrem influência do montante contratado (premissa adotada de $10 \mathrm{GW}$ ). Para valores muito menores que os limites de transmissão, as restrições não são acionadas e resultado é equivalente ao problema sem restrições. 
A teoria de portfólio de Markowitz foi aplicada para um conjunto de 15 PCHs reais e 22 usinas eólicas simuladas com os dados do Vortex, obtendo-se resultados semelhantes aos obtidos para as usinas do PROINFA.

Demonstrou-se que, assim como para ativos financeiros, a diversificação não exige um grande número de ativos. Para as usinas do PROINFA, foi evidenciado que o risco mínimo para uma carteira de ativos é obtido com 4 usinas eólicas (do total de 45 usinas). A variação do risco pelo número de ativos, com o emprego dos dados de velocidade de vento do Vortex e o aerogerador Wobben/Enercon, estabilizou em 4 usinas eólicas, para série histórica mensal, e 9 usinas, para a série histórica horária, de um total de 22 usinas possíveis (coordenadas).

Apenas para os dados do Vortex foi obtido o comportamento do fator de correlação da energia gerada entre duas coordenadas com a distância entre as usinas (coordenadas). Para um intervalo de distância entre as usinas de até $500 \mathrm{~km}$, há uma tendência de redução do fator de correlação com o aumento da distância. Com a série histórica em base mensal, o fator de correlação reduz 0,072 para cada $100 \mathrm{~km}$ de distância entre as coordenadas. Com a série histórica em base horária, o fator de correlação reduz 0,11 para cada $100 \mathrm{~km}$ de distância entre as coordenadas. No intervalo de distância entre $500 \mathrm{~km}$ e $3.000 \mathrm{~km}$, o fator de correlação não sofre alteração em função da distância entre as usinas. Para distâncias superiores a 3.000 $\mathrm{km}$, o fator de correlação volta a ter um comportamento de queda com o aumento da distância. Fatores de correlação negativos ou baixos são importantes para a aplicação da teoria de MVP.

Por fim, foram simuladas as receitas do Contrato de Energia de Reserva para a carteira atual e para a carteira otimizada com a mesma expectativa de geração, onde se demonstrou que a carteira otimizada, por possuir menor volatilidade de geração, resultou em uma receita mais estável e previsível ao longo do período do contrato, contudo para ambas as carteiras o resultado financeiro é o mesmo. Isso significa que os mecanimos de mitigação do risco da volatilidade da geração eólica previstos nos Contratos de Energia de Reserva estão bem dimensionados, inclusive para carteiras não otimizadas, na medida em que o resultado financeiro não se alterou de uma carteira para a outra.

No mesmo sentido, simulou-se a receita de um contrato de energia comercializado no mercado livre, para a carteira atual e para a carteira otimizada com a mesma expectativa de geração. O desvio padrão da expectativa de receira da 
carteira otimizada é $51 \%$ inferior ao da carteira atual. No caso, foi demonstrado que a probabilidade de perda (receita negativa) é 43\% menor para a carteira otimizada, demonstrando que a diversificação encontrada por meio da teoria de portfólio de Markowitz trouxe redução do risco financeiro de exposição ao mercado de curto prazo.

As otimizações realizadas com os dados de energia gerada obtidos das usinas do PROINFA têm limitações devido ao tamanho das séries históricas, amostragem apenas em base mensal, dispesão geográfica das usinas, influência do modelo e altura dos aerogeradores. Por sua vez, a utilização da série histórica de velocidade do vento do Vortex possibilitou a geração de longas séries históricas de energia gerada e fator de capacidade para 12 modelos de aerogeradores, em base mensal e horária, sem o efeito das máquinas instaladas e a diversidade das alturas. Não obstante, os dados do Vortex não são provenientes de medições diretas, mas de modelos matemáticos (Modelos de Mesoescala), obtidas do modelo climatológico WRF, o que também implica em limitações dos resultados. Séries longas de velocidades de vento medidas, em base horária, como aquelas disponíveis pelos empreendedores de parques eólicos para a EPE, seriam mais adequadas.

Apesar das limitações decorrentes dos dados utilizados, tendo em vista os resultados obtidos, recomenda-se a aplicação da teoria de portfólio de Markowitz como uma ferramenta de apoio ao planejamento setorial, face à crescente penetração de usinas intermetintes na matriz elétrica, com o objetivo de se perseguir portfólios ótimos de usinas (localização e fonte) que minimizem a volatilidade horária e mensal de geração, com a implementação de leilões regionais e por fonte. No mesmo sentido, a teoria de portfólio de Markowitz pode ser aplicada como uma ferramenta de apoio para a decisão de empreendedores, com o objetivo de buscar carteiras de usinas que maximizem a receita dos contratos, ou reduzam o risco das receitas. 


\subsection{TRABALHOS FUTUROS}

Para trabalhos futuros sugere-se a aplicação dos modelos de Sharpe, Treynor (1962) e Lintner (1965) e comparar os resultados com o modelo de Markowitz.

Como foi evidenciado que a otimização em base horária resulta em carteiras otimizadas diferentes das carteiras otimizadas em base mensal, para trabalhos futuros sugere-se a implementação das duas restrições para se obter uma carteira que minimize o risco em base horária e em base mensal.

A minimização da função objetivo visando reduzir a volatidade implica em uma carteira com menor expectativa de geração. Assim, para atender a mesma demanda, como resultado desse processo, há a necessidade de investimentos adicionais. Desta forma, para futuros trabalhos sugere-se avaliar o custo operativo de uma carteira não otimizada, em razão da necessidade de reserva girante, bem como a probabilidade de risco de déficit de carga, em contrapartida de uma carteira com volatilidade otimizada, porém com maior necessidade de investimentos, para atender a mesma demanda. 


\section{REFERÊNCIAS}

4Coffshore. Disponível em: http://www.4coffshore.com. Acesso em: 10 jun. de 2014.

ACKeRMANN, T. Wind Power in Power Systems. England: John Wiley \& Sons. 2005. ISBN: 0-470-85508-8.

ABEEólica. Boletim Mensal de Dados do Setor Eólico. Novembro de 2015. Disponível em: http://abeeolica.org.br/pdf/Boletim-de-Dados-ABEEolica-Novembro2015-Publico.pdf. Acessado em jan. 2016.

ALÉ, J. A. V.; SIMIONI, G. S.; HACK, P; S. Importância Da Calibração De Anemômetros Nos Empreendimentos Eólicos. Congresso Internacional De Metrologia Mecânica, 1, Rio de Janeiro, 2008.

ARAÚJO, M. R. O. P. Estudo Comparativo de Sistemas Eólicos Utilizando Modelos Probabilísticos de Velocidade de Vento. 103f. 1989. Dissertação (Mestrado em Engenharia Mecânica) - Universidade Federal do Rio de Janeiro (COPPE/UFRJ), Rio de Janeiro. 1989.

ASSAF Neto, A. Mercado Financeiro. São Paulo: Atlas, 2001.

ATLAS do Potencial Eólico Brasileiro. Camargo e Schumert, TrueWind Solutions, Centro de Pesquisas de Energia Elétrica (CEPEL). Brasília, 2001. Disponível em: http://www.cresesb.cepel.br/publicacoes/index.php?task=livro\&cid=1. Acesso em: 10 jun. 2014.

ATLAS do Potencial Eólico de Alagoas. Camargo e Schumert, Instituto de Tecnologia para o Desenvolvimento (LACTEC), Universidade Federal de Alagoas UFAL, Eletrobrás. Maceió, AL, 2008.

ATLAS do Potencial Eólico do Paraná. Camargo e Schumert, Instituto de Tecnologia para o Desenvolvimento (LACTEC). Curitiba, PR, 2007. ISBN 978-85-88519-03-9.

ATLAS do Potencial Eólico: Estado da Bahia - Projeto de Pesquisa e Desenvolvimento ANEEL. Companhia de Eletricidade do Estado da Bahia (COELBA), Camargo e Schumert. Salvador, BA, 2002.

ATLAS do Potencial Eólico: Estado do Ceará. Camargo e Schumert. Fortaleza, CE: Governo do Estado do Ceará, Secretaria de Infraestrutura, 2001.

ATLAS Eólico do Estado de São Paulo. São Paulo: Governo do Estado de São Paulo, Secretaria de Energia, 2012. ISBN 978-85-66444-00-1.

ATLAS Eólico: Espírito Santo. Odilon A. Camargo Amarante, Fabiano de Jesus Lima da Silva, Paulo Emiliano Piá de Andrade. Vitória, ES, 2009. 
ATLAS Eólico: Estado do Rio de Janeiro. Camargo e Schumert. Rio de Janeiro, RJ: Governo do Estado do Rio de Janeiro, Secretaria de Energia, da Indústria Naval e do Petróleo. 2002.

ATLAS Eólico: Minas Gerais. Odilon A. Camargo do Amarante, Fabiano de Jesus Lima da Silva, Paulo Emiliano Piá de Andrade. CEMIG., 2010.

ATLAS Eólico: Rio Grande do Sul. Camargo e Schumert. Porto Alegre, RS: SEMC, 2002.

AWEA. American Wind Energy Association. Wind Industry Annual Market Report (2012). American Wind Energy Association, Washington, DC. Disponível em: http://awea.files.cms-

plus.com/images/AWEA_USWindIndustryAnnualMarketReport2012_ExecutiveSum mary(2).pdf. Acesso em: 10 jun. 2014.

AWEA. American Wind Energy Association. Wind Energy Scenarios for 2020. American Wind Energy Association, Washington, DC. Disponível em: http://www.ewea.org/publications/reports/wind-energy-scenarios-for-2020/. Acesso em: 10 set. 2014.

BAR-LEV, D.; KATZ, S. A Portfolio Approach to Fossil Fuel Procurement in the Electric Utility Industry. Journal of Finance, v.30, n.3, 1976.

BOCCARD, N. Capacity Fator Of Wind Power Realized Values vs. Estimates. v. 37, n.7, apr. 2009, p.2679-2688.

BORO, S. R. Análise da Complementaridade Entre Fontes Renováveis Não Convencionais Como Mecanismo De Proteção Para Mitigação De Riscos De Mercado. Dissertação (mestrado em Sistemas de Potência). 223f. 214. Departamento de Engenharia de Energia e Automação Elétricas da Escola Politécnica da Universidade de São Paulo, São Paulo. 2014.

BORO, S. R.; RAMOS, D. S. Análise da Sensibilidade ao Risco em Um Portfólio Complementar Eólico-Hidráulico Através da Variação do CVAR Limite. Anais... Brasil Windpower, Rio de Janeiro, 2014.

BRASIL. Câmara de Comercialização de Energia Elétrica (CCEE). InfoLeilão. Versão n. $5.2013 . \quad$ São Paulo. Disponível em: http://www.ccee.org.br/portal/faces/pages_menu_header/biblioteca_virtual?tipo=Bo letim\&assunto=Leil\%C3\%A3o\&_afrLoop=159965458474652. Acesso em: 10 jun. 2014.

BRASIL. Casa Civil. Lei 10.438/2002. Brasília. Disponível em: http://www.planalto.gov.br/ccivil_03/leis/2002//10438.htm. Acesso em: 10 jun. 2014. 
BRASIL. Casa Civil. Lei 10.848/2004. Brasília. Disponível em: http://www.planalto.gov.br/ccivil_03/leis/2004//10848.htm. Acesso em: 10 jun. 2014.

BRASIL. Eletrobrás. Programa de Fontes Alternativas - PROINFA. Disponível em: http://www.eletrobras.gov.br/elb/data/Pages/LUMISABB61D26PTBRIE.htm. Acesso em: 10 jan. 2016.

BRASIL. Eletrobrás. Diretrizes para Estudos e Projetos de Pequenas Centrais Hidrelétricas. Janeiro de 2000. Disponível em: <http://www.eletrobras.com/acessoainformacao/data/Pages/LUMISF99678B3PTB RIE.htm>. Acesso em: 15/07/2015.

BRASIL. Ministério de Minas e Energia, Agência Nacional de Energia Elétrica (ANEEL). Resolução Normativa ANEEL 391/2009. Brasília. Disponível em: http://www.aneel.gov.br/cedoc/ren2009391.pdf. Acesso em: 10 jun. 2014.

BRASIL. Ministério de Minas e Energia, Agência Nacional de Energia Elétrica (ANEEL). Acompanhamento das Pequenas Centrais Hidrelétricas: Expansão da Oferta de Geração de Energia Elétrica. Julho de 2015. Disponível em: <http://www.aneel.gov.br/arquivos/ pdf/PCH_Cronograma_Eventos_jul_2015.pdf>. Acesso em: 15 jul. 2015.

BRASIL. Ministério de Minas e Energia, Agência Nacional de Energia Elétrica (ANEEL). Biblioteca virtual. Centro de Documentação da ANEEL - CDOC, 2015. Disponível em: <http://biblioteca.aneel.gov.br/index.html>. Acesso em: $08 \mathrm{dez}$. 2015.

BRASIL. Ministério de Minas e Energia, Agência Nacional de Energia Elétrica (ANEEL). Resolução Normativa ANEEL 165/2005. Brasília. Disponível em: http://www.aneel.gov.br/cedoc/ren2005165.pdf. Acesso em: 10 jun. 2014.

BRASIL. Ministério de Minas e Energia, Agência Nacional de Energia Elétrica (ANEEL). Edital Leilão de Fontes Alternativas 2010. Brasília. Disponível em: http://www.aneel.gov.br. Acesso em: 10 jun. 2014.

BRASIL. Ministério de Minas e Energia, Agência Nacional de Energia Elétrica (ANEEL). Edital Leilão de Energia Nova 2011 (A-5). Brasília. Disponível em: http://www.aneel.gov.br. Acesso em: 10 jun. 2014.

BRASIL. Ministério de Minas e Energia, Agência Nacional de Energia Elétrica (ANEEL). Edital Leilão de Energia de Reserva 2013. Brasília. Disponível em: http://www.aneel.gov.br. Acesso em: 10 jun. 2014.

BRASIL. Ministério de Minas e Energia, Empresa de Pesquisa Energética (EPE). Anuário Estatístico de Energia Elétrica 2013. Brasília, 2013. Disponível em: 
http://www.epe.gov.br/AnuarioEstatisticodeEnergiaEletrica/20130909_1.pdf. Acesso em: 10 jun. 2014.

BRASIL. Ministério de Minas e Energia, Empresa de Pesquisa Energética (EPE). Anuário Estatístico de Energia Elétrica 2012. Brasília, 2012. Disponível em: http://www.epe.gov.br/AnuarioEstatisticodeEnergiaEletrica/20120914_1.pdf. Acesso em: 10 jun. 2014.

BRASIL. Ministério de Minas e Energia, Empresa de Pesquisa Energética (EPE). Anuário Estatístico de Energia Elétrica 2011. Brasília, 2011. Disponível em: http://www.epe.gov.br/AnuarioEstatisticodeEnergiaEletrica/20111213_1.pdf.

Acesso em: 10 jun. 2014.

BRASIL. Ministério de Minas e Energia, Empresa de Pesquisa Energética (EPE). Balanço Energético Nacional 2011: Ano base 2010. Brasília, 2011. Disponível em: https://ben.epe.gov.br/downloads/Relatorio_Final_BEN_2011.pdf. Acesso em: 10 jun. 2014.

BRASIL. Ministério de Minas e Energia, Empresa de Pesquisa Energética (EPE). Nota Técnica 0134/2015-R1 - 2o LER/2015: Margens De Capacidade Para Escoamento De Energia Elétrica Pela Rede Básica, DIT E ICG. Brasília, 2015. Disponível em: http://www.epe.gov.br/leiloes/Documents/Leil\%C3\%A30\%20de\%20Reserva\%20(2 015)/NT0134-ONS-2015_\%202_LER\%202015\%20Margens.pdf. Acesso em: 10 jun. 2015.

BRASIL. Ministério de Minas e Energia, Empresa de Pesquisa Energética (EPE). Plano Decenal de Expansão de Energia 2022. Brasília, 2013. Disponível em: http://www.epe.gov.br/PDEE/20140124_1.pdf. Acesso em: 10 jun. 2014.

BRASIL. Ministério de Minas e Energia, Empresa de Pesquisa Energética (EPE). Plano Decenal de Expansão de Energia 2021. Brasília, 2012. Disponível em: http://www.epe.gov.br/PDEE/20130326_1.pdf. Acesso em: 10 jun. 2014.

BRASIL. Ministério de Minas e Energia, Empresa de Pesquisa Energética (EPE). Plano Decenal de Expansão de Energia 2020. Brasília, 2011. Disponível em: http://www.epe.gov.br/PDEE/20120302_1.pdf. Acesso em: 10 jun. 2014.

BRASIL. Ministério de Minas e Energia, Empresa de Pesquisa Energética (EPE). Plano Decenal de Expansão de Energia 2019. Brasília, 2010. Disponível em: http://www.epe.gov.br/PDEE/20100610_1.pdf. Acesso em: 10 jun. 2014.

BRASIL. Ministério de Minas e Energia, Empresa de Pesquisa Energética (EPE). Expansão da Geração. Empreendimentos Eólicos. Cálculo da Garantia Física de Empreendimentos Eólicos Considerando o P90. (Nota Técnica EPE-DEENT-072/2013-r0). 2013: Brasília. Disponível em: 
http://www.epe.gov.br/leiloes/Documents/Leil\%C3\%B5es\%202013/EPE-DEE-NT072_2013_r0.pdf. Acesso em: 10 jun. 2014.

BRASIL. Ministério de Minas e Energia. Agência Nacional de Energia Elétrica (ANEEL). Atlas de Energia Elétrica do Brasil. 2. ed. Brasília, 2005. Disponível em: http://www.aneel.gov.br/aplicacoes/Atlas/download.htm. Acesso em: 10 jun. 2014.

BRASIL. Ministério de Minas e Energia. Portaria MME 131/2013. Brasília. Disponível em: http://www.aneel.gov.br/cedoc/prt20130131mme.pdf. Acesso em: 10 jun. 2014.

BRASIL. Ministério de Minas e Energia. Portaria MME 21/2008. Brasília. Disponível em: http://www.aneel.gov.br/cedoc/prt2008021 mme.pdf. Acesso em: 10 jun. 2014.

BRASIL. Ministério de Minas e Energia. Portaria MME 258/2008. Brasília. Disponível em: http://www.aneel.gov.br/cedoc/prt20080258mme.pdf. Acesso em: 10 jun. 2014.

BRASIL. Ministério de Minas e Energia. Portaria MME 303/2004. Brasília. Disponível em: http://www.aneel.gov.br/cedoc/prt20040303mme.pdf. Acesso em: 10 jun. 2014.

BRASIL. Ministério de Minas e Energia. Portaria MME 45/2004. Brasília. Disponível em: http://www.aneel.gov.br/cedoc/prt20040045mme.pdf. Acesso em: 10 jun. 2014.

BRASIL. Ministério do Desenvolvimento Indústria e Comércio Exterior. Agência Brasileira de Desenvolvimento Industrial. Mapeamento da Cadeia Produtiva da Indústria Eólica no Brasil. 2014. Disponível em: http://investimentos.mdic.gov.br/public/arquivo/arq1410360044.pdf. Acesso em: 20 dez. 2014.

BRITO, N. R. O. O Efeito de Diversificação de Risco no Mercado Acionário Brasileiro. Revista de Administração da Universidade de São Paulo, v. 16, n. 2, 1981.

BRUNI, A. L.; FUENTES, J.; FAMÁ, R. A Moderna Teoria de Portfólios e a Contribuição dos Mercados Latinos na Otimização da Relação Risco Versus Retorno de Carteiras Internacionais: Evidências Empíricas Recentes (19961997). III Semead. FEA/USP. São Paulo: 1998.

CARVALHO, P. Geração Eólica. Fortaleza, CE, Brasil: Imprensa Universitária, 2003.

CASTRO, C. et al. Global Wind Power Potential: Physical and Technological limits. Energy Policy, v. 39, n. 10, oct. 2011, p. 6677-6682. ISSN 0301-4215. http://dx.doi.org/10.1016/j.enpol.2011.06.027. 
CHUPP, B. A.; HICKEY, E.; LOOMIS, D. G. Optimal Wind Portfolios in Illinois. The Electricity Journal, v. 25, n. 1, ja./feb. 2012, p. 46-56. ISSN 1040-6190. 10.1016/j.tej.2012.01.002.

(http://www.sciencedirect.com/science/article/pii/S1040619012000036).

CUSTÓDIO, R. dos S. Energia Eólica para Produção de Energia Elétrica. Rio de Janeiro: Eletrobrás, 2009. ISBN: 978-85-87083-09-8.

DAVID, S. M. G. R. Geração de Energia Elétrica no Brasil: uma Visão LegalRegulatória Sobre Riscos para o Desenvolvimento da Atividade e Mecanismos de Incentivo Estabelecidos pelo Poder Público. 160f. 2013. Dissertação (Mestrado em Engenharia Elétrica) - Universidade de São Paulo (POLI/USP), São Paulo, 2013.

DRAKE, B.; HUBACEK, K. What to Expect From a Greater Geographic Dispersion of Wind Farms? A Risk Portfolio Approach. Energy Policy, v.35, n. 8, p. 3999-4008. 2007.

ELTON, E. J.; GRUBER, M. J. Risk Reduction and Portfolio Size: An Analytical Solution. The Journal of Business, v. 50, n. 4, p. 415-437, 1977.

ELTON, E. J. et al. Tradução de A. Z. Sanvicente. Moderna Teoria de Carteiras e Análise de Investimentos. São Paulo: Atlas, 2004.

ENERCON. Curva de Potência do Aerogerador E126. Gama de produtos ENERCON. Alemanha: 2012. Disponível em: http://www.enercon.de/p/downloads/EN_PUE_pt_web.pdf. Acesso em: 10 jun. 2014.

EUROPEAN UNION. Offshore Wind Policy And Market Assessment. A Global Outlook. Facilitating Offshore Wind in India. 2014. Disponível em: http://www.gwec.net/wpcontent/uploads/2015/02/FOWIND_offshore_wind_policy_and_market_assessmen t_15-02-02_LowRes.pdf. Acessado em dez. 14.

EVANS, J. L.; ARCHER, S. H. Diversification And The Reduction Of Dispersion: An Empirical Analysis. The Journal of Finance, v. 23, n. 5, p. 761-767, 1968. Disponível em: http://www.jstor.org/stable/2325905.

FADIGAS, E. A. F. A. Energia Eólica. Barueri, SP: Manole, 2011. ISBN: 978-85204-3004-0.

FISHER, L.; LORIE, J. H. Some Studies of Variability of Returns on Investments in Common Stocks. The Journal of Business, v. 43, n. 2, p. 99-134, 1970. Disponível em: http://www.jstor.org/stable/2352105. 
GLOBAL Wind Energy Outlook 2010. Global Wind Energy Council (GWEC), Brussels, Belgium, 2010. Disponível em: http:/www.gwec.net/wpcontent/uploads/2010/11/GWEO_2010_lowRes.pdf. Acesso em: 10 jun. 2014.

GLOBAL Wind Energy Outlook 2011. Global Wind Energy Council (GWEC), Brussels, Belgium, 2011. Disponível em: http://www.gwec.net/wpcontent/uploads/2011/11/GWEO_2010_lowRes.pdf. Acesso em: 10 jun. 2014.

GLOBAL Wind Energy Outlook 2012. Global Wind Energy Council (GWEC), Brussels, Belgium, 2012. Disponível em: http://www.gwec.net/wpcontent/uploads/2012/11/GWEO_2012_lowRes.pdf. Acesso em: 10 jun. 2014.

GLOBAL Wind Energy Outlook 2013. Global Wind Energy Council (GWEC), Brussels, Belgium, 2013. Disponível em: http://www.gwec.net/wpcontent/uploads/2013/11/GWEO_2013_lowRes.pdf. Acesso em: 10 jun. 2014.

GLOBAL Wind Energy Outlook 2014. Global Wind Energy Council (GWEC), Brussels, Belgium, 2014. Disponível em: http://www.gwec.net/wpcontent/uploads/2014/11/GWEO_2014_lowRes.pdf. Acesso em: 10 jun. 2014.

GLOBAL Wind Report - Annual market update 2010. Global Wind Energy Council (GWEC), Brussels, Belgium, 2011. Disponível em: http://gwec.net/wpcontent/uploads/2012/06/GWEC_annual_market_update_2010_-

2nd_edition_April_2011.pdf. Acesso em: 10 jun. 2014.

GLOBAL Wind Report - Annual market update 2011. Global Wind Energy Council (GWEC), Brussels, Belgium, 2012. Disponível em: http://gwec.net/wpcontent/uploads/2012/06/Annual_report_2011_lowres.pdf. Acesso em: 10 jun. 2014.

GLOBAL Wind Report - Annual market update 2012. Global Wind Energy Council (GWEC), Brussels, Belgium, 2013. Disponível em: http://www.gwec.net/wpcontent/uploads/2012/06/Annual_report_2012_LowRes.pdf. Acesso em: 10 jun. 2014.

GLOBAL Wind Report - Annual market update 2013. Global Wind Energy Council (GWEC), Brussels, Belgium, 2014. Disponível em: http://www.gwec.net/wpcontent/uploads/2014/04/GWEC-Global-Wind-Report_9-April-2014.pdf. Acesso em: 10 jun. 2014.

GOOGLE MAPS. Distribuição Espacial das Coordenadas Selecionadas. 2015. Disponível em:<https://maps.google.com.br. Acesso em: 20 jul. 2015.

GUNN, L. K. Modelo de Portfólio para Comercialização de Energia Elétrica Proveniente de Novos Empreendimentos: Otimização Simultânea de Benefício e Risco. 112f. 2012. Tese (doutorado em Engenharia Mecânica) - Faculdade de Engenharia Mecânica, Universidade de Campinas, Campinas, SP. 2012. 
HENNESSEY, J. P. H. Jr. Some Aspects of Wind Power Statistics. Journal of Applied Meteorology, v. 16, n.2, p. 119-128, 1977.

HETZER, J.; YU, D. C.; BHATTARAI, K. An Economic Dispatch Model Incorporating Wind Power. IEEE Transactions on Energy Conversion, v. 23, n. 2, 2008.

IGLEZWICZ, B.; HOAGLIN, D.C. How to Derect and Handle Outliers. ASQC Basic References in Quality Control, v. 16, Wisconsin, 1994.

INSTITUTO DE CONTROLE DO ESPAÇO AÉREO (ICEA). Sistema de Geração e Disponibilização de Informações Climatológicas - Site Clima, 2015. Disponível em: <http://clima.icea.gov.br/clima/>. Acesso em: 01 jul. 2015.

INSTITUTO DE TECNOLOGIA PARA O DESENVOLVIMENTO (LACTEC). Manual de Avaliação Técnico-econômica de Empreendimentos Eólio-elétricos. Curitiba: Instituto de Tecnologia para o Desenvolvimento - LACTEC, Engenharia Eólica - Camargo Schubert., 2007.

INSTITUTO NACIONAL DE METEOROLOGIA (INMET). Banco de Dados Meteorológicos para Ensino e Pesquisa - BDMET. 2015. Disponível em: <http://www.inmet.gov.br/ portal/index.php?r=bdmep/bdmep>. Acesso em: 01 jul. 2015.

INSTITUTO NACIONAL DE PESQUISAS ESPACIAIS (INPE). Sistema de Organização Nacional de Dados Ambientais - SONDA. 2015. Disponível em: <http://sonda.ccst.inpe.br/ index.html>. Acesso em: 01 jul. 2015

JORNADA, D. H.; Incerteza de Medição: Guia Prático do Avaliador de Laboratórios - RM08. Rio Grande do Sul: Rede Metrológica, 2013.

LINTNER, John. Security prices, risk and maximal gains from diversification. Journal of Finance, 20(4): 587-615, Dec. 1965.

LU, X.; MCELROY, M. B.; KIVILUOMA, J. Global potential for wind-generated electricity. Proceedings of the National Academy of Sciences - PNAS 2, v. 27, n. 106 jun. 2009. p.10933-10938. doi:10.1073/pnas.0904101106.

MACEDO JR, J. S. Teoria do Prospecto: Uma Investigação Utilizando Simulação de Investimentos. 218f. 2003. Tese (Doutorado em Engenharia de Produção) - Universidade Federal de Santa Catarina, Florianópolis. 2003.

MARKOWITZ, H. Portfolio Selection. The Journal of Finance, Chicago Blackwell Publishing for the American Finance Association, v. 7, n. 1. p. 77-91, mar. 1952. http://www.jstor.org/stable/2975974. 
MARKOWITZ, H. Portfolio Selection: Efficient Diversification of Investment. New York: John Wiley \& Sons, 1959.

MARTINS, F. R.; GUARNIERI, R. A. e PEREIRA, E. B. O Aproveitamento da Energia Eólica. Revista Brasileira de Ensino de Física, São Paulo, v.30, n.1, 2008, p. 1-13. ISSN 1806-1117. Disponível em: http://dx.doi.org/10.1590/S180611172008000100005 . Acesso em: 13 jun. 2014.

MAUÉS, J. A. Comparação de Fontes Primarias para Geração de Energia Elétrica no Brasil Baseada em Conceito de Risco. 250 f. 2008. Tese (doutorado em Engenharia Mecânica) - Pontifícia Universidade Católica do Rio de Janeiro, Rio de Janeiro. 2008.

MICHAELIS Moderno Dicionário da Língua Portuguesa. Disponível em: http://michaelis.uol.com.br/moderno/portugues/. Acesso em: 14 jun. 2014.

MIGUEL, F. K.; RAMOS, D. S.; SECURATO, J. R. Aplicação da Teoria de Portfólio de Markowitz para a Carteira de Investimentos Eólicos no Brasil. Montevideo, Uruguay: Sixth IEEE/PES Transmission and Distribution: Latin America Conference and Exposition (T\&D-LA). 2012.

MIGUEL, F. K.; RAMOS, D. S.; SECURATO, J. R. Aplicação da Teoria de Carteiras de Markowitz em Portfólio de Usinas Eólicas. Anais... Encontro lbero Americano do CIGRÉ - ERIAC, 15, Foz do Iguaçu, 2013.

MIGUEL, F. K.; RAMOS, D. S.; SANTOS, R. N. Energia Eólica Offshore. Anais... Congresso Internacional de Bioenergia, 7, São Paulo, 2012.

MONTEZANO, B. E. M. Estratégias para Identificação de Sítios Eólicos Promissores Usando Sistema de Informação Geográfica e Algoritmos Evolutivos. 196f. 2012. Dissertação (Mestrado em Engenharia Civil) - Universidade Federal do Rio de Janeiro (COPPE/UFRJ), Rio de Janeiro. 2012.

NAGHETTINI, M.; PINTO, E. J. de A. Hidrologia Estatística. Belo Horizonte: CPRM, 2007, 552 p.

NATIONAL OCEANIC AND ATMOSPHERIC ADMINISTRATION (NOAA). NNDC Climate Data Online, 2015. Disponível em: <http://www7.ncdc.noaa.gov/CDO/ cdoselect.cmd>. Acesso em: 15 jul. 2015.

NEIJ L, D. A. P. et al. Experience Curves: a Tool for Energy Policy Assessment. Lund, Sweden: Environmental and Energy Systems Studies. Extool Project final report, 2003.

ORTIZ, G. P.; KAMPEL, M. Potencial de Energia Eólica Offshore na Margem do Brasil. In: Anais... Simpósio Brasileiro de Oceanografia, 5, Santos, SP, 2011. 
ORTIZ, E. R. T. Sistemas Fotovoltaicos e Eólicos: Metodologia para Análise da Complementaridade Espacial-Temporal com Aplicação no Dimensionamento e Analise do Risco Financeiro. 178f. 2014. Tese (doutorado em Sistemas de Potência) - Universidade de São Paulo, São Paulo. 2014.

OFFSHORE Wind Cost Reduction Task Force Report. jun. 2012. Disponível em: https://www.gov.uk/government/uploads/system/uploads/attachment_data/file/6677 6/5584-offshore-wind-cost-reduction-task-force-report.pdf. Acesso em: 10 jun. 2014.

PANTOJA, C. S. Teoria das Opções Reais: uma Abordagem em Energia Eólica. 13f. 2013. Dissertação (Mestrado em Engenharia Industrial). Pontifícia Universidade Católica do Rio de Janeiro (PUC-RJ), Rio de Janeiro. 2013.

PATEL, M., R. Wind and Solar Power Systems: Design, Analysis, and Operation. Second Edition. New York: Taylor \& Francis Group. 2006.

PEREIRA, L. M.; FAMÁ, R. Diversificação Internacional de Portfólios e a Integração dos Mercados em Desenvolvimento na América Latina e Estados Unidos. Anais... Semead, 6, São Paulo, FEA/USP, 2001.

PEREIRA, R. G. A. Análise de Investimento em Geração de Renovável a Partir da Teoria de Portfolio. 108f. 2014. Dissertação (mestrado em Engenharia Elétrica) - Instituto Alberto Luiz Coimbra de Pós-Graduação e Pesquisa em Engenharia Elétrica (COPPE), Universidade Federal do Rio de Janeiro, Rio de Janeiro. 2014.

PEREIRA, G. M. Projeto de Usinas Hidrelétricas. São Paulo: Oficina de Textos. ISBN: 978-85-7975-162-2, 2015.

PINTO, L. et al. Participação da Energia Eólica no Mercado Livre. São Paulo: ABEEólica, 2011.

PINTO, M. Fundamentos de Energia Eólica. São Paulo: LTC, 2013, 392 p.

PROJETO Asa Branca. Disponível em: http://www.usinaasabranca.com.br. Acesso em: 10 jun. 2014.

RAMOS, D.S.; GUARNIER, E.; WITZLER, L. T. Using the Seasonal Diversity Between Renewable Energy Sources to Mitigate the Effects of Wind Generation Uncertainties. Transmission and Distribution: Latin America Conference and Exposition (T\&D-LA), 2012 Sixth IEEE/PES, v.1, n.7, p.3-5, sept. 2012.

doi: 10.1109/TDC-LA.2012.6319142.

RAMOS, D.S. et al. Minimizing Market Risk by Trading Hydro-Wind Portfolio: A Complementarity Approach. European Energy Market (EEM), International 
Conference on the, v.1, n.8, p.27-31, may, 2013. doi: 10.1109/EEM.2013.6607300.

RIBEIRO, M. N. Comercialização de Energia Eólica no Brasil: Desenvolvimento de Sistemas de Apoio em Leilões para Agentes Geradores. Dissertação (Mestrado em Engenharia Elétrica) - Universidade de São Paulo (POLI/USP), São Paulo, 2013. 145f.

ROQUES, F.; HIROUX, C.; SAGUAN, M. Optimal Wind Power Deployment in Europe-A Portfolio Approach. Energy Policy, v.38, n.7, jul. 2010.

SAHA, S. et al. The NCEP Climate Forecast System Reanalysis. Bulletin of the American Society, n.91, p. 1015-1057.

SANTOS, A. H. M.; RIBEIRO, M. N.; CORRÊA, A. S. P. Uma discussão sobre Energia de Referência em Projetos de Energia Eólica. In: VII Congresso Brasileiro de Planejamento Energético, 2010, São Paulo. VII CBPE, 2010.

SECURATO, J. R. Decisões Financeiras em Condições de Risco. São Paulo: Atlas, 1996.

SECURATO, J. R. Medindo o Nível de Globalização da América Latina e dos Estados Unidos. Anais... CLADEA, 32, FEA/USP, 1997.

SEO, S. A Review and Comparison of Methods for Detecting Outliers in Univariate Data Sets. 2006. Thesis (master of sciences) - Graduate School of Public Health, University of Pittsburg, 2006.

SHARPE, W. F. Capital Asset Prices: A Theory of Market Equilibrium Under Conditions of Risk. The Journal of Finance, v. 19, n. 3, p. 425-442, 1964.

SHIFFLER, R.E. Maximum Z Scores and Outliers. The American Statistics, v. 42, n. 1 , p. $79-80,1988$.

SIEGFRIEDSEN, S.; LEHNHOFF, M.; PREHN, A. Offshore Wind Energy Potential Outside the European Union. Proceedings Global Wind Energy Conference, Paris, 2002.

SILVA, F. J. L.; AMARENTE, O. A. C. Certificação de Medições Anemométricas Certificação de Produção de Energia. Certificação Camargo e Schubert-CPE1122/13. Curitiba, 2013.

SILVA, P. de C.et al. Otimização dos Parâmetros da Distribuição de Weibull. XV Anais...Congresso Brasileiro de Engenharia Mecânica, São Paulo: 1999. 
SINDEN, G. Characteristics of the UK Wind Resource: long-term Patterns and Relationship to Electricity Demand. Energy Policy, n. 35, p.112-127, 2007.

SKAMAROCK, W. C. et al. Description of the Advanced Research WRF Version 3, NCAR Technical Note 475+STR. Boulder: National Center for Atmospheric Research, 2008.

SOARES, L. B. Seleção de Projetos de Investimento em Geração de Energia Elétrica. 111f. 2008. Dissertação (mestrado em Engenharia Industrial) - Pontifícia Universidade Católica do Rio de Janeiro, Rio de Janeiro. 2008.

SONDA. Sistema de Organização Nacional de Dados Ambientais. Rede Sonda. INPE, 2015. Disponível em:htpp://sonda.ccst.inpe.br. Acesso em: 10 jul. 2015.

SOUZA, A. G. Q. et al. North and Northeast Brazil Offshore Wind Power. In: Anais...Internacional Congresso f the Brazilian Geophysical Society, 13, Rio de Janeiro, RJ, Brasil, 2013.

SUISSE ÉOLE. Power Production. In: The Swiss Wind Power Data Website, 2015. Disponível em: <http://www.wind-data.ch/tools/powercalc.php?lng=en>. Acesso em: 15 jul. 2015.

THE EUROPEAN offshore wind industry - key trends and statistics 2010. European Wind Energy Association (EWAE), Brussels, Belgium, 2011. Disponível em: http://www.ewea.org/fileadmin/files/library/publications/statistics/20110121_Offshor e_stats_Full_Doc_final.pdf. Acesso em: 10 jun. 2014.

THE EUROPEAN offshore wind industry - key trends and statistics 2011. European Wind Energy Association (EWAE), Brussels, Belgium, 2012. Disponível em: http://www.ewea.org/fileadmin/files/library/publications/statistics/European_offshore _statistcs_2011.pdf. Acesso em: 10 jun. 2014.

THE EUROPEAN offshore wind industry - key trends and statistics 2012. European Wind Energy Association (EWAE), Brussels, Belgium, 2013. Disponível em: http://www.ewea.org/fileadmin/files/library/publications/statistics/European_offshore _statistcs_2012.pdf. Acesso em: 10 jun. 2014.

THE EUROPEAN offshore wind industry - key trends and statistics 2013. European Wind Energy Association (EWAE), Brussels, Belgium, 2014. Disponível em: http://www.ewea.org/fileadmin/files/library/publications/statistics/European_offshore _statistcs_2013.pdf. Acesso em: 10 jun. 2014.

THE EUROPEAN offshore wind industry - key trends and statistics 2014. European Wind Energy Association (EWAE), Brussels, Belgium, 2015. Disponível em: 
http://www.ewea.org/fileadmin/files/library/publications/statistics/European_offshore _statistcs_2014.pdf. Acesso em: 10 fev. 2015.

TREYNOR, J. L. Toward a Theory of Market Value of Risky Assets. 1962 manuscript. Revised 28/12/2002, with minor edits by Craig William French.

VAN DER ZWAAN, Bob et al. Cost Reductions for Offshore Wind Power: Exploring the Balance Between Scaling, Learning and R\&D. Renewable Energy, v. 41, p. 389-393, 2012.

VITERBO, Jean Carlo. Geração de Energia Elétrica a Partir da Fonte Eólica Offshore. Dissertação de Mestrado. São Paulo, 2008.

VORTEX FACTORIA DE CALCULS, S.L. Disponível em: http://www.vortexfdc.com/. Acesso em: 01 jul. 2015.

WIND force 10: A Blueprint to Achieve 10\% of the World's Electricity from Wind Power by 2020. European Wind Energy Association (EWAE), Forum for Energy and Development, Greenpeace International. Denmark. 1999. Disponível em: http://www.inforse.dk/doc/Windforce10.pdf. Acesso em: 10 jun. 2014. ISBN 1 871532248.

WIND Power. Special Report. Global Offshore. Jun. 2012. 